Bisri Ruchani I Subkhan Ridlo I Roch. Aris Hidayat Umi Masfiah I Moch. Lukluil Maknun

\title{
KATALOG
}

NASKAH KEAGAMAAN
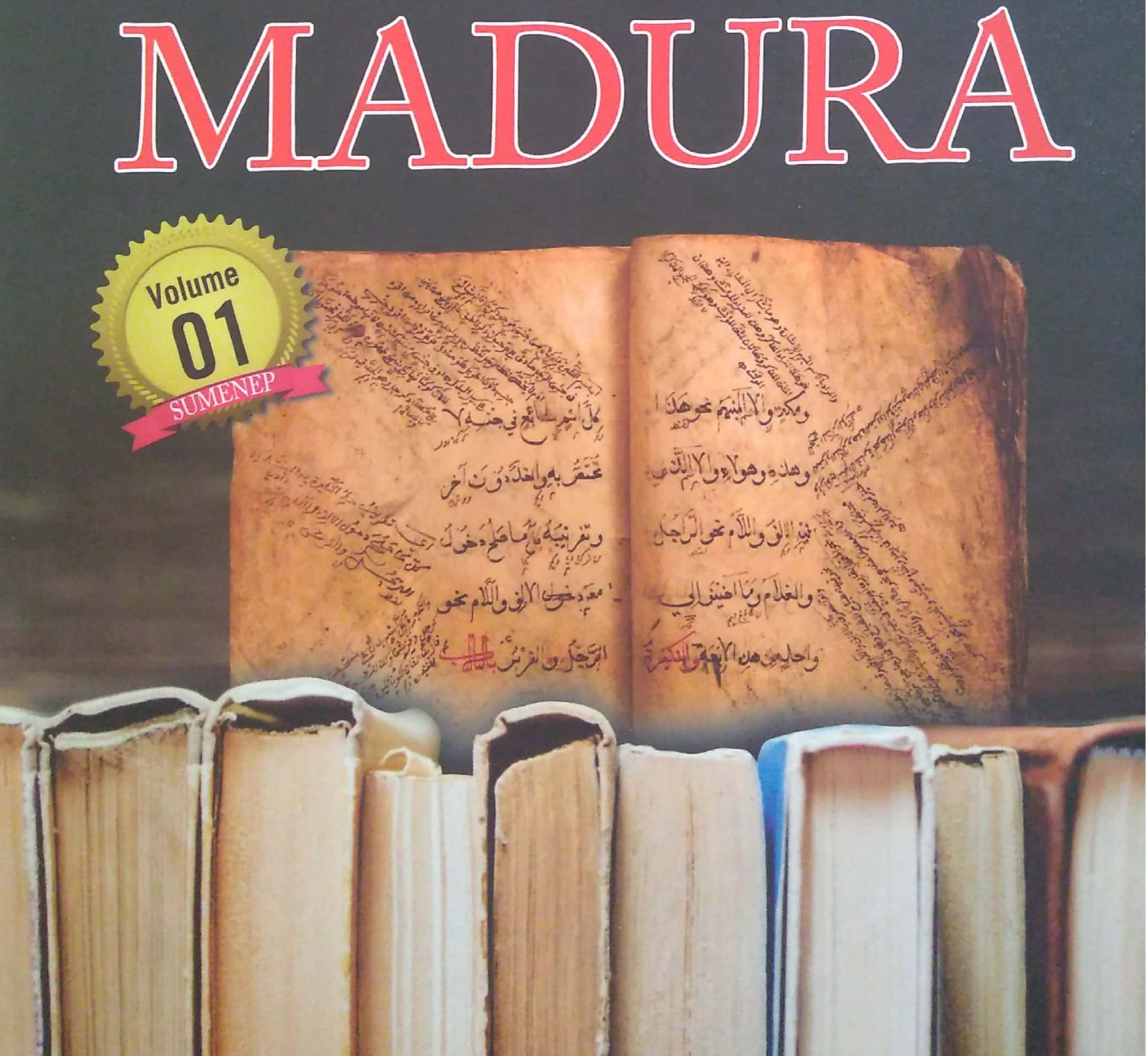


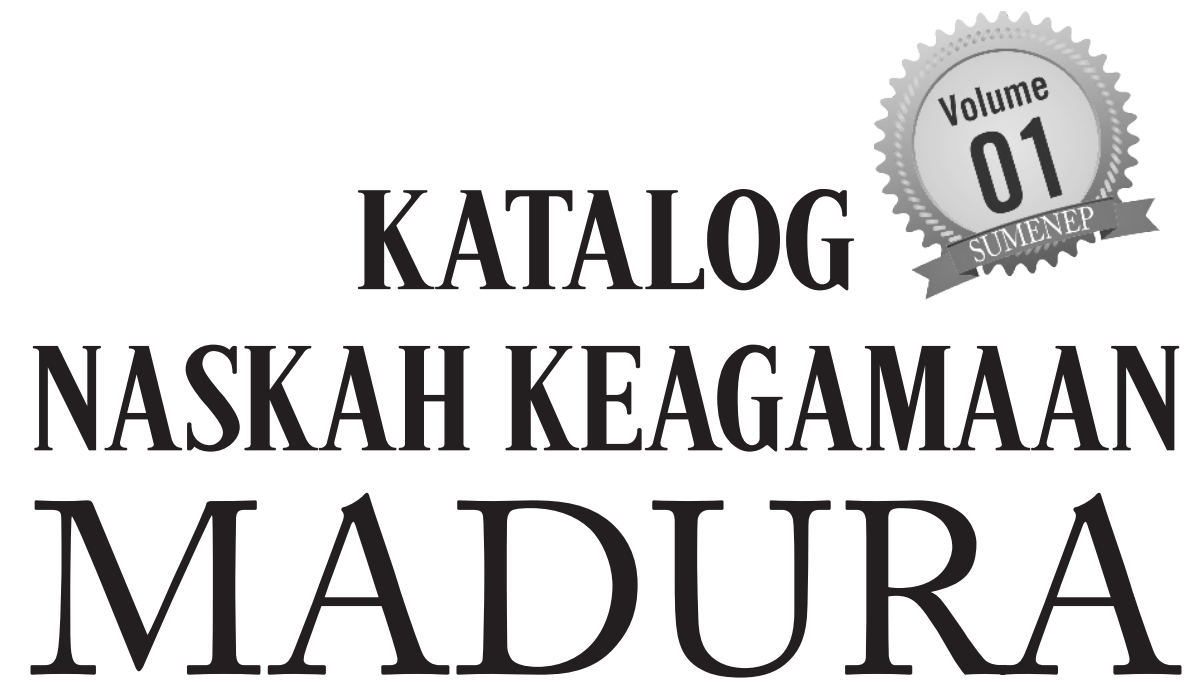

Bisri Ruchani I Subkhan Ridlo I Roch. Aris Hidayat Umi Masfiah I Moch. Lukluil Maknun 


\section{KATALOG NASKAH KEAGAMAAN MADURA VOLUME 1 SUMENEP}

\section{Penyunting:}

Moch. Lukluil Maknun dan Bisri Ruchani

\section{Penulis:}

Bisri Ruchani

Subkhan Ridlo

Roch. Aris Hidayat

Umi Masfiah

Moch. Lukluil Maknun

\section{Peneliti:}

Bisri Ruchani

Zakiyah

Anasom

Ilyas Supena

\section{Layouter}

Sigit Aulia Firdaus

\section{Design cover}

M. Syafiun Najib

Katalog Dalam Terbitan (KDT)

Maknun, Moch Lukluil dan Bisri Ruchani

Katalog Naskah Madura Volume 1 Sumenep/Moch Lukluil Maknun dan Bisri Ruchani (Cetakan Pertama), Yogyakarta: CV Bumi Intaran, 2017, xx+274 hlm; 24 cm

ISBN : 978-602-7731-76-9 ( no.jil. lengkap )

978-602- 7731-77-6 ( jil. 1 )

\section{Penerbit:}

CV. Arti Bumi Intaran Mangkuyudan MJ III/216 - Yogyakarta

Telp./Facs.: (0274) 380228 email: artibumiintaran gmail.com 


\section{KATA PENGANTAR}

Katalogisasi naskah-naskah nusantara telah banyak dilakukan. Akan tetapi, jika dicermati katalog-katalog yang sudah ada tersebut mengidentifikasi naskah yang sudah terkumpul di perpustakaan atau museum, yang konotasinya merupakan naskah yang berasal dari lingkungan kerajaan atau keraton. Jika benar demikian, maka inventarisasi dan identifikasi naskah yang ada di masyarakat belum banyak dilakukan.

Sudah mafhum bahwa naskah senantiasa dipengaruhi keadaan zaman, terkait bahasa dan kebudayaannya. Mengkaji naskah dapat memahami dan menghayati pandangan serta cita-cita yang menjadi pedoman hidup generasi sebelumnya. Menggali warisan nenek moyang yang agung nilainya di dalam naskah dapat diartikan pula sebagai usaha melestarikan dan mengembangkan kebudayaan bangsa Indonesia karena kebudayaan lama itu merupakan akar berpijaknya pandangan masyarakat saat ini.

Madura sangat tepat dijadikan sebagai lokasi penelusuran naskah keagamaan Islam. Madura sejak masa lampau telah menjadi basis penyebaran agama Islam dan masyarakatnya menjadi masyarakat muslim berpengaruh di Jawa Timur. Komunitas muslim di Madura menguat dengan majunya kerajaan muslim, kemudian diikuti merebaknya pusat-pusat pendidikan dari pondok pesantren, majelis taklim, dan madrasah diniyah.

Balai Penelitian dan Pengembangan Agama Semarang telah melakukan kegiatan inventarisasi dan digitalisasi naskah keagamaan pada tahun (2010-2012) di empat Kabupaten di Madura, yaitu Kabupaten Bangkalan, Kabupaten Sampang, Kabupaten Pamekasan, dan Kabupaten Sumenep. Kegiatan tersebut membuahkan hasil yang menggembirakan karena menghasilkan temuan berupa ratusan naskah keagamaan di Madura yang masih tersimpan di pesantren dan masyarakat. Hasil penelitian ini masih berupa identifikasi naskah dan foto digital. Sebagai langkah pengembangan hasil inventarisasi dan digitalisasi naskah, perlu dilaksanakan Penyusunan Naskah Keagamaan Madura dalam bentuk bibliografi berupa Katalog naskah.

Katalogisasi naskah keagamaan Madura dilakukan bertahap berdasarkan lokasi. Pada tahun 2016 ini, katalogisasi diawali dari naskah yang terkumpul di Sumenep. Meskipun naskah Sumenep yang dikumpulkan dalam katalog ini berjumlah ratusan, tetapi sebenarnya belum dapat mencakup keseluruhan naskah yang ada di seluruh wilayah Sumenep yang luasnya terbagi dalam 27 kecamatan. Keberadaan naskah di Sumenep berbeda dengan lokasi lainnya, karena sifatnya menyebar/tersimpan di tengah masyarakat, tidak menyatu di beberapa tempat.

Adapun nama-nama pemilik naskah yang ada di Sumenep dapat dilihat sebagai berikut.

\begin{tabular}{|c|c|c|l|l|}
\hline No & $\begin{array}{c}\text { Nama } \\
\text { Pemilik }\end{array}$ & Kode & Alamat & $\begin{array}{c}\text { Jumlah } \\
\text { Naskah }\end{array}$ \\
\hline 1 & $\begin{array}{l}\text { Kiai } \\
\text { Masduki }\end{array}$ & GPR 1 s.d. 14 & Gapura Barat, Gapura, Sumenep & 14 \\
\hline
\end{tabular}




\begin{tabular}{|c|c|c|c|c|}
\hline 2 & $\begin{array}{l}\text { Kiai Said } \\
\text { Abdullah }\end{array}$ & SMN 1 s.d. 3 & PP Matholiul Anwar Pengarangan Sumenep & 3 \\
\hline 3 & $\begin{array}{l}\text { Mushala } \\
\text { Kebon } \\
\text { Agung }\end{array}$ & KBA 1 & Sumenep & 1 \\
\hline 4 & $\begin{array}{l}\text { Fatony } \\
\text { Ahmad }\end{array}$ & GPR $15,17,22$ & Dusun Talesek, Gapura Barat, Gapura, Sumenep & 3 \\
\hline 5 & Ilyas & GPR 16,18 s.d. 21 & Durbugan Banjar Barat, Gapura Sumenep & 5 \\
\hline 6 & $\begin{array}{l}\text { Kiai } \\
\text { Abdul } \\
\text { Madjid }\end{array}$ & GPR 23, 24 & Lambi Cabi, Gapura Tengah, Gapura, Sumenep & 2 \\
\hline 7 & $\begin{array}{l}\text { Kiai } \\
\text { Mansur }\end{array}$ & GPR 25 & Lambi Cabi, Gapura Tengah, Gapura, Sumenep & 1 \\
\hline 8 & $\begin{array}{l}\text { Abdur } \\
\text { Rochim }\end{array}$ & GPR 26 & $\begin{array}{l}\text { Dusun Naikan Atas, Gapura Barat, Gapura, } \\
\text { Sumenep }\end{array}$ & 1 \\
\hline 9 & $\begin{array}{l}\text { Kiai } \\
\text { Hasan }\end{array}$ & GPR 27 s.d. 32 & $\begin{array}{l}\text { Dusun Lambi Cabi, Gapura Tengah, Gapura } \\
\text { Sumenep }\end{array}$ & 6 \\
\hline 10 & $\begin{array}{l}\text { Abdul } \\
\text { Wakhid }\end{array}$ & GPR 33, 34 & $\begin{array}{l}\text { Dusun Lambi Cabi, Gapura Tengah, Gapura, } \\
\text { Sumenep }\end{array}$ & 2 \\
\hline 11 & $\begin{array}{l}\text { Abdur } \\
\text { Rahim }\end{array}$ & GPR 35,37 & Lambi Cabi, Gapura Tengah, Gapura, Sumenep & 2 \\
\hline 12 & Ibnu Aqil & GPR 36 & $\begin{array}{l}\text { Dusun Pangabesan, Gapura Timur, Gapura, } \\
\text { Sumenep }\end{array}$ & 1 \\
\hline 13 & $\begin{array}{l}\text { Kiai } \\
\text { Zahidi } \\
\text { Bisri }\end{array}$ & GPR 38 s.d. 41 & $\begin{array}{l}\text { Dusun Pasar Pocok, Desa Paloklo'an, Gapura, } \\
\text { Sumenep }\end{array}$ & 4 \\
\hline 14 & $\begin{array}{l}\text { Kiai } \\
\text { Fayad/Ny } \\
\text { ai Zainab }\end{array}$ & GDG 1s.d. 3 & Pesantren Karai, Karai Gending, Sumenep & 3 \\
\hline 15 & $\begin{array}{l}\text { Kiai } \\
\text { Muchtar }\end{array}$ & $\begin{array}{l}\text { BT-BT 1 s.d. } 3,5,6 \text {, } \\
8 \text { s.d. } 12\end{array}$ & $\begin{array}{l}\text { Dusun Laok Saba, Nyabakan Timur, Batang- } \\
\text { Batang, Sumenep }\end{array}$ & 10 \\
\hline 16 & $\begin{array}{l}\text { Khosyieu } \\
\mathrm{n}\end{array}$ & BT-BT 4,13 s.d. 16 & $\begin{array}{l}\text { Dusun Laok Saba, Nyabakan Timur, Batang- } \\
\text { Batang, Sumenep }\end{array}$ & 5 \\
\hline 17 & Matnawi & BT-BT 7 & $\begin{array}{l}\text { Dusun Laok Saba, Nyabakan Timur, Batang- } \\
\text { Batang, Sumenep }\end{array}$ & 1 \\
\hline 18 & Muriksa & BT-BT 17 s.d. 19 & $\begin{array}{l}\text { Dusun Laok Saba, Nyabakan Timur, batang- } \\
\text { Batang }\end{array}$ & 3 \\
\hline 19 & $\begin{array}{l}\text { Abdrurrah } \\
\text { man }\end{array}$ & BT-BT 20 s.d. 23 & $\begin{array}{l}\text { Dusun Laok Saba, Nyabakan Timur, batang- } \\
\text { Batang }\end{array}$ & 4 \\
\hline 20 & $\begin{array}{l}\text { Kiai } \\
\text { Su'udi } \\
\text { Fadhal }\end{array}$ & $\begin{array}{l}\text { BT-BT } 24 \text { s.d. } 27 \\
\text { dan } \\
\text { JNGR/SUDFD/126 } \\
\text { s.d. } 132,134 \text { s.d. } \\
137 / 2012\end{array}$ & Dusun Nyabungan, Jenangger, Batang-Batang. & 15 \\
\hline 21 & H. Ahmad & BT-BT 28 s.d. 32 & Dusun Nyabungan, Jenangger, Batang-Batang. & 5 \\
\hline 22 & Aziz & BT-BT 33 s.d. 44 & Dusun Nyabungan, Jenangger, Batang-Batang. & 12 \\
\hline 23 & $\begin{array}{l}\text { Kiai } \\
\text { Khalid }\end{array}$ & BT-BT 45 s.d. 55 & Dusun Nyabungan, Jenangger, Batang-Batang. & 11 \\
\hline 24 & $\begin{array}{l}\text { Abd. } \\
\text { Mufid }\end{array}$ & GPT/MD/01/2012 & Gapura Sumenep & 1 \\
\hline 25 & $\begin{array}{l}\text { K.H. } \\
\text { Quraisyi }\end{array}$ & $\begin{array}{l}\text { LCGPRT/KHQ/02 } \\
\text { s.d. } 12 / 2012\end{array}$ & Lambi Cabi, Gapura Tengah, Gapura & 11 \\
\hline 26 & Albar & $\begin{array}{l}\text { TMD.BT.BT/ALB/ } \\
13 / 2012\end{array}$ & Tamendung, Batang-Batang & 1 \\
\hline 27 & $\begin{array}{l}\text { K.H. } \\
\text { Kholil }\end{array}$ & $\begin{array}{l}\text { LCGPTR/KH/14/ } \\
\text { s.d. } 17 / 2012\end{array}$ & Lambi Cabi, Gapura Tengah, Gapura & 4 \\
\hline
\end{tabular}




\begin{tabular}{|c|c|c|c|c|}
\hline 28 & $\begin{array}{l}\text { Nasiruddi } \\
\mathrm{n}\end{array}$ & $\begin{array}{l}\text { GPRB/NSR/18 s.d. } \\
\text { 20/2012 }\end{array}$ & Caremmi, Gapura Barat & 3 \\
\hline 29 & $\begin{array}{l}\text { K.H. } \\
\text { Samhadi } \\
\text { Siraj }\end{array}$ & $\begin{array}{l}\text { GPRB/SMHS/21 } \\
\text { s.d. } 29 / 2012\end{array}$ & Gapura Barat, Gapura & 9 \\
\hline 30 & $\begin{array}{l}\text { K.H. } \\
\text { Zahidi }\end{array}$ & $\begin{array}{l}\text { PJGGPR/KHZ/30 } \\
\text { s.d. 32/2012 }\end{array}$ & Pajagungan, Paloklokan, Gapura & 3 \\
\hline 31 & $\begin{array}{l}\text { Nyai } \\
\text { Halimah }\end{array}$ & $\begin{array}{l}\text { TNAR/HLMH/33/2 } \\
012\end{array}$ & Tanah Air, Rubaru & 1 \\
\hline 32 & $\begin{array}{l}\text { Nyai } \\
\text { Ummi } \\
\text { Kulsum }\end{array}$ & $\begin{array}{l}\text { GPRB/UKL/34 s.d. } \\
38 / 2012\end{array}$ & Talesek, Gapura Barat, Gapura & 5 \\
\hline 33 & K. Amir & $\begin{array}{l}\text { MDGT/AMR/39 } \\
\text { s.d. 40/2012 }\end{array}$ & Manding Timur, Manding & 2 \\
\hline 34 & Aziz & $\begin{array}{l}\text { BTLN/AZIZ/41/201 } \\
2\end{array}$ & Bantilan, Batu Putih & 1 \\
\hline 35 & Madani & $\begin{array}{l}\text { BTLN/MDN/42/201 } \\
2\end{array}$ & Bantilan, Batu Putih & 1 \\
\hline 36 & $\begin{array}{l}\text { Nyai } \\
\text { Dzurriyat }\end{array}$ & $\begin{array}{l}\text { SGG/DRYH/43 s.d. } \\
50 / 2012\end{array}$ & Sergang, Batu Putih & 8 \\
\hline 37 & $\begin{array}{l}\mathrm{KH} \\
\text { Syarbini }\end{array}$ & $\begin{array}{l}\text { PJG/SRBN/51 s.d. } \\
\text { 52/2012 }\end{array}$ & Pajung, Sergang, Batu Putih & 2 \\
\hline 38 & Maghfur & SGG/MGR/53/2012 & Sergang Batu Putih & 1 \\
\hline 39 & Fathur & $\begin{array}{l}\text { SGG/FTHR/54A } \\
\text { s.d. } 59 / 2012\end{array}$ & Sergang, Batu Putih & 7 \\
\hline 40 & Fauzan & $\begin{array}{l}\text { BLKN/FZN/60/201 } \\
2\end{array}$ & Bule'en, Batu Putih, Sumenep & 1 \\
\hline 41 & M. Zaini & SGG/ZNI/61/2012 & Sergang, Batu Putih & 1 \\
\hline 42 & Husnan & $\begin{array}{l}\text { BTLN/HSN/62 s.d. } \\
63 / 2012\end{array}$ & Bantilan, Batu Putih & 2 \\
\hline 43 & Basri & SGG/BSI/64/2012 & Sergang, Batu Putih & 1 \\
\hline 44 & Marwan & $\begin{array}{l}\text { BTLN/MRWN/65 } \\
\text { s.d. } 69 / 2012\end{array}$ & Bantilan, Batu Putih & 5 \\
\hline 45 & M Fahim & $\begin{array}{l}\text { SGG/MFHM/70 s.d. } \\
\text { 77/2012 }\end{array}$ & Sergang, Batu Putih & 8 \\
\hline 46 & Amir & $\begin{array}{l}\text { MDGT/AMR/78 } \\
\text { s.d. } 80 / 2012\end{array}$ & Manding Timur, Manding & 3 \\
\hline 47 & K.H. Alwi & $\begin{array}{l}\text { BTLN/ALWI/81 } \\
\text { s.d. } 85,98 / 2012\end{array}$ & Bantilan, Pajung, Batu Putih & 6 \\
\hline 48 & $\begin{array}{l}\text { Nyai } \\
\text { Su'adah }\end{array}$ & $\begin{array}{l}\text { PJG.SGG/SUAD/86 } \\
/ 2012\end{array}$ & Pajung, Sergang, Batu Putih & 1 \\
\hline 49 & $\begin{array}{l}\text { Nyai } \\
\text { Laila }\end{array}$ & $\begin{array}{l}\text { BTLN/LAILA/87/2 } \\
012\end{array}$ & Bantilan, Pajung, Batu Putih & 1 \\
\hline 50 & Daud & $\begin{array}{l}\text { MDT/DAUD/88 } \\
\text { s.d. } 89 / 2012\end{array}$ & Manding Timur, Manding & 2 \\
\hline 51 & $\begin{array}{l}\mathrm{Ny} \\
\text { Su'adah }\end{array}$ & $\begin{array}{l}\text { PJG.SGG/SUAD/90 } \\
/ 2012\end{array}$ & Pajung, Sergang, Batu Putih & 1 \\
\hline 52 & KH Amin & $\begin{array}{l}\text { PJG.SGG/AMIN/91 } \\
/ 2012\end{array}$ & Pajung, Sergang, Batu Putih & 1 \\
\hline 53 & KH Hasin & $\begin{array}{l}\text { LRKT/HSN/92/201 } \\
2\end{array}$ & Larangan Kerta, Batu Putih & 1 \\
\hline 54 & Jamaludin & $\begin{array}{l}\text { PJG } \\
\text { SGG/JMLD/93/201 } \\
2\end{array}$ & Pajung, Sergang, Batu Putih & 1 \\
\hline 55 & $\begin{array}{l}\text { Nyai } \\
\text { Kholishoh }\end{array}$ & $\begin{array}{l}\text { MDGT/CHLH/94/2 } \\
012\end{array}$ & Manding Timur, Manding & 1 \\
\hline
\end{tabular}




\begin{tabular}{|c|c|c|c|c|}
\hline 56 & Amir & $\begin{array}{l}\text { PJG.SGG/AMIN/95 } \\
/ 2012\end{array}$ & Pajung, Sergang, Batu Putih & 1 \\
\hline 57 & Jumawi & $\begin{array}{l}\text { BTLN/JMW/96/201 } \\
2\end{array}$ & Bantilan, Pajung, Batu Putih & 1 \\
\hline 58 & $\begin{array}{l}\text { M } \\
\text { Haitsam }\end{array}$ & $\begin{array}{l}\text { BTLN/MHSM/97/2 } \\
012\end{array}$ & Bantilan, Pajung, Batu Putih & 1 \\
\hline 59 & $\begin{array}{l}\text { Nyai } \\
\text { Dzurriyah }\end{array}$ & $\begin{array}{l}\text { SGG/DRYH/99/201 } \\
2\end{array}$ & Sergang Batu Putih & 1 \\
\hline 60 & $\begin{array}{l}\text { K.H. A } \\
\text { Waris }\end{array}$ & $\begin{array}{l}\text { MCT/AWR/100 s.d. } \\
101 / 2012\end{array}$ & Muncek Tengah Kenteng & 2 \\
\hline 61 & $\begin{array}{l}\text { Nyai } \\
\text { Musyarof } \\
\text { ah }\end{array}$ & $\begin{array}{l}\text { BTLN/MSRF/102/2 } \\
012\end{array}$ & Bantilan Batu Putih & 1 \\
\hline 62 & $\begin{array}{l}\text { Nyai Siti } \\
\text { Aisyah }\end{array}$ & $\begin{array}{l}\text { BLTN/STASH/103/ } \\
2012\end{array}$ & Bantilan Batu Putih & 1 \\
\hline 63 & Aswani & $\begin{array}{l}\text { BTLN/ASWN/104/ } \\
2012\end{array}$ & Bantilan Batu Putih & 1 \\
\hline 64 & $\begin{array}{l}\text { Nyai } \\
\text { Sunniyatu } \\
\mathrm{n} \\
\text { Nadhifah }\end{array}$ & $\begin{array}{l}\text { BTLN/SNTN/105/2 } \\
012\end{array}$ & Bantilan Batu Putih & 1 \\
\hline 65 & Misdah & $\begin{array}{l}\text { BTLN/MSDN/106/ } \\
2012\end{array}$ & Bantilan Batu Putih & 1 \\
\hline 66 & $\begin{array}{l}\text { Abdus } \\
\text { Samad }\end{array}$ & $\begin{array}{l}\text { BTLN/ABDSMD/1 } \\
07 \text { s.d. 109/2012 }\end{array}$ & Bantilan Batu Putih & 3 \\
\hline 67 & $\begin{array}{l}\text { Mutammi } \\
\text { mah }\end{array}$ & $\begin{array}{l}\text { BTLN/MTMH/110 } \\
\text { s.d. } 111 / 2012\end{array}$ & Bantilan Batu Putih & 2 \\
\hline 68 & Miski & $\begin{array}{l}\text { BTLN/MSK/112/ } \\
\text { s.d. } 1132012\end{array}$ & Bantilan Batu Putih & 2 \\
\hline 69 & $\begin{array}{l}\text { Mu'awana } \\
\mathrm{h}\end{array}$ & $\begin{array}{l}\text { BTLN/MWN/114 } \\
\text { s.d. 115/2012 }\end{array}$ & Bantilan Batu Putih & 2 \\
\hline 70 & $\begin{array}{l}\text { Arif } \\
\text { Sudarsono }\end{array}$ & $\begin{array}{l}\text { NYBK.BTBT/ARF } \\
\text { S/116 s.d. } 118 / 2012\end{array}$ & Nyabakan Timur Batang-Batang & 3 \\
\hline 71 & $\begin{array}{l}\text { Taufiq } \\
\text { Hidayat }\end{array}$ & $\begin{array}{l}\text { NYBK.TFQHDYT/ } \\
119 / 2012\end{array}$ & Nyabakan Timur Batang-Batang & 1 \\
\hline 72 & Hosmah & $\begin{array}{l}\text { JNGR/HSM/120 } \\
\text { s.d. } 125 / 2012\end{array}$ & Jenangger, Batang-batang & 6 \\
\hline 73 & Nikmah & $\begin{array}{l}\text { JRNBTPT/NIKMA } \\
\text { H/133/2012 }\end{array}$ & Juruan, Batu Putih & 1 \\
\hline 74 & K. Irsyad & $\begin{array}{l}\text { JNRG/SUDFD/138/ } \\
\text { s.d. } 139 / 2012\end{array}$ & Jenangger, Batang-batang & 2 \\
\hline 75 & Mawardi & $\begin{array}{l}\text { JNRG/MWRD/140 } \\
\text { s.d. } 141 / 2012\end{array}$ & Pajung, Batu Putih & 2 \\
\hline 76 & $\begin{array}{l}\text { H. } \\
\text { Madani }\end{array}$ & $\begin{array}{l}\text { PJGSGG/MDN/142 } \\
\text { s.d. } 143,145 \text { s.d. } \\
152 / 2012\end{array}$ & Pajung Sergang, Batu Putih & 10 \\
\hline 77 & Abdullah & $\begin{array}{l}\text { PJGSGG/ABDL/14 } \\
4 / 2012\end{array}$ & Pajung Sergang, Batu Putih & 1 \\
\hline 78 & $\begin{array}{l}\text { K.H. } \\
\text { Hasim }\end{array}$ & $\begin{array}{l}\text { PJGSGG/HSM/153 } \\
\text { s.d. 159/2012 }\end{array}$ & Pajung Sergang, Batu Putih & 7 \\
\hline 79 & $\begin{array}{l}\text { Nyai } \\
\text { Mu'awiya } \\
\mathrm{h}\end{array}$ & $\begin{array}{l}\text { PJGSGG/MWYH/1 } \\
60 \text { s.d. } 164 / 2012\end{array}$ & Pajung Sergang, Batu Putih & 5 \\
\hline & & \multicolumn{2}{|l|}{ Jumlah } & 268 \\
\hline
\end{tabular}


Klasifikasi keilmuan Islam mengacu kepada panduan yang disusun Kailani, yang menurunkan klasifikasi keagaman Islam dari DDC (Dewey Decimal Classification) dengan kode 297 atau 2x menjadi sepuluh klasifikasi turunan yang di dalamnya dapat dijabarkan kembali. Berikut dapat dilihat hasil klasifikasi naskah Sumenep berdasarkan klasifikasi Kailani.

$\begin{array}{clcc}\text { No } & \text { Klasifikasi } & \text { Kode } & \text { Jumlah Naskah } \\ 0 & \text { Keilmuan Islam Umum } & \text { IU } & 28 \\ 1 & \text { Alquran dan Ilmu yang Berkaitan } & \text { AQ } & 45 \\ 2 & \text { Hadits dan Ilmu yang Berkaitan } & \text { HD } & 3 \\ 3 & \text { Akaid dan Ilmu Kalam } & \text { AK } & 87 \\ 4 & \text { Fikih } & \text { FI } & 71 \\ 5 & \text { Akhlak dan tasawuf } & \text { AT } & 28 \\ 6 & \text { Sosial dan Budaya Islam } & \text { SB } & 2 \\ 7 & \text { Filsafat dan Perkembangannya } & \text { FIP } & 1 \\ 8 & \text { Aliran dan Sekte dalam Islam } & \text { AS } & 0 \\ 9 & \text { Sejarah Islam dan Bibliografi } & \text { SI } & 3 \\ & \quad \text { Jumlah } & & 268\end{array}$

Selanjutnya, panduan pembacaan katalog naskah sumenep adalah sebagai berikut.

\begin{tabular}{|c|c|c|c|c|}
\hline & $\begin{array}{l}\text { Kode } \\
\text { Inventarisasi }\end{array}$ & 2) Judul & 3) Kode Klas & 4) Klasifikasi \\
\hline 5) & $\begin{array}{l}\text { Nomor } \\
\text { Koleksi }\end{array}$ & 6) Bahasa & 7) Aksara & 8) Bentuk \\
\hline & Jml. Halaman & 10) Jml. Baris/hlm & $\begin{array}{l}\text { 11) Ukuran } \\
\text { Naskah }\end{array}$ & 12) Jenis Kertas \\
\hline \multicolumn{5}{|c|}{ 13) Pemilik } \\
\hline
\end{tabular}

15) Deskripsi 1

16) Deskripsi 2

17) Deskripsi 3

18) Gambar

Keterangan dari unsur-unsur yang dicantumkan dalam tiap item katalog dapat dijelaskan sebagai berikut;

1) Kode Inventarisasi, misalnya BLAS/SUM/16/IU/1. BLAS berarti Balai Penelitian dan Pengembangan Agama Semarang, SUM merupakan kode untuk naskah dari Kabupaten Sumenep Madura, 16 merupakan kode tahun penyusunan proyek katalog Sumenep yaitu tahun 2016, IU berarti "Ilmu Islam Umum" sebagai bagian dari kode klasifkasi keilmuan Islam versi Kailani, dan 1 merupakan nomor urut dari tiap klasifikasi keilmuan. 
2) Judul, misalnya "Kitab Saraf". Judul diambil langsung dari teks dalam naskah, jika memang sudah disebutkan, atau merupakan judul baru yang diberikan peneliti berdasarkan gambaran umum isi teks.

3) Kode Klas, merupakan kode klasifikasi Kailani dari 0-9.

4) Klasifikasi, misalnya "Ilmu Tata Bahasa Arab". Ini merupakan deskripsi dari kode klasifikasi, berdasar isi teks menurut macam keilmuan Islam versi Kailani.

5) Nomor Koleksi, misalnya "GPR 40". Ini merupakan penomoran awal yang diberikan oleh peneliti dalam penelitan "digitalisasi naskah Madura”. Nomor koleksi merupakan kode lokasi tempat diketemukannya naskah beserta nomor urut. Untuk tahun koleksi naskah tahun 2012, nomor koleksi dilengkapi dengan inisial nama pemilik naskah dan tahun penelitian/digitalisasi.

6) Bahasa, misalnya "Arab, Jawa". Ini artinya bahwa bahasa yang digunakan dalam teks menggunakan bahasa Arab dan bahasa Jawa.

7) Aksara, misalnya "Arab", disebutkan jenis aksara yang digunakan dalam teks.

8) Bentuk, misalnya "Prosa", disebutkan bentuk teks yang disajikan, biasanya berupa puisi (syair, syiir, tembang) atau prosa (natsar).

9) Jumlah Halaman, disebutkan jumlah halaman naskah (keseluruhan teks) yang tersedia.

10) Jumlah Baris perhalaman, disebutkan jumlah baris dalam teks naskah, baik dibuat rata-rata ataupun angka minimal dan maksimal.

11) Ukuran Naskah, ini merupakan ukuran halaman naskah dengan perhitungan panjang kali lebar dalam centimeter.

12) Bahan Naskah, atau di dalam katalog ini disebutkan langsung dengan "Jenis Kertas", misalnya "Kertas Daluwang".

13) Pemilik, misalnya "Kiai Zahidi Bisri", merupakan nama pemilik naskah pada saat penelitian digitalisasi dilakukan.

14) Alamat, misalnya "Dusun Pejagungan, Gapura Barat, Gapura, Sumenep. Ini merupakan alamat pemilik naskah pada saat penelitian, adakalanya alamat tertulis lengkap dari dusun, desa, kecamatan, hingga Kabupaten.

15) Deskripsi 1, merupakan paragraf deskripsi isi teks secara umum.

16) Deskripsi 2, merupakan paragraf deskripsi isi teks lebih rinci, atau yang ditonjolkan dari teks.

17) Deskripsi 3, merupakan paragraf keterangan perolehan naskah dan kondisi naskah secara umum.

18) Gambar, merupakan contoh tampilan foto digital dari naskah, biasanya merupakan halaman awal isi naskah, atau bagian yang dianggap mewakili teks.

Pada katalog ini terdapat beberapa keterangan dan tanda khusus yaitu; 
1. Nomor koleksi juga merupakan nomor file (foto digital naskah, menggantikan posisi rol film) yang disimpan oleh tim peneliti Balai Litbang Agama Semarang. Jika nomor koleksi dituliskan dengan dimiringkan, ini dimaksudkan bahwa file digital hilang/tidak ada.

2. Tanda () pada naskah berarti tidak terdapat deskripsi yang dapat disampaikan dari naskah, baik karena naskah rusak/susah diidentifikasi, atau memang tidak terdapat keterangan.

Contoh penyajian katalogisasi naskah keagamaan di Sumenep dapat dilihat sebagai berikut.

\begin{tabular}{|c|c|c|c|}
\hline $\begin{array}{l}\text { BLAS/SUM/16/IU/ } \\
9\end{array}$ & $\begin{array}{l}\text { KITAB AL- } \\
\text { JURUMIYAH }\end{array}$ & 0 & $\begin{array}{l}\text { Ilmu Tata } \\
\text { Bahasa Arab }\end{array}$ \\
\hline $\begin{array}{l}\text { GPRB/UKL/36/201 } \\
2\end{array}$ & Arab & Arab & Prosa \\
\hline $132 \mathrm{hlm}$. & 5 s.d 9 baris/hlm. & $27 \times 19$ & $\begin{array}{l}\text { Kertas } \\
\text { Daluwang }\end{array}$ \\
\hline \multicolumn{4}{|l|}{ Nyai Ummi Kulsum } \\
\hline \multicolumn{4}{|c|}{ Talesek, Gapura Tengah, Gapura } \\
\hline \multicolumn{4}{|c|}{$\begin{array}{l}\text { Teks terdiri atas dua teks. Teks pertama berjudul Jurumiyah, teks kedua tidak ada } \\
\text { judul. }\end{array}$} \\
\hline \multicolumn{4}{|c|}{$\begin{array}{l}\text { Naskah Jurumiyah menjelaskan ilmu nậwu mulai dari pengertian isim sampai } \\
\text { mufrad, jamak, dan sebagainya. }\end{array}$} \\
\hline \multicolumn{4}{|c|}{ Nyai Ummi Kulsum dari Nyai Aisyah dari K Abdul Aziz. Kondisi naskah mulai } \\
\hline
\end{tabular}

Transliterasi Arab-Latin katalog ini menggunakan Pedoman Transliterasi ArabLatin, berdasarkan SKB Menteri Agama dan Menteri Pendidikan dan Kebudayaan No. 158 Tahun 1987 dan 0543 b/U/ 1987.

Ahirnya, tim penyusun Katalog Keagamaan Sumenep menyampaikan banyak terimakasih kepada para pemilik naskah yang telah bersedia memberikan izin identifikasi dan katalogisasi naskah, serta kepada semua pihak yang berperan dalam mewujudkan katalog ini.

Tim Penyusun 


\section{PEDOMAN TRANSLITERASI}

Pedoman transliterasi yang digunakan adalah Sistem Transliterasi ArabLatin Berdasarkan SKB Menteri Agama dan Menteri P\&K RI no. 158/1987 dan No. 0543 b/U/1987 tertanggal 22 Januari 1988.

\section{Konsonan Tunggal}

\begin{tabular}{|c|c|c|c|}
\hline Huruf Arab & Nama & Huruf latin & Nama \\
\hline 1 & Alif & Tidak dilambangkan & Tidak dilambangkan \\
\hline ب & $\mathrm{Ba}$ & B & $\mathrm{Be}$ \\
\hline ت & $\mathrm{Ta}$ & $\mathrm{T}$ & $\mathrm{Te}$ \\
\hline ث & $\dot{\mathrm{Sa}}$ & $\dot{\mathrm{S}}$ & Es (dengan titik diatasnya) \\
\hline ج & Jim & $\mathrm{J}$ & $\mathrm{Je}$ \\
\hline$\tau$ & $\mathrm{Ha}$ & $\mathrm{H}$ & $\begin{array}{l}\text { Ha (dengan titik di } \\
\text { bawahnya) }\end{array}$ \\
\hline$\dot{\tau}$ & Kha & $\mathrm{Kh}$ & Ka dan $\mathrm{Ha}$ \\
\hline 2 & Dal & $\mathrm{D}$ & De \\
\hline j & Żal & $\dot{\mathrm{Z}}$ & $\mathrm{Z}$ (dengan titik di atasnya) \\
\hline נ & $\mathrm{Ra}$ & $\mathrm{R}$ & $\mathrm{Er}$ \\
\hline j & Zai & $\mathrm{Z}$ & Zet \\
\hline س & Sin & $\mathrm{S}$ & Es \\
\hline ش M & Syin & Sy & Es dab ye \\
\hline ص & Șad & S & $\begin{array}{c}\text { Es (dengan titik di } \\
\text { bawahnya) }\end{array}$ \\
\hline 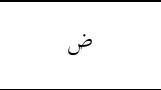 & Dad & D & $\begin{array}{c}\text { De (dengan titik di } \\
\text { bawahnya) }\end{array}$ \\
\hline$b$ & Ța & T? & $\begin{array}{l}\text { Te (dengan titik di } \\
\text { bawahnya) }\end{array}$ \\
\hline b & Zạ & $\mathrm{Z}$ & $\begin{array}{c}\text { Zet (dengan titik di } \\
\text { bawahnya) }\end{array}$ \\
\hline$\varepsilon$ & 'Ain & 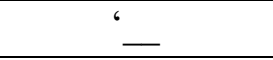 & Apostrof terbalik \\
\hline$\dot{\varepsilon}$ & Gain & G & $\mathrm{Ge}$ \\
\hline ف & $\mathrm{Fa}$ & $\mathrm{F}$ & Ef \\
\hline ق & Qaf & Q & Qi \\
\hline 5 & Kaf & K & $\mathrm{Ka}$ \\
\hline J & Lam & $\mathrm{L}$ & El \\
\hline
\end{tabular}




\begin{tabular}{|c|c|c|c|}
\hline$p$ & Mim & M & Em \\
\hline$\dot{s}$ & Nun & N & En \\
\hline, & Wau & W & Ha \\
\hline$ه$ & Ha & H & Apostrof \\
\hline$s$ & Hamzah & - & Ye \\
\hline$s$ & Ya & Y & \\
\hline
\end{tabular}

Hamzah ( $)$ yang terletak di awal kata mengikuti vokalnya tanpa diberi tanda apa pun. Jika ia terletak di tengah atau di akhir, maka ditulis dengan tanda (').

\section{Vokal}

Vokal bahasa Arab, seperti vokal bahasa Indonesia, terdiri atas vokal tunggal atau monoftong dan vokal rangkap atau diftong.

Vokal tunggal bahasa Arab yang lambangnya berupa tanda atau harakat, transliterasinya sebagai berikut:

\begin{tabular}{|c|c|c|c|}
\hline Tanda & Nama & Huruf latin & Nama \\
\hline 1 & Fatḥah & A & A \\
\hline 1 & Kasrah & I & I \\
\hline 1 & Dammah & U & U \\
\hline
\end{tabular}

Vokal rangkap bahasa Arab yang lambangnya berupa gabungan antara harakat dan huruf, transliterasinya berupa gabungan huruf, yaitu:

\begin{tabular}{|c|c|c|c|}
\hline Tanda & Nama & Huruf latin & Nama \\
\hline J & Fathah dan ya & $\mathrm{Ai}$ & A dan I \\
\hline$و$ & $\begin{array}{c}\text { Fathah dan } \\
\text { wau }\end{array}$ & $\mathrm{Au}$ & A dan U \\
\hline
\end{tabular}

Contoh:

كيف : kaifa هول : haula

\section{Maddah}

Maddah atau vokal panjang yang lambangnya berupa harkat dan huruf, transliterasinya berupa huruf dan tanda, yaitu: 


\begin{tabular}{|c|c|c|c|}
\hline Harkat dan Huruf & Nama & Huruf dan tanda & Nama \\
\hline \begin{tabular}{l|l|l} 
& $\ldots$ &
\end{tabular} & $\begin{array}{c}\text { fathah dan alif } \\
\text { atau ya }\end{array}$ & $\overline{\mathrm{a}}$ & a dan garis di at as \\
\hline ज? & kasrah dan ya & $\overline{\mathrm{i}}$ & i dan garis di atas \\
\hline - & dammah dan wau & $\overline{\mathrm{u}}$ & $\mathrm{u}$ dan garis di atas \\
\hline
\end{tabular}

$$
\begin{array}{ll}
\text { مات } & \text { : māta } \\
\text { رمى } & \text { : qà̄āa } \\
\text { فيل } & \text { : yamūtu }
\end{array}
$$

\section{Ta marbütah}

Transliterasi untuk ta marbütah ada dua, yaitu: ta marbütah yang hidup atau mendapat harkat fathah, kasrah, dan ḍammah, transliterasinya adalah [t]. Sedangkan ta marbütah yang mati atau mendapat harkat sukun, transliterasinya adalah [h].

Kalau pada kata yang berakhir dengan ta marbütah diikuti oleh kata yang menggunakan kata sandang al- serta bacaan kedua kata itu terpisah, maka ta marbūtah itu ditransliterasikan dengan ha (h). Contoh:

: rauḍah al-atfãl

al-madinah al-fạdilah

: : al-hikmah

\section{Syaddah (Tasydid)}

\begin{tabular}{|c|c|}
\hline ربنا & : rabbaña \\
\hline نجينا & : najjaīna \\
\hline الحق & : al-haqq \\
\hline الحج & : al-hajj \\
\hline نعّم & : nu“'ima \\
\hline عدو & : 'aduwwun \\
\hline
\end{tabular}

Syaddah atau tasydid yang dalam sistem tulisan Arab dilambangkan dengan sebuah tanda tasydid ( ${ }^{i}$ ), dalam transliterasi ini dilambangkan dengan perulangan huruf (konsonan ganda) yang diberi tanda syaddah.. Contoh: 
Jika huruf $ی$ ber-tasydid di akhir sebuah kata dan didahului oleh huruf kasrah ( ), maka ia ditransliterasi seperti huruf maddah (i). Contoh:

: :Ali (bukan 'Aliyy atau 'Aly)

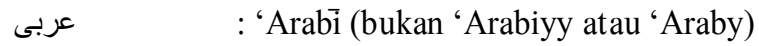

\section{Kata Sandang}

Kata sandang dalam sistem tulisan Arab dilambangkan dengan huruf ال (aliflam ma'arifah). Dalam pedoman transliterasi ini, kata sandang ditransliterasi seperti biasa, al-, baik ketika ia diikuti oleh huruf syamsiah maupun huruf qamariah. Kata sandang tidak mengikuti bunyi huruf langsung yang mengikutinya. Kata sandang ditulis terpisah dari kata yang mengikutinya dan dihubungkan dengan garis mendatar (-). Contohnya:

\begin{tabular}{|c|c|}
\hline 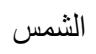 & : al-syamsu (bukan asy-syamsu) \\
\hline 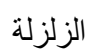 & : al-zalzalah (az-zalzalah) \\
\hline الفلسفة الفة & : al-falsafah \\
\hline الدلادُ & : al-bilādu \\
\hline
\end{tabular}

\section{Hamzah}

Aturan transliterasi huruf hamzah menjadi apostrof (') hanya berlaku bagi hamzah yang terletak di tengah dan akhir kata. Namun, bila hamzah terletak di awal kata, ia tidak dilambangkan, karena dalam tulisan Arab ia berupa alif. Contohnya:

$\begin{array}{ll}\text { تأمرون } & \text { : ta'murūna } \\ \text { النوء } & \text { : al-nau' } \\ \text { أمرت : syai'un } & \text { : umirtu }\end{array}$

\section{Penulisan Kata Arab yang Lazim digunakan dalam Bahasa Indonesia}

Kata, istil ah atau kalimat Arab yang ditransliterasi adalah kata, istilah atau kalimat yang belum dibakukan dalam bahasa Indonesia. Kata, istilah atau kalimat yang sudah lazim dan menjadi bagian dari pembendaharaan bahasa Indonesia, atau sudah sering ditulis dalam tulisan bahasa Indonesia, tidak lagi ditulis menurut cara transliterasi di atas. Misalnya kata Al-Qur'an (dari al-Qur'ān), Sunnah, khusus dan umum. Namun, bila kata-kata tersebut menjadi bagian dari satu rangkaian teks Arab, maka mereka harus ditransliterasi secara utuh. Contoh:

Fi Zilāl al-Qur'ān

\section{Al-Sunnah qabl al-tadwin}

Al-'Ibārāt bi 'umūm al-lafẓ lā bi khuṣūṣ al-sabab 


\section{Lafẓ al-Jalālah (ال山)}

Kata ,Allah yang didahului partikel seperti huruf jarr dan huruf lainnya atau berkedudukan sebagai muḍăf ilaih (frasa nominal), ditransli-terasi tanpa huruf hamzah. Contoh:

ديناله dinullāh billāh

Adapun ta marbütah di akhir kata yang disandarkan kepada lafž al-jalālah, ditransliterasi dengan huruf [t]. Contoh:

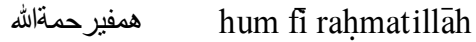

\section{Huruf Kapital}

Walau sistem tulisan Arab tidak mengenal huruf kapital (All Caps), dalam transliterasinya huruf-huruf tersebut dikenai ketentuan tentang penggunaan huruf kapital berdasarkan pedoman ejaan Bahasa Indonesia yang berlaku (EYD). Huruf kapital, misalnya, digunakan untuk menuliskan huruf awal nama diri (orang, tempat, bulan) dan huruf pertama pada permulaan kalimat. Bila nama diri didahului oleh kata sandang (al-), maka yang ditulis dengan huruf kapital tetap huruf awal nama diri tersebut, bukan huruf awal kata sandangnya. Jika terletak pada awal kalimat, maka huruf A dari kata sandang tersebut menggunakan huruf kapital (Al-). Ketentuan yang sama juga berlaku untuk huruf awal dari judul referensi yang didahului oleh kata sandang al-, baik ketika ia ditulis dalam teks maupun dalam catatan rujukan (CK, DP, CDK, dan DR). Contoh:

Wa mā Muḥammadun illā rasūı

Inna awwala baitin wựi ‘a linnāsi lallażī bi Bakkata mubārakan

Syahru Ramaḍān al-lażi unzila fỉh al-Qur'ān

Nașir al-Dīn al-Ṭusis

Abū Naṣr al-Farābi $\bar{i}$

Al-Gazāli

Al-Munqiż min al-Ḍalāl 


\section{DAFTAR ISI}

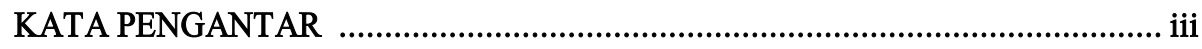

PEDOMAN TRANSLITERASI …………………….......................................

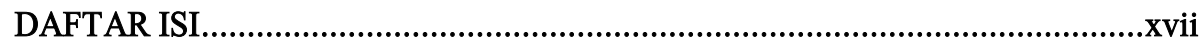

KATALOG NASKAH KEAGAMAAN KAB. SUMENEP

\begin{tabular}{|c|c|}
\hline & .........29 \\
\hline & - HADIS DAN ILMU YANG BERKAITAN \\
\hline & - AKAID DAN ILMU KALAM \\
\hline & - FIQIH .. \\
\hline & - AKHLAK DAN TASAWUF ......... \\
\hline & - SOSIAL DAN BUDAYA ISLAM \\
\hline & N PERKEMBA \\
\hline & M DAN BIBLIOGRAFI \\
\hline
\end{tabular}


Katalog Naskah Keagamaan Kab. Sumenep 



\section{IU \\ ISLAM UMUM}

\begin{tabular}{|l|l|l|l|}
\hline $\begin{array}{l}\text { BLAS/SUM/16/IU/ } \\
1\end{array}$ & KITAB ȘARAF & 0 & $\begin{array}{l}\text { Ilmu Tata Bahasa } \\
\text { Arab }\end{array}$ \\
\hline GPR 40 & Arab, Jawa Pegon & Arab & Prosa \\
\hline 90 hlm. & 7 baris/hlm. & $27 \times 18$ & Kertas Daluwang \\
\hline Kiai Zahidi Bisri & \\
\hline \multicolumn{2}{|l|}{ Dusun Pasar Pocok, Desa Paloklo'an, Gapura, Sumenep } \\
\hline
\end{tabular}

Naskah berisi materi tentang ilmu saraf.

Naskah berasal dari Kiai Zahidi Bisri dari Kiai Khudaifi, dari Kiai Masyhuri. Teks ditulis menggunakan tinta hitam dan merah tanpa penomoran halaman. Kondisi fisik naskah rusak, tidak bersampul, namun tulisan masih bisa dibaca.

\begin{tabular}{|l|l|l|l|}
\hline $\begin{array}{l}\text { BLAS/SUM/16/IU/ } \\
2\end{array}$ & $\begin{array}{l}\text { KITAB NAHWU } \\
\text { ȘARAF }\end{array}$ & 0 & $\begin{array}{l}\text { Ilmu Tata Bahasa } \\
\text { Arab }\end{array}$ \\
\hline BT-BT 10 & Arab & Arab & Prosa \\
\hline 68 hlm. & 13 baris/hlm. & $29 \times 19$ & Kertas Daluwang \\
\hline Kiai Muchtar & \\
\hline \multicolumn{2}{|l}{ Dusun Laok Saba, Nyabakan Timur, Batang-Batang, Sumenep } \\
\hline
\end{tabular}

Naskah berisi materi tentang praktik i'rab.

Naskah berasal dari Kiai Muchtar dari Kiai Mustaqim dari Kiai Siwallah dari Kiai Biramah. Kondisi naskah tanpa sampul, teks ditulis menggunakan tinta hitam dan merah. Kondisi naskah dalam keadaan rusak, tetapi tulisan masih dapat dibaca. 


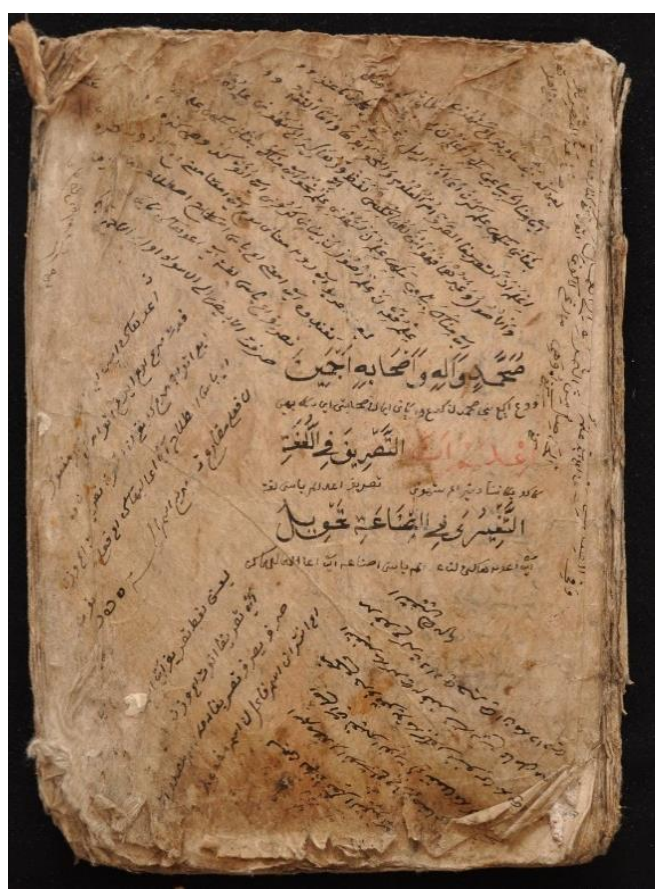

1126 GPR 40 HLM 1 DSC_0148

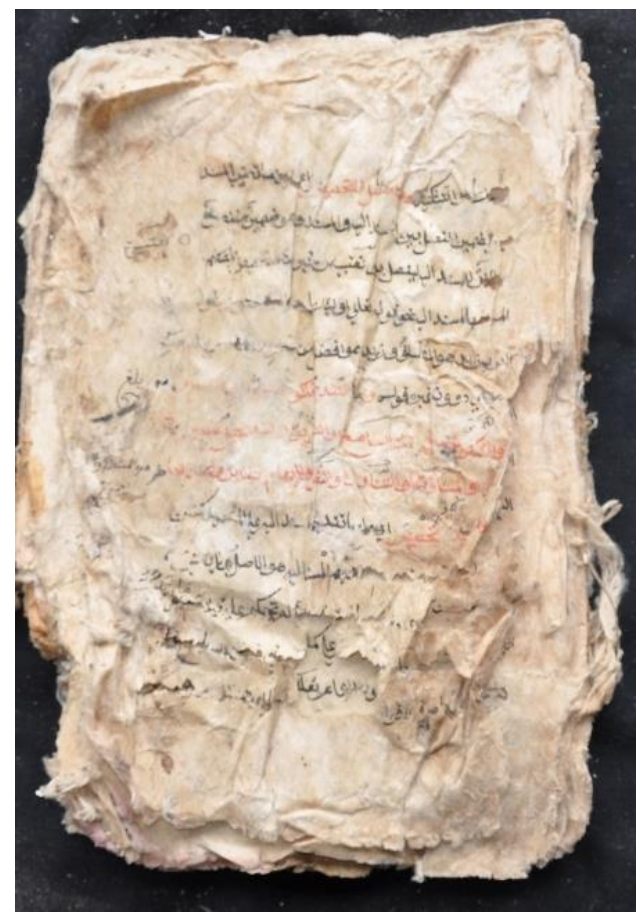

1140 BTBT 10 HLM 1 DSC_0068 


\begin{tabular}{|l|l|l|l|}
\hline $\begin{array}{l}\text { BLAS/SUM/16/IU/ } \\
\mathbf{3}\end{array}$ & $\begin{array}{l}\text { KITAB AL } \\
\text { AWĀMIL }\end{array}$ & $\mathbf{0}$ & $\begin{array}{l}\text { Almu Tata Bahasa } \\
\text { Arab }\end{array}$ \\
\hline $\begin{array}{l}\text { LCGPTR/KHQ/06/ } \\
2012\end{array}$ & Arab & Arab & Prosa \\
\hline 78 hlm. & 3 s.d. 5 baris/hlm. & $26.5 x 19$ & Kertas Daluwang \\
\hline K.H. Quraisyi & \\
\hline Lambi Cabi, Gapura Tengah, Gapura & \\
\hline
\end{tabular}

Naskah ini menjelaskan tentang ilmu nạwu.

Naskah ini tersimpan di rumah K.H. Quraisyi yang berasal dari kakeknya, K.H. Masyhuri.

\begin{tabular}{|l|l|l|l|}
\hline $\begin{array}{l}\text { BLAS/SUM/16/IU/ } \\
4\end{array}$ & $\begin{array}{l}\text { KITAB AL JĀNI } \\
\text { WA TAJWID }\end{array}$ & 0 & $\begin{array}{l}\text { Ilmu Tata Bahasa } \\
\text { Arab }\end{array}$ \\
\hline $\begin{array}{l}\text { LCGPTR/KHQ/11/ } \\
2012\end{array}$ & Arab & Arab & Prosa \\
\hline $12 \mathrm{hlm}$. & 10,21 baris/hlm. & $23.5 \times 18$ & Kertas Daluwang \\
\hline K.H. Quraisyi & \\
\hline Lambi Cabi, Gapura Tengah, Gapura & \\
\hline
\end{tabular}

Naskah ini menjelaskan tentang ilmu nạhwu dan teks kedua menjelaskan tentang ilmu tajwid.

Naskah ini tersimpan di rumah K.H. Quraisyi yang berasal dari kakeknya, K.H. Masyhuri. 


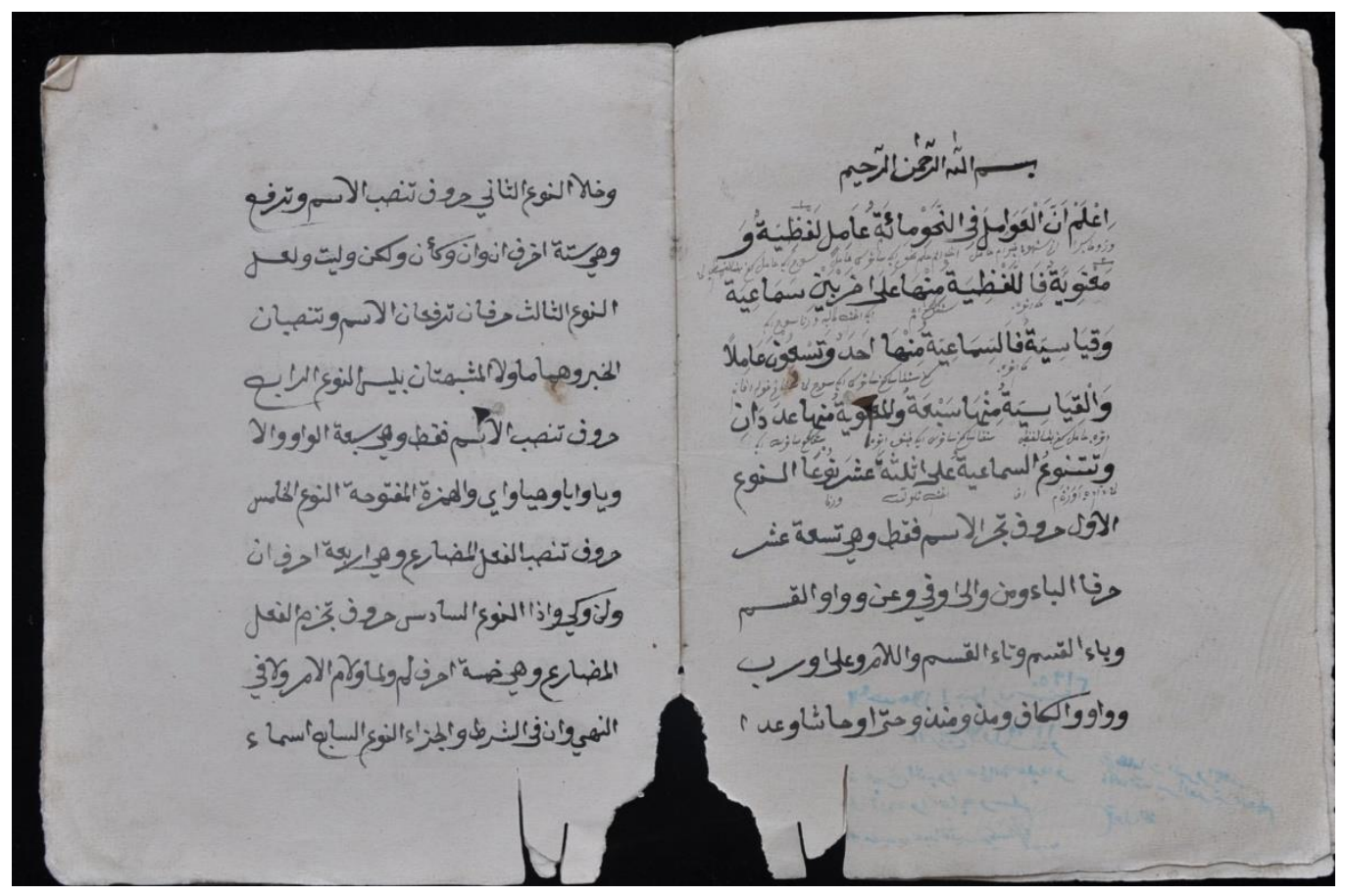

12011 LCGPTR KHQ 112012 HLM 1,2 Img0523 


\begin{tabular}{|l|l|l|l|}
\hline $\begin{array}{l}\text { BLAS/SUM/16/IU/ } \\
\mathbf{5}\end{array}$ & $\begin{array}{l}\text { KITAB AL- } \\
\text { AWĀMIL DAN } \\
\text { LAIN-LAIN }\end{array}$ & $\mathbf{0}$ & $\begin{array}{l}\text { Armu Tata Bahasa } \\
\text { Arab }\end{array}$ \\
\hline $\begin{array}{l}\text { LCGPTR/KH/14/2 } \\
012\end{array}$ & Arab, Jawa & Arab & Prosa \\
\hline $184 \mathrm{hlm}$. & 2 s.d. 11 baris/hlm. & 26x18 & Kertas Daluwang \\
\hline K.H. Kholil & \multicolumn{2}{|l}{} \\
\hline Lambi Cabi, Gapura Tengah, Gapura
\end{tabular}

Naskah ini berisi tentang pembahasan ilmu nậwu saraf. Di dalamnya ada pembahasan tentang 'amil dan dàmir.

Naskah ini tersimpan di rumah K.H. Kholil. Kondisi mulai rusak, teks masih dapat dibaca.

\begin{tabular}{|l|l|l|l|}
\hline $\begin{array}{l}\text { BLAS/SUM/16/IU/ } \\
6\end{array}$ & KITAB NAHWU & 0 & $\begin{array}{l}\text { Ilmu Tata Bahasa } \\
\text { Arab }\end{array}$ \\
\hline $\begin{array}{l}\text { LCGPTR/KH/16/2 } \\
012\end{array}$ & Arab & Arab & Prosa \\
\hline $\begin{array}{l}48 \mathrm{hlm} . \\
\text { K.H. Kholil }\end{array}$ & 9 baris/hlm. & $25.5 \times 18$ & Kertas Daluwang \\
\hline Lambi Cabi, Gapura Tengah, Gapura & \\
\hline
\end{tabular}

Naskah ini menjelaskan tentang ilmu nạ̣wu, tata cara meng -i'lal, isim, fi'il, dan kaidahkaidah nahwu yang lain.

Naskah ini tersimpan di rumah K.H. Kholil. Kondisi mulai rusak, teks masih dapat dibaca. 


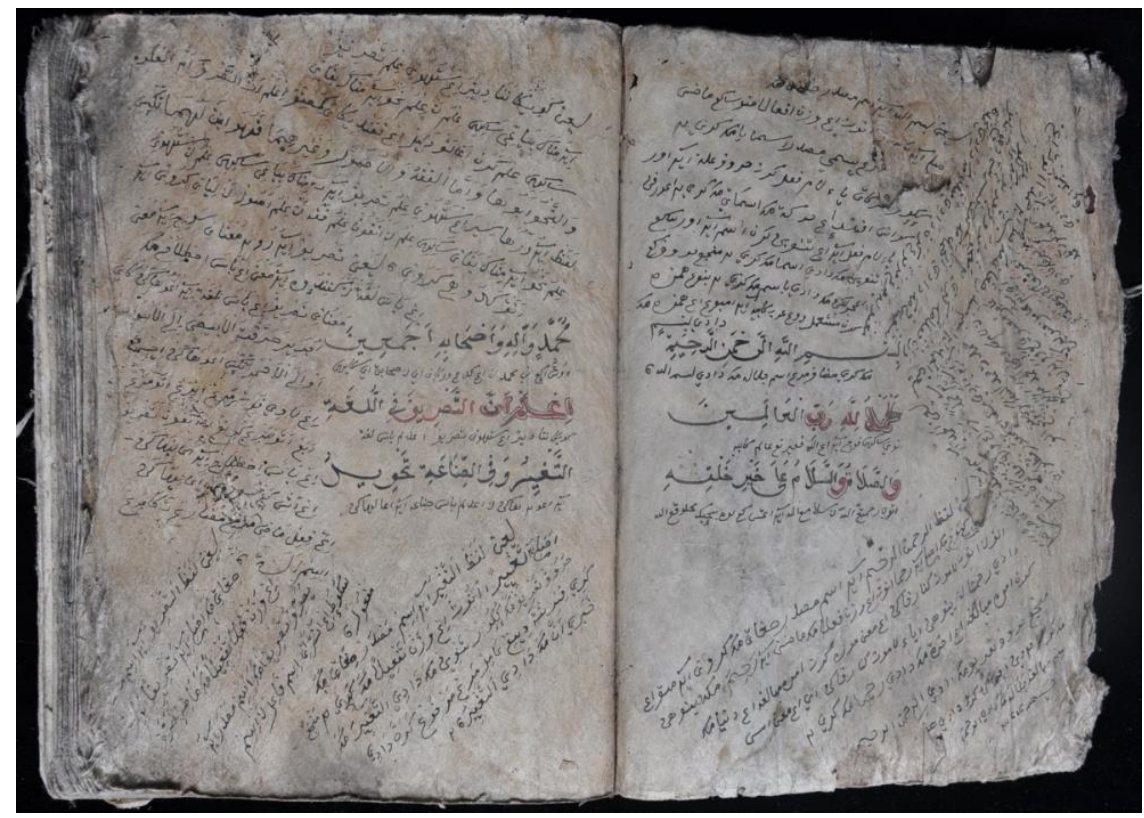

12014 LCGPTR KH 142012 HLM 1,2 Img0703

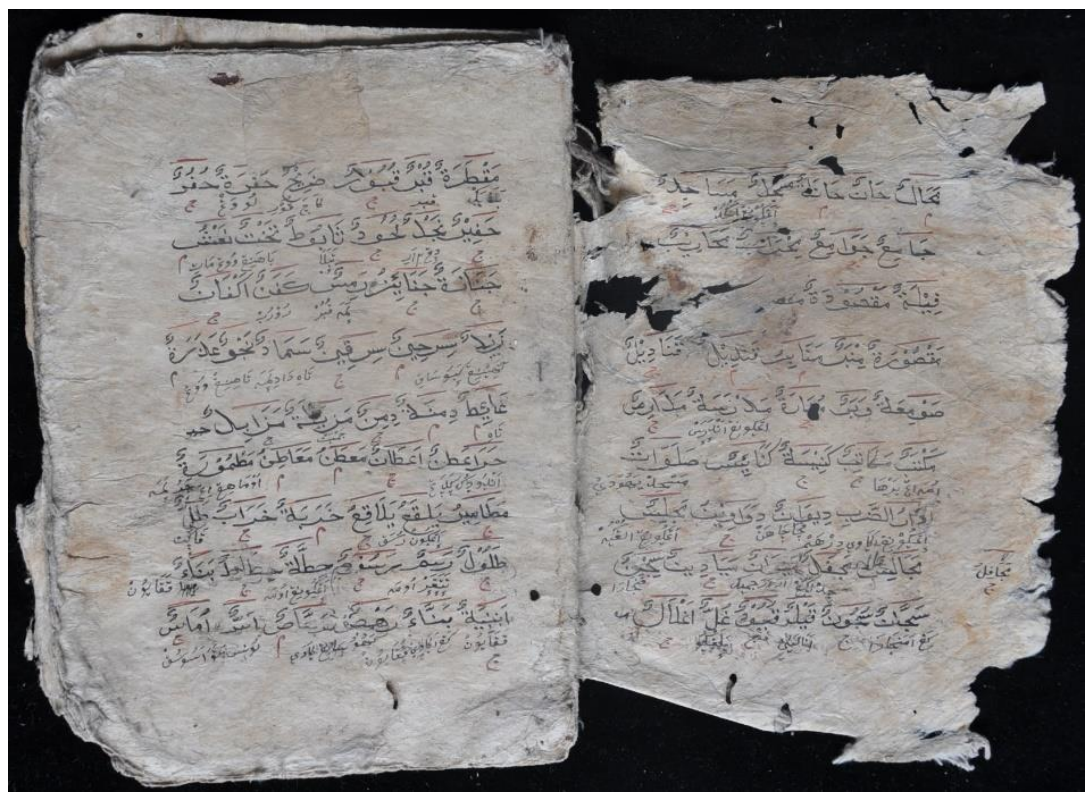

12016 LCGPTR KH 162012 HLM 2,3 Img0854 


\begin{tabular}{|l|l|l|l|}
\hline $\begin{array}{l}\text { BLAS/SUM/16/IU/ } \\
7\end{array}$ & $\begin{array}{l}\text { KITAB NAHWWU } \\
\text { ȘARAF }\end{array}$ & 0 & $\begin{array}{l}\text { Ilmu Tata Bahasa } \\
\text { Arab }\end{array}$ \\
\hline $\begin{array}{l}\text { GPRB/SMHS/23/2 } \\
012\end{array}$ & Arab & Arab & Prosa \\
\hline 236 hlm. & 5 baris/hlm. & $26 \times 18$ & Kertas Daluwang \\
\hline K.H. Samhadi Siraj & \\
\hline Gapura Barat, Gapura
\end{tabular}

Naskah ini berisi dua teks, yaitu ilmu nạhwu dan ilmu saraf.

Naskah ini berasal dari K.H. Samhadi Siraj, dari K.H.M. Siraj, dari K.H. Abdul Syakur. Kondisi naskah mulai rusak, teks masih terbaca.

\begin{tabular}{|l|l|l|l|}
\hline $\begin{array}{l}\text { BLAS/SUM/16/IU/ } \\
\mathbf{8}\end{array}$ & KITAB ȘARAF & $\mathbf{0}$ & $\begin{array}{l}\text { Ilmu Tata Bahasa } \\
\text { Arab }\end{array}$ \\
\hline $\begin{array}{l}\text { PJGGPR/KHZ/32/2 } \\
012\end{array}$ & Arab & Arab & Prosa \\
\hline $92 \mathrm{hlm}$. & 7 baris/hlm. & $26.5 \times 18.5$ & Kertas Daluwang \\
\hline K.H. Zahidi & \\
\hline \multicolumn{2}{|l}{ Pajagungan, Paloklokan, Gapura } \\
\hline
\end{tabular}

Naskah ini berisi tentang ilmu sarafjenis-jenis isim, fi'il, hurf, dan cara-cara mentasrif.

Naskah ini milik K.H. Zahidi dari K. Said. Kondisi naskah mulai rusak, teks masih terbaca. 


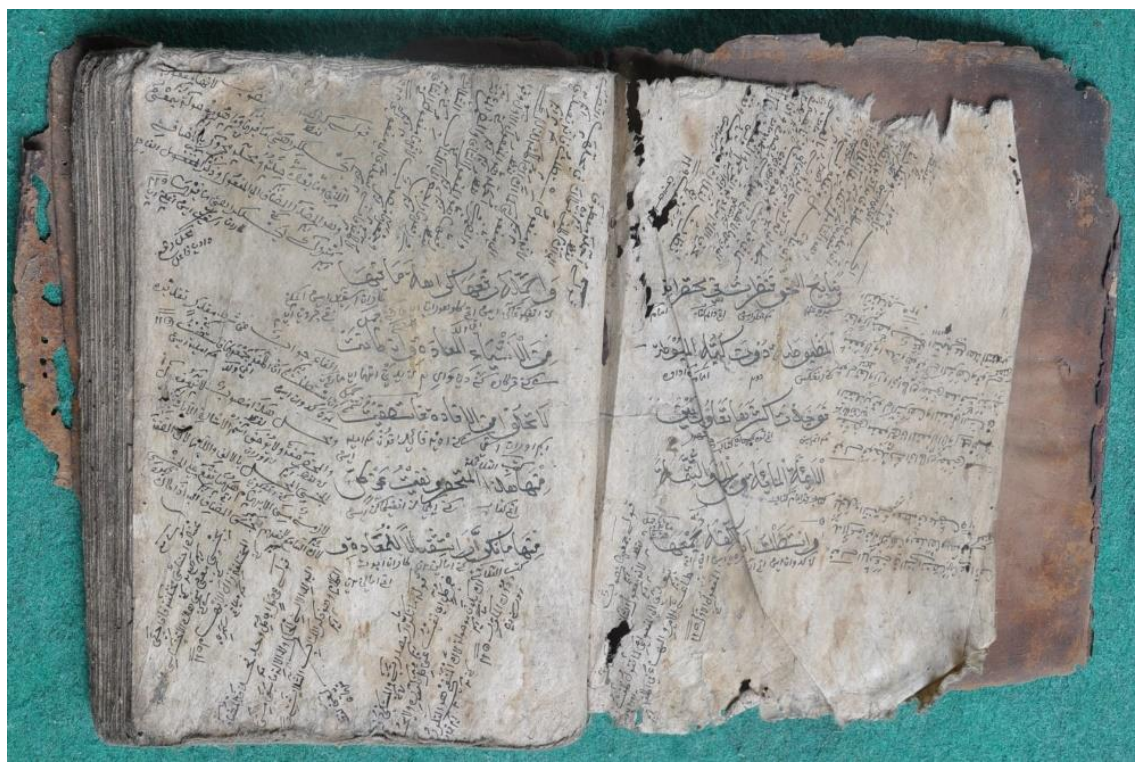

12023 GPRB SMHS 232012 HLM 2,3 Img1841

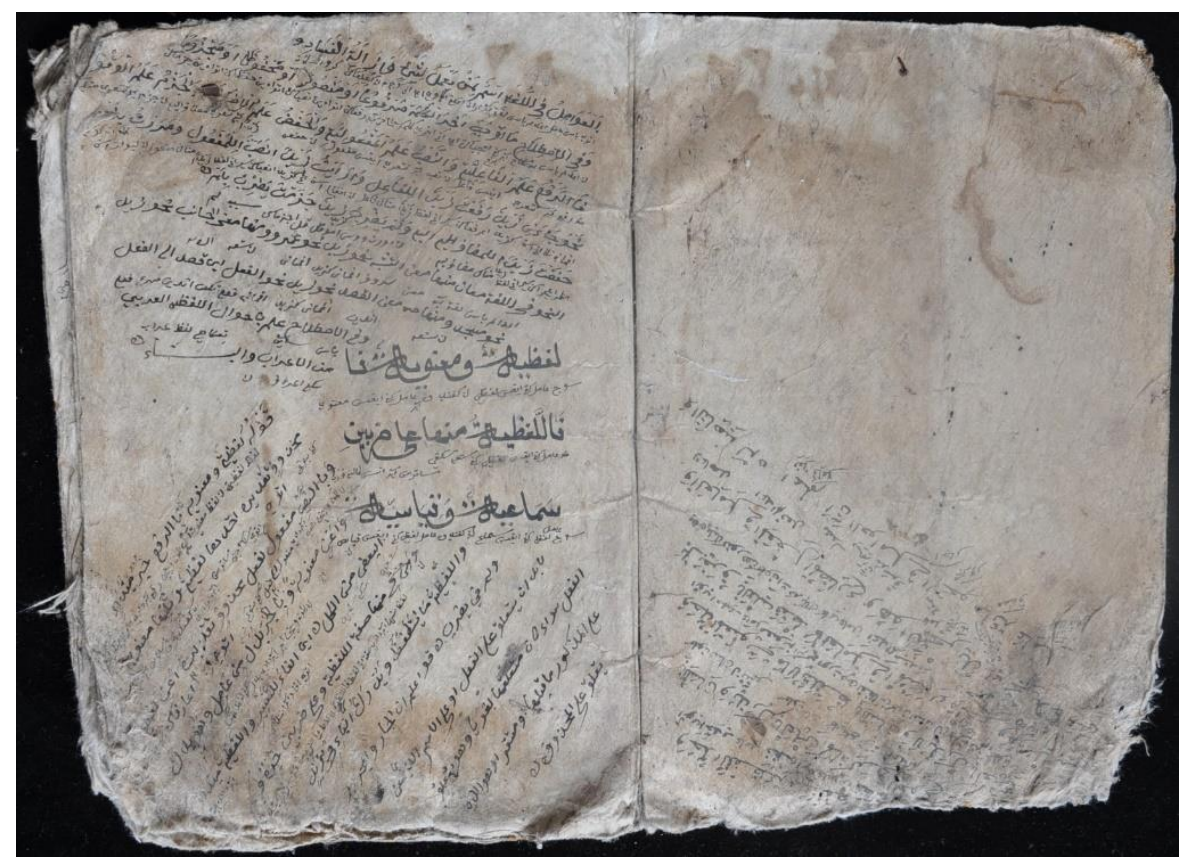

12032 PJGGPR KHZ 322012 HLM 1, 2 Img2399.jpg 


\begin{tabular}{|l|l|l|l|}
\hline $\begin{array}{l}\text { BLAS/SUM/16/IU/ } \\
\mathbf{9}\end{array}$ & $\begin{array}{l}\text { KITAB AL- } \\
\text { JURUMIYAH }\end{array}$ & $\mathbf{0}$ & $\begin{array}{l}\text { Ilmu Tata Bahasa } \\
\text { Arab }\end{array}$ \\
\hline $\begin{array}{l}\text { GPRB/UKL/36/201 } \\
2\end{array}$ & Arab & Arab & Prosa \\
\hline $132 \mathrm{hlm}$. & 5 s.d 9 baris/hlm. & $27 \times 19$ & Kertas Daluwang \\
\hline Nyai Ummi Kulsum \\
\hline \multicolumn{2}{|l}{ Talesek, Gapura Tengah, Gapura } \\
\hline
\end{tabular}

Teks terdiri at as dua teks. Teks pertama berjudul Jurumiyah, teks kedua tidak ada judul.

Naskah Jurumiyah menjelaskan ilmu nậwu mulai dari pengertian isim sampai mufrad, jamak, dan sebagainya.

Naskah milik Nyai Ummi Kulsum dari Nyai Aisyah dari K Abdul Aziz. Kondisi naskah mulai rusak, teks masih terbaca.

\begin{tabular}{|c|c|c|c|}
\hline $\begin{array}{l}\text { BLAS/SUM/16/IU/ } \\
10\end{array}$ & KITAB NAḤWU & 0 & $\begin{array}{l}\text { Ilmu Tata Bahasa } \\
\text { Arab }\end{array}$ \\
\hline $\begin{array}{l}\text { GPRB/UKL/37/201 } \\
2\end{array}$ & Arab & Arab & Prosa \\
\hline $36 \mathrm{hlm}$. & 3 s.d 5 baris/hlm. & $29 \times 19$ & Kertas Daluwang \\
\hline
\end{tabular}

Teks berisi tentang ilmu nạhwu.

Naskah milik Nyai Ummi Kulsum dari Nyai Aisyah dari K Abdul Aziz. Kondisi naskah mulai rusak, teks masih terbaca. 


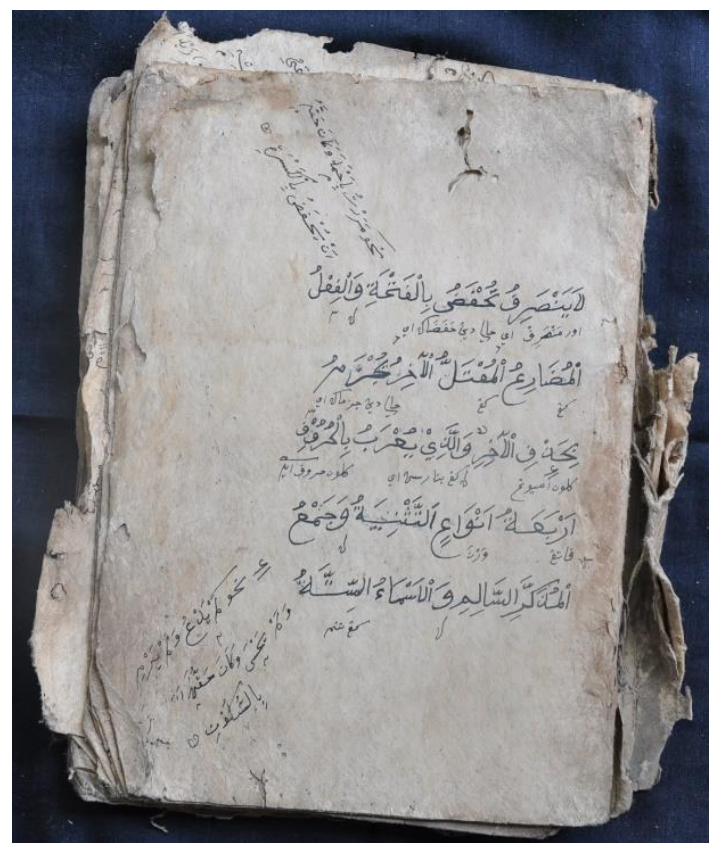

12036 GPRB UKL 362012 HLM 1 Img3

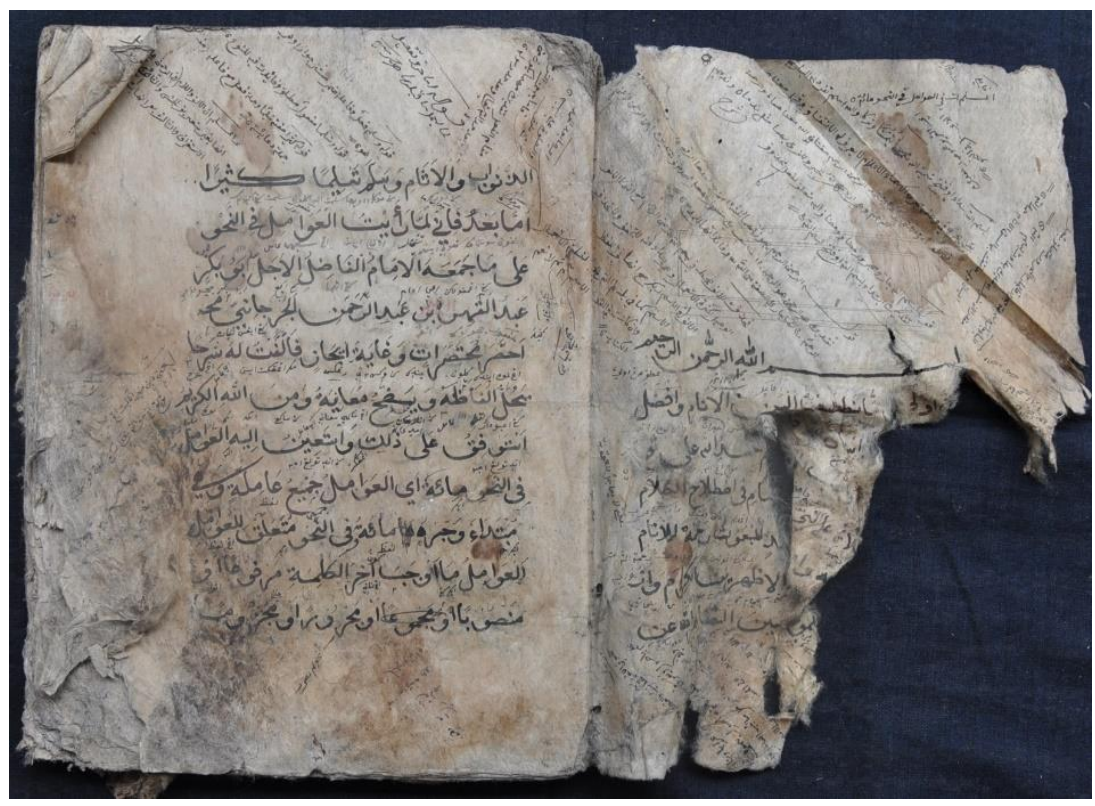

12037 GPRB UKL 372012 HLM 2,3 Img3197 


\begin{tabular}{|l|l|l|l|}
\hline $\begin{array}{l}\text { BLAS/SUM/16/IU/ } \\
11\end{array}$ & $\begin{array}{l}\text { KITAB AL- } \\
\text { MIȘBAH DAN } \\
\text { LAIN-LAIN }\end{array}$ & 0 & $\begin{array}{l}\text { Almu Tata Bahasa } \\
\text { Arab }\end{array}$ \\
\hline $\begin{array}{l}\text { PJG.SGG/SUAD/8 } \\
6 / 2012\end{array}$ & Arab & Arab dan Jawa & Prosa \\
\hline 238 hlm. & 5 s.d.13 baris/hlm. & $28 \times 20$ & Kertas Daluwang \\
\hline Nyai Su'adah & \\
\hline \multicolumn{2}{|l}{ Pajung, Sigang, Batu Putih } \\
\hline
\end{tabular}

Naskah berisi tiga teks. Teks pertama bernama Al Miṣbah menjelaskan ilmu nahwu dan isim nakirah, makrifat, istisna', macam-macam damir, sifat, dan ataf. Teks kedua bernama Qawa'idul I'rab disusun oleh Khalid bin Andullah al Azhari yang menjelaskan tentang fi'il isyarah. Teks ketiga, menjelaskan tentang Mutaqad lima puluh dengan bahasa Jawa, salat, bersuci, puasa, dan jual beli.

Naskah ini milik Nyai Su'adah dari KH Abdul Karim. Kondisi naskah cukup baik. Pada bagian awal teks berlubang.

\begin{tabular}{|l|l|l|l|}
\hline $\begin{array}{l}\text { BLAS/SUM/16/IU/ } \\
12\end{array}$ & $\begin{array}{l}\text { KITAB NAḤWU } \\
\text { DAN MANṬIQ }\end{array}$ & $\mathbf{0}$ & $\begin{array}{l}\text { Ilmu Tata Bahasa } \\
\text { Arab }\end{array}$ \\
\hline $\begin{array}{l}\text { PJG.SGG/SUAD/9 } \\
0 / 2012\end{array}$ & Arab & Arab & Prosa \\
\hline 164 hlm. & 13 baris/hlm. & $29 x 19$ & Kertas Daluwang \\
\hline Ny Su'ada & \\
\hline Pajung, Sigang, Batu Putih
\end{tabular}

Naskah ini berisi empat teks, teks pertama ditulis oleh Abdus Shorif, selesai penulisan hari Senin 25 Ramadan setelah isya. Teks ini menjelaskan awamil nạ̣wu menurut Syaikh Abi Abdul Ghafir Muhammad al Jurjani. Teks kedua bernama Mar'atun selesai penulisan hari Jumat setelah zuhur tanggal 14 Safar, teks ini menjelaskan tentang ilmu mantiq. Teks ketiga, memilik tiga bahasan yaitu bahwa manusia mempunyai kekuatan yang disebut zihnun, materi kedua me-nisbatkan sesuatu melalui ijab salab, bahasan ketiga menjelaskan tasawwur dan tasdiq dengan jalan nadar dan istidlal. Isi kelima menjelaskan perbedaan antara manusia dan hewan, isi keenam menjelaskan sesungguhnya para ulama menamakan tasawwur daruriyah al martabat dan seterusnya. Teks keempat, ditulis selesai pada malam Jumat yang menjelaskan ilmu balagah, ma'ani, badi'dan bayan.

Naskah ini milik dari Ny Su'ada dari KH Abd Karim. Kondisi naskah masih baik dan dapat dibaca. 


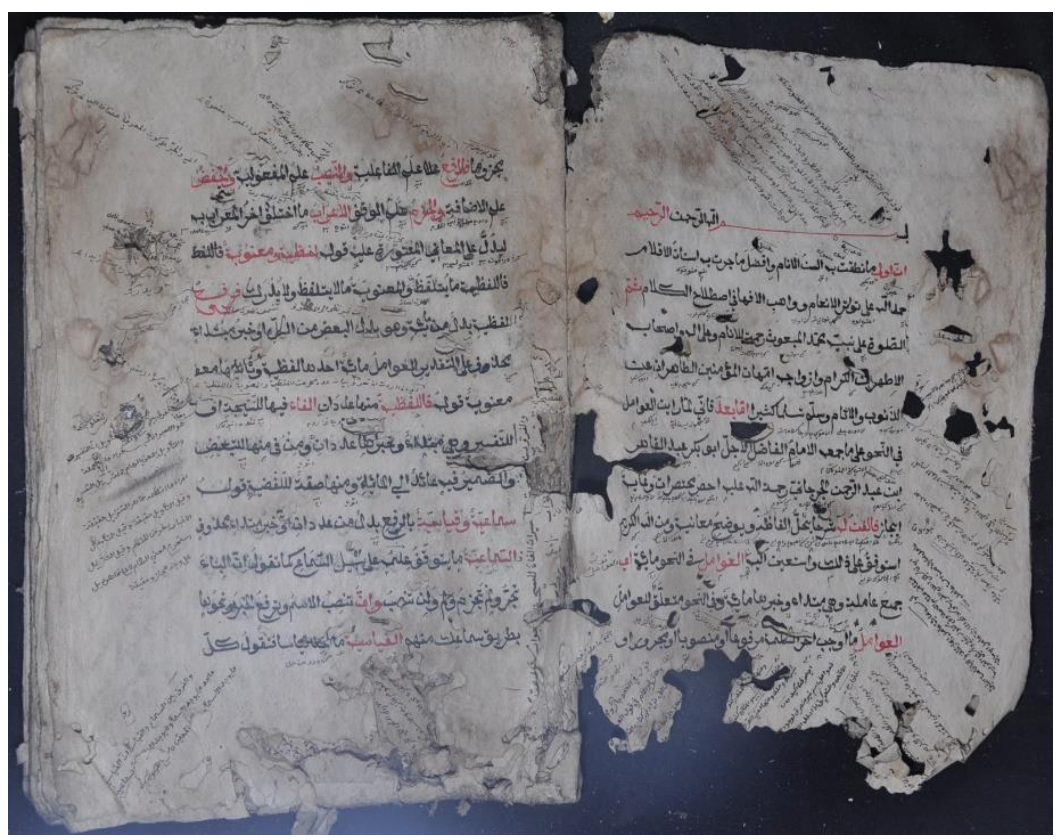

12091 PJGSGG SUAD 902012 HLM 1,2 Img7358 


\begin{tabular}{|l|l|l|l|}
\hline $\begin{array}{l}\text { BLAS/SUM/16/IU/ } \\
13\end{array}$ & KITAB NAHWU & 0 & $\begin{array}{l}\text { Armu Tata Bahasa } \\
\text { Arab }\end{array}$ \\
\hline $\begin{array}{l}\text { PJG.SGG/AMIN/9 } \\
1 / 2012\end{array}$ & Arab & Arab & Prosa \\
\hline 262 hlm. & 5 s.d. 17 baris/hlm. & $32 \times 19$ & Kertas Daluwang \\
\hline K.H. Amin & \\
\hline Pajung, Sigang, Batu Putih
\end{tabular}

Naskah ini berisi empat teks. Teks pertama menjelaskan tentang fi'il mabni ma'lum dan mabni majhul dalam ilmu saraf. Teks kedua Awamilu an Nabawi yang menjelaskan tentang hurf dalam ilmu nạwu. Teks ketiga, bernama kitab Damir yang menjelaskan tentang kedudukan damirdalam ilmu nahwu. Teks keempat bernama al Jurumiyah yang menjelaskan tentang ilmu nạhwu.

Naskah ini milik Kh Amin dari KH Saifudin. Kondisi naskah cukup baik.

\begin{tabular}{|l|l|l|l|}
\hline $\begin{array}{l}\text { BLAS/SUM/16/IU/ } \\
14\end{array}$ & $\begin{array}{l}\text { KITAB AL- } \\
\text { AWĀMIL }\end{array}$ & 0 & $\begin{array}{l}\text { Ilmu Tata Bahasa } \\
\text { Arab }\end{array}$ \\
\hline $\begin{array}{l}\text { BTLN/SNTN/105/ } \\
2012\end{array}$ & Arab dan Jawa & Arab dan Jawa & Prosa \\
\hline $180 \mathrm{hlm}$. & 7 baris/hlm. & $26.5 \times 18$ & Kertas Daluwang \\
\hline Nyai Sunniyat un Nadhifah \\
\hline \multicolumn{2}{|l}{ Bantilan Batu Putih } \\
\hline
\end{tabular}

Naskah ini berisi dua teks. Teks pertama menjelaskan tentang ilmu nahwu mulai dari awamil. Teks kedua ().

Naskah Nyai Sunniyatun Nadhifah dari Nyai Mariyatun. Kondisi naskah mulai rusak, teks masih terbaca. 


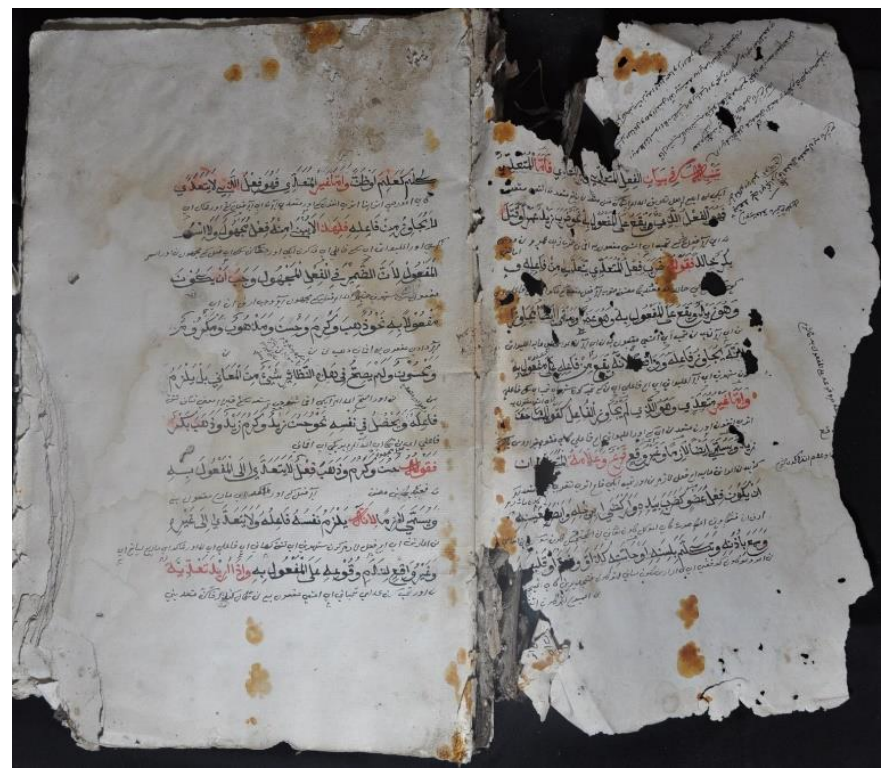

12092 PJGSGG AMIN 912012 HLM 2,3 Img9130.jpg

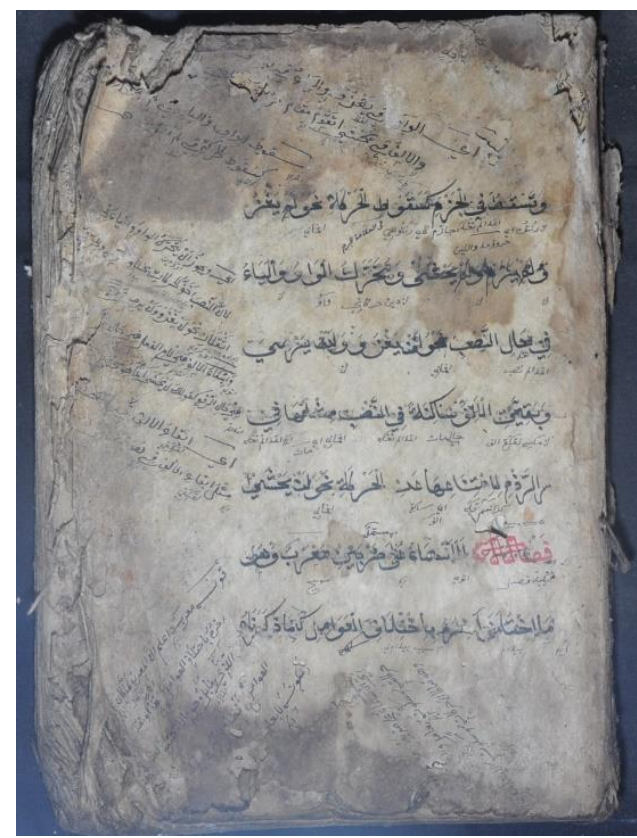

12106 BTLN SNTN 1052012 HLM 1 Img9773 


\begin{tabular}{|l|l|l|l|}
\hline $\begin{array}{l}\text { BLAS/SUM/16/IU/ } \\
15\end{array}$ & $\begin{array}{l}\text { KITAB } \\
\text { QAWAIDU L- } \\
\text { I'RAB }\end{array}$ & 0 & $\begin{array}{l}\text { Ilmu Tata Bahasa } \\
\text { Arab }\end{array}$ \\
\hline $\begin{array}{l}\text { JNGR/SUDFD/126 } \\
/ 2012\end{array}$ & Arab & Arab & Prosa \\
\hline 118 hlm. & 7 baris/hlm. & $21 \times 14.5$ & Kertas Daluwang \\
\hline Kiai Su'udi Fadhal & \multicolumn{2}{|l}{} \\
\hline Jenangger, Batang-batang
\end{tabular}

Teks naskah ini bernama Qawa'idul I'rab menjelaskan tata cara meng-i'rab suatu kalimat dalam bahasa Arab.

Naskah ini dimiliki oleh K Su'udi Fadlal dari Rosyidah dari K Irsyad dari KH Hadi dari Kamsah dari K Biramah. Naskah dalam kondisi baik.

\begin{tabular}{|l|l|l|l|}
\hline $\begin{array}{l}\text { BLAS/SUM/16/IU/ } \\
16\end{array}$ & $\begin{array}{l}\text { KITAB AL- } \\
\text { AWĀMIL, } \\
\text { JURUMIYAH }\end{array}$ & 0 & $\begin{array}{l}\text { Ilmu Tata Bahasa } \\
\text { Arab }\end{array}$ \\
\hline $\begin{array}{l}\text { JNGR/SUDFD/128 } \\
/ 2012\end{array}$ & Arab & Arab & Prosa \\
\hline 88 hlm. & $3,5,13$ baris/hlm. & $26 \times 18$ & Kertas Daluwang \\
\hline Kiai Su'udi Fadhal & & \\
\hline Jenangger, Batang-batang
\end{tabular}

Naskah ini berisi 3 teks, teks pertama bernama Kitab Awāmil, menjelaskan awämil dalam ilmu nahwu, teks kedua bernama Kitab Jurumiyah yang menjelaskan tentang ilmu nahwu, teks ketiga ditulis dengan aksara Arab bahasa Jawa, menjelaskan tentang isim damir.

Naskah ini dimiliki oleh K Su'udi Fadlal dari Rosyidah dari K Irsyad dari KH Hadi dari Kamsah dari K Biramah. Naskah dalam kondisi baik. 


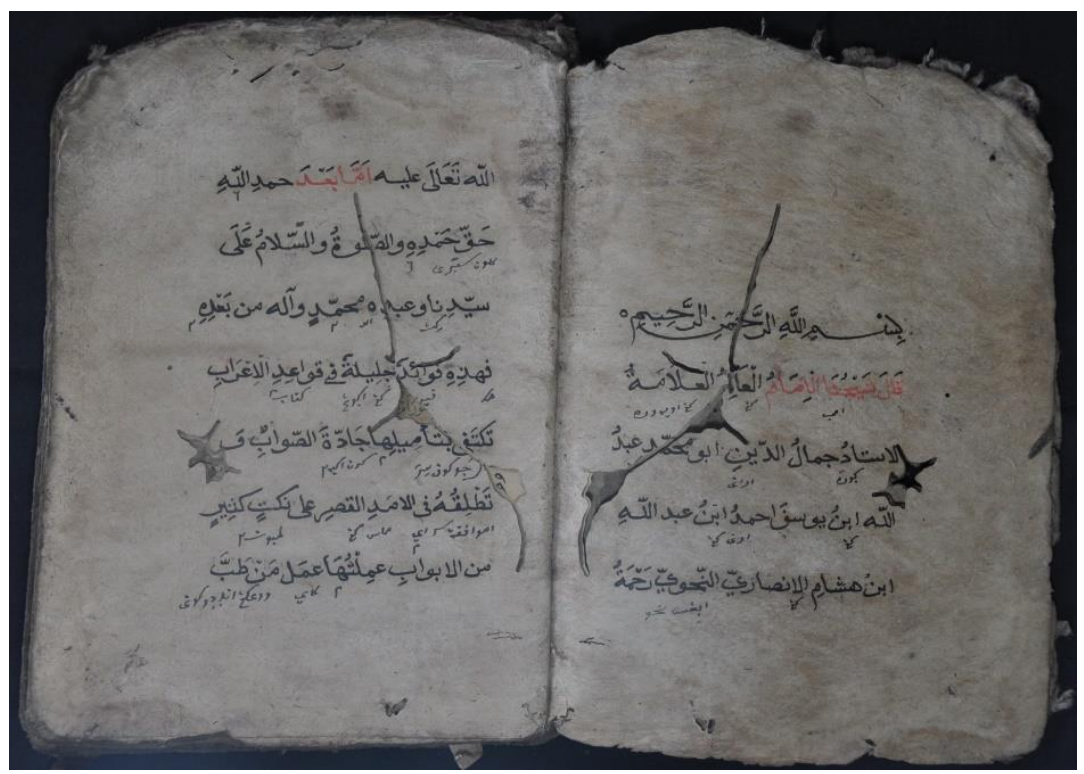

12127 JNGR SUDFD 1262012 HLM 1,2 Img10736

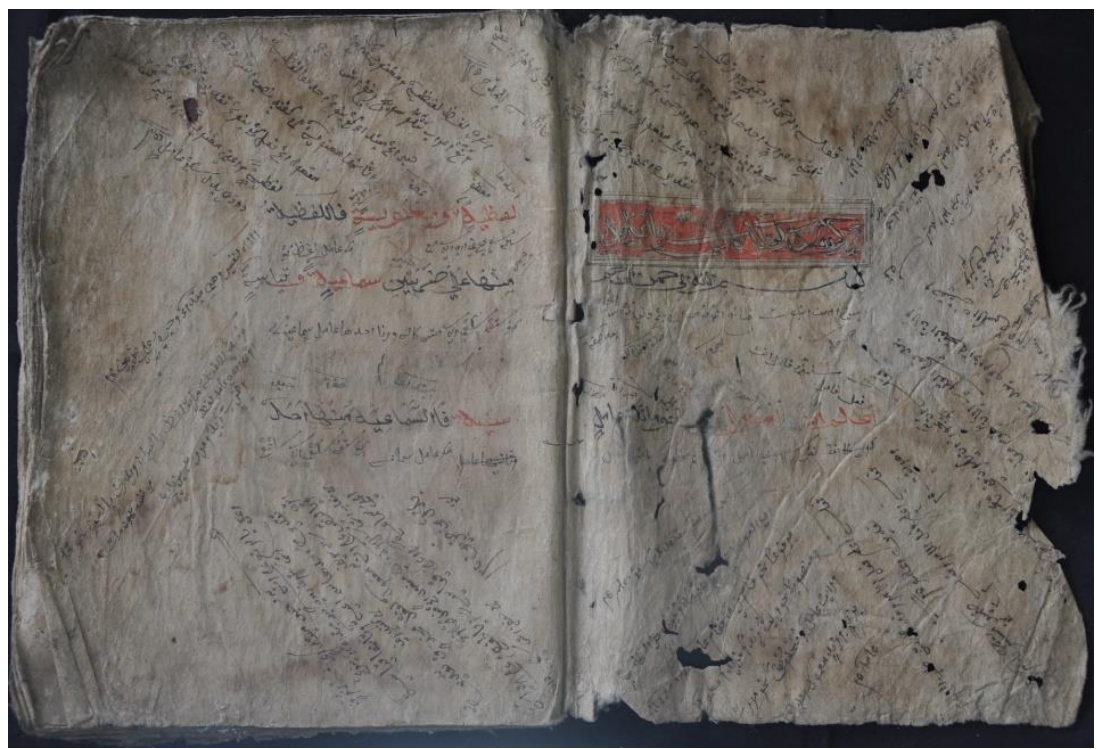

12129 JNGR SUDFHD128 2012 HLM 1,2 Img10820 


\begin{tabular}{|l|l|l|l|}
\hline $\begin{array}{l}\text { BLAS/SUM/16/IU/ } \\
17\end{array}$ & $\begin{array}{l}\text { KITAB DQ̄MIR } \\
\text { DAN KITAB } \\
\text { JURUMIYAH }\end{array}$ & 0 & $\begin{array}{l}\text { Ilmu Tata Bahasa } \\
\text { Arab }\end{array}$ \\
\hline $\begin{array}{l}\text { PJGSGG/HSM/155 } \\
\text { /2012 }\end{array}$ & Arab & Arab & Prosa \\
\hline 74 hlm. & 3 baris/hlm. & $27 \times 19$ & Kertas Daluwang \\
\hline K.H. Hasim & \\
\hline Pajung, Sergang, Batu Putih, Sumenep & \\
\hline
\end{tabular}

Teks pertama menjelaskan tentang damir muttasil dan damir munfasil, teks kedua bernama Kitab Jurumiyah menjelaskan tentang kalam atau kalimat kata yang berfaidah dan lebih dari satu. Kalam ada tiga, isim, fi'il, dan hurf.

Naskah ini dimiliki oleh KH Hasim dari KH Azhari. Kondisi naskah tergolong cukup baik.

\begin{tabular}{|l|l|l|l|}
\hline $\begin{array}{l}\text { BLAS/SUM/16/IU/ } \\
18\end{array}$ & $\begin{array}{l}\text { KITAB AL- } \\
\text { AWĀMIL }\end{array}$ & 0 & $\begin{array}{l}\text { Ilmu Tata Bahasa } \\
\text { Arab }\end{array}$ \\
\hline $\begin{array}{l}\text { PJGSGG/MWYH/1 } \\
64 / 2012\end{array}$ & Arab & Arab & Prosa \\
\hline & 3 baris/hlm. & $30.5 \times 22$ & Kertas Daluwang \\
\hline Nyai Mu'awiyah & \\
\hline \multicolumn{2}{|l}{ Pajung ,Sergang, Batu Putih, Sumenep } & \\
\hline
\end{tabular}

Teks bernama $\mathrm{Al}$ awamil, menjelaskan tentang Ilmu nahwu.

Naskah ini dimiliki oleh Nyai Mu'awiyah dari Nyai Dzuriyah. Kondisi naskah tergolong cukup baik. 


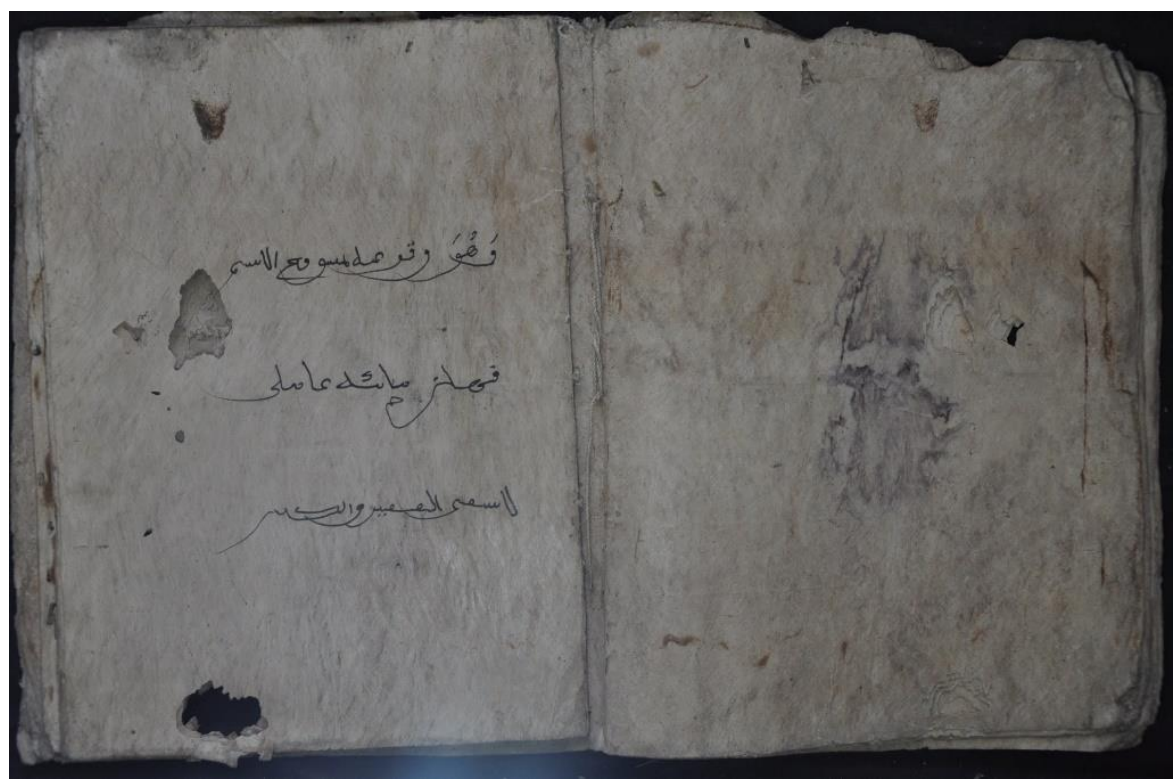

12156 PJGSGG HSM 1552012 HLM 1 Img12819

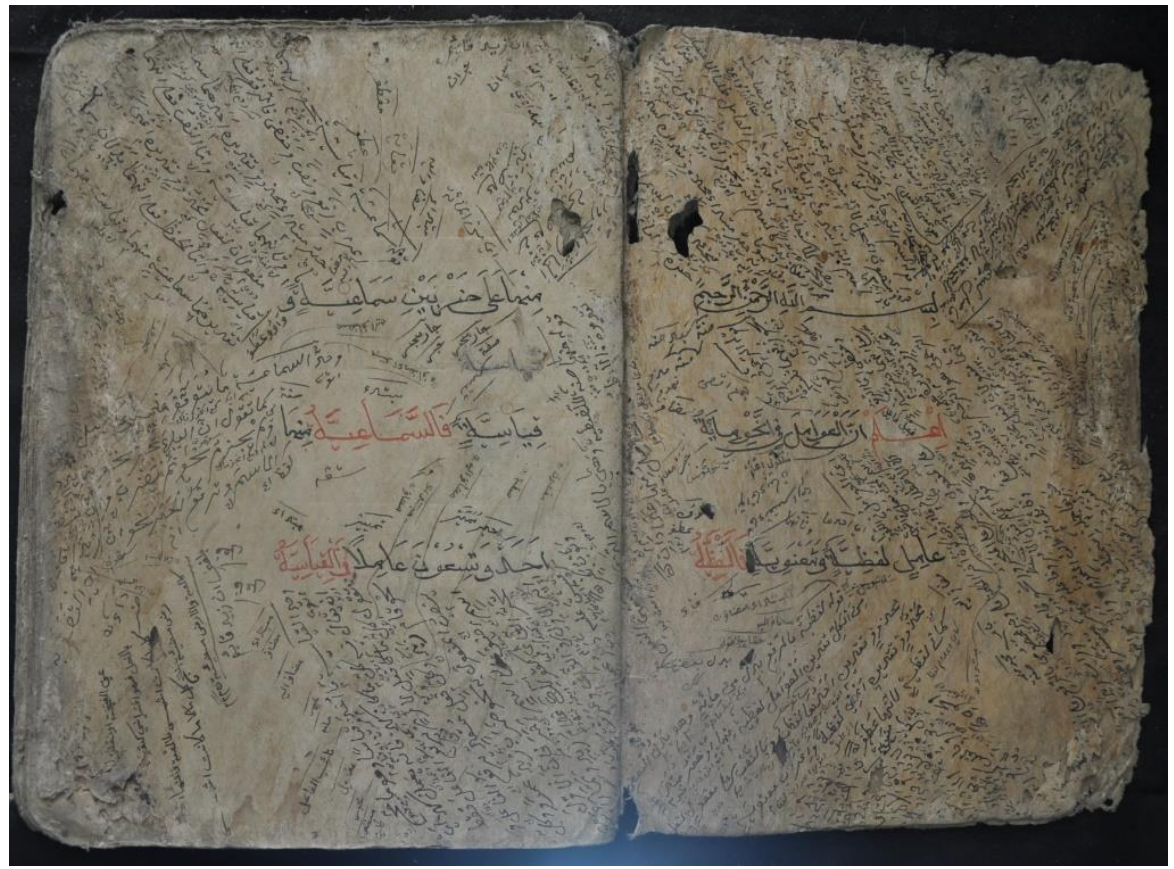

12165 PJGSGG MWYH 1642012 HLM 1,2 Img13086 


\begin{tabular}{|l|l|l|l|}
\hline $\begin{array}{l}\text { BLAS/SUM/16/IU/ } \\
19\end{array}$ & $\begin{array}{l}\text { KITAB } \\
\text { BALAGAH }\end{array}$ & 0 & $\begin{array}{l}\text { Ilmu Tata Bahasa } \\
\text { Arab }\end{array}$ \\
\hline KBA 1 & Arab & Arab & Prosa \\
\hline 6 hlm. & $21 \times 16.5$ & Kertas () \\
\hline \multicolumn{2}{|l|}{ Mushala Kebon Agung } & \\
\hline \multicolumn{2}{|l|}{ Sumenep }
\end{tabular}

Naskah berisi sastra Arab. Di beberapa halaman terdapat beberapa catatan seperti doa tarawih, hadis. Di kolofon tertulis 1333 H/1915. Naskah asalnya disimpan di musala Kebon Agung Sumenep.

Naskah ini milik Mushala Kebon Agung Sumenep, sekarang disimpan oleh Drs. H. Anashom dosen di UIN Walisongo Semarang. Kondisi naskah cukup baik.

\begin{tabular}{|l|l|l|l|}
\hline $\begin{array}{l}\text { BLAS/SUM/16/IU/ } \\
20\end{array}$ & $\begin{array}{l}\text { KITAB AL } \\
\text { JURUMIYAH }\end{array}$ & $\begin{array}{l}\text { Ilmu Tata Bahasa } \\
\text { Arab }\end{array}$ \\
\hline GPR 5 & Arab, Jawa Pegon & Arab, Arab pegon & prosa \\
\hline 80 hlm. & 5 baris/hlm. & $12 \times 8.5$ & Kertas () \\
\hline Kiai Masduki & \\
\hline \multicolumn{2}{|l|}{ Gapura Barat, Gapura, Sumenep } \\
\hline
\end{tabular}

Naskah menjelaskan tentang tata bahasa Arab. Naskah selesai ditulis pada hari senin ba'da subuh bulan Safar tanggal 27.

Naskah ini dikoleksi oleh Kiai Masduki Gapura, Kabupaten Sumenep. Kondisi naskah masih bisa dibaca dan baik meski ada beberapa halaman yang berlubang dimakan ngengat. 


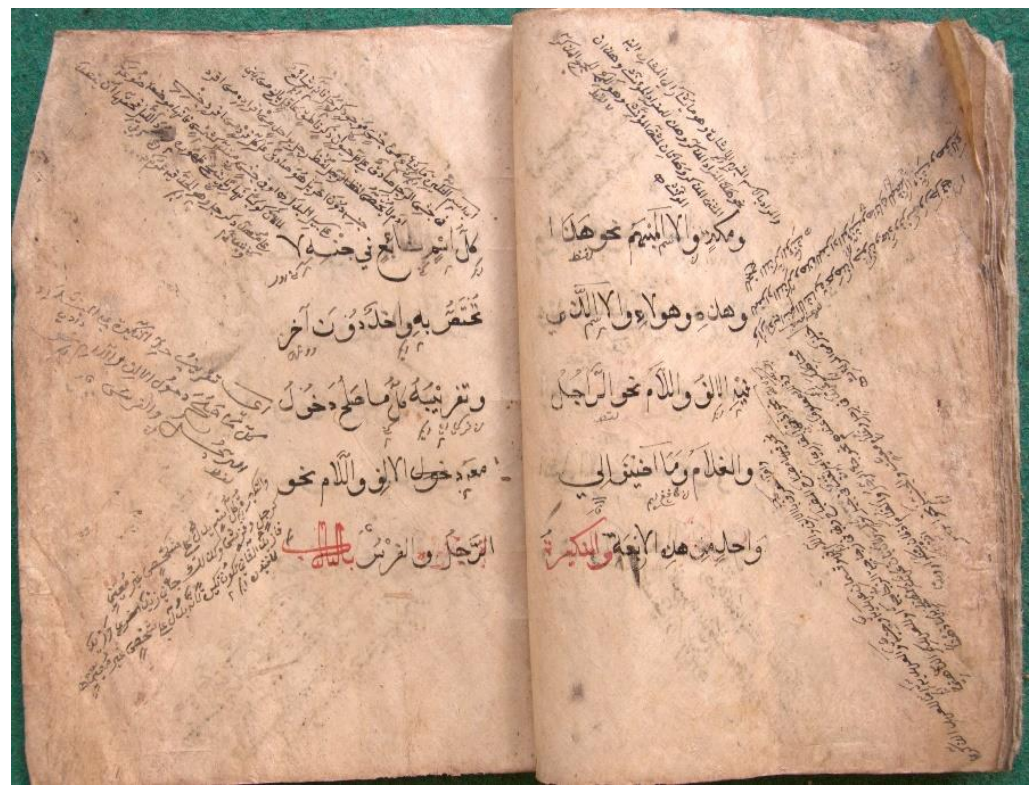

1005 GPR 05_DSC0079.3 


\begin{tabular}{|l|l|l|l|}
\hline $\begin{array}{l}\text { BLAS/SUM/16/IU/ } \\
21\end{array}$ & $\begin{array}{l}\text { KITAB NAḤWU } \\
\text { DAN MANṬIQ }\end{array}$ & $\mathbf{0}$ & $\begin{array}{l}\text { Ilmu Tata Bahasa } \\
\text { Arab dan ilmu } \\
\text { Mantiq }\end{array}$ \\
\hline $\begin{array}{l}\text { GPRB/UKL/38/201 } \\
2\end{array}$ & Arab & Arab & Prosa \\
\hline $128 \mathrm{hlm}$. & 5 s.d 11 baris/hlm. & $24 \times 18$ & Kertas Daluwang \\
\hline Nyai Ummu Kulsum \\
\hline \multicolumn{2}{|l|}{ Talesek, Gapura Tengah, Gapura } \\
\hline
\end{tabular}

Naskah berisi dua teks tentang ilmu nạ̣wu dan manțiq (logika berpikir).

Naskah ini milik Nyai Ummi Kulsum dari Nyai Aisyah dari K Abdul Aziz.

\begin{tabular}{|l|l|l|l|}
\hline $\begin{array}{l}\text { BLAS/SUM/16/IU/ } \\
22\end{array}$ & $\begin{array}{l}\text { KITAB AL- } \\
\text { MIȘBAH, } \\
\text { MA'RIFATUL } \\
\text { ISLAM WA } \\
\text { IMAN, }\end{array}$ & 0 & $\begin{array}{l}\text { Ilmu Tata Bahasa } \\
\text { Arab dan Ma'rifat }\end{array}$ \\
\hline $\begin{array}{l}\text { SGG/DRYH/50/20 } \\
12\end{array}$ & Arab & Arab & Prosa \\
\hline $232 \mathrm{hlm}$. & 5 baris/hlm. & $28.5 \times 20$ & Kertas Daluwang \\
\hline Nyai Dzurriyah & & \\
\hline Sergang, Batu Putih & \\
\hline
\end{tabular}

Naskah ini berisi tiga teks. Teks pertama berjudul Al-Miṣbah, teks kedua berjudul Ma'rifatul Iman, dan teks ketiga berjudul Ilmu Șaraf. Al-Misbah selesai ditulis pada hari Senin sebelum zuhur tanggal 18 Sya'ban tahun Hak.

Teks Al-Misbah menjelaskan tentang ilmu nahwu misalnya makna huruf bisa berarti laisa dan berarti isim dan fiil. Teks Ma'riftul Iman berisi makna Islam yaitu menegakkan perintah dan menjauhi larangan, sedangkan makna iman adalah membenarkan dengan hati dari segala yang disampaikan Allah. Teks ketiga berisi ilmu saraf yang dimulai dari tatacara men-tasrif dan selanjutnya.

Naskah ini milik Nyai Dzurriyah. Kondisi naskah mulai rusak, teks masih terbaca. 


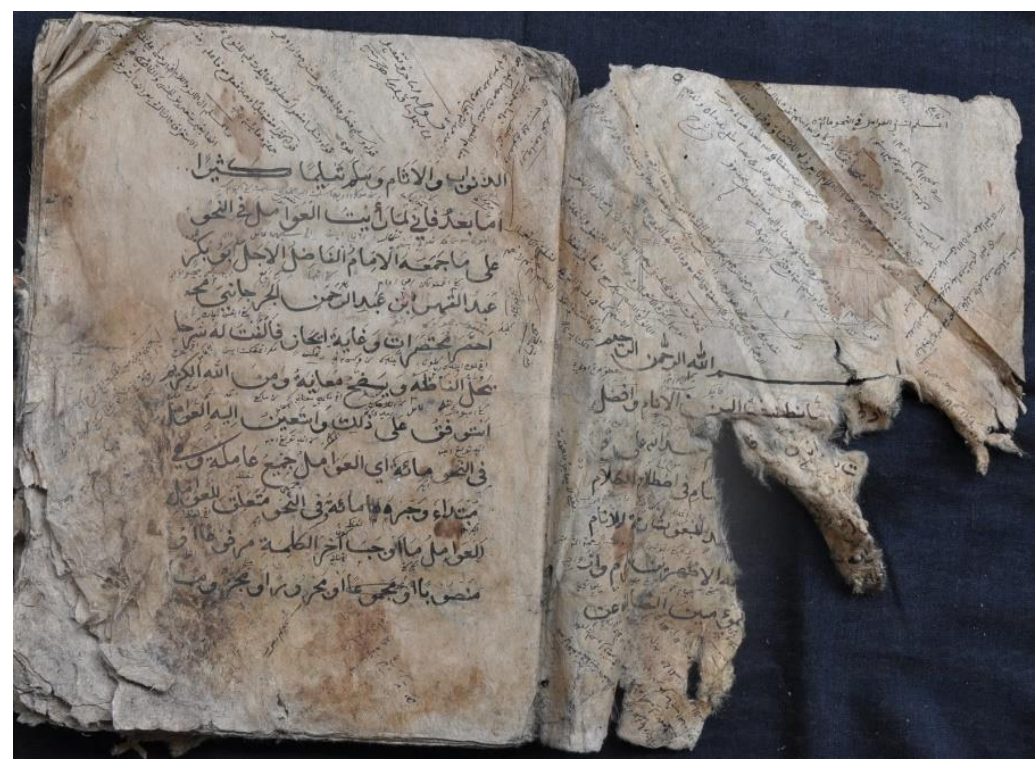

12038 GPRB UKL 382012 HLM 2,3 Img3224

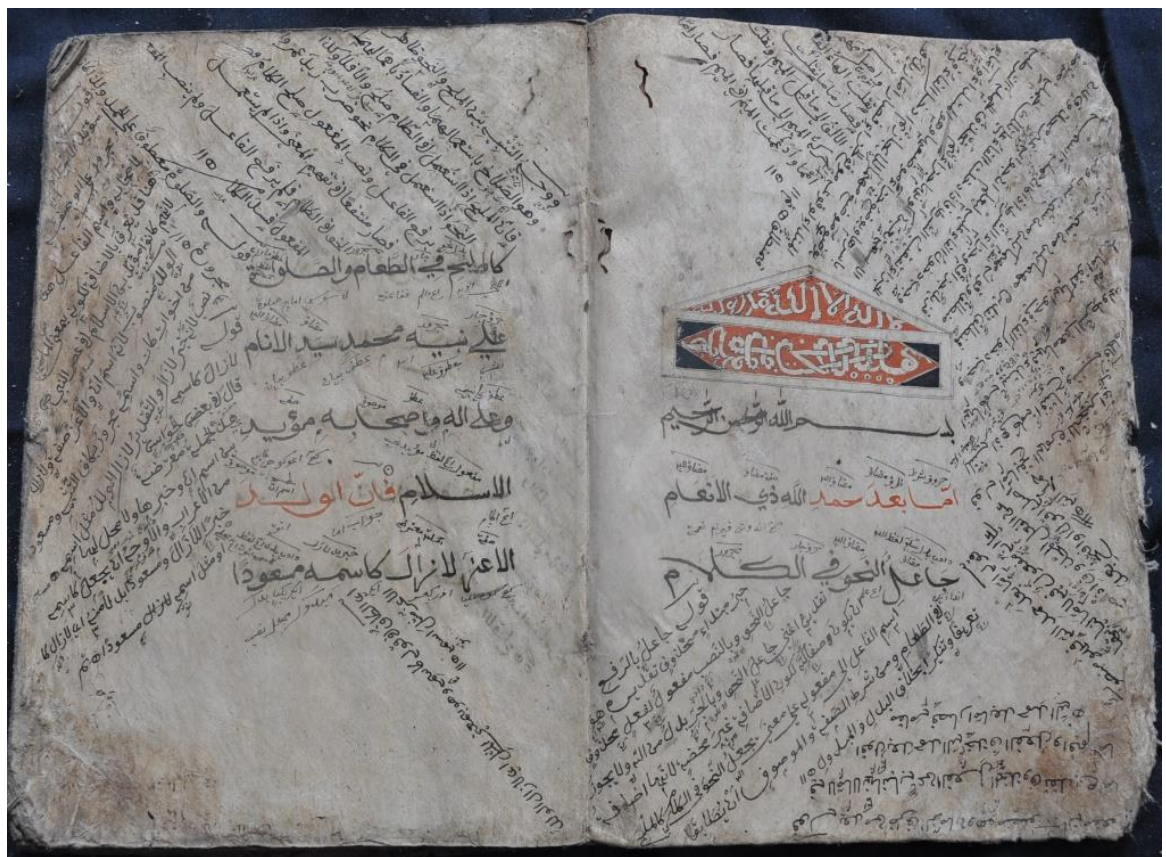

12050 SGG DRYH 502012 HLM 1,2 Img4914 


\begin{tabular}{|l|l|l|l|}
\hline $\begin{array}{l}\text { BLAS/SUM/16/IU/ } \\
23\end{array}$ & $\begin{array}{l}\text { KITAB NAHWU } \\
\text { DAN LAIN-LAIN }\end{array}$ & 0 & $\begin{array}{l}\text { Ilmu Tata Bahasa } \\
\text { Arab dan tasawuf }\end{array}$ \\
\hline GPT/MD/01/2012 & Arab & Arab & Prosa \\
\hline 168 hlm. & 3 s.d. 14 baris/hlm. & $22.5 \times 5.5$ & Kertas Daluwang \\
\hline Abd. Mufid & \\
\hline Gapura Sumenep
\end{tabular}

Naskah ini berisi delapan buah teks, teks pertama menjelaskan tentang ilmu nạhu, teks kedua dan ketiga menjelaskan doa, teks keempat tentang ilmu nahwu, teks kelima tentang tasawuf, teks keenam tentang Yasin Fadilah, teks ketujuh tentang ilmu fikih, dan teks kedelapan tentang ayat 15 .

Naskah ini dimiliki oleh Abd. Mufid dari K. Zarnaji dari KH Fadlol. Tahun dan tempat penyusunan, penulisan ulang, maupun pemrakarsa tidak dicantumkan. Naskah dalam kondisi baik dan bisa dibaca.

\begin{tabular}{|l|l|l|l|}
\hline $\begin{array}{l}\text { BLAS/SUM/16/IU/ } \\
24\end{array}$ & $\begin{array}{l}\text { KITAB } \\
\text { KHUTBAH }\end{array}$ & 0 & Islam umum \\
\hline GPR 41 & Arab & Arab & Prosa \\
\hline 68 hlm. & 8 baris/hlm. & 17 x11.5 & Kertas Eropa \\
\hline Kiai Zahidi Bisri & \\
\hline \multicolumn{2}{|l|}{ Dusun Pasar Pocok, Desa Paloklo'an, Gapura, Sumenep } \\
\hline
\end{tabular}

Naskah berisi tentang khutbah ied, khutbah haji, dan khutbah nikah.

Naskah berasal dari Kiai Zahidi Bisri dari Kiai Khudaifi dari Kiai Masyhuri. Kondisi naskah mulai rusak, teks masih terbaca. 


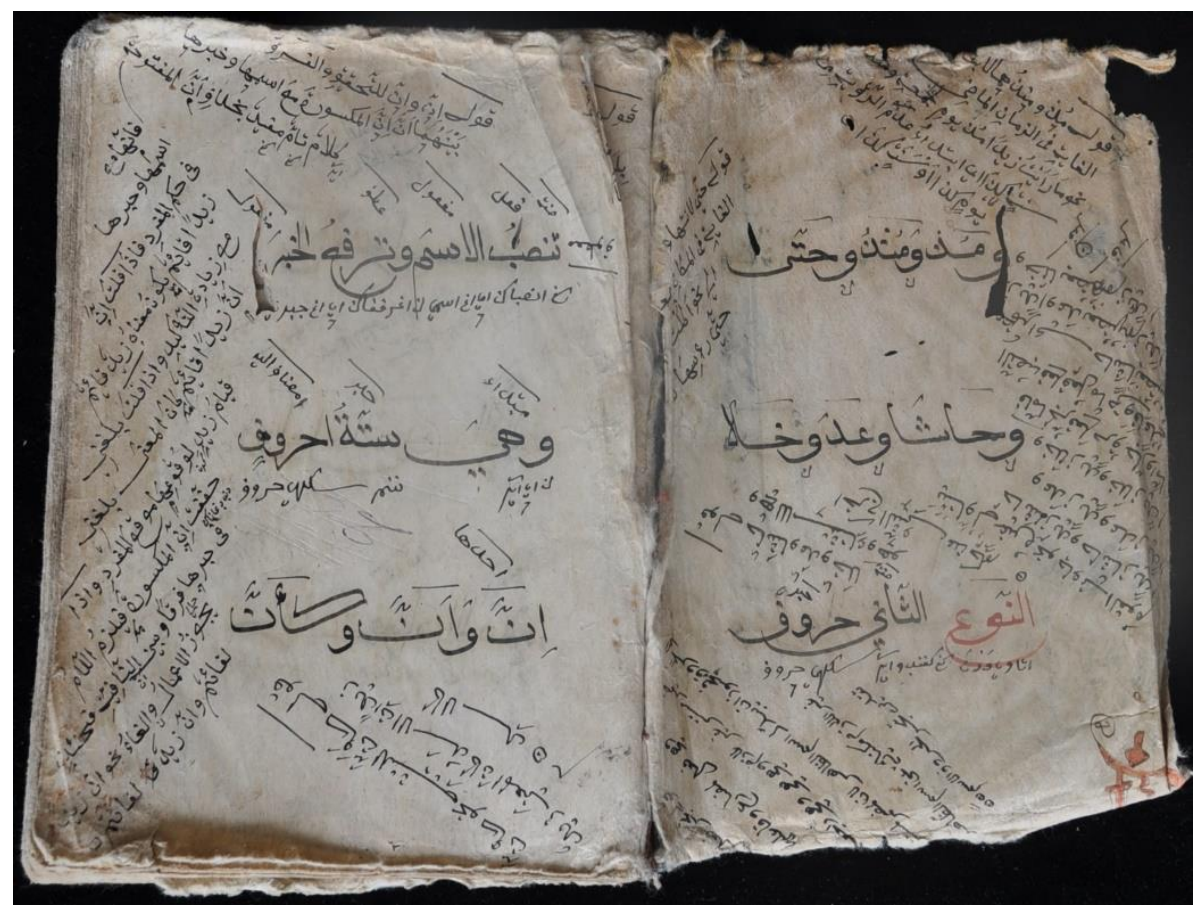

12001GPT MD 012012 HLM 2,3 Img1375

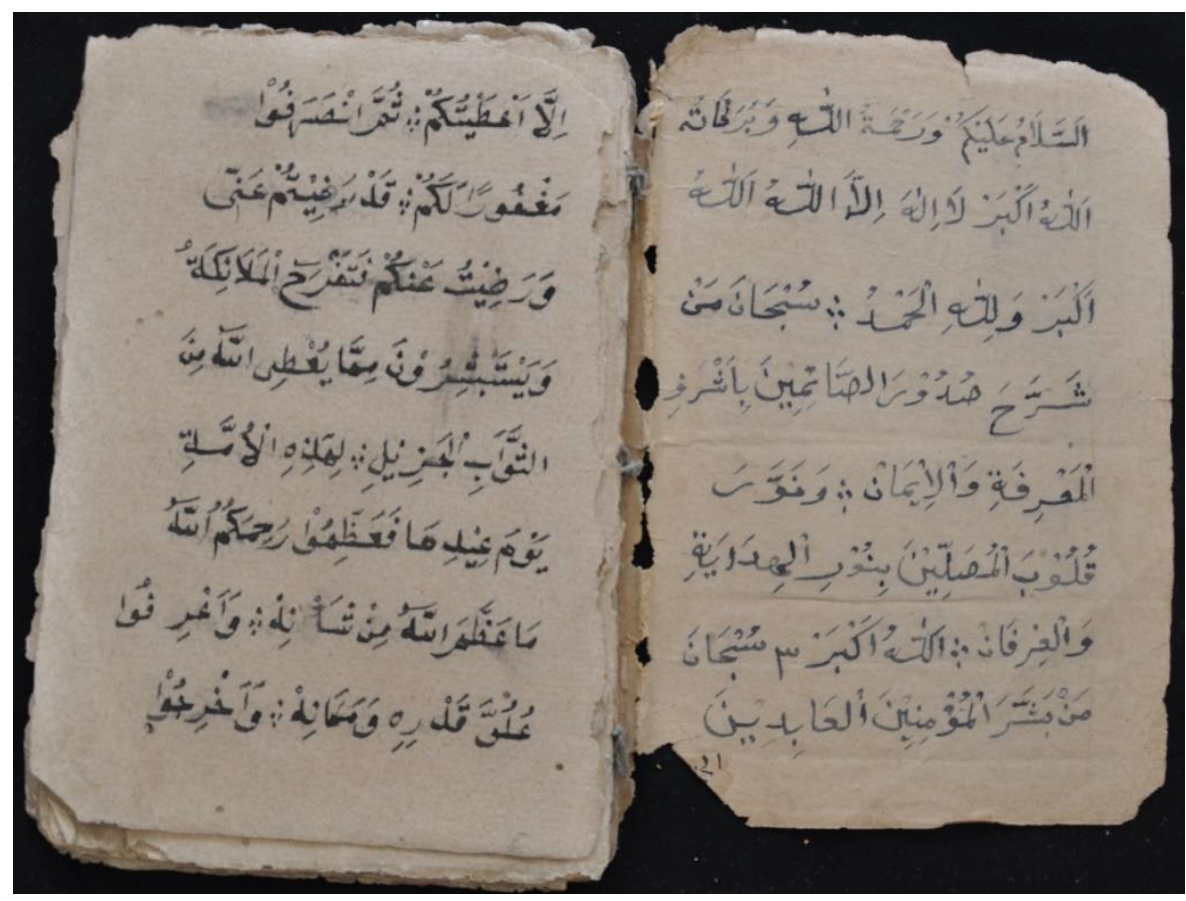

1127 GPR 41 HLM 1,2 DSC_0197 


\begin{tabular}{|l|l|l|l|}
\hline $\begin{array}{l}\text { BLAS/SUM/16/IU/ } \\
25\end{array}$ & $\begin{array}{l}\text { KITAB RUKUN } \\
\text { ISLAM }\end{array}$ & 0 & Islam umum \\
\hline BT-BT 4 & Arab, Jawa Pegon & Arab & Prosa \\
\hline $36 \mathrm{hlm}$. & 7 baris/hlm. & $28 \times 17.5$ & Kertas Daluwang \\
\hline Khasyieun & \\
\hline \multicolumn{2}{|l|}{ Dusun Laok Saba, Nyabakan Timur, Batang-Batang, Sumenep } \\
\hline
\end{tabular}

Naskah berisi tentang materi rukun Islam.

Naskah berasal dari Khosyieun dari Kiai Hasim dari Kiai Sowabi. Kondisi naskah tidak bersampul, dan teks ditulis menggunakan tinta hitam. Kondisi teks dalam keadaan baik dan tulisan masih bisa dibaca meskipun ada beberapa halaman yang hilang dan beberapa kertas dalam keadaan rusak.

\begin{tabular}{|l|l|l|l|}
\hline $\begin{array}{l}\text { BLAS/SUM/16/IU/ } \\
26\end{array}$ & $\begin{array}{l}\text { KITAB PRIMBON } \\
\text { TAHUN JAWA }\end{array}$ & 0 & Islam umum \\
\hline BT-BT 24 & Jawa & Arab & Prosa \\
\hline 68 hlm. & 13 baris/hlm. & $16 \times 10.5$ & Kertas Eropa \\
\hline Kiai Su'udi Fadhal \\
\hline \multicolumn{2}{|l}{ Dusun Nyabungan, Jenangger, Batang-Batang. } \\
\hline
\end{tabular}

Naskah ini berisi perincian tahun Jawa.

Naskah ini dimiliki oleh Kiai Su'udi Fadhal dari Kiai Irsyad dari Kiai Sodli dari Kiai Hadi. Tahun dan tempat penyusunan tidak disebutkan. Kondisi naskah rusak. Tinta menggunakan warna hitam. 


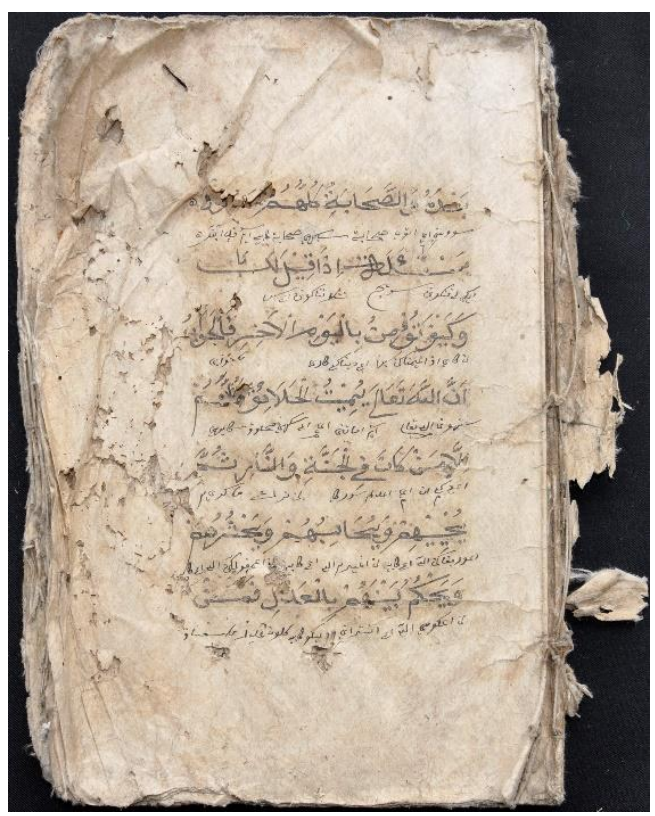

1134 BTBT 04 HLM 1_DSC0001

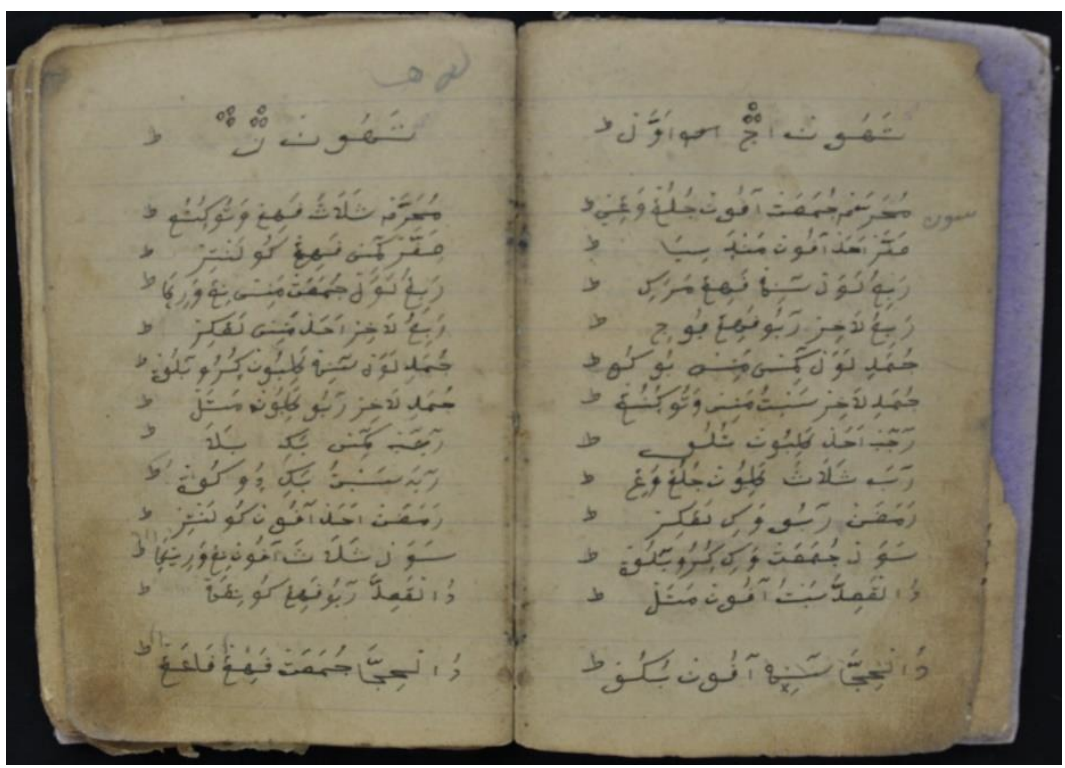

1154 BTBT 24 HLM 4,5 DSC_0004 


\begin{tabular}{|l|l|l|l|}
\hline $\begin{array}{l}\text { BLAS/SUM/16/IU/ } \\
27\end{array}$ & KITAB 0 & 0 & \\
\hline GPR 10 & Arab & Arab & Prosa \\
\hline 178 hlm. & 9 baris/hlm. & $31.5 \times 14.5$ & Kertas () \\
\hline Kiai Masduki & \\
\hline \multicolumn{2}{|l|}{ Gapura Barat, Gapura, Sumenep } \\
\hline
\end{tabular}

()

Naskah ini dikoleksi oleh Kiai Masduki Gapura, Kabupaten Sumenep. Naskah ini rusak tidak bisa dibaca.

\begin{tabular}{|l|l|l|l|}
\hline $\begin{array}{l}\text { BLAS/SUM/16/IU/ } \\
28\end{array}$ & KITAB 0 & 0 & \\
\hline $\begin{array}{l}\text { SGG/FTHR/55/201 } \\
2\end{array}$ & Arab & Arab & \\
\hline 40 hlm. & & $26 \times 17.5$ & Prosa \\
\hline Fathur & & \\
\hline Sergang, Batu Putih & & \\
\hline
\end{tabular}

()

Naskah milik Fathur dari KH Shiddiq. Kondisi naskah mulai rusak, teks masih terbaca. 


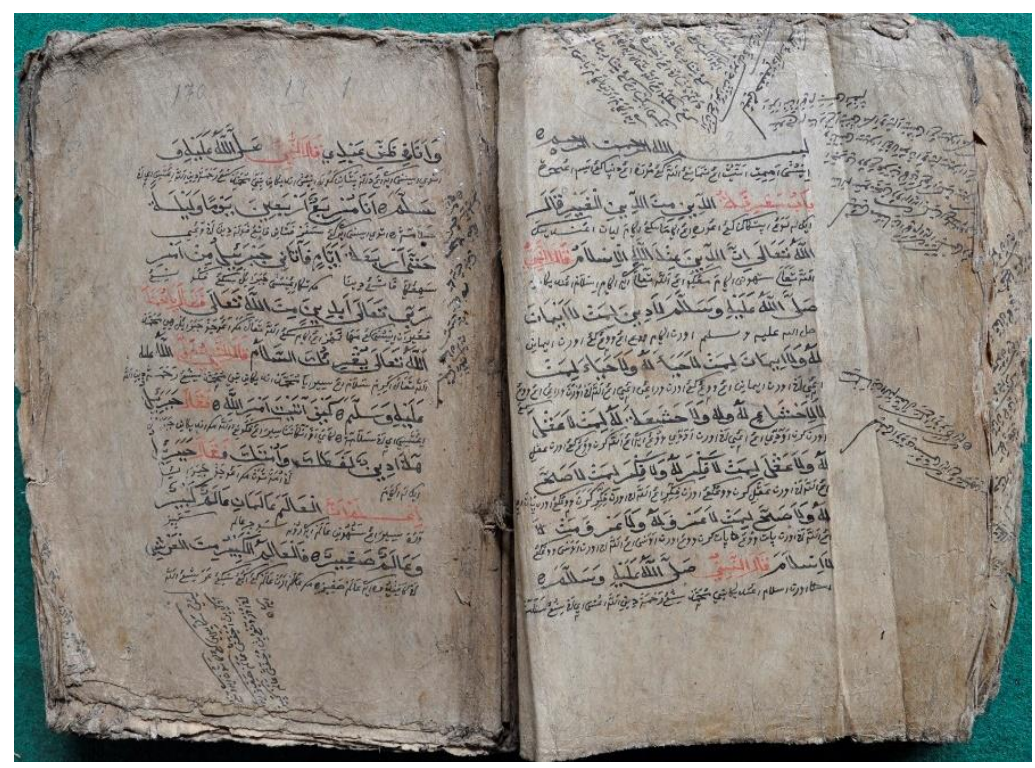

1010 GPR 10_DSC0011.2

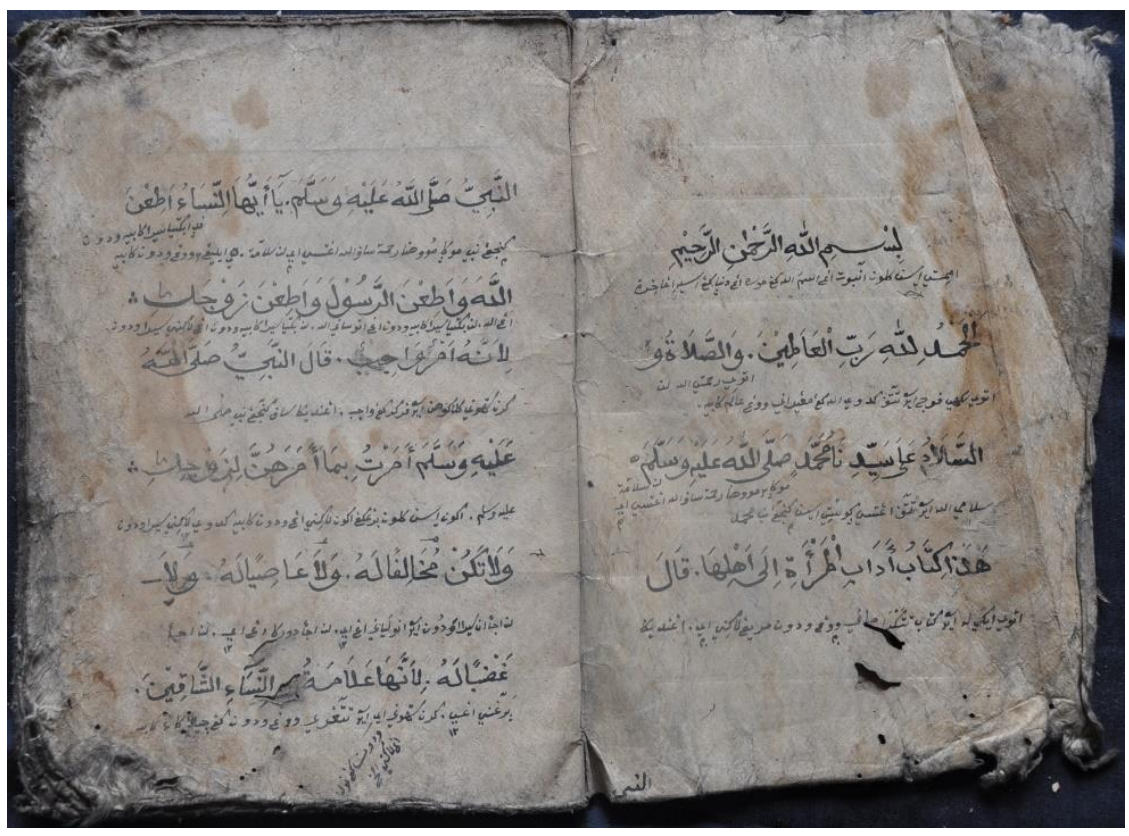

12056 SGG FTHR 552012 HLM 1,2 Img5235 


\section{AQ \\ Alquran dan Ilmu yang Berkaitan}

\begin{tabular}{|l|l|l|l|}
\hline $\begin{array}{l}\text { BLAS/SUM/16/AQ } \\
/ 1\end{array}$ & ALQURAN & 1 & Alquran \\
\hline $\begin{array}{l}\text { TMD.BT.BT/ALB/ } \\
13 / 2012\end{array}$ & Arab & Arab & Prosa \\
\hline $312 \mathrm{hlm}$. & 13 baris/hlm. & $26 \times 16.5$ & Kertas Daluwang \\
\hline Albar & \\
\hline \multicolumn{2}{|l}{ Tamendung, Batang-Batang }
\end{tabular}

Naskah ini berisi Mushaf Alquran dari surat Ali Imron sampai surat at-Tin.

Naskah ini tersimpan di rumah Albar dari Sya'ban. Kondisi naskah mulai rusak, teks masih terbaca.

\begin{tabular}{|l|l|l|l|}
\hline $\begin{array}{l}\text { BLAS/SUM/16/AQ } \\
/ 2\end{array}$ & ALQURAN & 1 & Alquran \\
\hline $\begin{array}{l}\text { GPRB/SMHS/21/2 } \\
012\end{array}$ & Arab & Arab & Prosa \\
\hline 544 hlm. & 15 baris/hlm. & $28 \times 19$ & Kertas Daluwang \\
\hline K.H. Samhadi Siraj & \multicolumn{2}{|l}{} \\
\hline Gapura Barat, Gapura
\end{tabular}

Naskah ini berisi Alquran.

Naskah ini berasal dari K.H. Samhadi Siraj, dari K.H.M. Siraj, dari K.H. Abdul Syakur. Kondisi naskah mulai rusak, teks masih terbaca. 


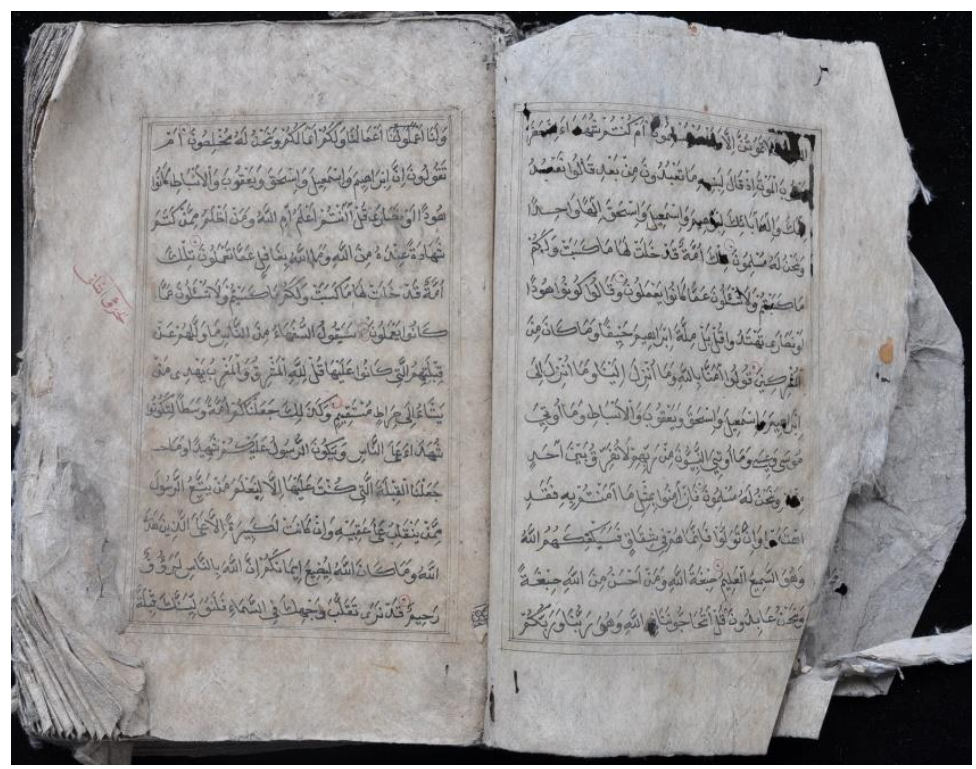

12013 TMDBTBT ALB 132012 HLM 5,6 Img0541

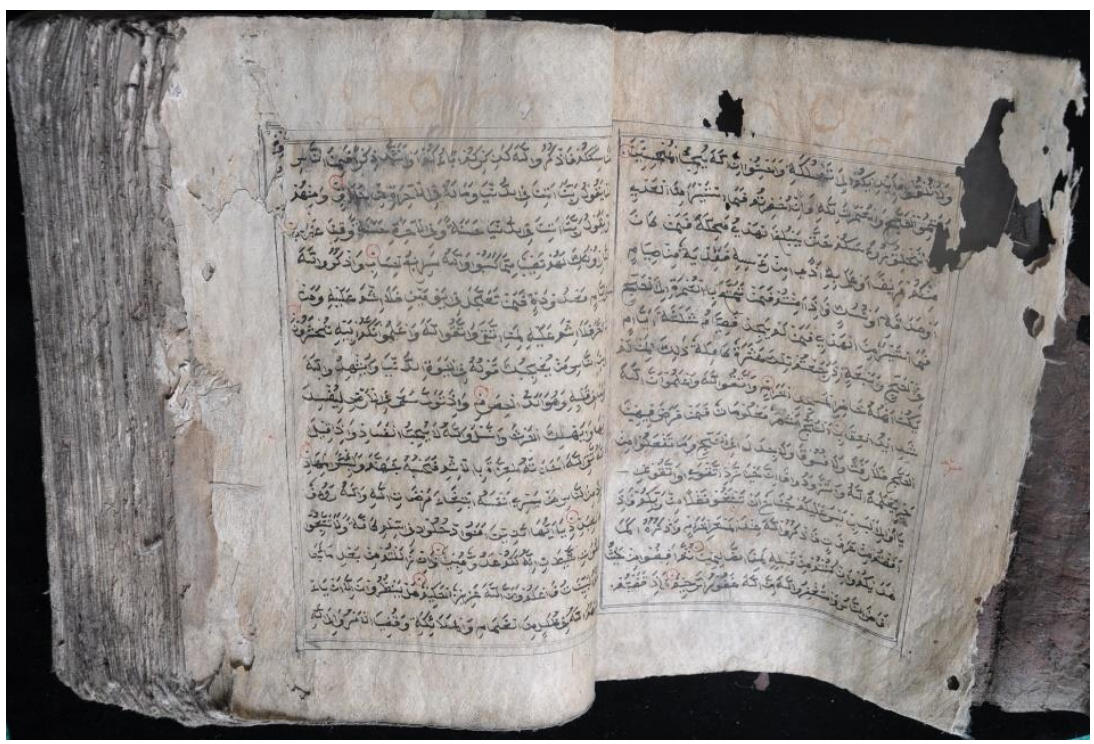

12021 GPRB SMHS 212012 HLM 5,6 Img1459 


\begin{tabular}{|l|l|l|l|}
\hline $\begin{array}{l}\text { BLAS/SUM/16/AQ } \\
\text { /3 }\end{array}$ & ALQURAN & 1 & Alquran \\
\hline $\begin{array}{l}\text { GPRB/SMHS/29/2 } \\
012\end{array}$ & Arab & Arab & Prosa \\
\hline 54 hlm. & 11 baris/hlm. & $19 x 15$ & Kertas Daluwang \\
\hline K.H. Samhadi Siraj & \\
\hline Gapura Barat, Gapura
\end{tabular}

Naskah ini berisi tentang ayat-ayat Alquran.

Naskah ini berasal dari K.H. Samhadi Siraj, dari K.H.M. Siraj, dari K.H. Abdul Syakur. Kondisi naskah mulai rusak, teks masih terbaca.

\begin{tabular}{|l|l|l|l|}
\hline $\begin{array}{l}\text { BLAS/SUM/16/AQ } \\
\text { (4 }\end{array}$ & ALQURAN & 1 & Alquran \\
\hline $\begin{array}{l}\text { BTLN/MRWN/66/ } \\
2012\end{array}$ & Arab & Arab & Prosa \\
\hline $130 \mathrm{hlm}$. & 15 baris/hlm. & $23 \times 17$ & Kertas Daluwang \\
\hline Marwan & & \\
\hline Bantilan, Batu Putih
\end{tabular}

Naskah ini berisi tentang Alquran dari Al-Baqāah hingga Al-A'raf.

Naskah ini milik Marwan dari Abdul Ghani. Kondisi naskah mulai rusak, teks masih terbaca. 


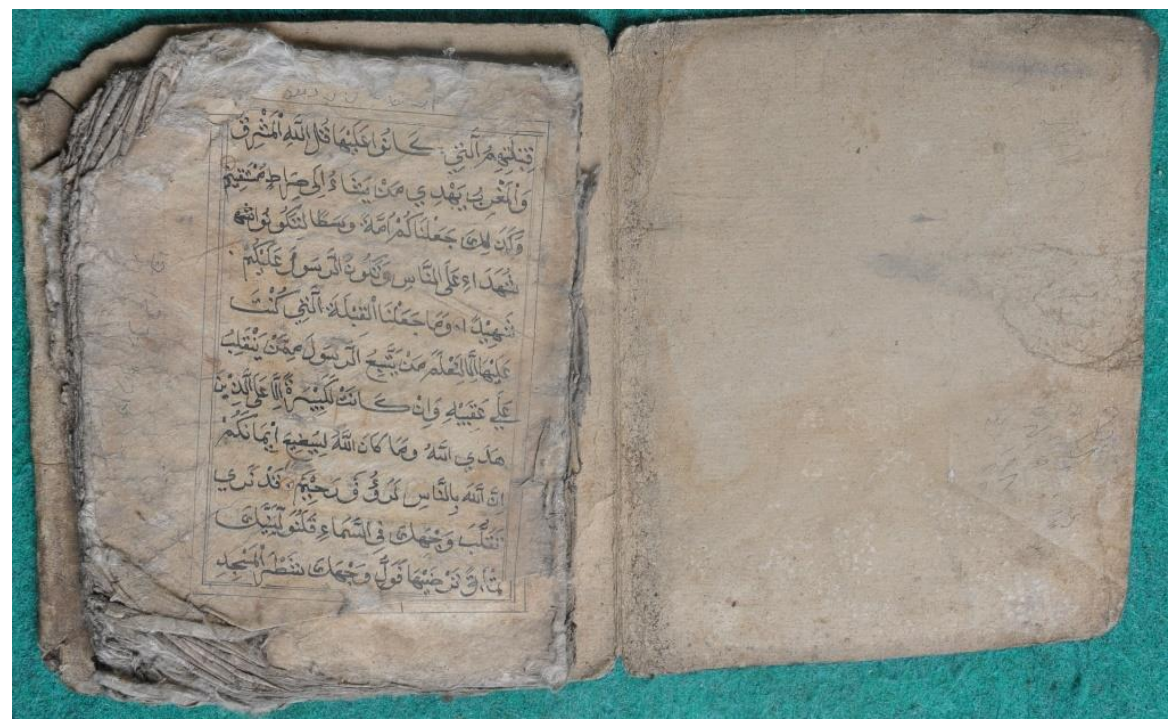

12029 GPRB SMHS 292012 HLM 1 Img2151

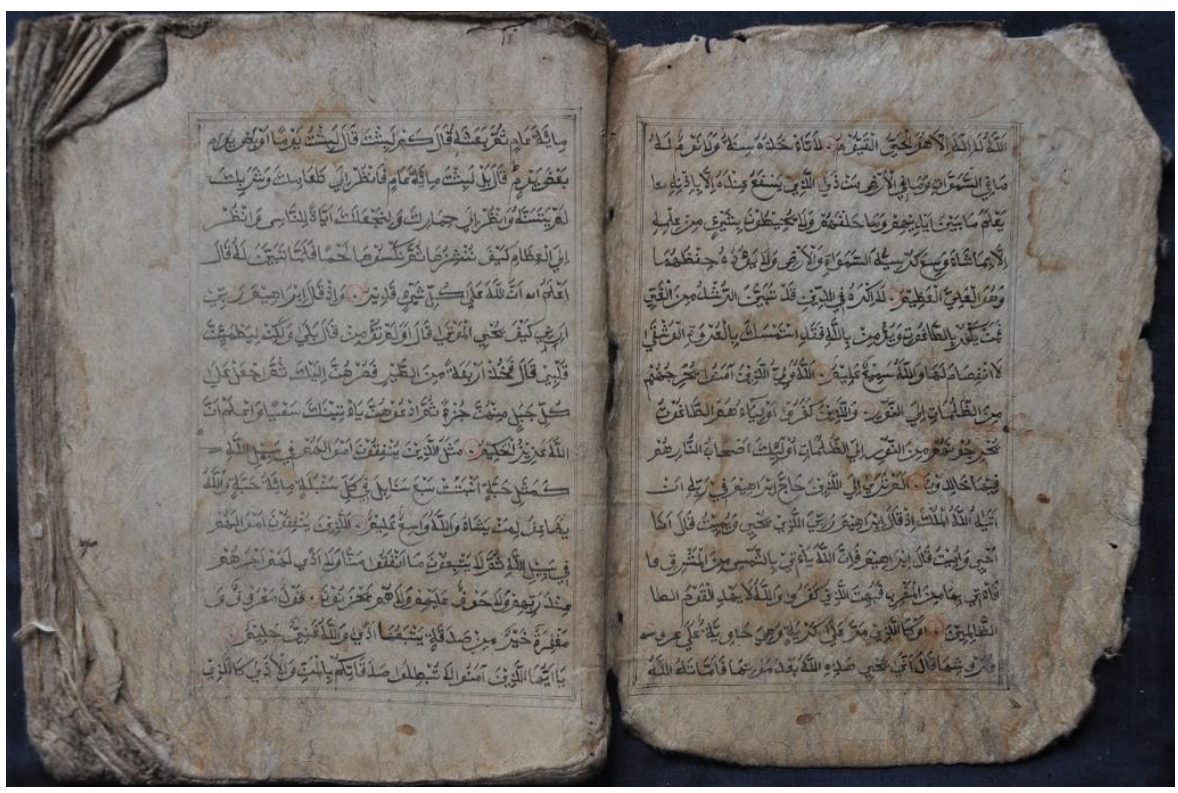

12067 BTLN MRWN 662012 HLM 2,3 Img5740 


\begin{tabular}{|l|l|l|l|}
\hline $\begin{array}{l}\text { BLAS/SUM/16/AQ } \\
\text { /5 }\end{array}$ & ALQURAN & 1 & Alquran \\
\hline $\begin{array}{l}\text { BTLN/JMW/96/20 } \\
12\end{array}$ & Arab & Arab & Prosa \\
\hline 486 hlm. & 15 baris/hlm. & $32 \times 21$ & Kertas Daluwang \\
\hline Jumawi & \multicolumn{2}{|l}{} \\
\hline Bantilan, Sergang, Batu Putih, Sumenep &
\end{tabular}

Teks ini berisi tentang Alquran dari surat al Fatihah sampai surat an-Nas.

Naskah ini berasal dari Jumawi dari K.H. Saqim. Kondisi naskah cukup baik.

\begin{tabular}{|l|l|l|l|}
\hline $\begin{array}{l}\text { BLAS/SUM/16/AQ } \\
\text { /6 }\end{array}$ & ALQURAN & 1 & Alquran \\
\hline $\begin{array}{l}\text { BTLN/MHSM/97/2 } \\
012\end{array}$ & Arab & Arab & Prosa \\
\hline 574 hlm. & 15 baris/hlm. & $27 \times 19$ & Kertas Daluwang \\
\hline M Haitsam & \multicolumn{2}{|l}{} \\
\hline Bantilan, Sergang, Batu Putih, Sumenep & \\
\hline
\end{tabular}

Teks ini berisi tentang Alquran dari surat al Fatihah sampai surat an-Nas.

Naskah ini berasal dari M Haitsam dari K.H. abdullah. Naskah ini kondisinya masih baik dan bisa dibaca. 


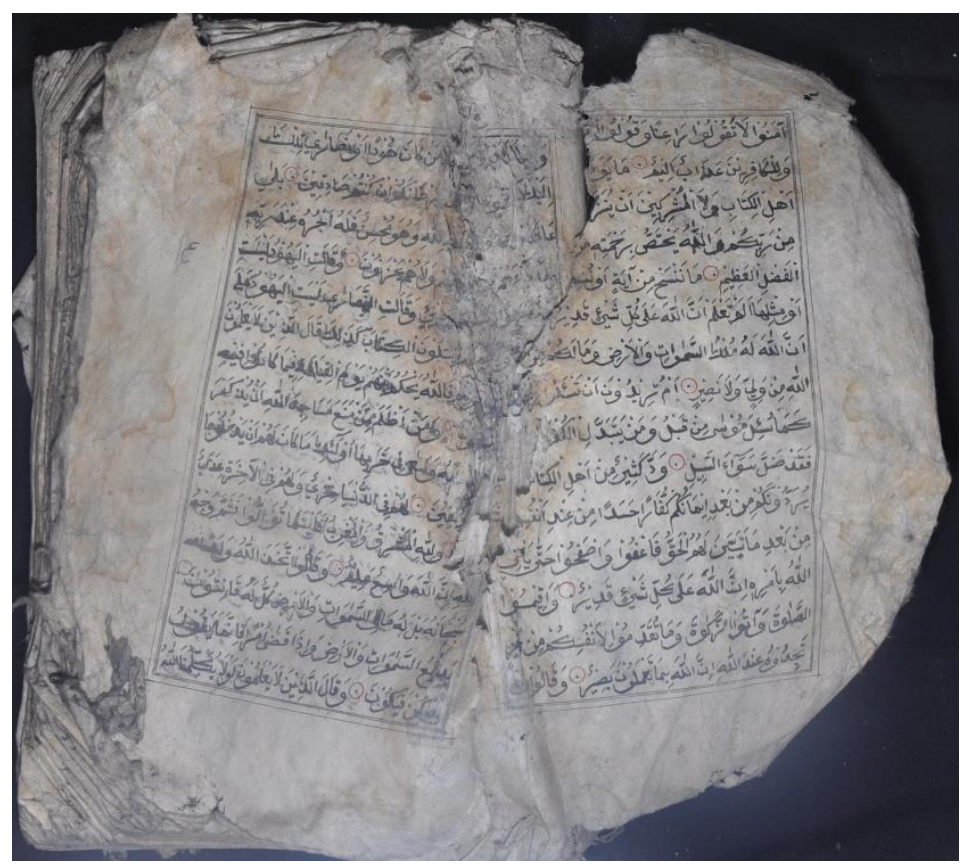

12097 BTLN JMW 962012 HLM 2,3 Img8160

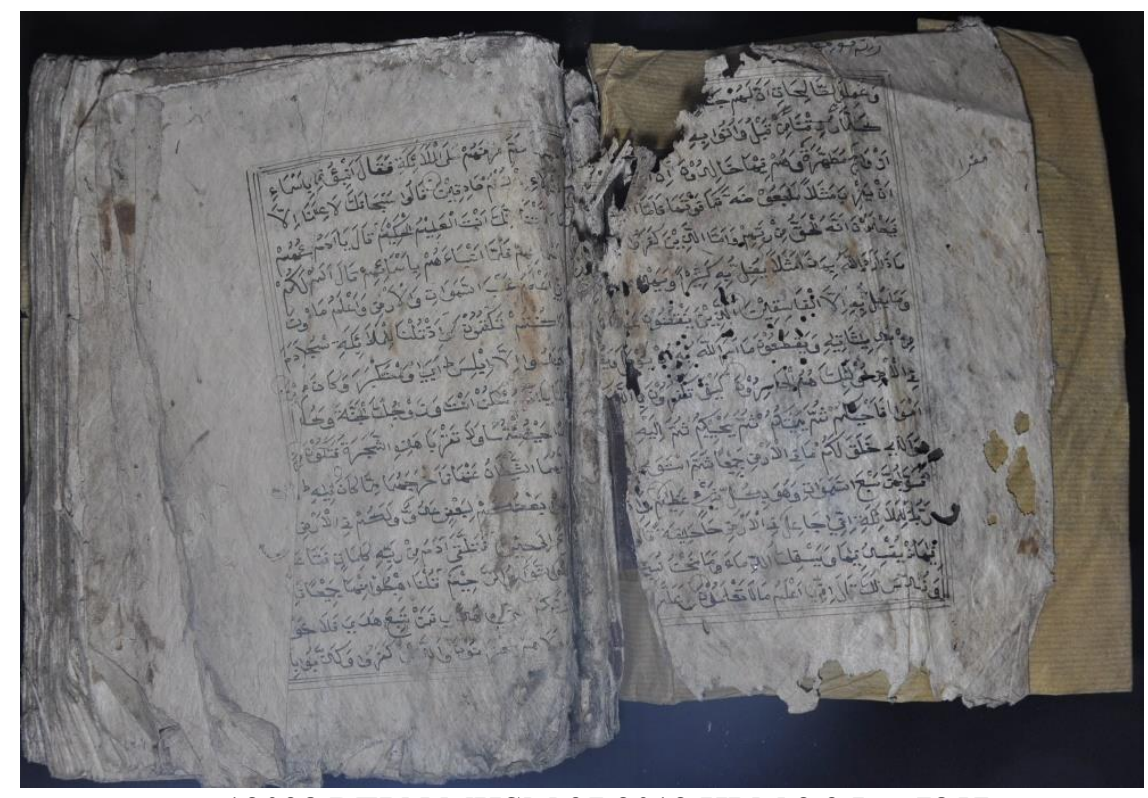

12098 BTLN MHSM 972012 HLM 2,3 Img7857 


\begin{tabular}{|l|l|l|l|}
\hline $\begin{array}{l}\text { BLAS/SUM/16/AQ } \\
/ 7\end{array}$ & ALQURAN & 1 & Alquran \\
\hline $\begin{array}{l}\text { PJG.SGG/ALWI/98 } \\
/ 2012\end{array}$ & Arab & Arab & Prosa \\
\hline $652 \mathrm{hlm}$. & 13 baris/hlm. & $25 \times 17$ & Kertas Daluwang \\
\hline K.H. Alwi & \\
\hline \multicolumn{2}{|l}{} \\
\hline
\end{tabular}

Teks ini berisi tentang Alquran dari surat al Fatihah sampai surat an-Nas.

Naskah ini berasal dari K.H. Alwi dari K.H. Syafi'uddin. Kondisi naskah mulai rusak, teks masih terbaca.

\begin{tabular}{|l|l|l|l|}
\hline $\begin{array}{l}\text { BLAS/SUM/16/AQ } \\
\mathbf{8}\end{array}$ & ALQURAN & 1 & Alquran \\
\hline $\begin{array}{l}\text { BLTN/ABDSMD/1 } \\
09 / 2012\end{array}$ & Arab & Arab & Prosa \\
\hline $58 \mathrm{hlm}$. & $11 \mathrm{baris} / \mathrm{hlm}$. & $20 \times 13.5$ & Kertas Daluwang \\
\hline Abdus Samad & & \\
\hline Bantilan Batu Putih & & \\
\hline
\end{tabular}

Naskah ini berisi Alquran tidak lengkap.

Naskah ini milik Abdus Somad dari Nyai Khuzaimah. Kondisi naskah mulai rusak, teks masih terbaca. 


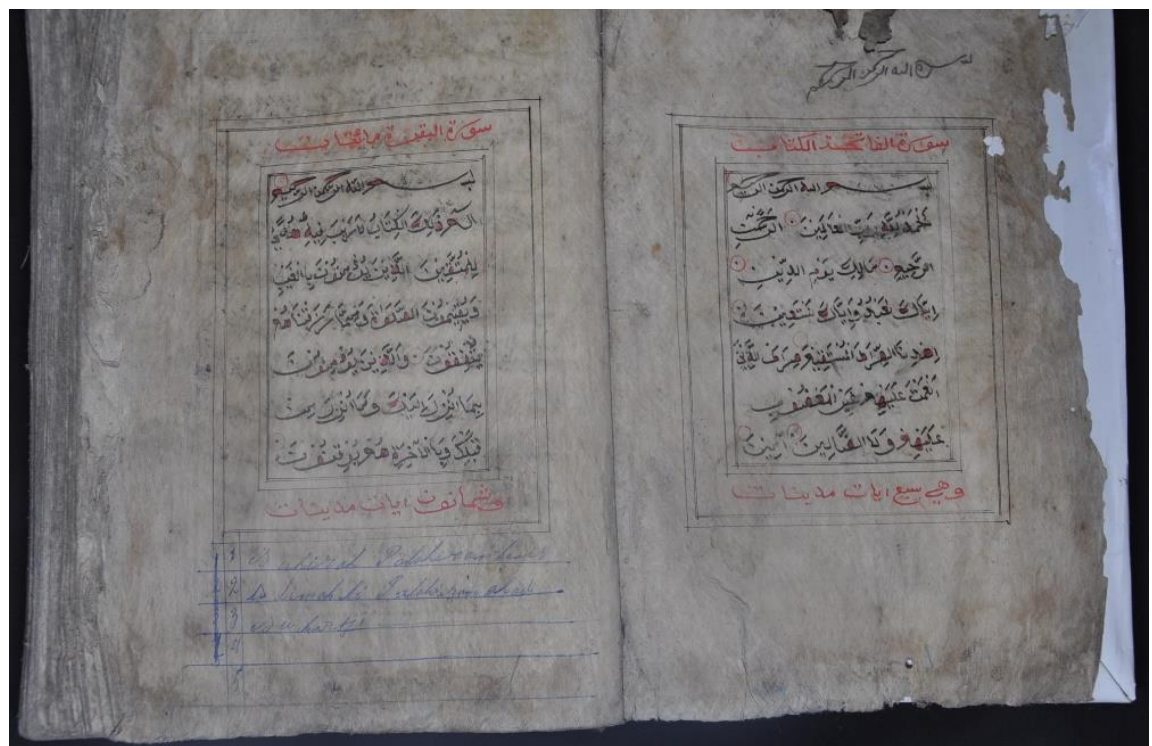

12099 PJGSGG ALWI 982012 HLM 1,2 Img8411

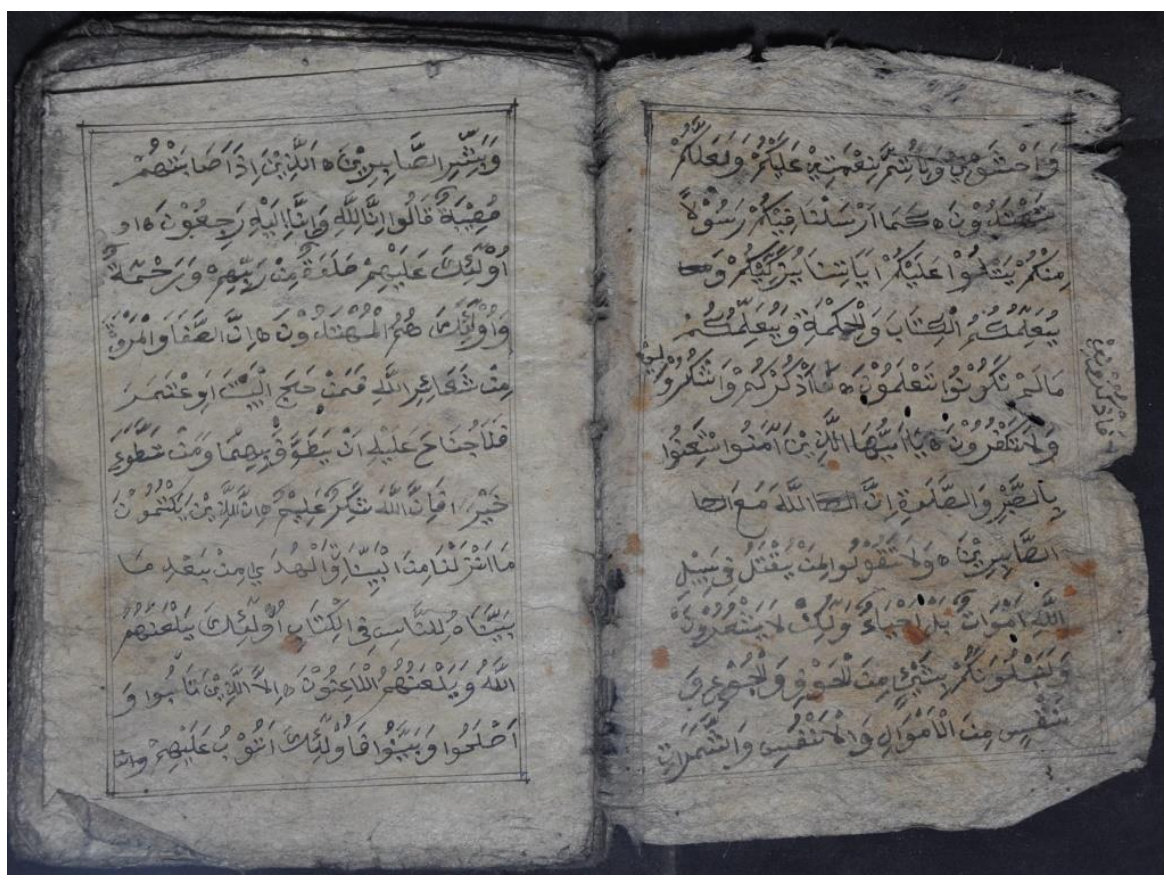

12110 BTLN ABDSMD 1092012 HLM 2,3 Img9981 


\begin{tabular}{|l|l|l|l|}
\hline $\begin{array}{l}\text { BLAS/SUM/16/AQ } \\
\text { 9 }\end{array}$ & ALQURAN & 1 & Alquran \\
\hline $\begin{array}{l}\text { NYBK.BTBT/ARF } \\
\text { S/116/2012 }\end{array}$ & Arab & Arab & Prosa \\
\hline 56 hlm. & 11 baris/hlm. & $20.5 \times 15.5$ & Kertas Daluwang \\
\hline Arif Sudarsono & \\
\hline \multicolumn{2}{|l}{ Nyabakan Timur Bat ang-Batang } \\
\hline
\end{tabular}

Naskah ini berisi Alquran surat Al-Baqāahah

Naskah ini milik Arif Sudarsono dari Syahral. Kondisi naskah mulai rusak, teks masih terbaca.

\begin{tabular}{|l|l|l|l|}
\hline $\begin{array}{l}\text { BLAS/SUM/16/AQ } \\
/ 10\end{array}$ & ALQURAN & 1 & Alquran \\
\hline $\begin{array}{l}\text { JNGR/HSM/120/20 } \\
12\end{array}$ & Arab & Arab & Prosa \\
\hline $48 \mathrm{hlm}$. & 13 baris/hlm. & $19 x 13$ & Kertas Daluwang \\
\hline \begin{tabular}{l} 
Hosmah \\
\hline Jenangger, Batang-batang
\end{tabular} \\
\hline
\end{tabular}

Naskah ini berisi Alquran surat Al-Baqāah tidak lengkap.

Naskah ini dimiliki oleh Hosmah dari K. Ahyar dari Kiai Abdullah. Tahun dan tempat penyusunan, penulisan ulang, maupun pemrakarsa tidak dicantumkan. Naskah dalam kondisi cukup baik/cukup bisa dibaca. 


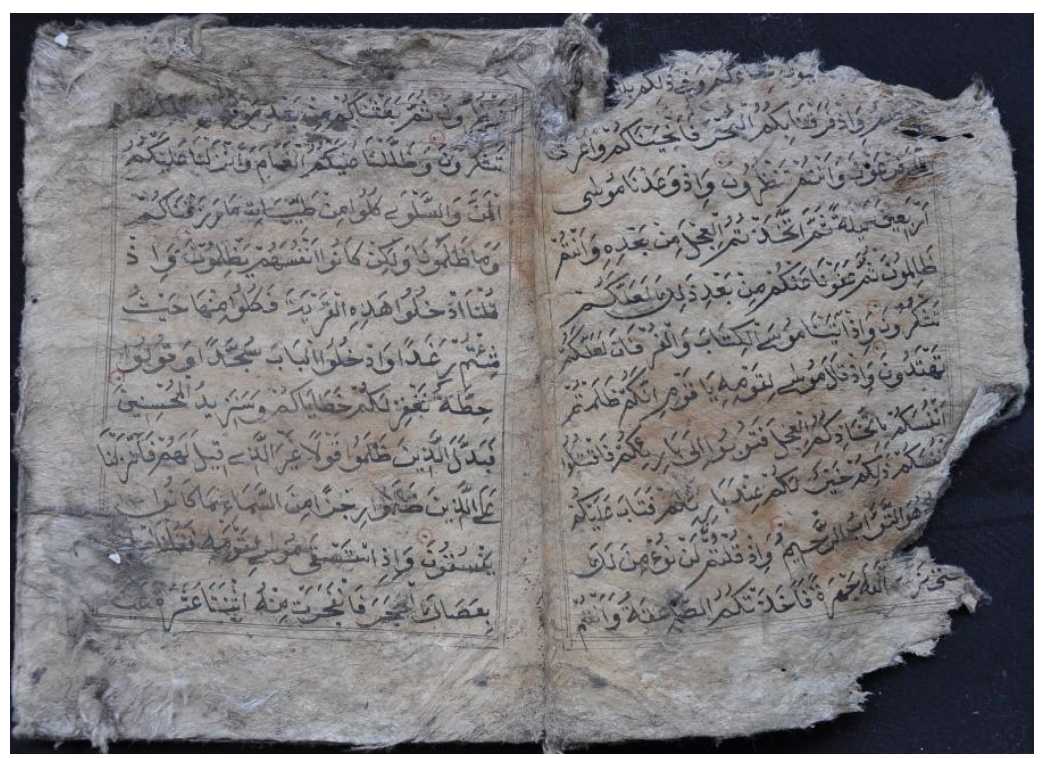

12117 NYBKBTBT ARFS 1162012 HLM 1,2 Img10344

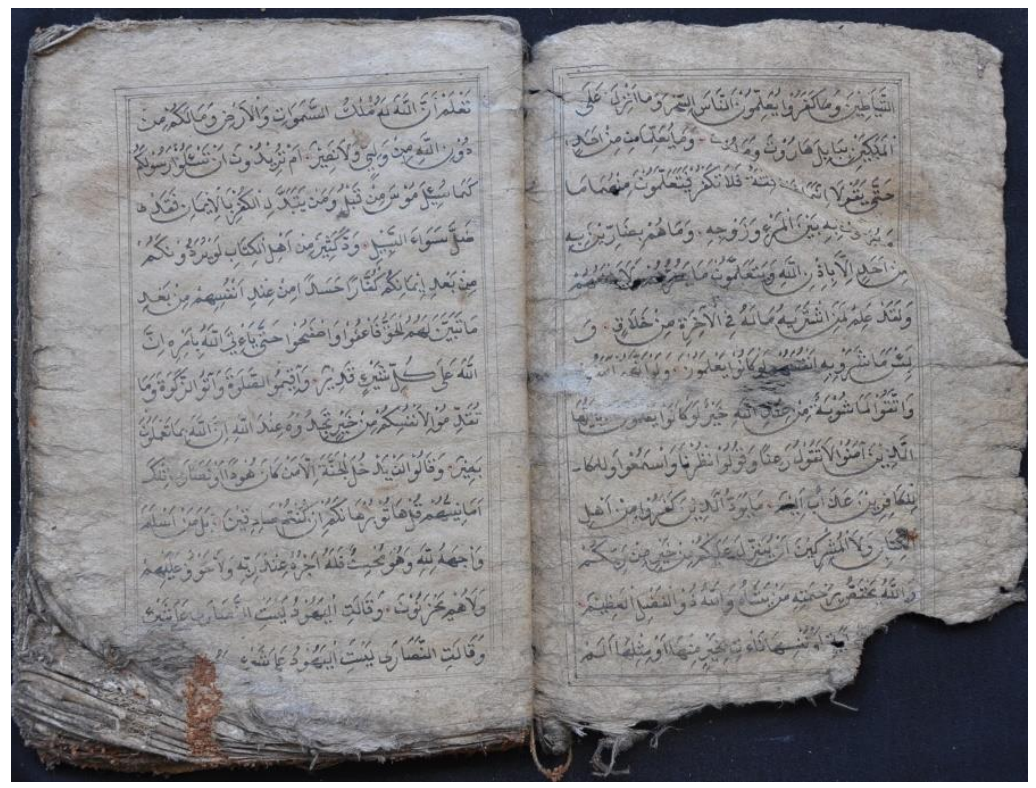

12121 JNGR HSM 1202012 HLM 2,3 Img10581 


\begin{tabular}{|l|l|l|l|}
\hline $\begin{array}{l}\text { BLAS/SUM/16/AQ } \\
/ 11\end{array}$ & ALQURAN & 1 & Alquran \\
\hline $\begin{array}{l}\text { JNGR/SUDFD/131 } \\
/ 2012\end{array}$ & Arab & Arab & Prosa \\
\hline $32 \mathrm{hlm}$. & 11 baris/hlm. & $18 x 11.5$ & Kertas Daluwang \\
\hline K. Su'udi Fadhal & \\
\hline Jenangger, Batang-batang
\end{tabular}

Naskah ini berisi Alquran, tetapi tidak lengkap.

Naskah ini dimilki oleh K. Su'udi Fadlal dari Rosyidah dari K. Irsyad dari K.H. Hadi dari K. Kamsiyah dari K. Biramah. Naskah dalam kondisi cukup baik/ cukup terbaca.

\begin{tabular}{|l|l|l|l|}
\hline $\begin{array}{l}\text { BLAS/SUM/16/AQ } \\
/ 12\end{array}$ & ALQURAN & 1 & Alquran \\
\hline $\begin{array}{l}\text { JRNBTPT/NIKMA } \\
\text { H/133/2012 }\end{array}$ & Arab & Arab & Prosa \\
\hline $452 \mathrm{hlm}$. & 15 baris/hlm. & $28.5 \times 20$ & Kertas Daluwang \\
\hline Nikmah & & \\
\hline Juruan, Batu Putih & & \\
\hline
\end{tabular}

Naskah ini berisi Alquran Surat Al-Baqarah sampai An-Nabā'.

Naskah ini dimiliki oleh Nikmah dari Bapak Moka' dari Bapak Moja. Naskah dalam kondisi cukup baik/cukup bisa dibaca. 


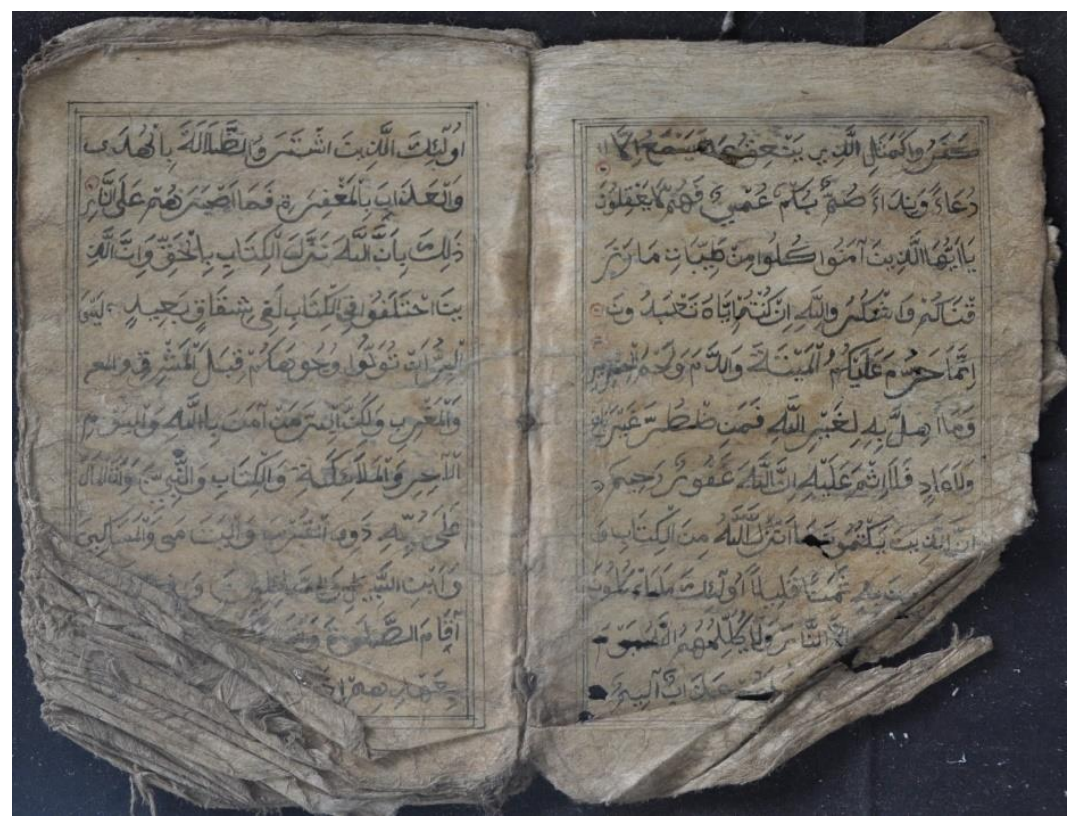

12132 JNGR SUDFD 1312012 HLM 4,5 Img11019

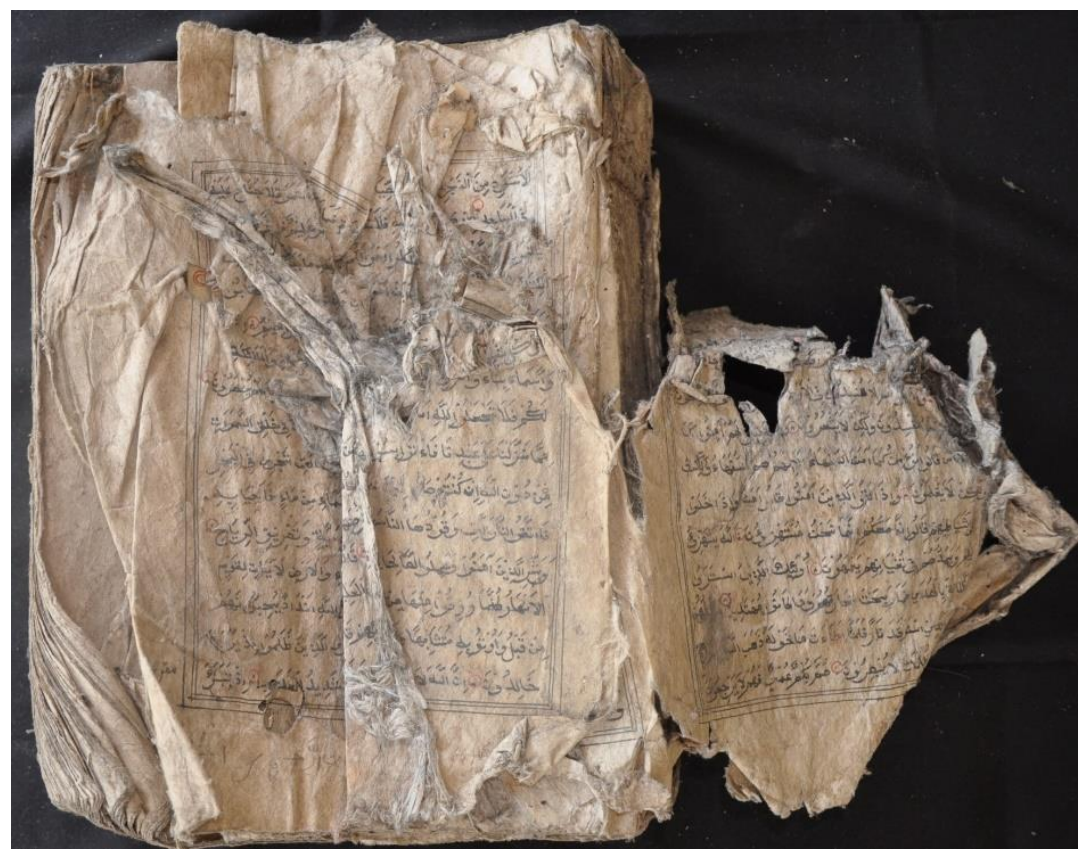

12134 JRNBTPT NIKMAH 1332012 HLM 2,3 Img11240 


\begin{tabular}{|l|l|l|l|}
\hline $\begin{array}{l}\text { BLAS/SUM/16/AQ } \\
/ 13\end{array}$ & ALQURAN & 1 & Alquran \\
\hline $\begin{array}{l}\text { JNRG/MWRD/140/ } \\
2012\end{array}$ & Arab & Arab & Prosa \\
\hline $468 \mathrm{hlm}$. & 13 baris/hlm. & $29 x 17$ & Kertas Daluwang \\
\hline Mawardi & & \\
\hline Pajung, Batu Putih & \\
\hline
\end{tabular}

Alquran Surat Ali Imran sampai Surat Aż-Zariyat.

Naskah ini dimiliki oleh Mawardi dari Nyai Fadhilah dari Nyai Musa'I dari K. Romli dari K. Mithal. Kondisi naskah cukup baik/cukup dapat dibaca.

\begin{tabular}{|l|l|l|l|}
\hline $\begin{array}{l}\text { BLAS/SUM/16/AQ } \\
/ 14\end{array}$ & ALQURAN & 1 & Alquran \\
\hline $\begin{array}{l}\text { JNRG/MWRD/141/ } \\
2012\end{array}$ & Arab & Arab & Prosa \\
\hline 210 hlm. & 15 baris/hlm. & $26.5 \times 19$ & Kertas Daluwang \\
\hline Mawardi & \\
\hline Pajung Sergang, Batu Putih
\end{tabular}

Naskah ini merupakan Alquran.

Naskah ini dimiliki oleh Mawardi dari Nyai Fadhilah dari Nyai Musa'I dari K. Romli dari K. Mithal. Kondisi naskah cukup baik/cukup dapat dibaca. 


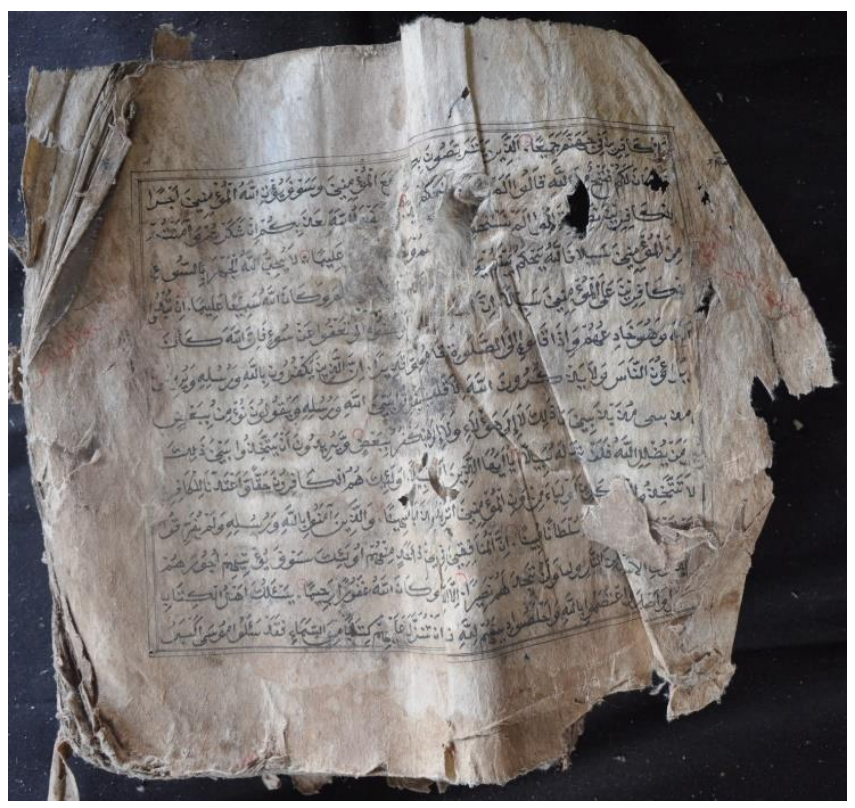

12141 JNGR MWRD 1402012 HLM 2,3 Img11491

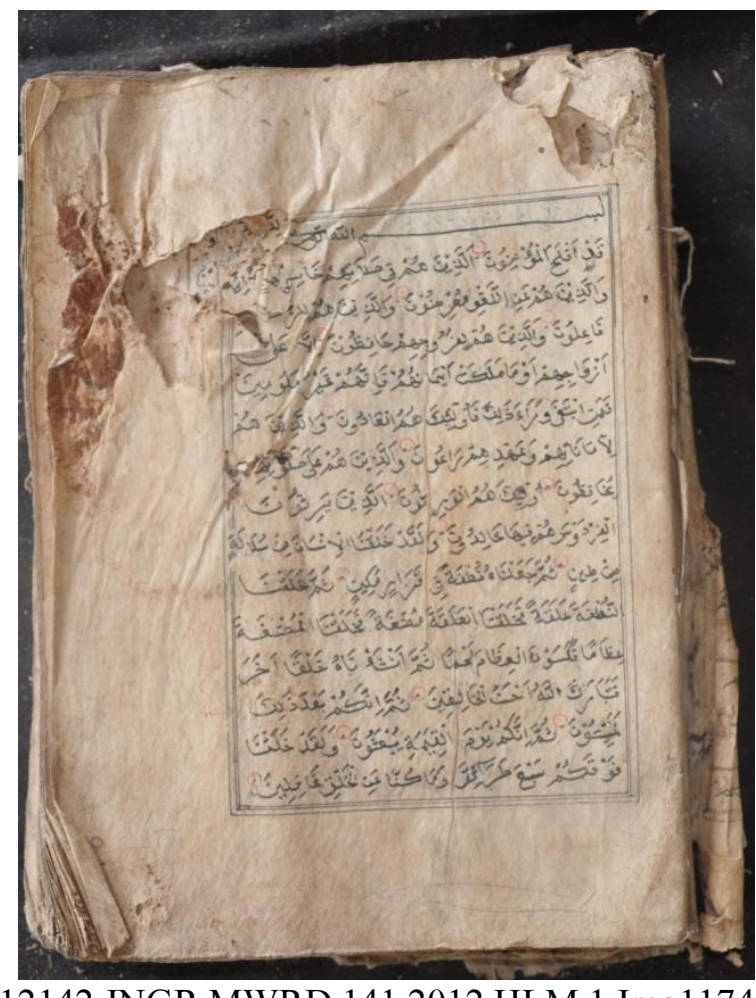

12142 JNGR MWRD 1412012 HLM 1 Img11749 


\begin{tabular}{|l|l|l|l|}
\hline $\begin{array}{l}\text { BLAS/SUM/16/AQ } \\
/ 15\end{array}$ & ALQURAN & 1 & Alquran \\
\hline GPR 19 & Arab & Arab & Prosa \\
\hline $182 \mathrm{hlm}$. & 15 baris/hlm. & $25 \times 18$ & Kertas Daluwang \\
\hline Ilyas & \\
\hline Durbugan Banjar Barat, Gapura Sumenep \\
\hline
\end{tabular}

Naskah berupa Kitab Alquran, tetapi tidak lengkap.

Naskah berasal dari Ilyas, dari Qosim, dari Kiai Idrur, dari Kiai Mahdi. Kondisi fisik naskah rusak, beberapa halaman berlubang, namun tulisan masih bisa dibaca.

\begin{tabular}{|l|l|l|l|}
\hline $\begin{array}{l}\text { BLAS/SUM/16/AQ } \\
/ 16\end{array}$ & $\begin{array}{l}\text { BAGIAN DARI } \\
\text { SURAT } \\
\text { ALQURAN }\end{array}$ & 1 & Alquran \\
\hline GPR 20 & Arab & Arab & Prosa \\
\hline $74 \mathrm{hlm}$. & 9 baris/hlm. & $20 \times 13.5$ & Kertas Daluwang \\
\hline Ilyas & \\
\hline Durbugan Banjar Barat, Gapura Sumenep \\
\hline
\end{tabular}

Naskah berupa bagian dari surat-surat Kitab Alquran.

Naskah berasal dari Ilyas, dari Qosim, dari Kiai Idrur, dari Kiai Mahdi. Kondisi fisik naskah rusak, tapi tulisan masih bisa dibaca. Tulisan menggunakan tinta hitam dan ada beberapa garis merah di bawah beberapa kata. 


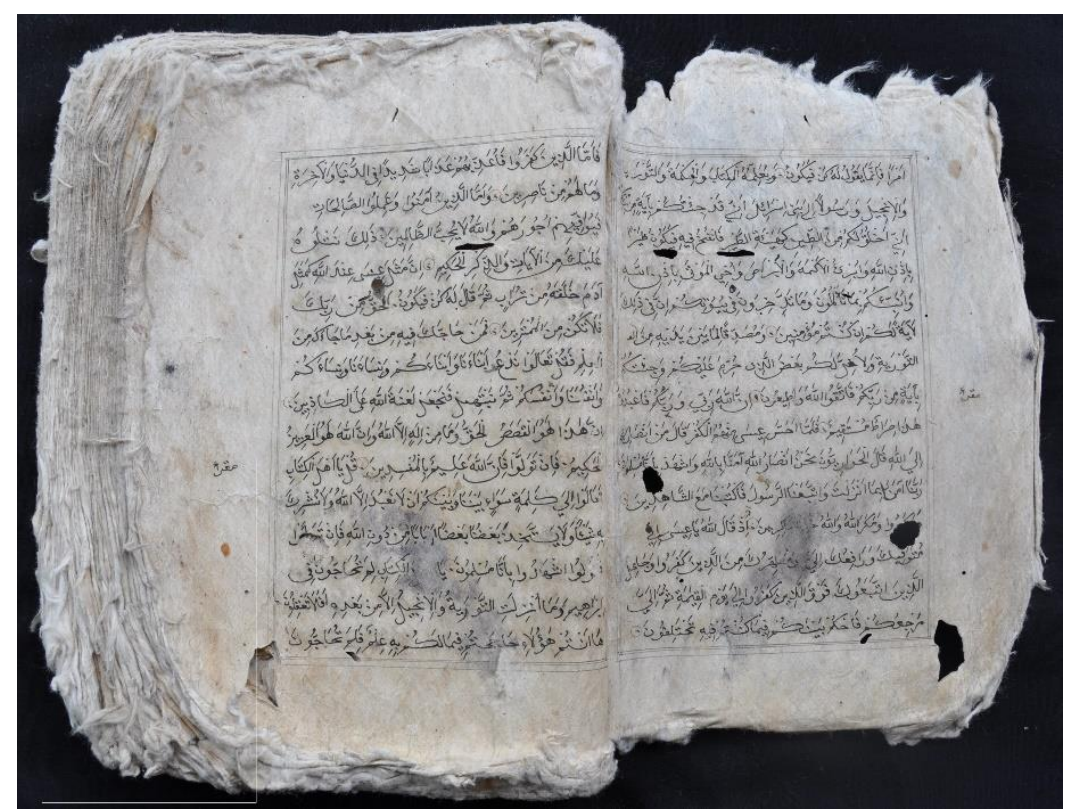

1105 GPR 19 HLM 2,3 DSC_0126

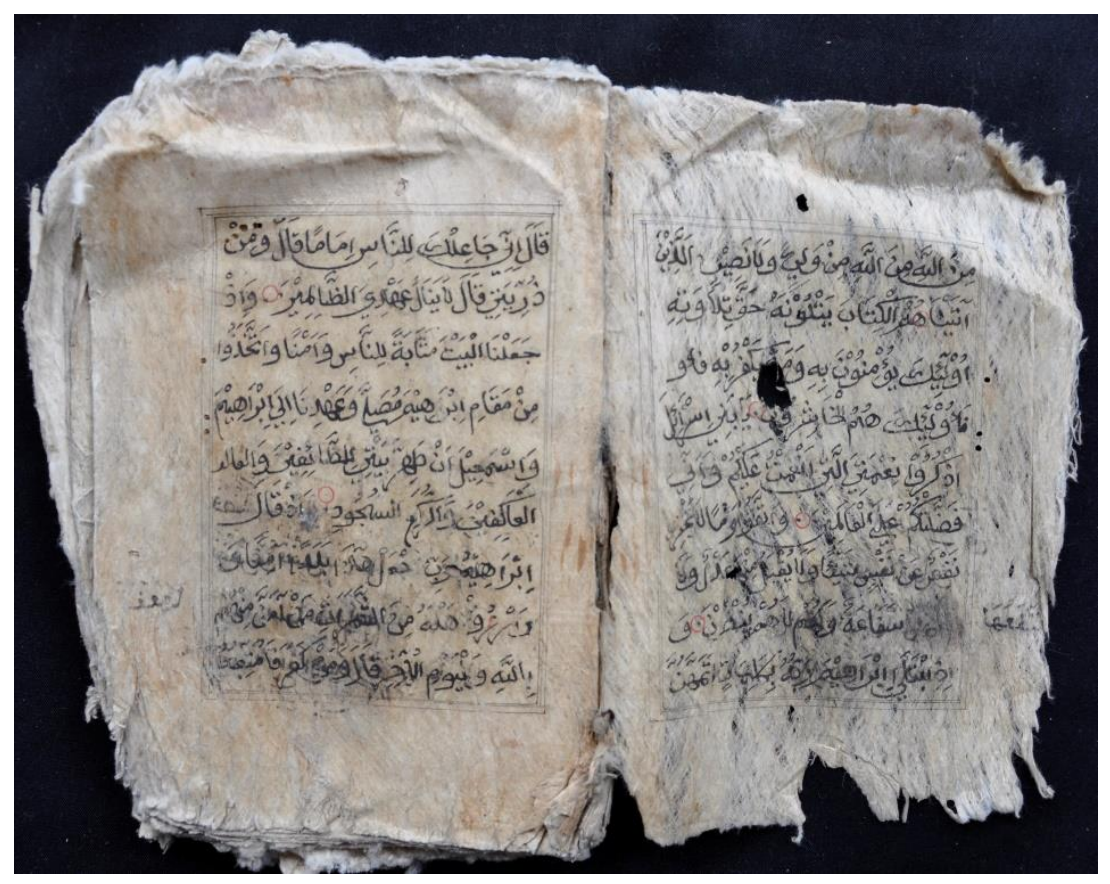

1106 GPR 20 HLM 2,3_DSC0150.JPG 


\begin{tabular}{|l|l|l|l|}
\hline $\begin{array}{l}\text { BLAS/SUM/16/AQ } \\
\text { /17 }\end{array}$ & ALQURAN & 1 & Alquran \\
\hline GPR 31 & Arab & Arab & Prosa \\
\hline $53 \mathrm{hlm}$. & 15 baris/hlm. & $21 \times 17.5$ & Kertas Eropa \\
\hline K.H. Hasan & \\
\hline Dusun Lambi Cabi, Gapura Tengah, Gapura Sumenep \\
\hline
\end{tabular}

Naskah berisi tentang pergaulan suami isteri sehari-hari.

Naskah milik Kiai Hasan dari ayahnya. Teks ditulis menggunakan tinta hitam, tanpa penomoran halaman. Kondisi naskah dalam keadaan baik, bersampul kertas tipis warna cokelat dan tulisan jelas terbaca.

\begin{tabular}{|l|l|l|l|}
\hline $\begin{array}{l}\text { BLAS/SUM/16/AQ } \\
/ 18\end{array}$ & ALQURAN & 1 & Alquran \\
\hline GPR 35 & Arab & Arab & Prosa \\
\hline $184 \mathrm{hlm}$. & 15 baris/hlm. & $28 \times 19.5$ & Kertas Daluwang \\
\hline Abdur Rahim & \\
\hline Dusun Nai'an Atas, Gapura Barat, Gapura Sumenep \\
\hline
\end{tabular}

Naskah berisi tentang Kitab Alquran yang dimulai dari surat An-Nisa.

Naskah milik Abdur Rochim dari bapaknya yang bernama Abdul Wakhid. Teks ditulis menggunakan tinta hitam serta tinta merah untuk penulisan awal surat dan ayatayat penting). Kondisi naskah dalam keadaan rusak, tetapi tulisan masih dapat dibaca. 


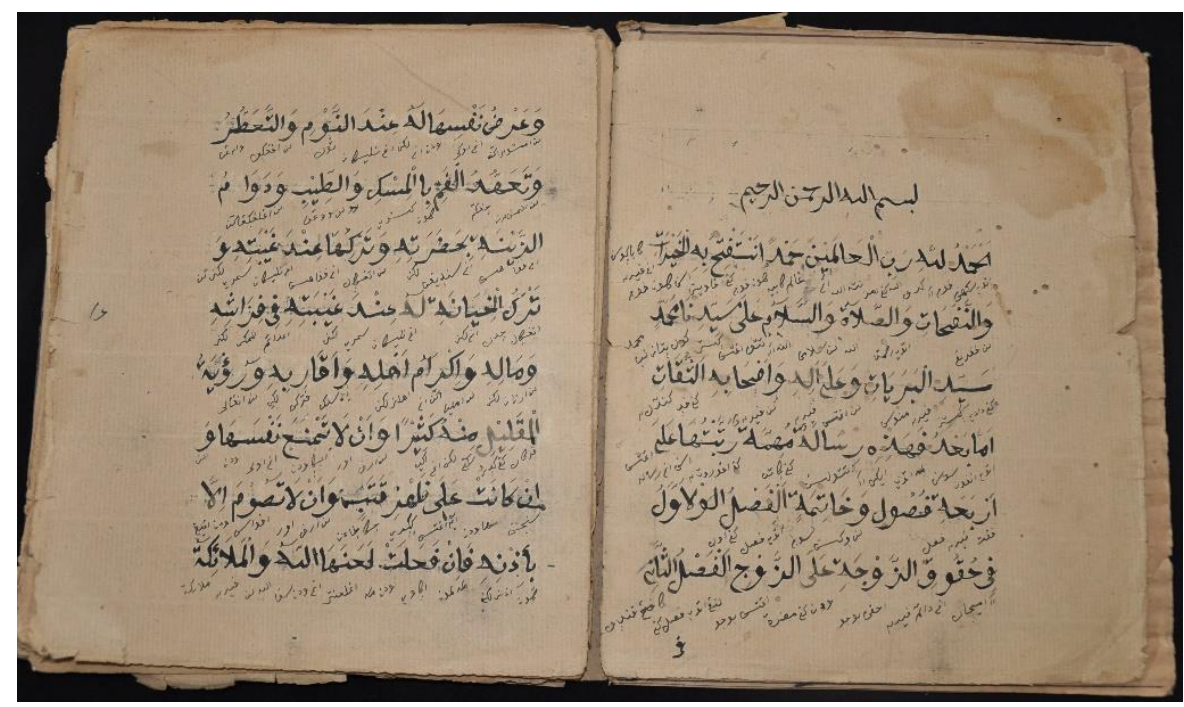

1117 GPR 31 HLM 1,2 DSC_0018

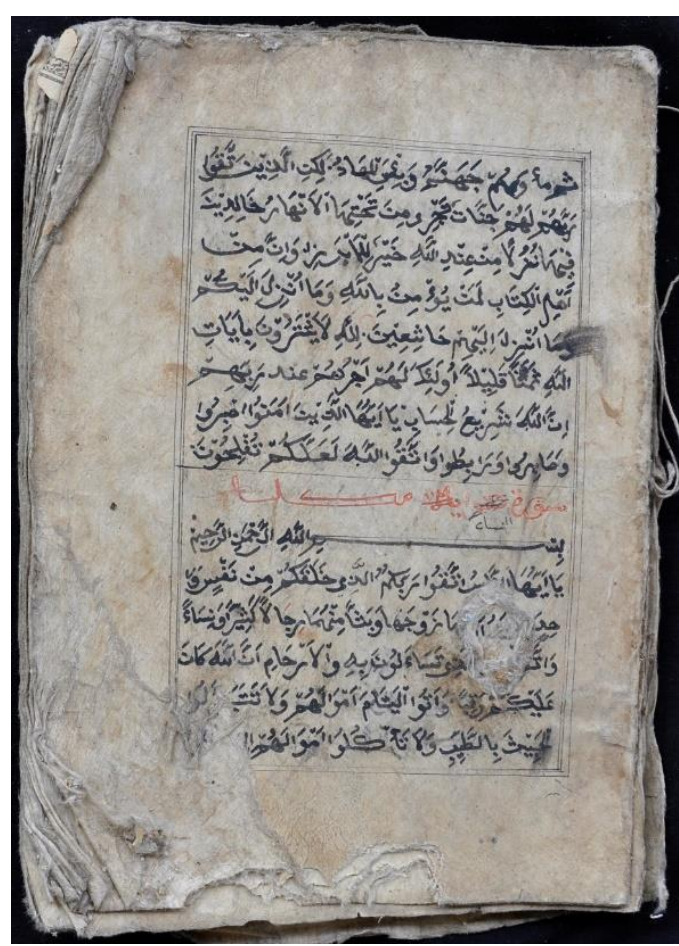

1121 GPR 35 HLM 1_DSC0168 


\begin{tabular}{|l|l|l|l|}
\hline $\begin{array}{l}\text { BLAS/SUM/16/AQ } \\
/ 19\end{array}$ & ALQURAN & 1 & Alquran \\
\hline GPR 37 & Arab & Arab & Prosa \\
\hline \multicolumn{2}{|l|}{} \\
\hline Abdur Rahim & 15 baris/hlm. & $31 \times 18$ & Kertas Eropa \\
\hline Dusun Nai'an Atas, Gapura Barat, Gapura Sumenep \\
\hline
\end{tabular}

Naskah berisi Alquran tidak lengkap. Isi dari Alquran tersebut yaitu; (1) surat alBaqāah, tidak lengkap hanya 6 halaman, (2) Ali Imran, tidak lengkap hanya 9 halaman, (3) an Nisa, tidak lengkap, hanya 30 halaman, (4) al-Ma'idah, lengkap, (5) al-An'am, lengkap, (6) al-A'raf, lengkap, (7) al-Anfal, lengkap, (8) at-Taubat, lengkap, (9) Yüus, lengkap, (10) Hūd, lengkap, (11) Yusuf, lengkap, (12) al- Rad, lengkap, (13) Ibrahim, lengkap, (14) al-Hijr, lengkap, (15) An-Nakhl, lengkap, (16) Al-Isra', tidak lengkap, hanya 7 halaman, (17), al-Kahfi, tidak lengkap, hanya 7 halaman, (18) Maryam, lengkap, (19) Tăha, lengkap, (20) al-Anbiya, lengkap, (21) al-Hajj, tidak lengkap, hanya 5 halaman, (22) al-Mu'minun, lengkap, (23) Nur, tidak lengkap, hanya 4 halaman, (24) al-Furqan, hanya 3 halaman, (25) As-Syura, hanya 4 halaman, (26) An-Naml, hanya 4 halaman, (27) al-Qișas, lengkap, (28) al-Ankabüt, lengkap, (29) ar Rūm, lengkap, (30) Luqmān, lengkap, (31) Sajdah, lengkap, (32) al-Ahzāab, lengkap, (33) as-Sabāa, lengkap, (34) Fatir, lengkap, (35) Ya asin, lengkap, (36) al-Saffat, lengkap, (37) Shāa, lengkap, (38) Al-Zumar, lengkap, (39) Gäfir, lengkap, (40) Fuṣsilat, lengkap, (41) As-Syüra, lengkap, (42) Al-Zuhrü, lengkap, (43) ad-Dukhāan, lengkap, (44) al-Jaliyah, lengkap, (45) alAhqaf, lengkap, (46) Muhammad, lengkap, (47) al-Fath, lengkap, (48) al-Hujurat, lengkap, (49) Qäf, lengkap, (50) al-Dzäriyat, lengkap, (51) al-Tür, lengkap, (52) alNajm, hanya 2 halaman, (53) Ar- Rahmān, hanya 2 halaman, (54) al-Waqi'ah, lengkap, (55) al-Ha $\overline{d i d}$, hanya 3 halaman.

Naskah milik Abdur Rochim dari bapaknya yang bernama Abdul Wakhid. Teks ditulis menggunakan tinta hitam dan merah untuk nama surat dan penjelas kata-kata tertentu. Kondisi fisik naskah dalam keadaan rusak, tetapi tulisan masih bisa dibaca.

\begin{tabular}{|l|l|l|l|}
\hline $\begin{array}{l}\text { BLAS/SUM/16/AQ } \\
\text { 20 }\end{array}$ & ALQURAN & 1 & Alquran \\
\hline BT-BT 7 & Arab, Jawa Pegon & Arab & Prosa \\
\hline 660 hlm. & 13 baris/hlm. & 27.7 x17.5 & $\begin{array}{l}\text { Kertas Daluwang } \\
\text { (Kertas kapas) }\end{array}$ \\
\hline Matnawi & \multicolumn{2}{|l}{} \\
\hline \multicolumn{2}{|l|}{ Dusun Laok Saba, Nyabakan Timur, Batang-Batang, Sumenep } \\
\hline
\end{tabular}


Naskah berupa Kitab Alquran.

Naskah milik Matnawi dari Kiai Subhan. Naskah tidak bersampul, teks ditulis menggunakan tinta hitam dan merah untuk nama surat. Naskah ini disalin oleh Kiai Siwallah. Kondisi naskah dalam keadaan baik dan tulisan masih dapat dibaca.

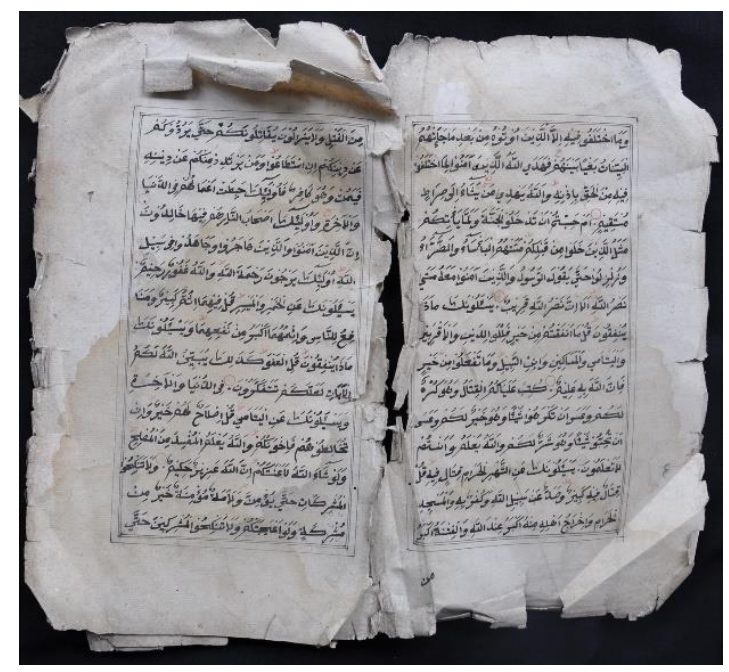

1123 GPR 37 HLM 2,3 DSC_0006

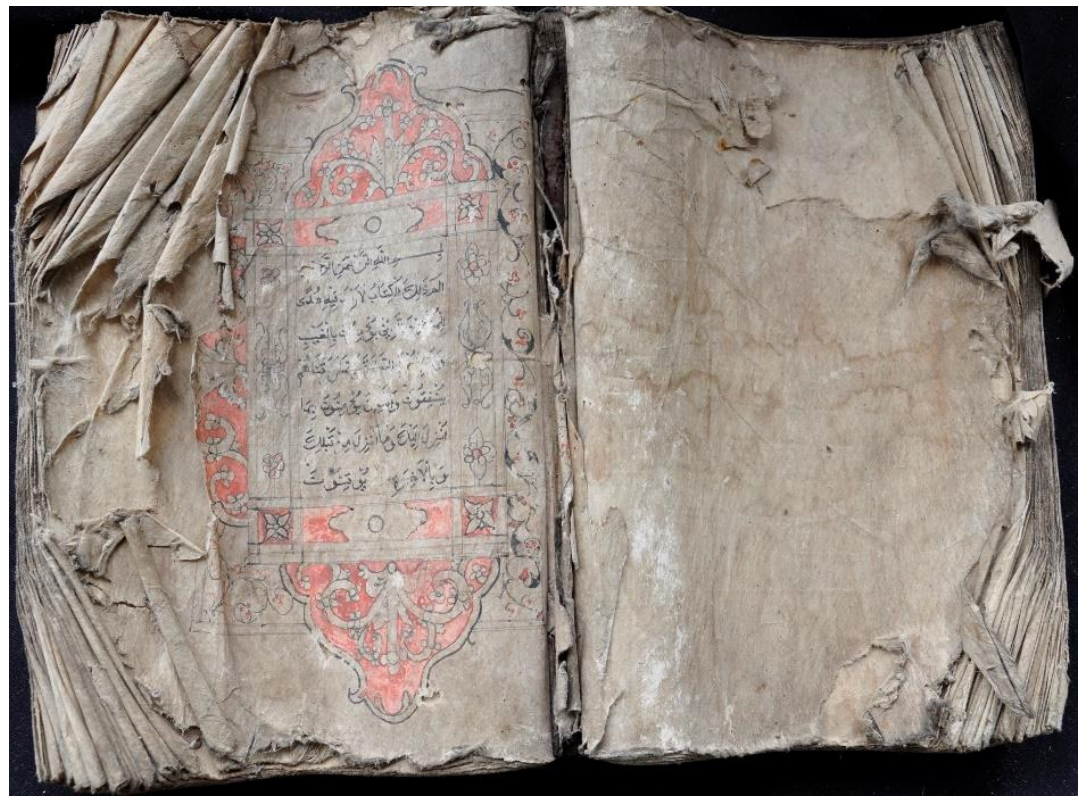

1137 BTBT 07 HLM 1_DSC0095 


\begin{tabular}{|l|l|l|l|}
\hline $\begin{array}{l}\text { BLAS/SUM/16/AQ } \\
\text { /21 }\end{array}$ & ALQURAN & 1 & Alquran \\
\hline BT-BT 11 & Arab & Arab & Alquran \\
\hline 116 hlm. & 9 baris/hlm. & $17 \times 12$ & Kertas Daluwang \\
\hline Kiai Muchtar \\
\hline \multicolumn{2}{|l|}{ Dusun Laok Saba, Nyabakan Timur, batang-Batang } \\
\hline
\end{tabular}

Naskah ini berisi Alquran surat al-Baqarah, Ali Imran.

Naskah ini dimiliki oleh Kiai Muchtar dari Kiai Mustaqim dari Kiai Siwallah dari Kiai Biramah. Tahun dan tempat penyusunan, penulisan ulang, maupun pemrakarsa tidak dicantumkan. Kondisi naskah bagian awal dan akhir rusak. Tinta menggunakan warna hitam, dan merah untuk nama surat dan sebagian ayat.

\begin{tabular}{|l|l|l|l|}
\hline $\begin{array}{l}\text { BLAS/SUM/16/AQ } \\
\text { /22 }\end{array}$ & ALQURAN & 1 & Alquran \\
\hline BT-BT 17 & Arab & Arab & Prosa \\
\hline $86 \mathrm{hlm}$. & 9 baris/hlm. & $12.5 \times 2.9$ & Kertas Daluwang \\
\hline Muriksa \\
\hline \multicolumn{2}{|l}{ Dusun Laok Saba, Nyabakan Timur, batang-Batang } \\
\hline
\end{tabular}

Naskah ini merupakan bagian dari Alquran yang terdiri dari beberapa surat saja.

Naskah ini dimiliki oleh Muriksa dari Dhu'an. Tahun dan tempat penyusunan tidak disebutkan. Kondisi naskah rusak, tet api masih dapat dibaca. Tinta menggunakan warna hitam dan merah. 


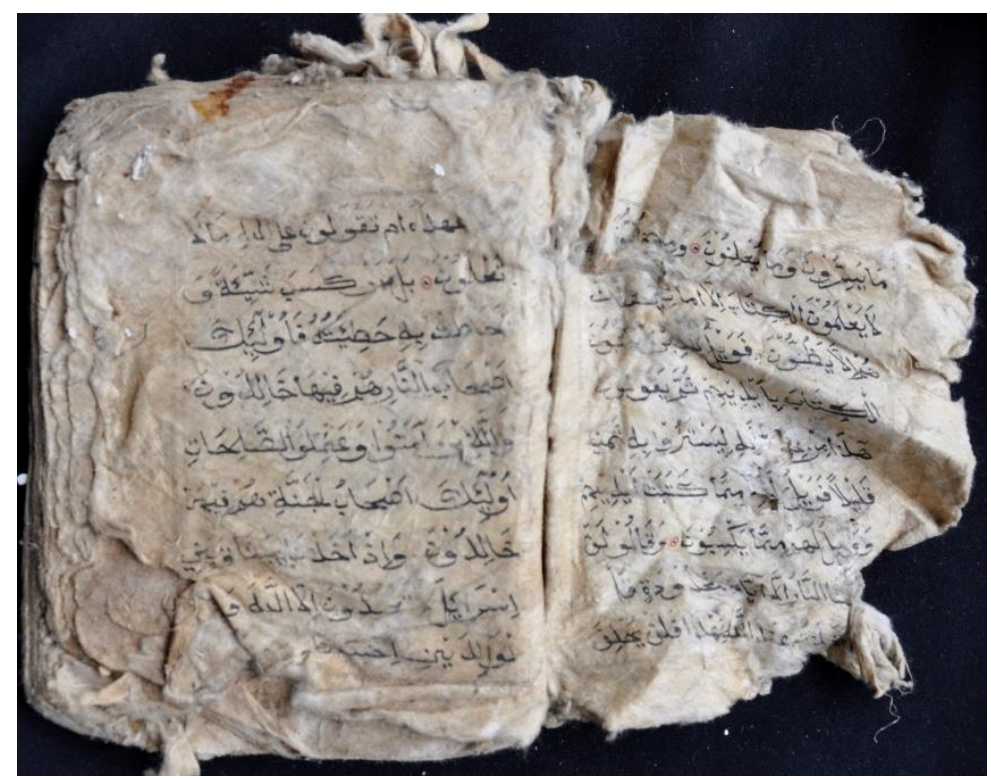

1141 BTBT 11 HLM 6,7 DSC0005

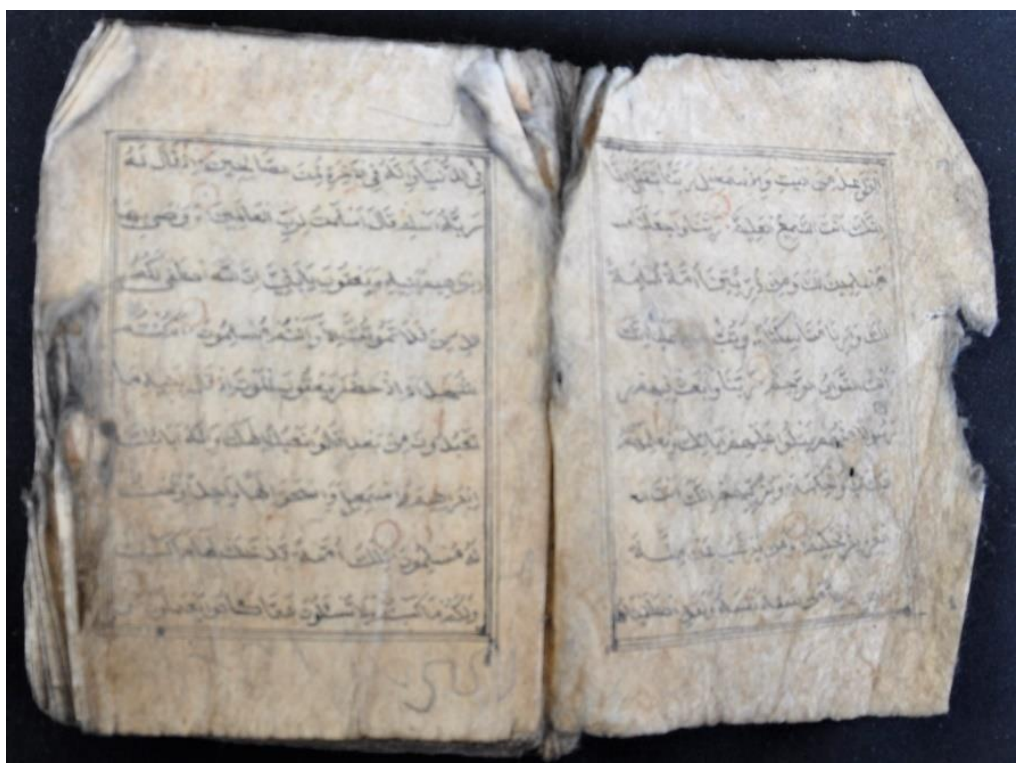

1147 BTBT 17 HLM 2,3_DSC0007.JPG 


\begin{tabular}{|l|l|l|l|}
\hline $\begin{array}{l}\text { BLAS/SUM/16/AQ } \\
\text { /23 }\end{array}$ & ALQURAN & 1 & Alquran \\
\hline BT-BT 18 & Arab & Arab & Prosa \\
\hline $226 \mathrm{hlm}$. & 15 baris/hlm. & $27.5 \times 14$ & Kertas Daluwang \\
\hline Muriksa \\
\hline \multicolumn{2}{|l|}{ Dusun Laok Saba, Nyabakan Timur, batang-Batang } \\
\hline
\end{tabular}

Naskah ini merupakan Alquran yang tidak lengkap.

Naskah ini dimiliki oleh Muriksa dari Dhu'an. Tahun dan tempat penyusunan tidak disebutkan. Kondisi naskah rusak, tetapi masih dapat dibaca. Tinta menggunakan warna hitam dan merah pada ayat tertentu dan batas antar surat.

\begin{tabular}{|l|l|l|l|}
\hline $\begin{array}{l}\text { BLAS/SUM/16/AQ } \\
\text { /24 }\end{array}$ & ALQURAN & 1 & Alquran \\
\hline BT-BT 19 & Arab & Arab & Prosa \\
\hline 41 hlm. & 15 baris/hlm. & $28 x 5.5$ & Kertas Daluwang \\
\hline Muriksa \\
\hline \multicolumn{2}{|l}{ Dusun Laok Saba, Nyabakan Timur, batang-Batang } \\
\hline
\end{tabular}

Naskah ini merupakan Alquran yang tidak lengkap.

Naskah ini dimiliki oleh Muriksa dari Dhu'an. Tahun dan tempat penyusunan tidak disebutkan. Kondisi naskah rusak, sebagian masih dapat dibaca. Tinta menggunakan warna hitam. 


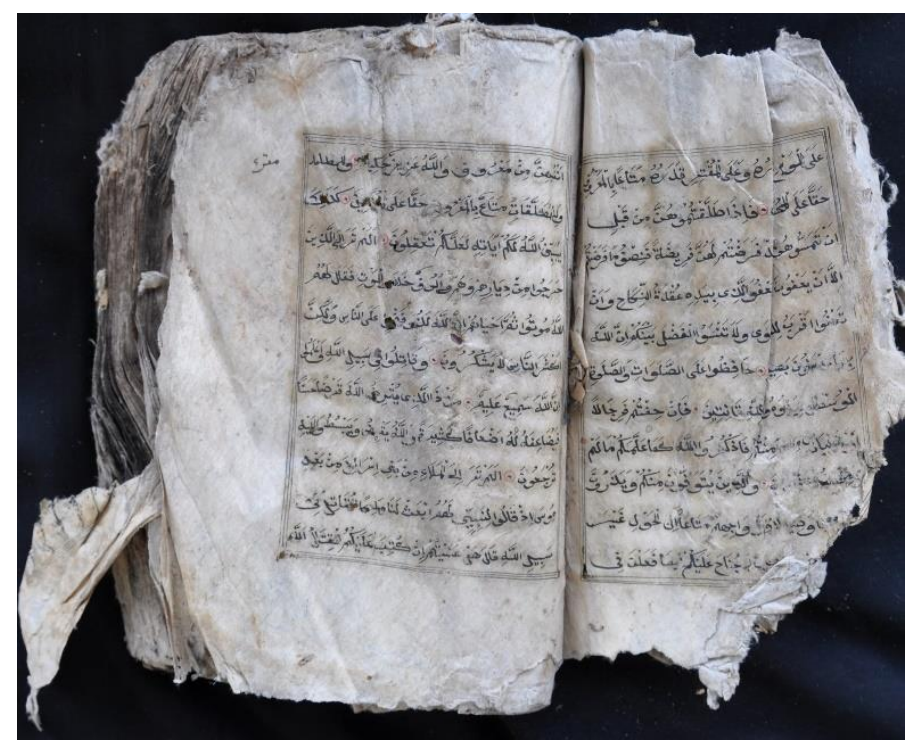

1148 BTBT 18 HLM 17,18 DSC_0009

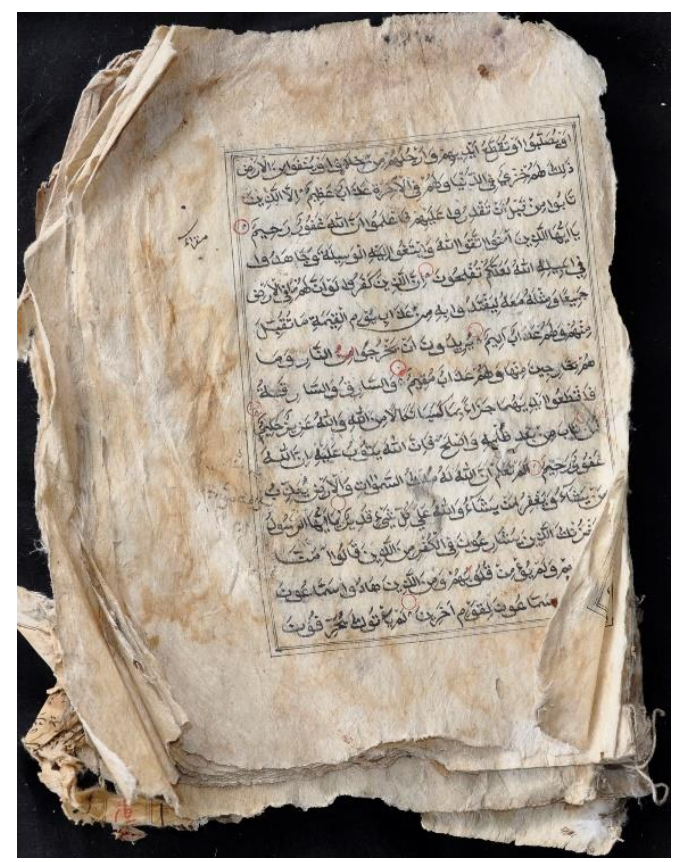

1149 BTBT 19 HLM 1_DSC0217 


\begin{tabular}{|l|l|l|l|}
\hline $\begin{array}{l}\text { BLAS/SUM/16/AQ } \\
\text { /25 }\end{array}$ & ALQURAN & 1 & Alquran \\
\hline BT-BT 21 & Arab & Arab & Prosa \\
\hline 109 hlm. & 15 baris/hlm. & $28.5 x 19$ & Kertas Daluwang \\
\hline Abdrurrahman \\
\hline \multicolumn{2}{|l}{ Dusun Laok Saba, Nyabakan Timur, batang-Batang } \\
\hline
\end{tabular}

Naskah ini merupakan Alquran yang tidak lengkap.

Naskah ini dimiliki oleh Abdurrahman dari Mudallah. Tahun dan tempat penyusunan tidak disebutkan. Kondisi naskah rusak, masih dapat dibaca. Tinta menggunakan warna hitam dan merah.

\begin{tabular}{|l|l|l|l|}
\hline $\begin{array}{l}\text { BLAS/SUM/16/AQ } \\
\text { /26 }\end{array}$ & ALQURAN & 1 & Alquran \\
\hline BT-BT 27 & Arab & Arab & Prosa \\
\hline 290 hlm. & 13 baris/hlm. & $27 \times 18.5$ & Kertas Daluwang \\
\hline Kiai Su'udi Fadhal \\
\hline \multicolumn{2}{|l}{ Dusun Nyabungan, Jenangger, Batang-Batang. } \\
\hline
\end{tabular}

Naskah ini merupakan Alquran.

Naskah ini dimiliki oleh Kiai Su'udi Fadhal dari Kiai Irsyad dari Kiai Sodli dari Kiai Hadi. Tahun dan tempat penyusunan tidak disebutkan. Kondisi naskah baik, beberapa bagian robek. Tinta menggunakan warna hitam, dan merah pada pembatas antar ayat. 


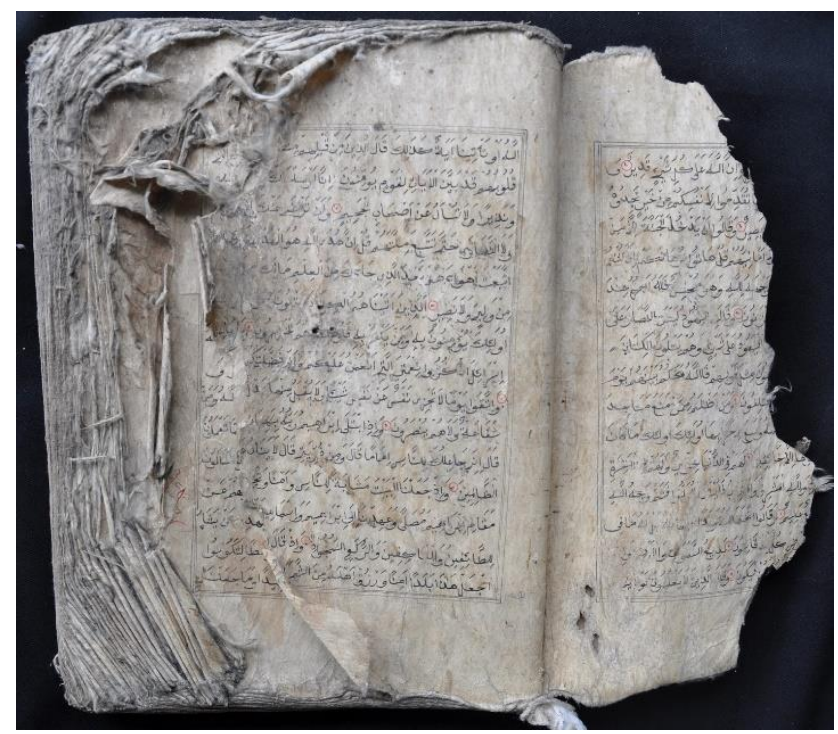

1151 BTBT 21 HLM 2,3 DSC_0043

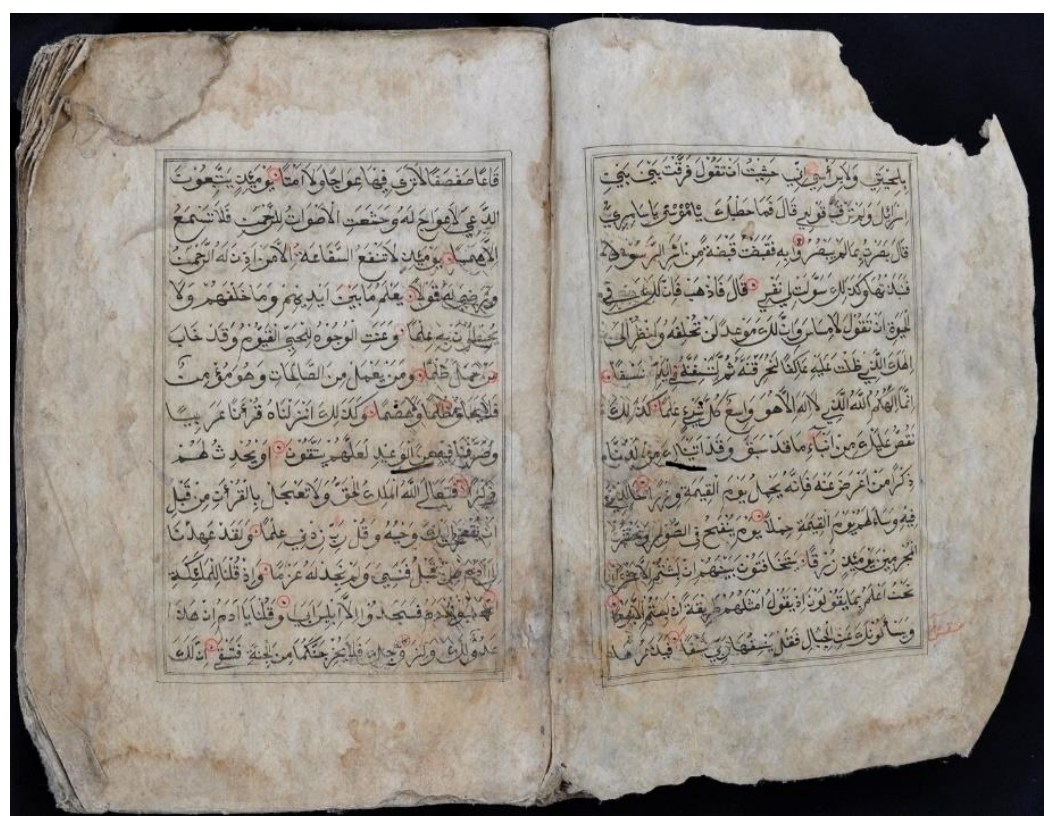

1157 BTBT 27 HLM 2,3_DSC0004 


\begin{tabular}{|l|l|l|l|}
\hline $\begin{array}{l}\text { BLAS/SUM/16/AQ } \\
\mathbf{2} 7\end{array}$ & ALQURAN & 1 & Alquran \\
\hline BT-BT 29 & Arab & Arab & Prosa \\
\hline $92 \mathrm{hlm}$. & 11 baris/hlm. & $23.5 \times 16.5$ & Kertas Daluwang \\
\hline H. Ahmad \\
\hline \multicolumn{2}{|l}{ Dusun Nyabungan, Jenangger, Batang-Batang. } \\
\hline
\end{tabular}

Naskah ini merupakan Alquran.

Naskah ini dimiliki oleh H. Ahmad dari Rumi dari Abdul Hadi. Tahun dan tempat penyusunan tidak disebutkan. Kondisi naskah rusak, tetapi masih dapat dibaca. Tinta menggunakan warna hitam dan merah pada akhir ayat dan pemisah surat.

\begin{tabular}{|l|l|l|l|}
\hline $\begin{array}{l}\text { BLAS/SUM/16/AQ } \\
\text { /28 }\end{array}$ & ALQURAN & 1 & Alquran \\
\hline BT-BT 36 & Arab & Arab & Prosa \\
\hline $70 \mathrm{hlm}$. & 13 baris/hlm. & $19.3 \times 13$ & Kertas Daluwang \\
\hline Aziz & \\
\hline Dusun Nyabungan, Jenangger, Batang-Batang. \\
\hline
\end{tabular}

Naskah ini merupakan Alquran, tiap akhir ayat diberi tanda lingkaran berwarna merah, teks dibingkai dengan dua garis.

Naskah ini dimiliki oleh Aziz dari haji As'ad dari Suhilal dari Kiai Siwallah. Tahun dan tempat penyusunan tidak disebutkan. Kondisi naskah berlubang-lubang di setiap halaman, masih dapat dibaca. Tinta menggunakan warna hitam merah pada pembatas antar surat dan lingkaran pada akhir surat. 


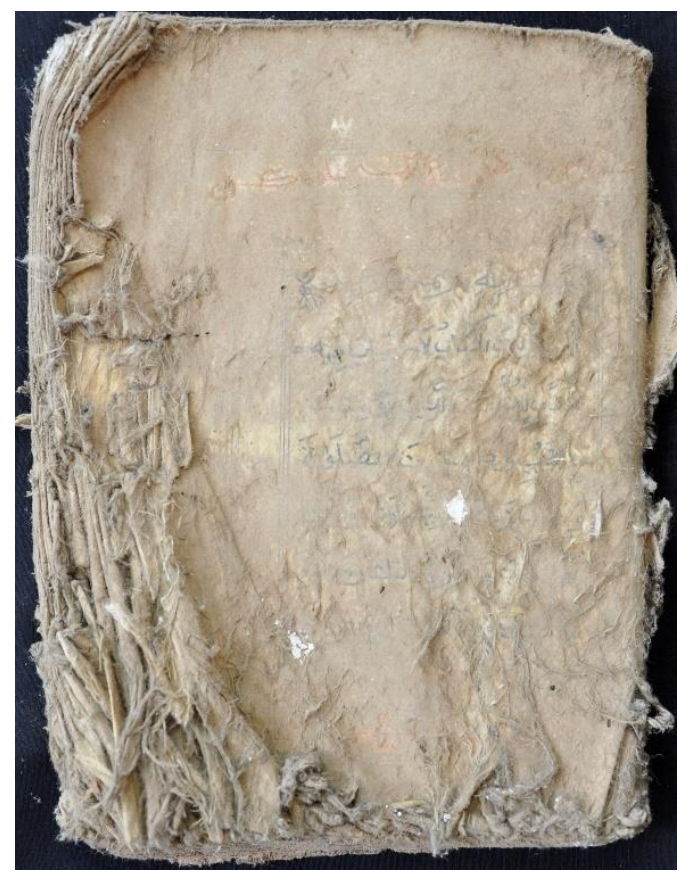

1159 BTBT 29 HLM 2,3_DSC0025

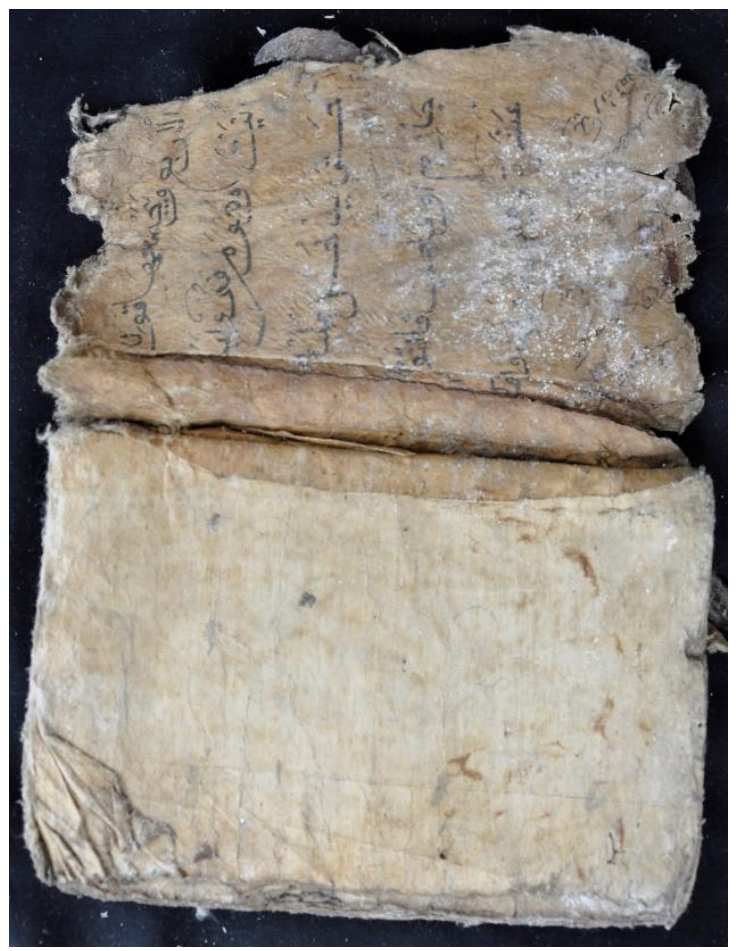

1166 BTBT 36 HLM 2,3_DSC0219 


\begin{tabular}{|l|l|l|l|}
\hline $\begin{array}{l}\text { BLAS/SUM/16/AQ } \\
\text { /29 }\end{array}$ & ALQURAN & 1 & Alquran \\
\hline BT-BT 38 & Arab & Arab & Prosa \\
\hline $636 \mathrm{hlm}$. & 13 baris/hlm. & $27.5 \times 17.5$ & Kertas Daluwang \\
\hline Aziz & \\
\hline Dusun Nyabungan, Jenangger, Batang-Batang. \\
\hline
\end{tabular}

Naskah ini merupakan Alquran.

Naskah ini dimiliki oleh Aziz dari H. As'ad dari Suhilal dari Kiai Siwallah. Tahun dan tempat penyusunan tidak disebutkan. Kondisi naskah rusak, masih dapat dibaca. Tinta menggunakan warna hitam, merah pada antara dua surat dan lingkaran pada akhir surat.

\begin{tabular}{|l|l|l|l|}
\hline $\begin{array}{l}\text { BLAS/SUM/16/AQ } \\
\text { /30 }\end{array}$ & ALQURAN & 1 & Alquran \\
\hline BT-BT 54 & Arab & Arab & Prosa \\
\hline $302 \mathrm{hlm}$. & 15 baris/hlm. & $27 \times 17.5$ & Kertas Daluwang \\
\hline Kiai Khalid & \\
\hline Dusun Nyabungan, Jenangger, Batang-Batang. \\
\hline
\end{tabular}

Naskah ini berisi teks Alquran 15 juz.

Naskah ini dimiliki oleh Kiai Khalid dari Kiai Fadlun dari Kiai Khomsidin. Tahun dan tempat penyusunan tidak disebutkan. Kondisi naskah baik, tanpa sampul, masih dapat dibaca. Tinta menggunakan warna hitam dan merah. 


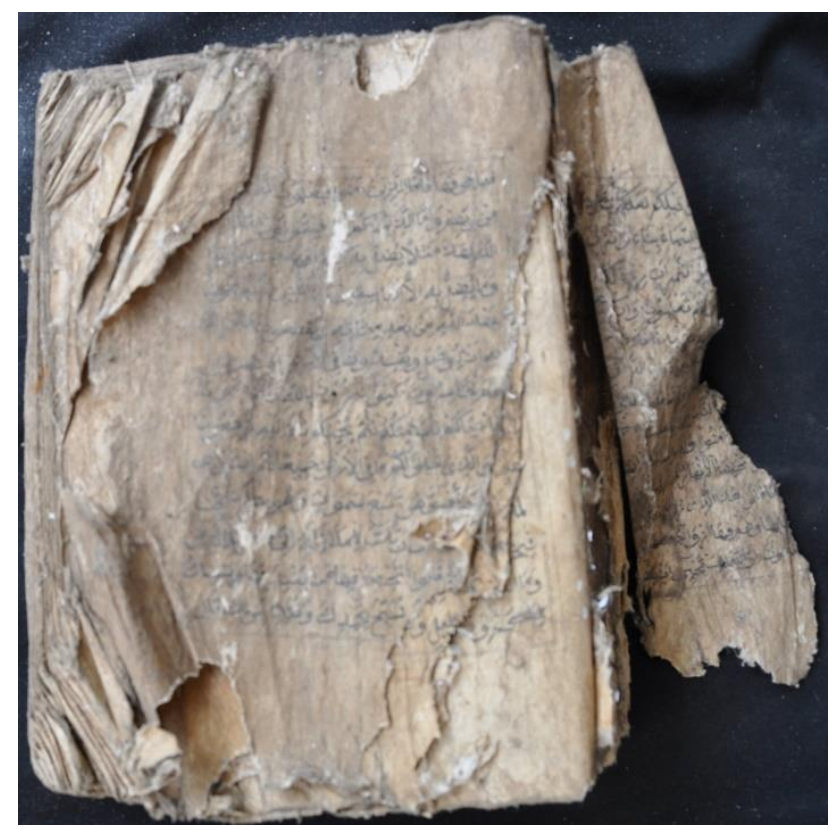

1168 BTBT 38 HLM 2,3 DSC_0099

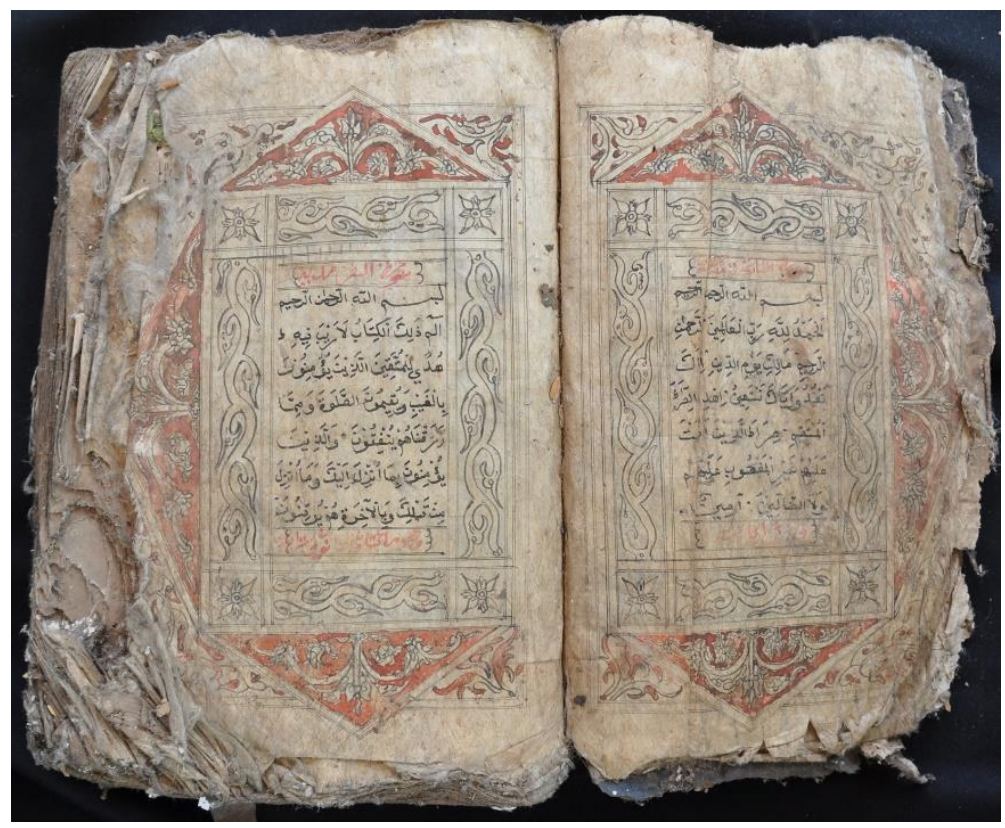

1184 BTBT 54 HLM 1,2 DSC_0003 


\begin{tabular}{|l|l|l|l|}
\hline $\begin{array}{l}\text { BLAS/SUM/16/AQ } \\
\text { /31 }\end{array}$ & ALQURAN & 1 & Alquran \\
\hline BT-BT 55 & Arab & Arab & Prosa \\
\hline 442 hlm. & 15 baris/hlm. & $30.5 \times 20$ & Kertas Daluwang \\
\hline Kiai Khalid & \\
\hline Dusun Nyabungan, Jenangger, Batang-Batang. \\
\hline
\end{tabular}

Naskah ini berisi teks Alquran.

Naskah ini dimiliki oleh Kiai Khalid dari Kiai Fadlun dari Kiai Khomsidin. Tahun dan tempat penyusunan tidak disebutkan. Kondisi naskah baik.

\begin{tabular}{|l|l|l|l|}
\hline $\begin{array}{l}\text { BLAS/SUM/16/AQ } \\
\text { /32 }\end{array}$ & ALQURAN & $\mathbf{1}$ & Alquran \\
\hline $\begin{array}{l}\text { TNAR/HLMH/33/2 } \\
012\end{array}$ & Arab & Arab & Prosa \\
\hline 498 hlm. & 18 baris/hlm. & $29 x 19$ & Kertas Daluwang \\
\hline Nyai Halimah & & \\
\hline Tanah Air, Rubaru & \\
\hline
\end{tabular}

Teks berisi ayat Kitab Alquran Surat Ali Imran sampai Surat al-Mursalat.

Naskah ini dimiliki oleh Nyai Halimah. Naskah cukup baik dan teks terbaca. 


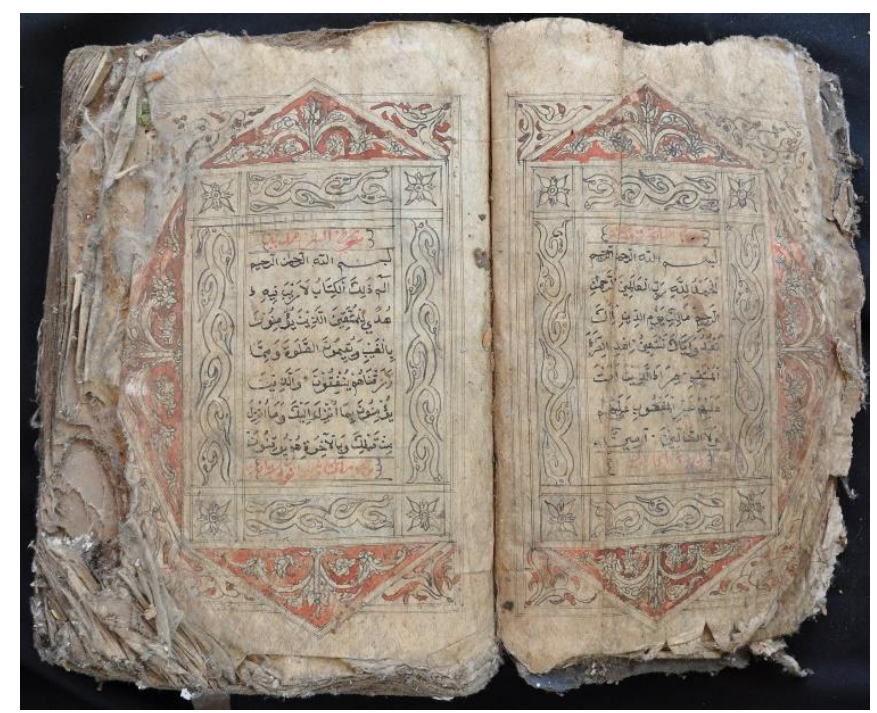

1184 BTBT 54 HLM 1,2 DSC 0003

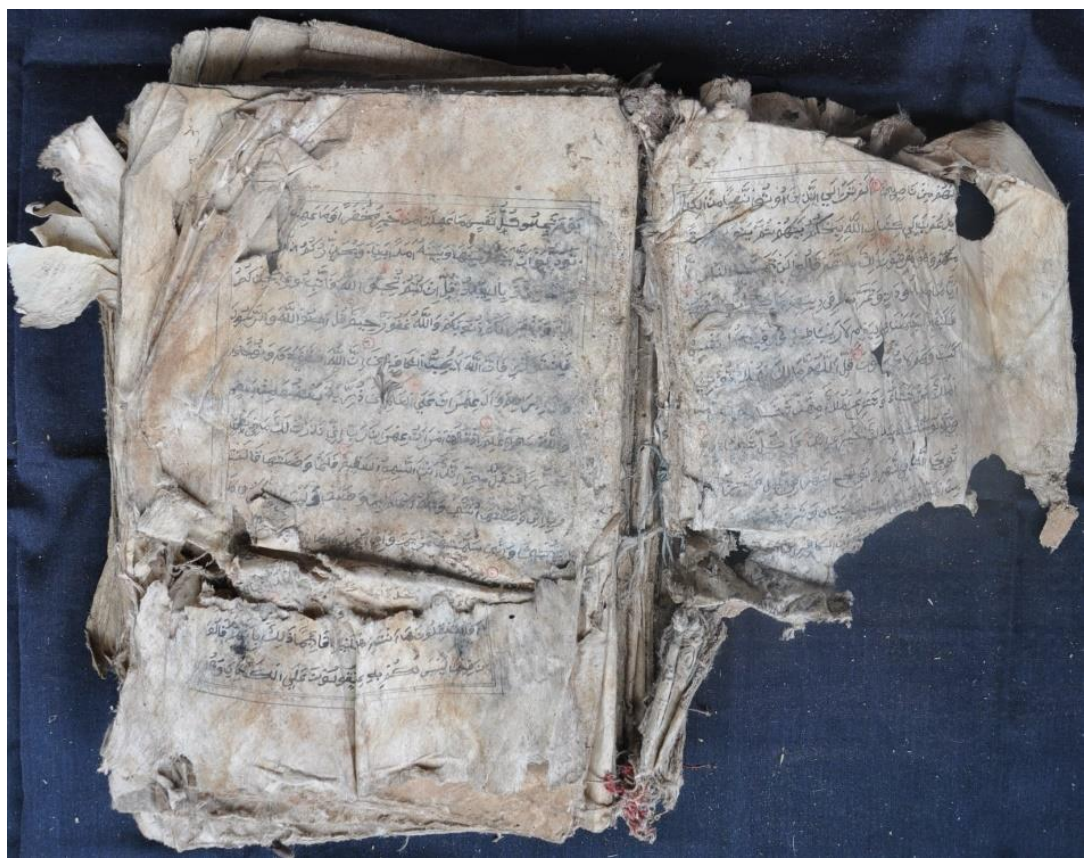

12033 TNAR HLMH 332012 HLM 2,3 Img2679 


\begin{tabular}{|l|l|l|l|}
\hline $\begin{array}{l}\text { BLAS/SUM/16/AQ } \\
\text { /33 }\end{array}$ & ALQURAN & 1 & Alquran \\
\hline $\begin{array}{l}\text { BTLN/AZIZ/41/20 } \\
12\end{array}$ & Arab & Arab & Prosa \\
\hline $946 \mathrm{hlm}$. & 11 baris/hlm. & $28 \times 16$ & Kertas Daluwang \\
\hline Aziz & & \\
\hline Bantilan, Batu Putih & \\
\hline
\end{tabular}

Teks berisi ayat-ayat Kitab Alquran.

Naskah ini milik Aziz dari K. Mariah. Naskah cukup baik dan teks terbaca.

\begin{tabular}{|l|l|l|l|}
\hline $\begin{array}{l}\text { BLAS/SUM/16/AQ } \\
\text { /34 }\end{array}$ & ALQURAN & 1 & Alquran \\
\hline $\begin{array}{l}\text { BTLN/MDN/42/20 } \\
12\end{array}$ & Arab & Arab & Prosa \\
\hline 562 hlm. & 13 baris/hlm. & $27 x 18$ & Kertas Daluwang \\
\hline Madani & & \\
\hline Bantilan, Batu Putih & \\
\hline
\end{tabular}

Teks berisi ayat-ayat Kitab Alquran.

Naskah ini milik Madani dari K. Hasyim. Naskah cukup baik dan teks terbaca. 


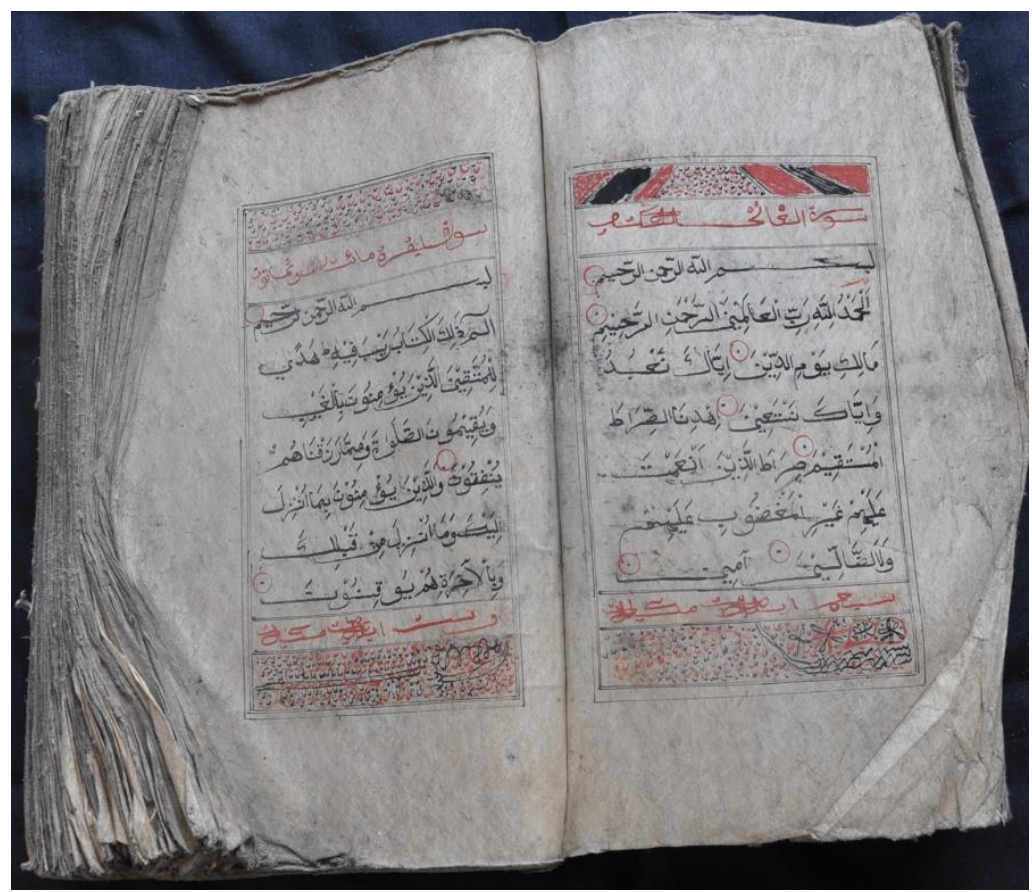

12041 BTLN AZIZ 412012 HLM 1,2 Img3372

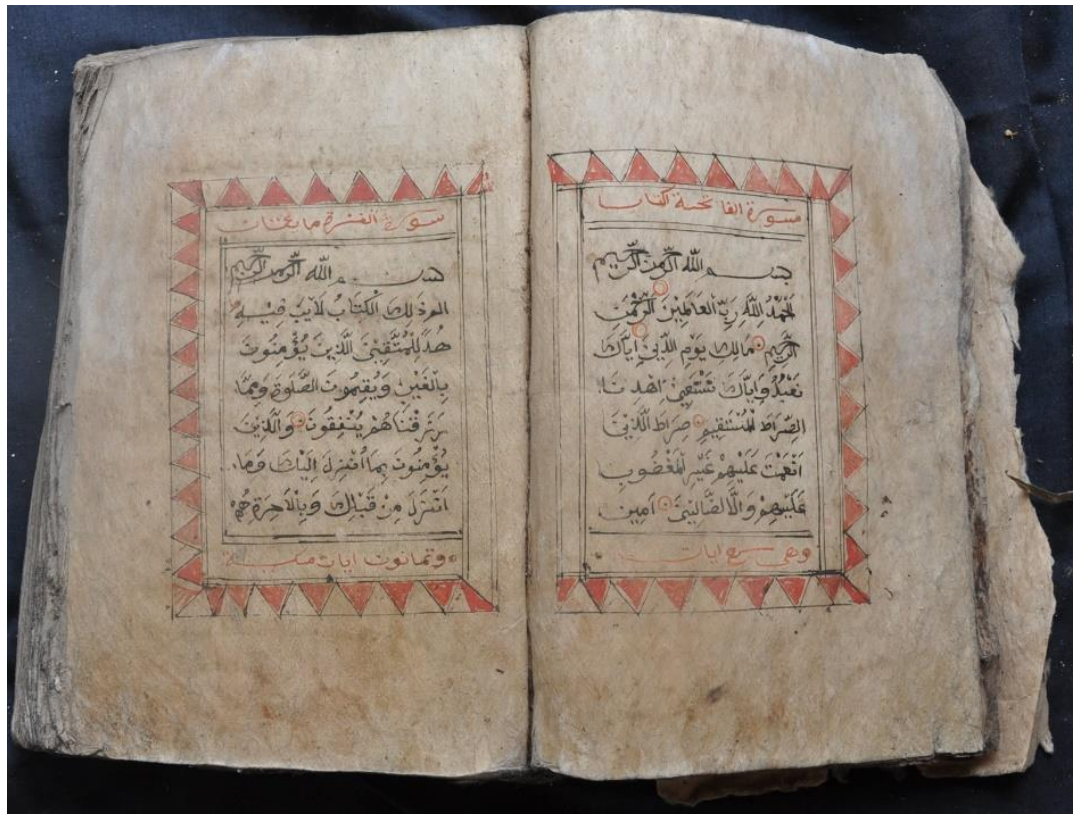

12042 BTLN MDN 422012 HLM 1,2 Img3878 


\begin{tabular}{|l|l|l|l|}
\hline $\begin{array}{l}\text { BLAS/SUM/16/AQ } \\
\text { /35 }\end{array}$ & $\begin{array}{l}\text { ALQURAN } \\
\text { SURAT AL- } \\
\text { BAQARAH }\end{array}$ & 1 & Alquran \\
\hline $\begin{array}{l}\text { SGG/FTHR/57/201 } \\
2\end{array}$ & Arab & Arab & Prosa \\
\hline $40 \mathrm{hlm}$. & 9 baris/hlm. & $24.5 \times 18$ & Kertas Daluwang \\
\hline Fathur & \\
\hline Sergang, Batu Putih & \\
\hline
\end{tabular}

Naskah ini merupakan bagian Alquran berisi surat al-Baqāah dengan makna gandul.

Naskah ini milik Fathur dari KH Shiddiq. Kondisi naskah mulai rusak, teks masih terbaca.

\begin{tabular}{|l|l|l|l|}
\hline $\begin{array}{l}\text { BLAS/SUM/16/AQ } \\
\text { /36 }\end{array}$ & ALQURAN & 1 & Alquran \\
\hline $\begin{array}{l}\text { SGG/DRYH/99/20 } \\
12\end{array}$ & Arab & Arab & Prosa \\
\hline $558 \mathrm{hlm}$. & 15 baris/hlm. & $31 \times 20.5$ & Kertas Daluwang \\
\hline Nyai Dzurriyah & & \\
\hline Sergang Batu Putih &
\end{tabular}

Naskah ini berisi Alquran surat al-Fatihah sampai Al-Nas.

Naskah ini berasal dari Nyai Dzuriyyah dari K. Abdul Ghaffar. Naskah cukup baik dan teks terbaca. 


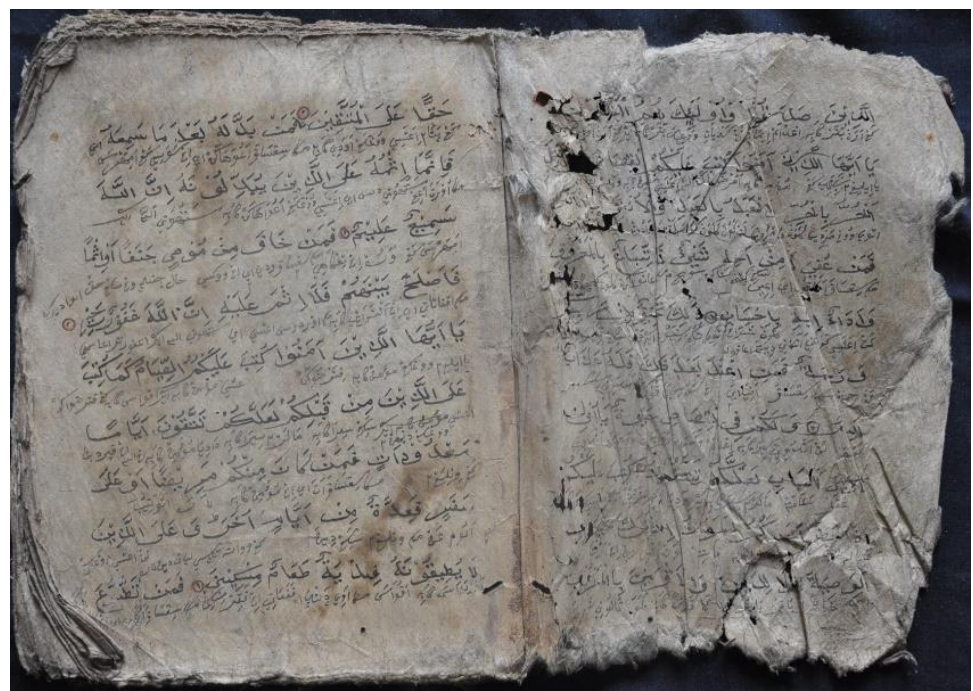

12058 SGG FTHR 572012 HLM 2,3 Img5285

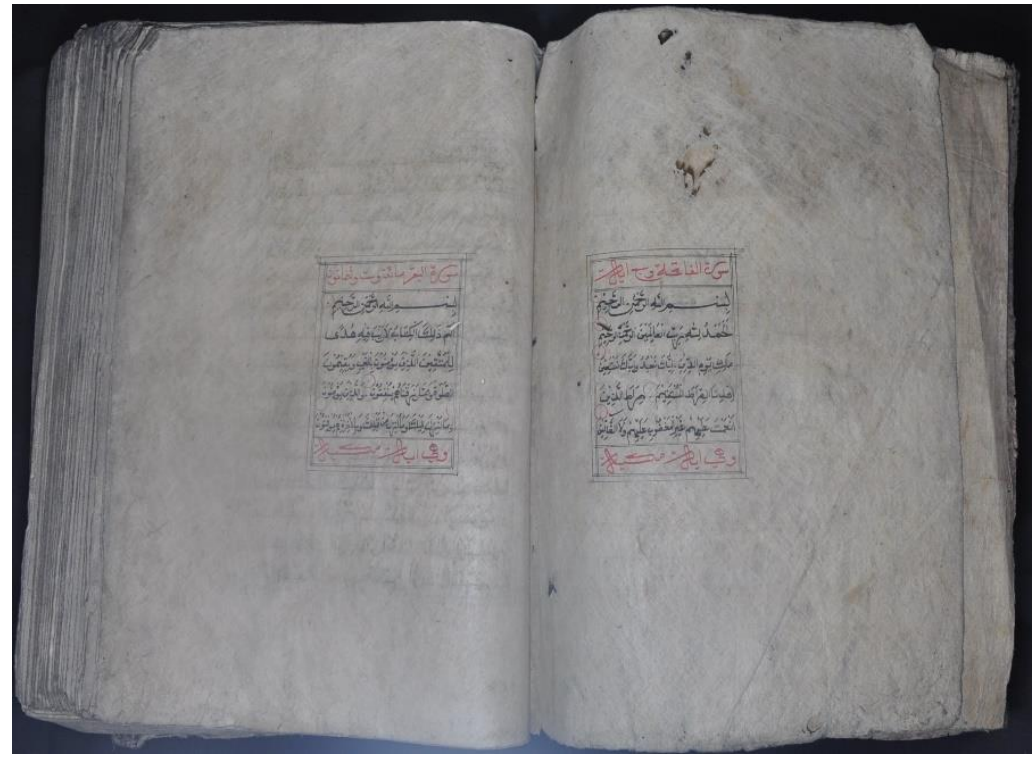

12100 SGG DRYH 992012 HLM 1,2 Img8764 


\begin{tabular}{|l|l|l|l|}
\hline $\begin{array}{l}\text { BLAS/SUM/16/AQ } \\
\text { /37 }\end{array}$ & $\begin{array}{l}\text { ALQURAN DAN } \\
\text { DOA }\end{array}$ & 1 & $\begin{array}{l}\text { Alquran dan Ilmu } \\
\text { Terkait }\end{array}$ \\
\hline $\begin{array}{l}\text { BTLN/MRWN/67/ } \\
2012\end{array}$ & Arab & Arab & Prosa \\
\hline $134 \mathrm{hlm}$. & 9 baris/hlm. & $21 \times 13.4$ & Kertas Daluwang \\
\hline Marwan & \\
\hline Bantilan, Batu Putih
\end{tabular}

Naskah ini terdiri dari dua teks. Teks pertama terdiri dari Alquran surat At-Taubah sampai surat As-Ṣaffat. Teks kedua tentang doa-doa.

Naskah ini milik Marwan dari Abdul Ghani. Kondisi naskah mulai rusak, teks masih terbaca.

\begin{tabular}{|l|l|l|l|}
\hline $\begin{array}{l}\text { BLAS/SUM/16/AQ } \\
\text { /38 }\end{array}$ & $\begin{array}{l}\text { KITAB TAFSIR } \\
\text { JUZ 28-30 }\end{array}$ & 1 & $\begin{array}{l}\text { Alquran dan Ilmu } \\
\text { Terkait }\end{array}$ \\
\hline $\begin{array}{l}\text { PJG } \\
\text { SGG/JMLD/93/201 } \\
2\end{array}$ & Arab & Arab & Prosa \\
\hline 172 hlm. & 13 baris/hlm. & $25 \times 16$ & Kertas Daluwang \\
\hline Jamaluddin & & \\
\hline \multicolumn{2}{|l}{ Pajung, Sergang, Batu Putih, Sumenep } \\
\hline
\end{tabular}

Teks ini merupakan sebuah tafsir Alquran yang ditulis mulai dari juz 28 sampai juz 30, yakni dimulai surat $\mathrm{Al}$ Fatihah dan berbagai surat Alquran yang diakhiri dengan surat an Nas.

Naskah ini berasal dari Jamaludin dari KH Abdul Aziz. Kondisi naskah mulai rusak, teks masih terbaca. 


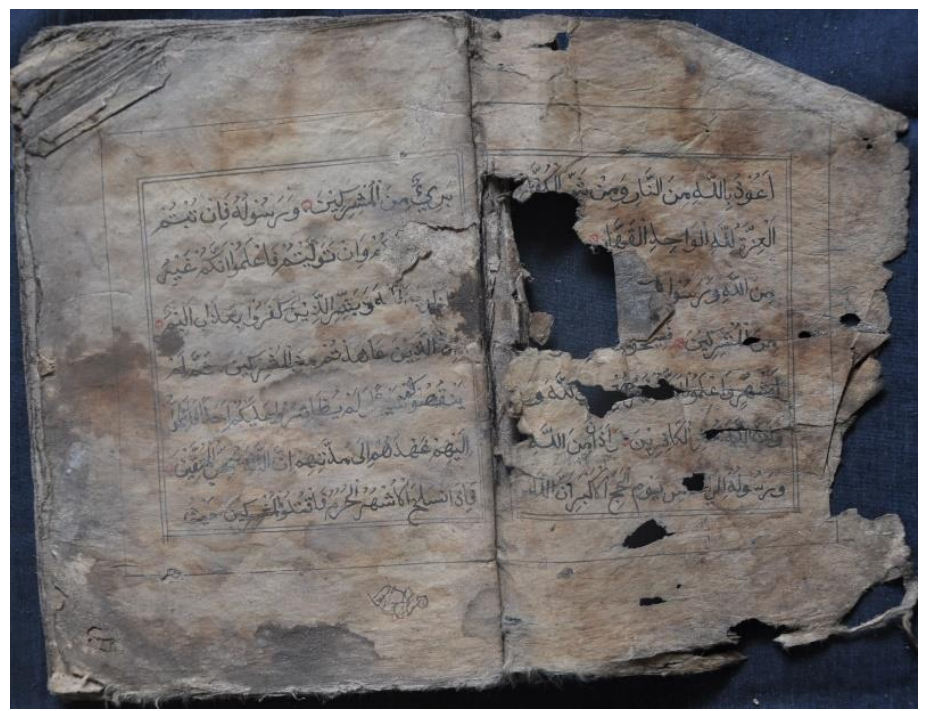

12068 BTLN MRWN 672012 HLM 2,3 Img5806

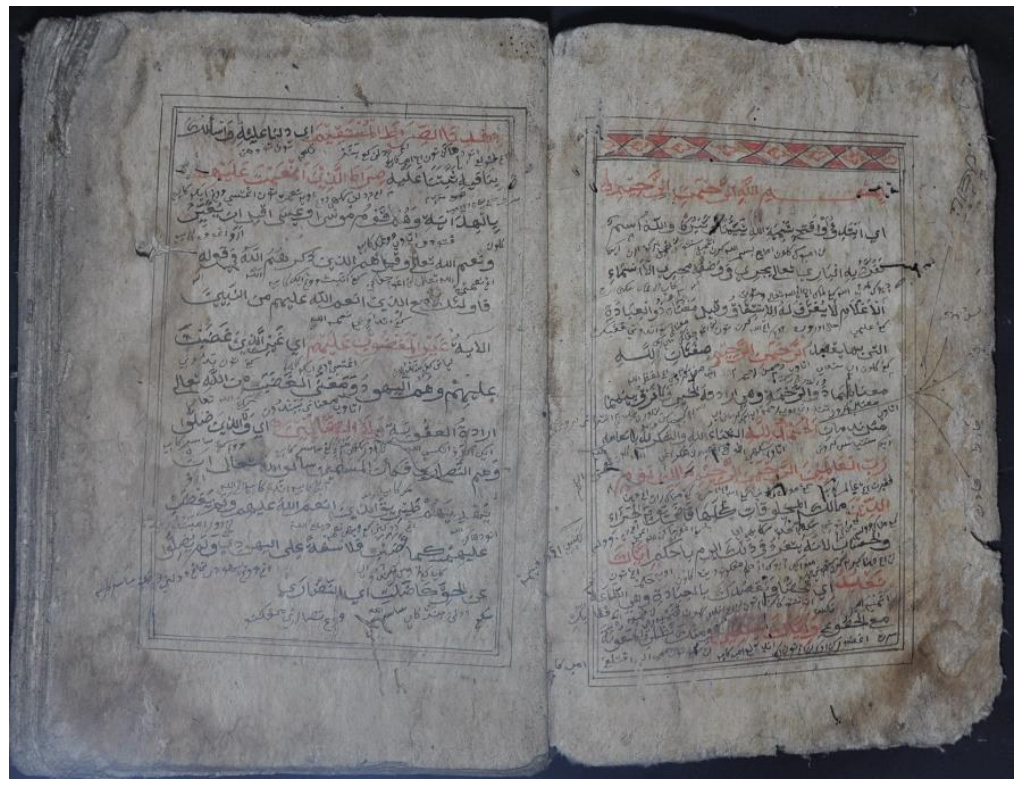

12094 PJGSGG JMLD 932012 HLM 1,2 Img7671 


\begin{tabular}{|l|l|l|l|}
\hline $\begin{array}{l}\text { BLAS/SUM/16/AQ } \\
\text { /38 }\end{array}$ & $\begin{array}{l}\text { KITAB TAFSIR } \\
\text { JUZ 28-30 }\end{array}$ & 1 & $\begin{array}{l}\text { Alquran dan Ilmu } \\
\text { Terkait }\end{array}$ \\
\hline $\begin{array}{l}\text { PJG } \\
\text { SGG/JMLD/93/201 } \\
2\end{array}$ & Arab & Arab & Prosa \\
\hline 172 hlm. & & Kertas Daluwang \\
\hline Jamaluddin & 13 baris/hlm. & $25 \times 16$ & \\
\hline \multicolumn{2}{|l}{ Pajung, Sergang, Batu Putih, Sumenep } \\
\hline
\end{tabular}

Teks ini merupakan sebuah tafsir Alquran yang ditulis mulai dari juz 28 sampai juz 30, yakni dimulai surat Al Fatihah dan berbagai surat Alquran yang diakhiri dengan surat an Nas.

Naskah ini berasal dari Jamaludin dari K.H. Abdul Aziz. Kondisi naskah mulai rusak, teks masih terbaca.

\begin{tabular}{|l|l|l|l|}
\hline $\begin{array}{l}\text { BLAS/SUM/16/AQ } \\
\text { /39 }\end{array}$ & $\begin{array}{l}\text { KITAB TAFSIR } \\
\text { ALQURAN }\end{array}$ & 1 & $\begin{array}{l}\text { Alquran dan Ilmu } \\
\text { Terkait }\end{array}$ \\
\hline $\begin{array}{l}\text { LCGPTR/KH/17/2 } \\
012\end{array}$ & Arab & Arab & Prosa \\
\hline 256 hlm. & 5 s.d. 7 baris/hlm. & & Kertas Daluwang \\
\hline K.H. Kholil & \\
\hline Lambi Cabi, Gapura Tengah, Gapura & \\
\hline
\end{tabular}

Naskah ini berisi 4 teks, pertama Alquran yang sudah diberi makna dengan aksara pegon, kedua tafsir Alquran, ketiga Alquran makna gandul, dan keempat ilmu nạhwu.

Naskah ini tersimpan di rumah K.H. Kholil. Naskah cukup baik, teks terbaca. 


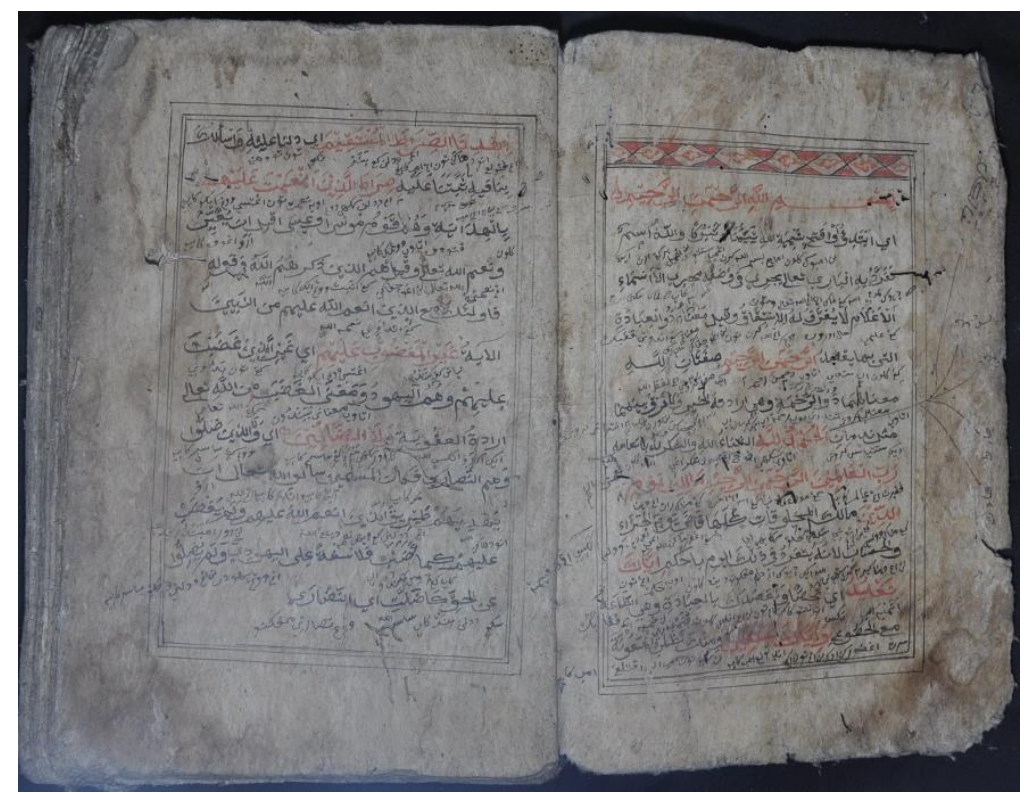

12094 PJGSGG JMLD 932012 HLM 1,2 Img7671

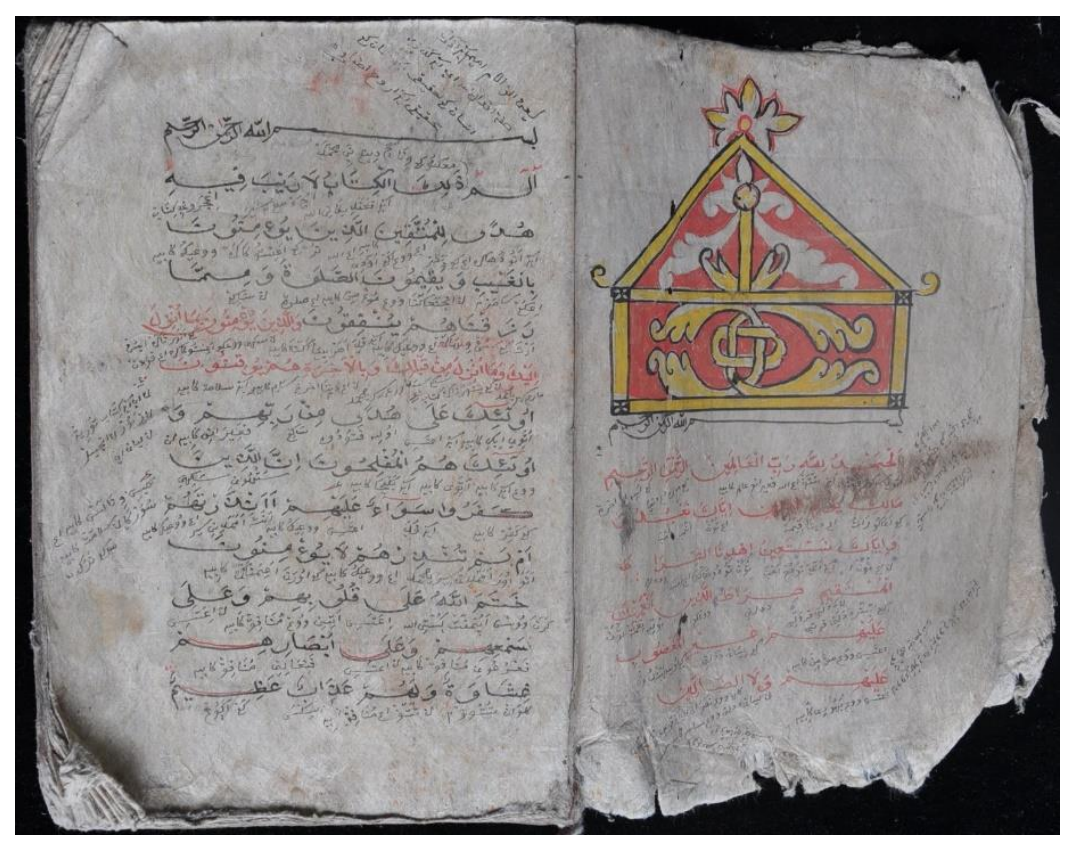

12017 LCGPTR KH 172012 HLM 1Img0880 


\begin{tabular}{|l|l|l|l|}
\hline $\begin{array}{l}\text { BLAS/SUM/16/AQ } \\
\text { /40 }\end{array}$ & $\begin{array}{l}\text { KITAB FADILAH } \\
\text { ALQURAN }\end{array}$ & 1 & $\begin{array}{l}\text { Alquran dan Ilmu } \\
\text { Terkait }\end{array}$ \\
\hline GPR 8 & Arab, Jawa & Arab, Arab pegon & prosa \\
\hline 207 hlm. & 15 baris/hlm. & $20.1 \times 14.5$ & Kertas berserat \\
\hline Kiai Maduki & \\
\hline \multicolumn{2}{|l|}{ Gapura Barat, Gapura, Sumenep } \\
\hline
\end{tabular}

Naskah ini berisi beberapa pasal. Pasal 1 menjelaskan keutamaan diturunkan Alquran dan manfaat membacanya yang disertai dengan hadis dan hikayat-hikayat. Pasal 2 keutamaan ilmu, orang berilmu akan meningkat beberapa derajat di dunia dan akhirat. Pasal 3 ketetapan saki. Pasal 4 tentang keagungan Allah.

Naskah ini dikoleksi oleh Kiai Masduki Gapura, Kabupaten Sumenep

\begin{tabular}{|c|c|c|c|}
\hline $\begin{array}{l}\text { BLAS/SUM/16/AQ } \\
\text { /41 }\end{array}$ & $\begin{array}{l}\text { KITAB TAFSIR } \\
\text { ALI IMRAN }\end{array}$ & 1 & $\begin{array}{l}\text { Alquran dan Ilmu } \\
\text { Terkait }\end{array}$ \\
\hline BT-BT 28 & Arab & Arab & Prosa \\
\hline 36 hlm. & 13 baris/hlm. & $20 \times 13.5$ & Kertas Daluwang \\
\hline \multicolumn{4}{|l|}{ H. Ahmad } \\
\hline
\end{tabular}

Naskah ini merupakan tafsir Alquran, surat Ali Imran ayat 9 sampai ayat 53.

Naskah ini dimiliki oleh H. Ahmad (menantu) dari Rumi dari Abdul Hadi. Tahun dan tempat penyusunan tidak disebutkan, nama penyalin Abdul Hadi. Kondisi naskah rusak, tetapi masih dapat dibaca. Tinta menggunakan warna hitam dan merah. 


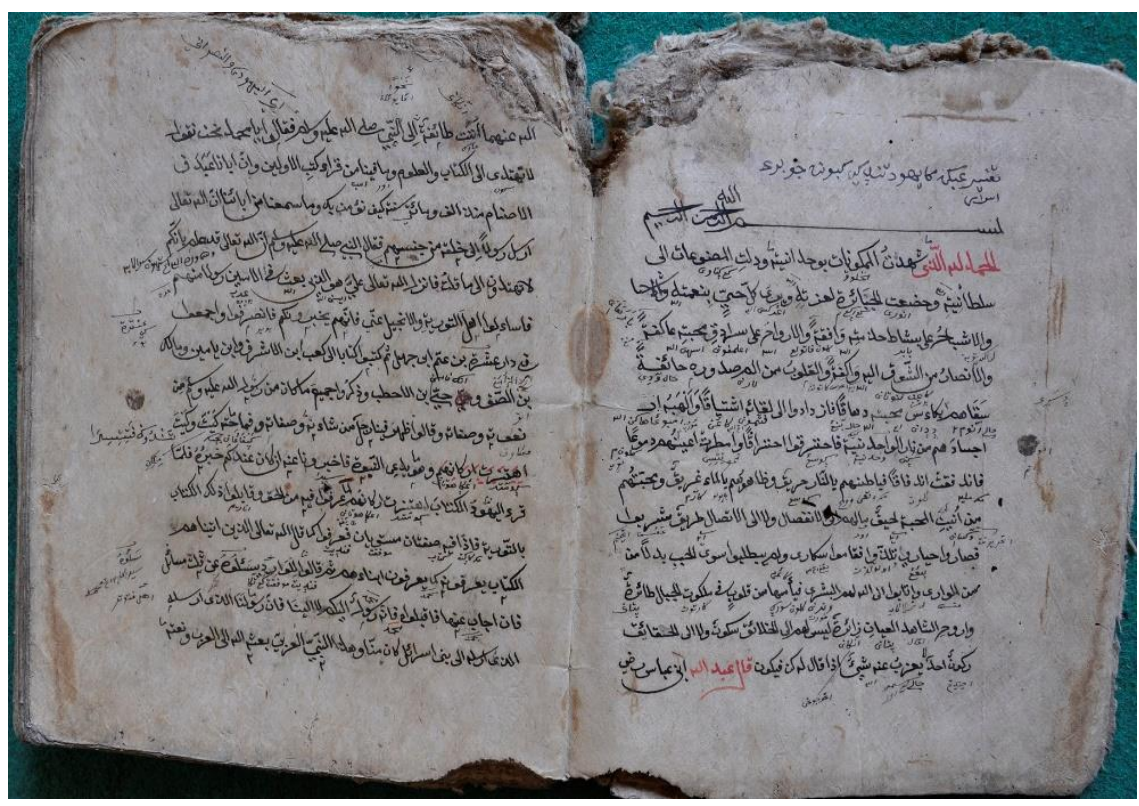

1008 GPR 08 _DSC0004

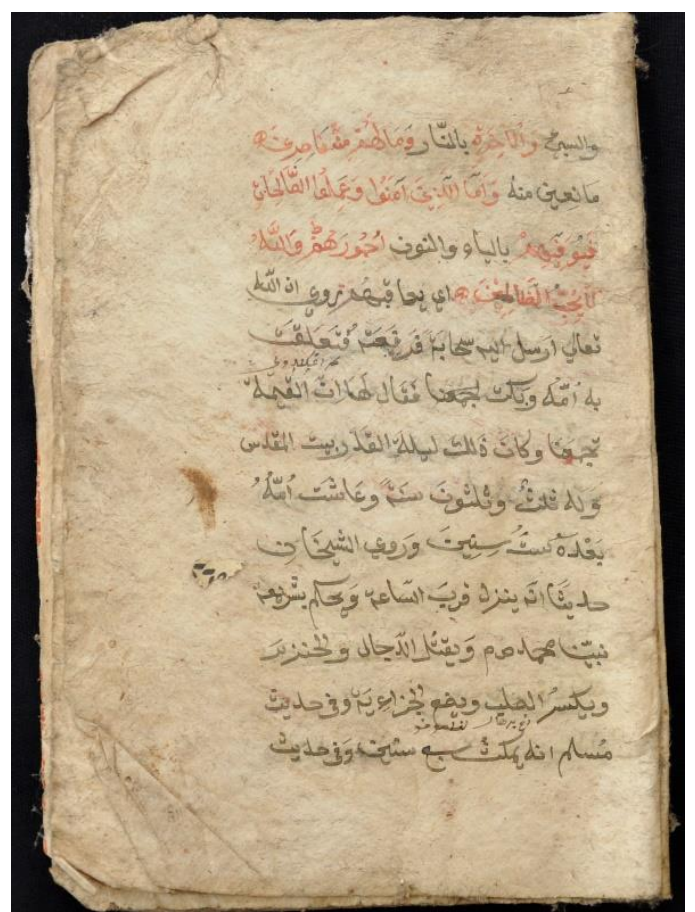

1158 BTBT 28 HLM 1_DSC0001 


\begin{tabular}{|l|l|l|l|}
\hline $\begin{array}{l}\text { BLAS/SUM/16/AQ } \\
\text { /42 }\end{array}$ & $\begin{array}{l}\text { KITAB JUZ 30, } \\
\text { TAHLIL, DAN } \\
\text { DOA }\end{array}$ & 1 & $\begin{array}{l}\text { Alquran dan Ilmu } \\
\text { Terkait }\end{array}$ \\
\hline BT-BT 31 & Arab & Arab & Prosa \\
\hline $80 \mathrm{hlm}$. & 7 baris/hlm. & $19 \times 14$ & Kertas Daluwang \\
\hline H. Ahmad & \\
\hline Dusun Nyabungan, Jenangger, Batang-Batang. \\
\hline
\end{tabular}

Naskah ini berisi Surat pendek juz 30, tahlil, dan inti surat.

Naskah ini dimiliki oleh H. Ahmad dari Rumi dari Abdul Hadi. Tahun dan tempat penyusunan tidak disebutkan. Kondisi naskah baik. Tinta menggunakan warna hitam.

\begin{tabular}{|l|l|l|l|}
\hline $\begin{array}{l}\text { BLAS/SUM/16/AQ } \\
\text { /43 }\end{array}$ & $\begin{array}{l}\text { KITAB TAHLIL } \\
\text { DAN DOA }\end{array}$ & 1 & $\begin{array}{l}\text { Alquran dan Ilmu } \\
\text { Terkait }\end{array}$ \\
\hline BT-BT 32 & Arab & Arab & Prosa \\
\hline 46 hlm. & 7 baris/hlm. & $13.5 \times 9$ & Kertas Daluwang \\
\hline H. Ahmad \\
\hline \multicolumn{2}{|l}{ Dusun Nyabungan, Jenangger, Batang-Batang. } \\
\hline
\end{tabular}

Naskah ini berisi tahlil dan doa.

Naskah ini dimiliki oleh H. Ahmad dari Rumi dari Abdul Hadi. Tahun dan tempat penyusunan tidak disebutkan, nama penyalin disebutkan Abdul Hadi. Kondisi naskah rusak, masih dapat dibaca. Tinta menggunakan warna hitam. 


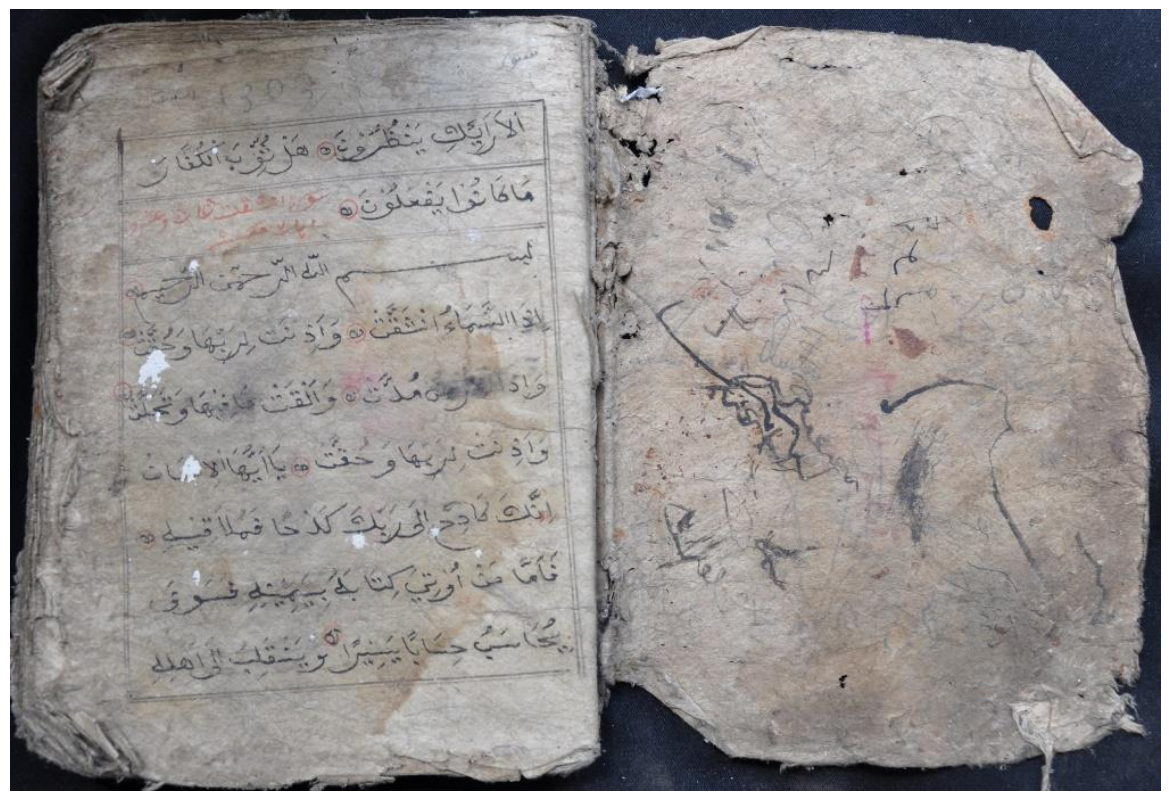

1161 BTBT 31 HLM 1 DSC_0154

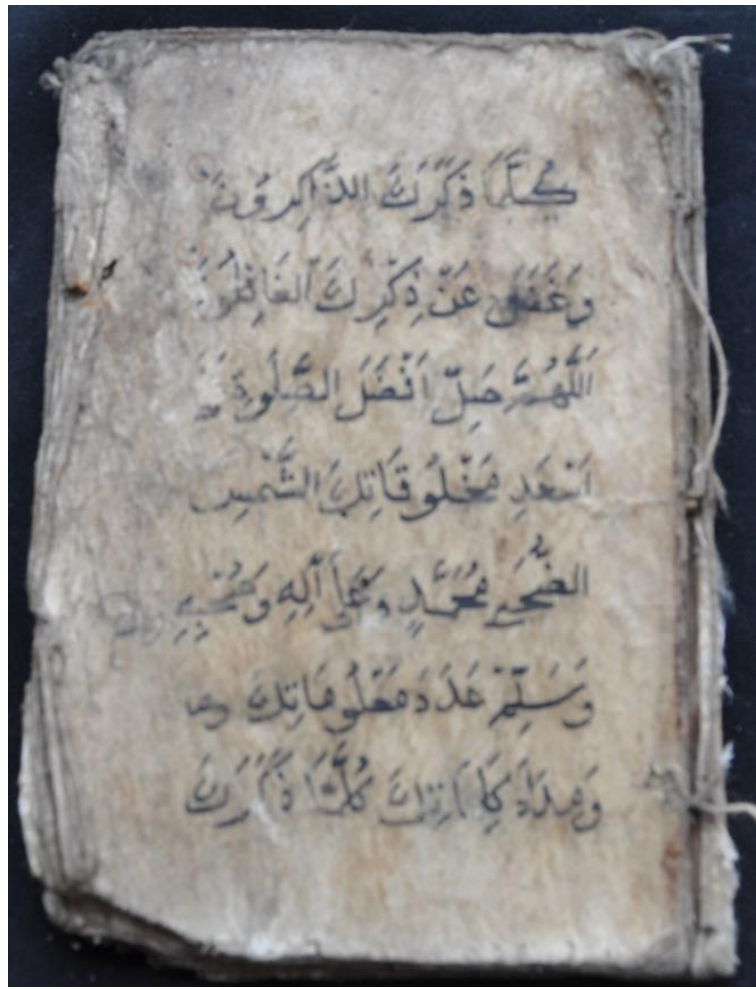

1162 BTBT 32 HLM 1 DSC_0202 


\begin{tabular}{|l|l|l|l|}
\hline $\begin{array}{l}\text { BLAS/SUM/16/AQ } \\
\text { /44 }\end{array}$ & $\begin{array}{l}\text { TAFSIR KITAB } \\
\text { ALQURAN }\end{array}$ & 1 & $\begin{array}{l}\text { Alquran dan Ilmu } \\
\text { terkait }\end{array}$ \\
\hline $\begin{array}{l}\text { GPRB/UKL/35/201 } \\
2\end{array}$ & Arab & Arab & Prosa \\
\hline $332 \mathrm{hlm}$. & 19 baris/hlm. & $28 \times 19$ & Kertas Daluwang \\
\hline Nyai Ummi Kulssum & \\
\hline \multicolumn{2}{|l}{ Talesek, Gapura Barat, Gapura } \\
\hline
\end{tabular}

Teks berisi penjelasan tentang tafsir Kitab Alquran.

Naskah ini merupakan tafsir Kitab Alquran tanpa makna gandul/jenggot. Bagian depan dan belakang naskah ini banyak yang hilang. Tafsir ini tanpa penjelasan.

Naskah ini milik Nyai Ummi Kulsum dari Nyai Aisyah dari K Abdul Aziz.

\begin{tabular}{|l|l|l|l|}
\hline $\begin{array}{l}\text { BLAS/SUM/16/AQ } \\
\text { /45 }\end{array}$ & $\begin{array}{l}\text { TAFSIR } \\
\text { ALQURAN }\end{array}$ & $\mathbf{1}$ & $\begin{array}{l}\text { Alquran dan Ilmu } \\
\text { terkait }\end{array}$ \\
\hline $\begin{array}{l}\text { SGG/DRYH/48/20 } \\
12\end{array}$ & Arab & Arab & Prosa \\
\hline $290 \mathrm{hlm}$. & 9 baris/hlm. & $24 \times 17$ & Kertas Daluwang \\
\hline Nyai Dzurriyah & & \\
\hline Sergang, Batu putih
\end{tabular}

Naskah ini berisi tafsir surat-surat dalam Kitab Alquran dan doa khatmil Qur'an lengkap.

Keterangan lebih rinci dari teks ini, teks tafsir ini telah diberi makna gandul/ jenggotan. Surat-surat Kitab Alquran yang disebutkan disini yakni S. Al-Fatihah, S. Yusuf, S. Al-Tanzil, S. Sahabat, S. Al-Munafiqun, S. Al-Hijr, S. At-Ṭalaq, S. AtTahrim, S. Al-Mulk, S. Al-Qalam, S. Al-Haqqah, S. Nuh, S. Al-Jin, S. Al-Muzammil, S. Al-Qiyamat, dan juz 30 dari Juz Amma.

Naskah ini milik Nyai Dzuriyah dari K.H. Asyhari. Kondisi naskah mulai rusak, teks masih terbaca. 


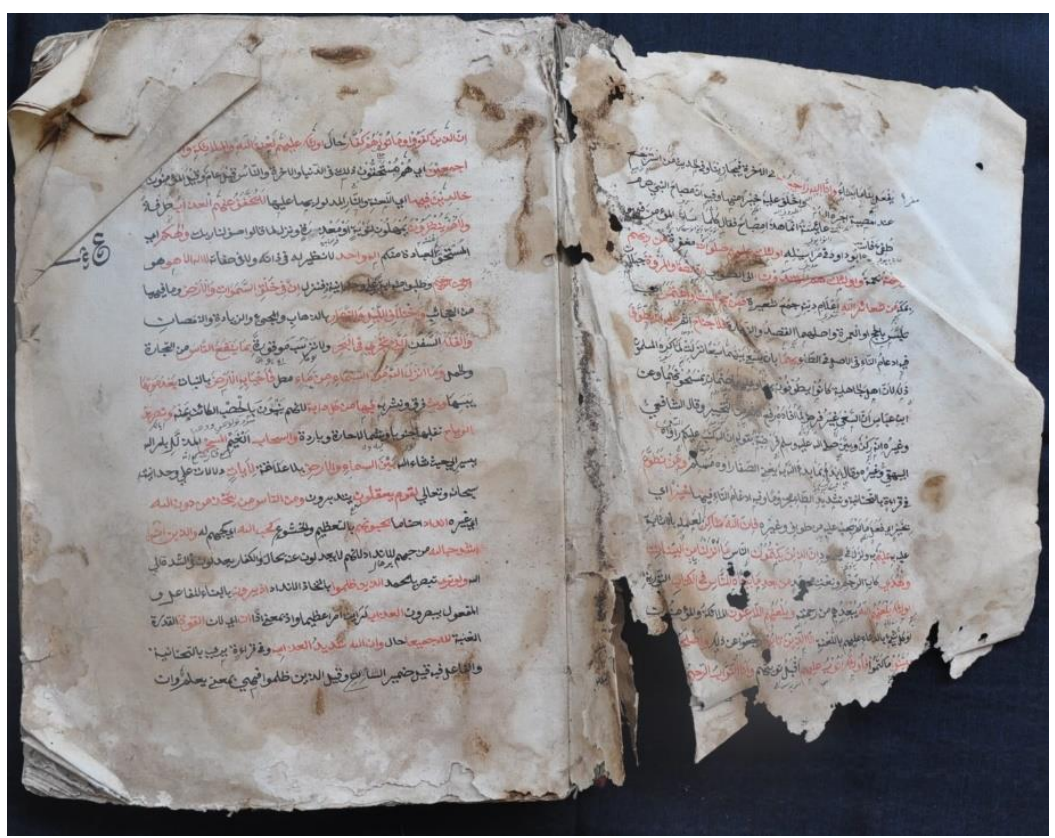

12035 GPRB UKL 352012 HLM 2,3 Img2946

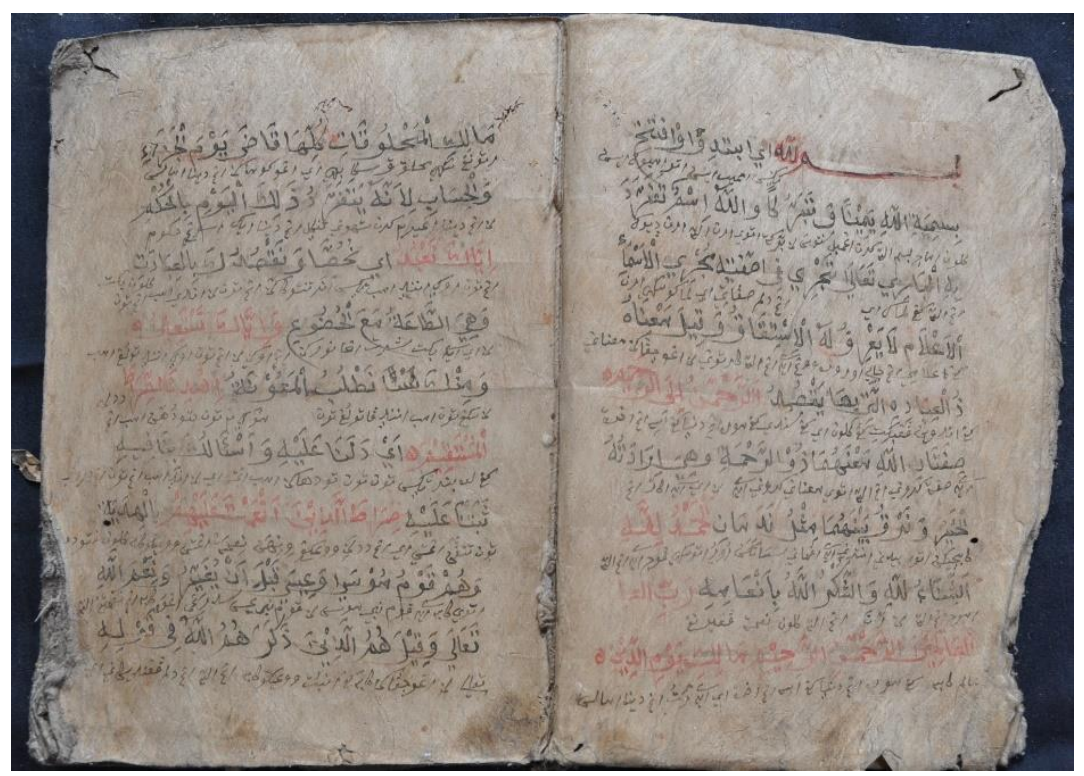

12048 SGG DRYH 482012 HLM 1,2 Img4619 


\section{HD}

\section{Hadits dan Ilmu yang Berkaitan}

\begin{tabular}{|l|l|l|l|l|}
\hline $\begin{array}{l}\text { BLAS/SUM/16 } \\
\text { /HD/1 }\end{array}$ & $\begin{array}{l}\text { KITAB } \\
\text { RISALAH } \\
\text { MUDHAKAR } \\
\text { AH DAN } \\
\text { LAIN-LAIN }\end{array}$ & 2 & $\begin{array}{l}\text { Hadits, dan } \\
\text { Tasawuf }\end{array}$ \\
\hline $\begin{array}{l}\text { BTLN/ALWI/8 } \\
2 / 2012\end{array}$ & Arab & Arab & Prosa \\
\hline $104 \mathrm{hlm}$. & 5 baris/hlm. & $20 \times 15$ & $\begin{array}{l}\text { Kertas } \\
\text { Daluwang }\end{array}$ \\
\hline & K.H. Alwi & \\
\hline & Bantilan, Pajung, Batu Putih, Sumenep & \\
\hline
\end{tabular}

Naskah ini berisi tiga teks. Teks pertama bernama Risalah Mużakarah selesai ditulis malam Jumat setelah isya 12 Rajab 1289 H/1872 M. Teks ini menjelaskan makna-makna doa. Kemudian teks kedua yang disusun oleh Shodri selesai pada waktu isya hari Selasa tanggal 12 Rabiul Awal 1289 H/1872 M. Naskah ini bernama Hadis Mautin Nabi yang menjelaskan tentang kalimat la ilaa ha illallah. Kalimat ini banyak sekali faedahnya antara lain bila seseorang akan disesatkan orang lain ia tidak akan tersesat. Teks ketiga bernama Fadilana majlisi taklim, teks ini menjelaskan tentang suasana ketika di belakang jamaah bersama Rasulullah ada yang meminta izin untuk masuk dalam jamaah, Rasul menjawab itu adalah iblis yang dilaknat oleh Allah SWT.

Naskah ini berasal dari K.H. Alwi dari K.H. Syafi'udin dari K.H. Syarkawi (sepuh). Tahun penyusunan, penulisan tidak disebutkan. Kondisi kitab pada bagian tengah bawah terbakar sedikit namun masih bisa dibaca.

\begin{tabular}{|l|l|l|l|}
\hline $\begin{array}{l}\text { BLAS/SUM/16/HD } \\
/ 2\end{array}$ & $\begin{array}{l}\text { KITAB HADITS } \\
\text { NURBUAT }\end{array}$ & 2 & Hadits, Sejarah \\
\hline $\begin{array}{l}\text { SGG/DRYH/43/20 } \\
12\end{array}$ & Jawa & Arab Pegon & Prosa \\
\hline 100 hlm. & $\begin{array}{l}11 \text { s.d } 15 \\
\text { baris/hlm. }\end{array}$ & $19.5 \times 14$ & Kertas Daluwang \\
\hline Nyai Dzurriyat & \multicolumn{2}{|l}{} \\
\hline Sergang, Batu Putih
\end{tabular}

Teks berisi tentang tugas para nabi, malaikat, dan sebagainya. 
Ciri khas naskah ini adalah semacam bacaan al-Barzanji yang ditulis dalam bentuk macapat.

Naskah ini milik Nyai Dzurriyah. Kondisi naskah mulai rusak, teks masih terbaca.

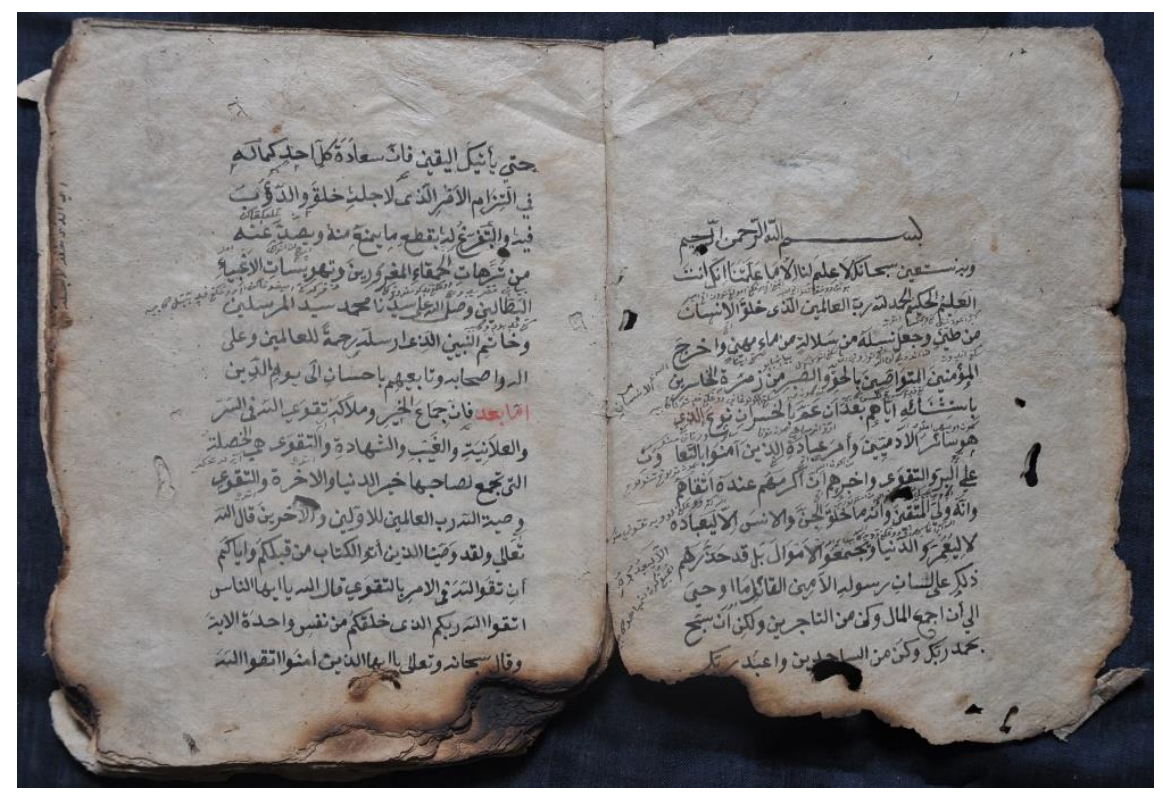

12083 BTLN ALWI 822012 HLM 1,2 Img6765

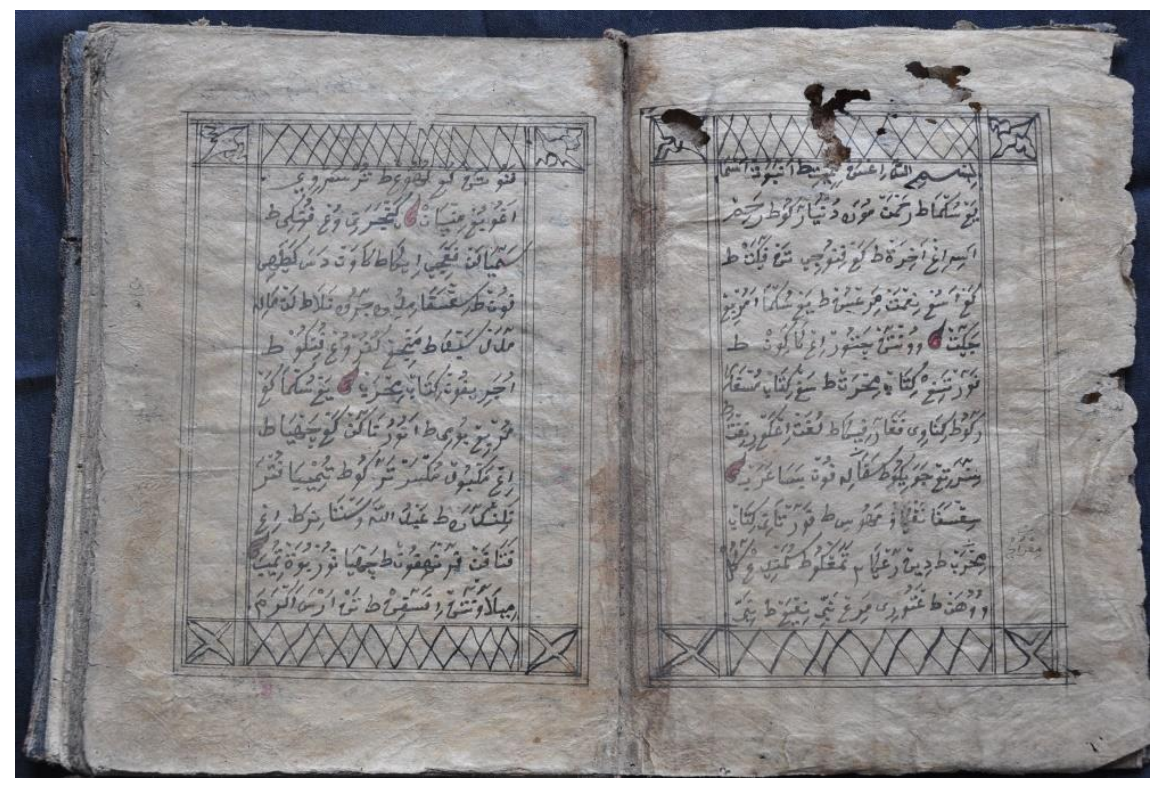

12043 SGG DRYH 432012 HLM 1,2 Img4182 


\begin{tabular}{|l|l|l|l|}
\hline $\begin{array}{l}\text { BLAS/SUM/16/HD } \\
/ 3\end{array}$ & $\begin{array}{l}\text { KITAB HADITS } \\
\text { NURBUAT }\end{array}$ & 2 & Hadits, Sejarah \\
\hline $\begin{array}{l}\text { SGG/DRYH/44/20 } \\
12\end{array}$ & Jawa & Arab Pegon & Prosa \\
\hline 168 hlm. & 7 baris/hlm. & $18.4 \times 14.7$ & Kertas Daluwang \\
\hline Nyai Dzurriyah & \multicolumn{2}{|l}{} \\
\hline Sergang, Batu Putih
\end{tabular}

Naskah disusun berdasarkan piwulang dari seorang guru bernama Bapak Tamsikin. Teks berisi tentang tugas para nabi, malaikat, dan sebagainya.

Naskah ini ditulis pada 17 Rabi'ul Awal Tahun Bak, Hari Kamis, 1300 H/1882 M dan selesai ditulis pada tanggal 27 Jumadil Akhir pada hari Rabu

Naskah ini milik Nyai Dzurriyah. Kondisi naskah mulai rusak, teks masih terbaca.

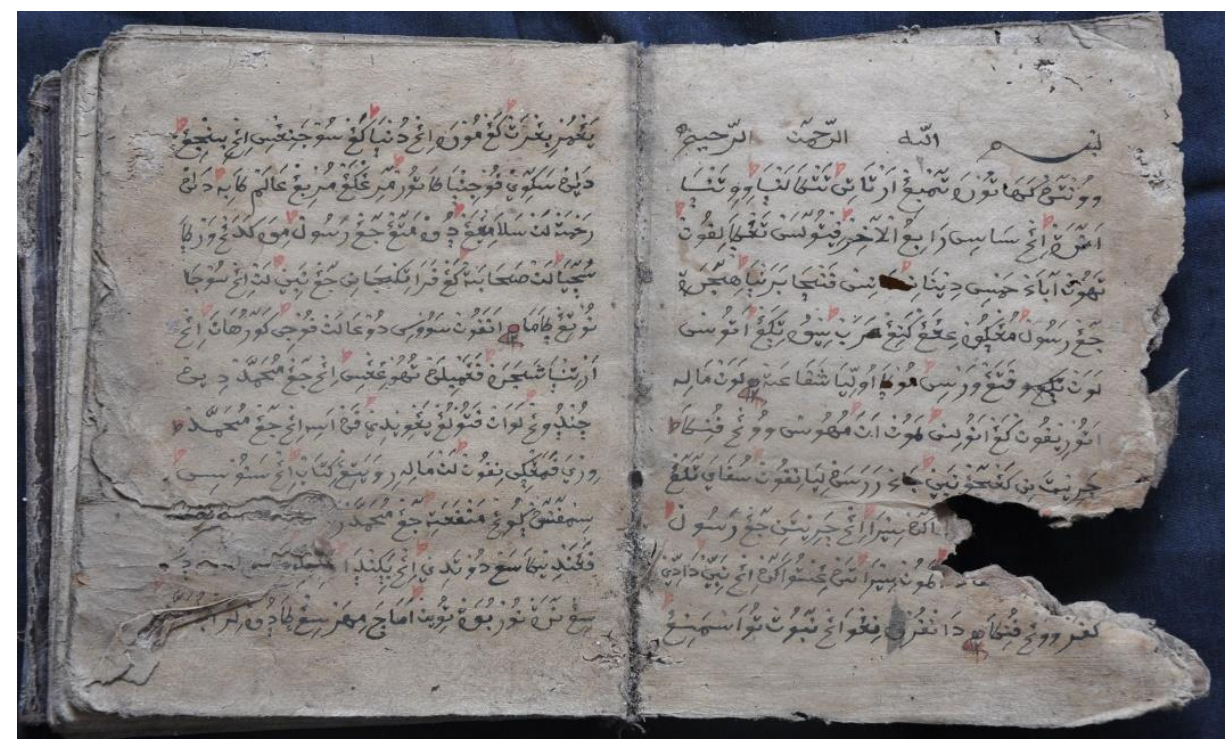

.12044 SGG DRYH 442012 HL M 1,2 Img4234 


Akaid dan Ilmu Kalam
\begin{tabular}{|l|l|l|l|}
\hline $\begin{array}{l}\text { BLAS/SUM/16/AK } \\
\text { /1 }\end{array}$ & KITAB TAUHID & $\mathbf{3}$ & Akaid \\
\hline SMN 2 & & & \\
\hline 412 hlm. & Arab & Arab & prosa \\
\hline Kiai Said Abdullah & & $20 x 13$ & Kertas () \\
\hline PP Matholiul Anwar Pengarangan Sumenep & \\
\hline
\end{tabular}

Kitab ini karya Muhamad Ibnu Yusuf As Sanusi Al Hasani. Berisi tentang ilmu akidah, penjelasannya dimulai dari masalah 'puji'. Puji dibagi kedalam 4 macam, kemudian dilanjutkan dilanjutkan dengan masalah akal, sifat wajib 20 macam, dan sifat muhal.

Naskah dimiliki oleh Kiai Sa'id Abdullah, Pengarangan Sumenep. Kondisi naskah masih cukup baik walau tulisan di beberapa hlaman tintanya mulai memudar. 


\begin{tabular}{|l|l|l|l|}
\hline $\begin{array}{l}\text { BLAS/SUM/16/AK } \\
\text { } 2\end{array}$ & KITAB ŻURAH & 3 & Akaid \\
\hline GPR 15 & Arab, Jawa Pegon & Arab & Prosa \\
\hline 24 hlm. & 7 baris/hlm. & $21.3 \times 17$ & Kertas Eropa \\
\hline Fatony Ahmad & \\
\hline Dusun Talesek, Gapura Barat, Gapura, Sumenep \\
\hline
\end{tabular}

Naskah berisi pembahasan tentang aqaid 50 .

Naskah berasal dari Fatony Ahmad dari Haji Abdurrachman (kakek dari Fatony Ahmad). Naskah bersampul kertas tipis warna cokelat, dan teks ditulis menggunakan tinta hitam dan merah. Pada sampul naskah terdapat tulisan; "hamdulillahi rabbil 'alamin wabihi nasta'inu 'ala umuriddunya waddin'. Kondisi naskah dalam keadaan rusak namun tulisan masih bisa dibaca.

\begin{tabular}{|l|l|l|l|}
\hline $\begin{array}{l}\text { BLAS/SUM/16/AK } \\
\text { 3 }\end{array}$ & KITAB TAUHID & 3 & Akaid \\
\hline GPR 22 & Arab, Jawa Pegon & Arab & Puisi, Prosa \\
\hline $216 \mathrm{hlm}$. & 17 baris/hlm. & $27.5 \times 19.5$ & Kertas Daluwang \\
\hline Fatony Ahmad \\
\hline \multicolumn{2}{|l}{ Dusun Talesek, Gapura Barat, Gapura, Sumenep } \\
\hline
\end{tabular}

Naskah berisi beberapa teks. Teks pertama tentang pengetahuan Islam dan Iman dengan penjelasan tata bahasanya (nahwu saraf-nya). Teks kedua, tentang tauhid. Teks ketiga, salinan dari kitab syarah "Umul Barahin" yakni kitab tentang tauhid. Teks keempat, tentang tauhid. Teks kelima, Layang Sukma berisi 50 pasal/bab, diantaranya bercerita tentang siksa kubur.

Naskah berasal dari Fatony Ahmad dari H. Abdurrahman (kakek dari Fatony Ahmad). Teks ini berbahasa Jawa dan beraksara Arab (pegon). Teks ditulis menggunakan tinta hitam dan tinta merah untuk penjelas. Kondisi fisik naskah dalam keadaan baik dan tulisan masih bisa dibaca. 


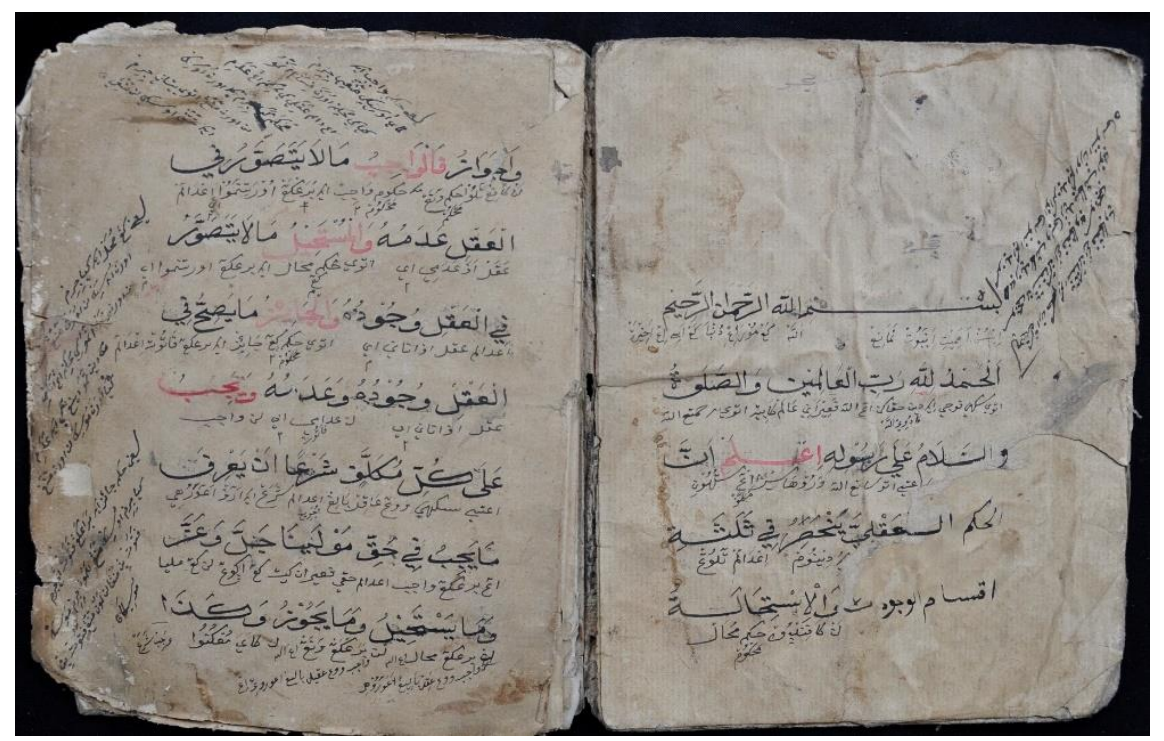

1101 GPR 15 HLM 2,3_DSC0126

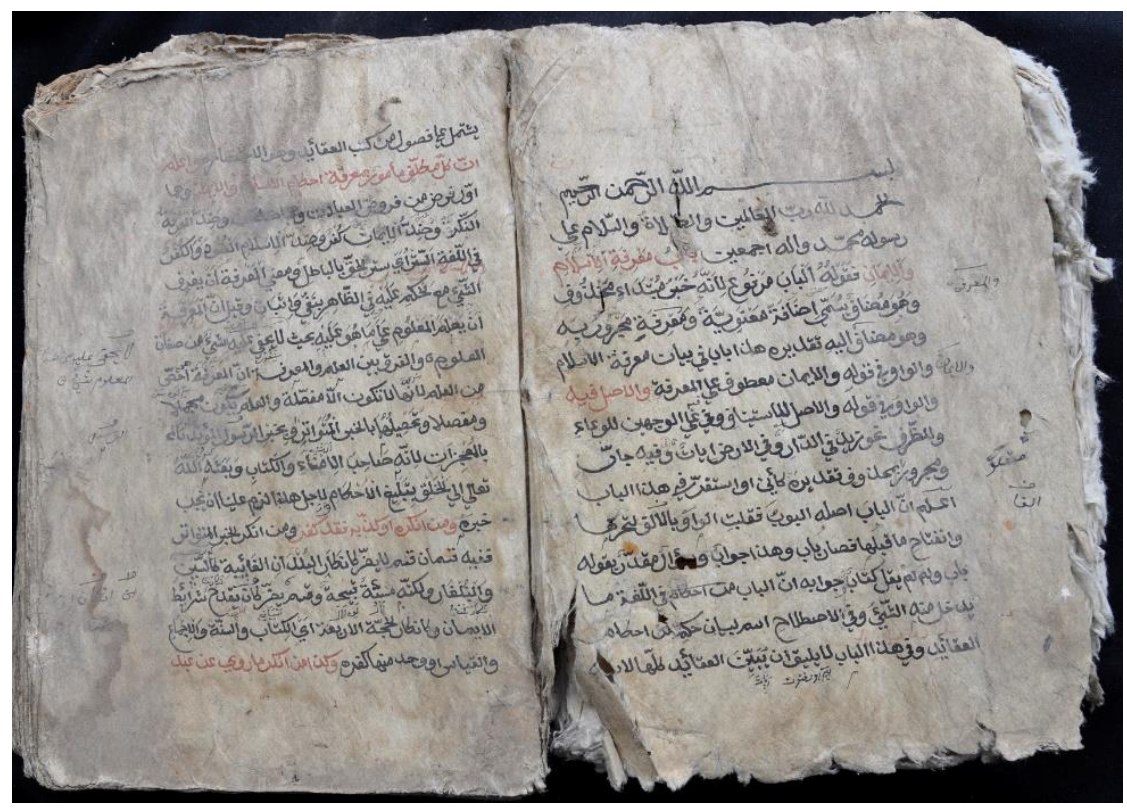

1108 GPR 22 HLM 2,3_DSC0190 


\begin{tabular}{|l|l|l|l|}
\hline $\begin{array}{l}\text { BLAS/SUM/16/AK } \\
\text { /4 }\end{array}$ & $\begin{array}{l}\text { KITAB AQAID } \\
\text { MADURA }\end{array}$ & $\mathbf{3}$ & Akaid \\
\hline GDG 1 & Madura & Arab & Prosa \\
\hline 18 hlm. & 14 baris/hlm. & $20 \times 16$ & Kertas Eropa \\
\hline Kiai Fayad/Nyai Zainab & \\
\hline \multicolumn{2}{|l|}{ Pesantren Karai, Karai Gending, Sumenep } \\
\hline
\end{tabular}

Naskah berisi tentang materi tauhid, Aqaid Madura. Naskah dikarang oleh Nyai Aisyah dan disalin oleh Nyai Zainab pada tahun 1981.

Naskah berasal dari Nyai Zainab dari Nyai Farhah, dari Nyai Rahbiyah, dari Nyai Aisyah selaku penulis. Teks naskah ditulis menggunakan tinta hitam, tanpa sampul, tanpa penomoran halaman dengan tulisan "Andrea Porden". Kondisi naskah dalam keadaan baik dan tulisan masih bisa dibaca.

\begin{tabular}{|l|l|l|l|}
\hline $\begin{array}{l}\text { BLAS/SUM/16/AK } \\
\text { /5 }\end{array}$ & $\begin{array}{l}\text { KITAB AQAID } \\
\text { MADURA }\end{array}$ & 3 & Akaid \\
\hline GDG 3 & Arab, Madura & Arab & Prosa \\
\hline 18 hlm. & 14 baris/hlm. & $20 \times 16$ & Kertas \\
\hline Kiai Fayad/Nyai Zainab & \\
\hline \multicolumn{2}{|l|}{ Pesantren Karai, Karai Gending, Sumenep } \\
\hline
\end{tabular}

Naskah berisi tentang tarekat Naqsabandiyah. Pada awal teks dijelaskan tentang adab/tata cara dalam melaksanakan ritual tarekat Naqsabandiyah, seperti wudu, duduk menghadap kiblat, diawali dengan membaca istigfar dilanjutkan dengan bacaan-bacaan lainnya.

Naskah berasal dari Nyai Zainab. Teks ditulis menggunakan tinta hitam. Kondisi naskah dalam keadaan baik dan tulisan masih bisa dibaca. 


\begin{tabular}{|l|l|l|l|}
\hline $\begin{array}{l}\text { BLAS/SUM/16/AK } \\
\text { /6 }\end{array}$ & KITAB TAUHID & 3 & Akaid \\
\hline BT-BT 2 & Arab & Arab & Prosa \\
\hline 244 hlm. & 7 baris/hlm. & $23.5 \times 16$ & Kertas Daluwang \\
\hline Kiai Muchtar & \\
\hline Dusun Laok Saba, Nyabakan Timur, Batang-Batang, Sumenep \\
\hline
\end{tabular}

Naskah berisi tentang tauhid, iman dan Islam.

Naskah berasal dari Kiai Muchtar dari Kiai Mustaqim dari Kiai Siwallah dari Kiai Biramah. Teks ditulis menggunakan tinta hitam. Kondisi naskah dalam keadaan baik, dan tulisan masih bisa dibaca.

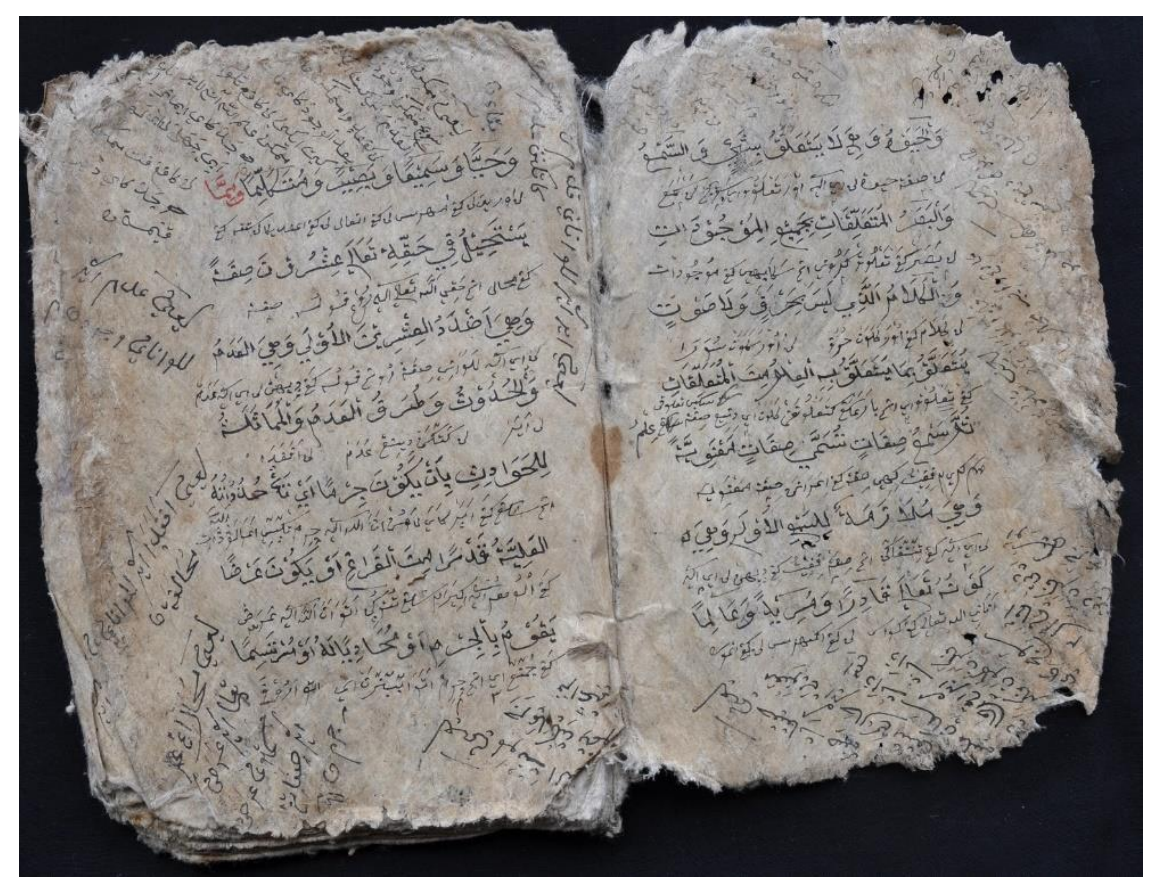

1132 BTBT 02 HLM 2,3 DSC_0127 


\begin{tabular}{|l|l|l|l|}
\hline $\begin{array}{l}\text { BLAS/SUM/16/AK } \\
\text { /7 }\end{array}$ & KITAB TAUHID & 3 & Akaid \\
\hline BT-BT 3 & Arab, Jawa Pegon & Arab & Prosa \\
\hline $68 \mathrm{hlm}$. & 7 baris/hlm. & $26 \times 17$ & $\begin{array}{l}\text { Kertas Daluwang } \\
\text { (Kertas kapas) }\end{array}$ \\
\hline Kiai Muchtar & \\
\hline \multicolumn{2}{|l|}{ Dusun Laok Saba, Nyabakan Timur, Batang-Batang, Sumenep } \\
\hline
\end{tabular}

Naskah berisi tentang keimanan dan praktek ibadah.

Naskah berasal dari Kiai Muchtar dari Kiai Mustaqim dari Kiai Siwallah dari Kiai Biramah. Teks ditulis menggunakan tinta hitam. Kondisi naskah dalam keadaan rusak, tetapi tulisan masih dapat dibaca.

\begin{tabular}{|l|l|l|l|}
\hline $\begin{array}{l}\text { BLAS/SUM/16/AK } \\
\text { 8 }\end{array}$ & KITAB TAUHID & $\mathbf{3}$ & Akaid \\
\hline BT-BT 5 & Arab, Jawa Pegon & Arab & Prosa \\
\hline 82 hlm. & 7 baris/hlm. & $30 \times 20$ & Kertas Daluwang \\
\hline Kiai Muchtar \\
\hline \multicolumn{2}{|l}{ Dusun Laok Saba, Nyabakan Timur, Batang-Batang, Sumenep } \\
\hline
\end{tabular}

Naskah berisi materi tentang tauhid dan fikih.

Naskah berasal dari Kiai Muchtar dari Kiai Mustaqim dari Kiai Siwallah dari Kiai Biramah. Naskah tanpa sampul, dan teks naskah ditulis menggunakan tinta hitam. Kondisi naskah dalam keadaan rusak, tetapi tulisan masih dapat dibaca. 


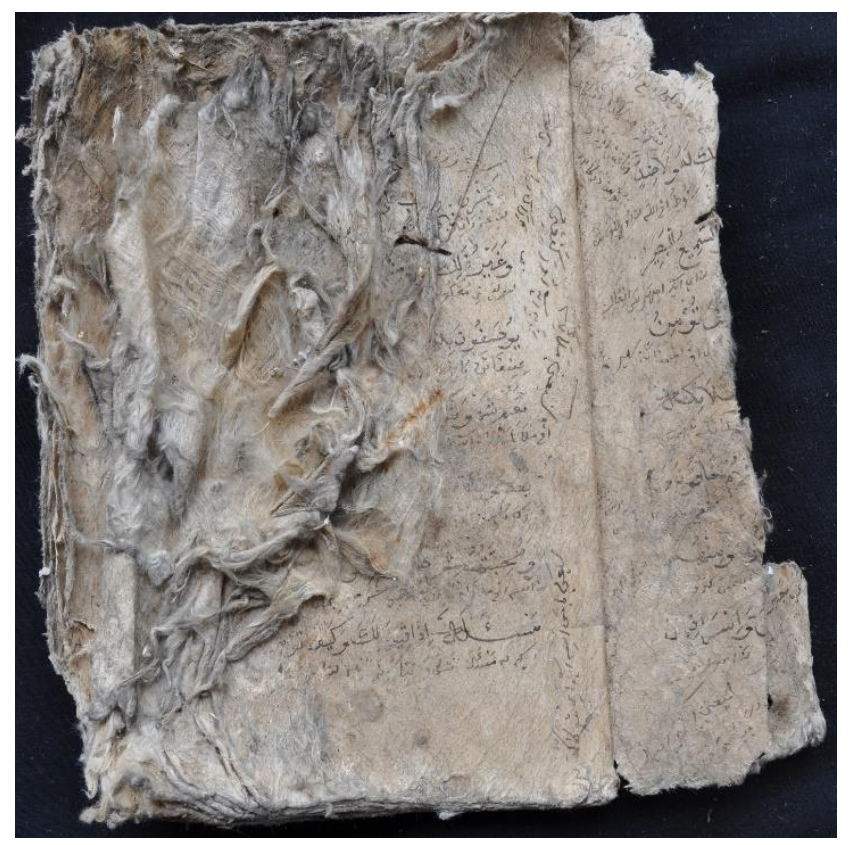

1133 BTBT 03 HLM 2,3 DSC_0163

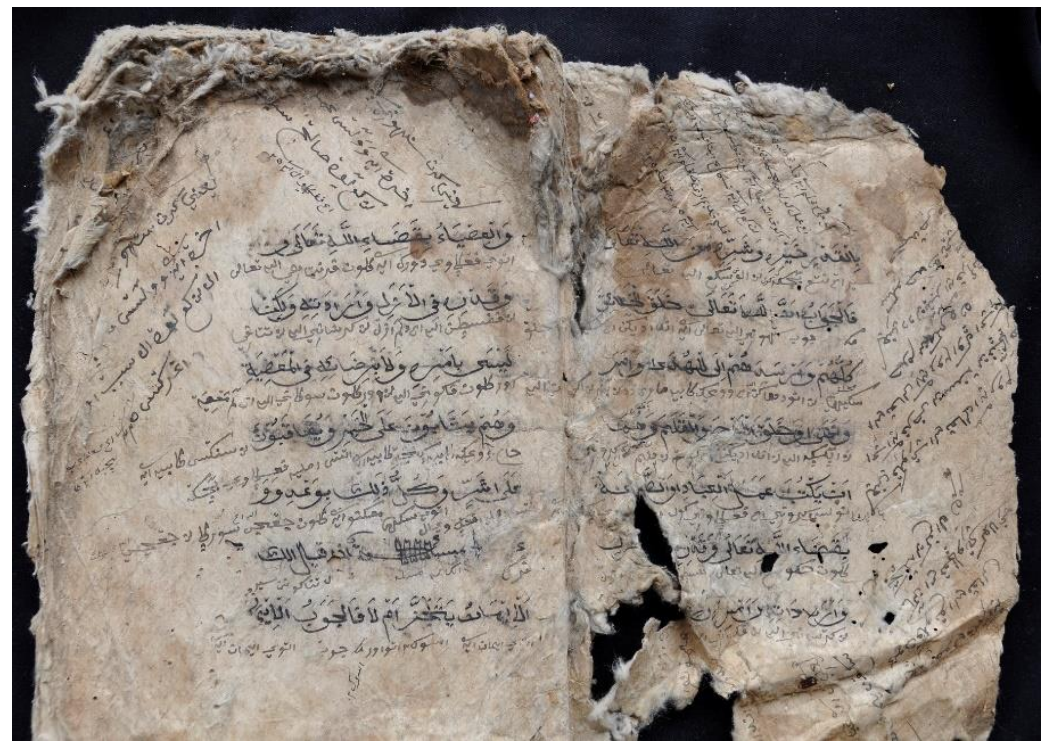

1135 BTBT 05 HLM 2,3_DSC0022 


\begin{tabular}{|l|l|l|l|}
\hline $\begin{array}{l}\text { BLAS/SUM/16/AK } \\
\text { 9 }\end{array}$ & KITAB TAUHID & $\mathbf{3}$ & Akaid \\
\hline BT-BT 9 & Arab, Jawa Pegon & Arab & Prosa \\
\hline $20 \mathrm{hlm}$. & 14 baris/hlm. & $30 \times 20$ & Kertas Daluwang \\
\hline Kiai Muchtar & \\
\hline Dusun Laok Saba, Nyabakan Timur, Batang-Batang, Sumenep \\
\hline
\end{tabular}

Naskah berisi materi tentang tauhid.

Naskah berasal dari Kiai Muchtar dari Kiai Mustaqim dari Kiai Siwallah dari Kiai Biramah. Naskah tanpa sampul, dan teks ditulis menggunakan tinta hitam dan merah. Kondisi naskah dalam keadaan rusak, tetapi tulisan masih dapat dibaca.

\begin{tabular}{|l|l|l|l|}
\hline $\begin{array}{l}\text { BLAS/SUM/16/AK } \\
/ 10\end{array}$ & KITAB AQAID 50 & 3 & Akaid \\
\hline $\begin{array}{l}\text { LCGPTR/KHQ/05/ } \\
2012\end{array}$ & Arab & Arab & Prosa \\
\hline 224 hlm. & 22 baris/hlm. & $26 x 13.5$ & Kertas Daluwang \\
\hline \begin{tabular}{l} 
K.H. Quraisyi \\
\hline Lambi Cabi, Gapura Tengah, Gapura
\end{tabular} \\
\hline
\end{tabular}

Secara umum naskah menguraikan tentang akidah atau akaid 50.

Naskah ini tersimpan di rumah K.H. Quraisyi yang berasal dari kakeknya, K.H. Masyhuri. 


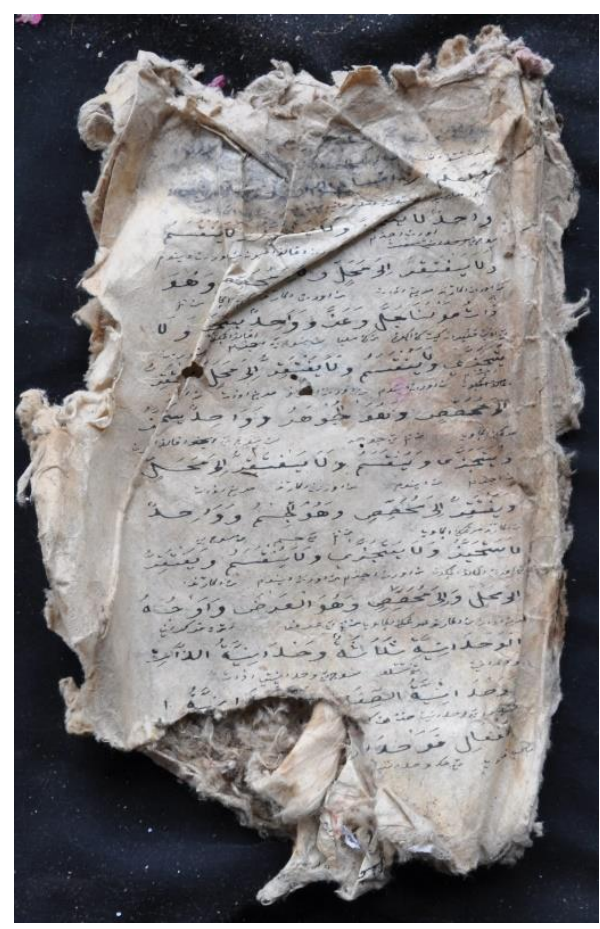

1139 BTBT 09 HLM 1 DSC 0056

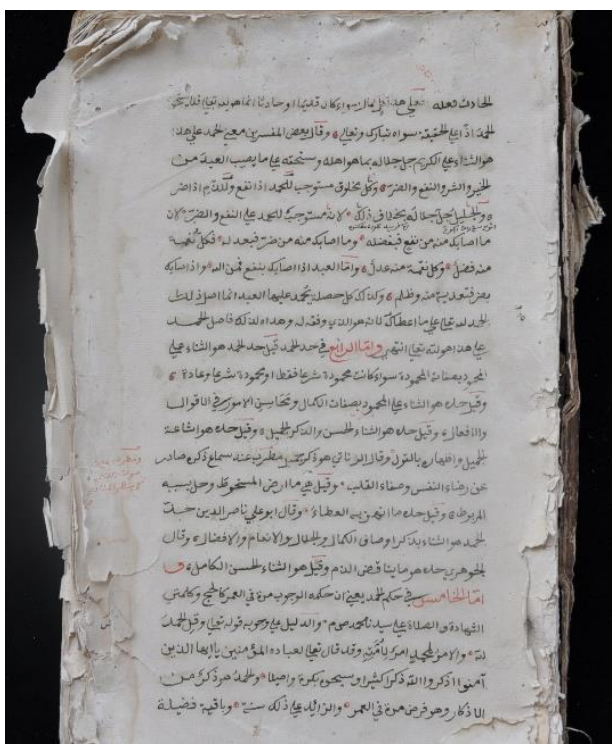

12005 LCGPTR KHQ 052012 HLM 1 Img0320 


\begin{tabular}{|l|l|l|l|}
\hline $\begin{array}{l}\text { BLAS/SUM/16/AK } \\
/ 11\end{array}$ & $\begin{array}{l}\text { KITAB AQAID 50 } \\
\text { DAN LAIN-LAIN }\end{array}$ & 3 & Akaid \\
\hline $\begin{array}{l}\text { GPRB/SMHS/28/2 } \\
012\end{array}$ & Arab & Arab & Prosa \\
\hline $96 \mathrm{hlm}$. & 7 baris/hlm. & $23.5 \mathrm{x} 17$ & Kertas Daluwang \\
\hline K.H. Samhadi Siraj & & \\
\hline Gapura Barat, Gapura & \\
\hline
\end{tabular}

Naskah ini terdiri dari tiga teks, yaitu: bab akidah (akaid 50), ilmu tasawuf, dan Akhlak.

Naskah ini berasal dari K.H. Samhadi Siraj, dari K.H.M. Siraj, dari K.H. Abdul Syakur.

\begin{tabular}{|l|l|l|l|}
\hline $\begin{array}{l}\text { BLAS/SUM/16/AK } \\
/ 12\end{array}$ & $\begin{array}{l}\text { KITAB AQAID 50 } \\
\text { DAN LAIN-LAIN }\end{array}$ & 3 & Akaid \\
\hline $\begin{array}{l}\text { PJGGPR/KHZ/30/2 } \\
012\end{array}$ & Arab & Arab & Prosa \\
\hline 308 hlm. & 7 baris/hlm. & $28 \times 18.5$ & Kertas Daluwang \\
\hline K.H. Zahidi & \\
\hline \multicolumn{2}{|l}{ Pajagungan, Paloklokan, Gapura } \\
\hline
\end{tabular}

Naskah ini terdiri dari sembilan teks, yaitu: teks pertama dan kedua berisi tentang Akidah (akaid 50), teks keempat menjelaskan syarat-syarat batin salat dan puasa, teks keenam dan ketujuh berisi tentang bab nikah, teks kedelapan berisi tentang kaifiyat menerima dan menolak sesuatu, kesembilan tentang ilmu dan akhlak.

Naskah ini milik K.H. Zahidi dari K. Said. Kondisi naskah mulai rusak, teks masih terbaca. 


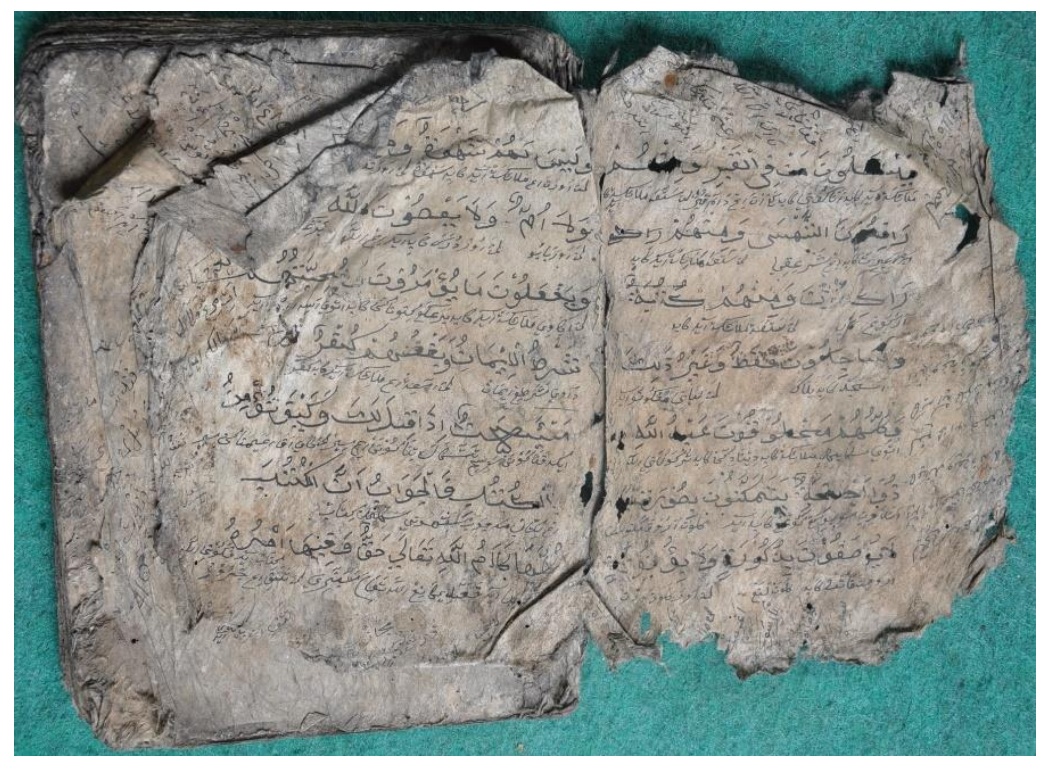

12028 GPRB SMHS 282012 HLM 2,3 Img2100

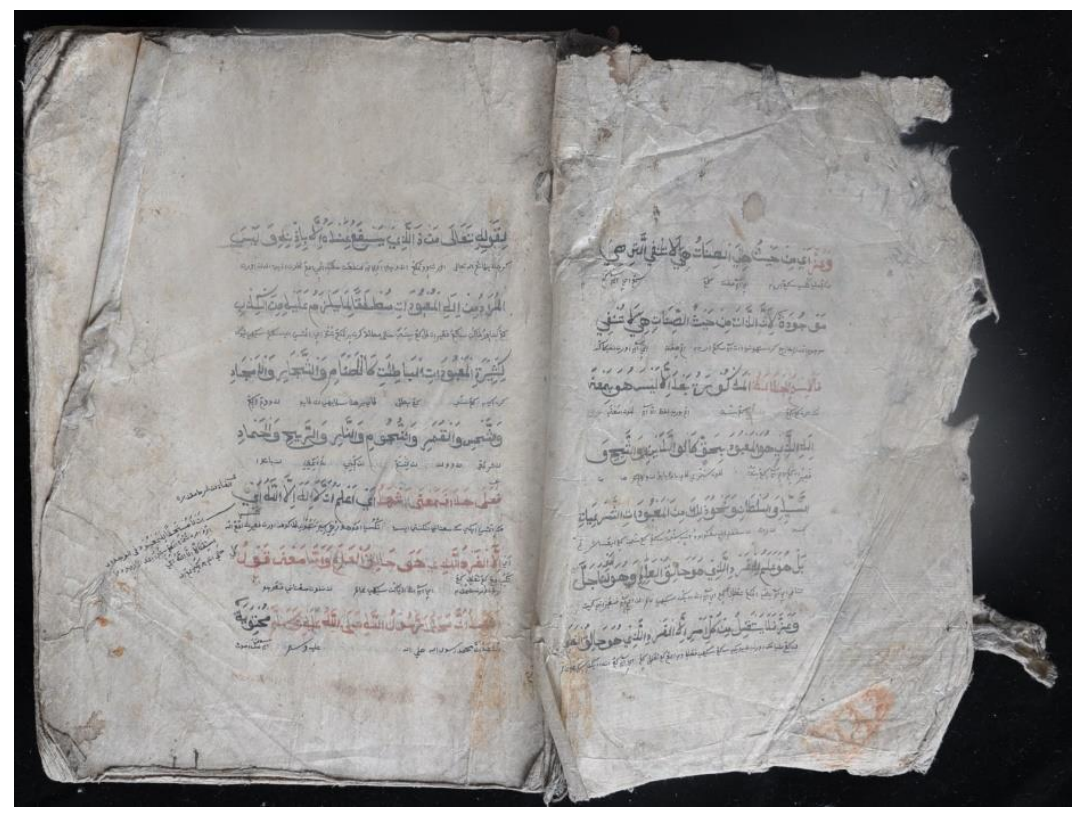

12030 PJGGPR KHZ 302012 HLM 4,5 Img2182 


\begin{tabular}{|l|l|l|l|}
\hline $\begin{array}{l}\text { BLAS/SUM/16/AK } \\
/ 13\end{array}$ & $\begin{array}{l}\text { KITAB } \\
\text { NURBUAT }\end{array}$ & 3 & Akaid \\
\hline $\begin{array}{l}\text { BLKN/FZN/60/201 } \\
2\end{array}$ & Jawa & Arab & Prosa \\
\hline $82 \mathrm{hlm}$. & 15 baris/hlm. & $20 \times 15.5$ & Kertas Daluwang \\
\hline Fauzan & \\
\hline \multicolumn{2}{|l}{ Bule'en, Batu Putih, Sumenep }
\end{tabular}

Naskah ini merupakan salinan dari kitab Nurbuwat. Naskah ini menjelaskan keistimewaan orang membaca akan memperoleh syafaat dari Nabi Muhamad SAW.

Naskah ini milik Fauzan dari K Juwani. Kondisi naskah cukup baik, teks terbaca.

\begin{tabular}{|l|l|l|l|}
\hline $\begin{array}{l}\text { BLAS/SUM/16/AK } \\
/ 14\end{array}$ & $\begin{array}{l}\text { KITAB } \\
\text { SAMARQANDI } \\
\text { DAN KITAB } \\
\text { SITTIN }\end{array}$ & $\mathbf{3}$ & Akaid \\
\hline BTLN/HSN/63/212 & Arab & Arab & Prosa \\
\hline $72 \mathrm{hlm}$. & 6 baris/hlm. & $21 \times 16$ & Kertas Daluwang \\
\hline Husnan & \multicolumn{2}{|l}{} \\
\hline Bantilan, Batu Putih
\end{tabular}

Naskah ini berisi dua teks, teks pertama bernama Samarqandi menjelaskan tentang akidah 50 dengan menggunakan hukum akal. Teks kedua bernama As-Sittin menjelaskan tentang 60 masalah peribadatan mulai dari wudu.

Naskah ini milik Husnan dari K. Sahrun. Kondisi naskah cukup baik, teks terbaca. 


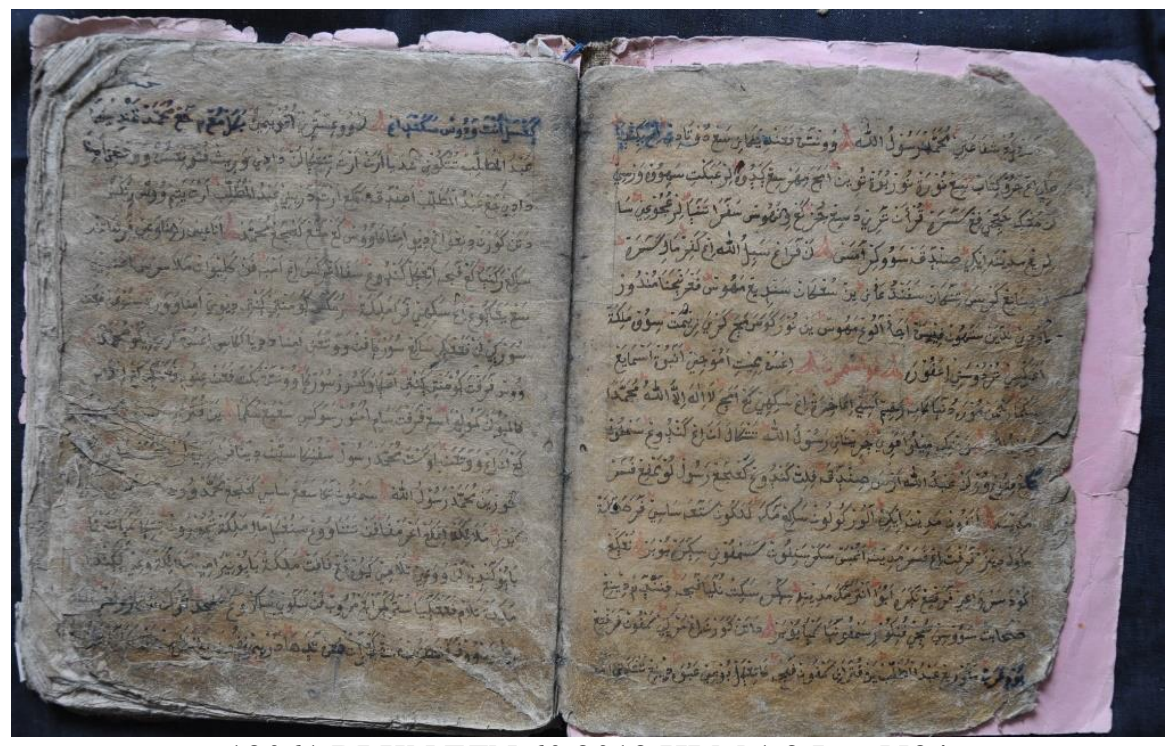

12061 BLKN FZN 602012 HLM 1,2 Img5524

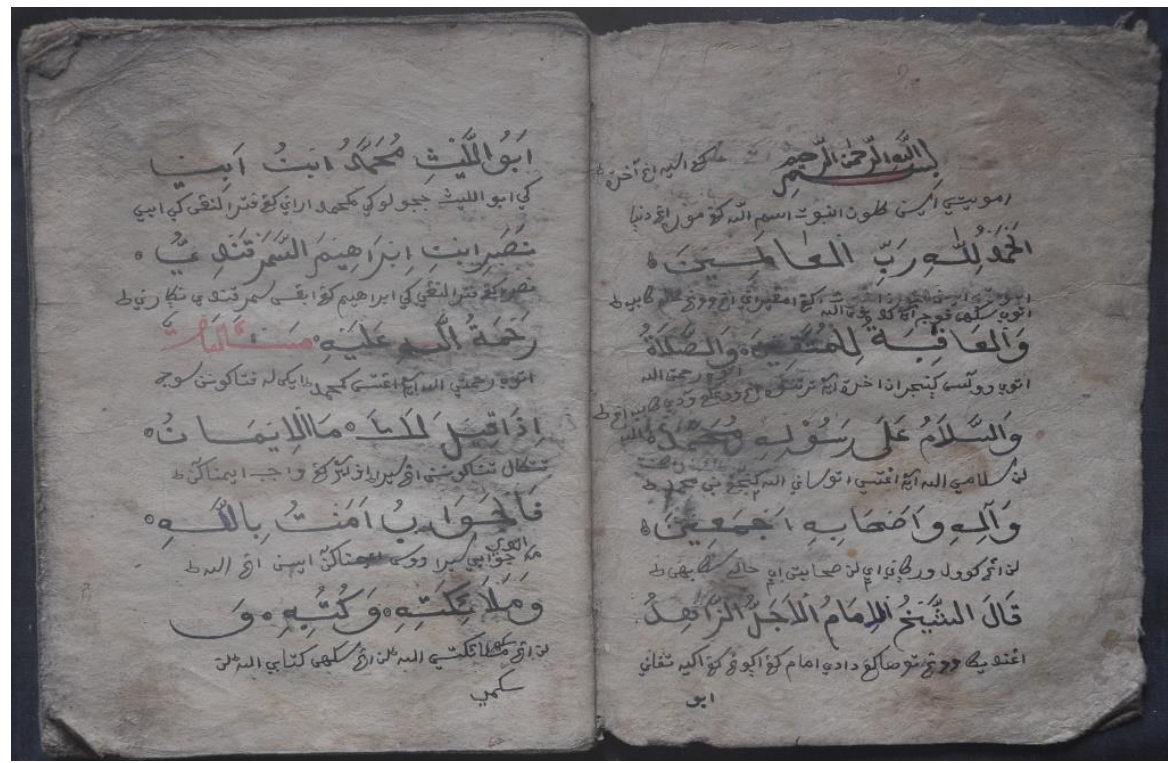

12064 BTLN HSN 632012 HLM 1,2 Img5623 


\begin{tabular}{|c|c|c|c|}
\hline $\begin{array}{l}\text { BLAS/SUM/16/AK } \\
/ 15\end{array}$ & $\begin{array}{l}\text { KITAB } \\
\text { TANBIHUL } \\
\text { GĀFILIN }\end{array}$ & 3 & Akaid \\
\hline $\begin{array}{l}\text { BTLN/MRWN/65/ } \\
2012\end{array}$ & Arab & Arab & Prosa \\
\hline $120 \mathrm{hlm}$. & 11 baris $/ \mathrm{hlm}$. & $17.5 \times 13$ & Kertas Daluwang \\
\hline
\end{tabular}

Naskah ini berisi tentang doa-doa.

Naskah ini milik Marwan dari Abdul Ghani. Kondisi naskah mulai rusak, teks masih terbaca.

\begin{tabular}{|l|l|l|l|}
\hline $\begin{array}{l}\text { BLAS/SUM/16/AK } \\
/ 16\end{array}$ & $\begin{array}{l}\text { KITAB RISALAH } \\
\text { NABI }\end{array}$ & $\mathbf{3}$ & Akaid \\
\hline $\begin{array}{l}\text { SGG/MFHM/74/20 } \\
12\end{array}$ & Arab & Arab & Prosa \\
\hline 366 hlm. & 7 baris/hlm. & $21.5 \times 16.5$ & Kertas Daluwang \\
\hline M Fahim & \\
\hline Sergang, Batu Putih, Sumenep
\end{tabular}

Menjelaskan tentang ilmu tauhid, bahwa Rasulullah diutus menyampaikan kitab untuk umatnya.

Naskah ini milik M Fahim dari K Shidiq dari Syamsudin. Kondisi naskah mulai rusak, teks masih terbaca. 


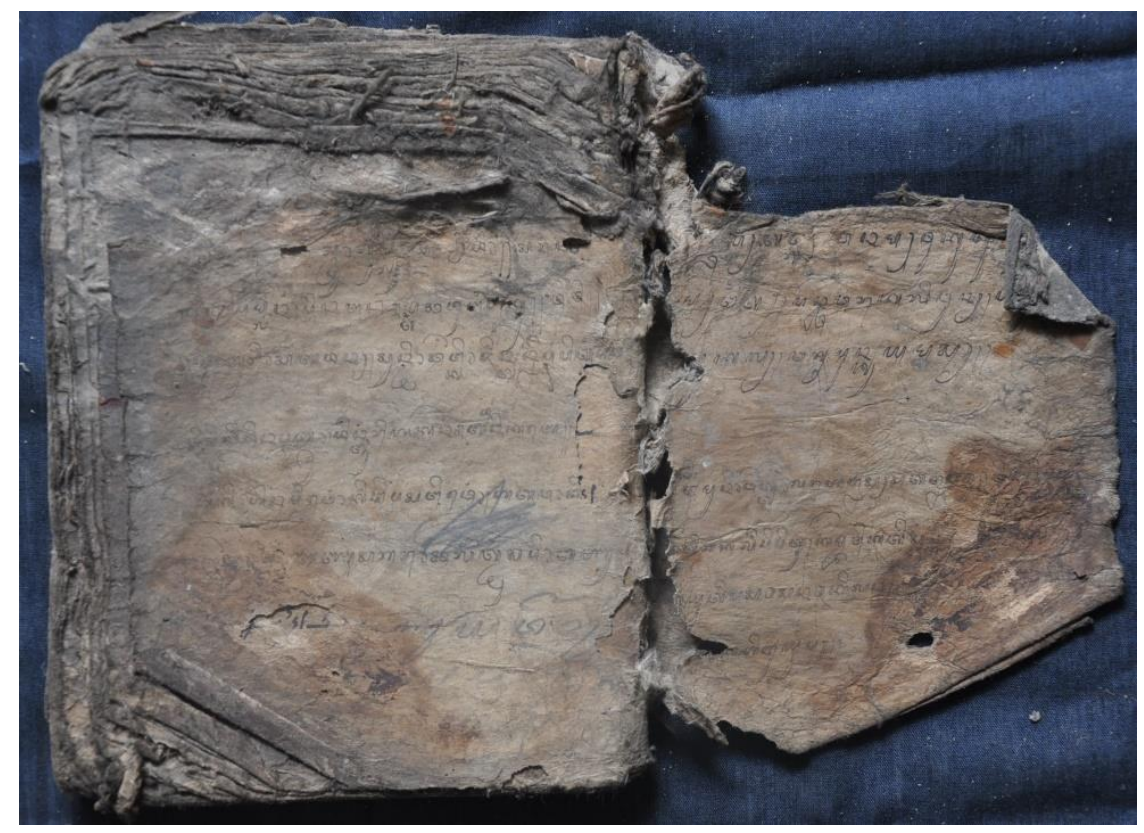

12066 BTLN MRWN 652012 HLM 1 Img5677

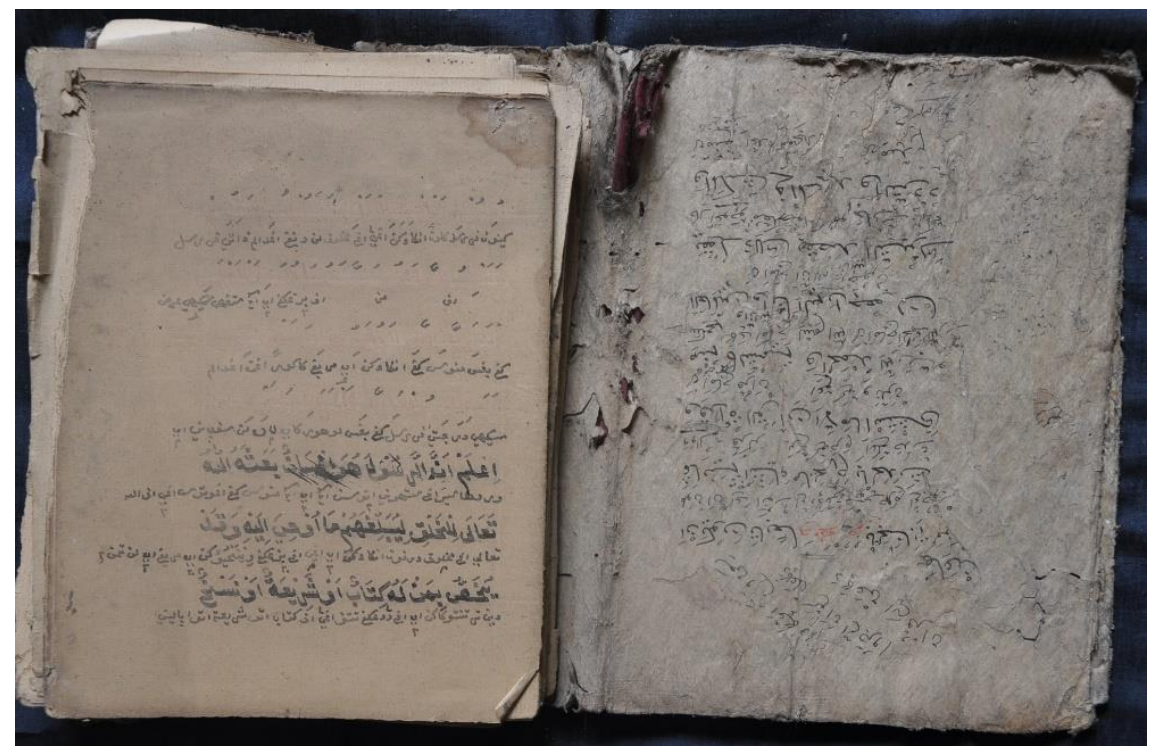

12075 SGG MFHM 742012 HLM 1Img6044 


\begin{tabular}{|l|l|l|l|}
\hline $\begin{array}{l}\text { BLAS/SUM/16/AK } \\
/ 17\end{array}$ & $\begin{array}{l}\text { KITAB } \\
\text { TAŻKIRAH DAN } \\
\text { LAIN-LAIN }\end{array}$ & 3 & Akaid \\
\hline $\begin{array}{l}\text { BTLN/ALWI/81/20 } \\
12\end{array}$ & Arab & Arab dan Jawa & Prosa \\
\hline $72 \mathrm{hlm}$. & 8 baris/hlm. & $20 \times 16$ & Kertas Daluwang \\
\hline K.H. Alwi & \\
\hline \multicolumn{2}{|l}{ Bantilan, Pajung, Batu Putih, Sumenep } \\
\hline
\end{tabular}

Teks dalam naskah ini bernama Bahjatul Ulum fi Syarh fi Bayani Akidatul Usū. Kitab ini menjelaskan tentang lafaz bismilahi itu nama khas yang wujud dari wujud Zat wajibul wujud(Allah). Dengan demikian kitab ini menjelaskan akidah tauhid.

Naskah ini berasal dari K.H. Alwi dari K.H. Syafi'udin dari K.H. Syarkawi (sepuh). Tahun penyusunan, penulisan tidak disebutkan. Kondisi kitab cukup baik dan bisa dibaca.

\begin{tabular}{|c|c|c|c|}
\hline $\begin{array}{l}\text { BLAS/SUM/16/AK } \\
/ 18\end{array}$ & 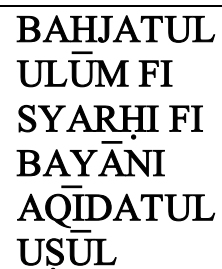 & 3 & Akaid \\
\hline $\begin{array}{l}\text { BTLN/ALWI/85/20 } \\
12\end{array}$ & Arab & Arab & Prosa \\
\hline $196 \mathrm{hlm}$. & 8 baris/hlm. & $24 \times 16$ & Kertas Daluwang \\
\hline \multicolumn{4}{|l|}{ K.H. Alwi } \\
\hline
\end{tabular}

Naskah berisi tiga teks, teks pertama bernama Tazkirah yang menjelaskan tentang malaikat yang mulia ada empat yaitu Jibril, Mikail, Israfil, dan Izrail. Teks kedua menjelaskan tata cara memulasara jenazah. Teks ini ditulis dengan bahasa Jawa aksara Arab. Kemudian teks ketiga merupakan kumpulan yang berisi doa-doa.

Naskah ini berasal dari K.H. Alwi dari K.H. Syafi'udin dari K.H. Syarkawi (sepuh). Tahun penyusunan, penulisan tidak disebutkan. Kondisi kitab ini cukup baik atau sedang. 


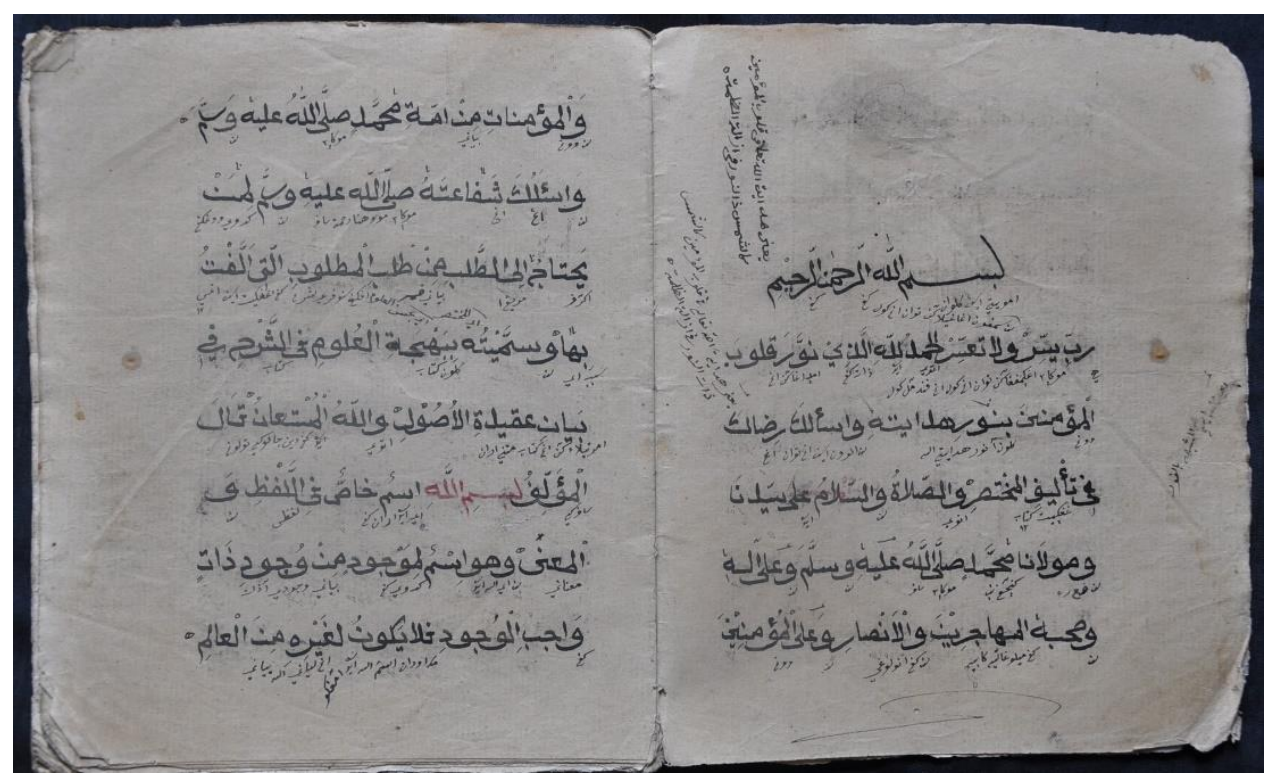

12082 BTLN ALWI 812012 HLM 1,2 Img6724

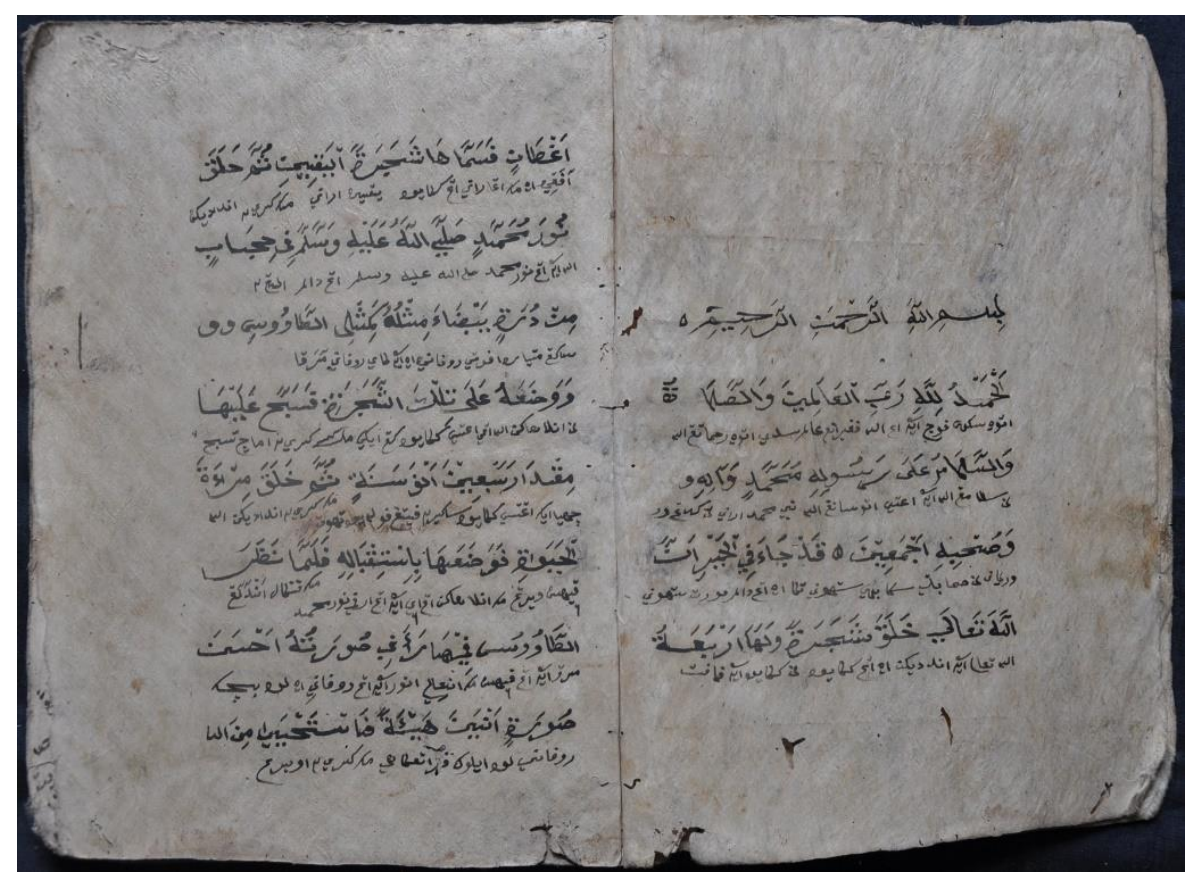

12086 BTLN ALWI 852012 HLM 1,2 Img6923 


\begin{tabular}{|l|l|l|l|}
\hline $\begin{array}{l}\text { BLAS/SUM/16/AK } \\
/ 19\end{array}$ & KITAB TAUHID & 3 & Akaid \\
\hline $\begin{array}{l}\text { MDT/DAUD/88/20 } \\
12\end{array}$ & Arab & Arab & Prosa \\
\hline $174 \mathrm{hlm}$. & 7 baris/hlm. & $25 \times 17$ & Kertas Daluwang \\
\hline Daud & & \\
\hline Manding Timur, Manding
\end{tabular}

Naskah ini berisi tiga teks. Teks pertama menjelaskan tentang iman antara Ahlus Sunnah, Qadariyah, Jabariyah, dan tentang af'al manusia. Kemudian teks kedua menjelaskan tentang hukum syar'i, hukum aqli, dan hukum adat untuk menjelaskan akidah lima puluh dengan perbandingan antara qadariyah, ahlus sunnah, dan jabariyah.Teks ketiga menjelaskan tentang salat dan bersuci.

Naskah ini milik Daud dari KH Syasumdin. Keadaan naskah baik dan bisa dibaca. Namun demikian tidak diketahui tahun penyusunan.

\begin{tabular}{|l|l|l|l|}
\hline $\begin{array}{l}\text { BLAS/SUM/16/AK } \\
\mathbf{2 0}\end{array}$ & $\begin{array}{l}\text { KITAB } \\
\text { KAIFIYATUL } \\
\text { BURHANI }\end{array}$ & $\mathbf{3}$ & Akaid \\
\hline $\begin{array}{l}\text { MDT/DAUD/89/20 } \\
12\end{array}$ & Arab & Arab & Prosa \\
\hline $94 \mathrm{hlm}$. & 7 baris/hlm. & $21 \times 17$ & Kertas Daluwang \\
\hline Daud & & \\
\hline \multicolumn{2}{|l}{ Manding Timur, Manding }
\end{tabular}

Naskah ini berisi dua teks. Teks pertama Kaifiyatul Burhani fi Aqidatil Ahli Iman yaitu kitab yang menerangkan tentang akidah 50 menurut hukum akal dan syari'at. Adapun teks kedua menjelaskan tentang kumpulan doa-doa.

Naskah ini milik Daud dari KH Syasumdin. Keadaan naskah baik dan bisa dibaca. Namun demikian tidak diketahui tahun penyusunan 


\begin{tabular}{|l|l|l|l|}
\hline $\begin{array}{l}\text { BLAS/SUM/16/AK } \\
/ 21\end{array}$ & $\begin{array}{l}\text { KITAB AQAID 50 } \\
\text { DAN LAIN-LAIN }\end{array}$ & $\mathbf{3}$ & Akaid \\
\hline $\begin{array}{l}\text { MDGT/CHLH/94/2 } \\
012\end{array}$ & Arab & Arab & Prosa \\
\hline $130 \mathrm{hlm}$. & 7 baris/hlm. & $26 \times 12$ & Kertas Daluwang \\
\hline Nyai Kholishoh & \\
\hline \multicolumn{2}{|l}{ Manding Timur, Manding } \\
\hline
\end{tabular}

Naskah berisi tujuh teks. Teks pertama bernama Akidah 50, menjelaskan ilmu tauhid akidah 50 dengan menggunakan hukum akal. Teks kedua menjelaskan tentang syahadat. Teks ketiga menjelaskan tentang kewajiban seorang muslim untuk mengetahui makna syahadat. Teks keempat bernama Kamilah Syahadat at Tabi'ah, menjelaskan tentang arti kalimat syahadat dan yang mengikutinya. Teks kelima bernama Ma'rifatu Al jauhar, menjelaskan asal mula penciptaan yang disebut dengan jauhar. Teks keenam bernama Bayani Alif, Alif berasal dari nuktah (zurrah). Zurrah adalah ruh yang tersembunyi, dan ruh yang tersembunyi itu adalah rahasia Tuhan. Teks ketujuh menjelaskan tentang (catatan) tentang wudu, salat, syahadat, dan doa-doa.

Naskah ini milik Nyai Khulishoh dari KH Amiruddin. Keadaan naskah cukup baik dan teks terbaca.

\begin{tabular}{|l|l|l|l|}
\hline $\begin{array}{l}\text { BLAS/SUM/16/AK } \\
\text { /22 }\end{array}$ & KITAB AQAID 50 & $\mathbf{3}$ & Akaid \\
\hline $\begin{array}{l}\text { JNGR/HSM/122/20 } \\
12\end{array}$ & Arab & Arab & Prosa \\
\hline 26 hlm. & 5 s.d. 7 baris/hlm. & $26.5 \times 19$ & Kertas Daluwang \\
\hline Hosmah & \\
\hline Jenangger, Batang-batang & \\
\hline
\end{tabular}

Naskah ini menjelaskan ilmu tauhid tentang akidah lima puluh dengan hukum akal.

Naskah ini dimiliki oleh Hosmah dari K Ahyar dari K Abdullah. Tahun dan tempat penyusunan, penulisan ulang, maupun pemrakarsa tidak dicantumkan. Naskah dalam kondisi cukup baik/cukup bisa dibaca. 


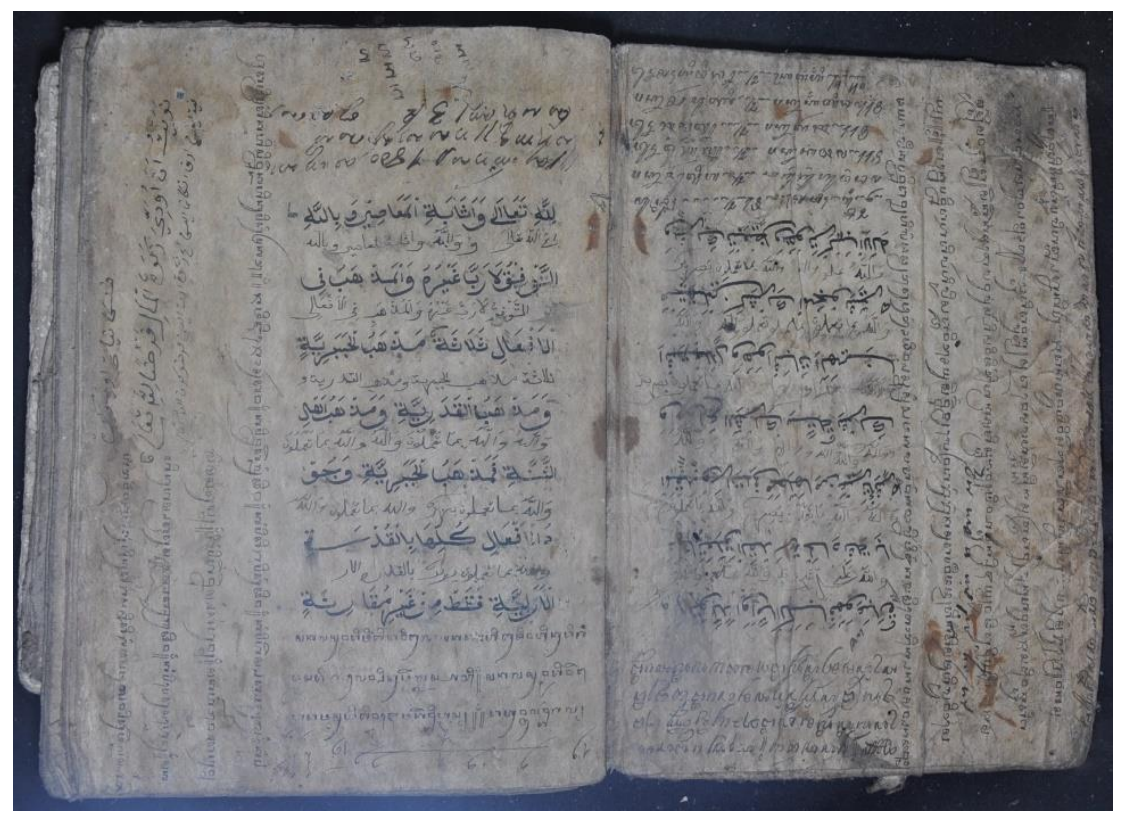

12089 MDT DAUD 882012 HLM 1,2 Img7220

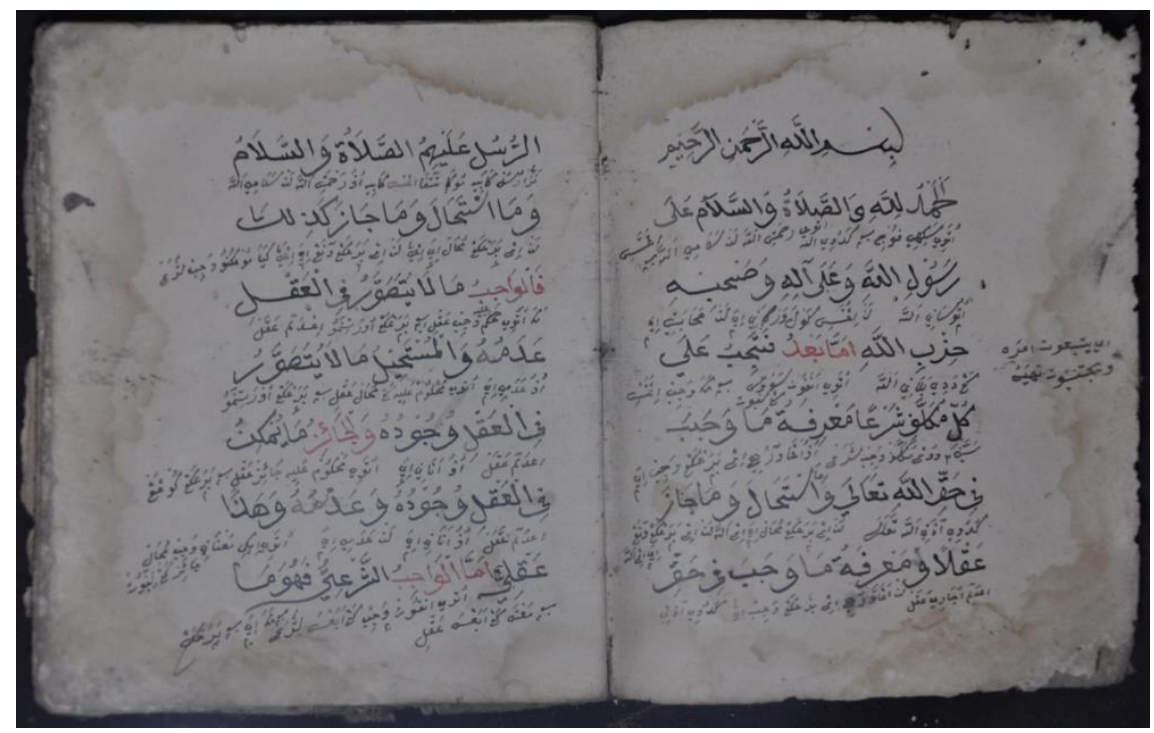

12090 MDT DAUD 892012 HLM 1,2 Img7310 


\begin{tabular}{|l|l|l|l|}
\hline $\begin{array}{l}\text { BLAS/SUM/16/AK } \\
\text { /23 }\end{array}$ & KITAB AQAID 50 & $\mathbf{3}$ & Akaid \\
\hline $\begin{array}{l}\text { PJGSGG/ABDL/14 } \\
4 / 2012\end{array}$ & Arab & Arab & Prosa \\
\hline $14 \mathrm{hlm}$. & 5 baris/hlm. & $24 \times 15.5$ & Kertas Daluwang \\
\hline Abdullah & \multicolumn{2}{|l}{} \\
\hline Pajung, Sergang, Batu Putih, Sumenep & \\
\hline
\end{tabular}

Naskah ini menjelaskan tentang Akidah lima puluh.

Naskah ini dimiliki oleh Abdullah dari KH Syarkowi. Kondisi naskah cukup baik.

\begin{tabular}{|l|l|l|l|}
\hline $\begin{array}{l}\text { BLAS/SUM/16/AK } \\
/ 24\end{array}$ & $\begin{array}{l}\text { KITAB } \\
\text { MA'RIFATUL } \\
\text { ISLAM }\end{array}$ & 3 & Akaid \\
\hline $\begin{array}{l}\text { PJGSGG/HSM/157 } \\
/ 2012\end{array}$ & Arab & Arab & Prosa \\
\hline $28 \mathrm{hlm}$. & 5 baris/hlm. & $20.5 \times 15$ & Kertas Daluwang \\
\hline K.H. Hasim & & \\
\hline \multicolumn{2}{|l}{ Pajung, Sergang, Batu Putih, Sumenep } & \\
\hline
\end{tabular}

Teks bernama Ma'rifatul Islam disusun oleh Imam Zahid, menjelaskan iman dengan tanya jawab, iman itu makhluk atau bukan, jawab iman itu hidayat yang diikrarkan dengan lisan dan ditasdikkan dengan hati.

Naskah ini dimiliki oleh KH Hasim dari KH Azhari. Kondisi naskah tergolong baik. 


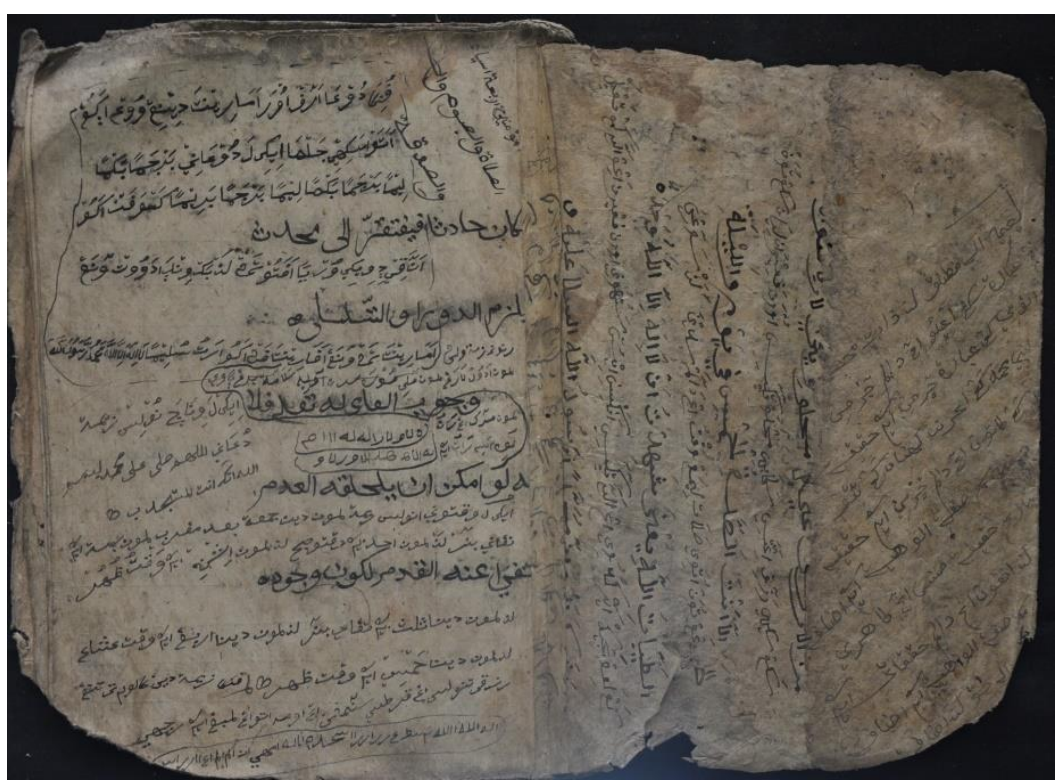

12145 PJGSGG ABDL 1442012 HLM 1 Img12139

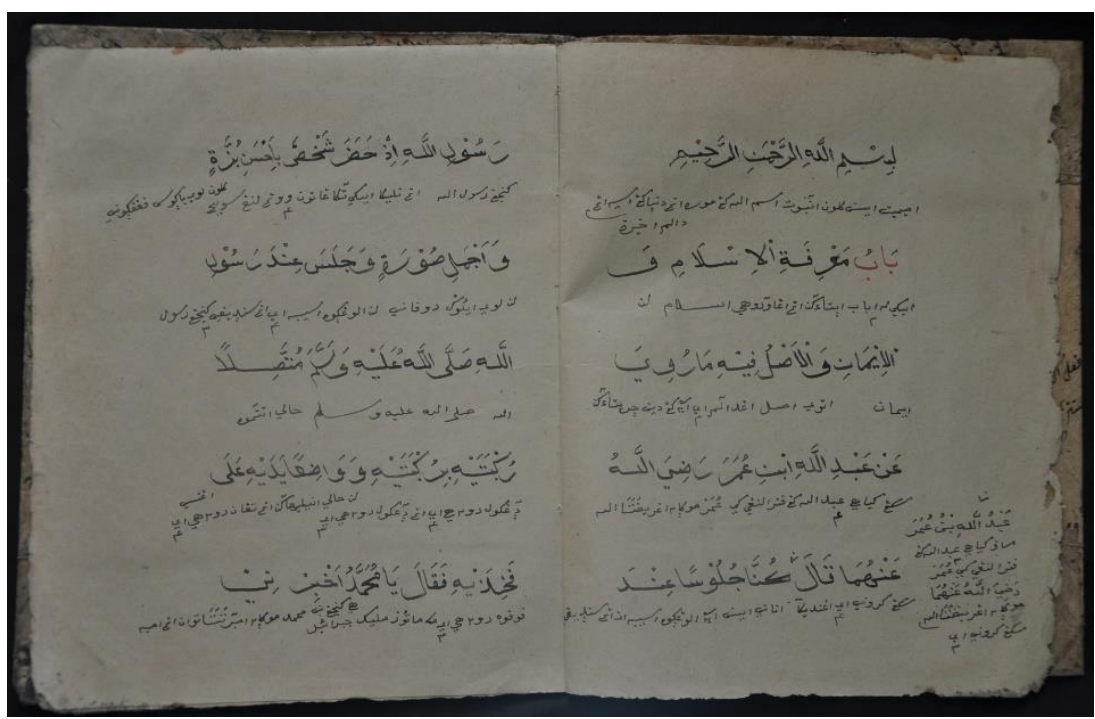

12158 PJGSGG HSM 1572012 HLM 1 Img 12864 


\begin{tabular}{|l|l|l|l|}
\hline BLAS/SUM/16/AK & KITAB & 3 & Akaid \\
& SAMARQANDI & & \\
\hline PJGSGG/MWYH/1 & Arab & Arab & Prosa \\
$61 / 2012$ & & $20.6 \times 16.5$ & Kertas Daluwang \\
\hline $38 \mathrm{hlm}$. & 7 baris/hlm. & \\
\hline Nyai Mu'awiyah & \\
\hline \multicolumn{2}{|l}{ Pajung ,Sergang, Batu Putih, Sumenep } & \\
\hline
\end{tabular}

Teks bernama Samarqandi, menjelaskan ilmu tauhid dengan model soal jawab.

Naskah ini dimiliki oleh Nyai Mu'awiyah dari Nyai Dzuriyah. Kondisi naskah tergolong cukup baik.

\begin{tabular}{|l|l|l|l|}
\hline $\begin{array}{l}\text { BLAS/SUM/16/AK } \\
\text { /26 }\end{array}$ & $\begin{array}{l}\text { KITAB } \\
\text { MACAPAT 0 }\end{array}$ & $\mathbf{3}$ & Akaid \\
\hline $\begin{array}{l}\text { PJGSGG/MWYH/1 } \\
62 / 2012\end{array}$ & Jawa & Arab & Prosa \\
\hline 37 hlm. & 12 baris/hlm. & $17 \times 10$ & Kertas Daluwang \\
\hline Nyai Mu'awiyah & \\
\hline \multicolumn{2}{|l|}{ Pajung,Sergang, Batu Putih, Sumenep } \\
\hline
\end{tabular}

Naskah ini berisi tembang Macapat.

Naskah ini dimiliki oleh Nyai Mu'awiyah dari Nyai Dzuriyah. Kondisi naskah tergolong cukup baik. 


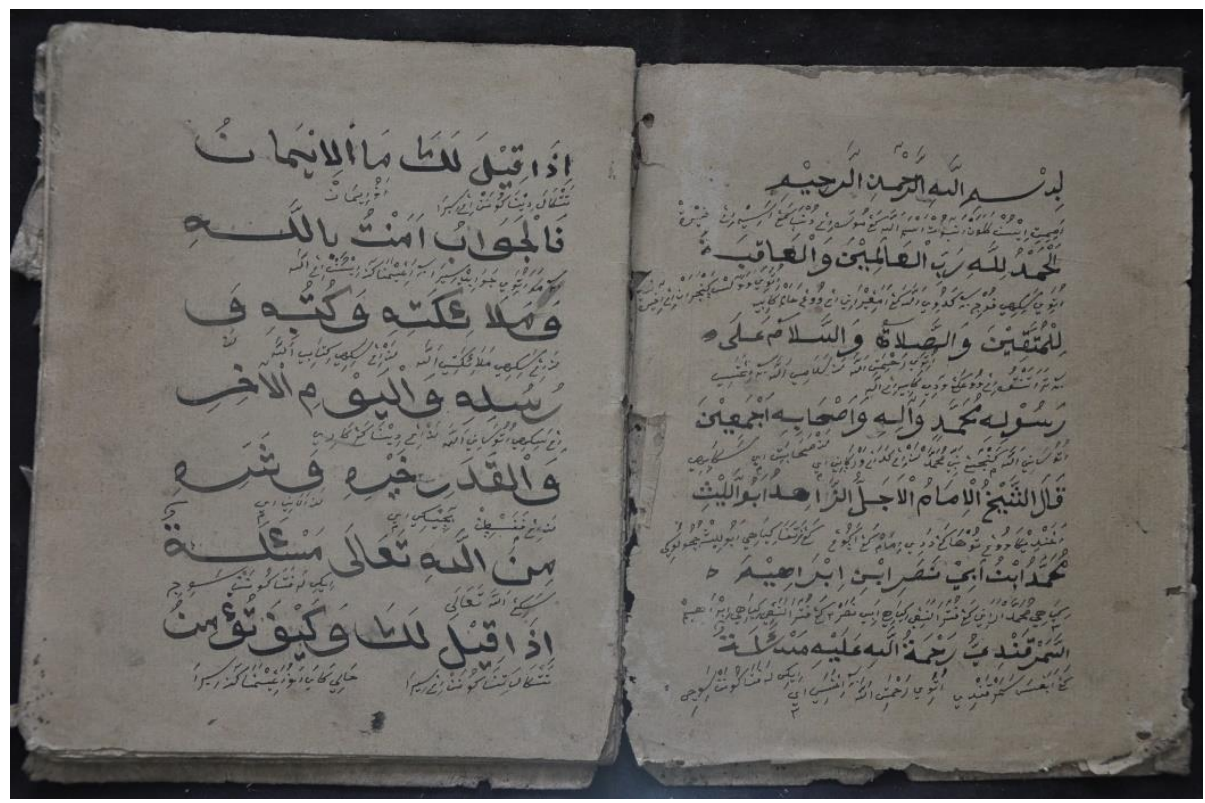

12162 PJGSGG MWYH 1612012 HLM 1,2 Img12973

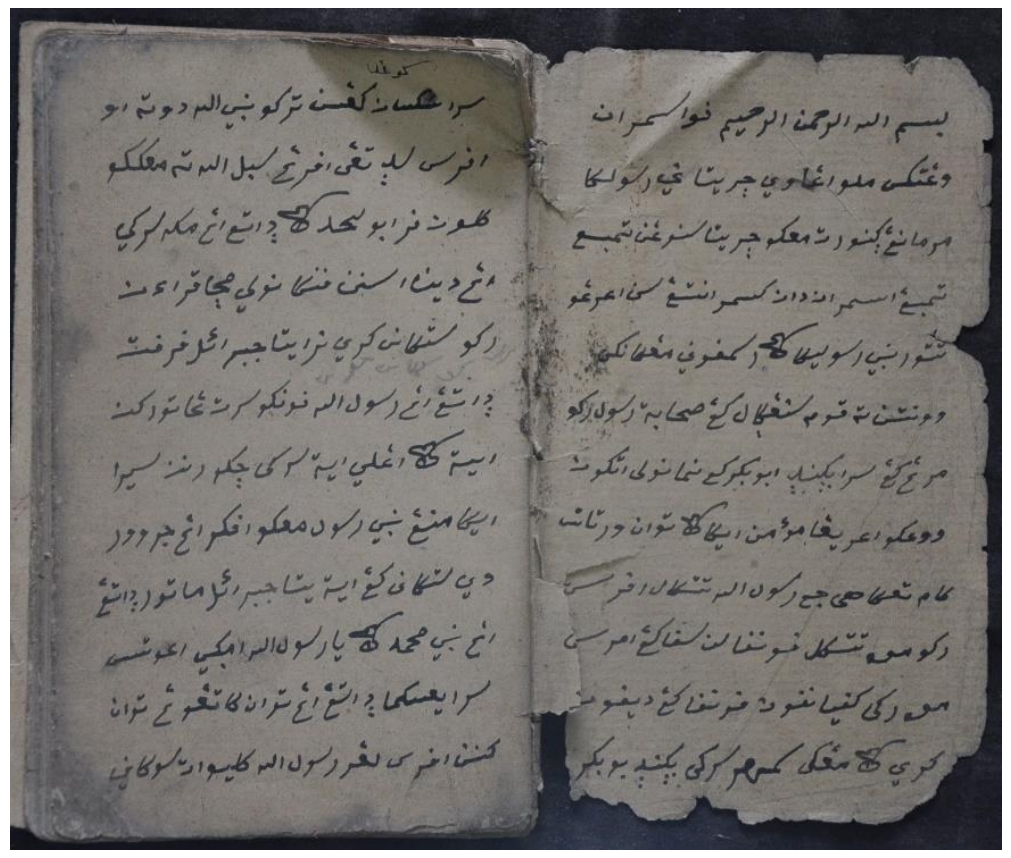

12163 PJGSGG MWYH 1622012 HLM 1,2 Img12995 


\begin{tabular}{|c|c|c|c|}
\hline $\begin{array}{l}\text { BLAS/SUM/16/AK } \\
/ 27\end{array}$ & 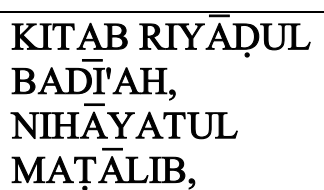 & 3 & Akaid \\
\hline $\begin{array}{l}\text { SGG/MFHM/75/20 } \\
12\end{array}$ & Arab & Arab & Prosa \\
\hline $164 \mathrm{hlm}$. & 11 baris $/ \mathrm{hlm}$. & $20 \times 16$ & Kertas Daluwang \\
\hline \multicolumn{4}{|l|}{ M Fahim } \\
\hline
\end{tabular}

Naskah ini berisi dua teks. Teks pertama berisi tentang Rukun Islam dan rukun Iman. Teks kedua berisi tentang keutamaan ilmu, dan ulama.

Naskah ini milik M Fahim dari K Shidiq dari Syamsudin. Kondisi naskah mulai rusak, teks masih terbaca.

\begin{tabular}{|l|l|l|l|}
\hline $\begin{array}{l}\text { BLAS/SUM/16/AK } \\
\text { /28 }\end{array}$ & KITAB TAUHID & $\mathbf{3}$ & Akaid \\
\hline $\begin{array}{l}\text { SGG/MFHM/77/20 } \\
12\end{array}$ & Arab & Arab & Prosa \\
\hline 94 hlm. & 7 s.d. 8 baris/hlm. & $21 \times 15$ & Kertas Daluwang \\
\hline M Fahim & \\
\hline Sergang, Batu Putih, Sumenep & \\
\hline
\end{tabular}

Naskah ini berisi tiga teks. Teks pertama berisi tentang Tauhid. Teks kedua menjelaskan akidah 50 dalam bentuk nazaman atau syair. Teks ketiga menjelaskan tentang tauhid.

Naskah ini milik M Fahim dari K Shidiq dari Syamsudin. Kondisi naskah mulai rusak, teks masih terbaca. 


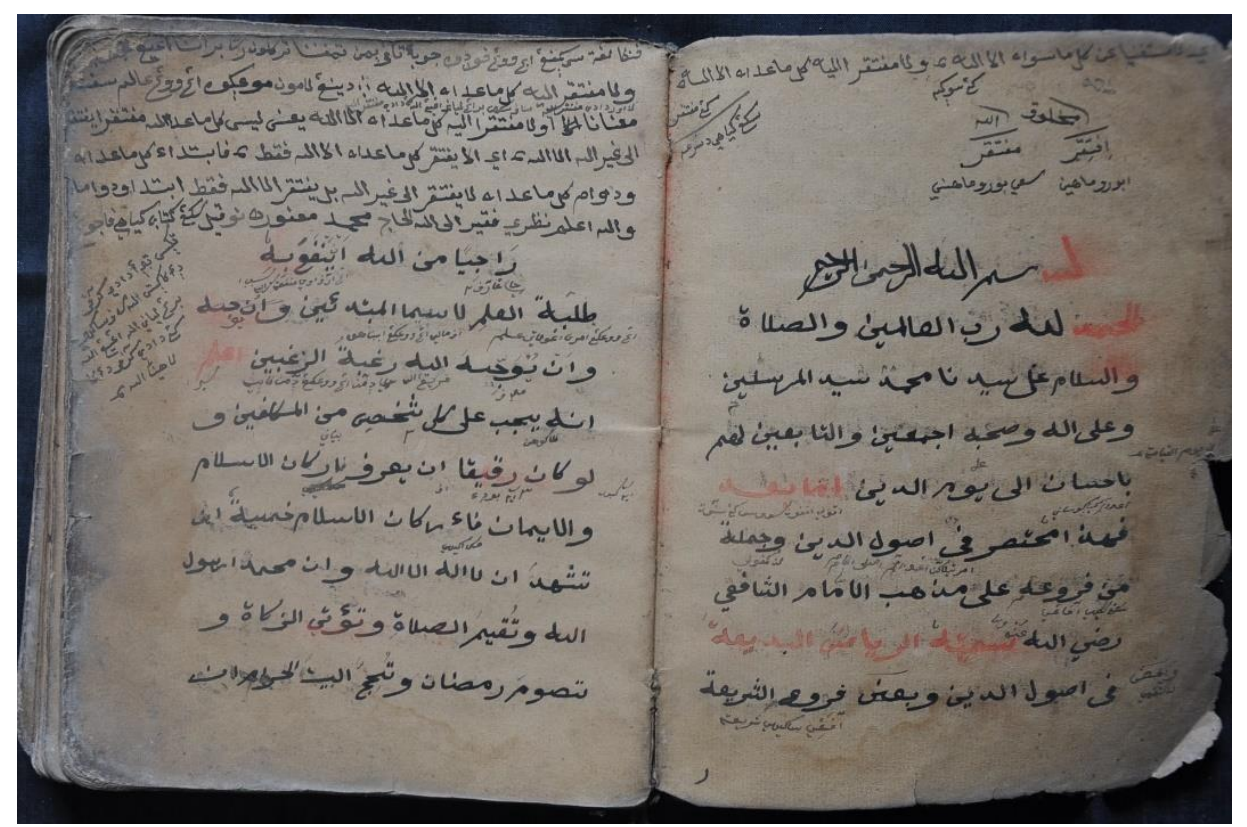

12076 SGG MFHM 752012 HLM 1,2 Img6232

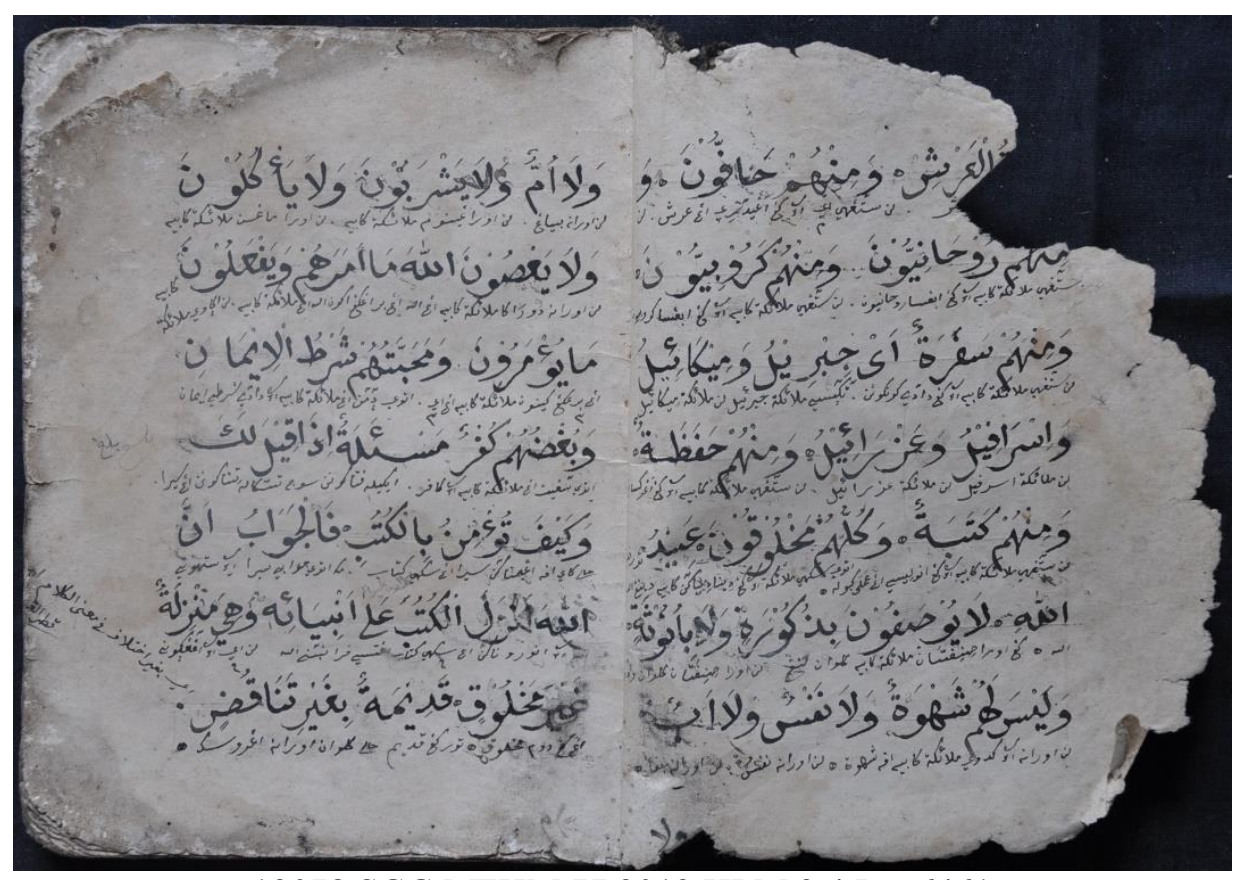

12078 SGG MFHM 772012 HLM 3,4 Img6461 


\begin{tabular}{|c|c|c|c|}
\hline $\begin{array}{l}\text { BLAS/SUM/16/AK } \\
/ 29\end{array}$ & \begin{tabular}{|l|} 
SYARAH \\
AQIDATU \\
UMMUL \\
BARĀHIN DAN \\
LAIN-LAIN \\
\end{tabular} & 3 & Akaid \\
\hline $\begin{array}{l}\mathrm{MCT} / \mathrm{AWR} / 101 / 20 \\
12\end{array}$ & Arab & Arab & Prosa \\
\hline $250 \mathrm{hlm}$. & 15 baris/hlm. & $29.5 \times 18$ & Kertas Daluwang \\
\hline
\end{tabular}

Naskah ini berisi tiga teks. Teks pertama bernama Aqidatul Ummul Barahini Fathul Mubini bisyarkhi Ummul Barahin, menjelaskan tentang tauhid akidah 50. Teks kedua bernama Syarah al-Mubarak menjelaskan tentang doa. Teks ketiga bernama Ushuluddinil I'tiqad disusun oleh Syaih Ihsanuddin al-Sumatrani dan disalin oleh Haris, menjelaskan tentang salat tidak sah kecuali dengan i'tiqad yang benar yaitu bersuci didasarkan hadis Nabi As-saifu sirahus salat.

Naskah berasal dari K.H. A Waris dari K.H. Miftakhul Khair dari K.H. Syamsul Arifin dari K.H. Moh Nur dari K.H. Abdul Kairan dari K.H. Zaidun (Syeh Umar).

\begin{tabular}{|l|l|l|l|}
\hline $\begin{array}{l}\text { BLAS/SUM/16/AK } \\
\text { /30 }\end{array}$ & $\begin{array}{l}\text { KITAB ŻURRAH } \\
\text { DANWADATUS } \\
\text { ȘAATT }\end{array}$ & $\mathbf{3}$ & Akaid \\
\hline $\begin{array}{l}\text { BTLN/MSRF/102/ } \\
2012\end{array}$ & Arab & Arab & Prosa \\
\hline $80 \mathrm{hlm}$. & 7 baris/hlm. & $27.5 \times 18$ & Kertas Daluwang \\
\hline Nyai Musyarofah & \multicolumn{2}{|l}{} \\
\hline Bantilan Batu Putih & \\
\hline
\end{tabular}

Naskah ini berisi dua teks. Teks pert ama Kitab Zurrah menjelaskan tentang akidah 50, teks kedua bernama Wadhatus Salat menjelaskan tentang arti penting syahadat.

Naskah milik Nyai Musyarofah dari Nyai Aminah. Kondisi naskah mulai rusak, teks masih terbaca. 


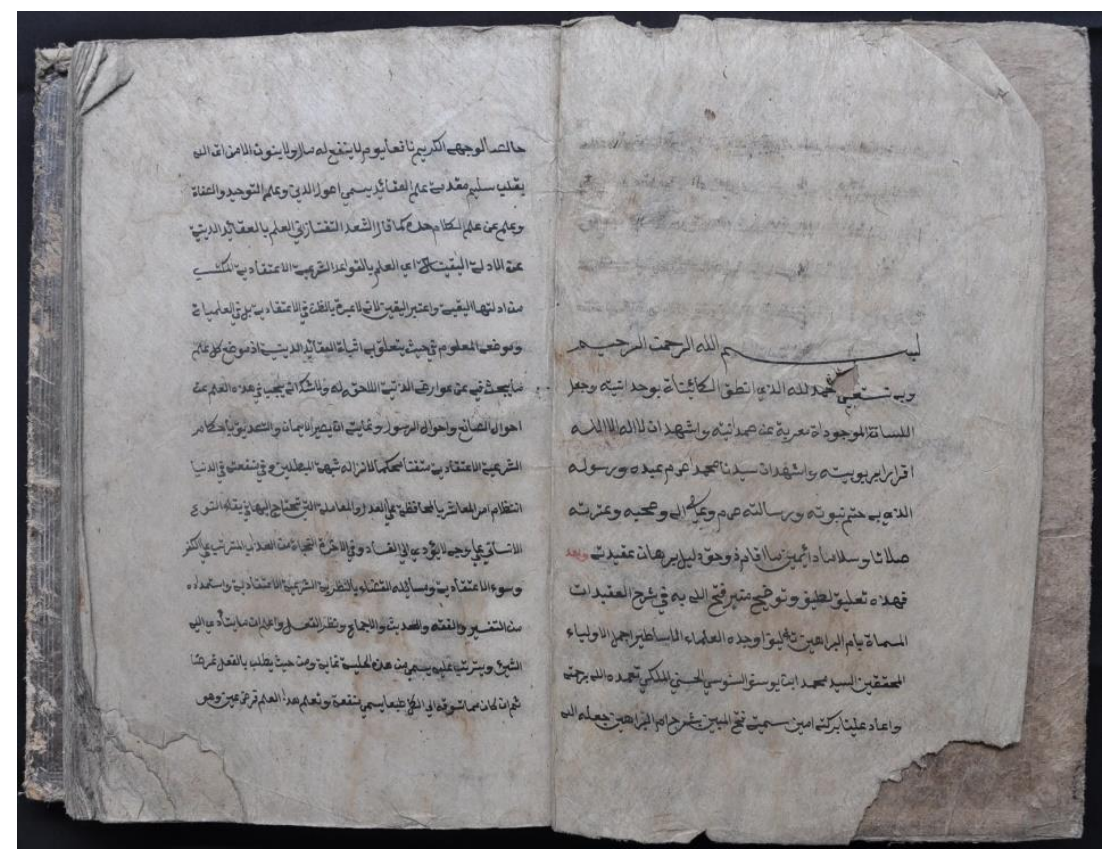

12102 MCT AWR 1012012 HLM 1,2 Img9472

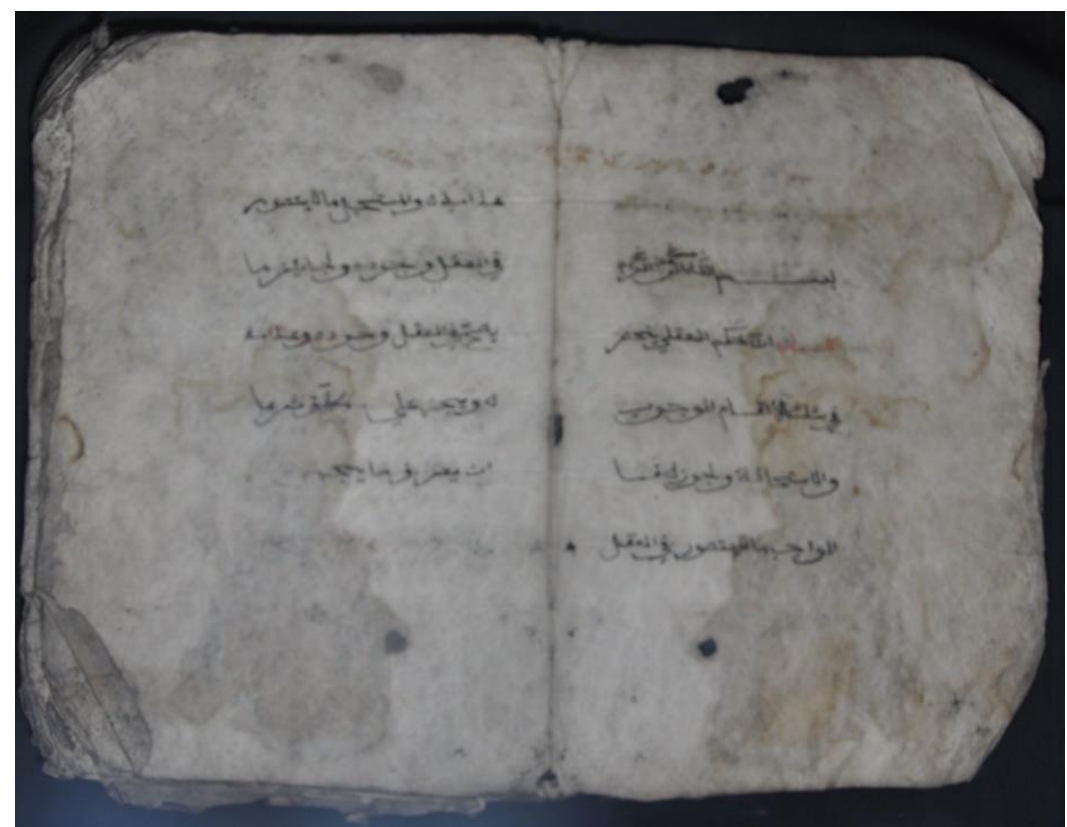

12103 BTLN MSRF 1022012 HLM 1,2 Img9606 


\begin{tabular}{|l|l|l|l|}
\hline $\begin{array}{l}\text { BLAS/SUM/16/AK } \\
\text { /31 }\end{array}$ & $\begin{array}{l}\text { KITAB } \\
\text { SAMARQANDI }\end{array}$ & $\mathbf{3}$ & Akaid \\
\hline $\begin{array}{l}\text { BLTN/STASH/103 } \\
\text { /2012 }\end{array}$ & Arab & Arab & Prosa \\
\hline $64 \mathrm{hlm}$. & 5 baris/hlm. & $26.5 \times 19$ & Kertas Daluwang \\
\hline Nyai Siti Aisyah & & \\
\hline Bantilan Batu Putih &
\end{tabular}

Naskah berisi dua teks. Teks pertama bernama Kitab Samarqandi menjelskan tentang akidah 50 yang dibuktikan dengan hukum akal, teks kedua menjelaskan ilmu fiqih tentang taharah, salat, syarat dan rukunnya.

Naskah ini milik Nyai Siti Aisyah dari Nyai Rabiah. Kondisi naskah mulai rusak, teks masih terbaca.

\begin{tabular}{|l|l|l|l|}
\hline $\begin{array}{l}\text { BLAS/SUM/16/AK } \\
\text { 32 }\end{array}$ & $\begin{array}{l}\text { KITAB } \\
\text { BAYĀNUL ALIF }\end{array}$ & 3 & Akaid \\
\hline $\begin{array}{l}\text { BTLN/ASWN/104/ } \\
2012\end{array}$ & Arab & Arab & Prosa \\
\hline 148 hlm. & 6 baris/hlm. & $23.5 \times 16$ & Kertas Daluwang \\
\hline Aswani & & \\
\hline Bantilan Batu Putih &
\end{tabular}

Naskah berisi empat Teks. Teks pertama bernama Zurrah menjelaskan kewajiban seseorang dalam beriman. Teks kedua bernama kitab Țalabul Ilmi menjelaskan bersuci, menjaga aurat, salat dengan syarat dan rukunnya. Teks ketiga bernama Bayanul alif menjelaskan tentang hukum akal yang dihubungkan dengan akidah 50 .

Naskah ini milik Aswani dari Abdul Ghani. Kondisi naskah mulai rusak, teks masih terbaca. 


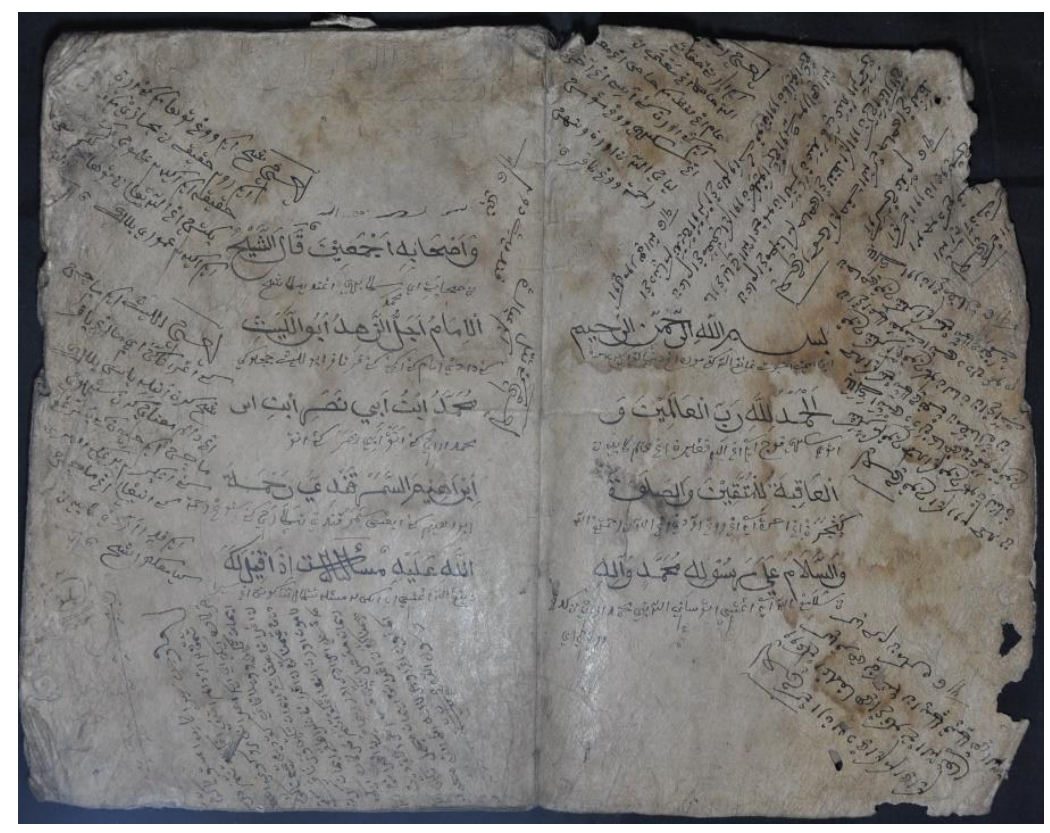

12104 BTLN STASH 1032012 HLM 1,2 Img9651

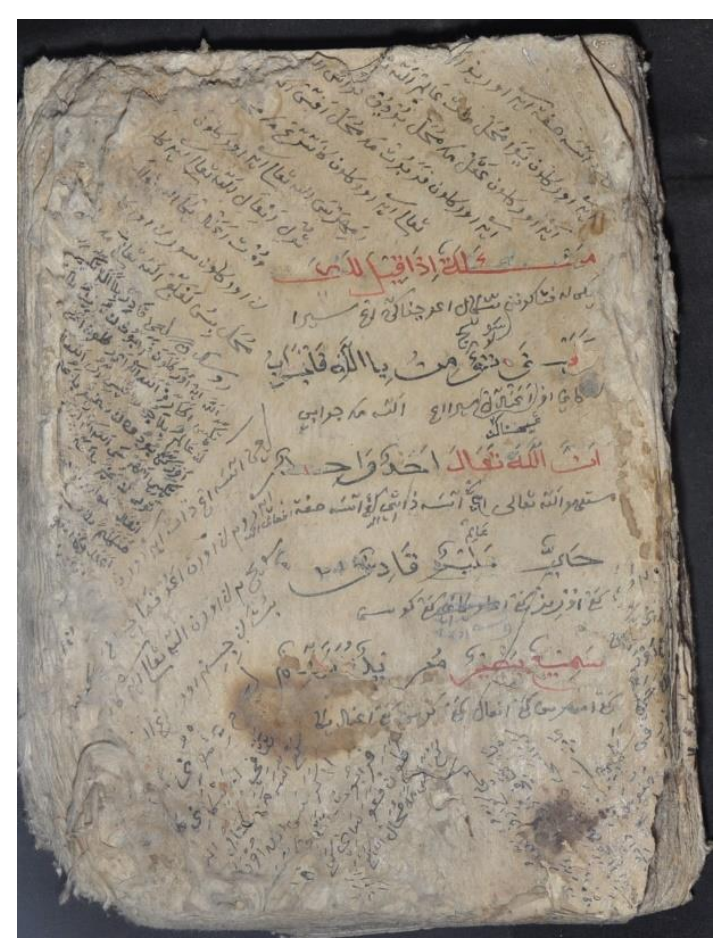

12105 BTLN STASN 1042012 HLM 1 Img9688 


\begin{tabular}{|l|l|l|l|}
\hline $\begin{array}{l}\text { BLAS/SUM/16/AK } \\
\text { /33 }\end{array}$ & $\begin{array}{l}\text { KAJNA ŻUL } \\
\text { FAKKHÄR }\end{array}$ & $\mathbf{3}$ & Akaid \\
\hline $\begin{array}{l}\text { BTLN/MSDN/106/ } \\
2012\end{array}$ & Arab & Arab & Prosa \\
\hline $58 \mathrm{hlm}$. & 7 baris/hlm. & $25 \times 17.5$ & Kertas Daluwang \\
\hline Misdah & & \\
\hline Bantilan Batu Putih &
\end{tabular}

Naskah ini berisi tiga teks. Teks pertama bernama Kajian Zul Fakhar disusun oleh Agud Ruhan menjelaskan makna syahadat menurut Asy'ariyah. Teks kedua bernama kitab Zurrah menjelaskan tentang akidah 50 menurut hukum akal. Teks ketiga berisi tentang doa-doa.

Naskah ini milik Misdah dari Musyarif. Kondisi naskah rusak, teks mulai sulit dibaca.

\begin{tabular}{|l|l|l|l|}
\hline $\begin{array}{l}\text { BLAS/SUM/16/AK } \\
\text { /34 }\end{array}$ & KITAB TAUHID & $\mathbf{3}$ & Akaid \\
\hline $\begin{array}{l}\text { BTLN/ABDSMD/1 } \\
07 / 2012\end{array}$ & Arab & Arab & Prosa \\
\hline 78 hlm. & 5,7 baris/hlm. & $25 \times 18$ & Kertas Daluwang \\
\hline Abdus Samad & \multicolumn{2}{|l}{} \\
\hline Bantilan Batu Putih & \\
\hline
\end{tabular}

Teks ini menjelaskan tentang jumlah rasul, kitab, dan syarat iman.

Naskah ini milik Abdus Somad dari Nyai Khuzaimah. Kondisi naskah cukup baik, teks terbaca. 


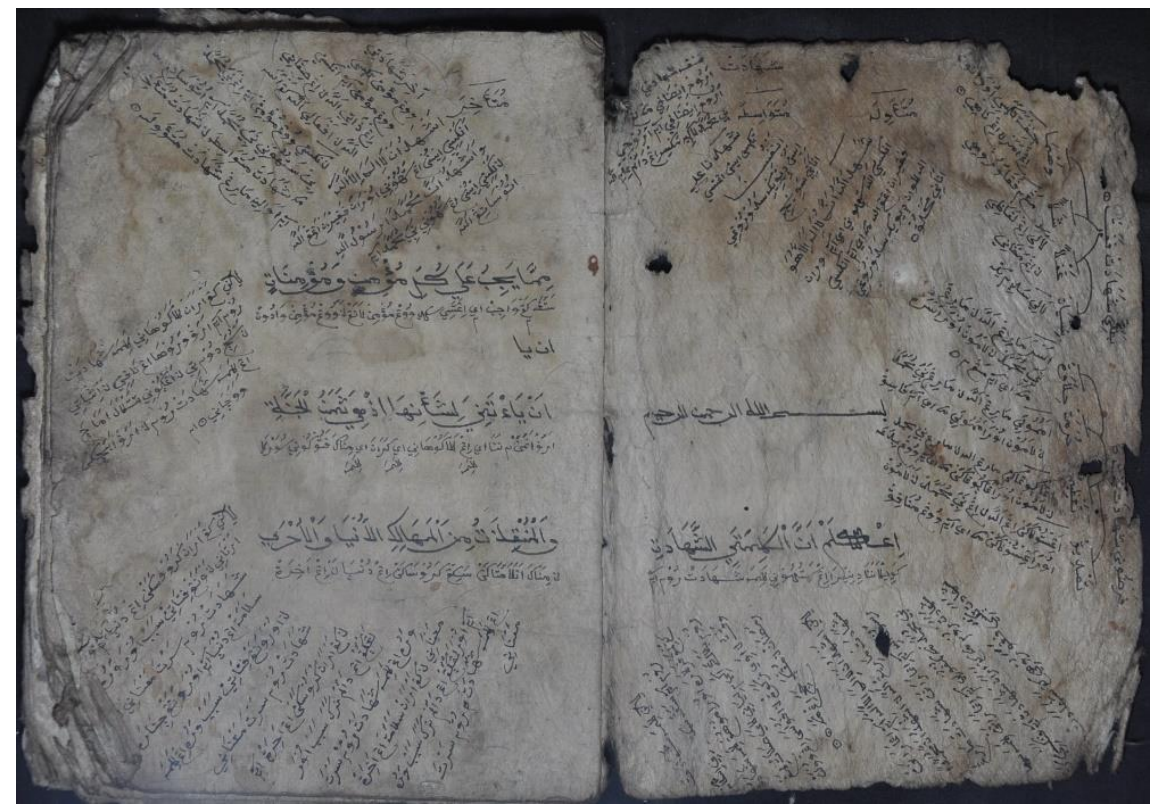

12107 BTLN MSDN 1062012 HLM 1,2 Img9867

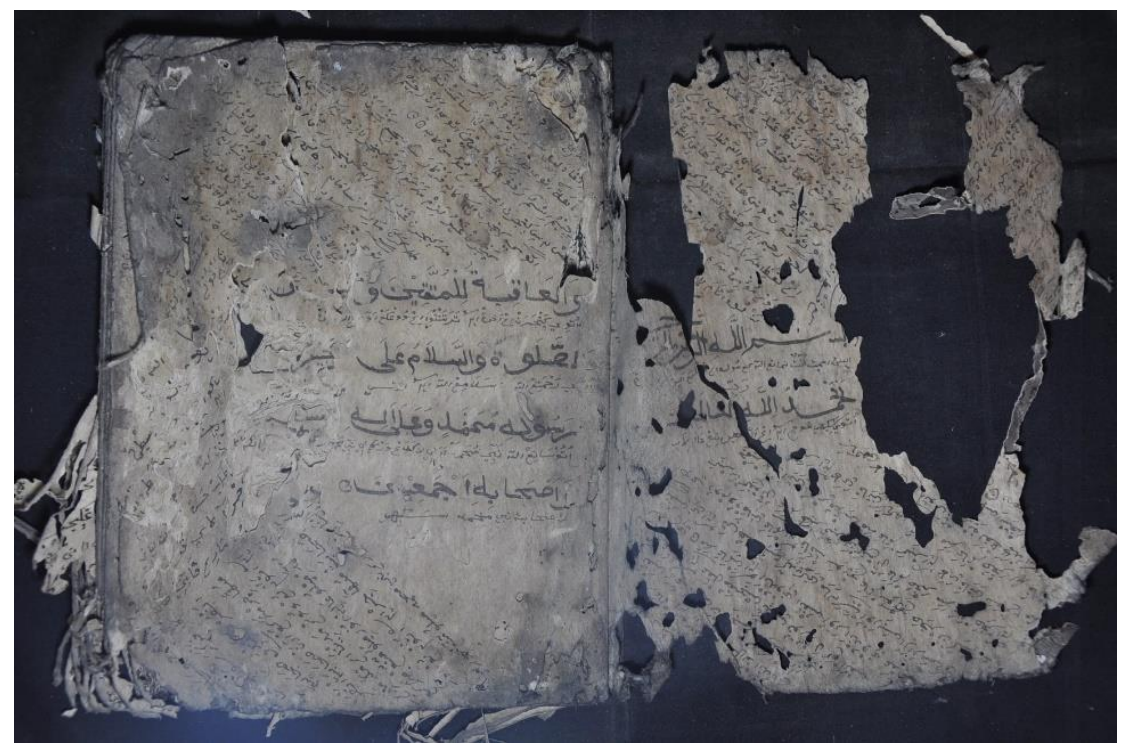

12108 BTLN ABDSMD 1072012 HLM 1,2 Img9905 


\begin{tabular}{|l|l|l|l|}
\hline $\begin{array}{l}\text { BLAS/SUM/16/AK } \\
\text { /35 }\end{array}$ & $\begin{array}{l}\text { KITAB DINUL } \\
\text { ISLĀM DAN } \\
\text { SAFINATUS } \\
\text { SAFAR }\end{array}$ & 3 & Akaid \\
\hline $\begin{array}{l}\text { BTLN/ABDSMD/1 } \\
08 / 2012\end{array}$ & Arab & Arab & Prosa \\
\hline 46 hlm. & 8 baris/hlm. & $20.5 \times 16.5$ & Kertas Daluwang \\
\hline Abdus Samad & & \\
\hline Bantilan Batu Putih & \\
\hline
\end{tabular}

Naskah ini berisi dua teks, teks pertama bernama Dinul Islam menjelaskan tentang iman dan Islam, teks kedua bernama Safinatus-safar menjelaskan tentang kemaksiatan yang dilakukan oleh semua anggota badan.

Naskah ini milik Abdus Somad dari Nyai Khuzaimah. Kondisi naskah mulai rusak, teks masih terbaca.

\begin{tabular}{|l|l|l|l|}
\hline $\begin{array}{l}\text { BLAS/SUM/16/AK } \\
\text { /36 }\end{array}$ & $\begin{array}{l}\text { KITAB NABI } \\
\text { DAN RASUL }\end{array}$ & 3 & Akaid \\
\hline $\begin{array}{l}\text { BTLN/MTMH/110/ } \\
2012\end{array}$ & Arab & Arab & Prosa \\
\hline $32 \mathrm{hlm}$. & 7 baris/hlm. & $27 \times 19$ & Kertas Daluwang \\
\hline Mutammimah & \multicolumn{2}{|l}{} \\
\hline Bantilan Batu Putih
\end{tabular}

Di antara isi naskah ini adalah kisah bahwa Allah mengutus Nabi dan Rasul berjumlah 330 orang, perbedaan rasul membawa syaraiat dan nabi tidak membawa syariat.

Naskah ini milik Mutammimah dari KH Hasyim. Kondisi naskah mulai rusak, teks masih terbaca. 


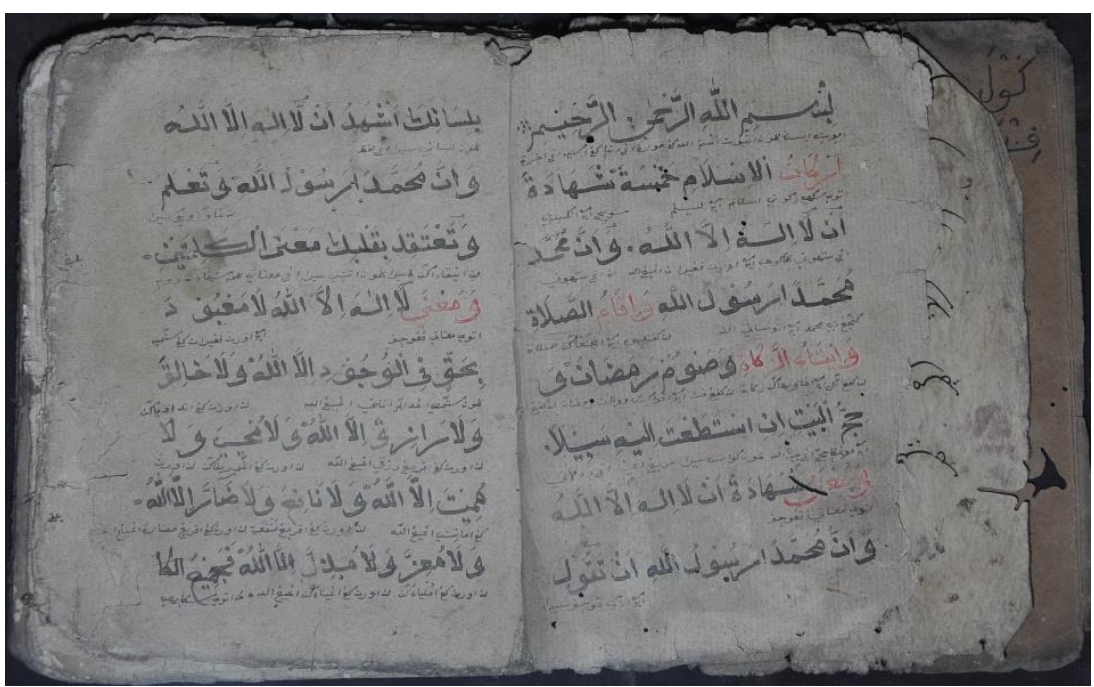

12109 BTLN ABDSMD 1082012 HLM 1,2 Img9952

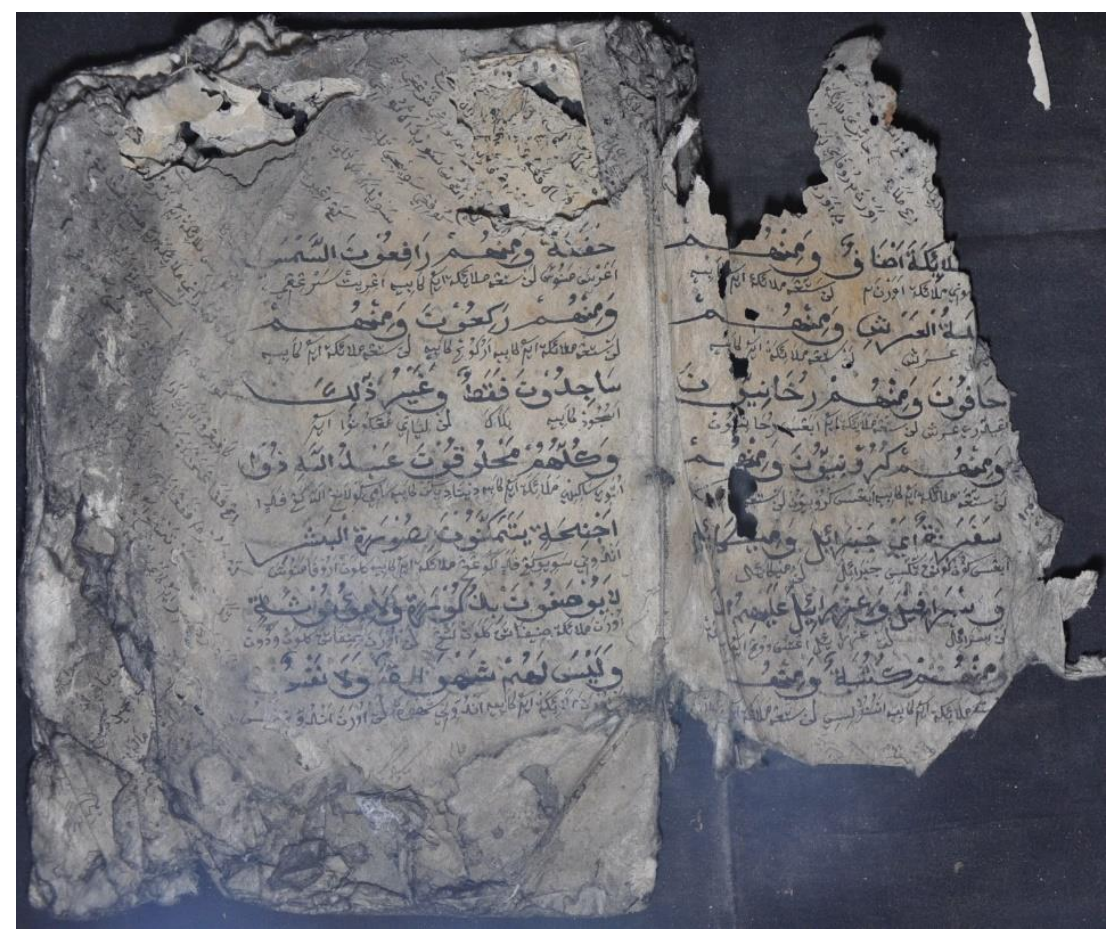

12111 BTLN MTMH 1102012 HLM 2,3 Img10019 


\begin{tabular}{|l|l|l|l|}
\hline $\begin{array}{l}\text { BLAS/SUM/16/AK } \\
\text { /37 }\end{array}$ & $\begin{array}{l}\text { KITAB } \\
\text { BAHJATUL } \\
\text { ULŪM }\end{array}$ & $\mathbf{3}$ & Akaid \\
\hline $\begin{array}{l}\text { BTLN/MSK/113/2 } \\
012\end{array}$ & Arab & Arab & Prosa \\
\hline $96 \mathrm{hlm}$. & 7 baris/hlm. & $20 \times 16$ & Kertas Daluwang \\
\hline Miski & & \\
\hline Bantilan Batu Putih & \\
\hline
\end{tabular}

Teks ini bernama Bahjatul Ulum menjelaskan tentang akidah 50, yaitu sifat lima puluh bagi Allah dan Rasul.

Naskah ini milik Miski dari K.H. Syamsudin. Kondisi naskah baik, teks terbaca.

\begin{tabular}{|l|l|l|l|}
\hline $\begin{array}{l}\text { BLAS/SUM/16/AK } \\
\text { /38 }\end{array}$ & KITAB TAUHID & $\mathbf{3}$ & Akaid \\
\hline $\begin{array}{l}\text { BTLN/MWN/114/2 } \\
012\end{array}$ & Arab & Arab & Prosa \\
\hline $198 \mathrm{hlm}$. & 7 baris/hlm. & $21.5 \times 16.5$ & Kertas Daluwang \\
\hline Mu'awanah & \\
\hline Bantilan Batu Putih
\end{tabular}

Naskah ini menjelaskan tentang syarat sah iman dan bagian -bagiannya.

Naskah ini milik Muawanah dari Nyai Jaibah. Kondisi naskah baik, teks terbaca. 


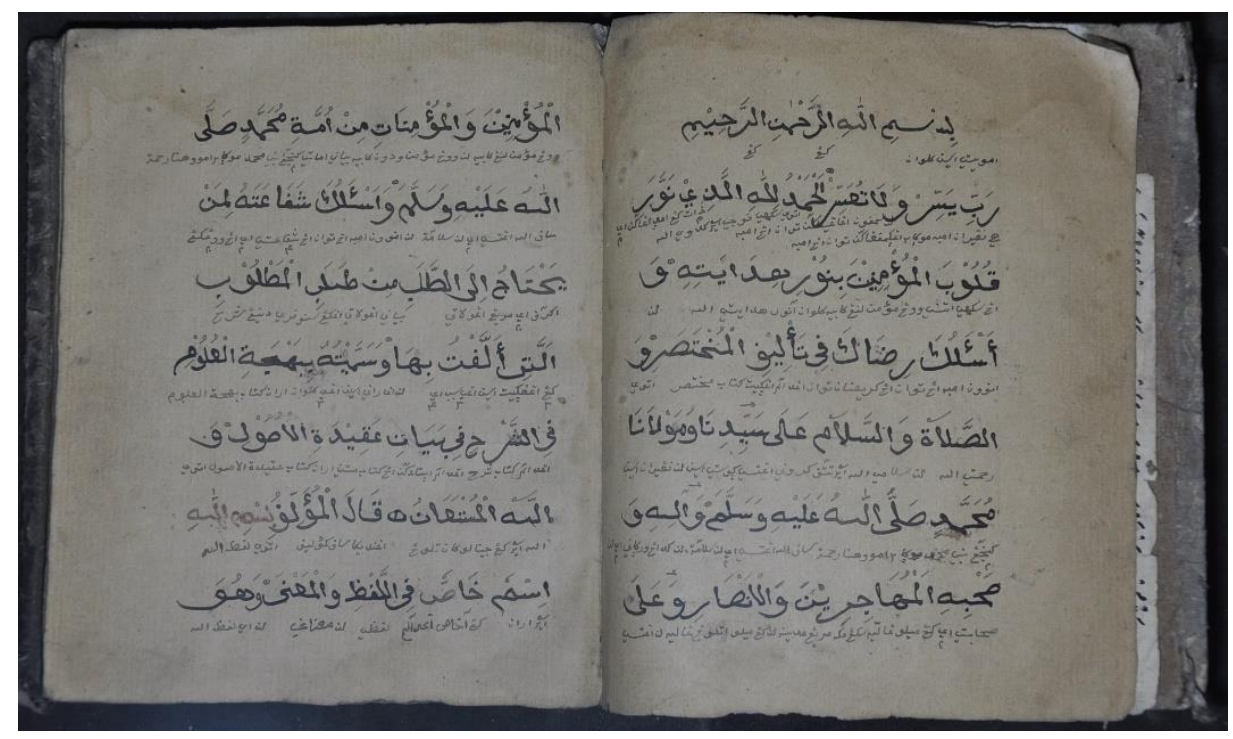

12114 BTLN MSK 1132012 HLM 1,2 Img10215

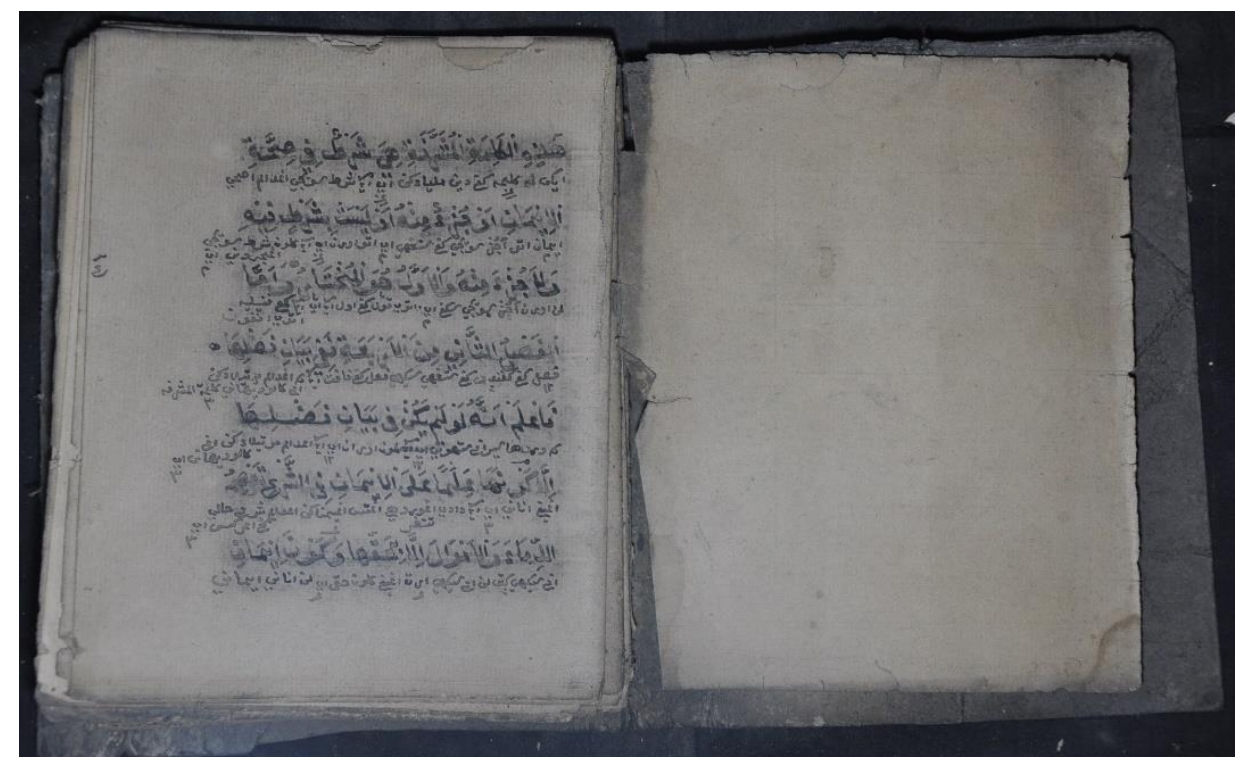

12115 BTLN MWN 1142012 HLM 1 Img10271 


\begin{tabular}{|l|l|l|l|}
\hline $\begin{array}{l}\text { BLAS/SUM/16/AK } \\
\text { /39 }\end{array}$ & KITAB ŻURRAH & 3 & Akaid \\
\hline $\begin{array}{l}\text { BTLN/MWN/115/2 } \\
012\end{array}$ & Arab & Arab & Prosa \\
\hline 34 hlm. & 5 baris/hlm. & $20.5 \times 16.5$ & Kertas Daluwang \\
\hline Mu'awanah & & \\
\hline Bantilan Batu Putih & & \\
\hline
\end{tabular}

Teks ini bernama Zurrah menjelaskan tentang sifat wajib, muhal, jaiz bagi Allah dan Rasul.

Naskah ini milik Muawanah dari Nyai Jaibah. Kondisi naskah cukup baik, teks terbaca.

\begin{tabular}{|l|l|l|l|}
\hline $\begin{array}{l}\text { BLAS/SUM/16/AK } \\
\text { /40 }\end{array}$ & $\begin{array}{l}\text { KITAB MACAM } \\
\text { FARDU }\end{array}$ & 3 & Akaid \\
\hline $\begin{array}{l}\text { NYBK.BTBT/ARF } \\
\text { S/117/2012 }\end{array}$ & Arab & Arab & Prosa \\
\hline 163 hlm. & 17 baris/hlm. & $27 x 19$ & Kertas Daluwang \\
\hline Arif Sudarsono & \\
\hline Nyabakan Timur Batang-Batang & \\
\hline
\end{tabular}

Naskah ini menjelaskan tentang fardu ada empat macam, yakni fardu ain, kifayah, qaimun, dan lazim. Fardu ain seperti melakukan rukun Islam, fardu kifayah seperti memandikan jenazah dan mensalatinya, fardu qaimun seperti mengimankan Allah, dan fardu lazim seperti mengimankan Rasul, malaikat, kitab, hari akhir, dan qada dan qadar.

Naskah ini milik Arif Sudarsono dari Syahral. Kondisi naskah mulai rusak, teks sebagian masih terbaca. 


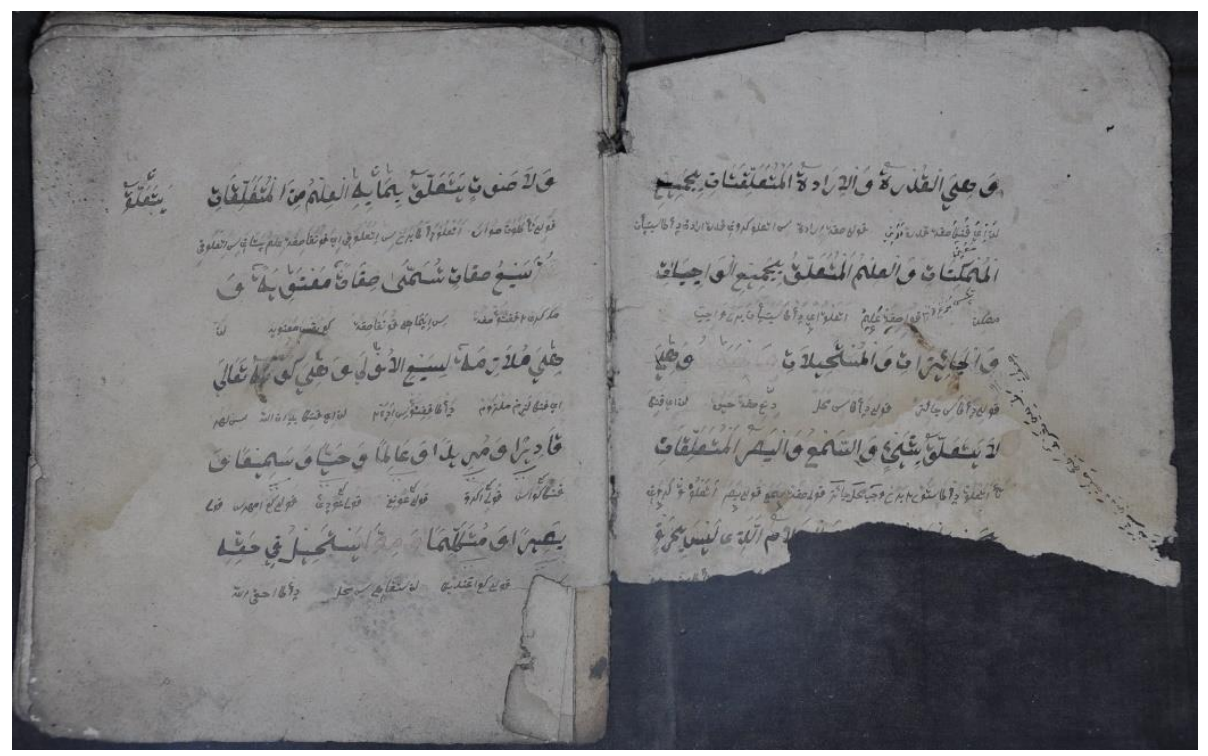

12116 BTLN MWN 1152012 HLM 2,3 Img10323

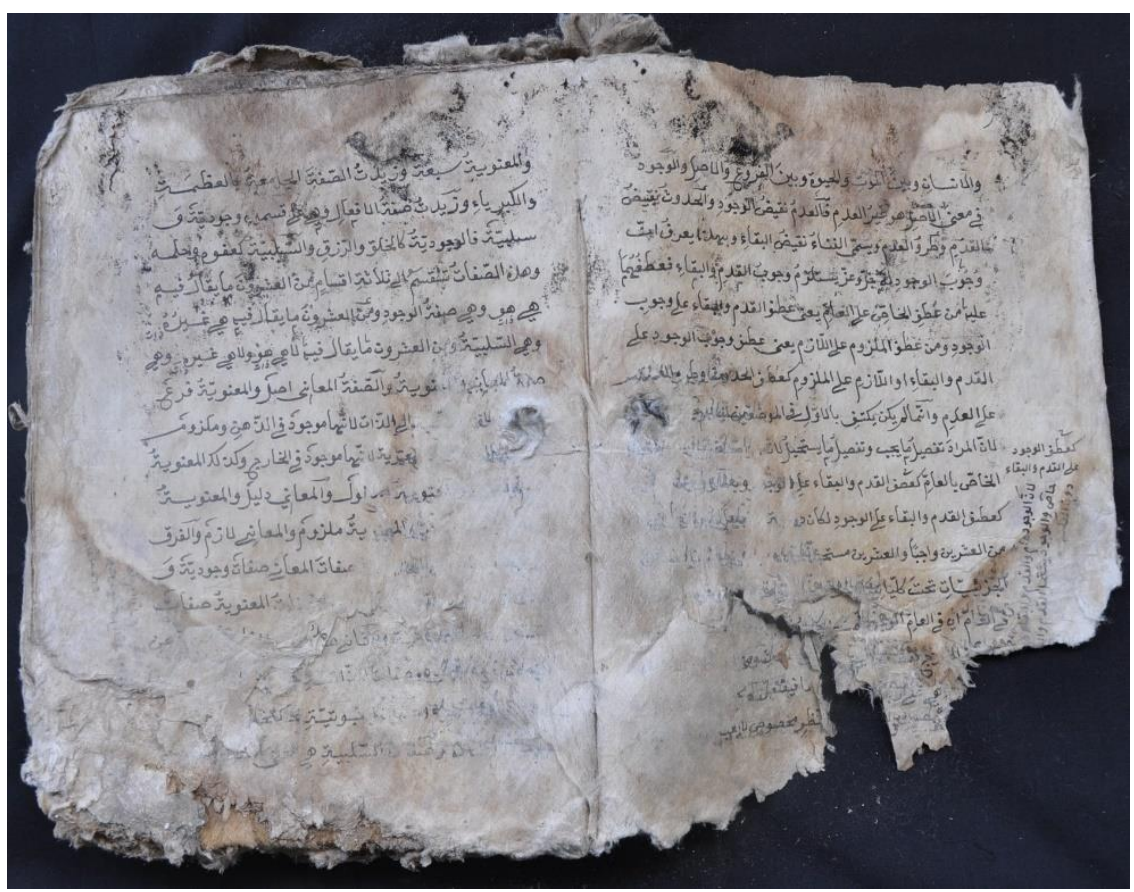

12118 NYBKBTBT ARFS 1172012 HLM 6,7 Img10377 


\begin{tabular}{|l|l|l|l|}
\hline $\begin{array}{l}\text { BLAS/SUM/16/AK } \\
\text { /41 }\end{array}$ & $\begin{array}{l}\text { KITAB TAUHID } \\
\text { DAN AKHLAK }\end{array}$ & 3,5 & $\begin{array}{l}\text { Akaid dan } \\
\text { Akhlak }\end{array}$ \\
\hline $\begin{array}{l}\text { MDGT/AMR/78/20 } \\
12\end{array}$ & Arab & Arab & Prosa \\
\hline $218 \mathrm{hlm}$. & 10 baris/hlm. & $20 \times 16$ & Kertas Daluwang \\
\hline Amir & & \\
\hline \multicolumn{2}{|l}{ Manding Timur, Manding, Sumenep } \\
\hline
\end{tabular}

Naskah ini berisi lima teks. Teks pertama disusun oleh H. Muhammad Syarkawi yang menjelaskan bagi umat Islam wajib mengetahui dan beriktikad dengan benar tentang sifat dua puluh bagi Allah baik wajib dan muhal, sifat wajib dan muhal bagi rasul, dan sifat jaiz bagi Allah dan rasul. Teks kedua menjelaskan tentang akhlak menurut pendapat Imam Ghazali apabila bangun dari tidur malam sebelum waktu subuh disunahkan untuk salat tahajud. Teks ketiga bernama Makrifatul Alami menjelaskan tentang kejadian penciptaan alam. Teks keempat menjelaskan tentang doa-doa. Teks kelima bernama kitab Ta'limul Muta'allim Ṭariqit Ta'allumi menjelaskan bahwa bila ingin anakmu menjadi seorang alim maka bawalah dia ke seorang Fuqaha, muqabah, mulyakan dan beri makan mereka.

Naskah ini berasal dari Amir dari K.H. Abdus Salam. Tahun penyusunan, penulisan, maupun pemrakarsa tidak dicantumkan. Kondisi naskah ini cukup baik dan bisa dibaca.

\begin{tabular}{|l|l|l|l|}
\hline $\begin{array}{l}\text { BLAS/SUM/16/AK } \\
\text { /42 }\end{array}$ & $\begin{array}{l}\text { KITAB RUKUN } \\
\text { IMAN DAN } \\
\text { LAIN-LAIN }\end{array}$ & $\mathbf{3 , 5}$ & $\begin{array}{l}\text { Akaid dan } \\
\text { Akhlak }\end{array}$ \\
\hline $\begin{array}{l}\text { PJGSGG/MDN/143 } \\
\text { /2012 }\end{array}$ & Arab & Arab & Prosa \\
\hline $256 \mathrm{hlm}$. & 7 baris/hlm. & $20 \times 16$ & Kertas Daluwang \\
\hline H. Madani & & \\
\hline \multicolumn{2}{|l|}{ Pajung Sergang, Batu Putih } \\
\hline
\end{tabular}

Naskah berisi empat teks, teks pertama menjelaskan rukun iman dengan Mazhab Asy'ariyah, teks kedua menjelaskan kewajiban muslim untuk mengi'tiqadkan makna syahadat, teks ketiga menjelaskan tentang siyam dan sahur, teks keempat bernama Sullamut Taufiq, di awal teks menjelaskan tentang keimanan dilanjutkan dengan menjelaskan peribadatan.

Naskah ini dimiliki oleh H. Madani dari K.H. Abd Karim. Kondisi naskah masih baik/masih dapat dibaca dengan baik. 


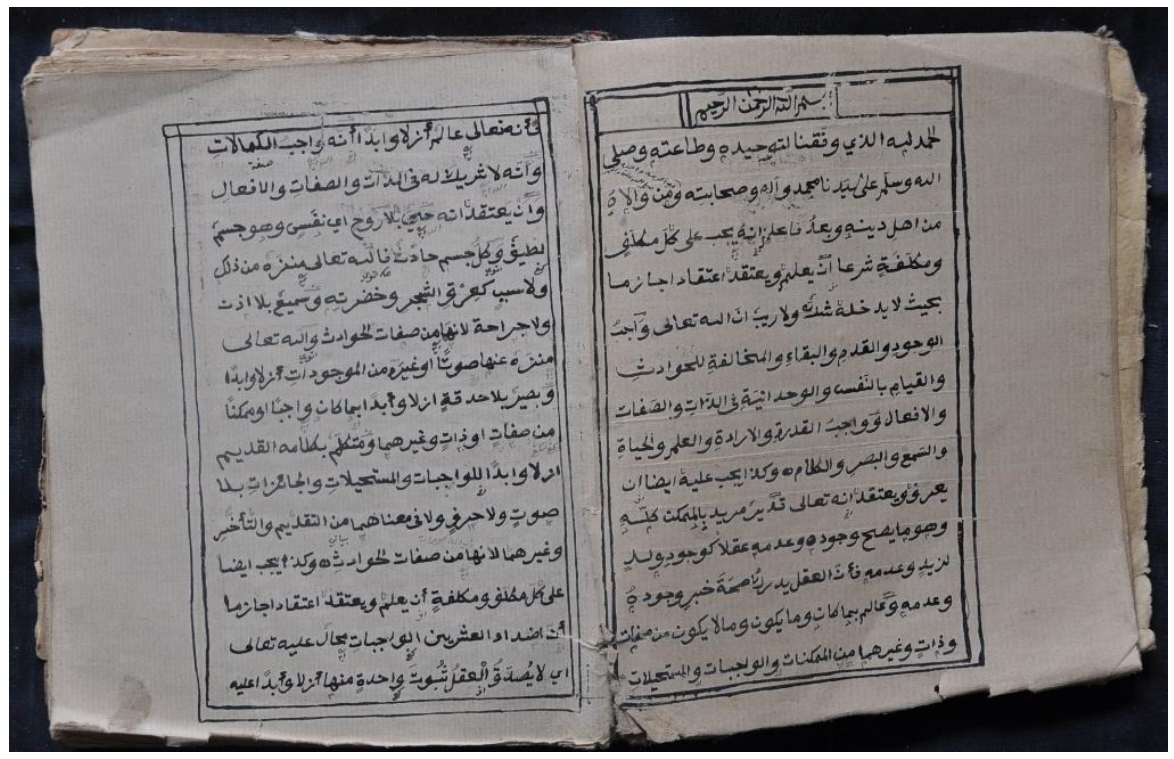

12079 MDGT AMR 782012 HLM 1,2 Img6515

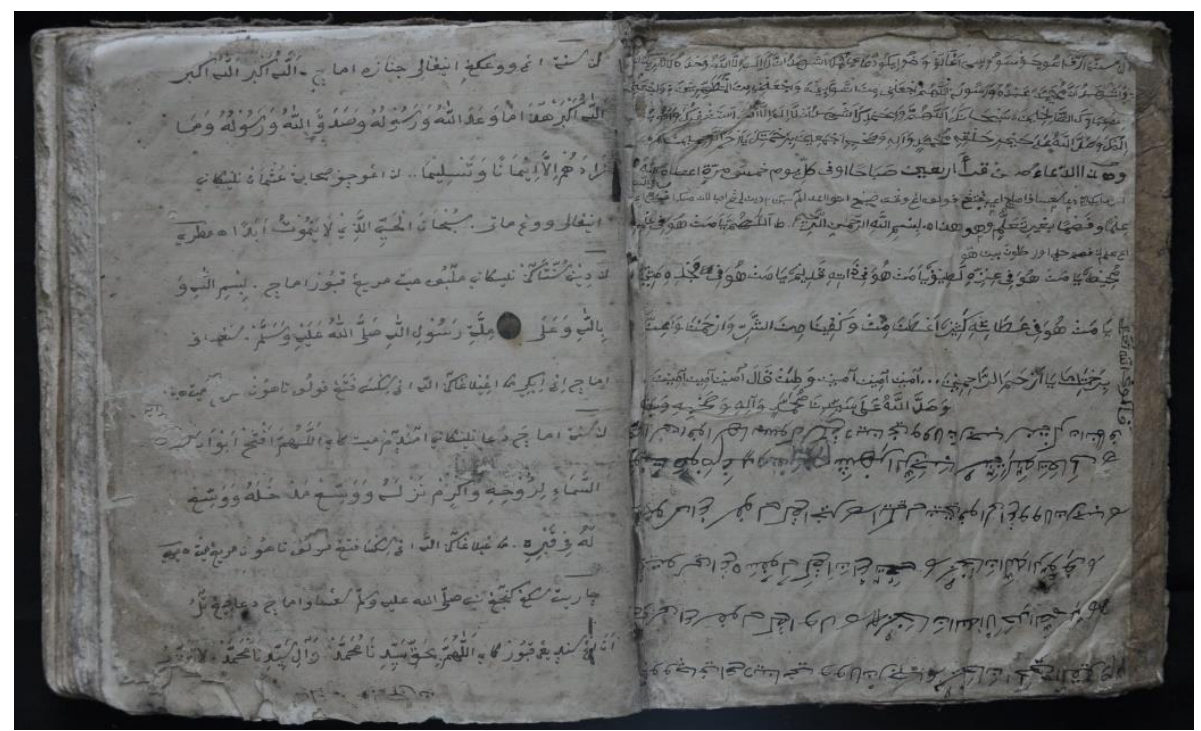

12144 PJGSGG ABDL 1432012 HLM 2 Img11997 


\begin{tabular}{|l|l|l|l|}
\hline $\begin{array}{l}\text { BLAS/SUM/16/AK } \\
\text { /43 }\end{array}$ & $\begin{array}{l}\text { KITAB TAUHID } \\
\text { DAN FIKIH }\end{array}$ & 3,4 & Akaid dan Fikih \\
\hline $\begin{array}{l}\text { GPRB/NSR/18/201 } \\
2\end{array}$ & Arab & Arab & Prosa \\
\hline $384 \mathrm{hlm}$. & 17 baris/hlm. & $30 \times 20.5$ & Kertas Daluwang \\
\hline Nasiruddin & \\
\hline Caremmi, Gapura Barat
\end{tabular}

Naskah ini berisi delapan teks, menjelaskan tentang tauhid dan fikih.

Naskah ini tersimpan di rumah Nasiruddin dari buyutnya, H. Ghazali. Kondisi naskah mulai rusak, teks masih terbaca.

\begin{tabular}{|l|l|l|l|}
\hline $\begin{array}{l}\text { BLAS/SUM/16/AK } \\
\text { /44 }\end{array}$ & $\begin{array}{l}\text { KITAB } \\
\text { SAFINATUS } \\
\text { SALĀT }\end{array}$ & 3,4 & Akaid dan Fikih \\
\hline $\begin{array}{l}\text { PJG/SRBN/51/201 } \\
2\end{array}$ & Arab & Arab & Prosa \\
\hline 48 hlm. & 10 baris/hlm. & $24 \times 18$ & Kertas Daluwang \\
\hline K.H. Syarbini & \multicolumn{2}{|l}{} \\
\hline Pajung, Sergang, Batu Putih
\end{tabular}

Naskah ini berisi dua teks. Teks pertama bernama Safinatus Salat berisi tata cara salat, teks kedua berjudul Sulam Taufiq berisi penjelasan mengenai adab bersujud, bahwa dalam bersujud tidak boleh seperti kita menjadi patung atau pepohonan.

Naskah ini milik K.H. Syarbini dari K.H. Sholihuddin dari K.H. Jail. Kondisi naskah baik, teks terbaca. 


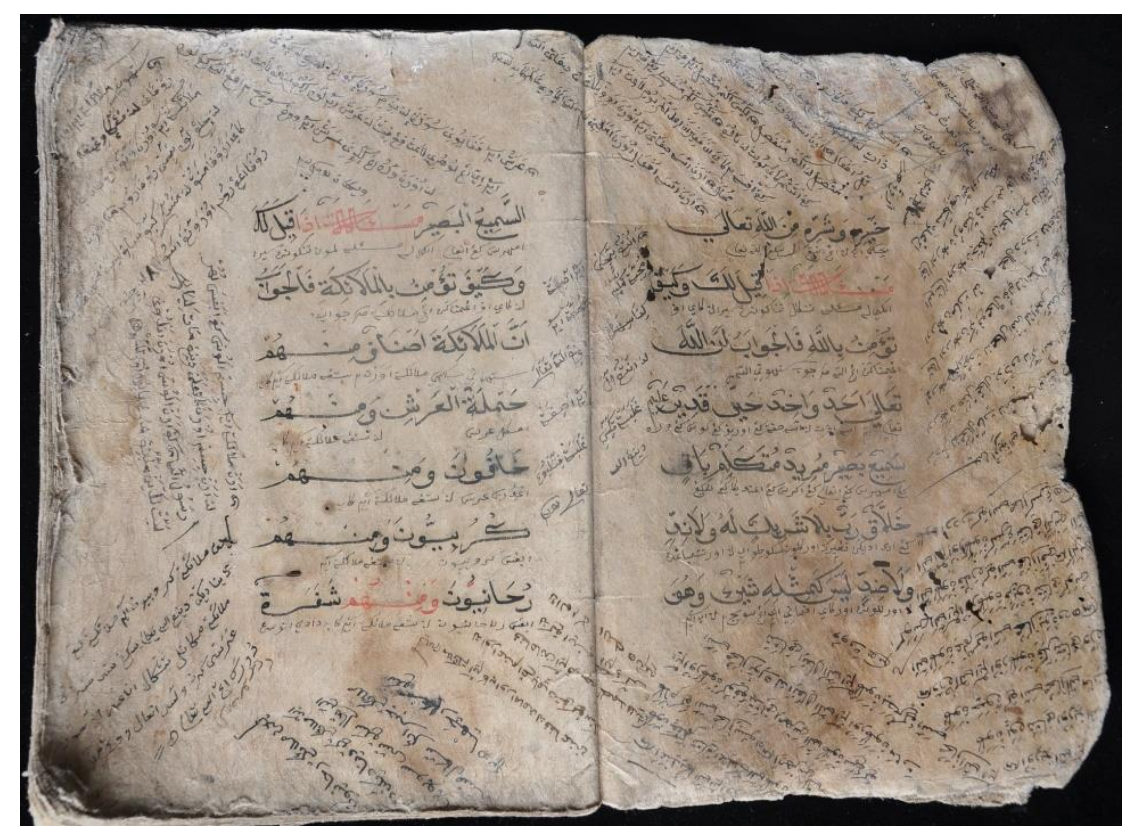

12018 GPRB NSR 182012 HLM 5,6 Img1033

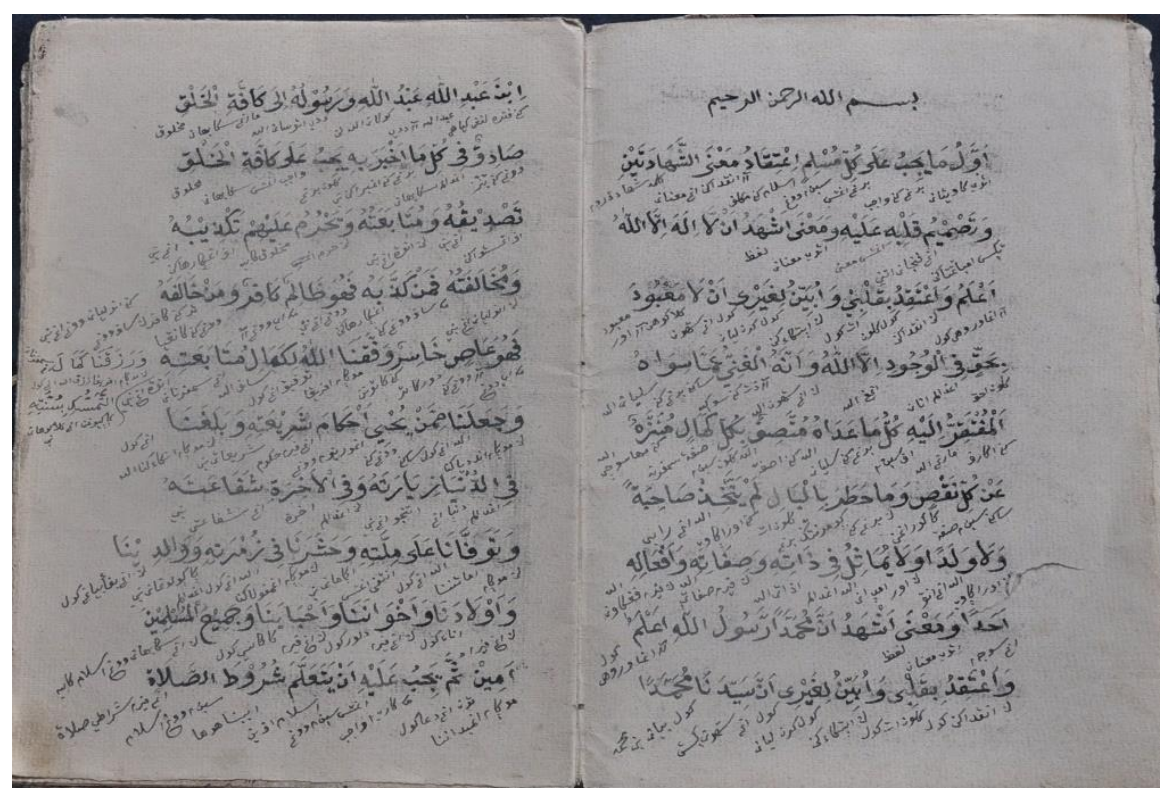

12051 PJG SRBN 512012 HLM 1,2 Img5037 


\begin{tabular}{|l|l|l|l|}
\hline $\begin{array}{l}\text { BLAS/SUM/16/AK } \\
\text { /45 }\end{array}$ & $\begin{array}{l}\text { KITAB AQĀID 50 } \\
\text { DAN SITTIN }\end{array}$ & 3,4 & Akaid dan Fikih \\
\hline $\begin{array}{l}\text { SGG/FTHR/54A/2 } \\
012\end{array}$ & Arab & Arab & Prosa \\
\hline 106 hlm. & 4 s.d 5 baris/hlm. & $26 \times 17.5$ & Kertas Daluwang \\
\hline Fathur & & \\
\hline Sergang, Batu Putih & & \\
\hline
\end{tabular}

Naskah ini berisi dua teks. Teks pertama berjudul Akidah 50, dan teks kedua berjudul Sittin.

Teks pertama berisi penjelasan tentang akidah 50. Teks kedua berisi penjelasan 60 masalah peribadatan mulai dari berwuḍu, salat, puasa, dan sebagainya.

Naskah ini milik Fathur dari K.H. Shiddiq. Kondisi naskah mulai rusak, teks masih terbaca.

\begin{tabular}{|l|l|l|l|}
\hline $\begin{array}{l}\text { BLAS/SUM/16/AK } \\
\text { /46 }\end{array}$ & $\begin{array}{l}\text { KITAB SITT̄NN, } \\
\text { AQIDATUL } \\
\text { UȘUL, DAN AL- } \\
\text { KALLIMAH }\end{array}$ & 3,4 & Akaid dan Fikih \\
\hline $\begin{array}{l}\text { SGG/FTHR/54B/20 } \\
12\end{array}$ & Arab & Arab & Prosa \\
\hline $82 \mathrm{hlm}$. & 6 baris/hlm. & $21 \times 15.5$ & Kertas Daluwang \\
\hline Fathur & & \\
\hline Sergang, Batu Putih & \\
\hline
\end{tabular}

Naskah ini berisi tiga teks. Teks pertama berjudul As-Sittin berisi penjelasan tentang peribadat an seperti wựu dan salat. Teks kedua berjudul Akidatul Ușul berisi penjelasan tentang akidah 50 menurut hukum akal dan syar'i. Teks ketiga berjudul Al-Kalimah berisi penjelasan tentang pentingnya mengetahui makna kalimat syahadat.

Teks As-Sittin selesai ditulis pada hari Rabu tanggal 29 Jumadil Akhir 1298 H/1880 M.Teks ketiga disalin oleh Syarqowi dari dusun Sergang Pajung Wates Wetan dan selesai ditulis pada hari Senin waktu Isya' tanggal 12 Rajab 1292 H/1875 M.

Naskah ini milik Fathur dari K.H. Shiddiq. Kondisi naskah mulai rusak, teks masih terbaca. 


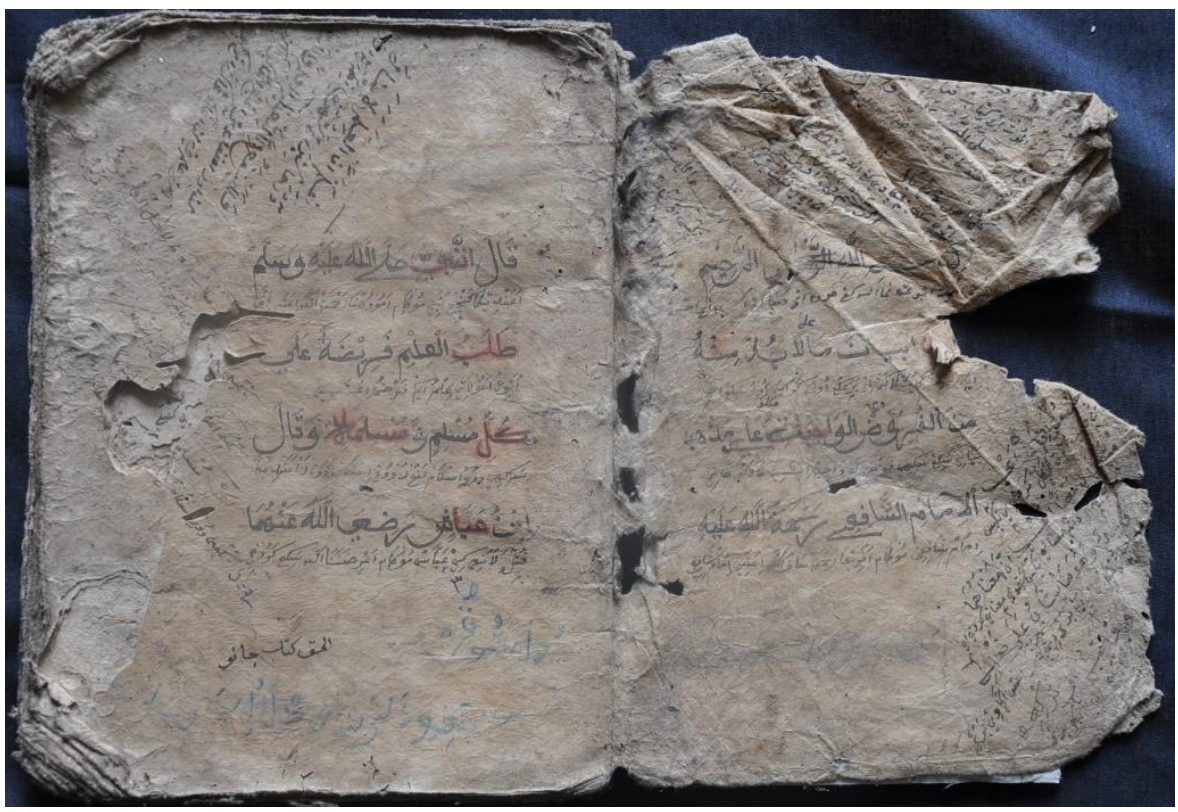

12054 SGG FTHR 54A 2012 HLM 2,3 Img5133

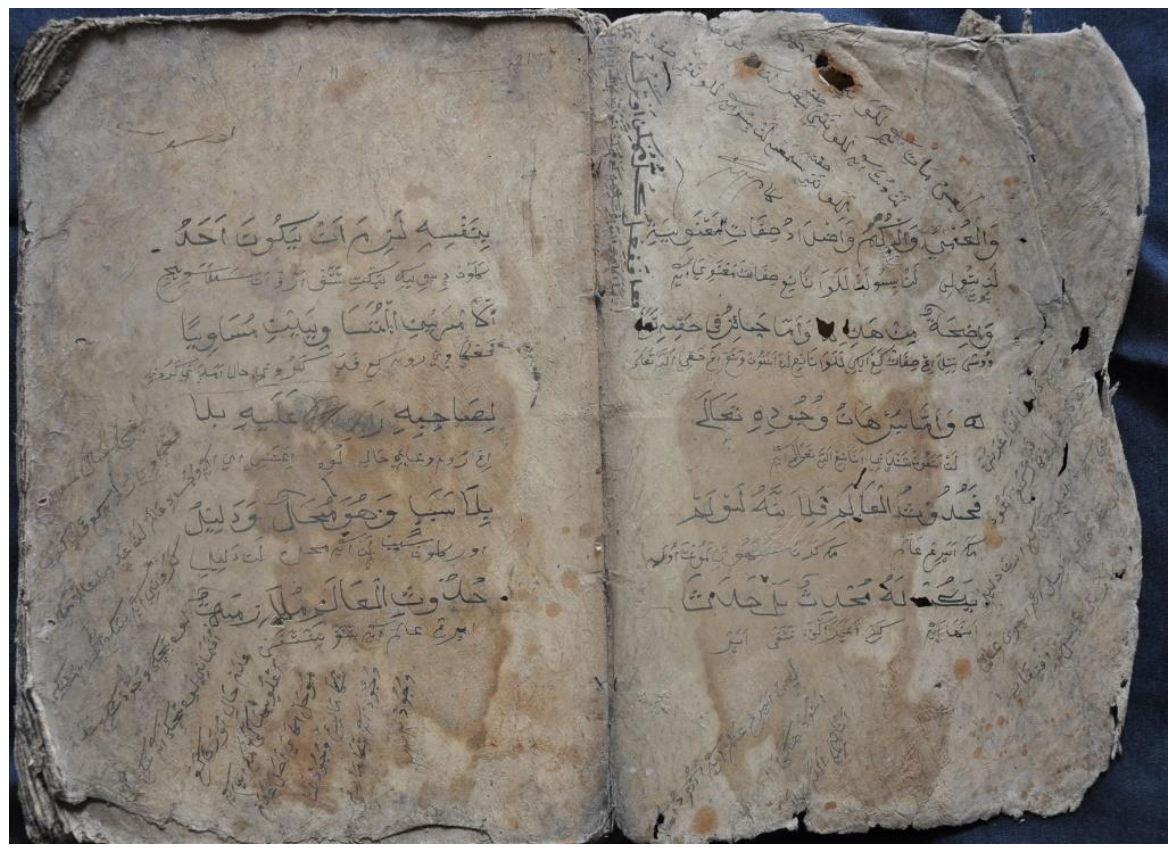

12055 SGG FTHR 54B 2012 HLM 4,5 Img5178 


\begin{tabular}{|l|l|l|l|}
\hline $\begin{array}{l}\text { BLAS/SUM/16/AK } \\
\text { /47 }\end{array}$ & $\begin{array}{l}\text { KITAB TANYA } \\
\text { JAWAB TAUHID } \\
\text { DAN FIKIH }\end{array}$ & 3,4 & Akaid dan Fikih \\
\hline $\begin{array}{l}\text { SGG/FTHR/56/201 } \\
2\end{array}$ & Arab & Arab & Prosa \\
\hline $50 \mathrm{hlm}$. & 6 baris/hlm. & $24.5 \times 17$ & Kertas Daluwang \\
\hline Fathur & & \\
\hline Sergang, Batu Putih & & \\
\hline
\end{tabular}

Naskah ini terdiri dari dua teks. Pertama menjelaskan tauhid dengan tanya jawab. Teks kedua menjelaskan bahwa siapa yang tidak tahu tata cara wuḍu dan salat maka salatnya tidak sah.

Naskah ini milik Fathur dari K.H. Shiddiq. Kondisi naskah mulai rusak, teks masih terbaca.

\begin{tabular}{|l|l|l|l|}
\hline $\begin{array}{l}\text { BLAS/SUM/16/AK } \\
\text { /48 }\end{array}$ & $\begin{array}{l}\text { KITAB IMAN } \\
\text { DAN KITAB } \\
\text { FIKIH }\end{array}$ & 3,4 & Akaid dan Fikih \\
\hline $\begin{array}{l}\text { BTLN/MRWN/69/ } \\
2012\end{array}$ & Arab & Arab & Prosa \\
\hline $24 \mathrm{hlm}$. & 7 baris/hlm. & $25.5 \times 19$ & Kertas Daluwang \\
\hline Marwan & & \\
\hline Bantilan, Batu Putih & \\
\hline
\end{tabular}

Naskah ini berisi dua teks, teks pertama berisi tentang iman dan teks kedua berisi tentang peribadatan, dimulai dari berwuḍu sampai berpuasa.

Naskah ini milik Marwan dari Abdul Ghani. Kondisi naskah mulai rusak, teks masih terbaca. 


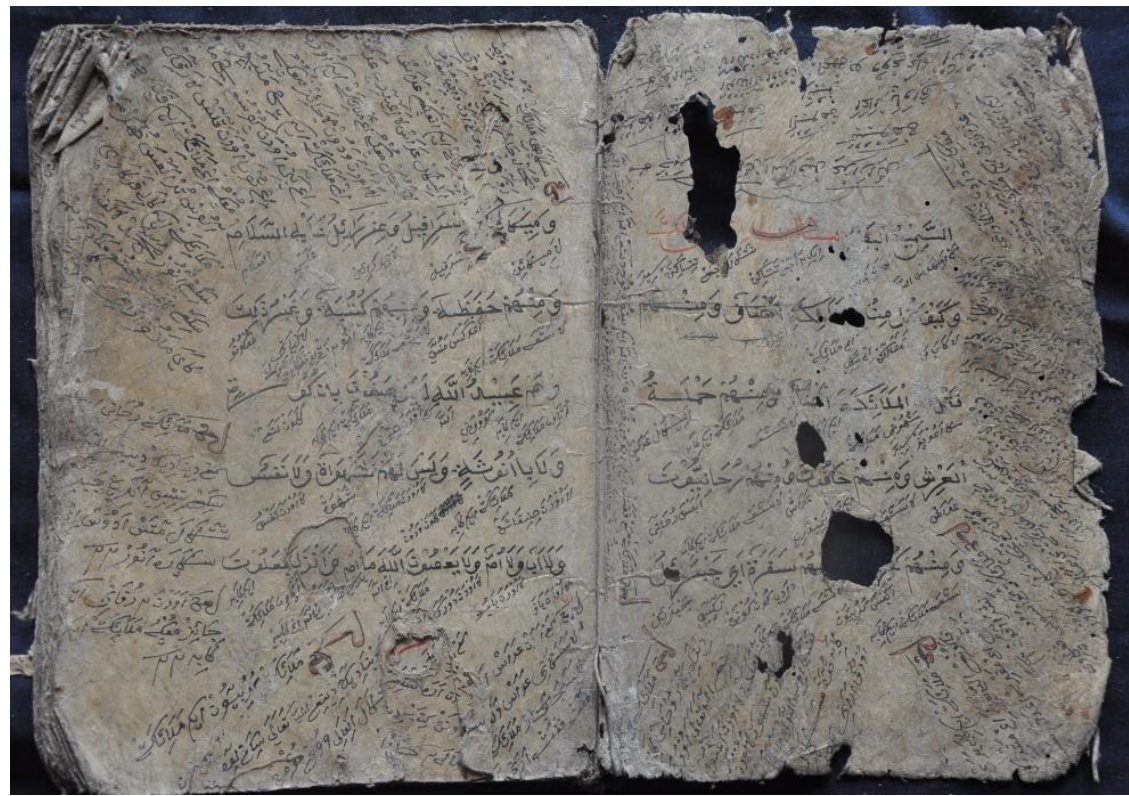

12057 SGG FTHR 562012 HLM 2,3 Img5257

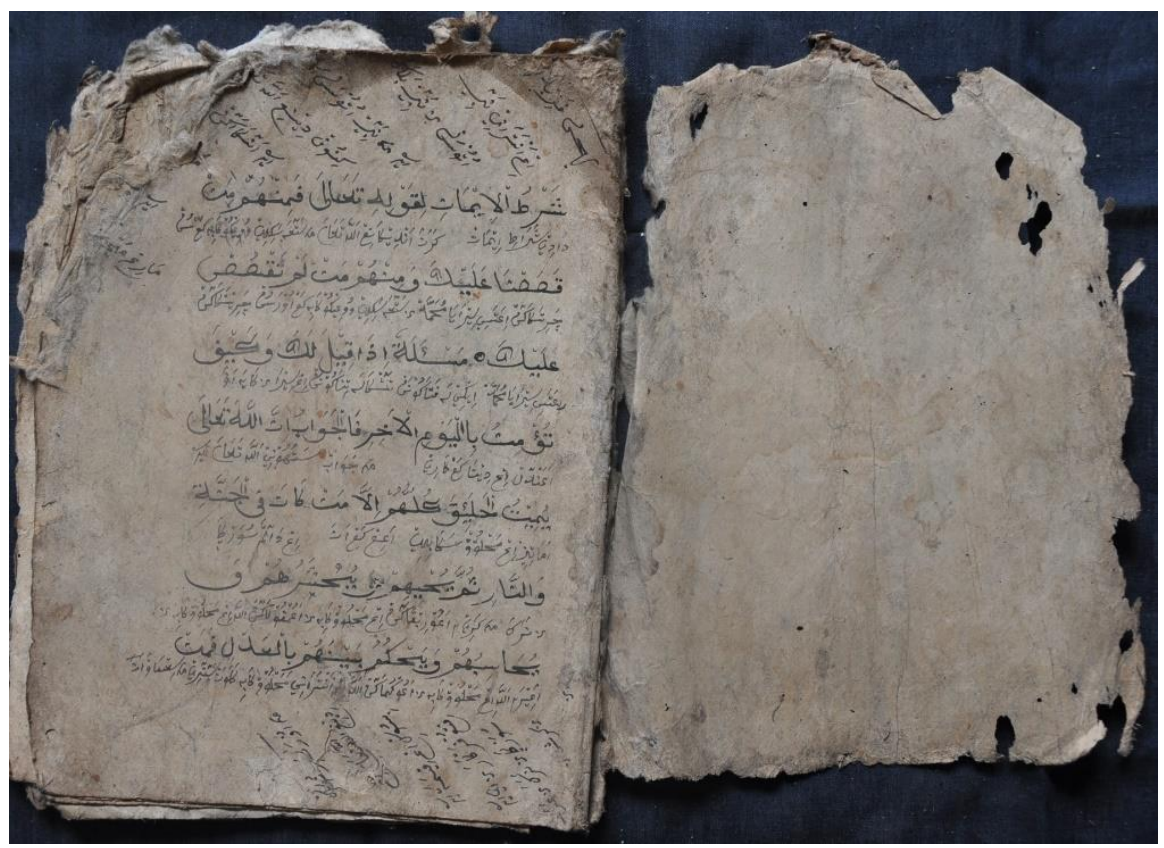

12070 BTLN MRWN 692012 HLM 1 Img5908 


\begin{tabular}{|l|l|l|l|}
\hline $\begin{array}{l}\text { BLAS/SUM/16/AK } \\
\text { /49 }\end{array}$ & $\begin{array}{l}\text { KITAB AQĀID 50 } \\
\text { DAN KITAB } \\
\text { SULLĀM } \\
\text { TAUFIQ }\end{array}$ & 3,4 & Akaid dan Fikih \\
\hline $\begin{array}{l}\text { SGG/MFHM/72/20 } \\
12\end{array}$ & Arab & Arab & Prosa \\
\hline 120 hlm. & 9 baris/hlm. & $23 \times 17$ & Kertas Daluwang \\
\hline M Fahim & \\
\hline \multicolumn{2}{|l}{ Sergang, Batu Putih, Sumenep } \\
\hline
\end{tabular}

Naskah ini berisi dua teks. Teks pertama berisi tentang akidah 50, yakni orang muslim untuk mengetahui sesuatu yang wajib, muhaldan jaiz. Teks kedua bernama kitab Sulam Taufiq menjelaskan tentang ibadah yang benar.

Naskah ini milik M Fahim dari K. Shidiq dari Syamsudin.

\begin{tabular}{|l|l|l|l|}
\hline $\begin{array}{l}\text { BLAS/SUM/16/AK } \\
\text { /50 }\end{array}$ & $\begin{array}{l}\text { KITAB } \\
\text { SAMARQANDI } \\
\text { DAN LAIN-LAIN }\end{array}$ & 3,4 & Akaid dan Fikih \\
\hline $\begin{array}{l}\text { BTLN/ALWI/83/20 } \\
12\end{array}$ & Arab & Arab & Prosa \\
\hline 102 hlm. & 7 baris/hlm. & $27 \times 18$ & Kertas Daluwang \\
\hline K.H. Alwi & \\
\hline Bantilan, Pajung, Batu Putih, Sumenep & \\
\hline
\end{tabular}

Naskah ini berisi lima teks. Teks pertama bernama Samarqandi menjelaskan tentang tauhid lima puluh dengan hukum akal, untuk mengetahui berapa jumlah rasul, nabi bukan merupakan syarat dari iman. Teks kedua menjelaskan tentang tata cara berwudu, sampai berhaji. Teks ketiga bernama makna syahadat karena menjauhkan dari api neraka. Teks keempat menjelaskan tentang hukum akal ada tiga macam yakni wajib, muhal, dan jaiz (tidak mungkin). Teks kelima menjelaskan tentang tata cara ibadah salat.

Naskah milik K.H. Alwi dari K.H. Syafi'udin dari K.H. Syarkawi (sepuh). Tahun penyusunan, penulisan tidak disebutkan. Kondisi kitab ini rusak. 


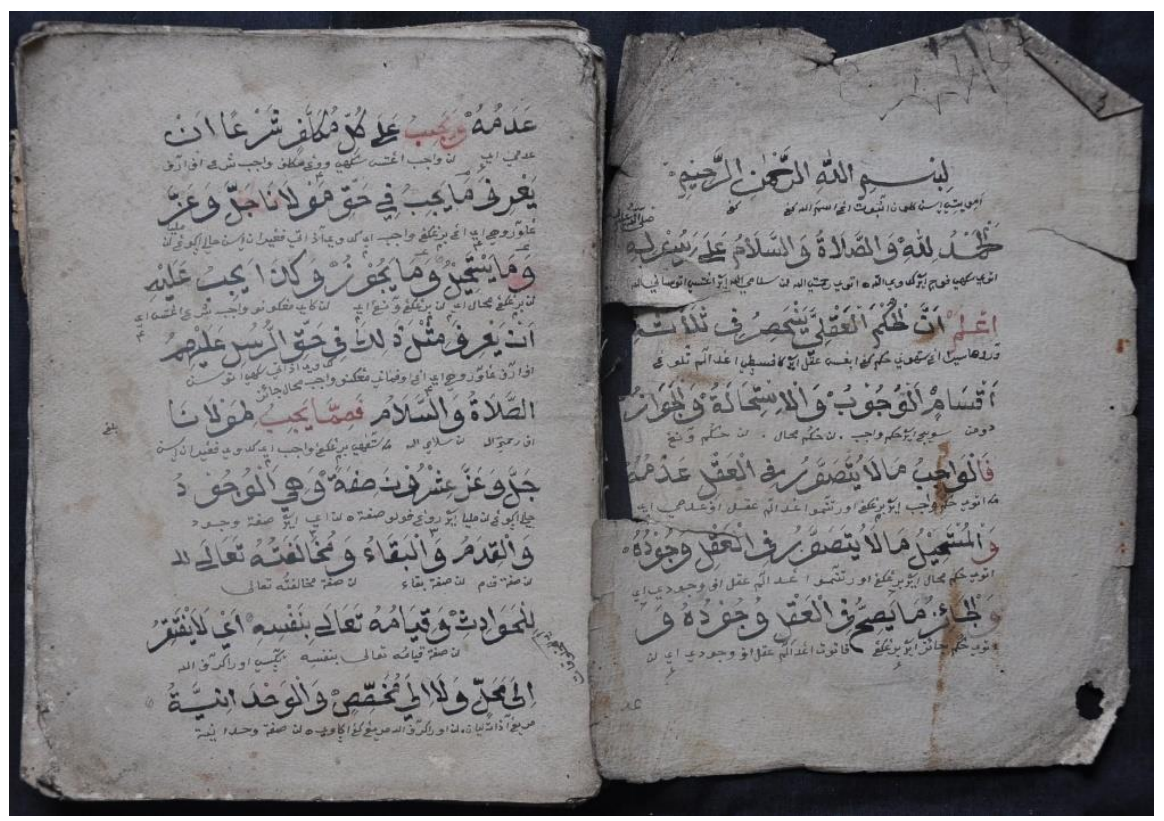

12073 SGG MFHM 722012 HLM 1,2 Img5965

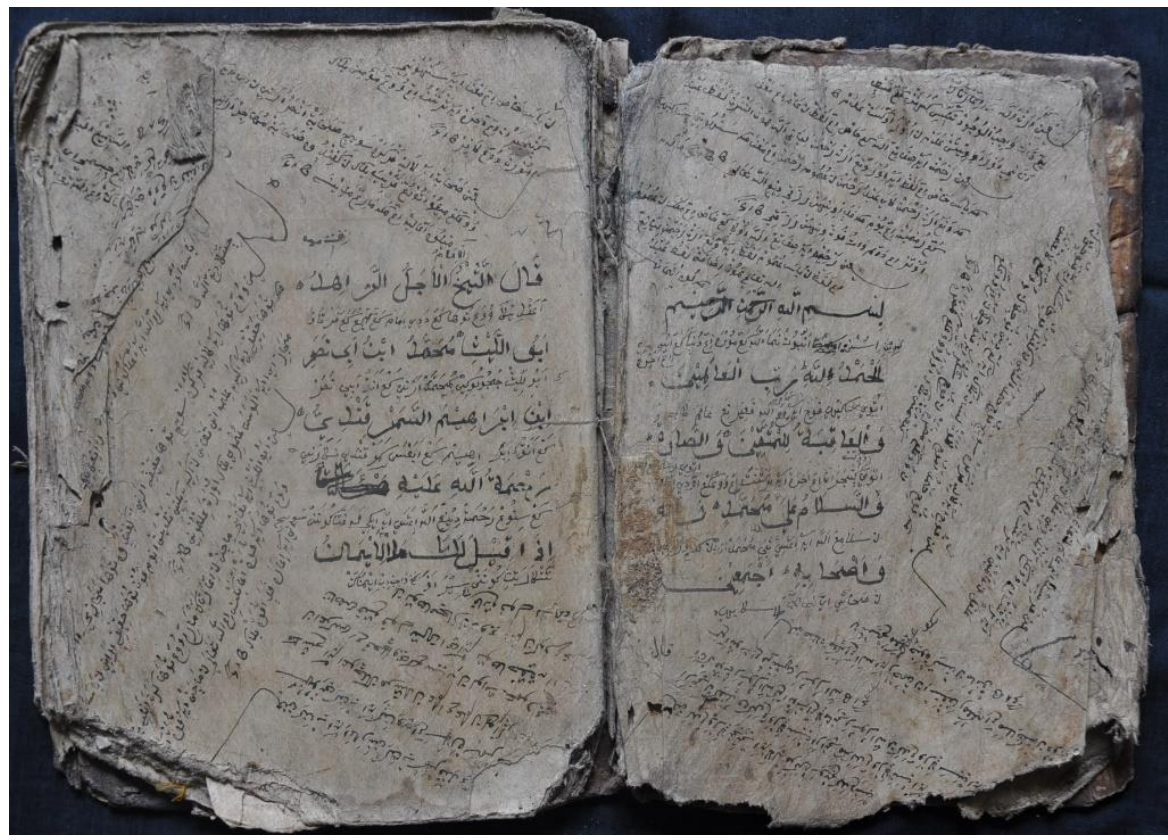

12084 BTLN ALWI 832012 HLM 1,2 Img6824 


\begin{tabular}{|l|l|l|l|}
\hline $\begin{array}{l}\text { BLAS/SUM/16/AK } \\
\text { /51 }\end{array}$ & $\begin{array}{l}\text { KITAB AQ̄AID 50 } \\
\text { DAN KITAB } \\
\text { BERSUCI }\end{array}$ & 3,4 & Akaid dan Fikih \\
\hline $\begin{array}{l}\text { JNGR/HSM/123/20 } \\
12\end{array}$ & Arab & Arab & Prosa \\
\hline $32 \mathrm{hlm}$. & 5 s.d. 7 baris/hlm. & $26 \times 19$ & Kertas Daluwang \\
\hline Hosmah & & \\
\hline Jenangger, Batang-batang &
\end{tabular}

Teks pertama bernama Samarqandi disusun oleh Abu Lais yang menjelaskan tentang akidah 50, teks kedua menjelaskan tentang bersuci menurut mazhab syafi'i.

Naskah ini dimiliki oleh Hosmah dari K. Ahyar dari K. Abdullah. Tahun dan tempat penyusunan, penulisan ulang, maupun pemrakarsa tidak dicantumkan. Naskah dalam kondisi cukup baik/cukup bisa dibaca.

\begin{tabular}{|l|l|l|l|}
\hline $\begin{array}{l}\text { BLAS/SUM/16/AK } \\
\text { /52 }\end{array}$ & $\begin{array}{l}\text { KITAB BERSUCI } \\
\text { DAN LAIN-LAIN }\end{array}$ & 3,4 & Akaid dan Fikih \\
\hline $\begin{array}{l}\text { JNGR/HSM/124/20 } \\
12\end{array}$ & Arab & Arab & Prosa \\
\hline $84 \mathrm{hlm}$. & 5 baris/hlm. & $20 \times 13.5$ & Kertas Daluwang \\
\hline Hosmah & \multicolumn{2}{|l}{} \\
\hline Jenangger, Batang-batang
\end{tabular}

Naskah ini terdiri dari tiga teks, teks pertama menjelaskan tata cara bersuci dari najis, berwudu, salat, teks kedua menjelaskan tentang hukum akal, teks ketiga menjelaskan tentang arti dua kalimah syahadat.

Naskah ini dimiliki oleh Hosmah dari K. Ahyar dari K. Abdullah. Tahun dan tempat penyusunan, penulisan ulang, maupun pemrakarsa tidak dicantumkan. Naskah dalam kondisi cukup baik/cukup terbaca. 


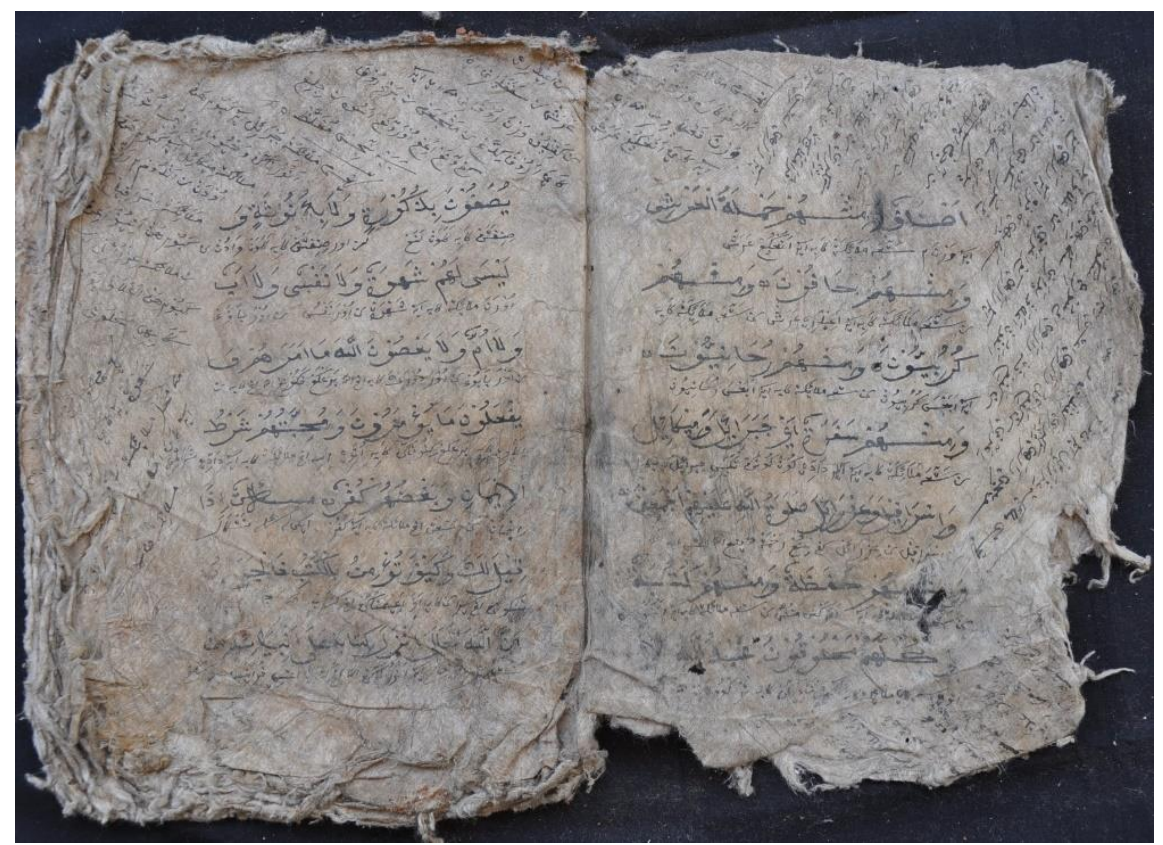

12124 JNGR HSM 1232012 HLM 4,5 Img10656

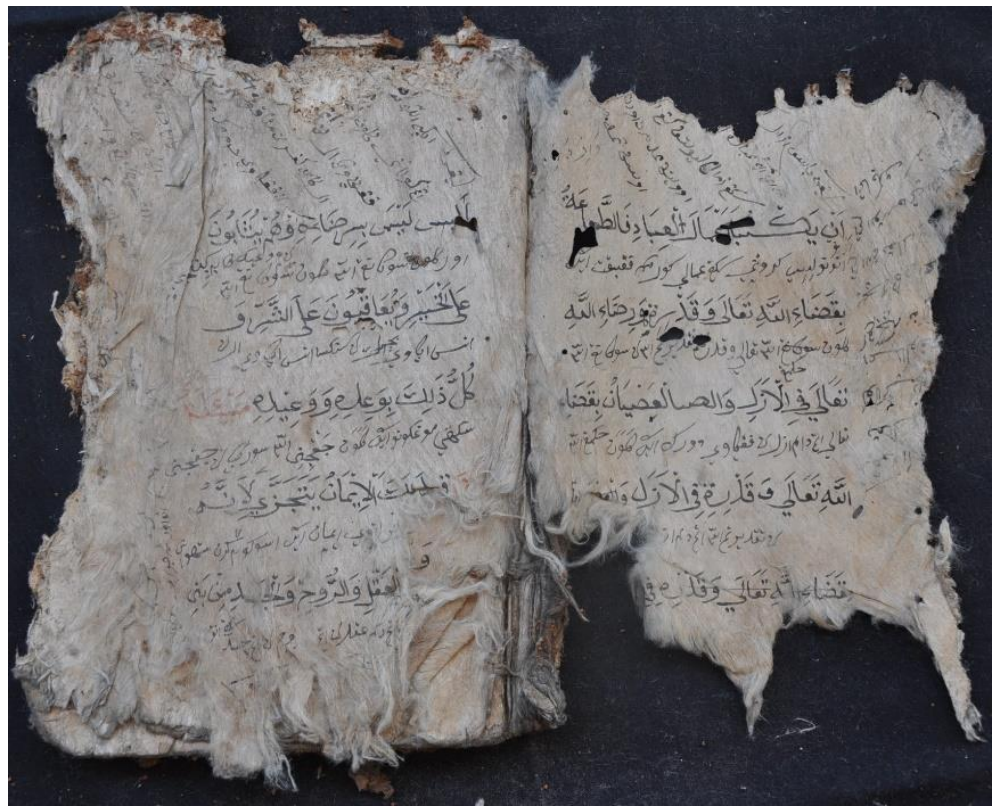

12125 JNGR HSM 1242012 HLM 2,3 Img10677 


\begin{tabular}{|l|l|l|l|}
\hline $\begin{array}{l}\text { BLAS/SUM/16/AK } \\
\text { /53 }\end{array}$ & ALQURAN & 3,4 & Akaid dan Fikih \\
\hline $\begin{array}{l}\text { JNRG/SUDFD/137 } \\
/ 2012\end{array}$ & Arab & Arab & Prosa \\
\hline $80 \mathrm{hlm}$. & 7 baris/hlm. & $27 \times 17$ & Kertas Daluwang \\
\hline Kiai Su'udi Fadhal & \\
\hline Jenangger, Batang-batang
\end{tabular}

Naskah ini merupakan Alquran.

Naskah ini dimiliki oleh K. Su'udi Fadlal dari Rosyidah dari K. Irsyad dari K.H. Hadi dari Kamsah dari K. Biramah. Naskah dalam kondisi cukup baik/cukup baik terbacanya.

\begin{tabular}{|l|l|l|l|}
\hline $\begin{array}{l}\text { BLAS/SUM/16/AK } \\
\text { /54 }\end{array}$ & $\begin{array}{l}\text { KITAB } \\
\text { MARDIYYAH } \\
\text { DAN MA'RIFATU } \\
\text { SYAHĀDAH }\end{array}$ & 3,4 & Akaid dan Fikih \\
\hline $\begin{array}{l}\text { JNRG/SUDFD/138 } \\
/ 2012\end{array}$ & Arab & Arab & Prosa \\
\hline 74 hlm. & 7 baris/hlm. & $30 x 18$ & Kertas Daluwang \\
\hline Kiai Irsyad & \\
\hline Jenangger, Batang-batang & \\
\hline
\end{tabular}

Naskah berisi dua teks. Teks pertama bernama Al-Mardiyah, menjelaskan tentang menjimak istri yang haid di bulan puasa adalah dosa besar dan wajib meng-qada puasanya bagi laki-laki, bagi wanita tidak wajib meng-qada puasa dan salatnya, teks kedua bernama Ma'rifatusy Syahadah, menjelaskan kewajiban seseorang untuk mengetahui makna yang terkandung dari syahadat.

Naskah ini dimiliki oleh K. Su'udi Fadlal dari Rosyidah dari K. Irsyad dari K.H. Hadi dari Kamsah dari K. Biramah. Naskah dalam kondisi cukup baik/cukup baik terbacanya. 


\begin{tabular}{|l|l|l|l|}
\hline $\begin{array}{l}\text { BLAS/SUM/16/AK } \\
\text { /55 }\end{array}$ & KITAB AQAID 50 & $\mathbf{3 , 4}$ & Akaid dan Fikih \\
\hline $\begin{array}{l}\text { JNRG/SUDFD/139 } \\
/ 2012\end{array}$ & Arab & Arab & Prosa \\
\hline $42 \mathrm{hlm}$. & 7 baris/hlm. & $26 \times 19$ & Kertas Daluwang \\
\hline Kiai Irsyad & \\
\hline Jenangger, Batang-batang
\end{tabular}

Naskah berisi tiga teks, teks pertama menjelaskan Ilmu Akidah lima puluh dengan model tanya jawab, teks kedua selesai penulisan pada hari Jumat setelah ashar tahun 1224 H/1809 M, menjelaskan tata cara beribadat menurut Mazhab Syafi'i, teks ketiga menjelaskan arti dari teks syahadat.

Naskah ini dimiliki oleh K. Su'udi Fadlal dari Rosyidah dari K. Irsyad dari K.H. Hadi dari Kamsah dari K. Biramah. Naskah dalam kondisi cukup baik/cukup baik terbacanya.

\begin{tabular}{|l|l|l|l|}
\hline $\begin{array}{l}\text { BLAS/SUM/16/AK } \\
\text { /56 }\end{array}$ & $\begin{array}{l}\text { KITAB IMAN } \\
\text { DAN LAIN-LAIN }\end{array}$ & 3,4 & Akaid dan Fikih \\
\hline GPR 14 & Arab & Arab & prosa \\
\hline $122 \mathrm{hlm}$. & 5 baris/hlm. & $28.5 \times 19$ & Kertas () \\
\hline Kiai Masduki & \\
\hline \multicolumn{2}{|l}{ Gapura Barat, Gapura, Sumenep } \\
\hline
\end{tabular}

Naskah berisi tiga teks. Teks pertama menjelaskan tentang bagaimana cara kit a beriman kepada Allah, kitab-Nya. Teks kedua menjelaskan fikih madzhab syafi'i antara lain kewajiban menuntut ilmu, wajib melaksanakan rukun Islam, wuḍ, salat. Teks ketiga menjelaskan bahwa wajib mengetahui syahadat bagi mukmin.

Naskah ini dikoleksi oleh Kiai Masduki Gapura, Kabupaten Sumenep 


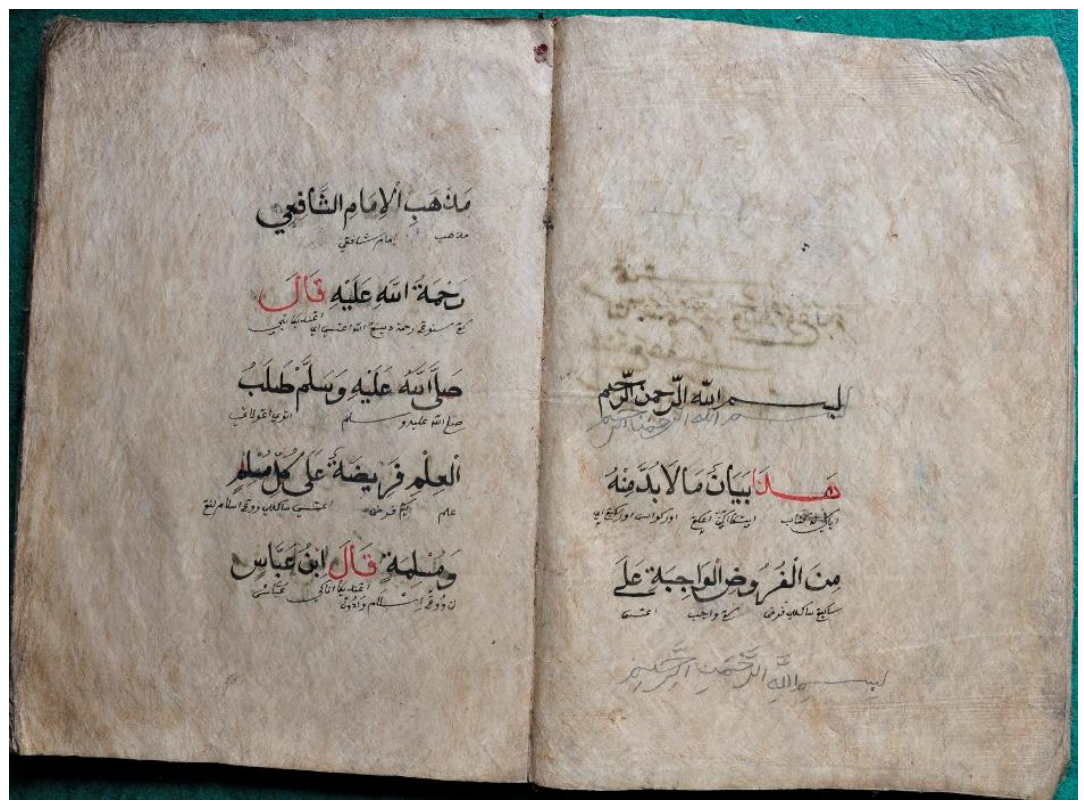

1014 GPR 14_DSC0257.2 


\begin{tabular}{|l|l|l|l|}
\hline $\begin{array}{l}\text { BLAS/SUM/16/AK } \\
\text { /57 }\end{array}$ & KITAB SITT̄N & 3,4 & $\begin{array}{l}\text { Akaid dan } \\
\text { Hukum } \\
\text { Islam/Fikih }\end{array}$ \\
\hline $\begin{array}{l}\text { PJGSGG/MWYH/1 } \\
60 / 2012\end{array}$ & Arab & Arab & Prosa \\
\hline $52 \mathrm{hlm}$. & 9 baris/hlm. & $25 \times 18$ & Kertas Daluwang \\
\hline Nyai Mu'awiyah & \\
\hline \multicolumn{2}{|l}{ Pajung ,Sergang, Batu Putih, Sumenep } \\
\hline
\end{tabular}

Teks bernama Kitab Sittin menjelaskan tentang 60 masalah peribadatan baik tentang ilmu tauhid, ilmu fikih.

Naskah ini dimiliki oleh Nyai Mu'awiyah dari Nyai Dzuriyah. Kondisi naskah tergolong cukup baik.

\begin{tabular}{|l|l|l|l|}
\hline $\begin{array}{l}\text { BLAS/SUM/16/AK } \\
\text { /58 }\end{array}$ & $\begin{array}{l}\text { KITAB SIFAT } \\
\text { ALLAH DAN } \\
\text { NABI }\end{array}$ & $\mathbf{3}$ & $\begin{array}{l}\text { Akaid dan Ilmu } \\
\text { kalam }\end{array}$ \\
\hline BT-BT 12 & Arab & Arab & Prosa \\
\hline $36 \mathrm{hlm}$. & 5 baris/hlm. & $22 \times 14$ & Kertas Daluwang \\
\hline Kiai Muchtar \\
\hline \multicolumn{2}{|l}{ Dusun Laok Saba, Nyabakan Timur, batang-Batang } \\
\hline
\end{tabular}

Naskah ini berisi keterangan Sifat-sifat wajib, muhal, jaiz bagi Allah, dan rasul.

Naskah ini dimiliki oleh Kiai Muchtar dari Kiai Mustaqim dari Kiai Siwallah dari Kiai Biramah. Tahun dan tempat penyusunan, penulisan ulang, maupun pemrakarsa tidak dicant umkan. Kondisi naskah rusak. Tinta menggunakan warna hitam. 


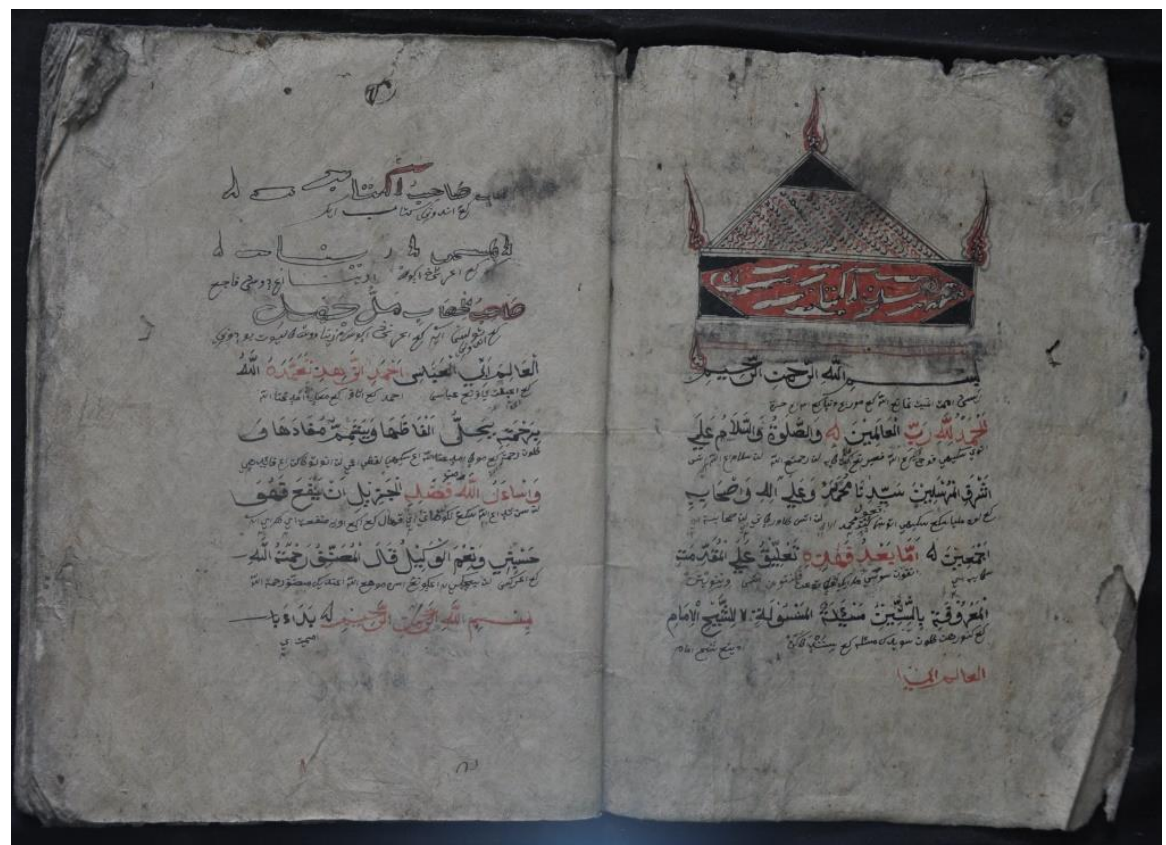

12161 PJGSGG MWYH 1602012 HLM 1,2 Img12943

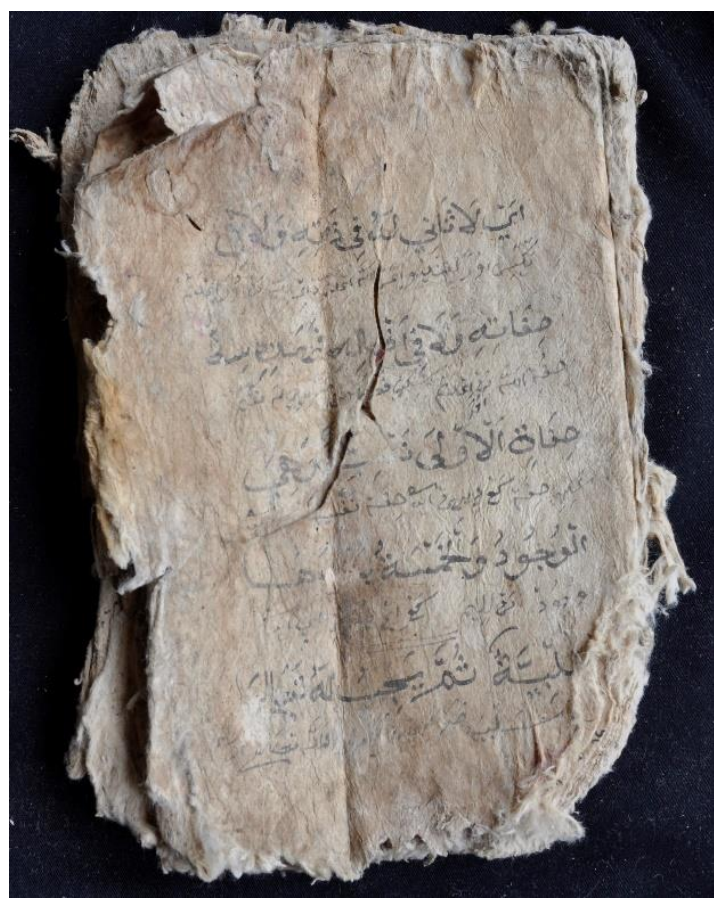

1142 BTBT 12 HLM 1_DSC0064 


\begin{tabular}{|l|l|l|l|}
\hline $\begin{array}{l}\text { BLAS/SUM/16/AK } \\
\text { /59 }\end{array}$ & $\begin{array}{l}\text { KITAB } \\
\text { MUTAQAD 50, } \\
\text { DAN KITAB } \\
\text { SUHUF. }\end{array}$ & 3 & $\begin{array}{l}\text { Akaid dan Ilmu } \\
\text { kalam }\end{array}$ \\
\hline BT-BT 14 & Arab & Arab & Prosa \\
\hline $50 \mathrm{hlm}$. & 10 baris/hlm. & $21 \times 17$ & Kertas Eropa \\
\hline Khasyieun & \\
\hline \multicolumn{2}{|l}{ Dusun Laok Saba, Nyabakan Timur, batang-Batang } \\
\hline
\end{tabular}

Naskah ini berisi Berisi tentang mu'taqad lima puluh yang wajib diimani oleh setiap muslim apabila seorang muslim tidak mengimani salah satu sifat tersebut maka ia dapat menjadi kufur. Kitab dan suhuf yang diturunkan seperti kitab Taurat, Zabur, Injil, dan Alquran juga suhuf nabi Ibrahim, nabi Tsis, dan yang lain.

Naskah ini dimiliki oleh Khasyieun dari Kiai Muhabi dari Kiai Hasyim dari Kiai Sawabi. Tahun dan tempat penyusunan tidak disebutkan. Kondisi naskah rusak, tetapi masih dapat dibaca. Tinta menggunakan warna hitam dan merah.

\begin{tabular}{|l|l|l|l|}
\hline $\begin{array}{l}\text { BLAS/SUM/16/AK } \\
\text { /60 }\end{array}$ & $\begin{array}{l}\text { KITAB TUGAS } \\
\text { MALAIKAT }\end{array}$ & $\mathbf{3}$ & $\begin{array}{l}\text { Akaid dan Ilmu } \\
\text { kalam }\end{array}$ \\
\hline BT-BT 15 & Arab & Arab & Posa \\
\hline $94 \mathrm{hlm}$. & 11 baris/hlm. & $18 \times 13.5$ & Kertas Daluwang \\
\hline Khasyieun & \\
\hline Dusun Laok Saba, Nyabakan Timur, batang-Batang \\
\hline
\end{tabular}

Naskah ini menjelaskan tentang keimanan atau tauhid, pembagian kerja malaikat Jibril, Mikail, Israfil, Izrail.

Naskah ini dimiliki oleh Khasyieun dari Kiai Muhabi dari Kiai Hasyim dari Kiai Sawabi. Tahun dan tempat penyusunan tidak disebutkan. Kondisi naskah rusak, tetapi masih dapat dibaca. Tinta menggunakan warna hitam. 


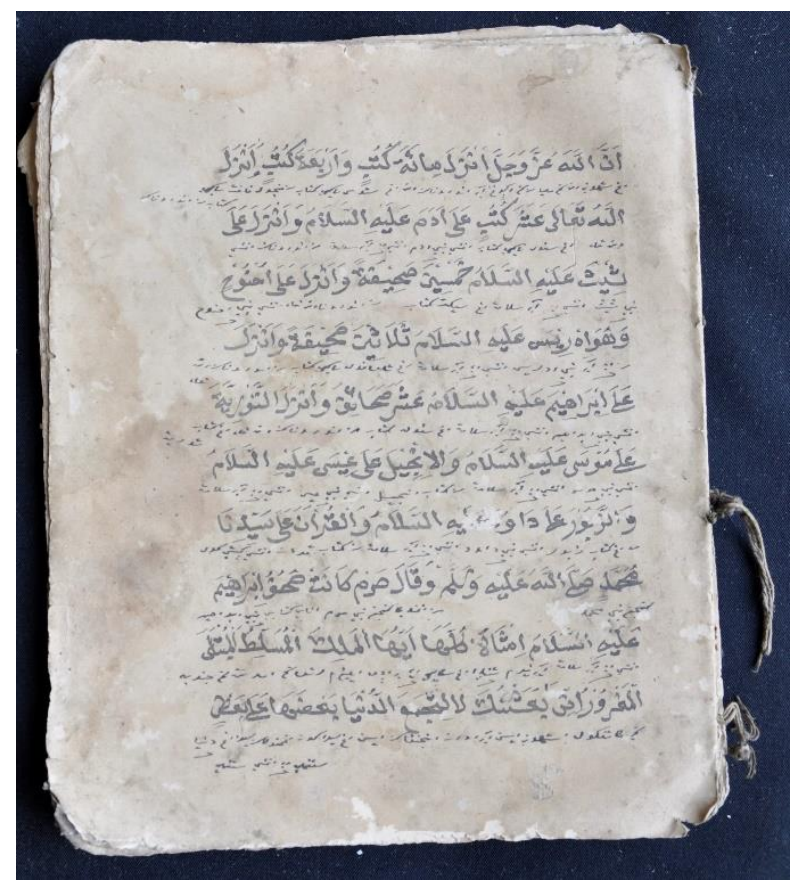

1144 BTBT 14 HLM 1_DSC0074

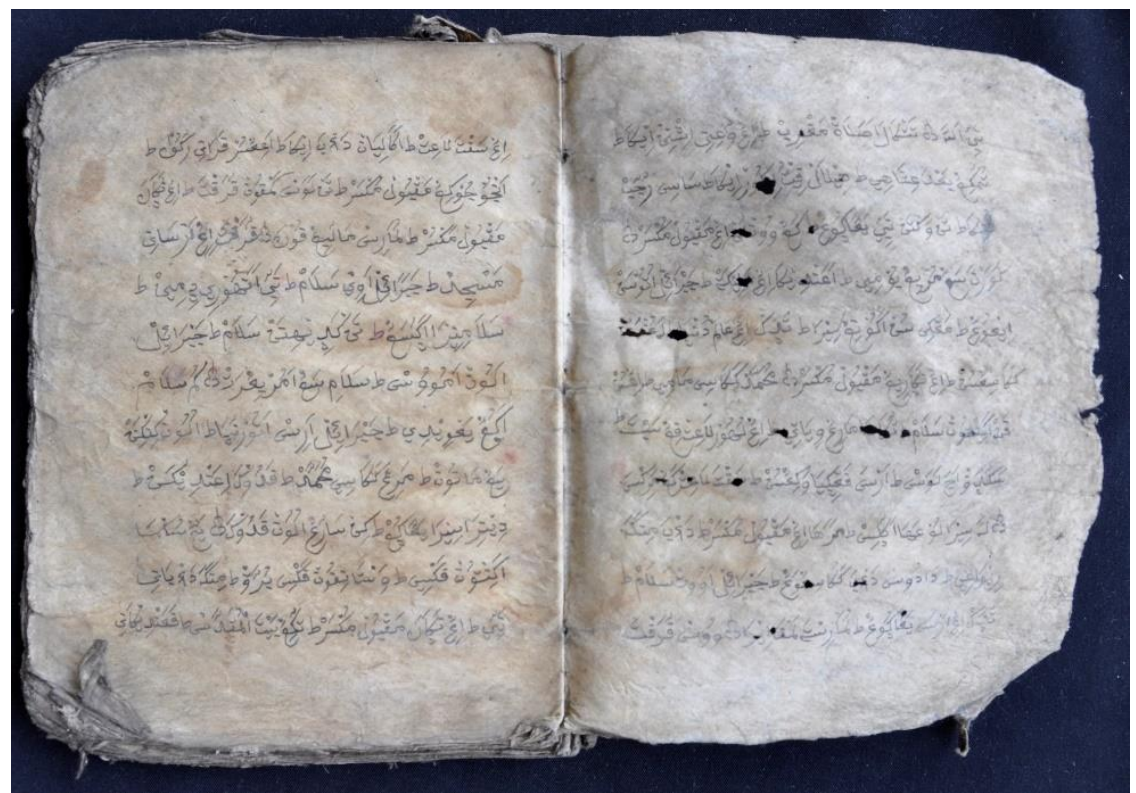

1145 BTBT 15 HLM 2,3_DSC0102 


\begin{tabular}{|l|l|l|l|}
\hline $\begin{array}{l}\text { BLAS/SUM/16/AK } \\
\text { /61 }\end{array}$ & KITAB TAUHID & 3 & $\begin{array}{l}\text { Akaid dan Ilmu } \\
\text { kalam }\end{array}$ \\
\hline BT-BT 16 & Arab & Arab & Prosa, Mocopat \\
\hline $58 \mathrm{hlm}$. & 11 baris/hlm. & $21 \times 17$ & Kertas Eropa \\
\hline Khasyieun & \\
\hline \multicolumn{2}{|l}{ Dusun Laok Saba, Nyabakan Timur, batang-Batang } \\
\hline
\end{tabular}

Naskah ini menjelaskan tentang ilmu tauhid.

Naskah ini dimiliki oleh Khasyieun dari Kiai Muhabi dari Kiai Hasyim dari Kiai Sawabi. Tahun dan tempat penyusunan tidak disebutkan. Kondisi naskah rusak, tetapi masih dapat dibaca. Tinta menggunakan warna hitam.

\begin{tabular}{|l|l|l|l|}
\hline $\begin{array}{l}\text { BLAS/SUM/16/AK } \\
/ 62\end{array}$ & $\begin{array}{l}\text { MISYKATUL } \\
\text { ANWAR }\end{array}$ & 3 & $\begin{array}{l}\text { Akaid dan Ilmu } \\
\text { Kalam }\end{array}$ \\
\hline $\begin{array}{l}\text { MDGT/AMR/39/20 } \\
12\end{array}$ & Arab & Arab & Prosa \\
\hline 48 hlm. & 6 baris/hlm. & $24 \times 15$ & Kertas Daluwang \\
\hline Kiai Amir & & \\
\hline \multicolumn{2}{|l}{ Manding Timur, Manding }
\end{tabular}

Naskah berisi dua teks. Teks pertama tentang penjelasan syahadat dan teks kedua tentang manfaat ilmu dan berguru.

Keterangan lebih rinci mengenai penjelasan syahadat yakni teks ini menjelaskan kewajiban seorang muslim untuk mengetahui makna dua kalimat syahadat. Teks kedua menjelaskan bahwa hidup seseorang tidak bermanfaat kecuali mengagungkan ilmu dan ahlinya antara lain guru.

Naskah ini milik K. Amir dari K. Abdus Salam. Kondisi cukup baik, teks masih terbaca. 


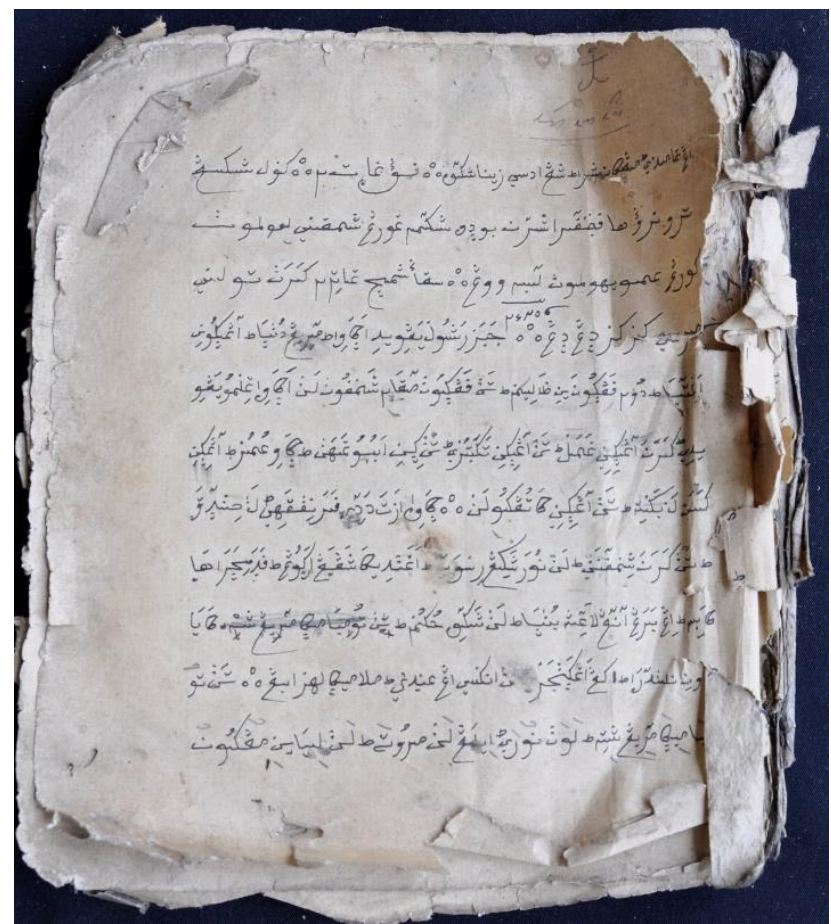

1146 BTBT16 HLM 1_DSC0153

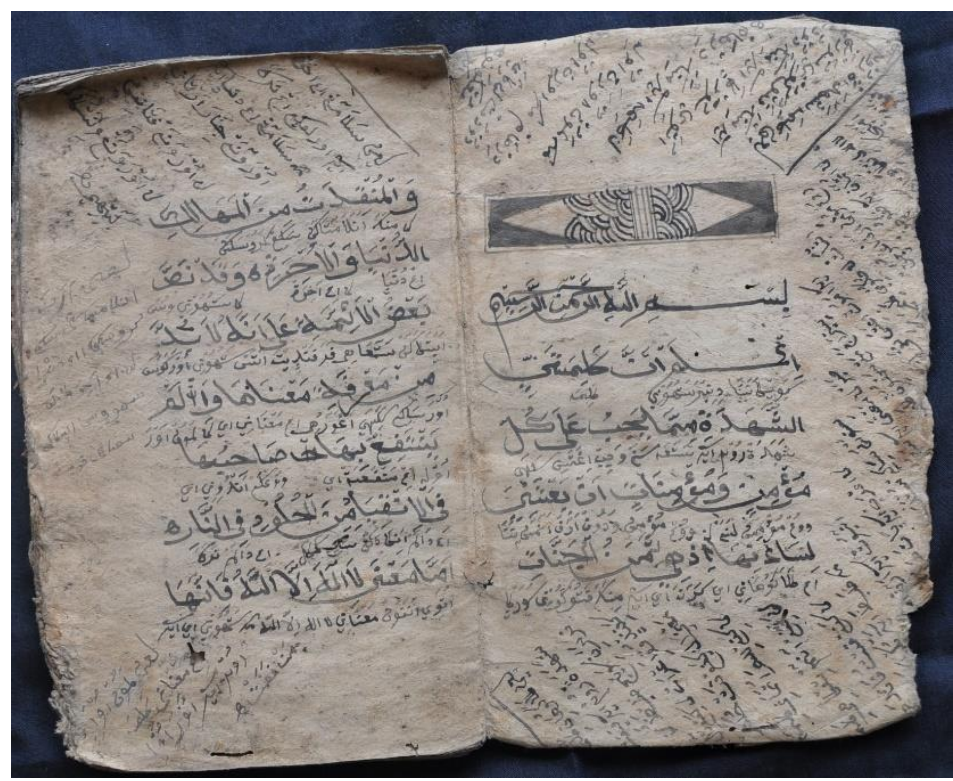

12039 MDGTAMR 392012 HLM 1,2 Img3294 


\begin{tabular}{|l|l|l|l|}
\hline $\begin{array}{l}\text { BLAS/SUM/16/AK } \\
\text { /63 }\end{array}$ & $\begin{array}{l}\text { KITAB AL- } \\
\text { MIFTAH, DAN } \\
\text { KITAB SYARAY }\end{array}$ & 3 & $\begin{array}{l}\text { Akaid dan Ilmu } \\
\text { Kalam }\end{array}$ \\
\hline $\begin{array}{l}\text { SGG/DRYH/46/20 } \\
12\end{array}$ & Arab & Arab & Prosa \\
\hline $250 \mathrm{hlm}$. & 17 baris/hlm. & $30 \times 19.5$ & Kertas Daluwang \\
\hline Nyai Dzurriyah & & \\
\hline Sergang, Batu Putih & \\
\hline
\end{tabular}

Naskah ini berisi sembilan teks.

Keterangan lebih rinci dari teks pertama, teks ini berjudul Al-Miftah berisi tentang ma'rifat al-iman, teks kedua bernama Kitab Samarqandi yang menjelaskan tentang rukun iman yang dipahami secara rasional, teks ketiga berjudul Syarah Sittin membahas tentang rukun iman yang dipahami secara rasional, teks ketiga berjudul Syarah Sittin membahas tentang 60 masalah peribadatan, teks keempat berjudul kitab Kalimat Syahadat berisi tentang makna dua kalimat syahadat, teks kelima berjudul Sittina masalah berisi tentang fikih, teks keenam berjudul Syarah Kalimat Syahadat berisi tentang pentingnya makna syahadat untuk diketahui setiap muslim, teks ketujuh berjudul Kitab Al-Mufid berisi akidah 50, teks kedelapan berjudul Kitab Talmisani Syarah Durratil Fakhirah yang menjelaskan tentang akidah 50, dan teks kesembilan berjudul Fathul Mubin Syarah Ummul Barahin yang menjelaskan tentang akidah 50.

Naskah ini milik Nyai Dzuriyah dari K.H. Asyhari. Kondisi naskah mulai rusak, teks masih terbaca.

\begin{tabular}{|l|l|l|l|}
\hline $\begin{array}{l}\text { BLAS/SUM/16/AK } \\
\text { /64 }\end{array}$ & $\begin{array}{l}\text { KITAB } \\
\text { SYAHADAT } \\
\text { DAN FIKIH } \\
\text { ISTINJA' }\end{array}$ & 3,4 & $\begin{array}{l}\text { Akaid dan Ilmu } \\
\text { kalam, Fikih }\end{array}$ \\
\hline BT-BT 22 & Arab & Arab & Prosa \\
\hline $70 \mathrm{hlm}$. & $3,5,7$ baris/hlm. & $27 x 18$ & Kertas Daluwang \\
\hline Abdrurrahman & \\
\hline \multicolumn{2}{|l}{ Dusun Laok Saba, Nyabakan Timur, batang-Batang } \\
\hline
\end{tabular}

Naskah ini berisi dua teks. Teks pertama menjelaskan makna syahadat menurut ilmu tauhid. Teks kedua menjelaskan tentang tata cara bersuci, dari hadas, tata cara salat, puasa ramadan, dan haji menurut madzhab Syafi’i.

Naskah ini dimiliki oleh Abdurrahman dari Mudallah. Tahun dan tempat penyusunan tidak disebutkan. Kondisi naskah rusak, masih dapat dibaca. Tinta menggunakan warna hitam dan merah. 


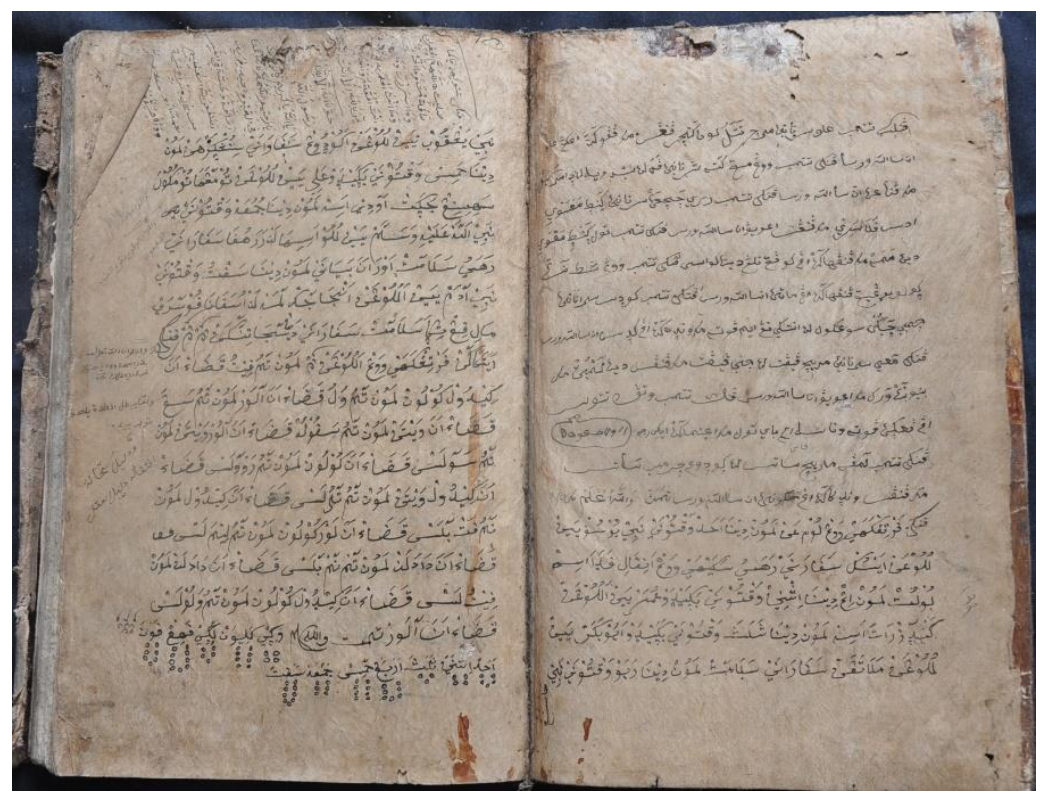

12046 SGG DRYH 462012 HLM 2,3 Img4418

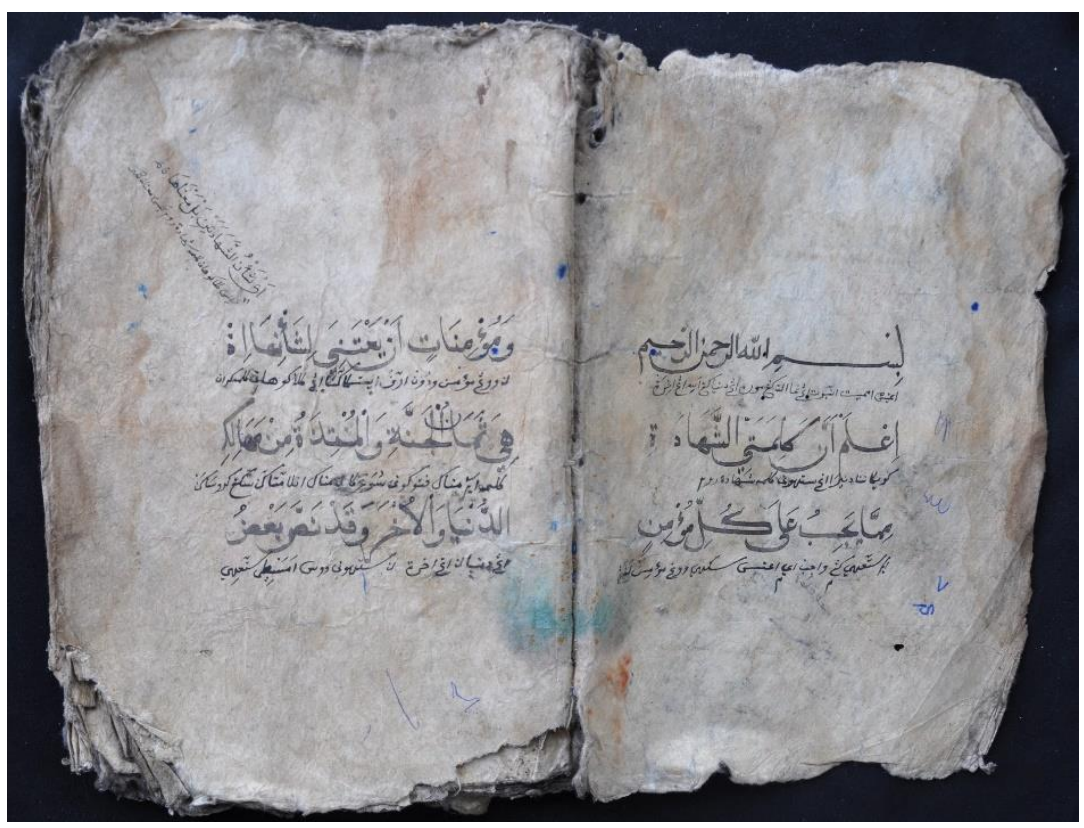

1152 BTBT 22 HLM 2,3 DSC_0157 


\begin{tabular}{|l|l|l|l|}
\hline $\begin{array}{l}\text { BLAS/SUM/16/AK } \\
\text { /65 }\end{array}$ & $\begin{array}{l}\text { KITAB FIKIH } \\
\text { SYAFI'I DAN } \\
\text { TAUHID } \\
\text { MATURIDIYAH }\end{array}$ & 3,4 & $\begin{array}{l}\text { Akaid dan Ilmu } \\
\text { kalam, Fikih }\end{array}$ \\
\hline BT-BT 23 & Arab & Arab & Prosa \\
\hline $30 \mathrm{hlm}$. & 7 baris/hlm. & $23.5 \times 19$ & Kertas Daluwang \\
\hline Abdrurrahman & \\
\hline \multicolumn{2}{|l}{ Dusun Laok Saba, Nyabakan Timur, batang-Batang } \\
\hline
\end{tabular}

Naskah ini berisi dua teks. Teks pertama menjelaskan ilmu tauhid mengikuti aliran Maturidiyah Samarkandi. Teks kedua berisi fikih menurut madzhab Syafi'i diawali dengan tata cara berwuḍu, bersuci dari buang air, dan salat.

Naskah ini dimiliki oleh Abdurrahman dari Mudallah. Tahun dan tempat penyusunan tidak disebutkan. Kondisi naskah rusak, masih dapat dibaca. Tinta menggunakan warna hitam.

\begin{tabular}{|l|l|l|l|}
\hline $\begin{array}{l}\text { BLAS/SUM/16/AK } \\
\text { /66 }\end{array}$ & $\begin{array}{l}\text { KITAB TANYA } \\
\text { JAWAB FIKIH } \\
\text { DAN TAUHID } \\
\text { MADZHAB } \\
\text { SYAFI' }\end{array}$ & 3,4 & $\begin{array}{l}\text { Akaid dan Ilmu } \\
\text { kalam, Fikih }\end{array}$ \\
\hline BT-BT 25 & Arab & Arab & Prosa \\
\hline $62 \mathrm{hlm}$. & 5 baris/hlm. & $25 \times 19.5$ & Kertas Daluwang \\
\hline Kiai Su'udi Fadhal & \\
\hline \multicolumn{2}{|l|}{ Dusun Nyabungan, Jenangger, Batang-Batang. } \\
\hline
\end{tabular}

Naskah ini berisi tanya jawab masalah tauhid dan fikih menurut madzhab Syafi'i tentang bersuci dan salat.

Naskah ini dimiliki oleh Kiai Su'udi Fadhal dari Kiai Irsyad dari Kiai Sodli dari Kiai Hadi. Tahun dan tempat penyusunan tidak disebutkan. Kondisi naskah rusak, tetapi masih dapat dibaca. Tinta menggunakan warna hitam. 


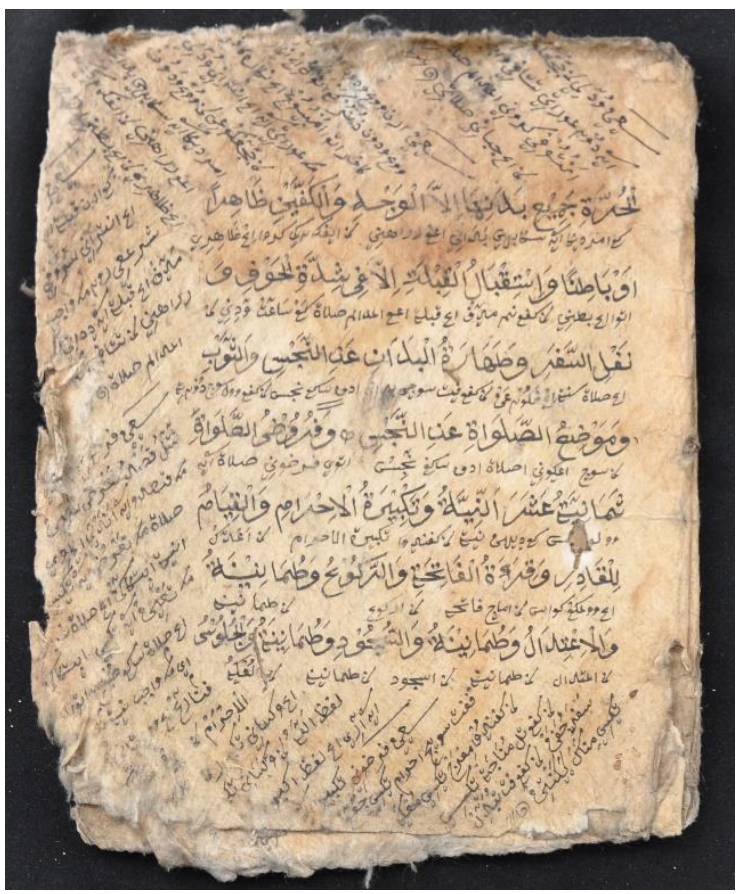

1153 BTBT 23 HLM 1 DSC_0197

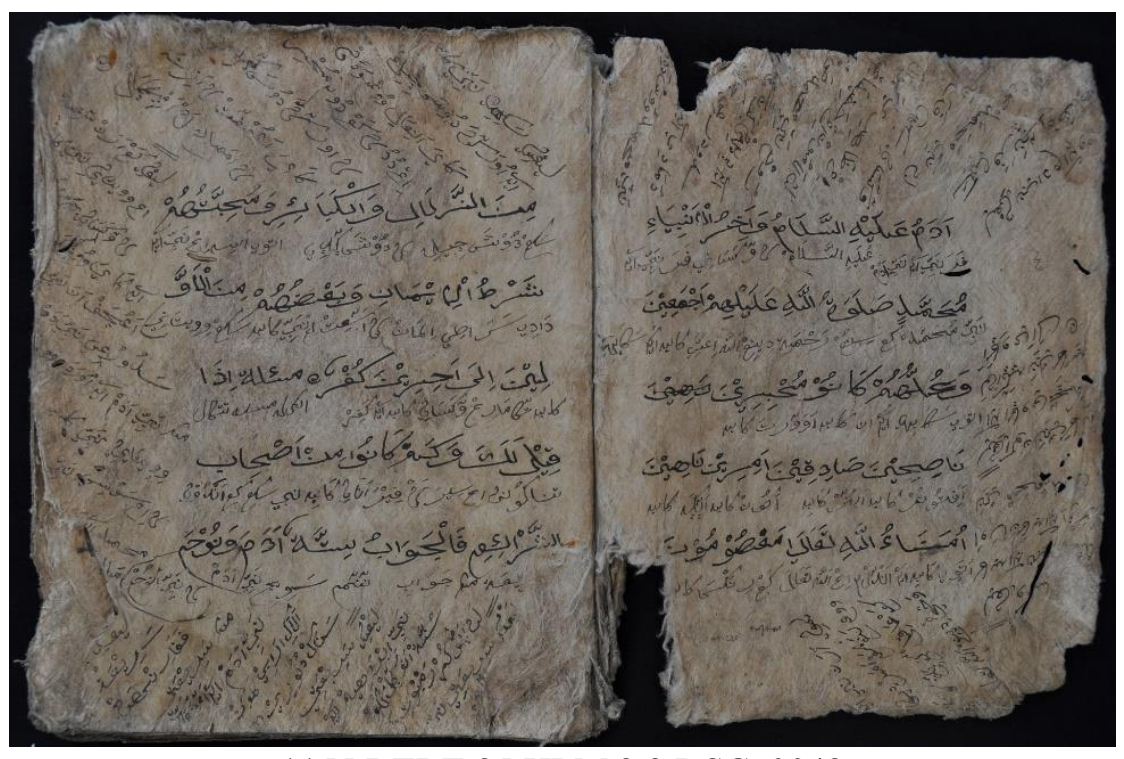

1155 BTBT 25 HLM 2,3 DSC_0042 


\begin{tabular}{|l|l|l|l|}
\hline $\begin{array}{l}\text { BLAS/SUM/16/AK } \\
\text { /67 }\end{array}$ & $\begin{array}{l}\text { KITAB RUKUN } \\
\text { IMAN DAN } \\
\text { RUKUN ISLAM }\end{array}$ & 3,4 & $\begin{array}{l}\text { Akaid dan Ilmu } \\
\text { kalam, Fikih }\end{array}$ \\
\hline BT-BT 30 & Arab & Arab & Prosa \\
\hline $112 \mathrm{hlm}$. & 5 baris/hlm. & $23.5 \times 6$ & Kertas Daluwang \\
\hline H. Ahmad & \\
\hline Dusun Nyabungan, Jenangger, Batang-Batang. \\
\hline
\end{tabular}

Naskah ini memuat tiga teks. Teks pertama berupa teks tauhid, teks ditulis dengan tanya jawab seperti tugas malaikat, nabi, rasul. Teks kedua berisi teks fikih menjelaskan tentang arti syahadat, salat, puasa, zakat, dan haji. Teks ketiga berisi teks tauhid menjelaskan tentang sifat wajib, muhal, dan jaiz kemudian dijelaskan pula bahwa sifat 20 tersebut dikelompokkan menjadi 4 macam, yaitu, sifat nafsiyah, salbiyah, ma'ani, dan sifat ma'nawiyah.

Ketiga teks diberi makna gandul dengan menggunakan bahasa Jawa, pada kiri, kanan, atas, bawah di luar teks diberi catatan dengan bahasa Jawa.

Naskah ini dimiliki oleh H. Ahmad dari Rumi dari Abdul Hadi. Tahun dan tempat penyusunan tidak disebutkan. Kondisi naskah sebagian kecil rusak, masih dapat dibaca. Tinta menggunakan warna hitam.

\begin{tabular}{|l|l|l|l|}
\hline $\begin{array}{l}\text { BLAS/SUM/16/AK } \\
\text { /68 }\end{array}$ & $\begin{array}{l}\text { KITAB FIKIH } \\
\text { WUDU DAN } \\
\text { TAUHID }\end{array}$ & 3,4 & $\begin{array}{l}\text { Akaid dan ilmu } \\
\text { kalam, Fikih }\end{array}$ \\
\hline BT-BT 33 & Arab & Arab & Prosa \\
\hline $132 \mathrm{hlm}$. & 5 baris/hlm. & $21 \times 15$ & Kertas Daluwang \\
\hline Aziz & \multicolumn{2}{|l}{} \\
\hline Dusun Nyabungan, Jenangger, Batang-Batang. \\
\hline
\end{tabular}

Naskah ini berisi tiga teks; 1) Teks pertama tauhid, berisi tentang Iman adalah hidayah Allah dengan pembenaran dalam hati, diucapkan di lisan, dan dilakukan dalam perbuatan, hidayah bukan makhluk; 2) Teks kedua fikih, menjelaskan wudu dapat batal karena keluarnya sesuatu dari qubul atau dubur, tidur yang tidak tetap duduknya, hilang akal, mabuk; 3) Teks ketiga ilmu tauhid, menjelaskan hukum akal untuk mendasari pembuktian keyakinan.

Naskah ini dimiliki oleh Aziz dari Haji As'ad dari Suhilal dari Kiai Siwallah. Tahun dan tempat penyusunan tidak disebutkan. Kondisi naskah sebagian rusak, masih dapat dibaca. Tinta menggunakan warna hitam. 


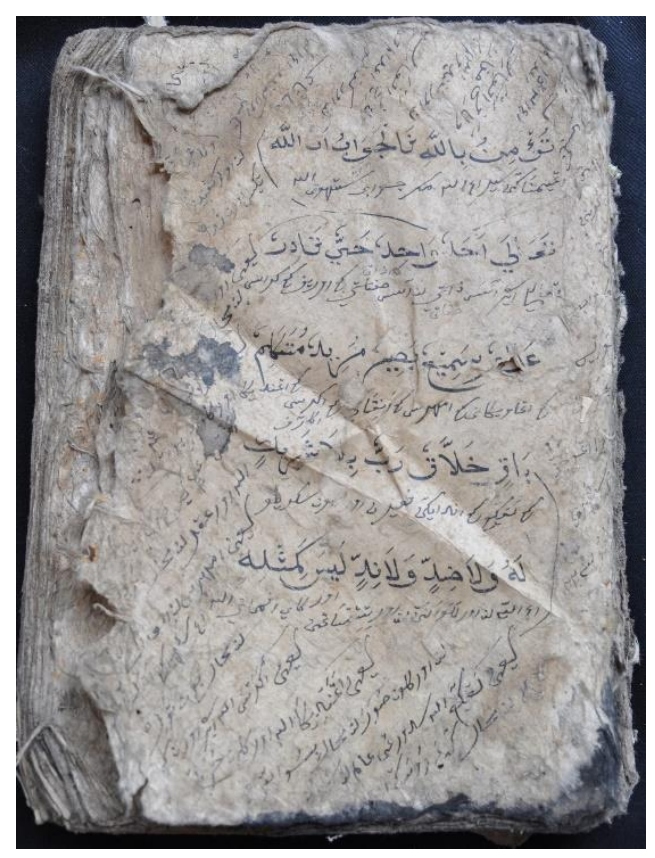

1160 BTBT 30 HLM 1 DSC_0080

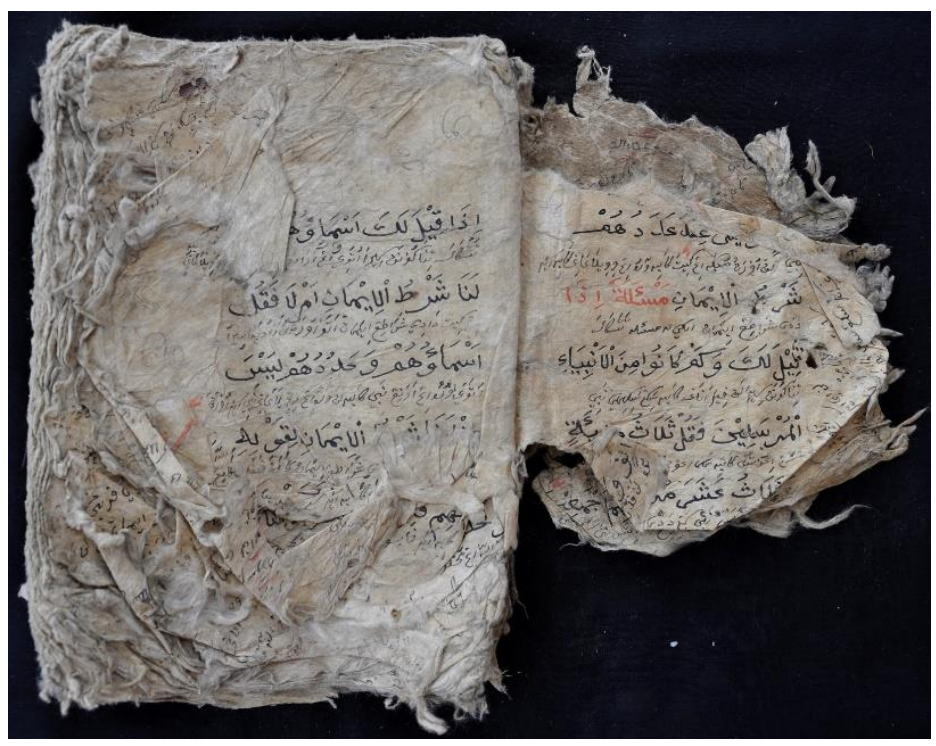

1163 BTBT 33 HLM 6,7_DSC0005 


\begin{tabular}{|l|l|l|l|}
\hline $\begin{array}{l}\text { BLAS/SUM/16/AK } \\
\text { /69 }\end{array}$ & $\begin{array}{l}\text { KITAB FIKIH } \\
\text { DAN TAUHID }\end{array}$ & 3,4 & $\begin{array}{l}\text { Akaid dan Ilmu } \\
\text { kalam, Fikih }\end{array}$ \\
\hline BT-BT 35 & Arab & Arab & Puisi \\
\hline $190 \mathrm{hlm}$. & 7 baris/hlm. & $19.5 \times 14.5$ & Kertas Daluwang \\
\hline Aziz & \multicolumn{2}{|l}{} \\
\hline \multicolumn{2}{|l|}{ Dusun Nyabungan, Jenangger, Batang-Batang. } \\
\hline
\end{tabular}

Naskah ini terdapat tiga teks, yaitu; 1) teks fikih menjelaskan waktu salat, tata cara salat; 2) teks kedua menjelaskan tentang akidah menurut kitab Aqidatul Awam yaitu mu'taqad lima puluh yang wajib diimani; 3) teks ketiga menerangkan mengenai tauhid tingkatan iman, tertinggi imannya Malaikat kemudian para nabi, orang mukmin, mu'allaf, munafik, mazhab imam empat yang hak ada Hanafi, Syafi'i, Maliki, Hambali, menjelaskan tentang wuḍu, salat, taubat, puasa zakat, haji, jual beli, khiyar, ketiga teks diberi makna gandul dengan bahasa Jawa.

Naskah ini dimiliki oleh Aziz dari haji As'ad dari Suhilal dari Kiai Siwallah. Waktu dan tempat penyusunan disebutkan: Teks Safinah selesai ditulis hari sabtu waktu istiwak, disusun di Bangkalan madura, pengarang Chamim. Kondisi naskah banyak lubang, masih dapat dibaca. Tinta menggunakan warna hitam, dan merah pada bagianbagian penting.

\begin{tabular}{|l|l|l|l|}
\hline $\begin{array}{l}\text { BLAS/SUM/16/AK } \\
\text { /70 }\end{array}$ & $\begin{array}{l}\text { KITAB } \\
\text { SAMARQANDI, } \\
\text { SITTIN, } \\
\text { SYARTUL IMAN }\end{array}$ & 3,4 & $\begin{array}{l}\text { Akaid dan Ilmu } \\
\text { kalam, Fikih }\end{array}$ \\
\hline BT-BT 39 & Arab, Jawa & Arab & Prosa \\
\hline 100 hlm. & $7,7,14$ baris/hlm. & $18 \times 20$ & Kertas Daluwang \\
\hline Aziz & \\
\hline \multicolumn{2}{|l|}{ Dusun Nyabungan, Jenangger, Batang-Batang. } \\
\hline
\end{tabular}

Naskah ini berisi tiga teks; 1) Teks pertama menjelaskan tentang tanya jawab tentang rukun iman dan rinciannya dengan pembuktian menggunakan hukum akal kemudian dijelaskan dengan Alquran, teks ini diberi makna gandul dan kiri, kanan, atas, bawah diberi penjelasan dengan bahasa Jawa 2) teks kedua kitab Sittin, selesai penulisan pada hari Jumat menjelaskan tentang tata cara beribadah, teks ini berbahasa arab dan diberi makna gandul; 3) teks ketiga menjelaskan tentang kecukupan iman, teks ini berbahasa Jawa,

Naskah ini dimiliki oleh Aziz dari haji As'ad dari Suhilal dari Kiai Siwallah. Tahun dan tempat penyusunan tidak disebutkan, terdapat keterangan Kitab Sittin, Kitab 
Syarthul Iman selesai penulisan pada hari Jum'at. Kondisi naskah cukup baik, masih dapat dibaca. Tinta menggunakan warna hitam merah.

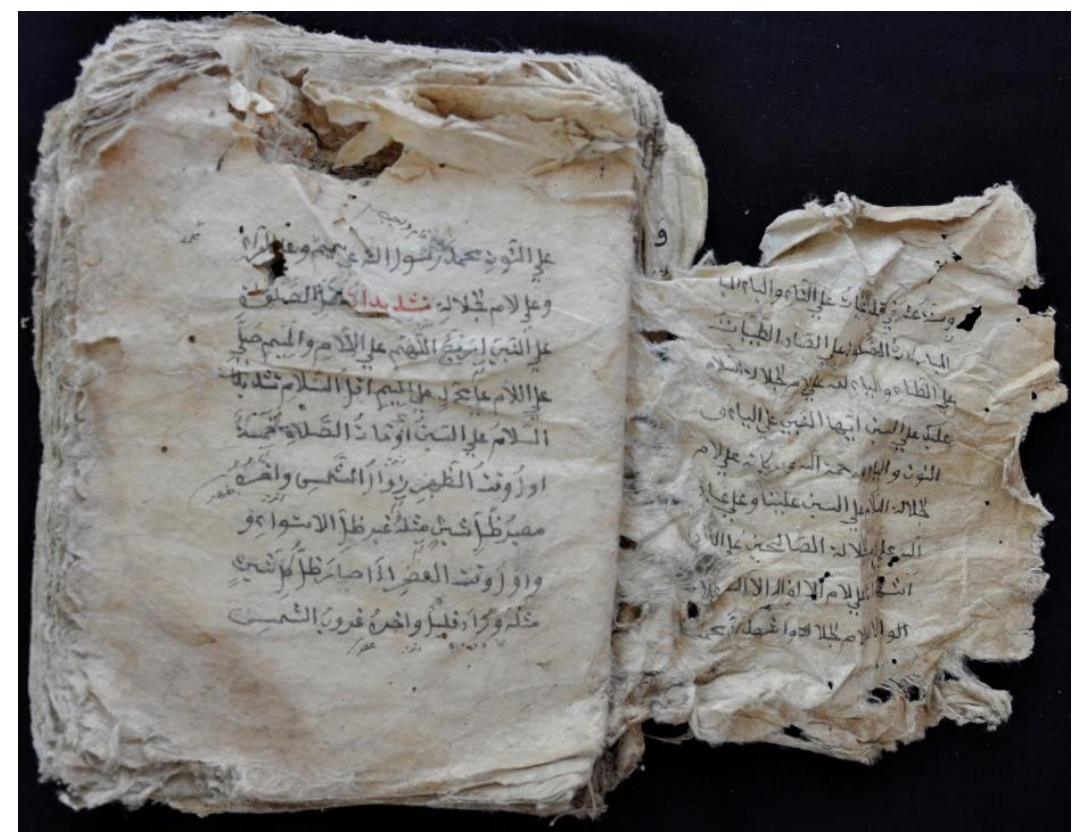

1165 BTBT 35 HLM 2,3_DSC0119

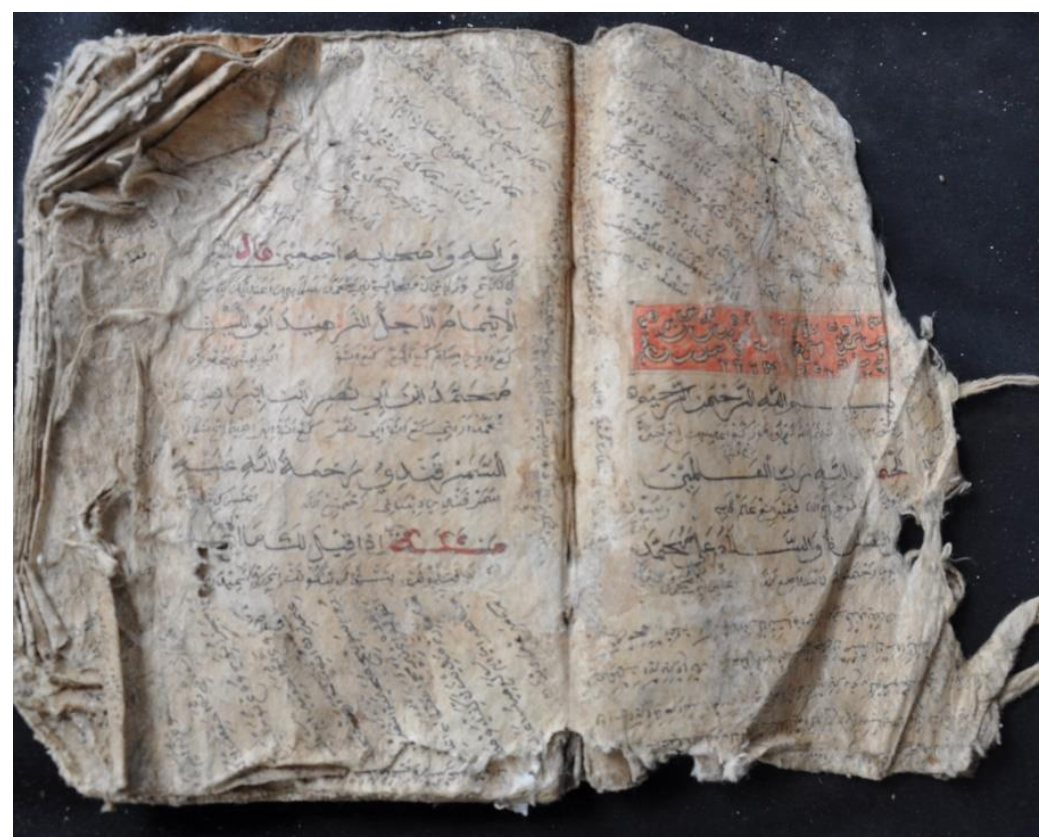

1169 BTBT 39 HLM 1,2 DSC_0135 


\begin{tabular}{|l|l|l|l|}
\hline $\begin{array}{l}\text { BLAS/SUM/16/AK } \\
\text { /71 }\end{array}$ & $\begin{array}{l}\text { KITAB } \\
\text { MU'TAQAD 50 } \\
\text { DAN LAIN-LAIN }\end{array}$ & 3,4 & $\begin{array}{l}\text { Akaid dan Ilmu } \\
\text { kalam, Fikih }\end{array}$ \\
\hline BT-BT 40 & Arab, Jawa & Arab & Prosa \\
\hline 204 hlm. & 6 baris/hlm. & $25.5 \times 17.6$ & Kertas Daluwang \\
\hline Aziz & \\
\hline \multicolumn{2}{|l|}{ Dusun Nyabungan, Jenangger, Batang-Batang. } \\
\hline
\end{tabular}

Naskah terdiri atas lima teks, teks pertama berisi tentang tauhid, teks kedua kitab Sittin menjelaskan tentang fikih ibadah, teks ketiga menjelaskan syahadat versi keimaan, teks keempat menjelaskan tentang tauhid mu'taqad lima puluh, dan teks kelima menjelaskan tentang tata cara membaca Alquran atau tajwid. Di dalam teks ini terdapat makna gandul dengan bahasa Jawa, di kiri, kanan, atas, bawah juga terdapat catatan sebagai keterangan atau penjelasan.

Naskah ini dimiliki oleh Aziz. Tahun dan tempat penyusunan tidak disebutkan. Kondisi naskah cukup baik, masih dapat dibaca. Tinta menggunakan warna hitam merah.

\begin{tabular}{|l|l|l|l|}
\hline $\begin{array}{l}\text { BLAS/SUM/16/AK } \\
\text { /72 }\end{array}$ & $\begin{array}{l}\text { KITAB } \\
\text { MU'TAQAD 50 } \\
\text { DAN KITAB } \\
\text { FIKIH BERSUCI }\end{array}$ & 3,4 & $\begin{array}{l}\text { Akaid dan Ilmu } \\
\text { kalam, Fikih }\end{array}$ \\
\hline BT-BT 47 & Arab & Arab & Prosa \\
\hline 72 hlm. & 7 baris/hlm. & $25 \times 16$ & Kertas Daluwang \\
\hline Kiai Khalid & \\
\hline \multicolumn{2}{|l}{ Dusun Nyabungan, Jenangger, Batang-Batang. } \\
\hline
\end{tabular}

Naskah ini terdiri dari dua buah teks yang menjelaskan akidah 50 atau mu'taqad lima puluh dan fikih tentang bersuci. Teks ini berbahasa Arab diberi makna gandul berbahasa Jawa aksara Arab.

Naskah ini dimiliki oleh Kiai Khalid dari Kiai Fadlun dari Kiai Khomsidin. Tahun dan tempat penyusunan tidak disebutkan. Kondisi naskah baik, tanpa sampul, masih dapat dibaca. Tinta menggunakan warna hitam. 


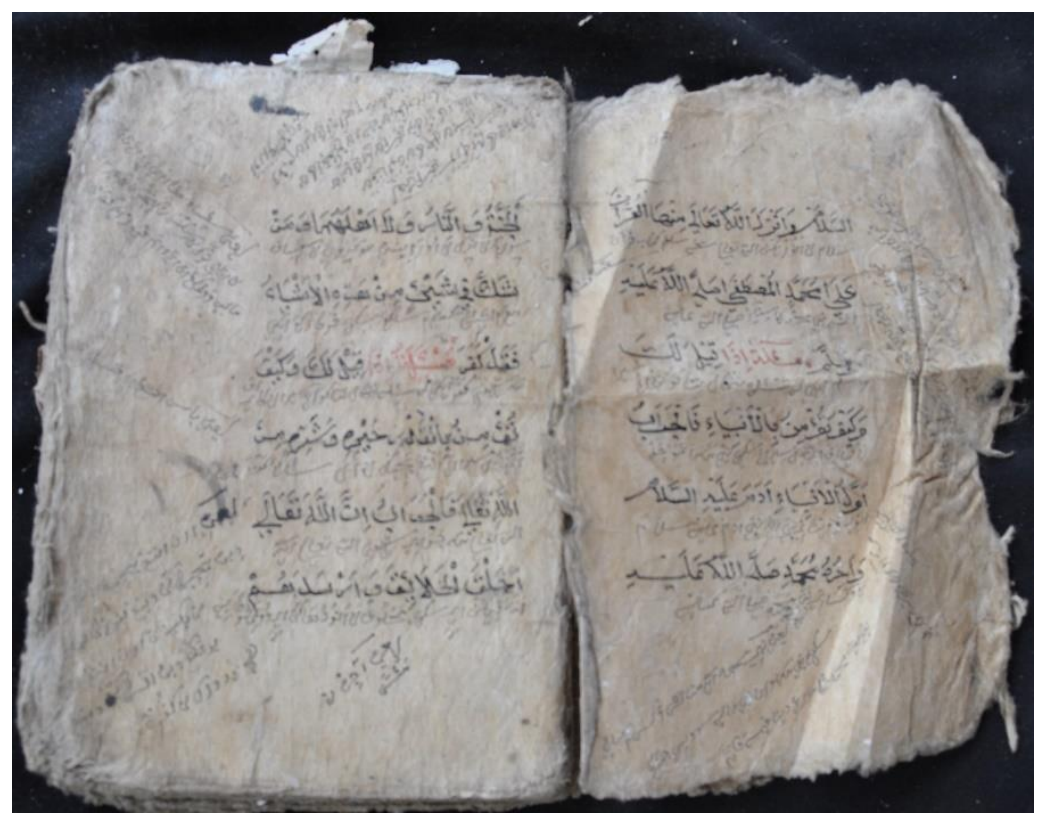

1170 BTBT 40 HLM 6,7 DSC_0216

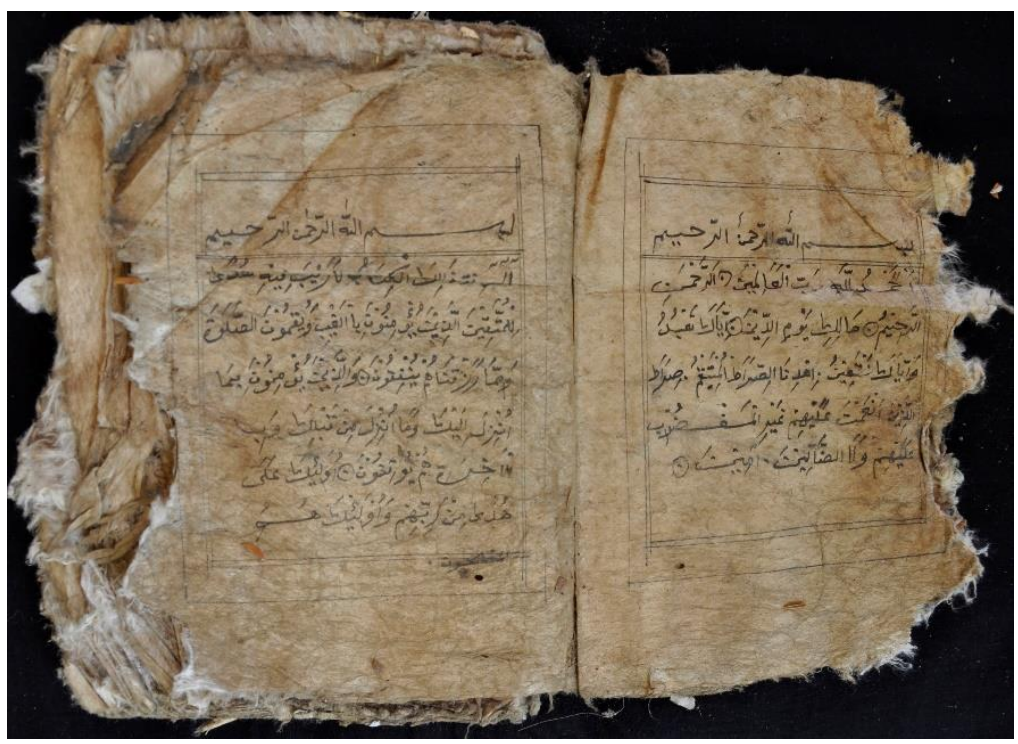

1177 BTBT 47 HLM 1,2_DSC0081 


\begin{tabular}{|l|l|l|l|}
\hline $\begin{array}{l}\text { BLAS/SUM/16/AK } \\
\text { /73 }\end{array}$ & $\begin{array}{l}\text { KITAB TAUHID } \\
\text { DAN KITAB } \\
\text { NIKAH }\end{array}$ & 3,4 & $\begin{array}{l}\text { Akaid dan Ilmu } \\
\text { kalam, Fikih }\end{array}$ \\
\hline BT-BT 48 & Arab & Arab & Prosa \\
\hline $102 \mathrm{hlm}$. & 5 baris/hlm. & $26 \times 18$ & Kertas Daluwang \\
\hline Kiai Khalid & \\
\hline Dusun Nyabungan, Jenangger, Batang-Batang. \\
\hline
\end{tabular}

Naskah ini terdiri atas tiga buah teks, teks pertama menjelaskan tauhid, teks kedua menjelaskan masalah pernikahan, dan teks ketiga menjelaskan tentang tauhid.

Naskah ini dimiliki oleh Kiai Khalid dari Kiai Fadlun dari Kiai Khomsidin. Tahun dan tempat penyusunan tidak disebutkan. Kondisi naskah baik. Tinta menggunakan warna hitam.

\begin{tabular}{|l|l|l|l|}
\hline $\begin{array}{l}\text { BLAS/SUM/16/AK } \\
\text { /74 }\end{array}$ & $\begin{array}{l}\text { KITAB NAMA } \\
\text { NABI 330 DAN } \\
\text { KITAB FIKIH }\end{array}$ & 3,4 & $\begin{array}{l}\text { Akaid dan ilmu } \\
\text { kalam, fikih }\end{array}$ \\
\hline BT-BT 51 & Arab & Arab & Prosa \\
\hline $134 \mathrm{hlm}$. & 7 baris/hlm. & $28.5 \times 19$ & Kertas Daluwang \\
\hline Kiai Khalid & \\
\hline Dusun Nyabungan, Jenangger, Batang-Batang. \\
\hline
\end{tabular}

Naskah berisi dua teks. Teks pertama menerangkan tentang berapa nabi dan rasul yang harus diimani berjumlah tiga ratus tiga puluh, iman adalah hidayah, teks kedua menjelaskan tata cara istinja' (bersuci dari buang air), berwuḍ, salat, puasa zakat, haji.

Naskah ini dimiliki oleh Kiai Khalid dari Kiai Fadlun dari Kiai Khomsidin. Tahun dan tempat penyusunan tidak disebutkan. Kondisi naskah rusak, tetapi masih dapat dibaca. Tinta menggunakan warna hitam dan merah. 


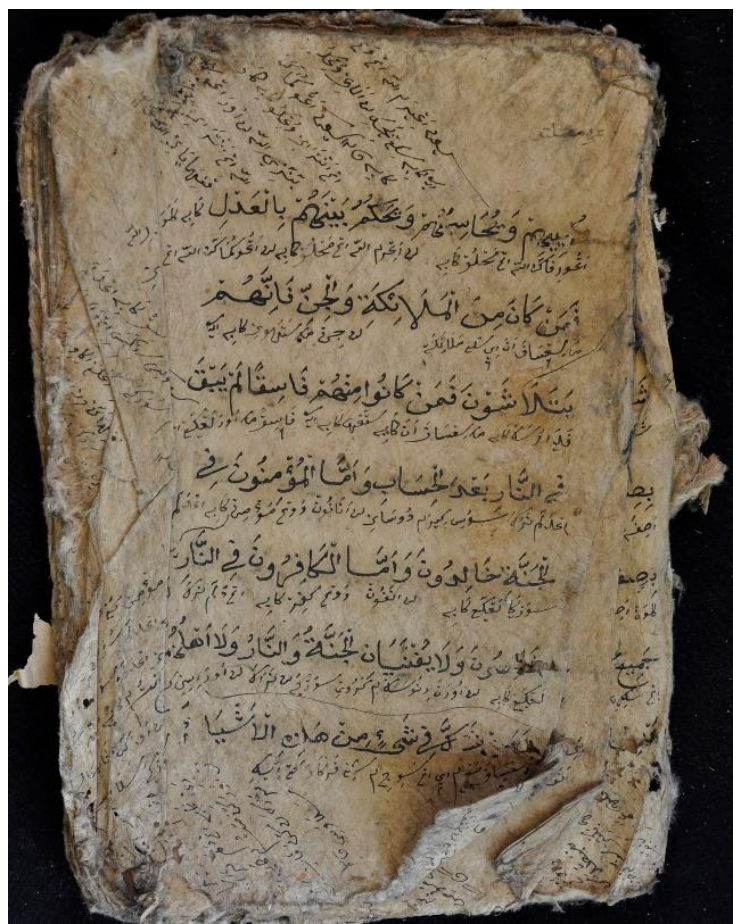

1178 BTBT 48 HLM 1_DSC0127

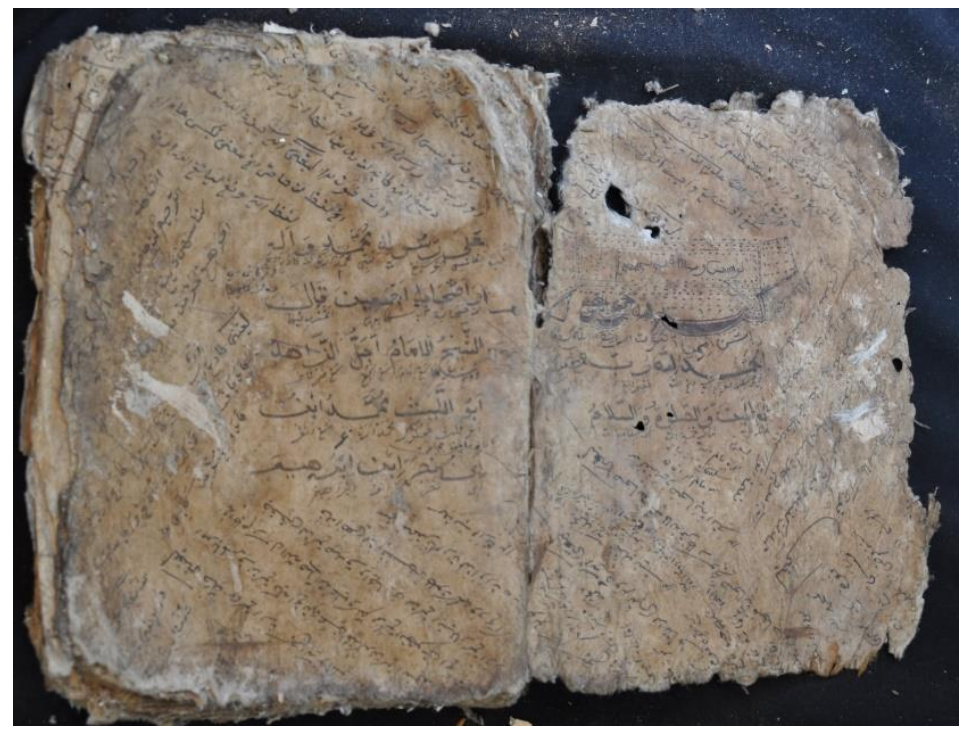

1181 BTBT 51 HLM 1,2 DSC_0137 


\begin{tabular}{|l|l|l|l|}
\hline $\begin{array}{l}\text { BLAS/SUM/16/AK } \\
\text { /75 }\end{array}$ & $\begin{array}{l}\text { KITAB FIKIH, } \\
\text { TAUHID, DAN } \\
\text { DOA }\end{array}$ & 3,4 & $\begin{array}{l}\text { Akaid dan Ilmu } \\
\text { kalam, Fikih, } \\
\text { Akhlak dan } \\
\text { tasawuf }\end{array}$ \\
\hline BT-BT 49 & Arab & Arab & Prosa \\
\hline $80 \mathrm{hlm}$. & 7 baris/hlm. & $28 \times 18$ & Kertas Daluwang \\
\hline Kiai Khalid \\
\hline \multicolumn{2}{|l}{} \\
\hline
\end{tabular}

Naskah ini berisi tiga teks, teks pertama menjelaskan tentang tata cara bersuci, salat, puasa, zakat, dan haji, teks kedua menjelaskan tentang sifat-sifat Allah dan Rasul Nya, teks ketiga berisi doa-doa. Pada teks pertama dan kedua diberi makna jenggotan/gandul dengan bahasa Jawa. Selain itu, pada bagian margin/di samping atas, bawah, kanan, dan kiri teks terdapat keterangan dengan bahasa Jawa.

Naskah ini dimiliki oleh Kiai Khalid dari Kiai Fadlun dari Kiai Khomsidin. Tahun dan tempat penyusunan tidak disebutkan. Kondisi naskah baik.

\begin{tabular}{|l|l|l|l|}
\hline $\begin{array}{l}\text { BLAS/SUM/16/AK } \\
\text { /76 }\end{array}$ & $\begin{array}{l}\text { KITAB } \\
\text { MU'TAQAD 50 } \\
\text { DAN LAIN-LAIN }\end{array}$ & 3,4 & $\begin{array}{l}\text { Akaid dan Ilmu } \\
\text { kalam, Fikih, } \\
\text { Akhlak dan } \\
\text { tasawuf }\end{array}$ \\
\hline BT-BT 53 & Arab & Arab & Prosa \\
\hline $74 \mathrm{hlm}$. & 9 baris/hlm. & $26.5 \times 18.5$ & Kertas Daluwang \\
\hline Kiai Khalid & \\
\hline \multicolumn{2}{|l|}{ Dusun Nyabungan, Jenanger, Batang-Batang. } \\
\hline
\end{tabular}

Dalam naskah ini terdapat lima teks. Teks pertama tauhid menjelaskan mu'taqad 50, teks kedua menjelaskan tata cara berwuḍ, salat, puasa teks ini bernama Kitab Sittin, ditulis oleh Kiai Lancing, teks ketiga menjelaskan tentang tauhid, teks keempat berisi tentang mu'taqad 50. Teks-teks tersebut diberi makna gandul berbahasa Jawa.

Naskah ini dimiliki oleh Kiai Khalid dari Kiai Fadlun dari Kiai Khomsidin. Tahun dan tempat penyusunan tidak disebutkan. Kondisi naskah sedang, masih dapat dibaca. Tinta menggunakan warna hitam. 


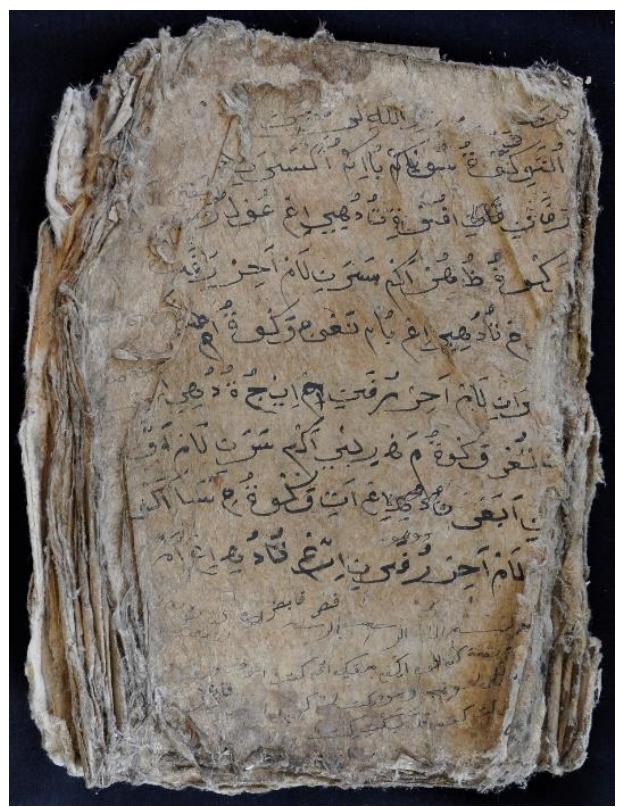

1179 BTBT 49 HLM 1_DSC0165

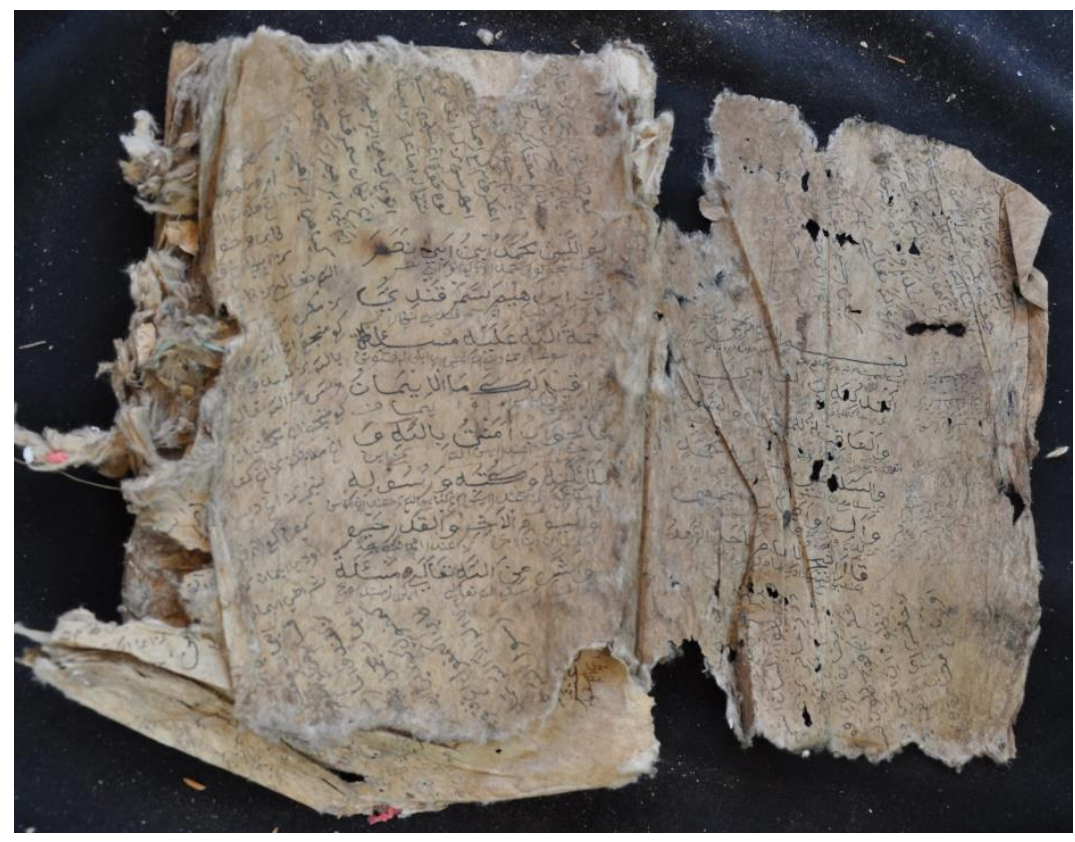

1183 BTBT 53 HLM 1,2 DSC_0228 


\begin{tabular}{|l|l|l|l|}
\hline $\begin{array}{l}\text { BLAS/SUM/16/AK } \\
/ 77\end{array}$ & $\begin{array}{l}\text { KITAB AWĀMIL } \\
\text { DAN LAIN-LAIN }\end{array}$ & 3 & $\begin{array}{l}\text { Akaid dan Ilmu } \\
\text { Tata Bahasa } \\
\text { Arab }\end{array}$ \\
\hline $\begin{array}{l}\text { JNGR/SUDFD/130 } \\
/ 2012\end{array}$ & Arab dan Jawa & Arab & Prosa \\
\hline 148 hlm. & 3 s.d. 7 baris/hlm. & $27.5 \times 19$ & Kertas Daluwang \\
\hline Kiai Su'udi Fadhal & \multicolumn{2}{|l}{} \\
\hline Jenangger, Batang-batang
\end{tabular}

Teks pertama menjelaskan tentang ilmu saraf yang ditulis oleh Abdul Kabir selesai hari Ahad, teks kedua bernama Kitab Awamil menjelaskan 'amil dalam ilmu nahwu, teks keempat bernama damir, ditulis oleh Madhiyul Jahli dengan aksara Arab Bahasa Jawa, selesai penulisan 23 Rajab Tahun Zak Hijrah Nabi, menjelaskan tentang isim dämir, isim mausul, teks kelima ditulis oleh Irsyad selesai hari Sabtu sebelum zuhur 29 Rajab 1271 H/ $1854 \mathrm{M}$, menjelaskan tentang kewajiban muslim untuk mengetahui iman dan Islam.

Naskah ini dimiliki oleh K Su'udi Fadlal dari Rosyidah dari K Irsyad dari KH Hadi dari Kamsah dari K Biramah. Naskah dalam kondisi baik.

\begin{tabular}{|l|l|l|l|}
\hline $\begin{array}{l}\text { BLAS/SUM/16/AK } \\
\text { /78 }\end{array}$ & $\begin{array}{l}\text { KITAB } \\
\text { SAMARQANDI } \\
\text { DAN LAIN-LAIN }\end{array}$ & 3,5 & $\begin{array}{l}\text { Akaid, Akhlak, } \\
\text { Tasawuf, Fikih }\end{array}$ \\
\hline $\begin{array}{l}\text { PJGSGG/ABDL/14 } \\
2 / 2012\end{array}$ & Arab & Arab & Prosa \\
\hline $202 \mathrm{hlm}$. & 7 baris/hlm. & $20 x 15.5$ & Kertas Daluwang \\
\hline H. Madani & & \\
\hline \multicolumn{2}{|l|}{ Pajung Sergang, Batu Putih }
\end{tabular}

Naskah berisi tujuh teks. Teks pertama bernama Samarqandi, menjelaskan tentang Ilmu Tauhid dengan tanya jawab. Teks kedua bernama Sittin selesai penulisan Bulan Rabi'ul Akhir bakda zuhur, menjelaskan tentang enam puluh masalah peribadatan seperti najis, hadas kecil dan besar, salat, siyam, zakat. Teks ketiga menjelaskan niat memandikan jenazah. Teks keempat bernama Kitab Zurroh, menjelaskan kewajiban mukallaf untuk beri'tikad 50. Teks kelima ditulis oleh Abdul Ghofar, menjelaskan kewajiban mukallaf untuk menget ahui makna syahadat.Teks keenam ditulis oleh Abdul Ghofar menjelaskan Ilmu Fikih mulai dari bersuci, salat diakhiri dengan fadilah doa.Teks ketujuh bernaama Nihayah Al-Mathlab, menjelaskan tentang etika ustaz terhadap murid.

Naskah ini dimiliki oleh Abdullah dari K.H. Syarkowi. Kondisi naskah masih baik. 


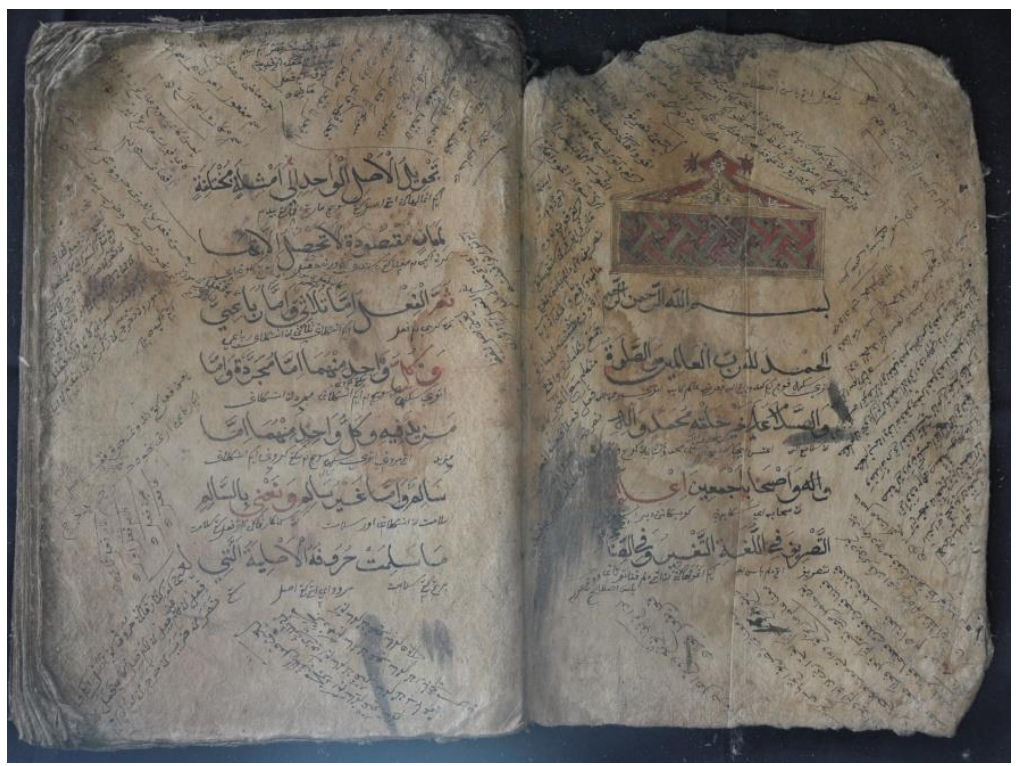

12131 JNGR SUDFD 1302012 HLM 1,2 Img10941

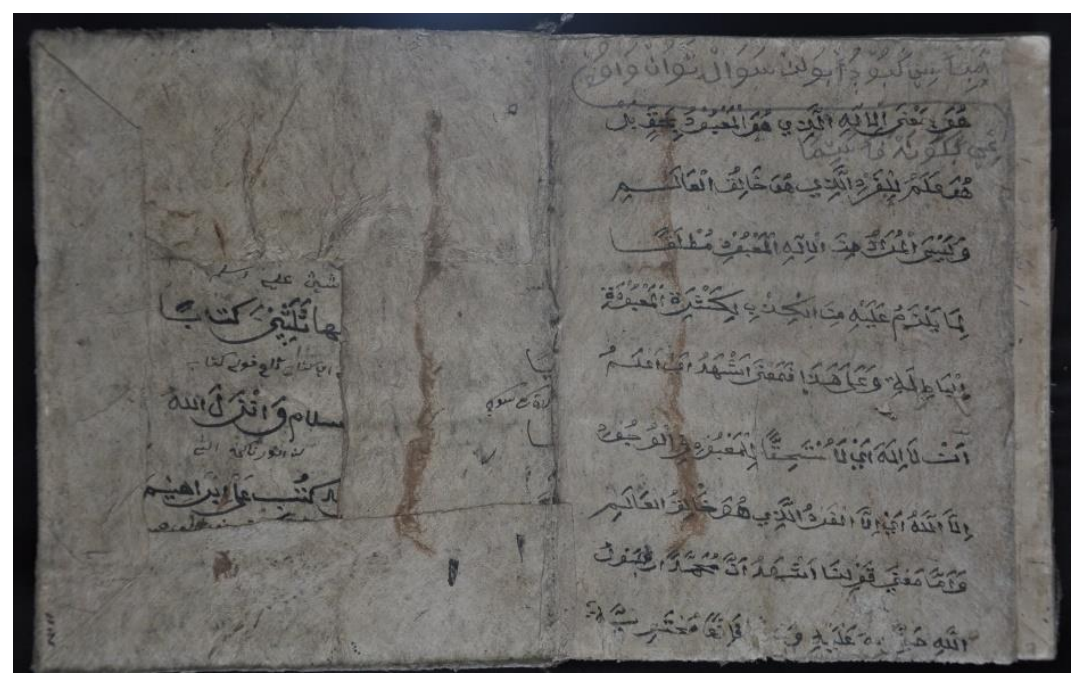

12143 PJGSGG ABDL 1422012 HLM 1 Img11863 


\begin{tabular}{|l|l|l|l|}
\hline $\begin{array}{l}\text { BLAS/SUM/16/AK } \\
\text { /79 }\end{array}$ & $\begin{array}{l}\text { KITAB BERSUCI } \\
\text { DAN LAIN-LAIN }\end{array}$ & 3,4 & $\begin{array}{l}\text { Akaid, } \\
\text { Akhlak/Tasawuf, } \\
\text { dan Hukum } \\
\text { Islam/Fikih }\end{array}$ \\
\hline $\begin{array}{l}\text { PJGSGG/HSM/159 } \\
/ 2012\end{array}$ & Arab & Arab & Prosa \\
\hline 66 hlm. & 9 baris/hlm. & $28 \times 20.5$ & Kertas Daluwang \\
\hline K.H. Hasim & & \\
\hline Pajung, Sergang, Batu Putih, Sumenep & \\
\hline
\end{tabular}

Naskah ini ada tiga teks, teks pertama menjelaskan tentang najis, wudu, salat, puasa. Teks kedua berisi doa setelah wudu, doa azan, salat, teks ketiga berisi Kitab Al Hadis An Nabi, selesai penulisan hari Jumat Bulan Sya'ban 1313 H/1895 M, menjelaskan macam-macam azab.

Naskah ini dimiliki oleh K.H. Hasim dari K.H. Azhari. Kondisi naskah tergolong cukup baik.

\begin{tabular}{|l|l|l|l|}
\hline $\begin{array}{l}\text { BLAS/SUM/16/AK } \\
/ 80\end{array}$ & $\begin{array}{l}\text { KITAB RISALAH } \\
\text { AD-DUROR L- } \\
\text { BAHIYAH }\end{array}$ & 3,5 & $\begin{array}{l}\text { Akaid, } \\
\text { Akhlak/Tasawuf, } \\
\text { Hukum } \\
\text { Islam/Fikih }\end{array}$ \\
\hline $\begin{array}{l}\text { PJGSGG/MDN/145 } \\
/ 2012\end{array}$ & Arab & Arab & Rrosa \\
\hline 170 hlm. & 7 baris/hlm. & $20 \times 15$ & Kertas Daluwang \\
\hline H. Madani & & \\
\hline \multicolumn{2}{|l|}{ Pajung Sergang Sergang, Batu Putih } \\
\hline
\end{tabular}

Teks dalam naskah ini bernama Risalah Ad-Duror Al-Bahiyah disusun oleh Sayid Al Bakri Syato menjelaskan tentang akhlak/tasawuf atau perilaku dalam salat dilanjutkan dengan arti iman kepada Allah dan seterusnya, dilanjutkan dengan masalah peribadatan.

Naskah ini dimiliki oleh H. Madani dari K. Abdul Karim Kondisi naskah tergolong baik. 


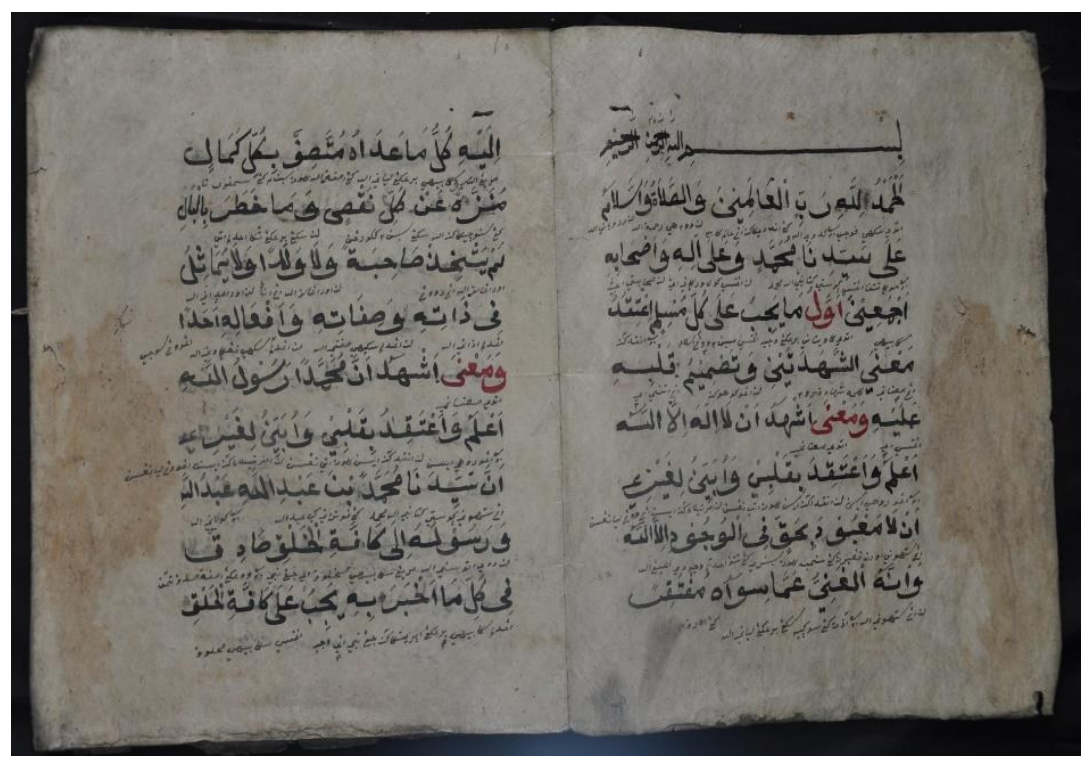

12160 PJGSGG HSM 1592012 HLM 1,2 Img12906

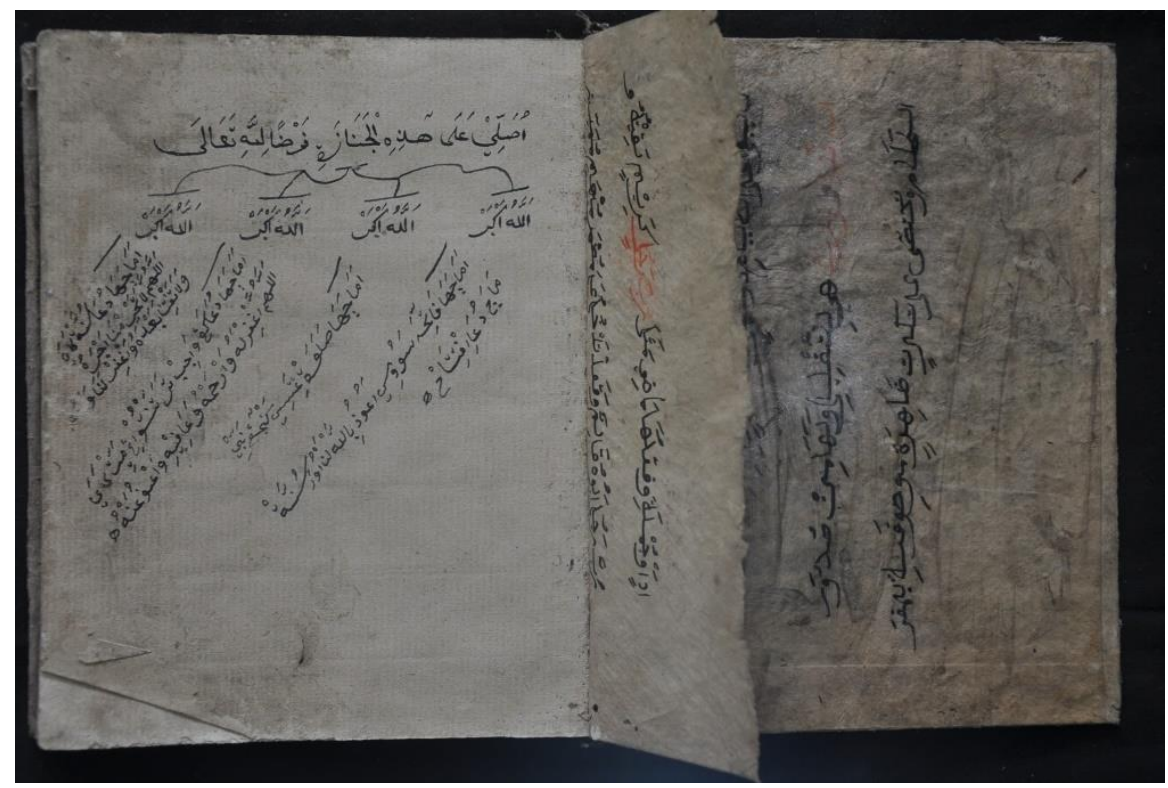

12146 PJGSGG ABDL 1452012 HLM 2 Img12150 


\begin{tabular}{|l|l|l|l|}
\hline $\begin{array}{l}\text { BLAS/SUM/16/AK } \\
\text { /81 }\end{array}$ & KITAB TAUHID & $\mathbf{3 , 5}$ & $\begin{array}{l}\text { Akaid, } \\
\text { Akhlak/Tasawuf, } \\
\text { Hukum } \\
\text { Islam/Fikih }\end{array}$ \\
\hline $\begin{array}{l}\text { PJGSGG/ABDL/14 } \\
6 / 2012\end{array}$ & Jawa dan Madura & Arab & Prosa \\
\hline $38 \mathrm{hlm}$. & $\begin{array}{l}13 \text { s.d. } 14 \\
\text { baris/hlm. }\end{array}$ & $20.8 \times 15.5$ & Kertas Daluwang \\
\hline H. Madani & \multicolumn{2}{|l}{} \\
\hline \multicolumn{2}{|l|}{ Pajung Sergang Sergang, Batu Putih } \\
\hline
\end{tabular}

Teks pertama menjelaskan kewajiban seorang mukallaf untuk mengetahui Allah, teks kedua menjelaskan tentang kebut uhan orang hidup dalam beribadah, teks ketiga disusun 27 Rajab menjelaskan salat sunah dan doa-doanya, teks keempat bernama Akidatul Awam, menjelaskan akidah bagi orang awam dengan sifat wajib, muhal, dan jaiz bagi Allah dan Rasul, teks kelima tentang doa-doa, teks keenam menjelaskan tentang niat salat qabliyah dan salat ba'diyah.

Naskah ini dimiliki oleh H. Madani dari K. Abdul Karim Kondisi naskah tergolong baik.

\begin{tabular}{|l|l|l|l|}
\hline $\begin{array}{l}\text { BLAS/SUM/16/AK } \\
\text { /82 }\end{array}$ & KITAB TAUHID & 3,5 & $\begin{array}{l}\text { Akaid, } \\
\text { Akhlak/Tasawuf, } \\
\text { Hukum } \\
\text { Islam/Fikih }\end{array}$ \\
\hline $\begin{array}{l}\text { PJGSGG/MDN/147 } \\
\text { /2012 }\end{array}$ & Arab & Arab & Prosa \\
\hline 14 hlm. & 7 baris/hlm. & $20 \times 14$ & Kertas Daluwang \\
\hline H. Madani & \multicolumn{2}{|l}{} \\
\hline \multicolumn{2}{|l|}{ Pajung Sergang Sergang, Batu Putih } \\
\hline
\end{tabular}

Naskah berisi dua teks. Teks pertama menjelaskan bahwa hidayat surga ada 4 macam, yakni amal saleh, cinta auliya, perintah Allah, dan syafaat. Teks kedua menjelaskan tentang barunya ciptaan Allah.

Naskah ini dimiliki oleh H. Madani dari K. Abdul Karim Kondisi naskah tergolong cukup baik. 


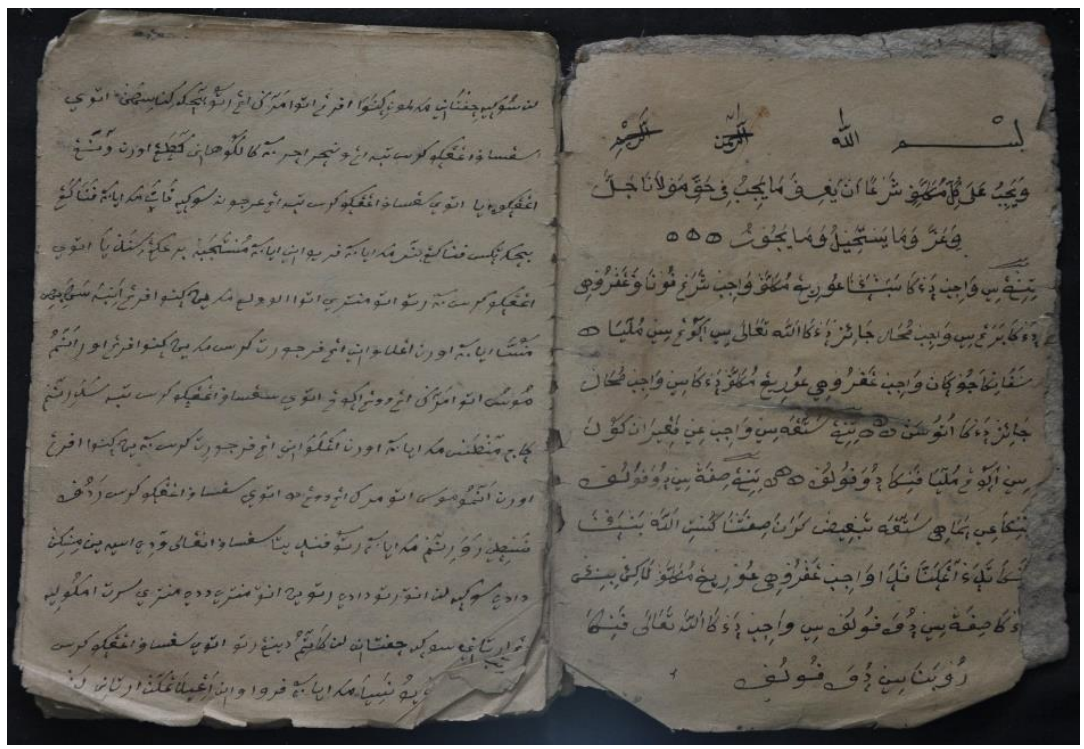

12147 PJGSGG ABDL 1462012 HLM 1,2 Img12242

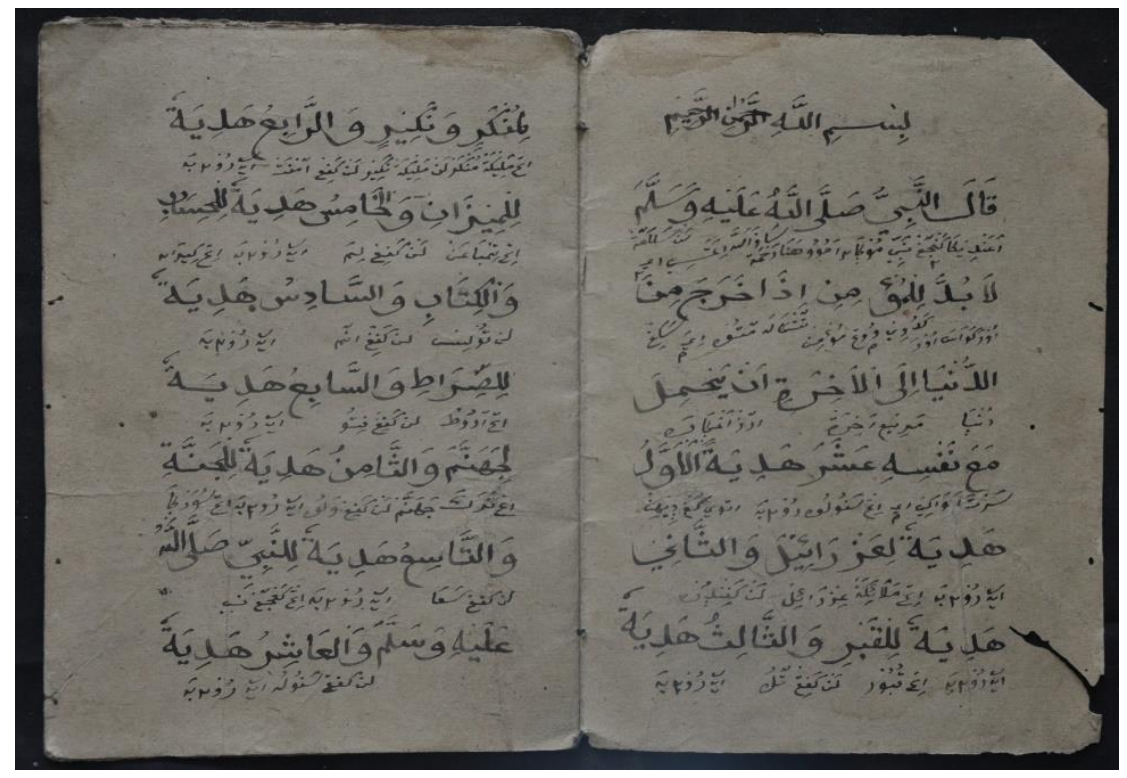

12148 PJGSGG MDN 1472012 HLM 1,2 Img12265 


\begin{tabular}{|l|l|l|l|}
\hline $\begin{array}{l}\text { BLAS/SUM/16/AK } \\
\text { /83 }\end{array}$ & $\begin{array}{l}\text { KITAB } \\
\text { SYAHADAT } \\
\text { DAN LAIN-LAIN }\end{array}$ & 3,4 & $\begin{array}{l}\text { Akaid, } \\
\text { Akhlak/Tasawuf, } \\
\text { Hukum } \\
\text { Islam/Fikih, Ilmu } \\
\text { Alquran/Tajwid }\end{array}$ \\
\hline $\begin{array}{l}\text { PJGSGG/HSM/153 } \\
/ 2012\end{array}$ & Arab & Arab & Kertas Daluwang \\
\hline $88 \mathrm{hlm}$. & 7 s.d. 27 baris/hlm. & $27.3 \times 19$ & \\
\hline K.H. Hasim & \\
\hline \multicolumn{2}{|l|}{ Pajung, Sergang, Batu Putih, Sumenep } \\
\hline
\end{tabular}

Naskah berisi enam teks. Teks pertama menjelaskan tentang syirik Majusi, Nasrani, Jahiliyah, Falasifah. Teks kedua bernama kitab Syahadah, menjelaskan tentang dua kalimat syahadat. Teks ketiga menjelaskan wudu, syariat, tarekat, hakikat dan makrifat. Teks keempat menjelaskan syahadat, syariat, tarekat, hakikat, dan makrifat. Teks kelima menjelaskan tentang penciptaan alam. Teks keenam menjelaskan tentang bacaan Alquran atau ilmu tajwid.

Naskah ini dimiliki oleh K.H. Hasim dari K.H. Azhari. Kondisi naskah tergolong cukup baik.

\begin{tabular}{|l|l|l|l|}
\hline $\begin{array}{l}\text { BLAS/SUM/16/AK } \\
\text { 84 }\end{array}$ & $\begin{array}{l}\text { KITAB TAUHID, } \\
\text { NAHWU, DAN } \\
\text { KITAB SITTIN }\end{array}$ & 3,4 & $\begin{array}{l}\text { Akaid, Fikih, dan } \\
\text { Ilmu Tata Bahasa } \\
\text { Arab }\end{array}$ \\
\hline $\begin{array}{l}\text { BTLN/ALWI/84/20 } \\
12\end{array}$ & Arab & Arab & Prosa \\
\hline $90 \mathrm{hlm}$. & 7 baris/hlm. & $25 \times 18$ & Kertas Daluwang \\
\hline K.H. Alwi & \multicolumn{2}{|l}{} \\
\hline \multicolumn{2}{|l|}{ Bantilan, Pajung, Batu Putih, Sumenep }
\end{tabular}

Naskah ini berisi empat teks. Teks pertama menjelaskan tentang sifat wajib bagi Allah dapat dibagi menjadi empat yakni nafsiyah, salbiah, ma'ani, dan ma'nawiyah. Teks kedua menjelaskan tentang awamil dalam ilmu saraf. Teks ketiga bernama kitab Sittin menjelaskan tanya jawab enam puluh masalah peribadat an. Teks keempat bernama kitab Sittin yang menjelaskan tentang tanya jawab enam puluh masalah ibadat.

Naskah ini berasal dari K.H. Alwi dari K.H. Syafi'udin dari K.H. Syarkawi (sepuh). Tahun penyusunan, penulisan tidak disebutkan. Kondisi kitab ini rusak. 


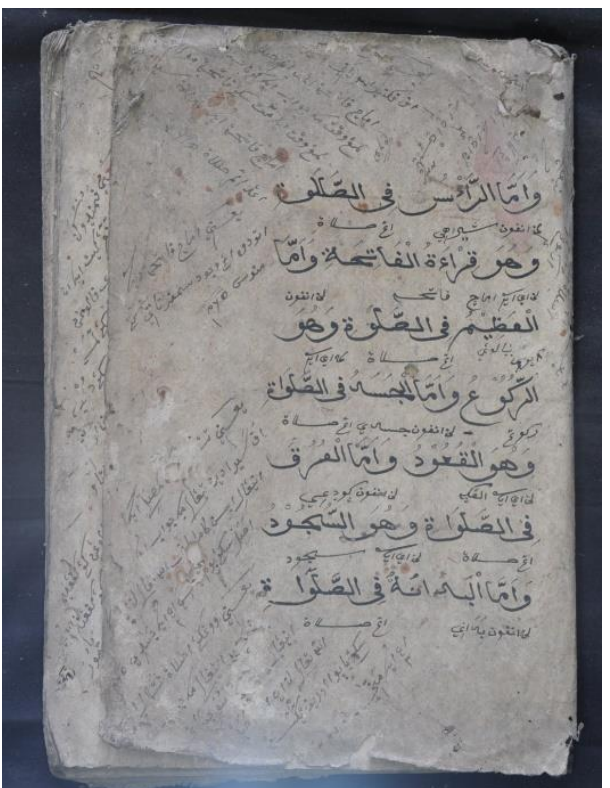

12154 PJGSGG HSM 153212 HLM 1,2 Img12736

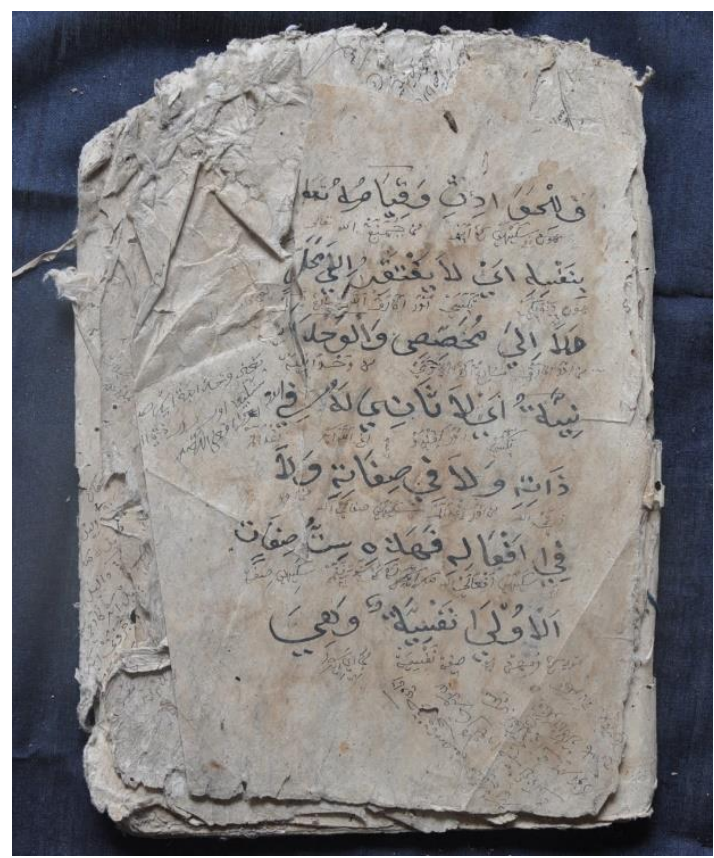

12085 BTLN ALWI 842012 HLM 1,2 Img6874 


\begin{tabular}{|l|l|l|l|}
\hline $\begin{array}{l}\text { BLAS/SUM/16/AK } \\
\mathbf{8 5}\end{array}$ & $\begin{array}{l}\text { KITAB AT- } \\
\text { TAUBAT }\end{array}$ & 3 & $\begin{array}{l}\text { Akaid, Ilmu Tata } \\
\text { Bahasa Arab }\end{array}$ \\
\hline $\begin{array}{l}\text { SGG/DRYH/45/20 } \\
12\end{array}$ & Arab & Arab & Prosa \\
\hline 176 hlm. & 3 s.d 4 baris/hlm. & $17.5 \times 12.3$ & Kertas Daluwang \\
\hline Nyai Dzurriyah & \multicolumn{2}{|l}{} \\
\hline Sergang, Batu Putih
\end{tabular}

Naskah ini berisi dua teks. Teks pertama berisi tentang taubat, teks kedua berisi ilmu nạ̣wu.

Keterangan lebih rinci dari teks pertama, teks ini menjelaskan syarat-syarat taubat yang diambil dari berbagai kitab yaitu Ihya' Ulumuddin, Alquran Ilallah, Gayatu alQuswa dan Syarah Juman tentang kekhasan para nabi dalam beribadat. Teks kedua berisi ilmu nạhwu yang menjelaskan awämil dalam ilmu nạhwu.

Naskah ini milik Nyai Dzuriyah dari K.H. Asyhari. Kondisi naskah mulai rusak, teks masih terbaca.

\begin{tabular}{|l|l|l|l|}
\hline $\begin{array}{l}\text { BLAS/SUM/16/AK } \\
\text { /86 }\end{array}$ & $\begin{array}{l}\text { KITAB AL- } \\
\text { URRAT }\end{array}$ & 3 & $\begin{array}{l}\text { Akaid, Tata } \\
\text { Bahasa }\end{array}$ \\
\hline $\begin{array}{l}\text { SGG/DRYH/49/20 } \\
12\end{array}$ & Arab & Arab & Prosa \\
\hline 224 hlm. & 3 s.d 7 baris/hlm. & $26 x 19$ & Kertas Daluwang \\
\hline Nyai Dzurriyah & & \\
\hline Sergang, Batu Putih & & \\
\hline
\end{tabular}

Naskah ini berisi 10 teks yang isinya bermacam-macam.

Teks pertama berjudul Al-'Urrat berisi tasrifan ilmu saraf, yang membatalkan pernikahan, dan syarat iman. Teks kedua berjudul Al-Urrat berisi sedakah untuk mayyit sebelum tiga hari hukumnya haram. Teks ketiga berjudul Huratul khamsi berisi tentang la ilaha illa Allah yang disadur dari Kitab Huratul Khamsi, Ihya 'Ulumuddin, dan lainnya. Teks keempat berjudul Martabat Kalimataini berisi dua kalimat syahadat. Teks kelima berjudul Syarah Nun berisi tentang hamdalah yang dibagi menjdi enam bagian, 4 bagian di Kitab Alquran dan 2 bagian di hadits. Teks keenam berjudul Surat AlFatihah. Teks ketujuh berjudul Syarah dua kalimat syahadat yang menjelaskan tentang seorang muslim wajib untuk mengetahui makna dua kalimat syahadat. Teks kedelapan berjudul makna dua kalimat syahadat. Teks kesembilan berjudul Makna Kalimat 
Syahadat berisi pentingnya dua kalimat syahadat. Teks kesepuluh berjudul Syartul Iman berisi seseorang yang beriman harus memenuhi syarat bukan sekedar bersaksi saja.

Naskah ini milik Nyai Dzuriyah dari K.H. Asyhari. Kondisi naskah cukup baik, teks terbaca.

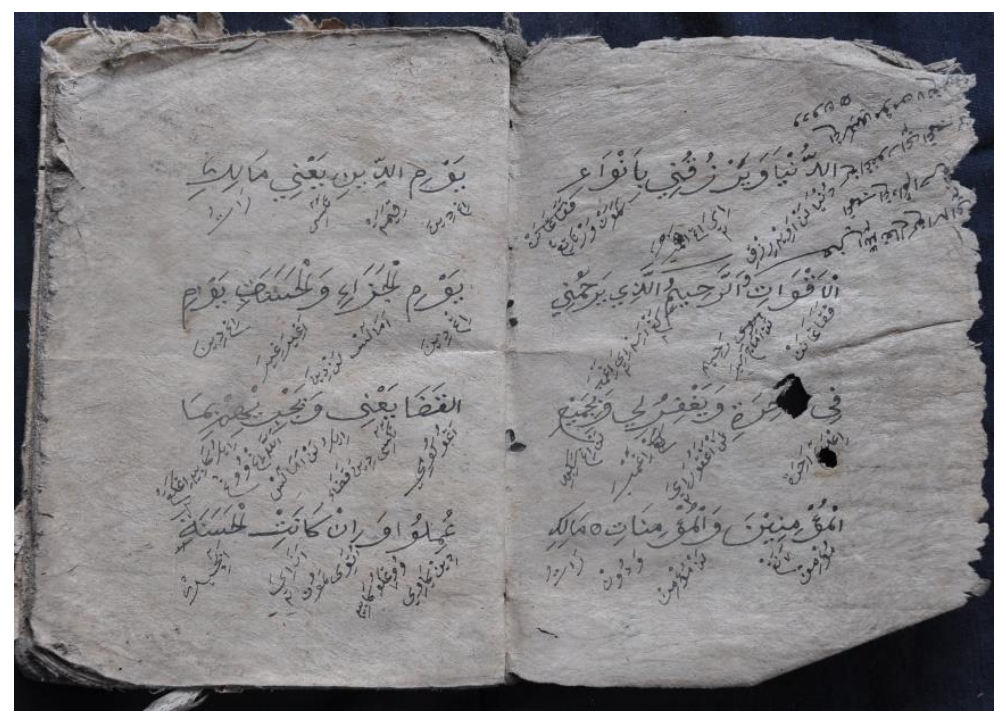

12045 SGG DRYH 452012 HLM 1,2 Img4321

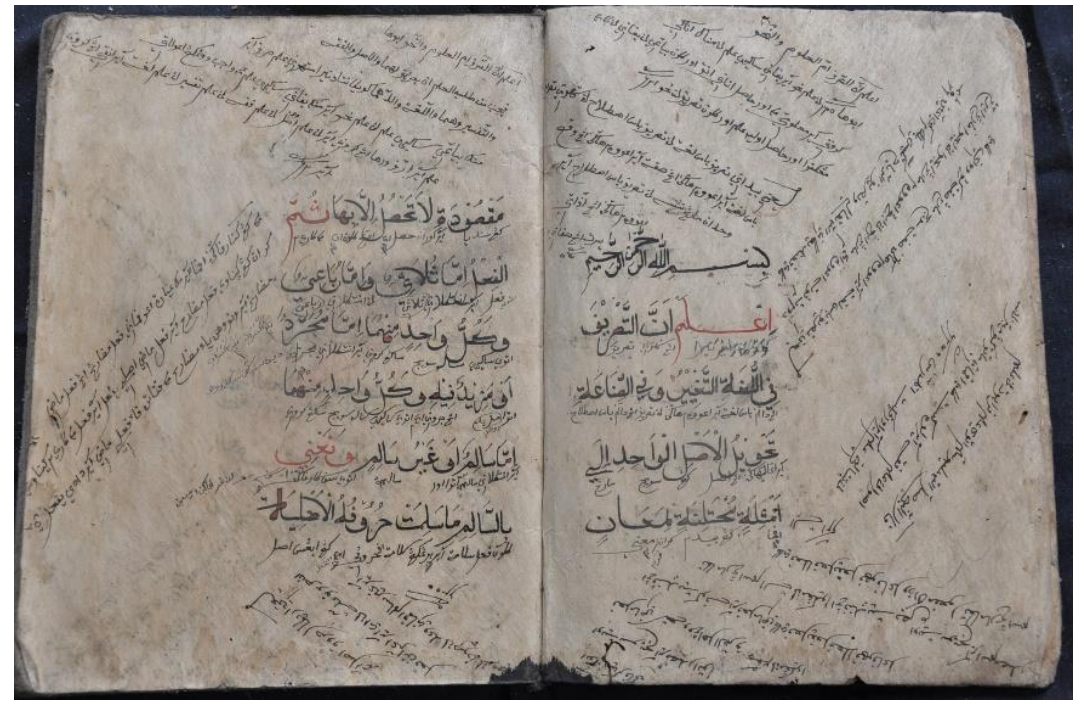

12049 SGG DRYH 492012 HLM 1,2 Img4796 


\begin{tabular}{|l|l|l|l|}
\hline $\begin{array}{l}\text { BLAS/SUM/16/AK } \\
\text { /87 }\end{array}$ & $\begin{array}{l}\text { KITAB TAUHID } \\
\text { DAN KITAB } \\
\text { KHAMSATUL } \\
\text { ABWABIN }\end{array}$ & 3,5 & $\begin{array}{l}\text { Akhlak/Tasawuf } \\
\text { dan Hukum } \\
\text { Islam/Fikih }\end{array}$ \\
\hline $\begin{array}{l}\text { PJGSGG/HSM/158 } \\
/ 2012\end{array}$ & Arab & Arab & Prosa \\
\hline 42 hlm. & 9 baris/hlm. & $25 \times 18$ & Kertas Daluwang \\
\hline K.H. Hasim & \\
\hline \multicolumn{2}{|l|}{ Pajung, Sergang, Batu Putih, Sumenep } \\
\hline
\end{tabular}

Teks pertama menjelaskan arti alif, yaitu nuktah atau titik, makna titik żurah aatau molekul, makna żurah ruh khafi, sirrul ilahi. Teks kedua bernama Kitab Khamsatu Abwabin, menjelaskan tentang mandi janabat, siapa yang berwudu dengan baik.

Naskah ini dimiliki oleh K.H. Hasim dari K.H. Azhari. Kondisi naskah tergolong cukup baik.

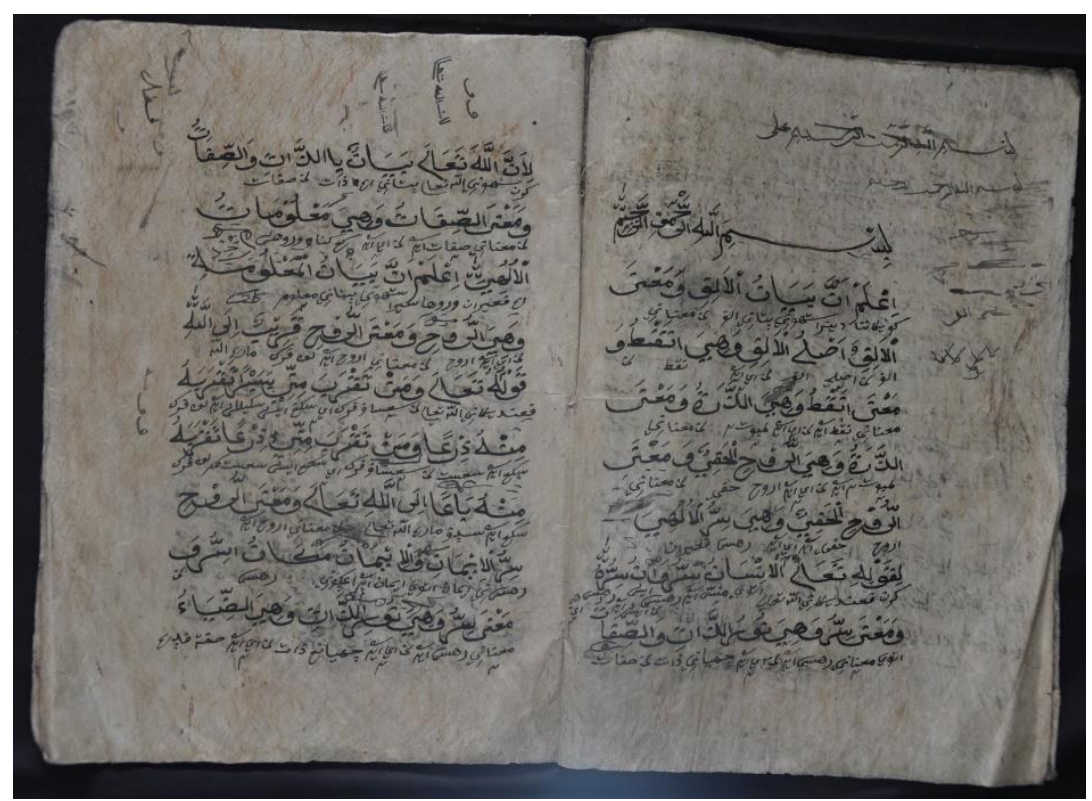

12159 PJGSGG HSM 1582012 HLM 1 Img12882 


\section{FI}

Fiqih

\begin{tabular}{|l|l|l|l|}
\hline $\begin{array}{l}\text { BLAS/SUM/16/FI/ } \\
1\end{array}$ & $\begin{array}{l}\text { KITAB FIKIH } \\
\text { SYAFIIYAH }\end{array}$ & 4 & Fikih \\
\hline $\begin{array}{l}\text { BTLN/MRWN/68/ } \\
2012\end{array}$ & Arab & Arab & Prosa \\
\hline 62 hlm. & 9 baris/hlm. & $19 \times 14$ & Kertas Daluwang \\
\hline Marwan & \multicolumn{2}{l}{} \\
\hline Bantilan, Batu Putih
\end{tabular}

Naskah ini berisi tentang tatacara beribadat dan bersuci menurut pendapat Imam Syafi'i, dimulai dari macam air, menghilangkan najis, sampai pada puasa dan haji.

Naskah ini milik Marwan dari Abdul Ghani. Kondisi naskah mulai rusak, teks masih terbaca.

\begin{tabular}{|l|l|l|l|}
\hline $\begin{array}{l}\text { BLAS/SUM/16/FI/ } \\
2\end{array}$ & $\begin{array}{l}\text { KITAB } \\
\text { KAIFIYATU S- } \\
\text { ȘALAT }\end{array}$ & 4 & Fikih \\
\hline GPR 7 & Arab & Arab, Arab pegon & prosa \\
\hline 44 hlm. & 13 baris/hlm. & $21 . x 16.5$ & Kertas () \\
\hline Kiai Masduki & \\
\hline \multicolumn{2}{|l|}{ Gapura Barat, Gapura, Sumenep } \\
\hline
\end{tabular}

Naskah berhuruf Arab ada beberapa kalimat diberi makna dengan huruf pegon dengan bahasa jawa. Di kolofon tertulis naskah milik H. Muhtar bin H.Abdul Kadir Tamun Bara' Kampung Masjid. Selesai ditulis pada malam selasa, maghrib, bulan haji tanggal 20 tahun ha.

Naskah ini dikoleksi oleh Kiai Masduki Gapura. Kondisi naskah cukup baik, teks masih terbaca. 


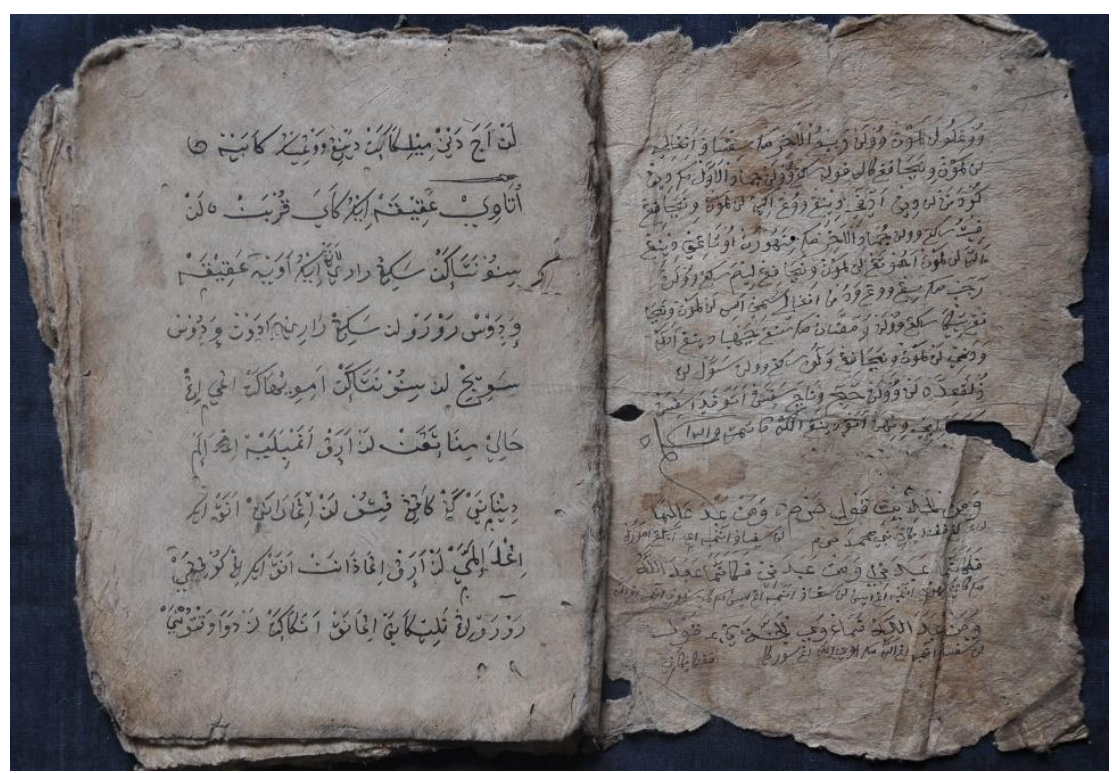

\section{BTLN MRWN 682012 HLM 1,2}

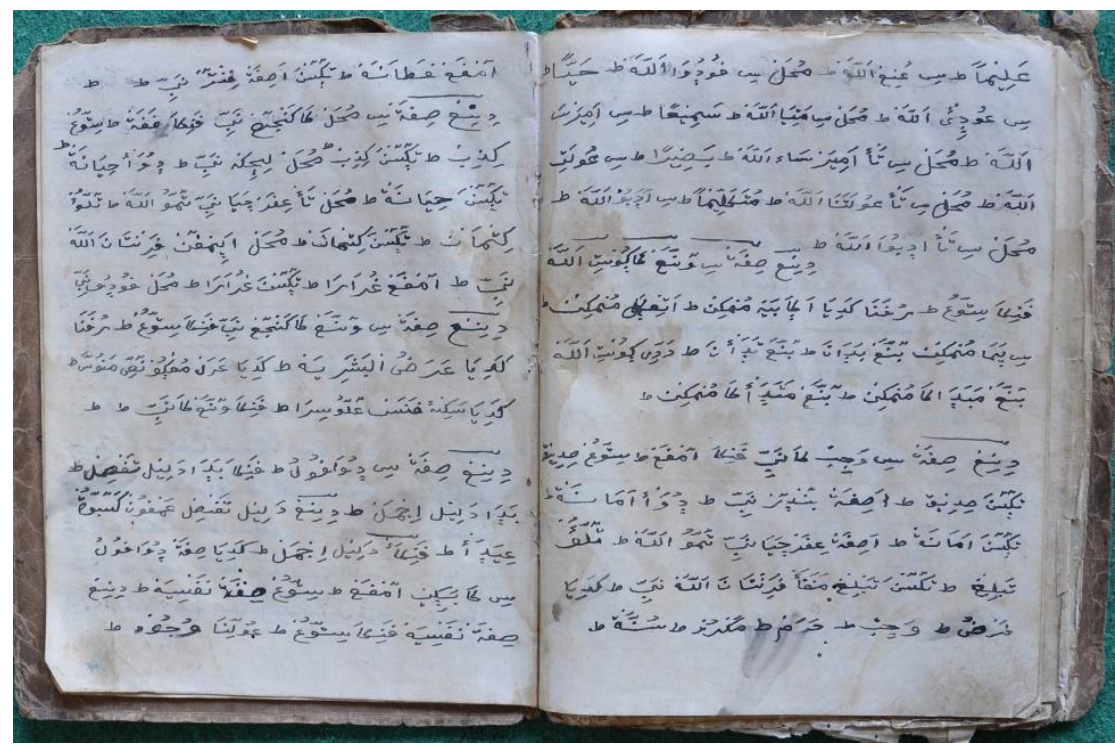

1007 GPR 07 DSC0151.2 


\begin{tabular}{|l|l|l|l|}
\hline $\begin{array}{l}\text { BLAS/SUM/16/FI/ } \\
\mathbf{3}\end{array}$ & KITAB FIKIH & $\mathbf{4}$ & Fikih \\
\hline GPR 13 & Jawa & Arab, Arab pegon & Prosa \\
\hline 190 hlm. & 13 baris/hlm. & $20 x 14$ & Kertas () \\
\hline Kiai Masduki & \\
\hline \multicolumn{2}{|l|}{ Gapura Barat, Gapura, Sumenep }
\end{tabular}

Naskah berisi tentang fikih diawali dengan sesuatu yang wajib diketahui oleh seorang muslim, kemudian dilanjutkan bab haid, nifas, mandi, larangan laki-laki memakai perhiasan, bab dimakruhkan dalam puasa, hajat, dan tatakramanya.

Naskah ini dikoleksi oleh Kiai Masduki Gapura. Kondisi naskah mulai rusak, teks sebagian masih terbaca.

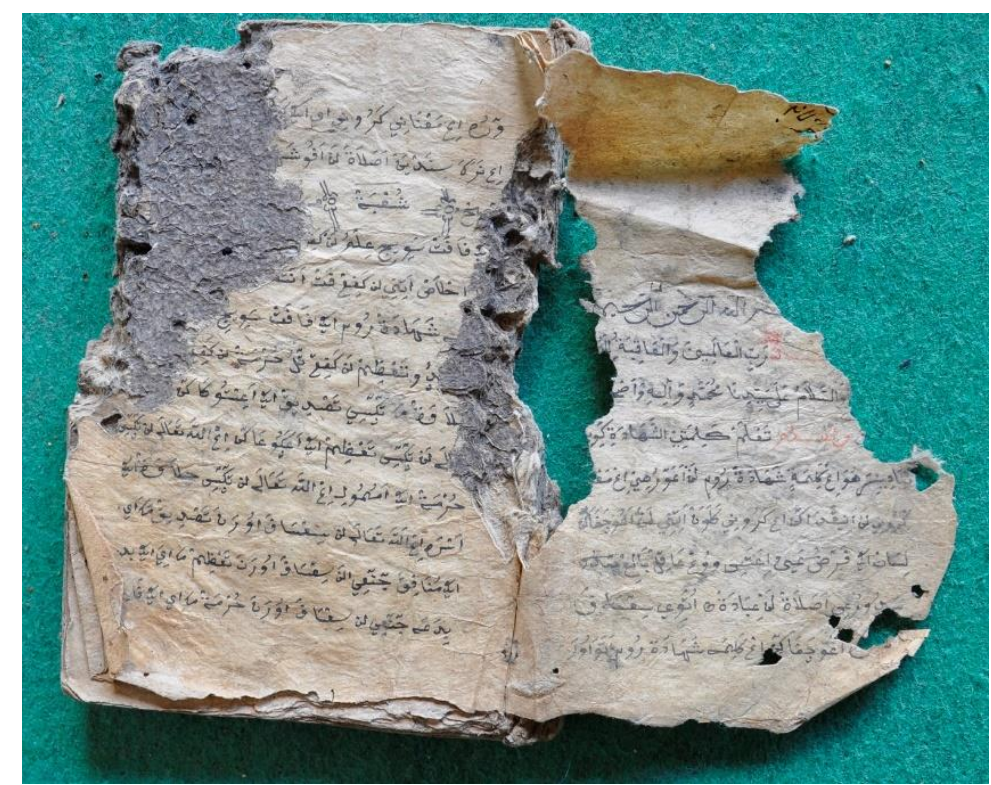

1013 GPR 13_DSC0050 


\begin{tabular}{|l|l|l|l|}
\hline $\begin{array}{l}\text { BLAS/SUM/16/FI/ } \\
4\end{array}$ & $\begin{array}{l}\text { KITAB FATHUL } \\
\text { WAHAB BI } \\
\text { SYARHI } \\
\text { MINHAJUT } \\
\text { TULLĀB }\end{array}$ & 4 & Fikih \\
\hline SMN 3 & Arab & Arab & prosa \\
\hline 250 hlm. & $21 \times 16.5$ & Kertas () \\
\hline Kiai Said Abdullah & \\
\hline PP Matholiul Anwar Pengarangan Sumenep & \\
\hline
\end{tabular}

Teks berisi fikih. Di kolofon tertulis Kitab Fathul Wahab bi Syarhi Minhajut Tulab ........ Abu Yahya Zakariya al Anshori al Syafi'i.

Naskah ini milik Kiai Said Abdullah dan disimpan di Pondok Pesantren Matholiul Anwar, Pengarangan Sumenep. Naskah terdiri satu jilid, bersampul kulit. Teks masih bisa dibaca meski terdapat beberapa halaman yang rusak.

\begin{tabular}{|l|l|l|l|}
\hline $\begin{array}{l}\text { BLAS/SUM/16/FI/ } \\
5\end{array}$ & $\begin{array}{l}\text { RIȘALATUL } \\
\text { MUHIMMAH } \\
\text { (HAK DAN } \\
\text { KEWAJIBAN } \\
\text { SUAMI ISTERI) }\end{array}$ & 4 & Fikih \\
\hline GPR 17 & Arab & Arab & Prosa \\
\hline 70 hlm. & 7 baris/hlm. & $22.5 \times 16.5$ & Kertas Daluwang \\
\hline Fatony Ahmad & \\
\hline \multicolumn{2}{|l|}{ Dusun Talesek, Gapura Barat, Gapura, Sumenep } \\
\hline
\end{tabular}

Naskah berisi tentang hak dan kewajiban suami dan istri. Terdapat empat bab dalam teks meliputi; Pertama hak istri terhadap suami. Kedua, hak suami terhadap istri. Ketiga, salatnya perempuan di rumah dan fadilahnya seperti salat bersama nabi Muhammad saw. Keempat, penghormatan suami kepada istri. Beberapa kata dan kalimat diberi terjemahan model jenggotan/gandul dengan aksara Arab bahasa Jawa (pegon). Pada sampul luar ada tulisan Syaikh Umar Sadli, sedangkan di sampul dalam tertulis nama Musa dan nama kampung Batum, namun tidak diketahui dengan jelas apakah itu merujuk kepada nama penulis/penyalin naskah dan tempat penyalinan.

Naskah berasal dari Fatony Ahmad dari H. Abdurrahman (kakek dari Fatony Ahmad). Kondisi fisik naskah rusak, namun tulisan masih bisa dibaca. 


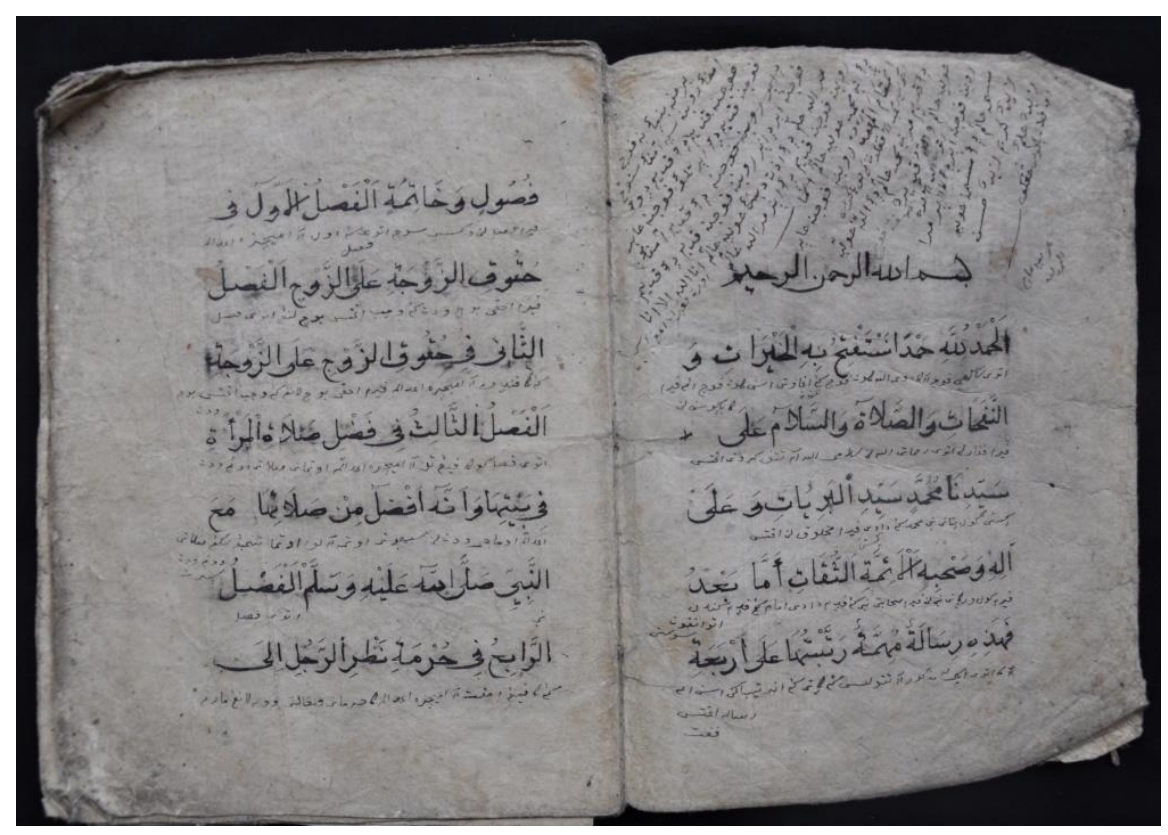

1103 GPR 17 HLM 2,3 DSC_0082 


\begin{tabular}{|l|l|l|l|}
\hline $\begin{array}{l}\text { BLAS/SUM/16/FI/ } \\
6\end{array}$ & $\begin{array}{l}\text { KITAB FIKIH } \\
\text { (SALINAN } \\
\text { SULAM TAUFIK) }\end{array}$ & 4 & Fikih \\
\hline GPR 18 & Arab, Jawa Pegon & Arab & Prosa \\
\hline $149 \mathrm{hlm}$. & 10 baris/hlm. & $24.5 \times 17.5$ & Kertas Eropa \\
\hline Ilyas & \\
\hline Durbugan Banjar Barat, Gapura Sumenep \\
\hline
\end{tabular}

Naskah berisi beberapa teks tentang fikih dan tauhid. Naskah diperkirakan merupakan salinan dari kitab Sulam Taufik. Pada halaman dalam terdapat kalimat "lailaha illa allah muhammadurrasullah" dan kata "Allah" "Muhammad" gambar ka'bah dan kata "bismillairrahmanirahim." Teks dilengkapi dengan terjemahan aksara Arab dan bahasa Jawa (pegon) model jenggotan/gandul. Juga, murad atau penjelasan dengan bahasa Jawa dan aksara Arab (pegon).

Naskah milik Ilyas, dari Qosim, dari Kiai Idrur, dari Kiai Mahdi. Kondisi naskah dalam keadaan baik, tapi jilidan lepas. Naskah bersampul kertas karton warna cokelat dan teks ditulis dengan menggunakan tinta hitam dan merah (penjelas). Kondisi naskah dalam keadaan baik, tetapi jilidan lepas.

\begin{tabular}{|l|l|l|l|}
\hline $\begin{array}{l}\text { BLAS/SUM/16/FI/ } \\
7\end{array}$ & $\begin{array}{l}\text { KITAB FIKIH } \\
\text { ȘALAT }\end{array}$ & 4 & Fikih \\
\hline GPR 21 & Arab, Jawa Pegon & Arab & Puisi, Prosa \\
\hline $12 \mathrm{hlm}$. & 13 baris/hlm. & $22 \times 16.8$ & Kertas \\
\hline Ilyas & \multicolumn{2}{l|}{} \\
\hline Durbugan Banjar Barat, Gapura Sumenep \\
\hline
\end{tabular}

Naskah berisi tentang tata cara salat.

Naskah milik Ilyas, dari Qosim, dari Kiai Idrur, dari Kiai Mahdi. Naskah tanpa sampul dan ditulis menggunakna tinta hitam. Kondisi fisik naskah dalam keadaan baik dan tulisan masih bisa dibaca. 


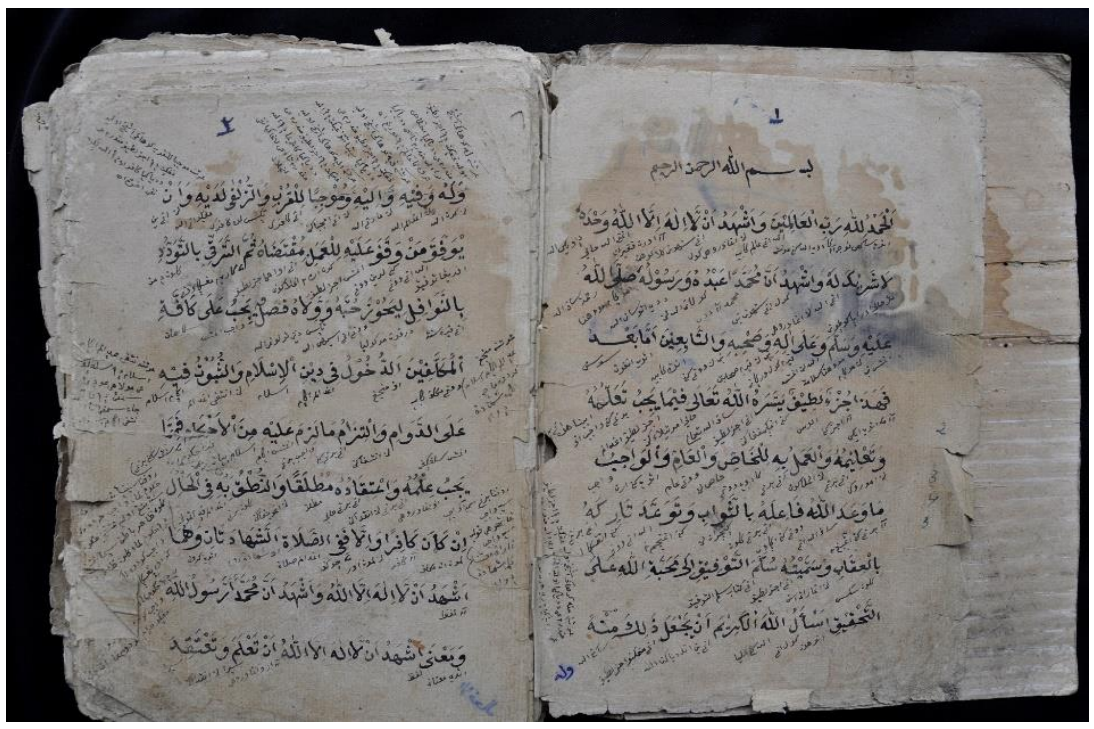

1104 GPR 18 HLM 1,2_DSC0044

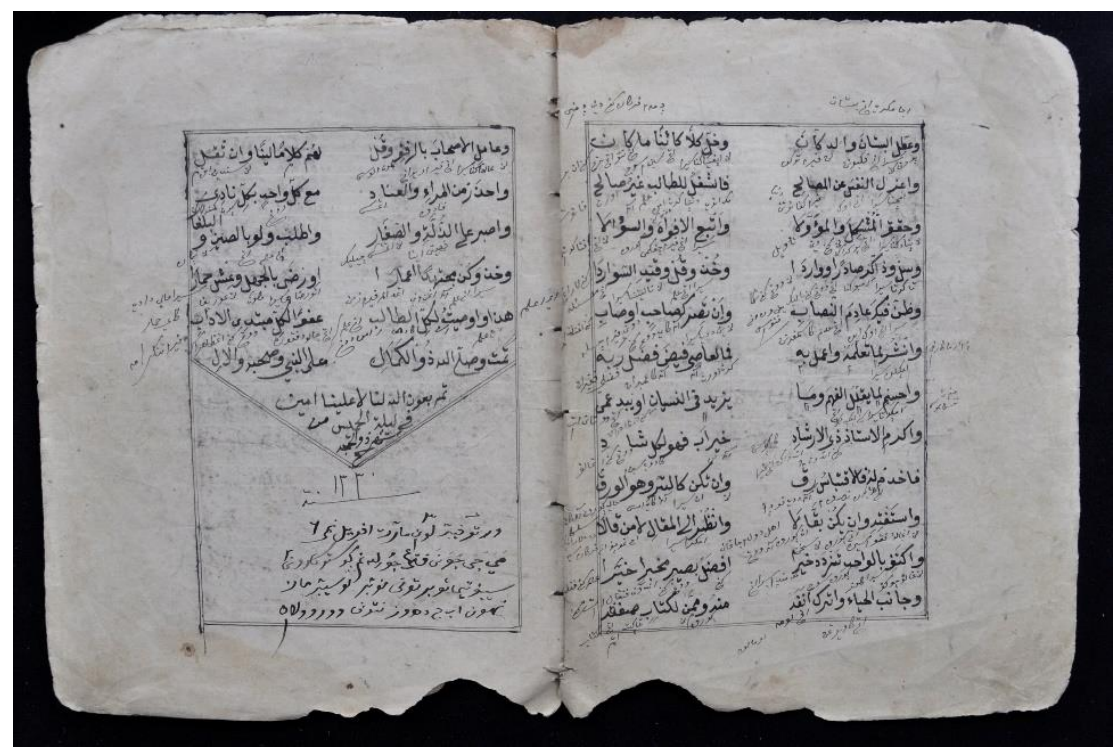

1107 GPR 21 HLM 2,3_DSC0141 


\begin{tabular}{|l|l|l|l|}
\hline $\begin{array}{l}\text { BLAS/SUM/16/FI/ } \\
\mathbf{8}\end{array}$ & $\begin{array}{l}\text { KITAB FIKIH } \\
\text { NIKAH }\end{array}$ & $\mathbf{4}$ & Fikih \\
\hline GPR 23 & Arab, Jawa Pegon & Arab & Prosa \\
\hline 193 hlm. & 11 baris/hlm. & $29.6 \times 19.8$ & Kertas Daluwang \\
\hline Kiai Abdul Madjid \\
\hline $\begin{array}{l}\text { Disimpan oleh cucu Kyai Abdul Madjid yang bernama Abdul Wakhid di dusun } \\
\text { Lambi Cabi, Gapura Tengah, Gapura, Sumenep }\end{array}$
\end{tabular}

Naskah berisi tentang fikih nikah meliputi adab nikah, rukun nikah, syarat nikah, dan haramnya nikah.

Naskah milik Abdul Wakhid dari ayahnya bernama Kiai Masduki, dan dari ayahnya bernama Kiai Abdul Majid. Kondisi fisik naskah dalam keadaan baik dan tulisan masih bisa dibaca. Teks ditulis dengan menggunakan tinta warna hitam.

\begin{tabular}{|l|l|l|l|}
\hline $\begin{array}{l}\text { BLAS/SUM/16/FI/ } \\
\mathbf{9}\end{array}$ & $\begin{array}{l}\text { KITAB } \\
\text { MA'RIFAT AN- } \\
\text { NIKAH }\end{array}$ & 4 & Fikih \\
\hline GPR 24 & Arab, Jawa Pegon & Arab & Prosa \\
\hline 72 hlm. & 7 baris/hlm. & $29 \times 19.5$ & Kertas Daluwang \\
\hline Kiai Abdul Madjid \\
\hline $\begin{array}{l}\text { Disimpan oleh cucu Kyai Abdul Madjid yang bernama Abdul Wakhid di dusun } \\
\text { Lambi Cabi, Gapura Tengah, Gapura, Sumenep }\end{array}$ \\
\hline
\end{tabular}

Naskah berisi dua teks, yakni teks pertama berisi pembahasan tentang tauhid dan teks kedua berisi pembahasan tentang nikah.

Naskah milik Abdul Wakhid dari ayahnya bernama Kiai Masduki, dan dari ayahnya bernama Kiai Abdul Majid. Teks ditulis dengan menggunakan tinta hitam. Kondisi fisik naskah rusak, tetapi tulisan masih bisa dibaca. 


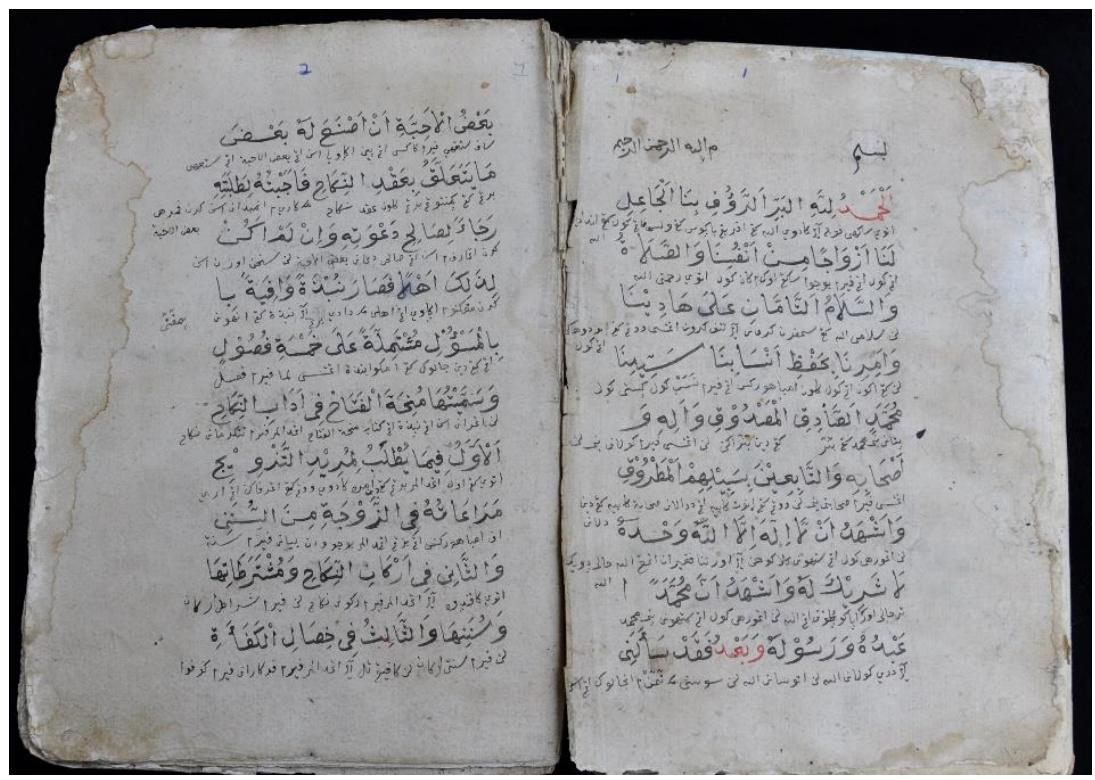

1109 GPR 23 HLM 2,3_DSC0008

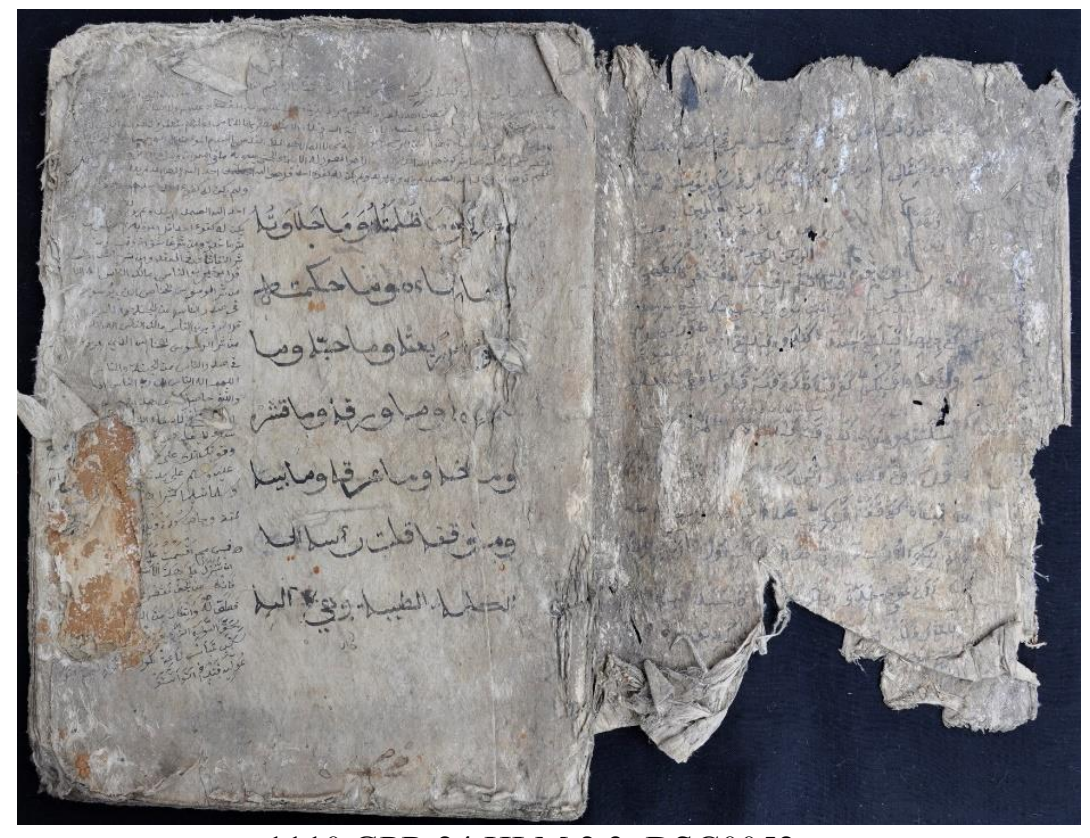

1110 GPR 24 HLM 2,3_DSC0052 


\begin{tabular}{|l|l|l|l|}
\hline $\begin{array}{l}\text { BLAS/SUM/16/FI/ } \\
10\end{array}$ & $\begin{array}{l}\text { KITAB SULAM } \\
\text { TAUFIK }\end{array}$ & 4 & Fikih \\
\hline GPR 27 & Arab & Arab & Prosa \\
\hline 140 hlm. & 7 baris/hlm. & $20 \times 16.5$ & Kertas Eropa \\
\hline K.H. Hasan & \\
\hline Dusun Lambi Cabi, Gapura Tengah, Gapura Sumenep & \\
\hline
\end{tabular}

Naskah berisi pembahasan tentang materi fikih.

Naskah milik Kiai Hasan dari bapaknya yang bernama Kiai Hasan. Teks ditulis menggunakan tinta hitam dan merah (penjelas), tanpa penomoran halaman, bersampul kertas tipis warna cokelat tetapi dalam keadaan rusak. Kondisi fisik naskah dalam keadaan rusak, tetapi tulisan masih bisa dibaca.

\begin{tabular}{|l|l|l|l|}
\hline $\begin{array}{l}\text { BLAS/SUM/16/FI/ } \\
11\end{array}$ & $\begin{array}{l}\text { KITAB SULAM } \\
\text { TAUFIK }\end{array}$ & 4 & Fikih \\
\hline GPR 28 & Arab, Jawa Pegon & Arab & Prosa \\
\hline $67 \mathrm{hlm}$. & 15 baris/hlm. & $24 \times 17.5$ & Kertas Eropa \\
\hline K.H. Hasan & \\
\hline Dusun Lambi Cabi, Gapura Tengah, Gapura Sumenep & \\
\hline
\end{tabular}

Naskah berisi tentang materi fikih salat dan akhlak.

Naskah milik Kiai Hasan dari bapaknya yang bernama Kiai Hasan. Kondisi fisik naskah yaitu jilidnya dalam keadaan rusak, namun tulisan masih bisa dibaca. Teks ditulis menggunakan tinta warna hitam, bersampul kertas tipis warna cokelat dan terdapat penomoran halaman pada kanan atas tiap halaman. 


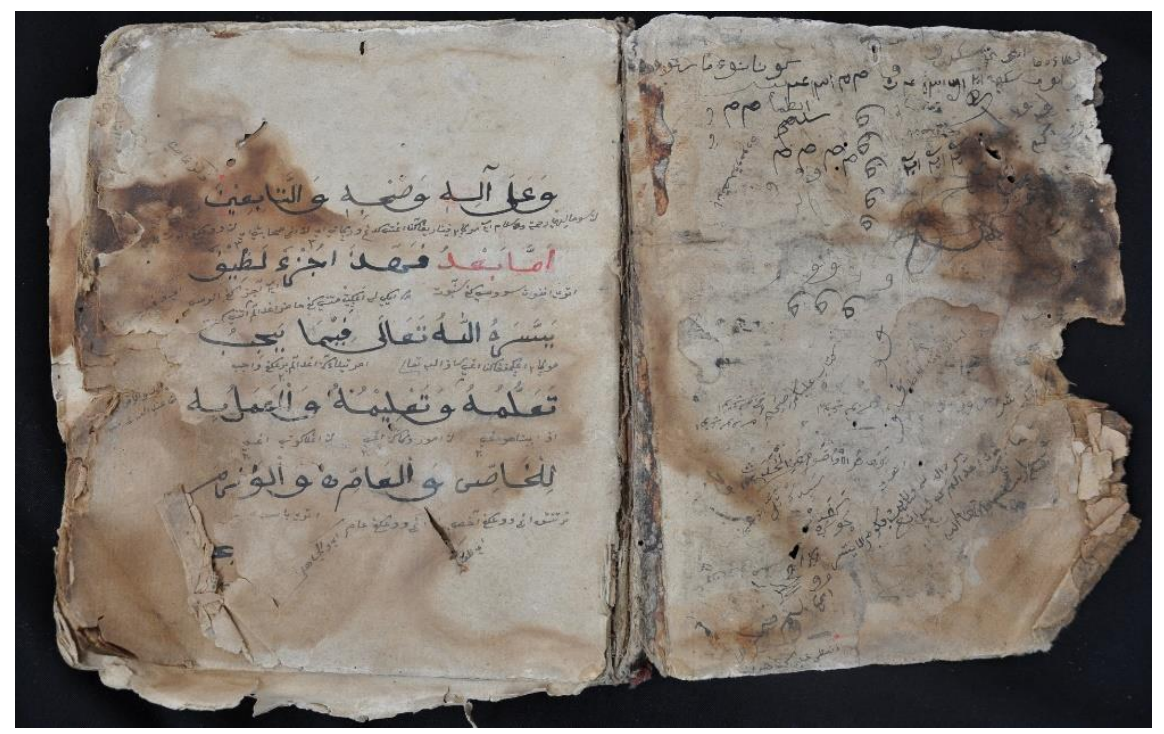

1113 GPR 27 HLM 1 DSC_0006

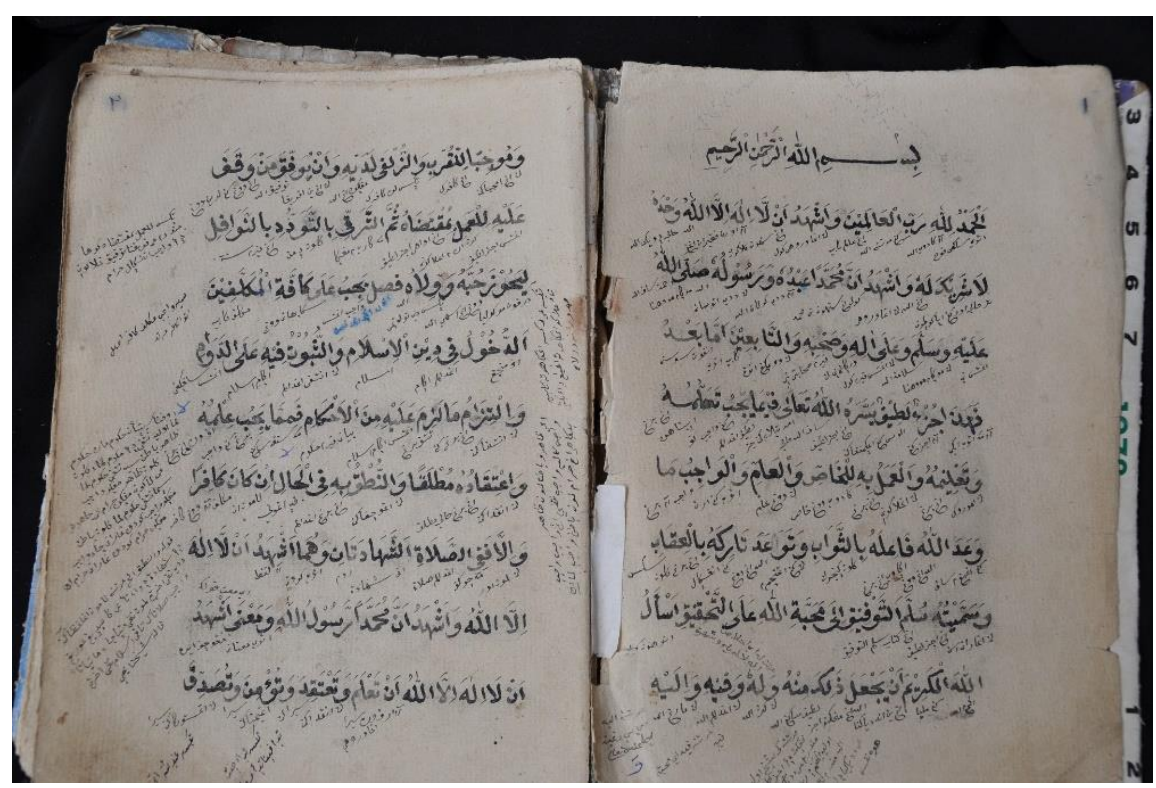

1114 GPR 28 HLM 1,2 DSC_0094 


\begin{tabular}{|l|l|l|l|}
\hline $\begin{array}{l}\text { BLAS/SUM/16/FI/ } \\
\mathbf{2}\end{array}$ & KITAB FIKIH & 4 & Fikih \\
\hline GPR 29 & Arab, Jawa Pegon & Arab & Prosa \\
\hline 151 hlm. & 12 baris/hlm. & $21 \times 17$ & Kertas Eropa \\
\hline K.H. Hasan & \\
\hline Dusun Lambi Cabi, Gapura Tengah, Gapura Sumenep \\
\hline
\end{tabular}

Naskah berisi materi fikih dari pembahasan tentang taharah sampai pembahasan masalah haji.

Naskah milik Kiai Hasan dari bapaknya yang bernama Kiai Hasan. Teks ditulis menggunakan tinta hitam, bersampul kertas tipis warna cokelat, dan kondisi naskah dalam keadaan rusak, namun tulisan masih bisa dibaca.

\begin{tabular}{|l|l|l|l|}
\hline $\begin{array}{l}\text { BLAS/SUM/16/FI/ } \\
13\end{array}$ & KITAB ȘALAT & 4 & Fikih \\
\hline GPR 30 & Arab, Jawa Pegon & Arab & Prosa \\
\hline 26 hlm. & 15 baris/hlm. & $24 \times 18$ & Kertas Eropa \\
\hline K.H. Hasan & \\
\hline Dusun Lambi Cabi, Gapura Tengah, Gapura Sumenep & \\
\hline
\end{tabular}

Naskah berisi tentang pembahasan keutamaan salat.

Naskah milik Kiai Hasan dari Kiai Usman. Naskah bersampul kertas tipis warna cokelat. Teks ditulis menggunakan tinta hitam tanpa penomoran halaman. Kondisi naskah dalam keadaan rusak, tetapi tulisan masih bisa dibaca. 


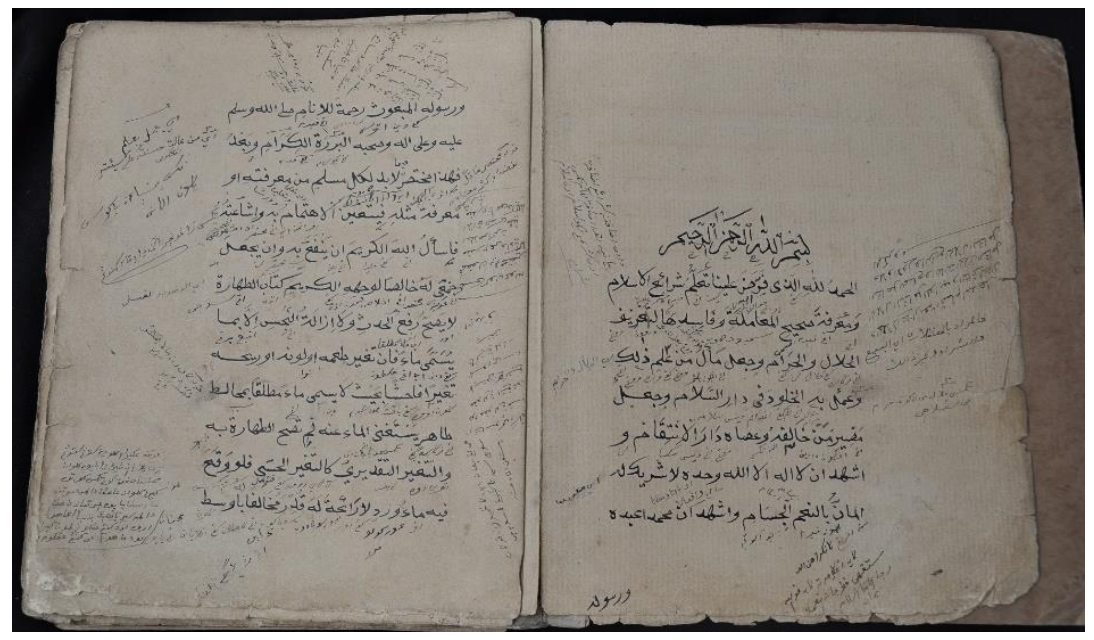

1115 GPR 29 HLM 1,2 DSC_0132

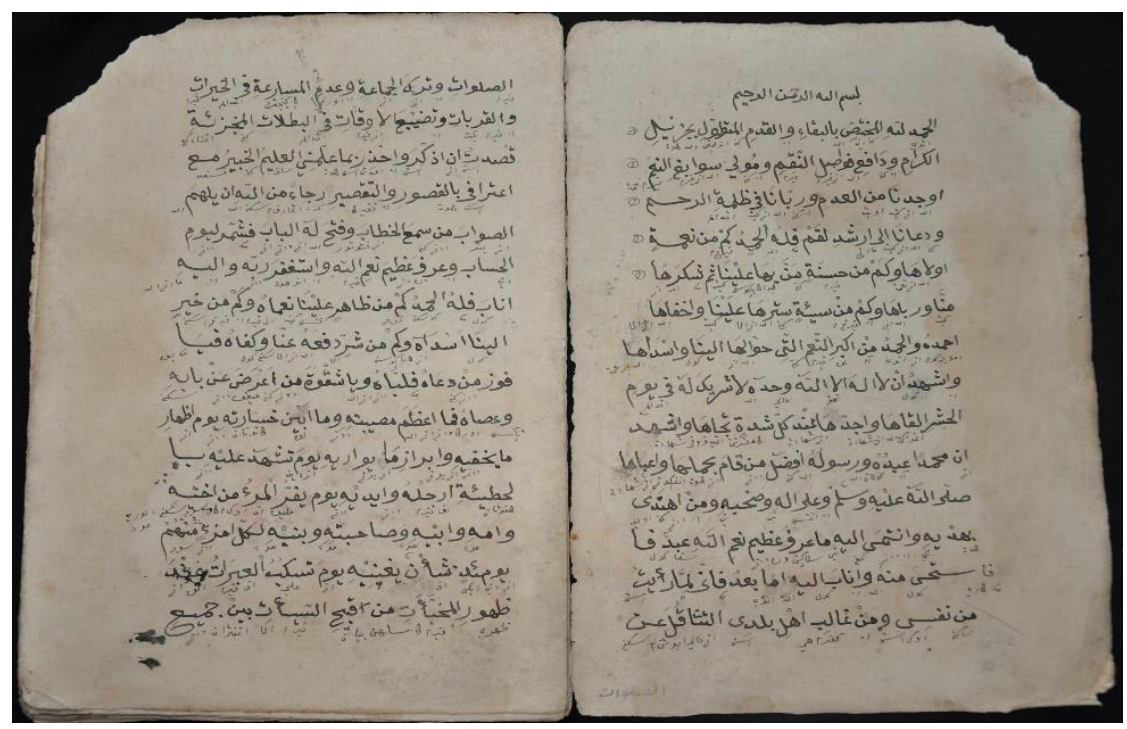

1116 GPR 30 HLM 1,2 DSC_0002 


\begin{tabular}{|l|l|l|l|}
\hline $\begin{array}{l}\text { BLAS/SUM/16/FI/ } \\
\mathbf{1 4}\end{array}$ & $\begin{array}{l}\text { KITAB FIKIH } \\
\text { MUAMALAH }\end{array}$ & 4 & Fikih \\
\hline GPR 32 & Arab, Jawa Pegon & Arab & Prosa \\
\hline $40 \mathrm{hlm}$. & 9 baris/hlm. & $25 \times 18$ & Kertas Eropa \\
\hline K.H. Hasan & \\
\hline Dusun Lambi Cabi, Gapura Tengah, Gapura Sumenep & \\
\hline
\end{tabular}

Naskah berisi tentang fikih muamalah.

Naskah milik Kiai Hasan dari bapaknya yang bernama Kiai Hasan. Teks ditulis dengan menggunakan tinta hitam dan tanpa penomoran halaman. Kondisi naskah dalam keadaan baik, tanpa sampul dan tulisan dapat dibaca dengan jelas.

\begin{tabular}{|l|l|l|l|}
\hline $\begin{array}{l}\text { BLAS/SUM/16/FI/ } \\
15\end{array}$ & KITAB SAFINAH & 4 & Fikih \\
\hline GPR 33 & Arab, Jawa Pegon & Arab & Prosa \\
\hline $54 \mathrm{hlm}$. & 7 baris/hlm. & $22 \times 17$ & Kertas Daluwang \\
\hline Abdul Wakhid & \\
\hline Dusun Lambi Cabi, Gapura Tengah, Gapura, Sumenep, Madura \\
\hline
\end{tabular}

Naskah berisi pembahasan tentang materi fikih, disusun di Batudinding, Gapura Barat, Gapura. Teks ditulis menggunakan tinta hitam, tanpa penomoran halaman.

Naskah milik Abdul Wakhid dari Kiai Haji Hafid. Kondisi fisik naskah dalam keadaan rusak, bersampul depan dengan kertas tipis warna coklat tanpa sampul belakang, dan tulisan masih bisa dibaca. 


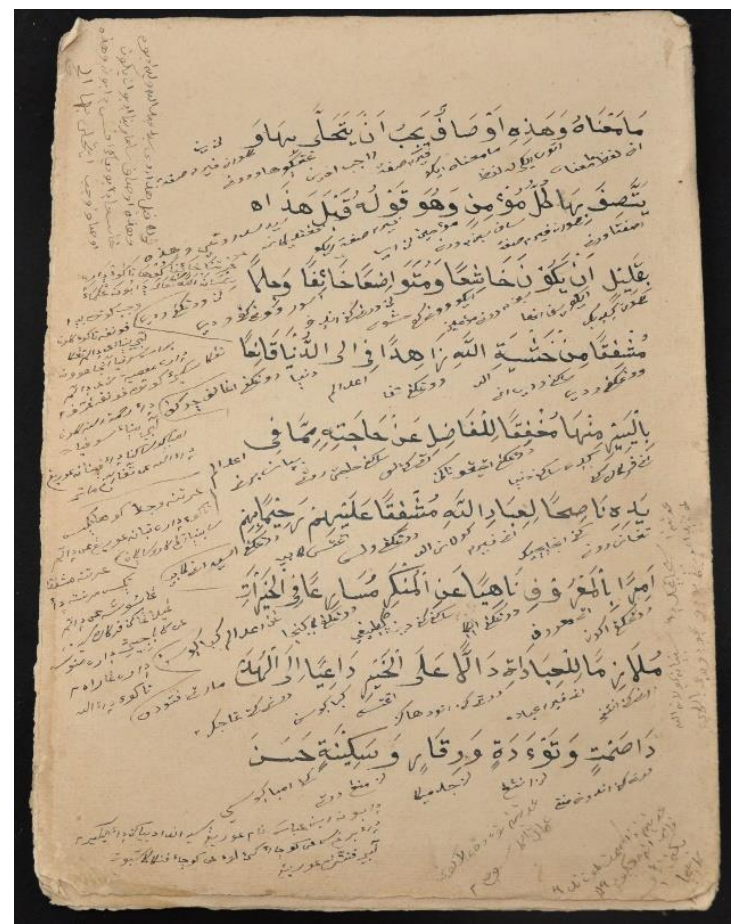

1118 GPR 32 HLM 1 DSC_0049

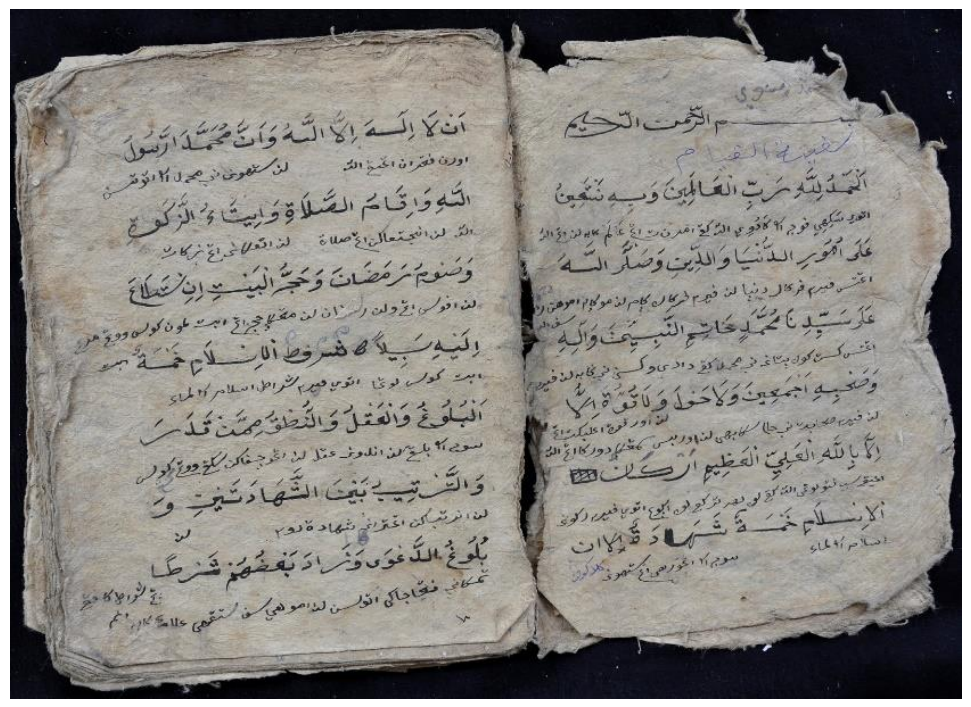

1119 GPR 33 HLM 1,2_DSC0126 


\begin{tabular}{|l|l|l|l|}
\hline $\begin{array}{l}\text { BLAS/SUM/16/FI/ } \\
16\end{array}$ & KITAB SAFINAH & 4 & Fikih \\
\hline GPR 34 & Arab, Jawa Pegon & Arab & Puisi \\
\hline 18 hlm. & 13 baris/hlm. & $24 \times 18$ & Kertas Eropa \\
\hline Abdul Wakhid & \\
\hline Dusun Lambi Cabi, Gapura Tengah, Gapura, Sumenep, Madura \\
\hline
\end{tabular}

Naskah berisi pembahasan tentang tasawuf. Teks ditulis menggunakan tinta hitam.

Naskah milik Abdul Wakhid dari Kiai Hafid. Kondisi fisik naskah dalam keadaan baik, tanpa sampul dan tulisan masih bisa dibaca.

\begin{tabular}{|l|l|l|l|}
\hline $\begin{array}{l}\text { BLAS/SUM/16/FI/ } \\
17\end{array}$ & $\begin{array}{l}\text { KITAB SULAM } \\
\text { TAUFIK }\end{array}$ & 4 & Fikih \\
\hline GPR 39 & Arab, Jawa Pegon & Arab & Prosa \\
\hline 82 hlm. & 19 dan 6 baris/hlm. & $24 \times 16$ & Kertas Eropa \\
\hline Kiai Zahidi Bisri \\
\hline \multicolumn{2}{|l|}{ Dusun Pasar Pocok, Desa Paloklo'an, Gapura, Sumenep } \\
\hline
\end{tabular}

Naskah berisi materi tentang fikih dan tauhid.

Naskah milik Kiai Zahidi Bisri dari Kiai Khudaifi, dari Kiai Masyhuri. Teks ditulis dengan menggunakan tinta hitam dengan cap kertas berupa gambar seperti Gajah. Kondisi fisik naskah dalam keadaan rusak, tetapi tulisan masih bisa dibaca. 


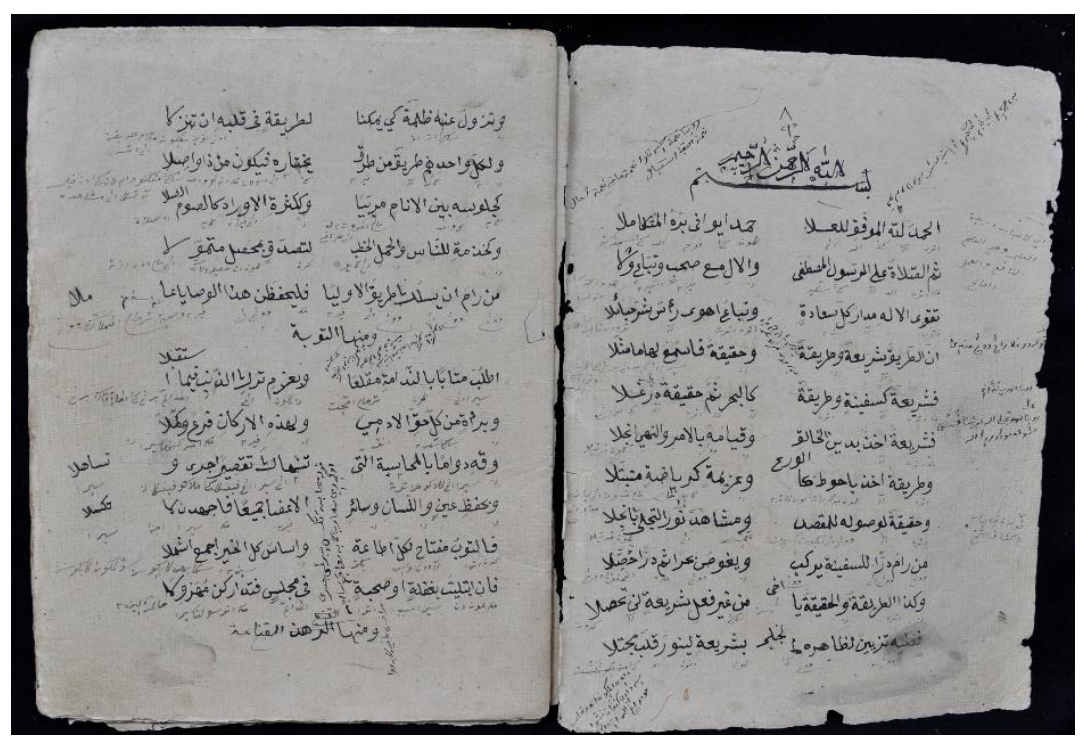

1120 GPR 34 HLM 1,2_DSC0158

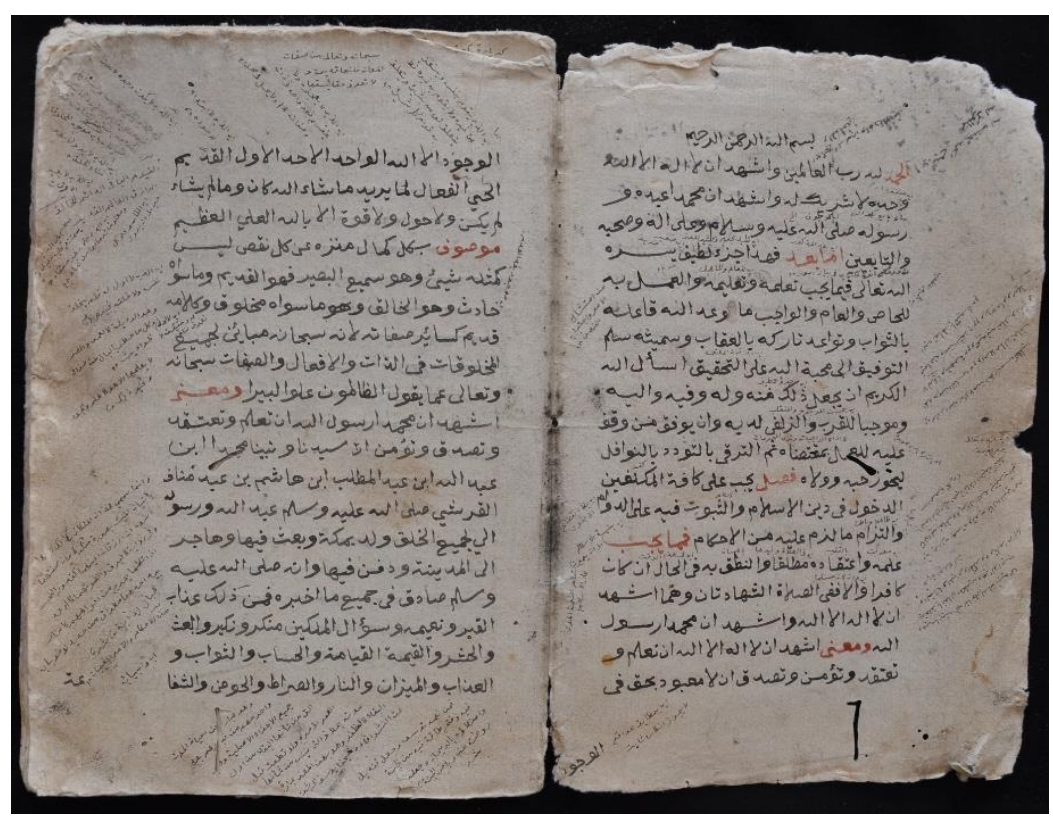

1125 GPR 39 HLM 4,5 DSC_0106 


\begin{tabular}{|l|l|l|l|}
\hline $\begin{array}{l}\text { BLAS/SUM/16/FI/ } \\
18\end{array}$ & $\begin{array}{l}\text { KITAB UȘ̄L } \\
\text { FIKIH WÄ AL- } \\
\text { I'TIQAD DAN } \\
\text { KITAB TAQRIB }\end{array}$ & 4 & Fikih \\
\hline BT-BT 1 & Arab, Jawa & Arab & Prosa \\
\hline 244 hlm. & 7 baris/hlm. & $24.8 \times 17$ & Kertas Daluwang \\
\hline Kiai Muchtar & \\
\hline \multicolumn{2}{|l}{ Dusun Laok Saba, Nyabakan Timur, Batang-Batang, Sumenep } \\
\hline
\end{tabular}

Naskah berisi dua teks, yakni naskah Uṣul Fikih dan naskah kitab Taqrīib.

Naskah milik Kiai Muchtar dari Kiai Mustaqim dari Kiai Siwallah dari Kiai Biramah. Teks ditulis menggunakan tinta hitam dan tinta merah untuk penulisan kata fasal. Naskah ini memiliki iluminasi pada halaman 1 dan halaman 60. Kondisi naskah dalam keadaan baik dan tulisan masih dapat dibaca, namun beberapa bagian at as kertas rusak/sobek.

\begin{tabular}{|l|l|l|l|}
\hline $\begin{array}{l}\text { BLAS/SUM/16/FI/ } \\
19\end{array}$ & $\begin{array}{l}\text { KITAB UȘŪL } \\
\text { FIKIH WA AL- } \\
\text { I'TIQAD DAN } \\
\text { KITAB TAQRIB }\end{array}$ & 4 & Fikih \\
\hline BT-BT 6 & Arab, Jawa Pegon & Arab & Prosa \\
\hline 31 hlm. & 7 baris/hlm. & $26 \times 18$ & Kertas Daluwang \\
\hline Kiai Muchtar & \\
\hline \multicolumn{2}{|l|}{ Dusun Laok Saba, Nyabakan Timur, Batang-Batang, Sumenep } \\
\hline
\end{tabular}

Naskah berisi tentang materi fikih.

Naskah milik Kiai Muchtar dari Kiai Mustaqim dari Kiai Siwallah dari Kiai Biramah. Naskah tanpa sampul dan teks ditulis menggunakan tinta hitam. Kondisi naskah dalam keadaan rusak, namun tulisan masih dapat dibaca. 


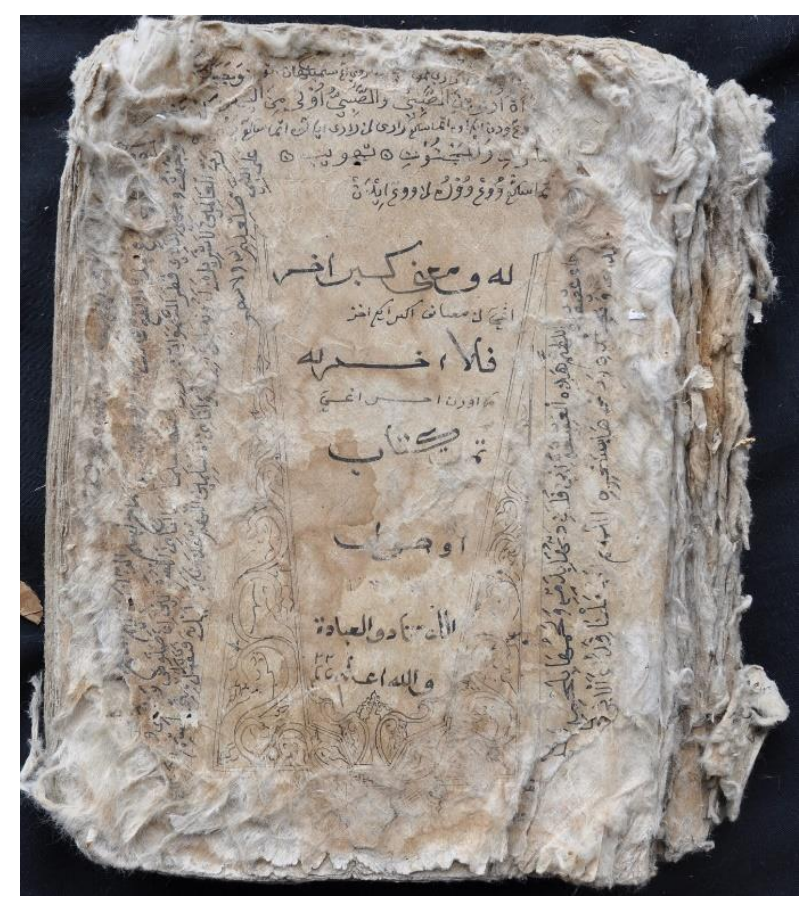

1131 BTBT 01 HLM 1 DSC_0001

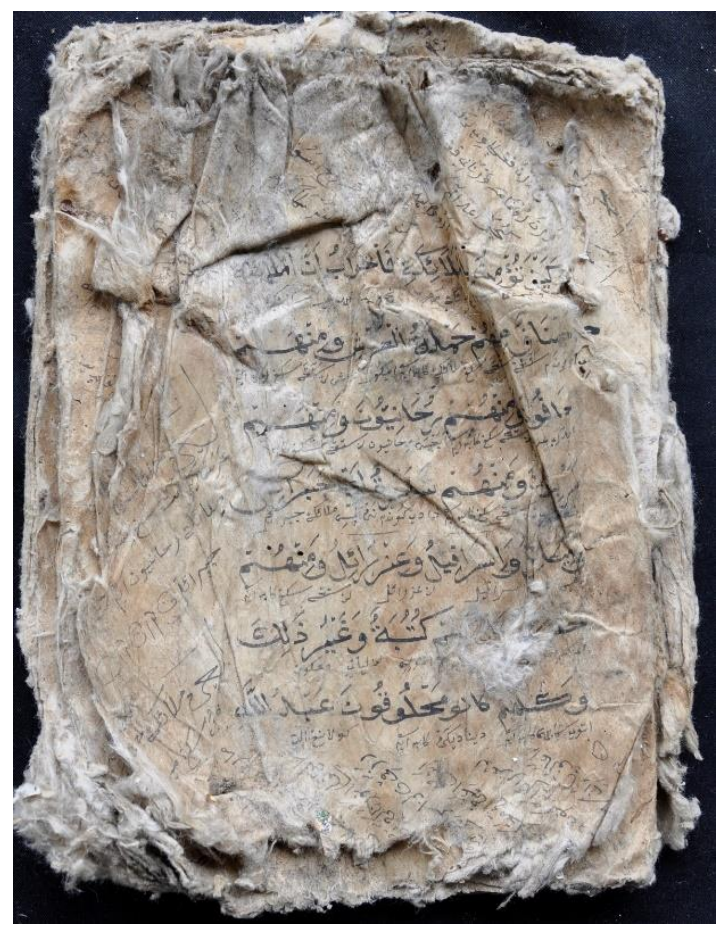

1136 BTBT 06 HLM 1_DSC0065 


\begin{tabular}{|l|l|l|l|}
\hline $\begin{array}{l}\text { BLAS/SUM/16/FI/ } \\
20\end{array}$ & KITAB FIKIH & 4 & Fikih \\
\hline BT-BT 8 & Arab, Jawa Pegon & Arab & Prosa \\
\hline 102 hlm. & 14 baris/hlm. & $31 \times 21$ & Kertas Daluwang \\
\hline Kiai Muchtar \\
\hline \multicolumn{2}{|l|}{ Dusun Laok Saba, Nyabakan Timur, Batang-Batang, Sumenep } \\
\hline
\end{tabular}

Naskah berisi tentang materi fikih.

Naskah milik Kiai Muchtar dari Kiai Mustaqim dari Kiai Siwallah dari Kiai Biramah. Naskah ditulis menggunakan tint a hitam dan merah, tanpa sampul dan tanpa nomor halaman. Kondisi naskah dalam keadaan rusak, tetapi tulisan masih dapat dibaca dengan baik.

\begin{tabular}{|l|l|l|l|}
\hline $\begin{array}{l}\text { BLAS/SUM/16/FI/ } \\
21\end{array}$ & $\begin{array}{l}\text { KITAB FIKIH } \\
\text { WUDU, SALAT, } \\
\text { DAN QUNUT }\end{array}$ & 4 & Fikih \\
\hline BT-BT 26 & Arab & Arab & Prosa \\
\hline $8 \mathrm{hlm}$. & 7 baris/hlm. & $20 \times 15.5$ & Kertas Daluwang \\
\hline Kiai Su'udi Fadhal \\
\hline \multicolumn{2}{|l}{ Dusun Nyabungan, Jenangger, Batang-Batang. } \\
\hline
\end{tabular}

Naskah ini menerangkan tentang wuḍu, salat, dan doa qunut.

Naskah ini dimiliki oleh Kiai Su'udi Fadhal dari Kiai Irsyad dari Kiai Sodli dari Kiai Hadi. Tahun dan tempat penyusunan tidak disebutkan. Kondisi naskah rusak, tetapi masih dapat dibaca. Tinta menggunakan warna hitam. 


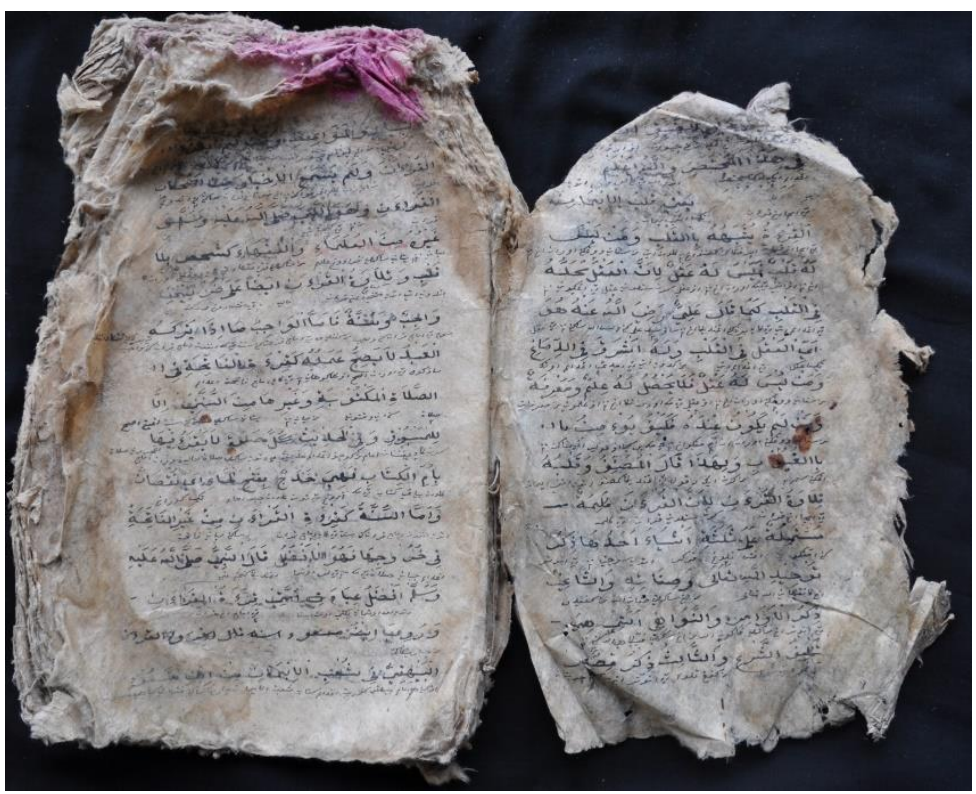

1138 BTBT 08 HLM 2,3 DSC_0002

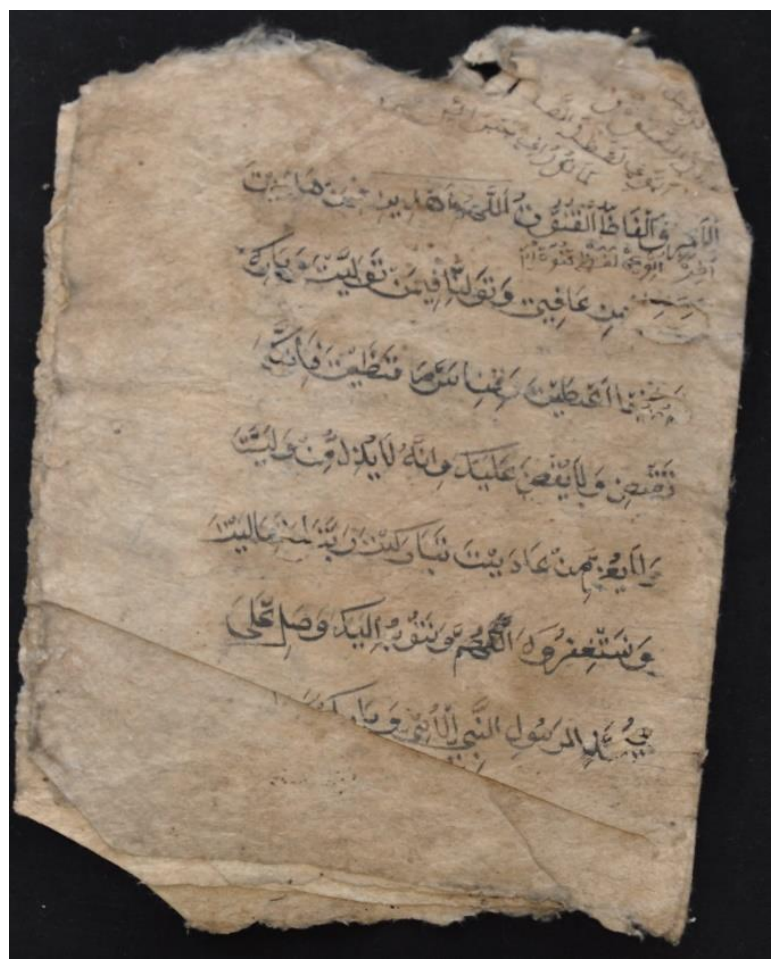

1156 BTBT 26 HLM 1 DSC_0074 


\begin{tabular}{|l|l|l|l|}
\hline $\begin{array}{l}\text { BLAS/SUM/16/FI/ } \\
22\end{array}$ & $\begin{array}{l}\text { KITAB KUFUR } \\
\text { DAN TAUBAT }\end{array}$ & 4 & Fikih \\
\hline BT-BT 34 & Arab & Arab & Prosa \\
\hline 101 hlm. & 7 baris/hlm. & $21 \times 15.3$ & Kertas Daluwang \\
\hline Aziz & \multicolumn{2}{|l}{} \\
\hline Dusun Nyabungan, Jenangger, Batang-Batang. &
\end{tabular}

Naskah ini menjelaskan seorang yang menjadi kufur ia wajib mengucapkan dua kalimat syahadat, dan wajib taubat, juga gugur keislamannya, dan seorang muslim terbunuh sedang ia tidak meninggalkan sebab malas maka ia tetap dipandang sebagai seorang muslim.

Naskah ini dimiliki oleh Aziz dari Haji As'ad dari Suhilal dari Kiai Siwallah. Tahun dan tempat penyusunan tidak disebutkan. Kondisi naskah bagian depan lusuh, masih dapat dibaca. Tinta menggunakan warna hitam.

\begin{tabular}{|l|l|l|l|}
\hline $\begin{array}{l}\text { BLAS/SUM/16/FI/ } \\
23\end{array}$ & $\begin{array}{l}\text { KITAB RUKUN } \\
\text { ISLAM DAN } \\
\text { ISTINJA' }\end{array}$ & 4 & Fikih \\
\hline BT-BT 42 & Arab & Arab & Prosa \\
\hline $52 \mathrm{hlm}$. & 5 baris/hlm. & $26.5 \times 13$ & Kertas Daluwang \\
\hline Aziz & & \\
\hline \multicolumn{2}{|l|}{ Dusun Nyabungan, Jenangger, Batang-Batang. } \\
\hline
\end{tabular}

Naskah ini menjelaskan tentang tiang agama Islam yang lima, syahadat, salat, puasa, zakat, dan haji bila kuasa menjalankan; kemudian menjelaskan tentang tata najis, berwudu, salat, puasa, dan zakat.

Naskah ini dimiliki oleh Aziz dari haji As'ad dari Suhilal dari Kiai Siwallah. Tahun dan tempat penyusunan tidak disebutkan. Kondisi naskah rusak, tetapi masih dapat dibaca. Tinta menggunakan warna hitam. 


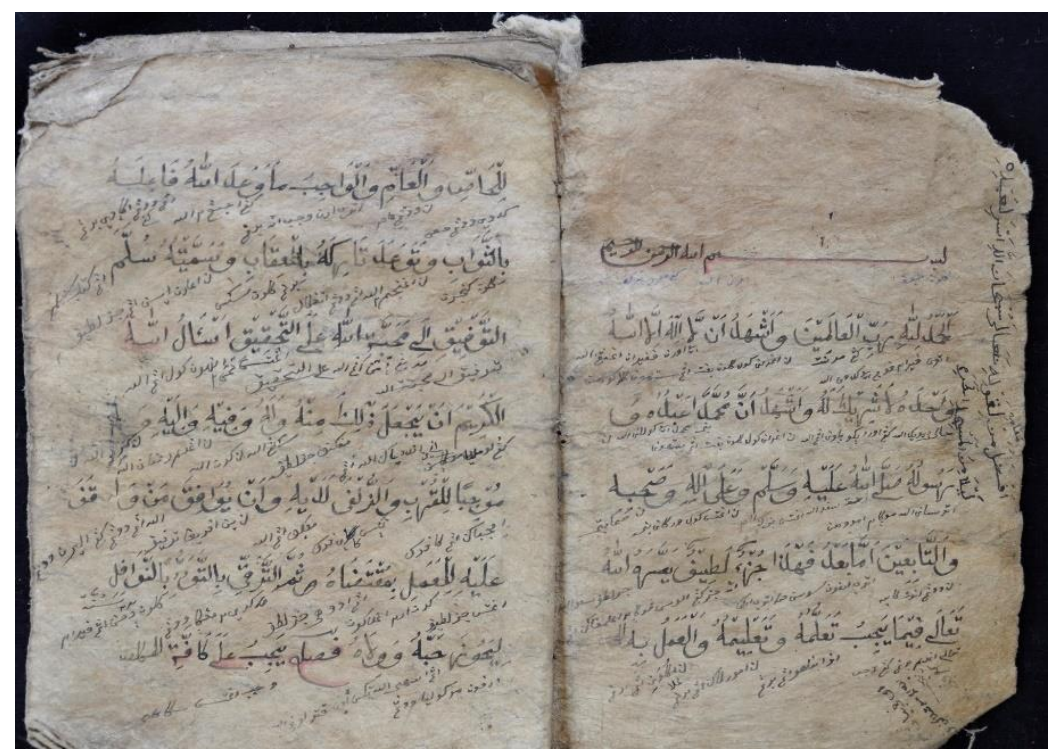

1164 BTBT 34 HLM 1,2_DSC0064

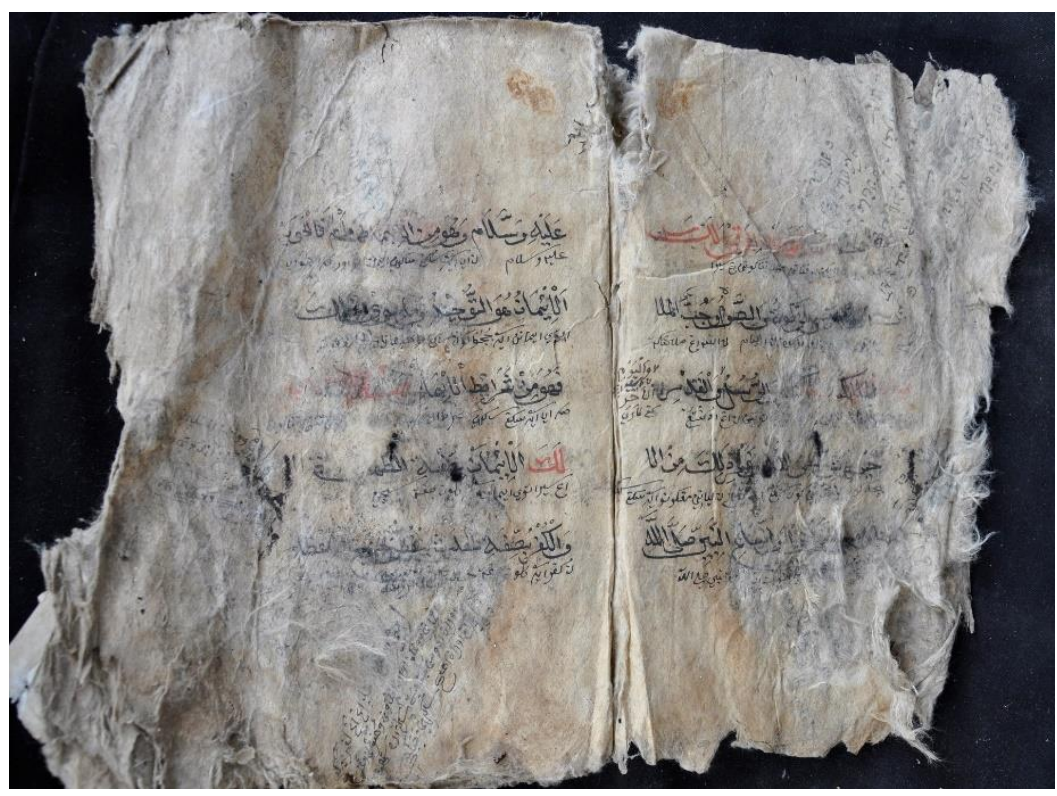

1172 BTBT 42 HLM 5,6_DSC0003 


\begin{tabular}{|l|l|l|l|}
\hline $\begin{array}{l}\text { BLAS/SUM/16/FI/ } \\
24\end{array}$ & AL-IDAH & 4 & Fikih \\
\hline BT-BT 50 & Arab & Arab & \\
\hline 250 hlm. & 9 baris/hlm. & $29 \times 21$ & Prosa \\
\hline Kiai Khalid & Kertas Daluwang \\
\hline \multicolumn{2}{|l|}{ Dusun Nyabungan, Jenangger, Batang-Batang. } \\
\hline
\end{tabular}

Naskah ini berisi tentang bersuci dari najis, hadas besar atau kecil, salat wajib, melayat, puasa, haji, jual beli, wakaf, gadai, faraid, wakalah, membayar kifarat, nadzar, doa dan penjelasannya.

Naskah ini dimiliki oleh Kiai Khalid dari Kiai Fadlun dari Kiai Khomsidin. Tahun dan tempat penyusunan tidak disebutkan. Kondisi naskah baik. Tinta menggunakan warna hitam dan merah.

\begin{tabular}{|l|l|l|l|}
\hline $\begin{array}{l}\text { BLAS/SUM/16/FI/ } \\
25\end{array}$ & $\begin{array}{l}\text { KITAB WUDU } \\
\text { DAN ȘALAT }\end{array}$ & 4 & Fikih \\
\hline BT-BT 52 & Arab & Arab & Prosa \\
\hline 34 hlm. & 7 baris/hlm. & $25 \times 19$ & Kertas Daluwang \\
\hline Kiai Khalid & \multicolumn{2}{|l|}{} \\
\hline \multicolumn{2}{|l|}{ Dusun Nyabungan, Jenangger, Batang-Batang. } \\
\hline
\end{tabular}

Naskah ini menjelaskan tentang wuḍu, salat wajib, salat-salat sunah. Teks ini berbahasa Arab diberi makna gandul. Selain itu, di kanan, kiri, atas, bawah diberi catatan atau penjelasan (murod).

Naskah ini dimiliki oleh Kiai Khalid dari Kiai Fadlun dari Kiai Khomsidin. Tahun dan tempat penyusunan tidak disebutkan. Kondisi naskah cukup baik. Tinta menggunakan warna hitam. 


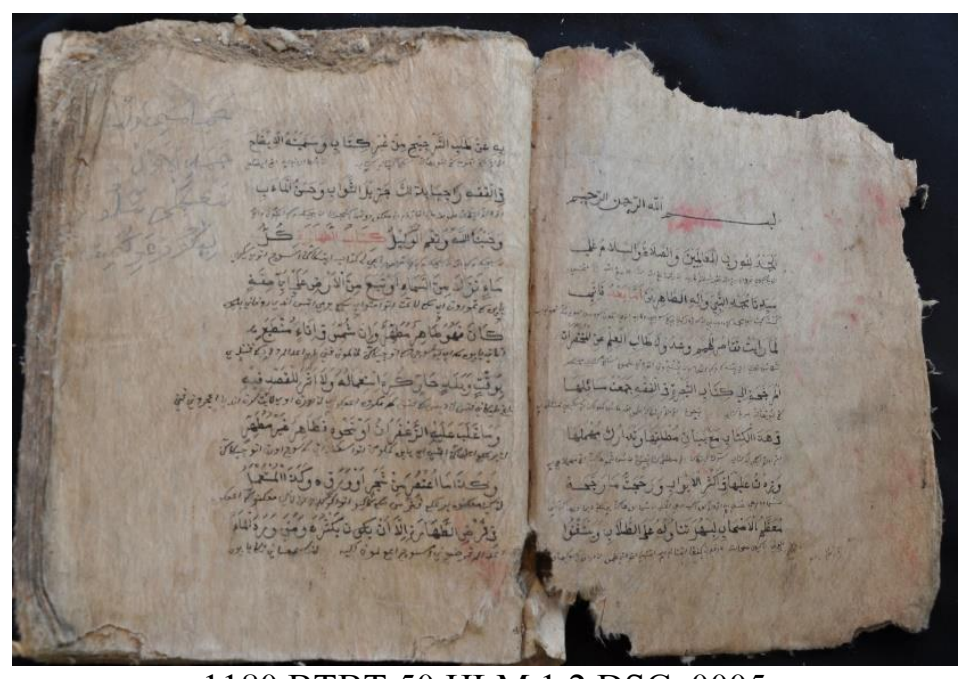

1180 BTBT 50 HLM 1,2 DSC_0005

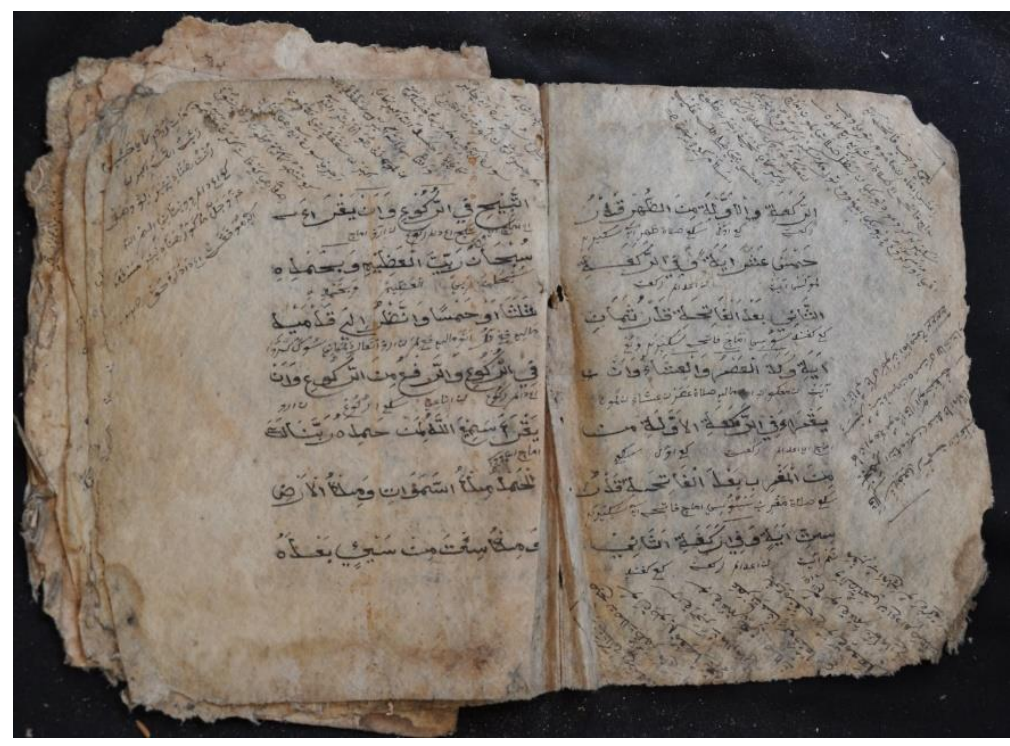

1182 BTBT 52 HLM 2,3 DSC_0209 


\begin{tabular}{|l|l|l|l|}
\hline $\begin{array}{l}\text { BLAS/SUM/16/FI/ } \\
\mathbf{2 6}\end{array}$ & $\begin{array}{l}\text { KITAB CARA } \\
\text { ȘLAT }\end{array}$ & 4 & Fikih \\
\hline $\begin{array}{l}\text { LCGPRT/KHQ/02/ } \\
2012\end{array}$ & Arab & Arab & Prosa \\
\hline $86 \mathrm{hlm}$. & 15 baris/hlm. & $23.5 \times 17$ & Kertas Daluwang \\
\hline K.H. Quraisyi & \\
\hline Lambi Cabi, Gapura Tengah, Gapura & \\
\hline
\end{tabular}

Naskah ini berisi tentang tata cara salat.

Naskah ini tersimpan di rumah K.H. Quraisyi dari K.H. Masyhuri. Kondisi naskah mulai rusak, teks masih terbaca.

\begin{tabular}{|l|l|l|l|}
\hline $\begin{array}{l}\text { BLAS/SUM/16/FI/ } \\
27\end{array}$ & $\begin{array}{l}\text { KITAB } \\
\text { ARBA'ATU } \\
\text { FUȘULIN }\end{array}$ & 4 & Fikih \\
\hline $\begin{array}{l}\text { LCGPRT/KHQ/03/ } \\
2012\end{array}$ & Arab & Arab & Prosa \\
\hline $22 \mathrm{hlm}$. & 14 baris/hlm. & $23.5 \times 16.5$ & Kertas Daluwang \\
\hline K.H. Quraisyi & \\
\hline Lambi Cabi, Gapura Tengah, Gapura \\
\hline
\end{tabular}

Naskah ini berisi tentang tata cara salat.

Naskah ini tersimpan di rumah K.H. Quraisyi dari K.H. Masyhuri. Kondisi naskah mulai rusak, teks masih terbaca. 


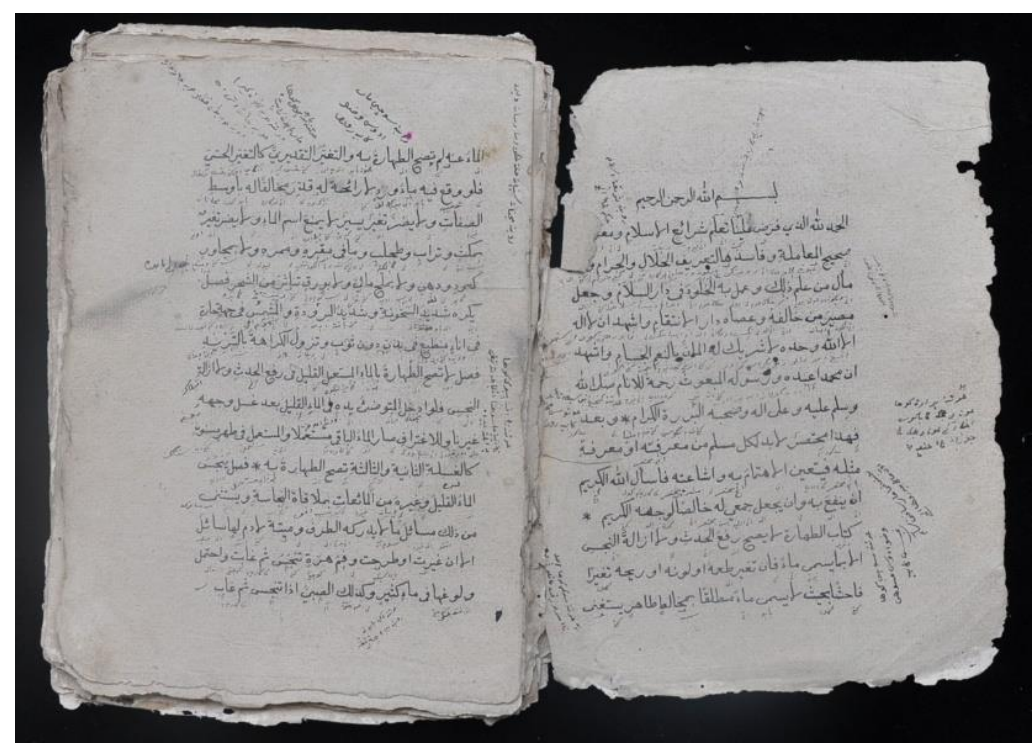

12002 LCGPRT KHQ 022012 HLM 1,2 Img0210

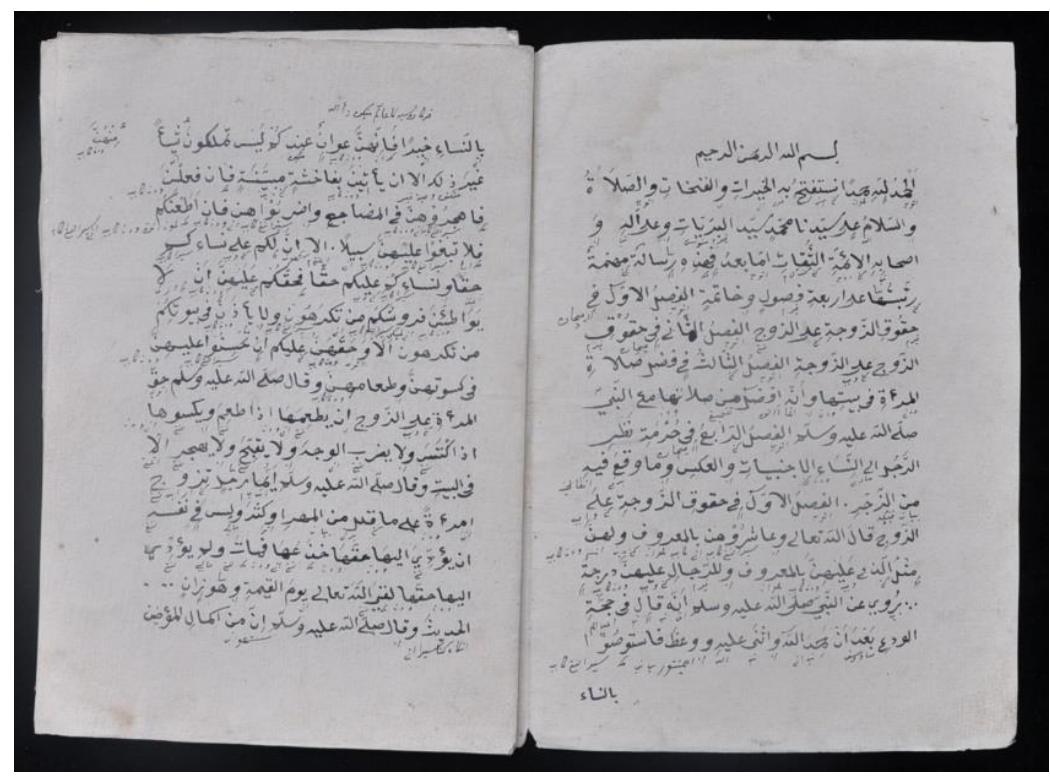

12003 LCGPRT KHQ 032012 HLM 1,2 Img0258 


\begin{tabular}{|l|l|l|l|}
\hline $\begin{array}{l}\text { BLAS/SUM/16/FI/ } \\
28\end{array}$ & KITAB FIKIH & 4 & Fikih \\
\hline $\begin{array}{l}\text { LCGPRT/KHQ/04/ } \\
2012\end{array}$ & Arab & Arab & Prosa \\
\hline $24 \mathrm{hlm}$. & 13 baris/hlm. & $23.5 \times 17.5$ & Kertas Daluwang \\
\hline K.H. Quraisyi & \\
\hline Lambi Cabi, Gapura Tengah, Gapura & \\
\hline
\end{tabular}

Naskah ini menjelaskan tentang tata cara berwudu, salat, dan puasa.

Naskah ini tersimpan di rumah K.H. Quraisyi dari K.H. Masyhuri. Kondisi naskah baik, teks masih terbaca.

\begin{tabular}{|l|l|l|l|}
\hline $\begin{array}{l}\text { BLAS/SUM/16/FI/ } \\
29\end{array}$ & $\begin{array}{l}\text { KITAB } \\
\text { MUNAKAHAT }\end{array}$ & 4 & Fikih \\
\hline $\begin{array}{l}\text { LCGPTR/KHQ/09/ } \\
2012\end{array}$ & Arab & Arab & Prosa \\
\hline $28 \mathrm{hlm}$. & 9 baris/hlm. & $25 \times 17$ & Kertas Daluwang \\
\hline K.H. Quraisyi & \\
\hline Lambi Cabi, Gapura Tengah, Gapura & \\
\hline
\end{tabular}

Naskah ini menjelaskan tentang Hukum dan tata cara pernikahan/munakahat.

Naskah ini tersimpan di rumah K.H. Quraisyi yang berasal dari kakeknya, K.H. Masyhuri. Kondisi naskah baik, teks terbaca. 


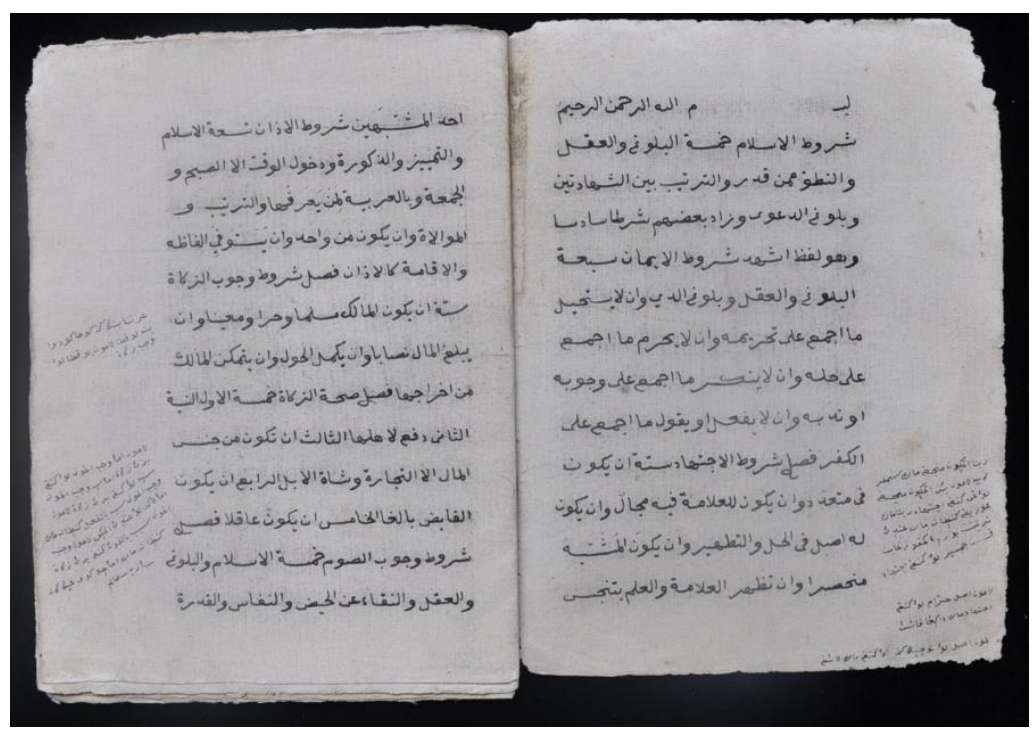

12004 LCGPRT KHQ 042012 HLM 1,2 Img0271

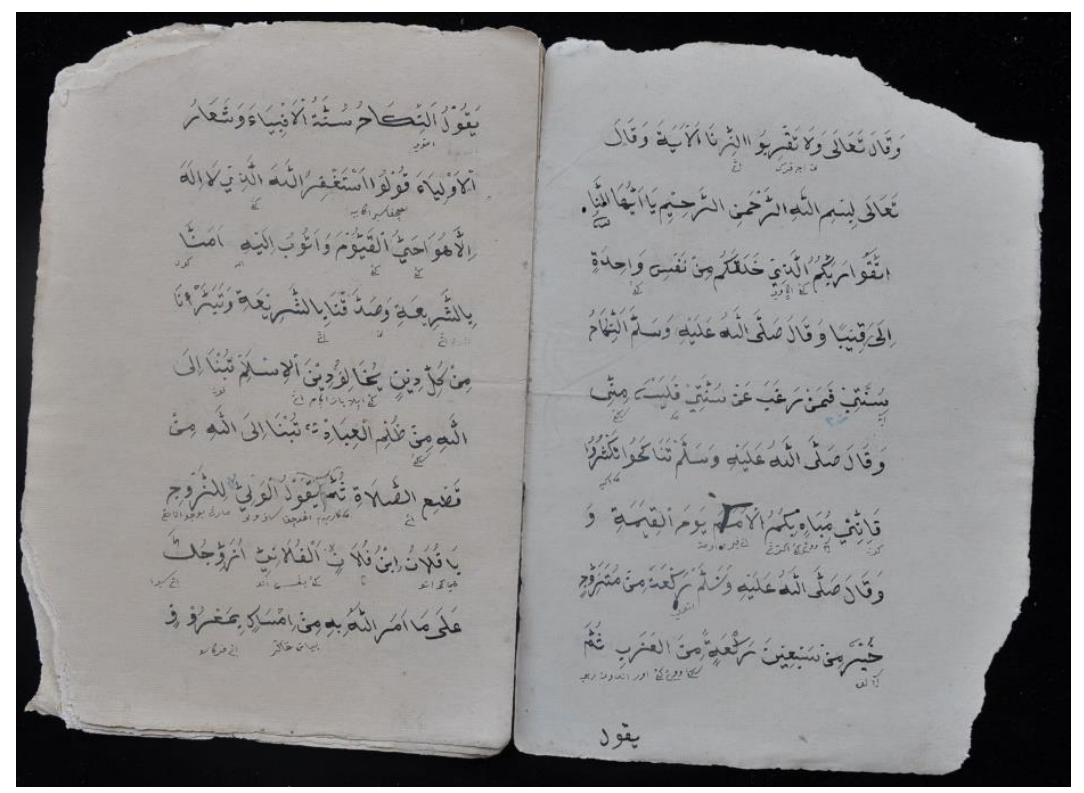

12009 LCGPTR KHQ 092012 HLM 1,2 Img0492 


\begin{tabular}{|l|l|l|l|}
\hline $\begin{array}{l}\text { BLAS/SUM/16/FI/ } \\
30\end{array}$ & $\begin{array}{l}\text { KITAB } \\
\text { FAȘALATAN }\end{array}$ & 4 & Fikih \\
\hline $\begin{array}{l}\text { LCGPTR/KHQ/10/ } \\
2012\end{array}$ & Arab & Arab & Prosa \\
\hline $24 \mathrm{hlm}$. & 21 baris/hlm. & $23.5 \times 17$ & Kertas Daluwang \\
\hline K.H. Quraisyi & \\
\hline Lambi Cabi, Gapura Tengah, Gapura & \\
\hline
\end{tabular}

Naskah ini menjelaskan tentang tata cara berwudu dan salat.

Naskah ini tersimpan di rumah K.H. Quraisyi yang berasal dari kakeknya, K.H. Masyhuri. Kondisi naskah baik, teks terbaca.

\begin{tabular}{|l|l|l|l|}
\hline $\begin{array}{l}\text { BLAS/SUM/16/FI/ } \\
31\end{array}$ & KITAB FIKIH & 4 & Fikih \\
\hline $\begin{array}{l}\text { LCGPTR/KH/15/2 } \\
012\end{array}$ & Arab & Arab & Prosa \\
\hline 108 hlm. & $\begin{array}{l}10 \text { s.d. } 12 \\
\text { baris/hlm. }\end{array}$ & $30 x 21$ & Kertas Daluwang \\
\hline K.H. Kholil & \multicolumn{2}{|l}{} \\
\hline Lambi Cabi, Gapura Tengah, Gapura \\
\hline
\end{tabular}

Naskah ini berisi tiga teks, pertama menjelaskan tentang tata cara berwudu, kedua menjelaskan aqaid, dan ketiga menjelaskan tata cara salat.

Naskah ini tersimpan di rumah K.H. Kholil. Kondisi naskah mulai rusak, teks masih terbaca. 


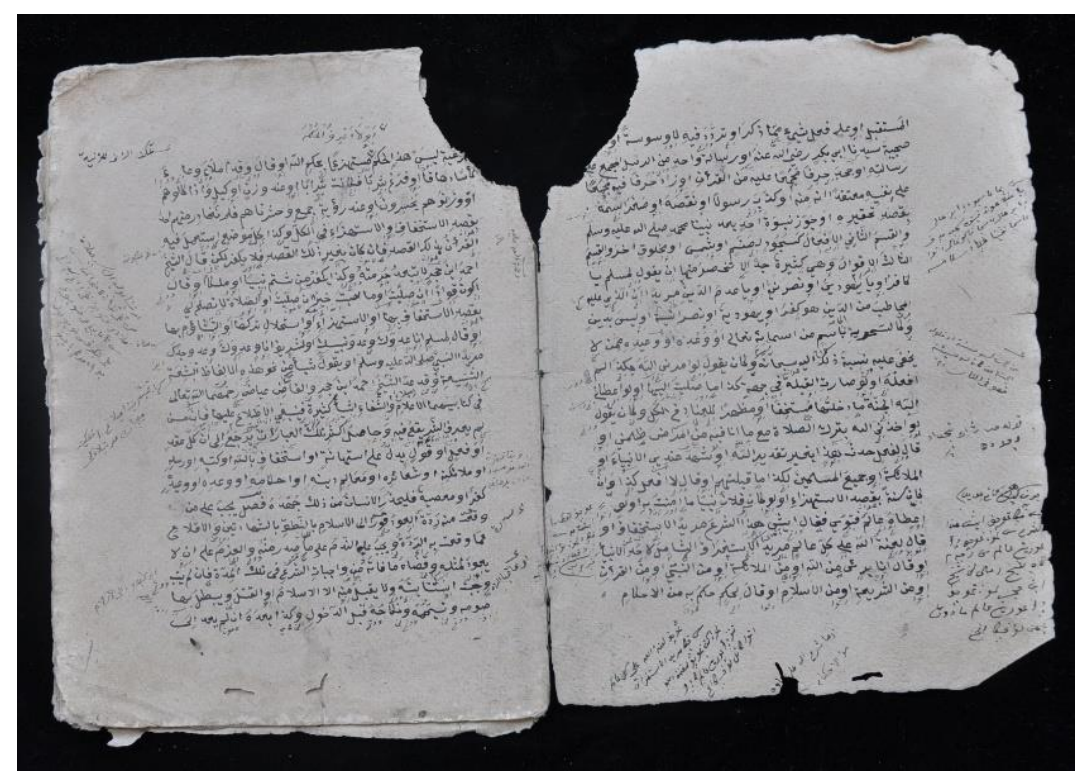

12010 LCGPTR KHQ 102012 HLM 2,3 Img0508

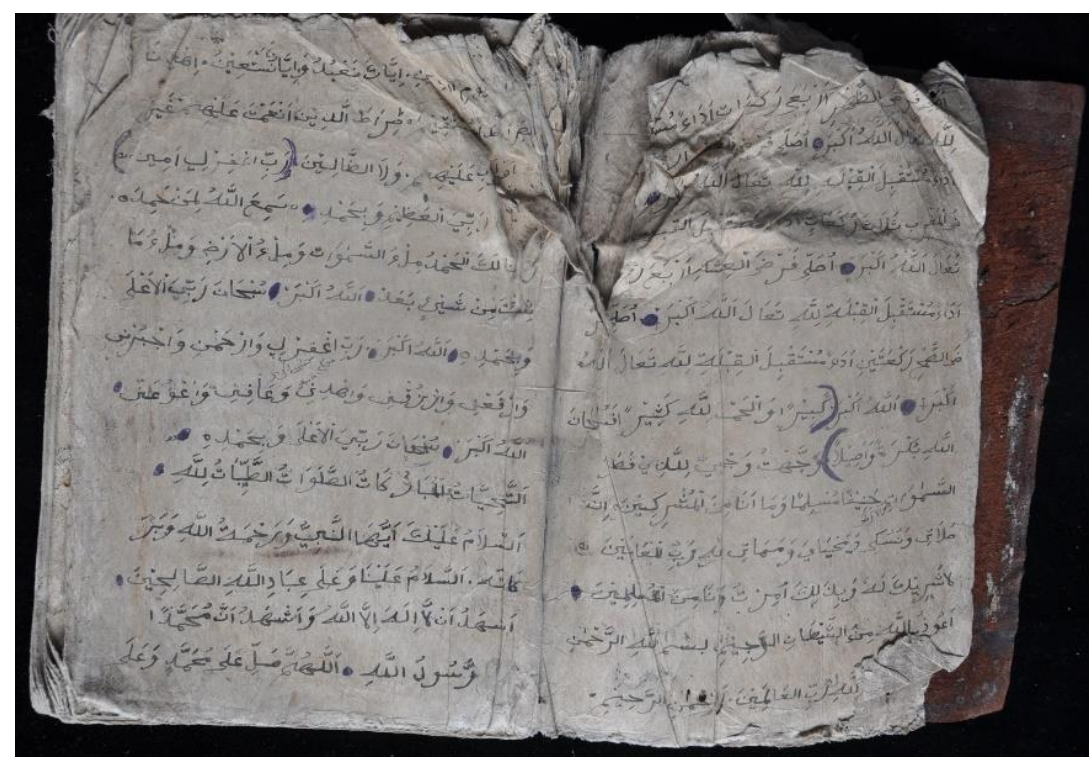

12015 LCGPTR KH 152012 HLM 1,2 Img0800 


\begin{tabular}{|l|l|l|l|}
\hline $\begin{array}{l}\text { BLAS/SUM/16/FI/ } \\
32\end{array}$ & KITAB AL IDAH & 4 & Fikih \\
\hline $\begin{array}{l}\text { GPRB/NSR/19/201 } \\
2\end{array}$ & Arab & Arab & Prosa \\
\hline 312 hlm. & 9 baris/hlm. & $29 \times 18.5$ & Kertas Daluwang \\
\hline Nasiruddin & \multicolumn{2}{|l}{} \\
\hline Caremmi, Gapura Barat
\end{tabular}

Naskah ini menjelaskan tentang tata cara salat, puasa, haji, jual beli, gadai, dan sebagainya.

Naskah ini tersimpan di rumah Nasiruddin dari buyutnya, H. Ghazali. Kondisi naskah cukup baik, teks masih terbaca.

\begin{tabular}{|l|l|l|l|}
\hline $\begin{array}{l}\text { BLAS/SUM/16/FI/ } \\
33\end{array}$ & KITAB FIKIH & 4 & Fikih \\
\hline $\begin{array}{l}\text { GPRB/SMHS/22/2 } \\
012\end{array}$ & Arab & Arab & Prosa \\
\hline 194 hlm. & 13 baris/hlm. & $26.5 \times 19$ & Kertas Daluwang \\
\hline \begin{tabular}{l} 
K.H. Samhadi Siraj \\
\hline Gapura Barat, Gapura
\end{tabular} \\
\hline
\end{tabular}

Naskah ini menjelaskan tentang taharah, wuḍu, salat, puasa, dan haji.

Naskah ini berasal dari K.H. Samhadi Siraj, dari K.H.M. Siraj, dari K.H. Abdul Syakur. 


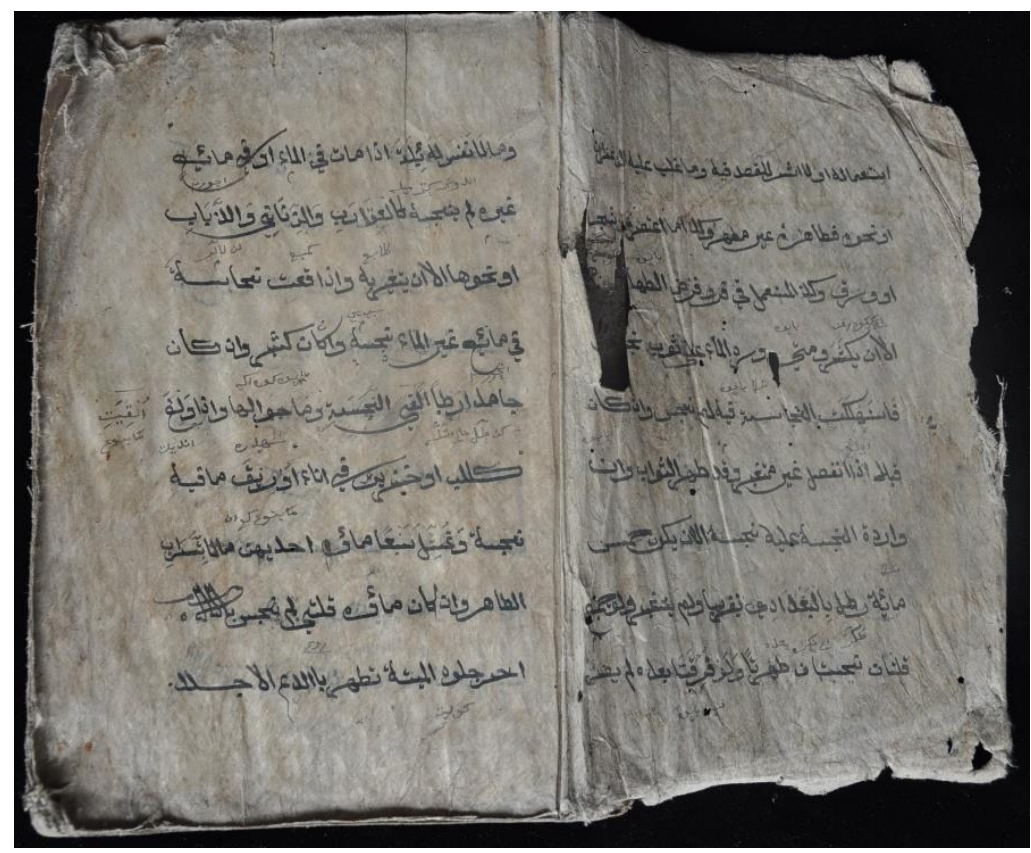

12019 GPRB NSR 192012 HLM 2,3 Img1160

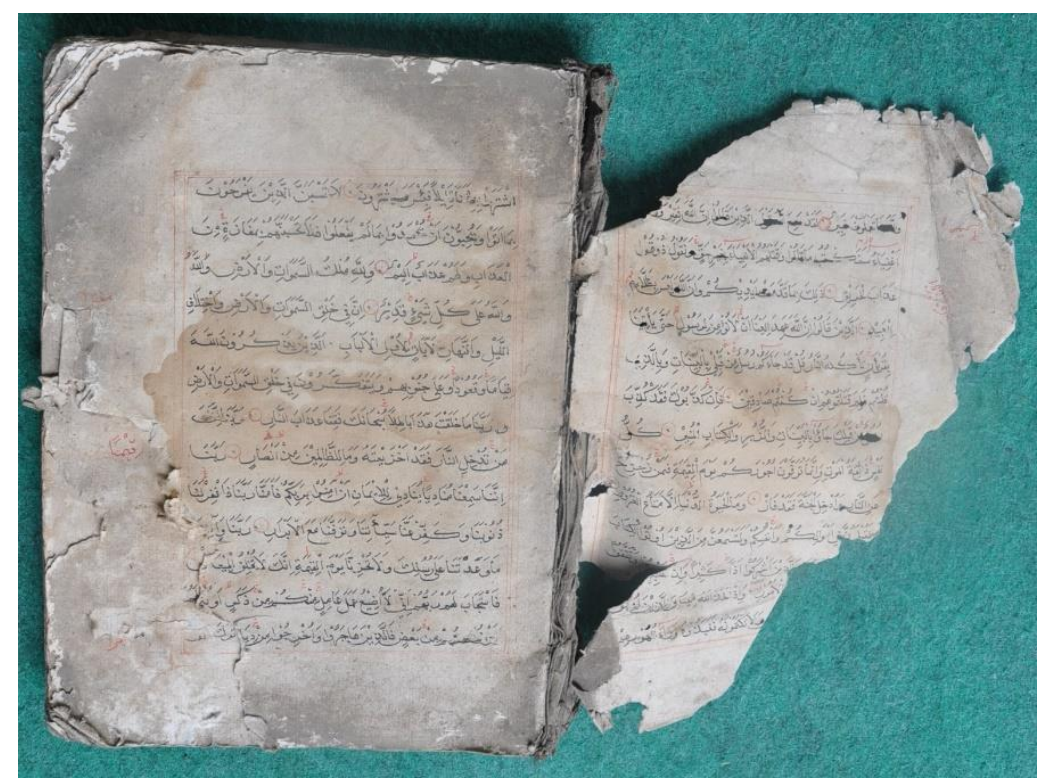

12022 GPRB SMHS 222012 HLM 2,3 Img 1742 


\begin{tabular}{|l|l|l|l|}
\hline $\begin{array}{l}\text { BLAS/SUM/16/FI/ } \\
34\end{array}$ & $\begin{array}{l}\text { KITAB } \\
\text { SAFINATU Ṣ } \\
\text { ȘALAT }\end{array}$ & 4 & Fikih \\
\hline $\begin{array}{l}\text { GPRB/SMHS/24/2 } \\
012\end{array}$ & Arab & Arab & Prosa \\
\hline $52 \mathrm{hlm}$. & 7 baris/hlm. & $21 \times 17$ & Kertas Daluwang \\
\hline K.H. Samhadi Siraj & & \\
\hline Gapura Barat, Gapura
\end{tabular}

Naskah ini menjelaskan tentang tata cara wuḍu salat, bersuci, puasa.

Naskah ini berasal dari K.H. Samhadi Siraj, dari K.H.M. Siraj, dari K.H. Abdul Syakur.

\begin{tabular}{|l|l|l|l|}
\hline $\begin{array}{l}\text { BLAS/SUM/16/FI/ } \\
35\end{array}$ & $\begin{array}{l}\text { KITAB } \\
\text { SAFINATU N } \\
\text { NAJA }\end{array}$ & 4 & Fikih \\
\hline $\begin{array}{l}\text { GPRB/SMHS/25/2 } \\
012\end{array}$ & Arab & Arab & Prosa \\
\hline 68 hlm. & 7 baris/hlm. & $25.5 \times 18$ & Kertas Daluwang \\
\hline K.H. Samhadi Siraj & & \\
\hline Gapura Barat, Gapura
\end{tabular}

Naskah ini menjelaskan tentang tata cara wuḍu salat, bersuci, puasa, dan doa-doa.

Naskah ini berasal dari K.H. Samhadi Siraj, dari K.H.M. Siraj, dari K.H. Abdul Syakur. 


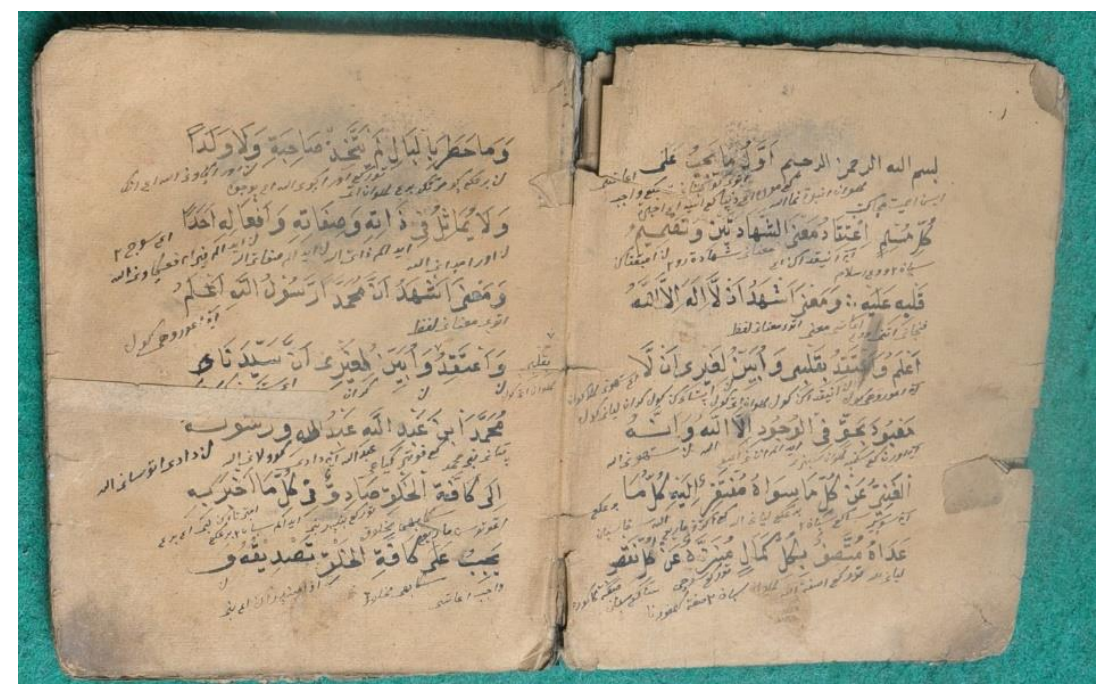

12024 GPRB SMHS 242012 HLM 1,2 Img1965

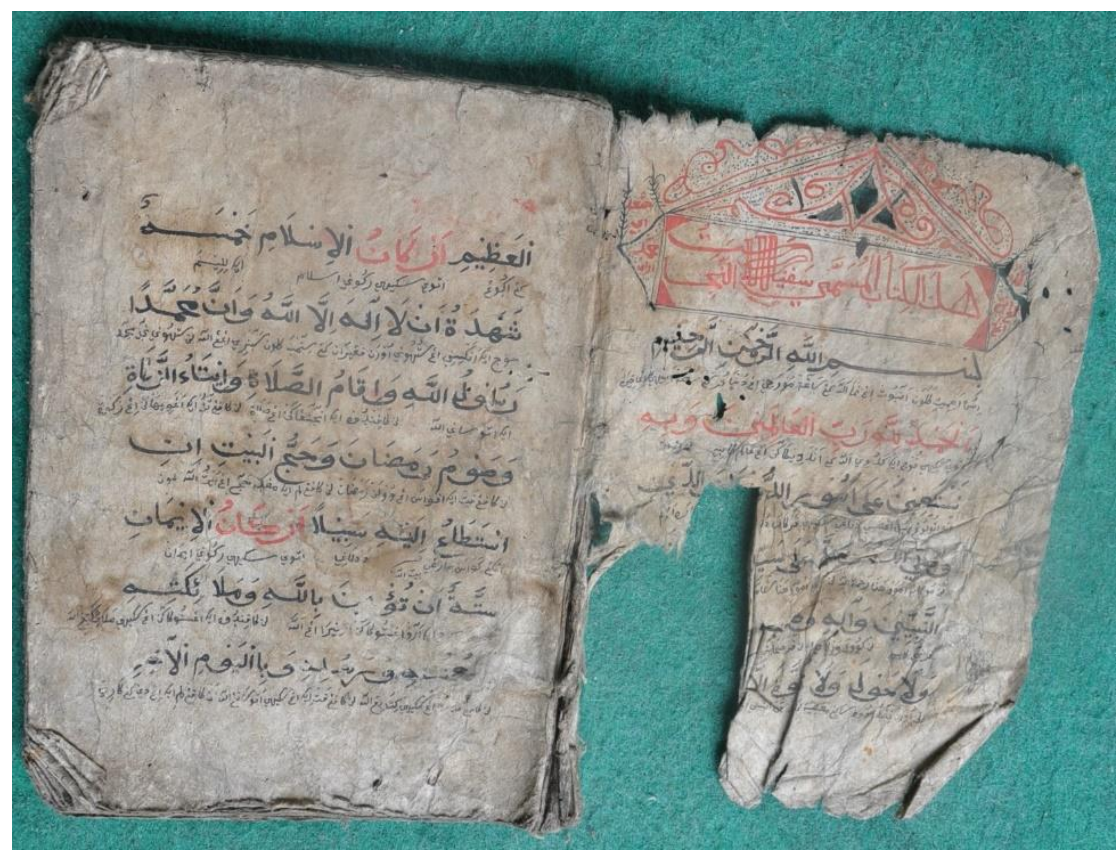

12025 GPRB SMHS 252012 HLM 1,2 Img1992 


\begin{tabular}{|l|l|l|l|}
\hline $\begin{array}{l}\text { BLAS/SUM/16/FI/ } \\
36\end{array}$ & KITAB FIKIH & 4 & Fikih \\
\hline $\begin{array}{l}\text { PJGGPR/KHZ/31/2 } \\
012\end{array}$ & Arab & Arab & Prosa \\
\hline $92 \mathrm{hlm}$. & 13 baris/hlm. & $26 \times 16.5$ & Kertas Daluwang \\
\hline K.H. Zahidi & \\
\hline \multicolumn{2}{|l}{ Pajagungan, Paloklokan, Gapura } \\
\hline
\end{tabular}

Naskah ini menjelaskan tentang tata cara wudu, syarat rukun salat, syarat, rukun dan hal-hal yang membatalkan puasa.

Naskah ini milik K.H. Zahidi dari K. Said. Kondisi naskah mulai rusak, teks masih terbaca.

\begin{tabular}{|c|c|c|c|}
\hline $\begin{array}{l}\text { BLAS/SUM/16/FI/ } \\
37\end{array}$ & $\begin{array}{l}\text { KITAB BERSUCI, } \\
\text { SALAT, DAN } \\
\text { PUASA }\end{array}$ & 4 & Fikih \\
\hline $\begin{array}{l}\text { GPRB/UKL/34/201 } \\
2\end{array}$ & Arab & Arab & Prosa \\
\hline $384 \mathrm{hlm}$. & 7 baris/hlm. & $28.5 \times 18$ & Kertas Daluwang \\
\hline
\end{tabular}

Teks berisi penjelasan tentang ibadah dalam Islam.

Keterangan terinci tentang bagian isi teks tersebut adalah sebagai berikut. 1 . Keterangan tentang bersuci, 2. Keterangan tentang salat termasuk syarat dan rukun salat, 3. Keterangan tentang puasa.

Naskah ini milik Nyai Ummi Kulsum dari Nyai Aisyah dari K Abdul Aziz. Kondisi naskah mulai rusak, teks masih terbaca. 


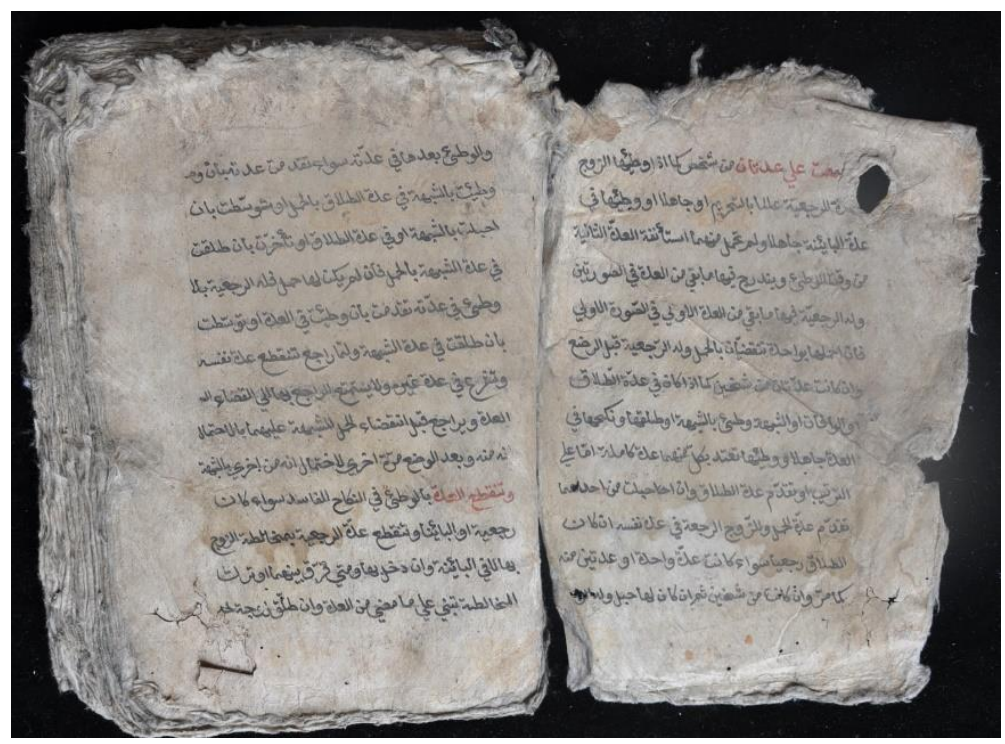

12031 PJGGPR KHZ 312012 HLM 2, 3 Img2349.jpg

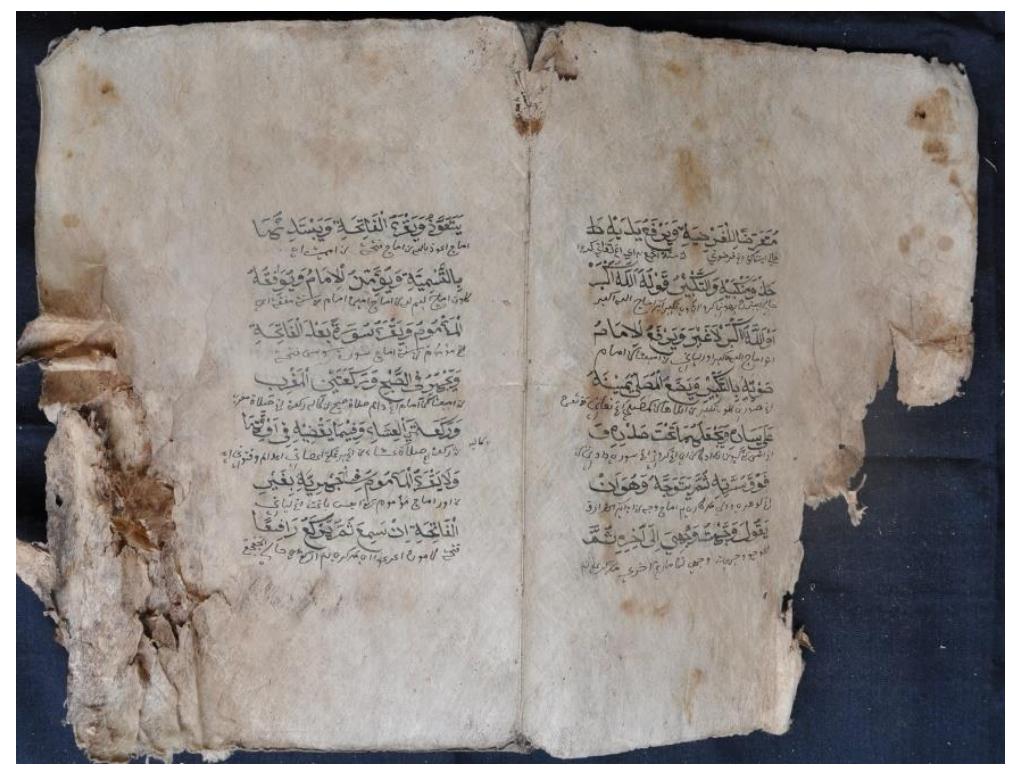

12034 GPRB UKL 342012 HLM 8,9 Img2486 


\begin{tabular}{|l|l|l|l|}
\hline $\begin{array}{l}\text { BLAS/SUM/16/FI/ } \\
38\end{array}$ & $\begin{array}{l}\text { KITAB SULLĀM } \\
\text { TAUFIQ }\end{array}$ & 4 & Fikih \\
\hline $\begin{array}{l}\text { SGG/DRYH/47/20 } \\
12\end{array}$ & Arab & Arab & Prosa \\
\hline $84 \mathrm{hlm}$. & 8 baris/hlm. & $28 \times 19$ & Kertas Daluwang \\
\hline Nyai Dzurriyah & & \\
\hline Sergang, Batu Putih & \\
\hline
\end{tabular}

Naskah ini berisi teks tentang tatacara bersuci dan beribadah.

Naskah ini milik Nyai Dzuriyah dari K.H. Asyhari. Kondisi naskah mulai rusak, teks masih terbaca.

\begin{tabular}{|l|l|l|l|}
\hline $\begin{array}{l}\text { BLAS/SUM/16/FI/ } \\
39\end{array}$ & KITAB FADA'IL & 4 & Fikih \\
\hline $\begin{array}{l}\text { PJG/SRBN/52/201 } \\
2\end{array}$ & Arab & Arab & Prosa \\
\hline 34 hlm. & 7 baris/hlm. & $21 \times 17$ & Kertas Daluwang \\
\hline K.H. Syarbini & \multicolumn{2}{|l}{} \\
\hline Pajung, Batu Putih
\end{tabular}

Naskah ini berjudul Kitab Fadail berisi antara lain kelebihan bulan satu dibandingkan dengan bulan lain, pahala berjalan ke majelis zikir pada bulan Ramadhan yaitu Allah akan mencatat setiap langkah seperti beribadah seratus tahun.

Naskah ini milik K.H. Syarbini dari KH Sholihuddin dari KH Jail. Kondisi naskah mulai rusak, teks masih terbaca. 


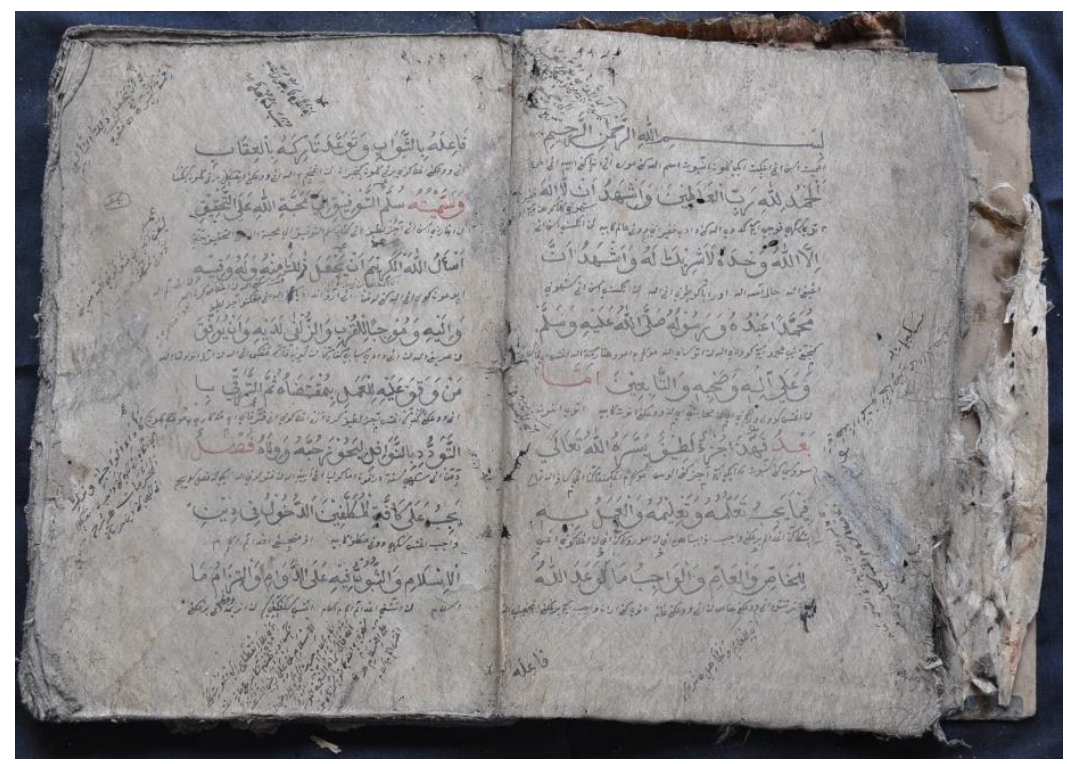

12047 SGG DRYH 472012 HLM 2,3 Img4566

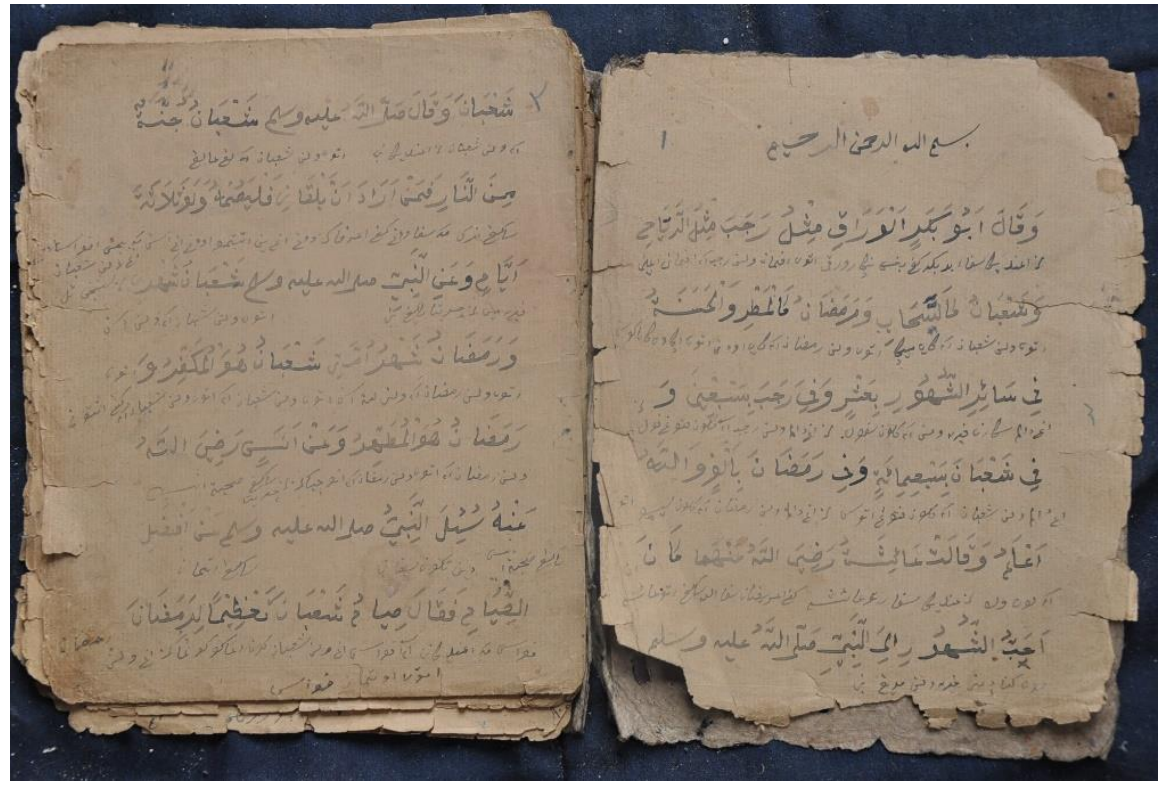

12052 PJG SRBN 522012 HLM 1,2 Img5066 


\begin{tabular}{|l|l|l|l|}
\hline $\begin{array}{l}\text { BLAS/SUM/16/FI/ } \\
40\end{array}$ & KITAB FIKIH & 4 & Fikih \\
\hline $\begin{array}{l}\text { SGG/FTHR/58/201 } \\
2\end{array}$ & Arab & Arab & Prosa \\
\hline 60 hlm. & 9 baris/hlm. & $32 \times 20$ & Kertas Daluwang \\
\hline Fathur & & \\
\hline Sergang, Batu Putih & \\
\hline
\end{tabular}

Naskah terdiri dari dua teks. Teks pertama menjelaskan bahwa seorang lelaki, mukmin, balig, tidak ada udzur salat berjamah adalah fardu kifayah, dan fardu ain bila salat Jumat dan teks kedua kitab Sulam Taufiq menjelaskan salah satu maksiatnya badan berani dengan kedua orang tua.

Naskah ini milik Fathur dari KH Shiddiq. Kondisi naskah mulai rusak, teks masih terbaca.

\begin{tabular}{|l|l|l|l|}
\hline $\begin{array}{l}\text { BLAS/SUM/16/FI/ } \\
\mathbf{1}\end{array}$ & $\begin{array}{l}\text { KITAB SYARAH } \\
\text { FIKIH } \\
\text { MUAMALAH }\end{array}$ & 4 & Fikih \\
\hline $\begin{array}{l}\text { SGG/FTHR/59/201 } \\
2\end{array}$ & Arab & Arab & Prosa \\
\hline $350 \mathrm{hlm}$. & 19 baris/hlm. & $33 \times 22$ & Kertas Daluwang \\
\hline Fathur & & \\
\hline Sergang, Batu Putih & \\
\hline
\end{tabular}

Naskah ini merupakan syarah sebuah kitab fikih. Naskah menjelaskan tentang masalah muamalah, munakahat, dan jinayat.

Naskah ini milik Fathur dari K.H. Shiddiq. Kondisi naskah mulai rusak, teks masih terbaca. 


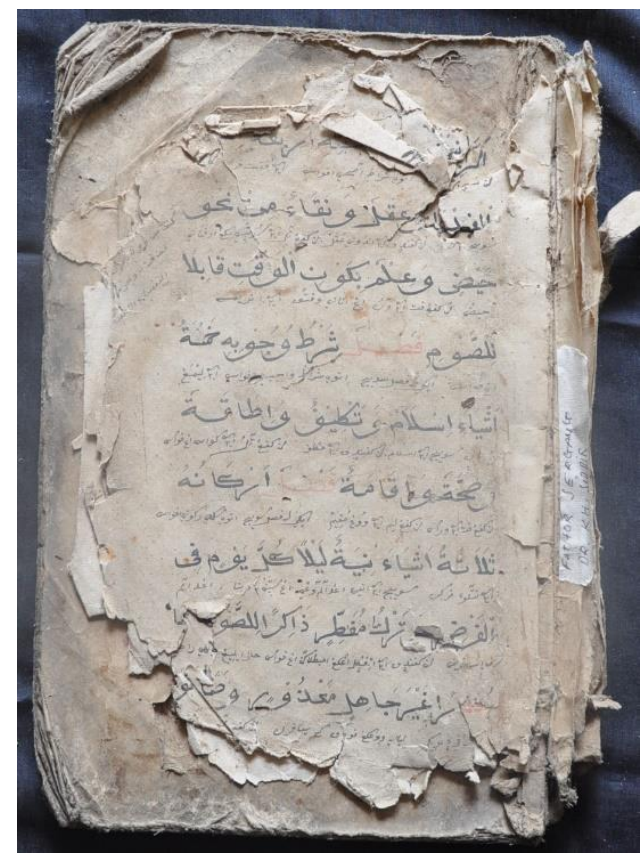

12059 SGG FTHR 582012 HLM 1 Img5306

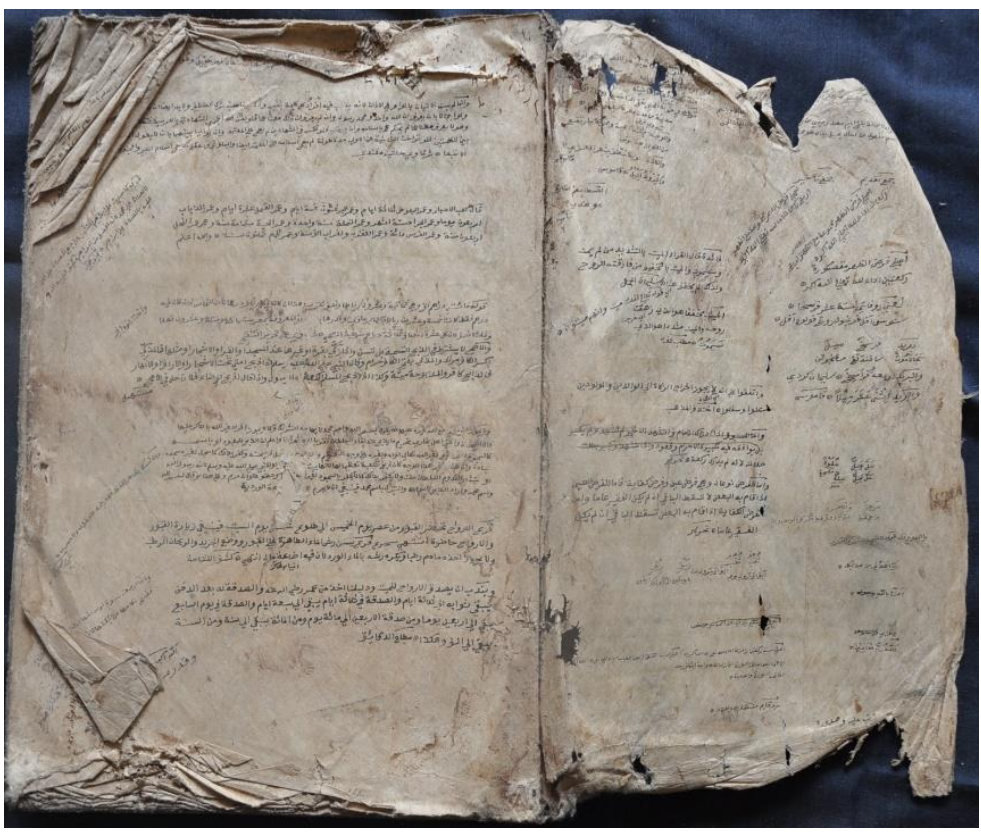

12060 SGG FTHR 592012 HLM 2,3 Img5340 


\begin{tabular}{|l|l|l|l|}
\hline $\begin{array}{l}\text { BLAS/SUM/16/FI/ } \\
\mathbf{4 2}\end{array}$ & KITAB BERSUCI & 4 & Fikih \\
\hline SGG/ZNI/61/2012 & Arab & Arab & Prosa \\
\hline $70 \mathrm{hlm}$. & 6 baris/hlm. & $20.5 \times 16$ & Kertas Daluwang \\
\hline M. Zaini & \multicolumn{2}{|l}{} \\
\hline Sergang, Batu Putih
\end{tabular}

Naskah hanya satu Teks. Naskah ini menjelaskan tentang berwuḍu, menghilangkan najis, dan sebagainya.

Naskah ini milik M. Zaini dari K. Wardi dari K.H. Murtala. Kondisi naskah rusak, sebagian teks masih terbaca.

\begin{tabular}{|l|l|l|l|}
\hline $\begin{array}{l}\text { BLAS/SUM/16/FI/ } \\
43\end{array}$ & KITAB FIKIH & 4 & Fikih \\
\hline SGG/BSI/64/2012 & Arab & Arab & Prosa \\
\hline 18 hlm. & 5 baris/hlm. & $24.5 \times 18.5$ & Kertas Daluwang \\
\hline Basri & \multicolumn{2}{|l}{} \\
\hline Sergang, Batu Putih
\end{tabular}

Naskah ini menjelaskan tentang ilmu fikih.

Naskah ini milik Basri dari K. Tsumma. Kondisi naskah mulai rusak, teks masih terbaca. 


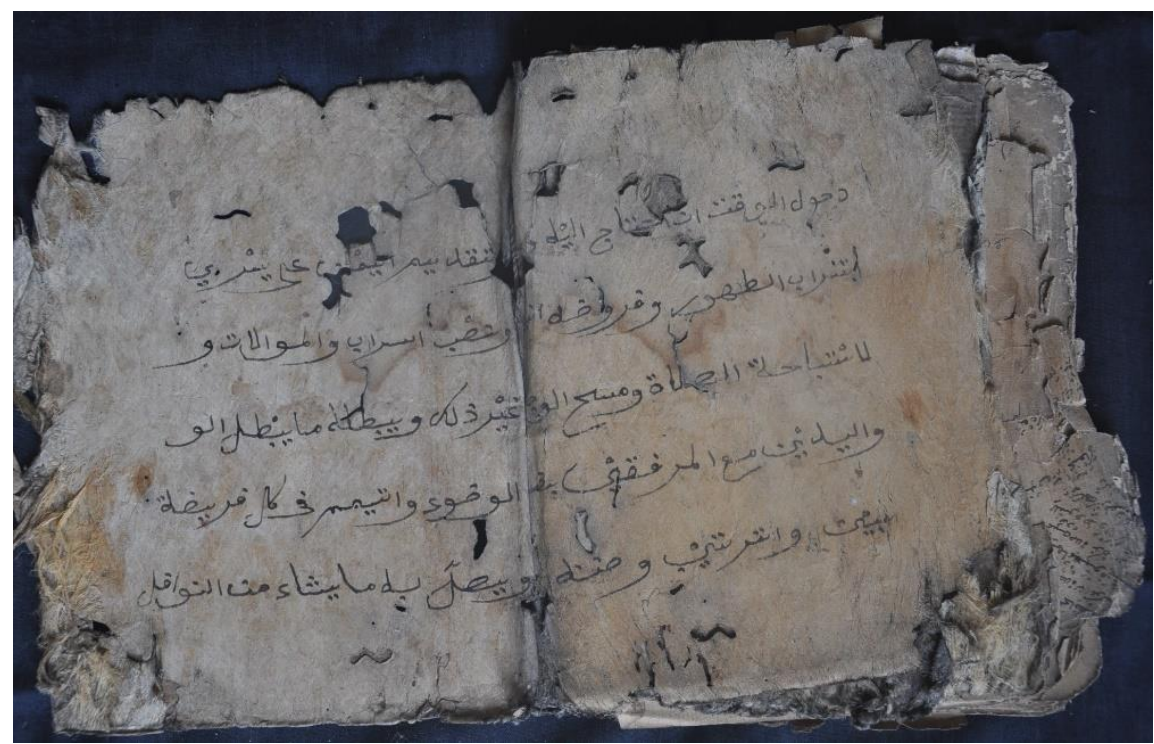

12062 SGG ZNI 612012 HLM 1,2 Img5564

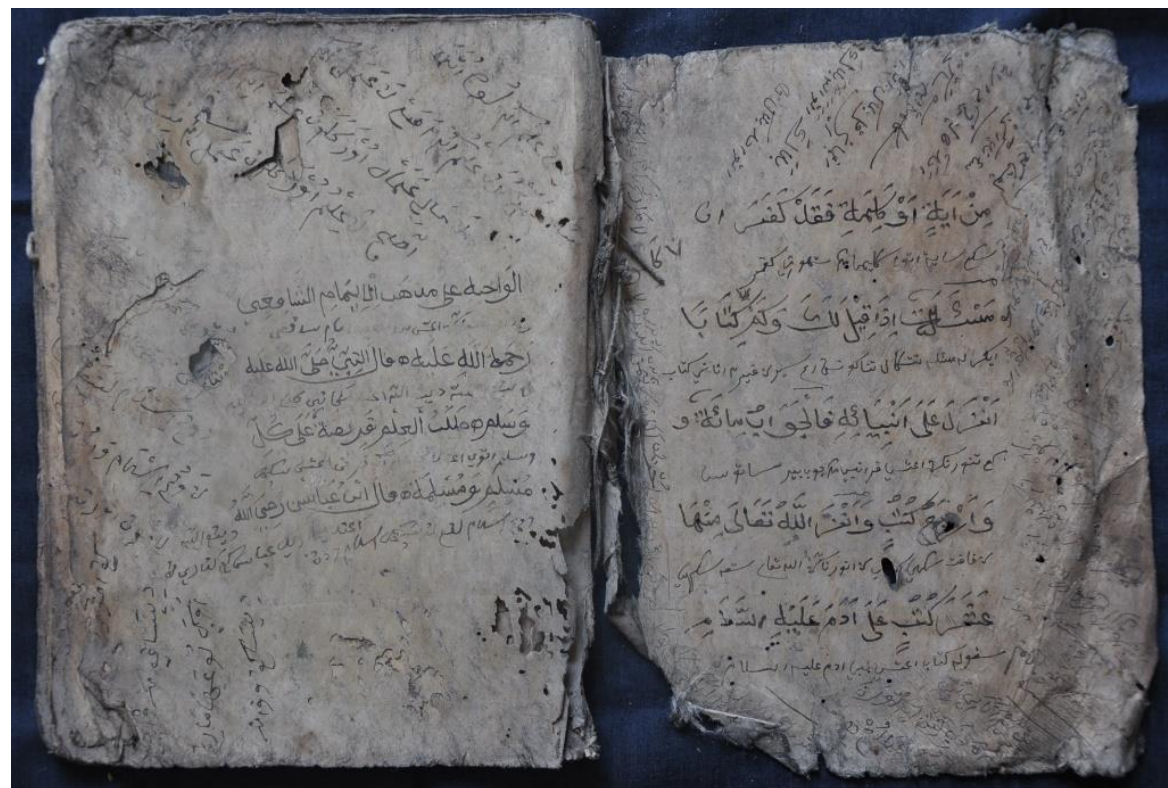

12065 SGG BSI 642012 HLM 2,3 Img5666 


\begin{tabular}{|l|l|l|l|}
\hline $\begin{array}{l}\text { BLAS/SUM/16/FI/ } \\
44\end{array}$ & $\begin{array}{l}\text { KITAB SITT̄N } \\
\text { DAN DOA }\end{array}$ & 4 & Fikih \\
\hline $\begin{array}{l}\text { SGG/MFHM/73/20 } \\
12\end{array}$ & Arab & Arab & Prosa \\
\hline $20 \mathrm{hlm}$. & 13 baris/hlm. & $21 \times 17$ & Kertas Daluwang \\
\hline M Fahim & \\
\hline Sergang, Batu Putih, Sumenep & \\
\hline
\end{tabular}

Naskah terdiri dari dua teks. Teks pertama kitab Sittin menjelaskan enampuluh masalah agama, seperti kewajiban mendirikan salat Jumat bagi suatu pedukuhan yang penduduknya empat puluh orang. Maksiatnya badan telinga, mata, dan sebagainya. Teks kedua tentang doa-doa.

Naskah ini milik M. Fahim dari K. Shidiq dari Syamsudin. Kondisi naskah cukup baik, teks terbaca.

\begin{tabular}{|l|l|l|l|}
\hline $\begin{array}{l}\text { BLAS/SUM/16/FI/ } \\
\mathbf{4 5}\end{array}$ & $\begin{array}{l}\text { KITAB FATHU } \\
\text { ŻL IZZI DAN } \\
\text { LAIN-LAIN }\end{array}$ & 4 & Fikih \\
\hline $\begin{array}{l}\text { SGG/MFHM/76/20 } \\
12\end{array}$ & Arab & Arab & Prosa \\
\hline 134 hlm. & 11 baris/hlm. & $20.5 \times 15.5$ & Kertas Daluwang \\
\hline M Fahim & \\
\hline \multicolumn{2}{|l|}{} \\
\hline
\end{tabular}

Naskah ini berisi tujuh teks; (1) Berisi tentang syarat dan rukunnya salat. (2) Salat dan doa-doanya. (3) Bersuci dari hadas, najis, sunah bersiwak. (4) Cara salat. (5) Menafsirkan hadits. (6) Tentang salat. (7) Tentang akidah atau iman.

Naskah ini milik M. Fahim dari K. Shidiq dari Syamsudin. Kondisi naskah cukup baik, teks terbaca. 


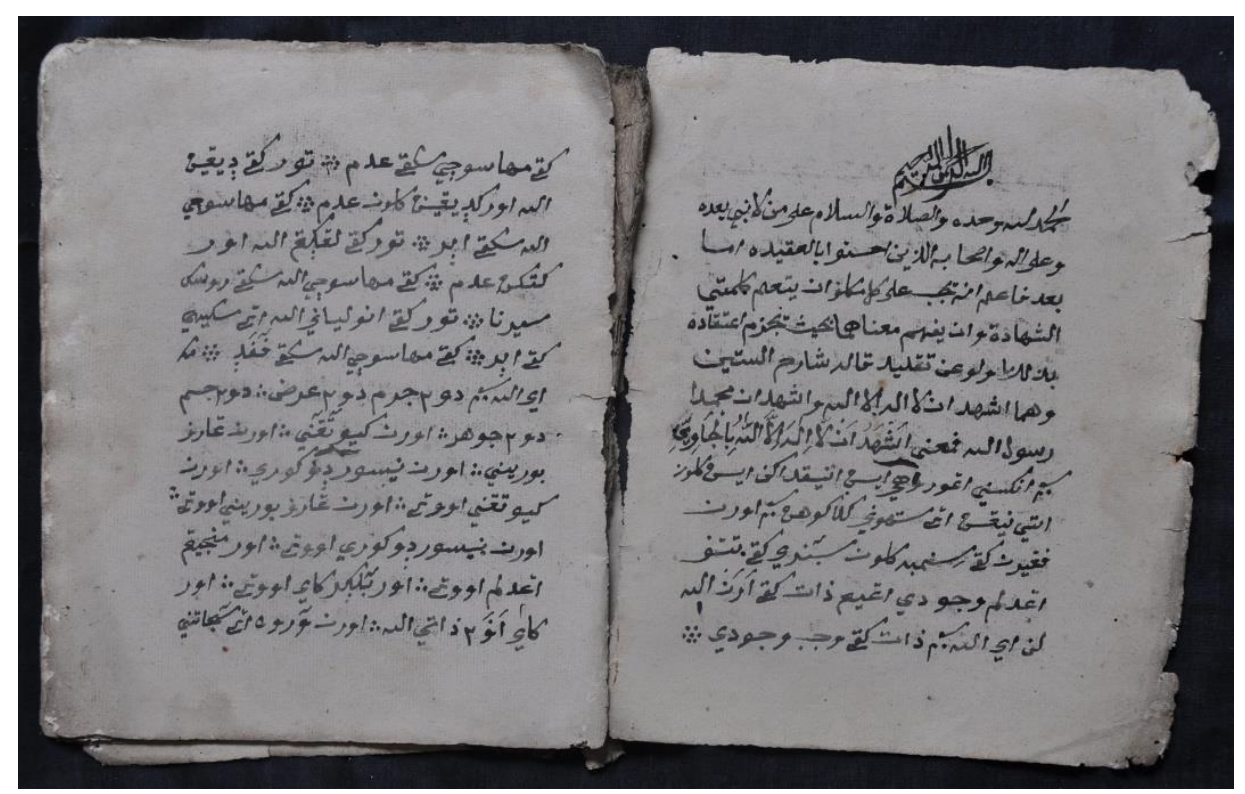

12074 SGG MFHM 732012 HLM 1,2 Img6028

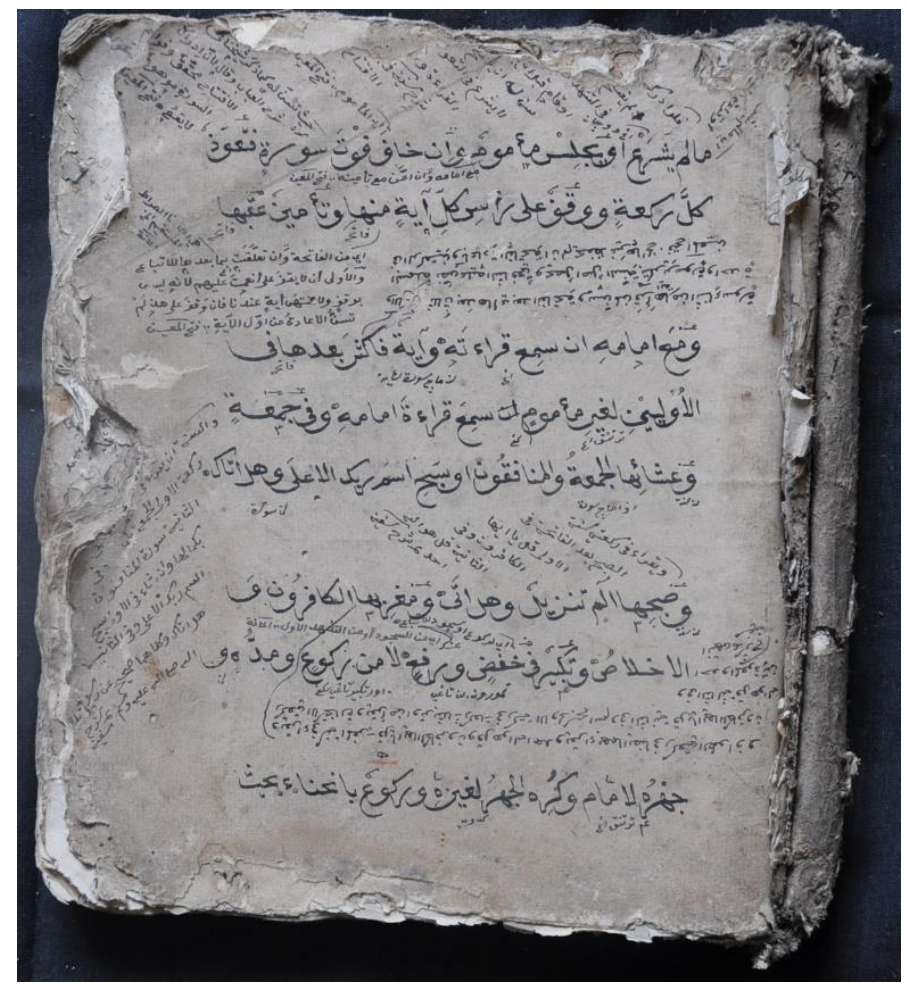

12077 SGG MFHM 762012 HLM 1 Img6319 


\begin{tabular}{|l|l|l|l|}
\hline $\begin{array}{l}\text { BLAS/SUM/16/FI/ } \\
46\end{array}$ & $\begin{array}{l}\text { KITAB SULAM } \\
\text { TAUFIQ }\end{array}$ & 4 & Fikih \\
\hline $\begin{array}{l}\text { MDGT/AMR/79/20 } \\
12\end{array}$ & Arab & Arab & Prosa \\
\hline $126 \mathrm{hlm}$. & 7 baris/hlm. & $21 \times 16$ & Kertas Daluwang \\
\hline Amir & \multicolumn{2}{|l}{} \\
\hline Manding Timur, Manding, Sumenep
\end{tabular}

Naskah ini berisi satu teks, Sulam Taufiq menjelaskan tentang kewajiban seorang mukalaf masuk agama Islam dengan benar selamanya.

Naskah ini berasal dari Amir dari K.H. Abdus Salam. Tahun penyusunan, penulisan, maupun pemrakarsa tidak dicantumkan. Kondisi naskah ini cukup baik dan bisa dibaca.

\begin{tabular}{|l|l|l|l|}
\hline $\begin{array}{l}\text { BLAS/SUM/16/FI/ } \\
47\end{array}$ & $\begin{array}{l}\text { KITAB } \\
\text { DURRATUL } \\
\text { FAKHIRAH }\end{array}$ & 4 & Fikih \\
\hline $\begin{array}{l}\text { MDGT/AMR/80/20 } \\
12\end{array}$ & Arab & Arab & Prosa \\
\hline $50 \mathrm{hlm}$. & 6 baris/hlm. & $22 \times 15$ & Kertas Daluwang \\
\hline Amir & & \\
\hline Manding Timur, Manding, Sumenep & \\
\hline
\end{tabular}

Teks naskah ini bernama Ad Durrotul Fakhirah. Teks ini menjelaskan tentang sifat dua puluh dikelompokkan menjadi empat, yakni sifat nafsiyah, salbiyah, ma'ani, dan ma'nawiyah.

Naskah milik dari Amir dari K.H. Abdus Salam. Tahun penyusunan, penulisan, maupun pemrakarsa tidak dicantumkan. Kondisi naskah ini cukup baik dan bisa dibaca. 


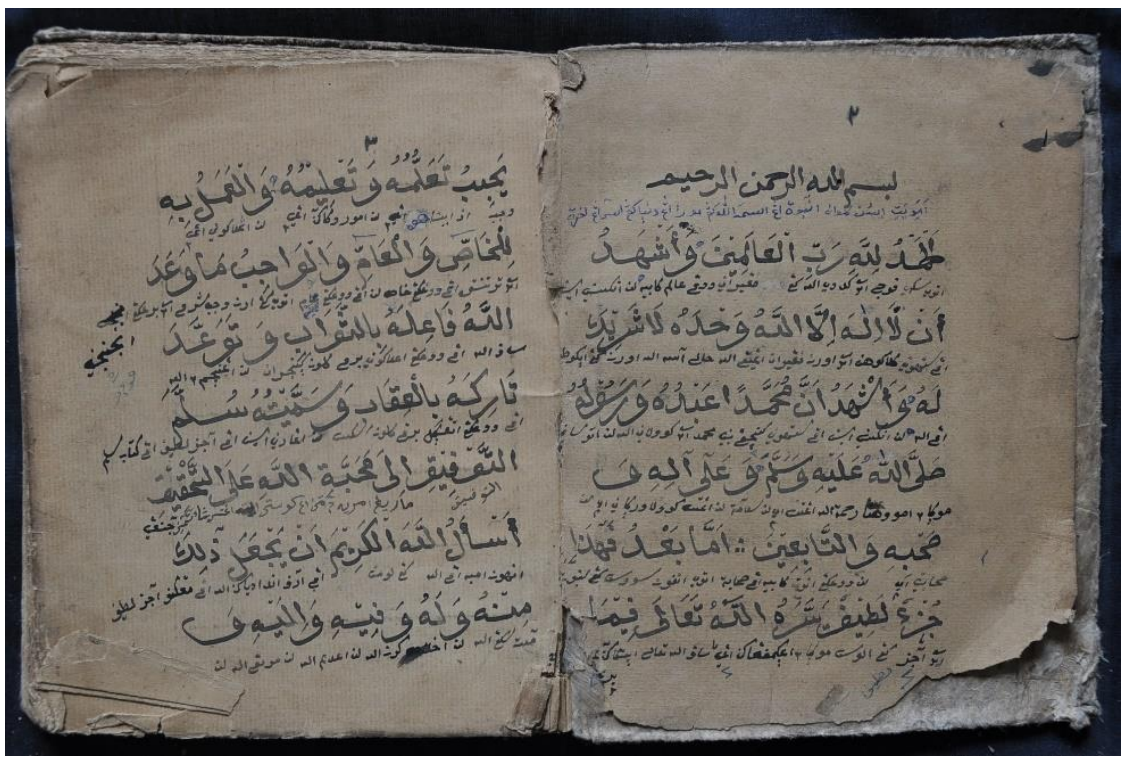

12080 MDGT AMR 792012 HLM 1,2 Img6630

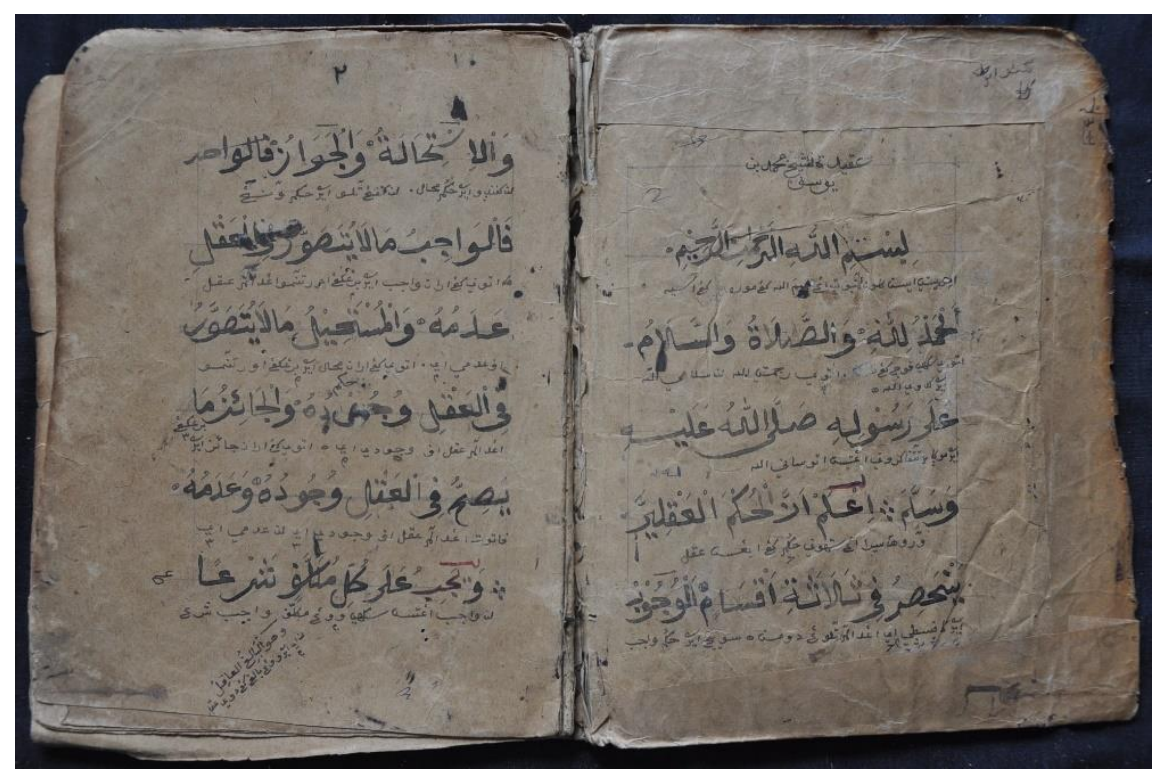

12081 MDGT AMR 802012 HLM 1,2 Img6694 


\begin{tabular}{|l|l|l|l|}
\hline $\begin{array}{l}\text { BLAS/SUM/16/FI/ } \\
\mathbf{4}\end{array}$ & KITAB FIKIH & 4 & Fikih \\
\hline $\begin{array}{l}\text { BTLN/LAILA/87/2 } \\
012\end{array}$ & Arab & Arab & Prosa \\
\hline $152 \mathrm{hlm}$. & 11 baris/hlm. & $26 \times 17$ & Kertas Daluwang \\
\hline Nyai Laila & \\
\hline Bantilan, Pajang, Batu Putih
\end{tabular}

Naskah ini berisi tentang tata cara mandi besar, azan dan iqamat, salat jama' dan qasar, dan zakat.

Naskah ini milik Nyai Laila dari Nyai Zahrotin. Kondisi cukup baik dan bisa dibaca. Tahun penyusunan tidak diketahui.

\begin{tabular}{|l|l|l|l|}
\hline $\begin{array}{l}\text { BLAS/SUM/16/FI/ } \\
49\end{array}$ & $\begin{array}{l}\text { KITAB } \\
\text { MINHAJUL } \\
\text { QAWIM DAN } \\
\text { KITAB FARAID }\end{array}$ & 4 & Fikih \\
\hline $\begin{array}{l}\text { LRKT/HSN/92/201 } \\
2\end{array}$ & Arab & Arab & Prosa \\
\hline 162 hlm. & 17 baris/hlm. & $20 \times 10$ & Kertas Daluwang \\
\hline K.H. Hasin & \\
\hline \multicolumn{2}{|l}{ Larangan Kerta, Batu Putih } \\
\hline
\end{tabular}

Naskah ini berisi dua teks . Teks pertama bernama kitab Minhajul Qawim, ditulis selesai Senin waktu dhuha tanggal 27 Jumadil Awwal 1367 H/1947 M. Teks ini menjelaskan beberapa model jual beli. Teks kedua menjelaskan faraị (waris) dari kitab Fathul Wahhäb selesai ditulis malam Selasa waktu isya.

Naskah ini milik K.H. Hasim dari Nyi Ahun. Kondisi naskah baik, teks terbaca. 


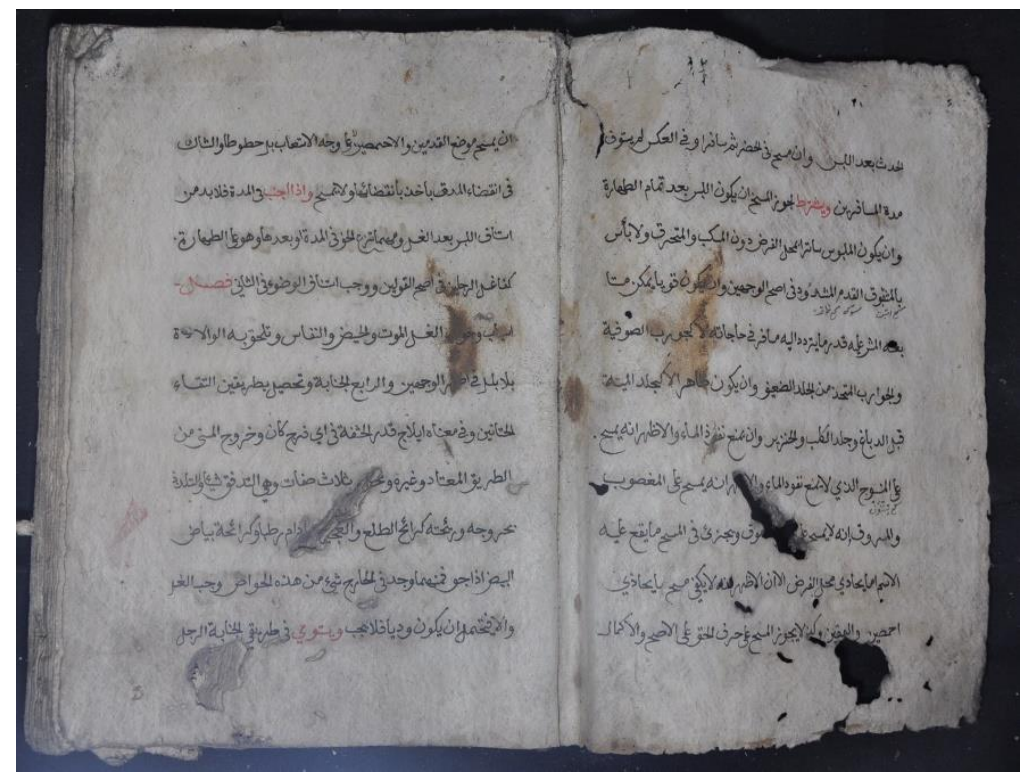

12088 BTLN LAILA 872012 HLM 2,3 Img7149

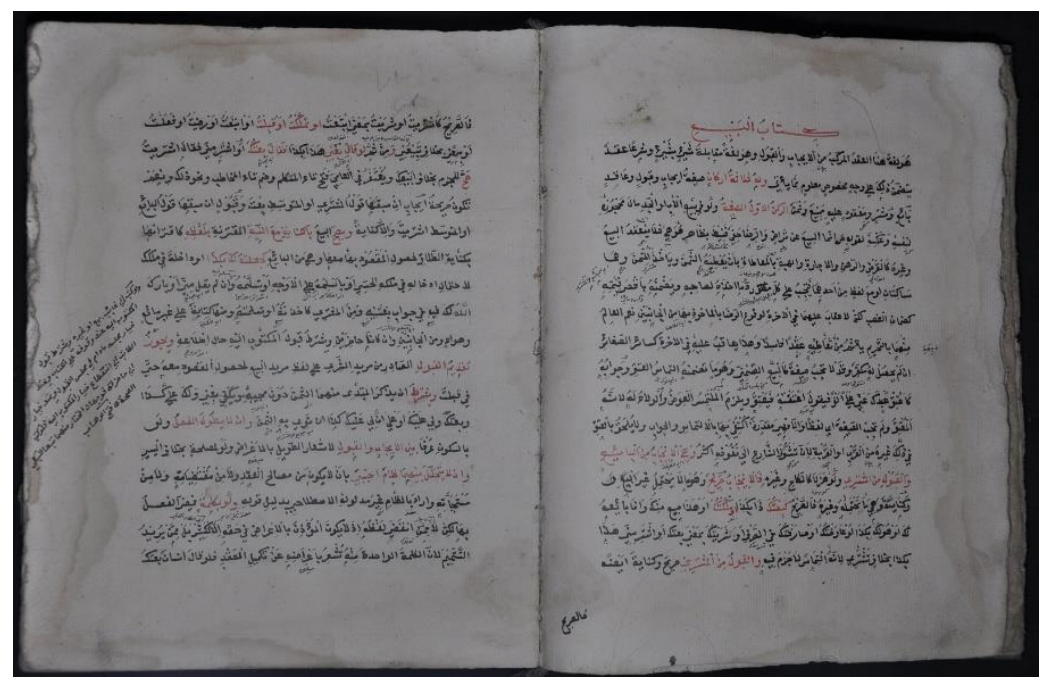

12093 LKRT HSN 922012 HLM 1,2 Img7583 


\begin{tabular}{|l|l|l|l|}
\hline $\begin{array}{l}\text { BLAS/SUM/16/FI/ } \\
\mathbf{5 0}\end{array}$ & $\begin{array}{l}\text { KITAB AS-SILĀH } \\
\text { FI BAYĀNI } \\
\text { NIKAH }\end{array}$ & $\mathbf{4}$ & Fikih \\
\hline $\begin{array}{l}\text { PJG.SGG/AMIN/9 } \\
5 / 2012\end{array}$ & Arab & Arab & Prosa \\
\hline $8 \mathrm{hlm}$. & 9 baris/hlm. & $21 \times 17$ & Kertas Daluwang \\
\hline Amir & & \\
\hline Pajung, Sergang, Batu Putih, Sumenep & \\
\hline
\end{tabular}

Teks bernama As Silahu fi Bayani an Nikah disusun oleh Imam Nawawi dan disalin oleh KH Kholil Bangkalan menjelaskan tentang tat acara nikah menurut Islam.

Naskah milik Amir dan K.H. Syafi'udin. Kondisi naskah naskah cukup baik.

\begin{tabular}{|l|l|l|l|}
\hline $\begin{array}{l}\text { BLAS/SUM/16/FI/ } \\
51\end{array}$ & $\begin{array}{l}\text { SULLĀM } \\
\text { FAD̄LAH DAN } \\
\text { LAIN-LAIN }\end{array}$ & 4 & Fikih \\
\hline $\begin{array}{l}\text { BTLN/MTMH/111/ } \\
2012\end{array}$ & Arab & Arab & Prosa \\
\hline $198 \mathrm{hlm}$. & 5,9 baris/hlm. & $20 \times 16$ & Kertas Daluwang \\
\hline Mutammimah & & \\
\hline Bantilan Batu Putih &
\end{tabular}

Naskah berisi enam teks. Teks pertama bernama Fadilah menjelaskan keut amaan orang berilmu, keutamaan salat, dan rahasia salat. Teks kedua menjelaskan tentang tatacara berpuasa Ramadhan. Teks ketiga menjelaskan tentang rukun Islam. Teks keempat menjelaskan tentang tatacara salat yang benar. Teks kelima bernama Sullam Taufiq menjelaskan tentang tata cara beribadah mulai bersuci, berwudu, salat, puasa, zakat, dan haji. Teks keenam menjelaskan tentang syarat, rukun, dan yang membatalkan pernikahan.

Naskah ini milik Mutammimah dari K.H. Hasyim. Kondisi naskah mulai rusak, banyak berlubang, teks masih terbaca. 


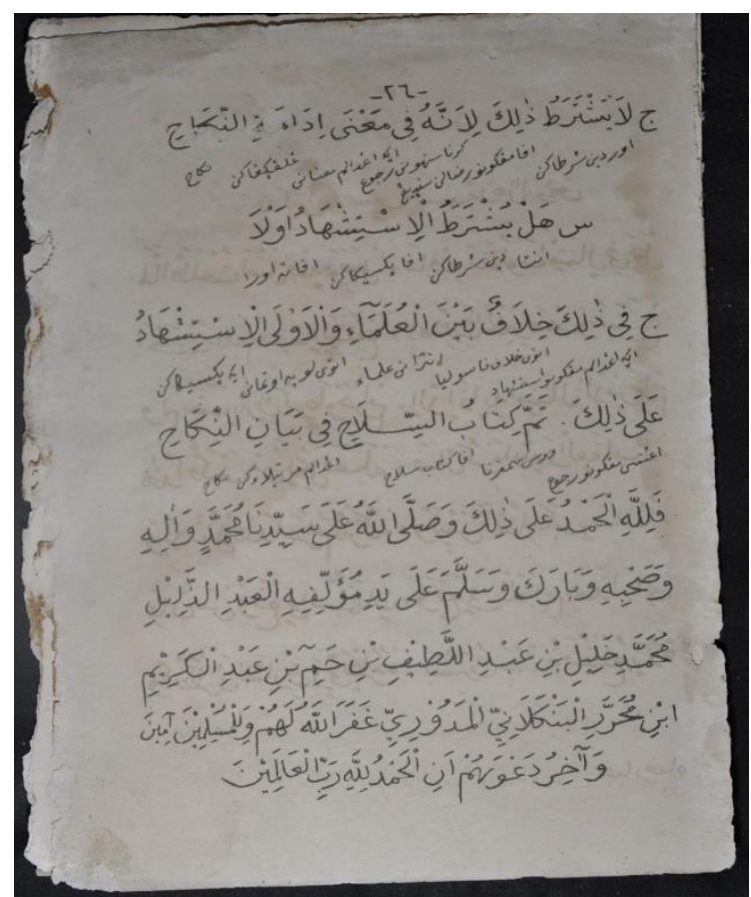

12096 PJGSGG AMIN 952012 HLM 1 Img9261

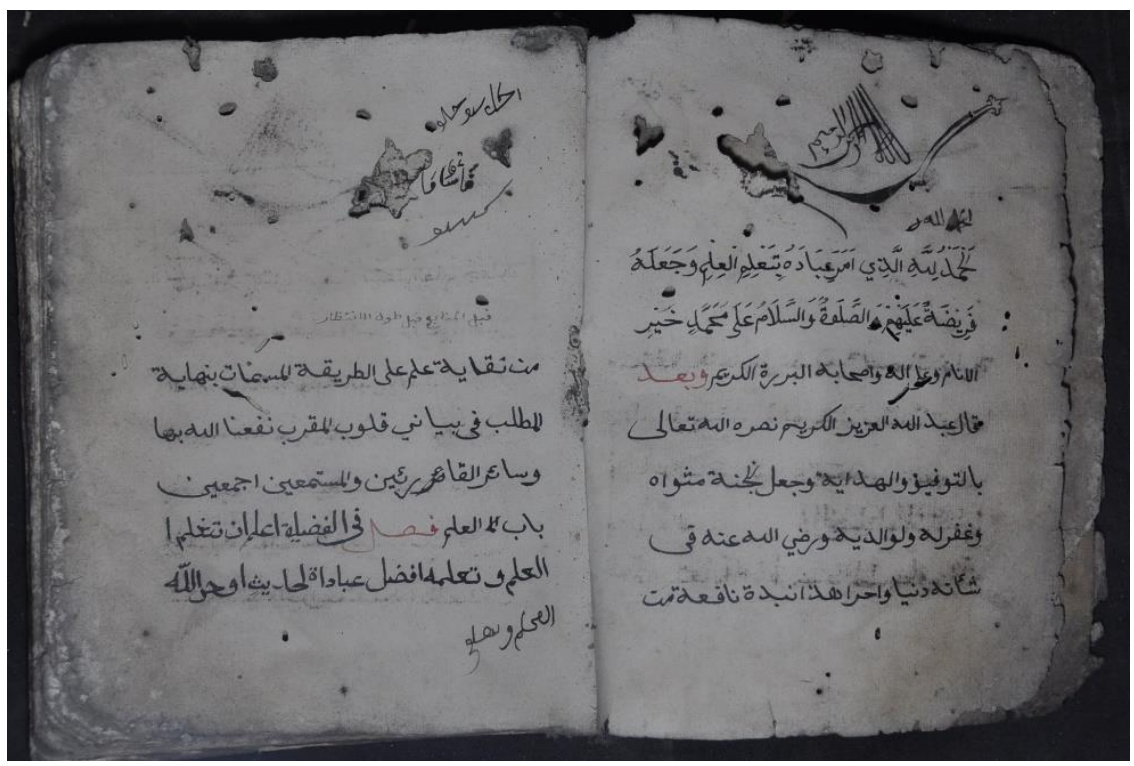

12112 BTLN MTMH 1112012 HLM 1,2 Img10040 


\begin{tabular}{|l|l|l|l|}
\hline $\begin{array}{l}\text { BLAS/SUM/16/FI/ } \\
\mathbf{5 2}\end{array}$ & KITAB BERSUCI & 4 & Fikih \\
\hline $\begin{array}{l}\text { JNGR/HSM/121/20 } \\
12\end{array}$ & Arab & Arab & Prosa \\
\hline $\begin{array}{l}42 \mathrm{hlm} . \\
\text { Hosmah }\end{array}$ & 6 baris/hlm. & $21.5 \mathrm{x} 14$ & Kertas Daluwang \\
\hline Jenangger, Batang-batang \\
\hline
\end{tabular}

Naskah berisi teks yang menjelaskan ilmu fikih seperti tata cara berwudu, mandi janabah, salat.

Naskah ini dimiliki oleh Hosmah dari K. Ahyar dari K. Abdullah. Tahun dan tempat penyusunan, penulisan ulang, maupun pemrakarsa tidak dicantumkan. Naskah dalam kondisi cukup baik/cukup bisa dibaca.

\begin{tabular}{|l|l|l|l|}
\hline $\begin{array}{l}\text { BLAS/SUM/16/FI/ } \\
\mathbf{5 3}\end{array}$ & KITAB SAFINAH & 4 & Fikih \\
\hline $\begin{array}{l}\text { JNGR/SUDFD/127 } \\
/ 2012\end{array}$ & Arab & Arab & \\
\hline $34 \mathrm{hlm}$. & 8 baris/hlm. & $22 \times 16$ & Prosa \\
\hline K iai Su'udi Fadhal & & \\
\hline Jenangger, Batang-batang & \\
\hline
\end{tabular}

Teks dalam naskah ini bernama Safinah disalin oleh Makiyat bin Maruriyah Desa Jadung, Pinggiran, Sumenep. Menjelaskan tentang tata cara bersuci, berwudu, salat, puasa.

Naskah ini dimiliki oleh K. Su'udi Fadlal dari Rosyidah dari K. Irsyad dari K.H. Hadi dari Kamsah dari K. Biramah. Naskah dalam kondisi baik. 


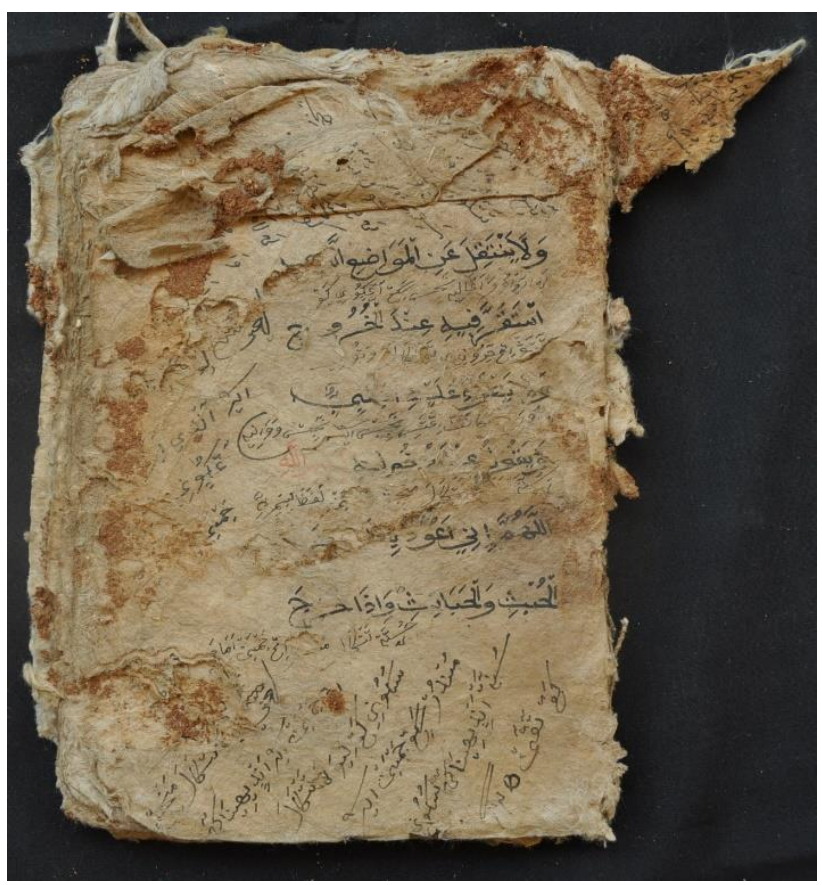

12122 JNGR HSM 1212012 HLM 1 Img10607

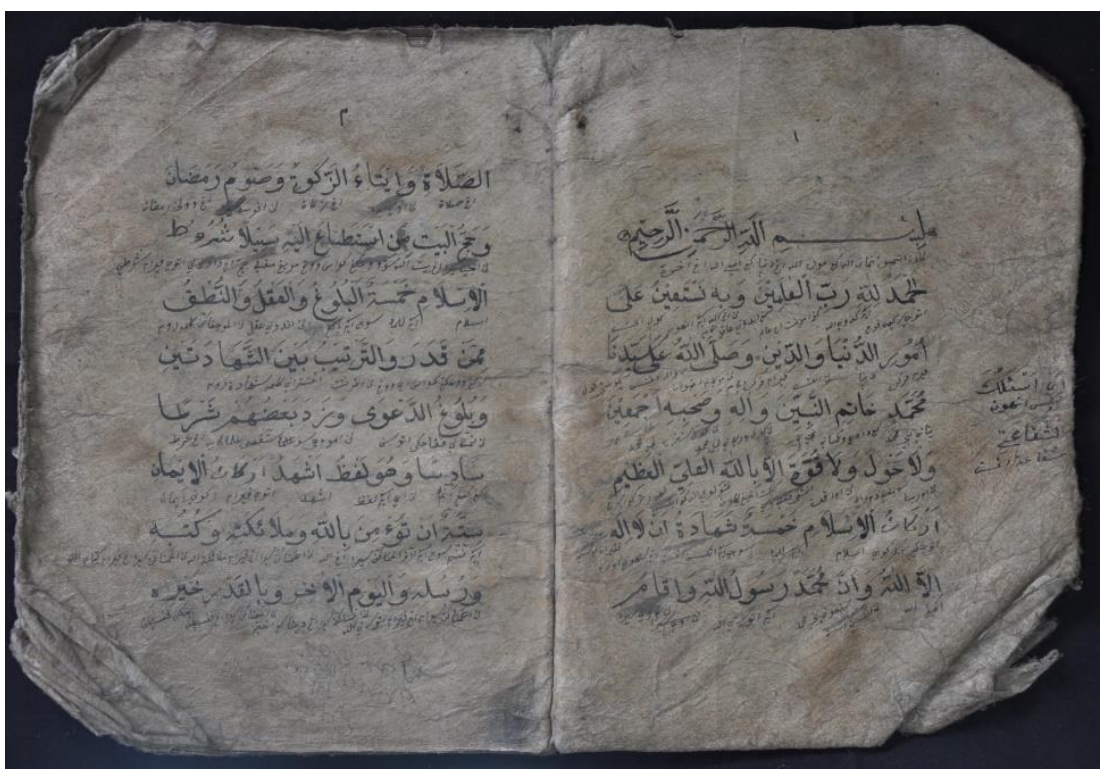

12128 JNGR SUDFD 1272012 HLM 1,2 Img10799 


\begin{tabular}{|l|l|l|l|}
\hline $\begin{array}{l}\text { BLAS/SUM/16/FI/ } \\
\mathbf{5 4}\end{array}$ & $\begin{array}{l}\text { KITAB FIKIH } \\
\text { ȘALAT }\end{array}$ & 4 & Fikih \\
\hline $\begin{array}{l}\text { JNGR/SUDFD/132 } \\
/ 2012\end{array}$ & Arab & Arab & Prosa \\
\hline $24 \mathrm{hlm}$. & 7 baris/hlm. & $19 \times 14$ & Kertas Daluwang \\
\hline K iai Su'udi Fadhal & \\
\hline Jenangger, Batang-batang
\end{tabular}

Isi Teks menjelaskan syarat sahnya salat dan sesuatu yang membatalkan.

Naskah ini dimiliki oleh K Su'udi Fadlal dari Rosyidah dari K Irsyad dari KH Hadi dari Kamsah dari K Biramah. Naskah dalam kondisi cukup baik/cukup terbaca.

\begin{tabular}{|l|l|l|l|}
\hline $\begin{array}{l}\text { BLAS/SUM/16/FI/ } \\
55\end{array}$ & $\begin{array}{l}\text { KITAB BERSUCI } \\
\text { DAN ȘALAT }\end{array}$ & 4 & Fikih \\
\hline $\begin{array}{l}\text { JNGR/SUDFD/134 } \\
/ 2012\end{array}$ & Arab & Arab & Prosa \\
\hline $24 \mathrm{hlm}$. & 6 baris/hlm. & $16 x 13$ & Kertas Daluwang \\
\hline K iai Su'udi Fadhal & \\
\hline Jenangger, Batang-batang
\end{tabular}

Teks menjelaskan tentang tata cara istinja', wuḍu, mandi besar, tayamum, syarat sah dan rukun salat.

Naskah ini dimiliki oleh K. Su'udi Fadlal dari Rosyidah dari K. Irsyad dari K.H. Hadi dari Kamsah dari K. Biramah. Naskah dalam kondisi cukup baik/cukup terbaca. 


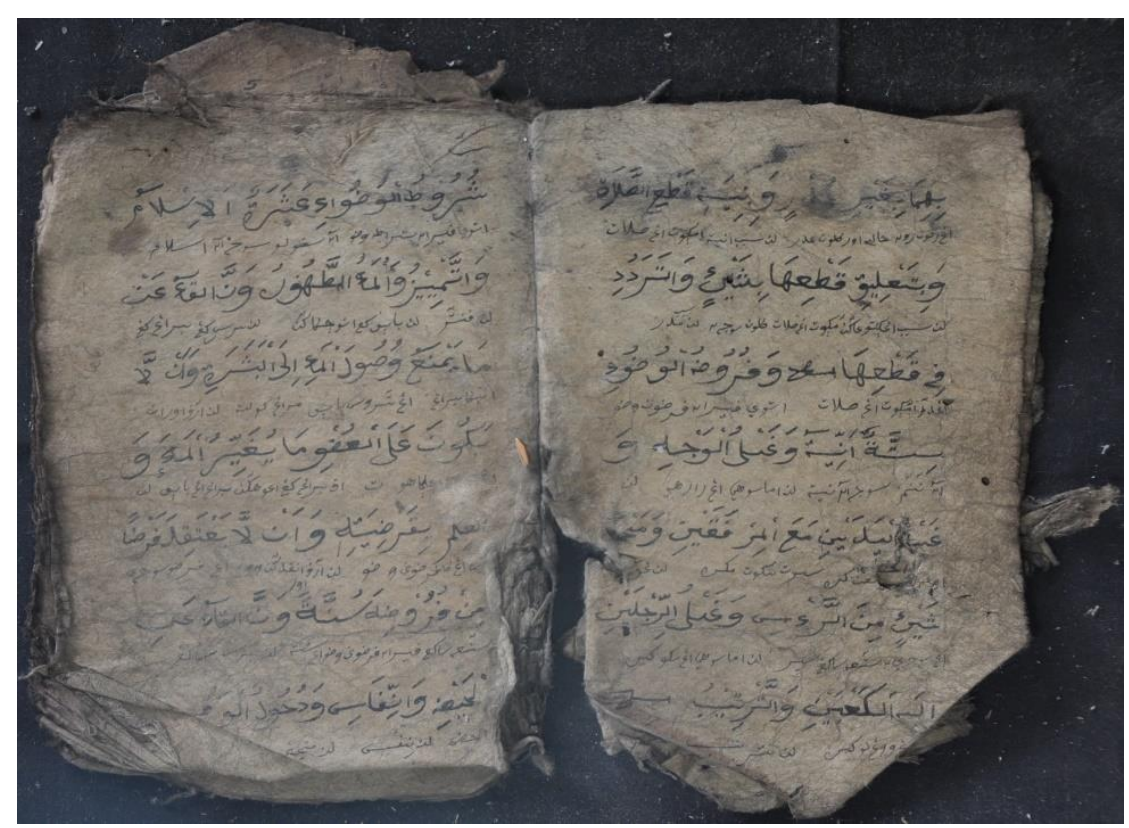

12133 JNGR SUDFD 1322012 HLM 6,7 Img11038

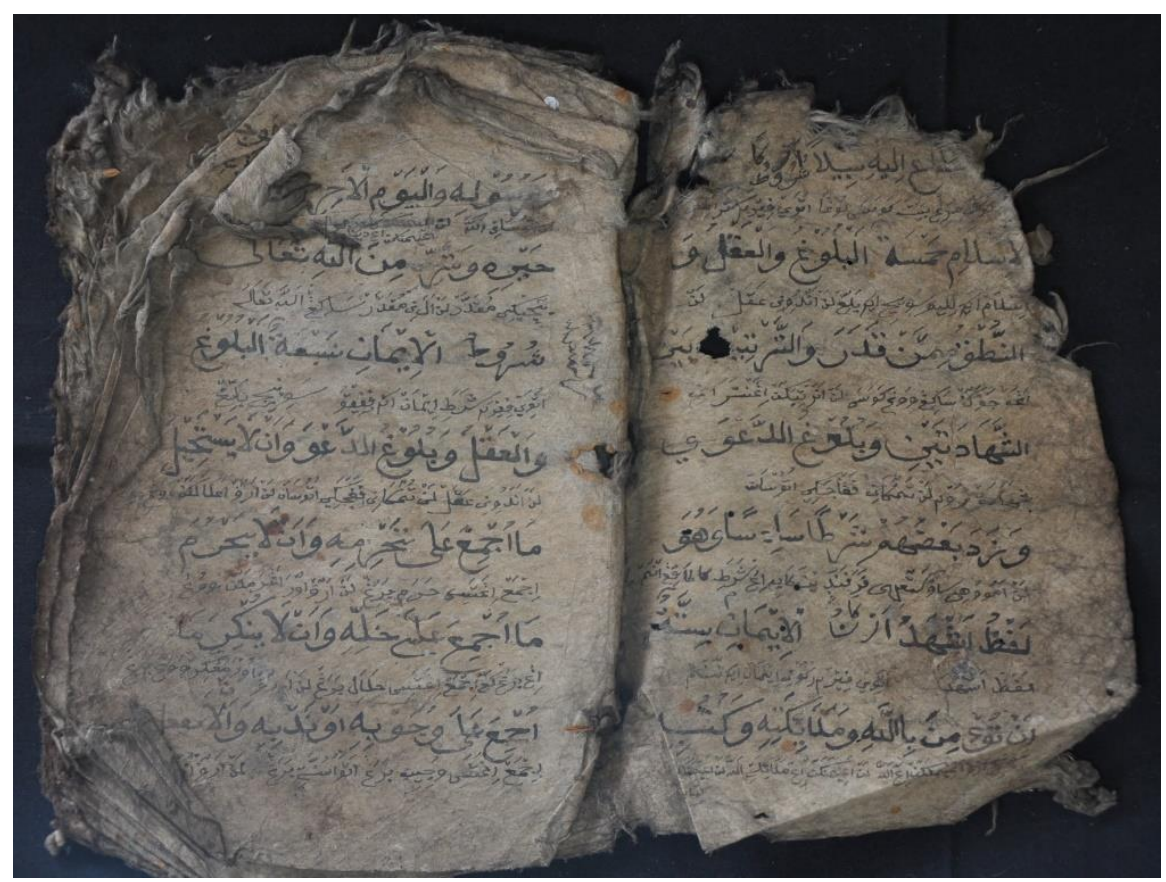

12135 JNGR SUDFD 1342012 HLM 1,2 Img11050 


\begin{tabular}{|l|l|l|l|}
\hline $\begin{array}{l}\text { BLAS/SUM/16/FI/ } \\
\mathbf{5 6}\end{array}$ & $\begin{array}{l}\text { KITAB SAFINAH } \\
\text { DAN LAIN-LAIN }\end{array}$ & 4 & Fikih \\
\hline $\begin{array}{l}\text { JNGR/SUDFD/136 } \\
/ 2012\end{array}$ & Arab & Arab & Prosa \\
\hline $34 \mathrm{hlm}$. & 11 baris/hlm. & $27 \times 17$ & Kertas Daluwang \\
\hline K iai Su'udi Fadhal & \\
\hline Jenangger, Batang-batang
\end{tabular}

Naskah berisi dua teks. Teks pertama bernama Safinah selesai disalin pada hari senin menjelaskan thaharah, tayamum, salat, dan masalah zakat. Teks kedua bernama Hidayatul Mubtadi Limas'alatil Muqtadi menjelaskan tentang tata cara salat jama'ah.

Naskah ini dimiliki oleh K. Su'udi Fadlal dari Rosyidah dari K. Irsyad dari K.H. Hadi dari Kamsah dari K. Biramah. Naskah dalam kondisi cukup baik/cukup terbaca.

\begin{tabular}{|l|l|l|l|}
\hline $\begin{array}{l}\text { BLAS/SUM/16/FI/ } \\
\text { 57 }\end{array}$ & $\begin{array}{l}\text { KITAB SAF̄NAH } \\
\text { DAN KITAB } \\
\text { ANISATUL } \\
\text { MUTTAQIN }\end{array}$ & 4,5 & $\begin{array}{l}\text { Fikih dan } \\
\text { Tasawuf }\end{array}$ \\
\hline GPR 2 & Arab, Jawa & Arab, Arab pegon & Prosa \\
\hline 275 hlm. & 5 dan 22 baris/hlm. & $14.5 \times 9.5$ & Kertas berserat \\
\hline Kiai Masduki & \\
\hline \multicolumn{2}{|l|}{ Gapura Barat, Gapura, Sumenep } \\
\hline
\end{tabular}

Naskah berisi dua teks. Teks pertama teks fikih dari kitab Safinah, selesai penulisan hari ahad bulan Rabiul Awal 1180 H, tanpa penyalin, tanpa judul naskah, berisi wuḍu, mandi wajib, haram bagi yang ber-jinabat, haram bagi yang haid, macam najis, nifas, rukun salat, mandi. Teks kedua tentang tasawuf dengan judul Anisatul Muttaqin berisi bayanil ghoflah, bayanil i'lam, nayanil aqli.

Naskah ini dikoleksi oleh Kiai Masduki Gapura, Kabupaten Sumenep. Naskah baik, teks jelas terbaca. 


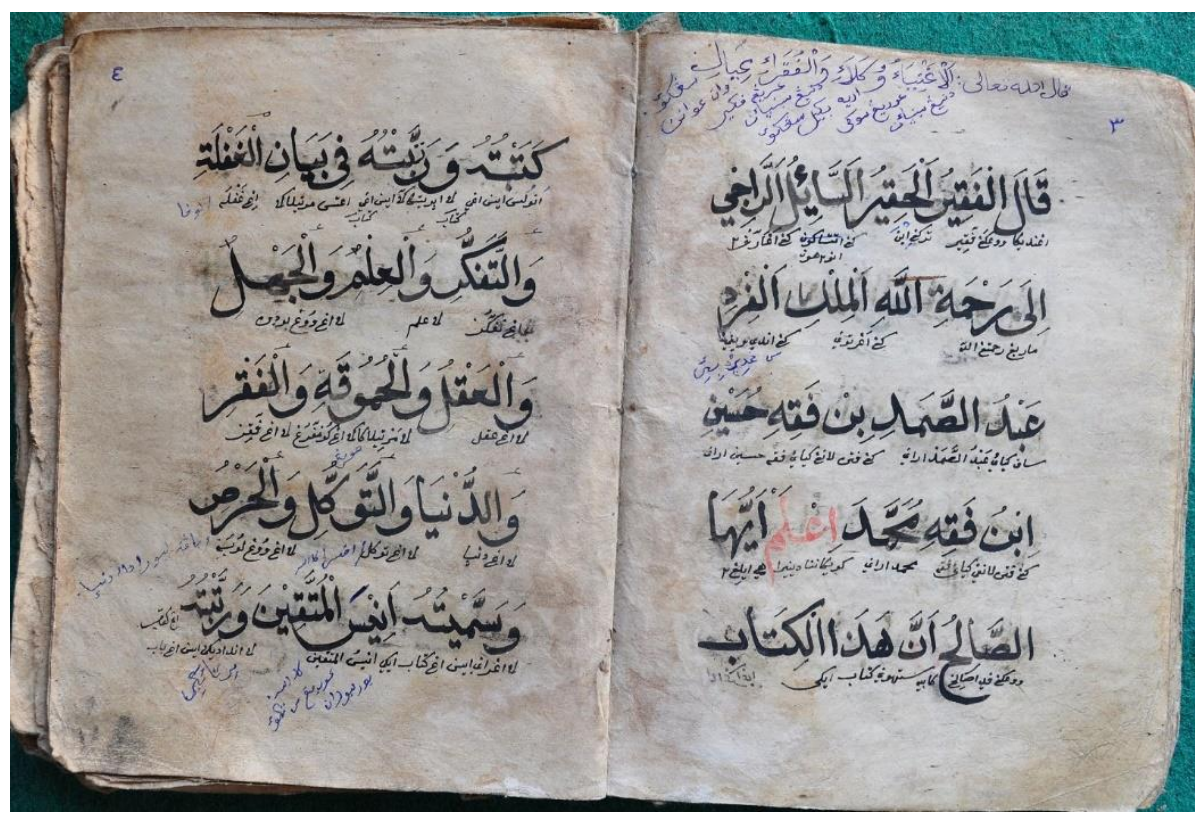

1002 GPR 02_DSC0045.2 


\begin{tabular}{|l|l|l|l|}
\hline $\begin{array}{l}\text { BLAS/SUM/16/FI/ } \\
\mathbf{5 8}\end{array}$ & $\begin{array}{l}\text { KITAB FADILAH } \\
\text { DAN LAIN-LAIN }\end{array}$ & $\mathbf{4 , 5}$ & $\begin{array}{l}\text { Fikih dan } \\
\text { Tasawuf }\end{array}$ \\
\hline $\begin{array}{l}\text { GPRB/NSR/20/201 } \\
2\end{array}$ & Arab & Arab & Prosa \\
\hline $122 \mathrm{hlm}$. & 8 baris/hlm. & $26.5 \times 18.5$ & Kertas Daluwang \\
\hline Nasiruddin & \\
\hline Caremmi, Gapura Barat
\end{tabular}

Naskah ini berisi tujuh teks, yaitu: tentang fadilah, doa mayit, syariat salat, penciptaan alam raya, keutamaan berbuat baik pada kedua orang tua, ilmu tauhid, ilmu akidah.

Naskah ini tersimpan di rumah Nasiruddin dari buyutnya, H. Ghazali. Kondisi naskah cukup baik, ada bagian yang hilang, teks masih terbaca.

\begin{tabular}{|l|l|l|l|}
\hline $\begin{array}{l}\text { BLAS/SUM/16/FI/ } \\
\text { 59 }\end{array}$ & $\begin{array}{l}\text { KITAB MAKNA } \\
\text { SALAT DAN } \\
\text { BERSUCI, DAN } \\
\text { KITAB TAJWID }\end{array}$ & 4 & $\begin{array}{l}\text { Fikih dan Tata } \\
\text { Bahasa }\end{array}$ \\
\hline GPR 11 & Arab & Arab & prosa \\
\hline $20 \mathrm{hlm}$. & 16 baris/hlm. & $28 \times 19.5$ & Kertas () \\
\hline Kiai Masduki & \multicolumn{2}{|l}{} \\
\hline \multicolumn{2}{|l|}{ Gapura Barat, Gapura, Sumenep } \\
\hline
\end{tabular}

Naskah berisi dua teks. Teks pertama menjelaskan makna salat, mulai dari wuḍu dengan menggunakan air sesungguhnya tidak akan hilang ini termasuk sifat uluhiyah, dengan menggunakan selain air (tayamum) bila keadaan darurat. Takbiratul ihram menjelaskan keesaan Tuhan. Surat Fatihah menunjukkan kesempurnan manusia. Ruku' dijelaskan bahwa semua yang diciptakan kedalam jenis baru dibawah ilahiyah. Teks kedua menjelaskan tentang ilmu tajwid namun tidak lengkap, seperti halaman terakhir hilang, penjelasan hanya sampai bacaan idgam.

Naskah ini dikoleksi oleh Kiai Masduki Gapura, Kabupaten Sumenep. Naskah baik, teks jelas terbaca. 


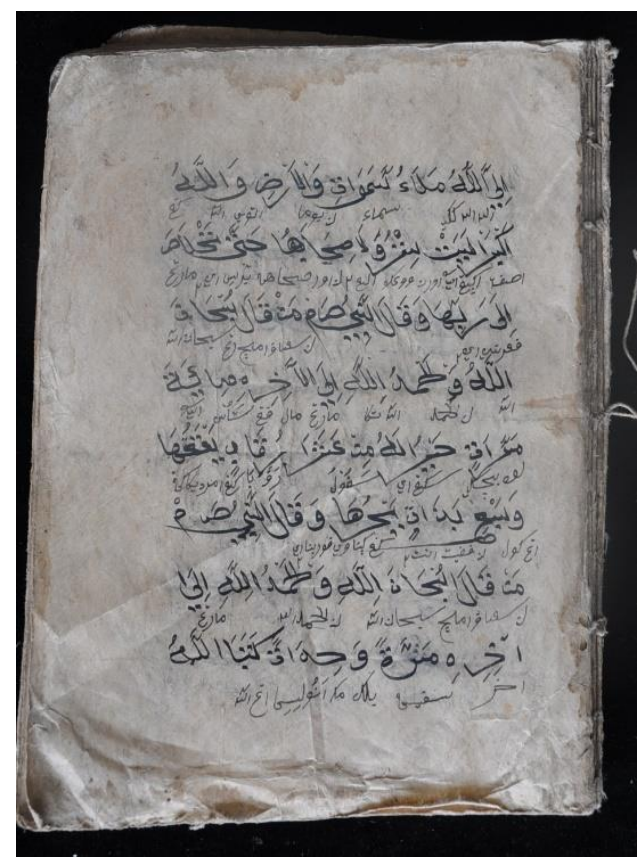

12020 GPRB NSR 202012 HLM 1 Img1312

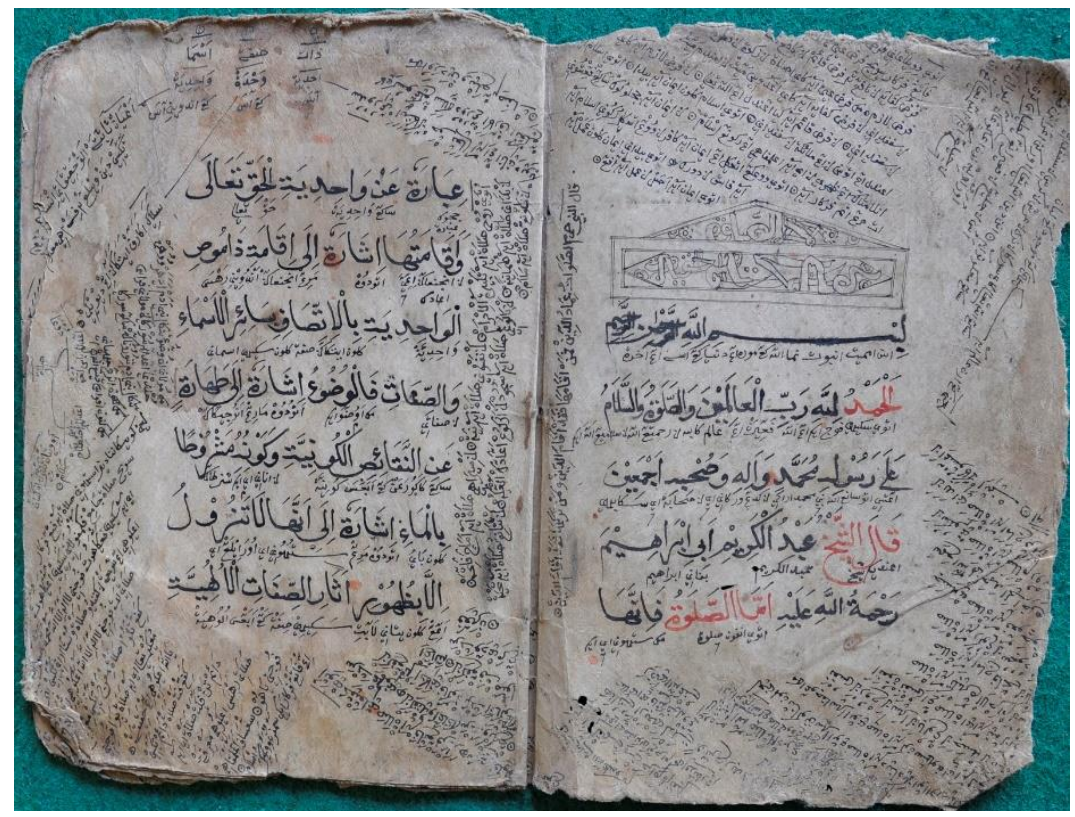

1011 GPR 11_DSC0097.2 


\begin{tabular}{|l|l|l|l|}
\hline $\begin{array}{l}\text { BLAS/SUM/16/FI/ } \\
60\end{array}$ & $\begin{array}{l}\text { KITAB } \\
\text { MAQĀMAT }\end{array}$ & 4,3 & Fikih dan Tauhid \\
\hline GPR 1 & Arab jawa & Arab, Arab pegon & Prosa \\
\hline 168 hlm. & $\begin{array}{l}13 \text { s.d.14 } \\
\text { baris/hlm. }\end{array}$ & $14 \times 11.5$ & Kertas berserat \\
\hline Kiai Masduki & \\
\hline \multicolumn{2}{|l|}{ Gapura Barat, Gapura, Sumenep }
\end{tabular}

Naskah ini berisi empat teks. Teks pertama berupa teks fikih taharah, wudu, salat. Teks ini tidak terdapat nama penuls/penyalin serta waktu penulisan. Teks kedua berupa tembang sinom berisi tentang ubudiyah. Kitab ini merupkan warta dari wali Syaikh Muhamad Ibnu Abd Karim Saman, dinukil dari wasiat Syaikh Tajuddin bin Syaikh Zakaria seorang wali sufi. Teks ketiga berisi tembang kasmaran berisi tasawuf dituis oleh Kyai Sumber bernama Abu Mukti al Hajj Muhamad Maghfur selesai 3-6-1312 H. Teks keempat berisi tembang mas kumambang berisi tauhid, selesi ditulis waktu dhuha hari 3 tanggal 6 tahun bak tidak diketahui penulis/penyalin naskah.

Naskah ini dikoleksi oleh Kiai Masduki Gapura, Kabupaten Sumenep. Naskah baik, teks jelas terbaca.

\begin{tabular}{|l|l|l|l|}
\hline $\begin{array}{l}\text { BLAS/SUM/16/FI/ } \\
61\end{array}$ & $\begin{array}{l}\text { KITAB FIKIH } \\
\text { BERSUCI DAN } \\
\text { KITAB SIFAT } \\
\text { ALLAH }\end{array}$ & 4,3 & $\begin{array}{l}\text { Fikih, Akaid dan } \\
\text { ilmu kalam }\end{array}$ \\
\hline BT-BT 20 & Arab & Arab & Prosa \\
\hline 37 hlm. & 7 baris/hlm. & $28 \times 19$ & Kertas Daluwang \\
\hline Abdrurrahman & \\
\hline \multicolumn{2}{|l|}{ Dusun Laok Saba, Nyabakan Timur, batang-Batang } \\
\hline
\end{tabular}

Naskah ini berisi dua buah teks, teks pertama memuat tat acara bersuci dari hadas, mandi jinabat, salat. Teks kedua memuat sifat-sifat Allah. Teks diberi makna gandul/jenggotan pada tiap kata/kalimat. Di kanan dan kiri teks (margin) terdapat catatan-catat

Naskah ini dimiliki oleh Abdurrahman dari Mudallah. Tahun dan tempat penyusunan tidak disebutkan. Kondisi naskah sebagian rusak sebagian baik, masih dapat dibaca. Tinta menggunakan warna hitam dan merah. 


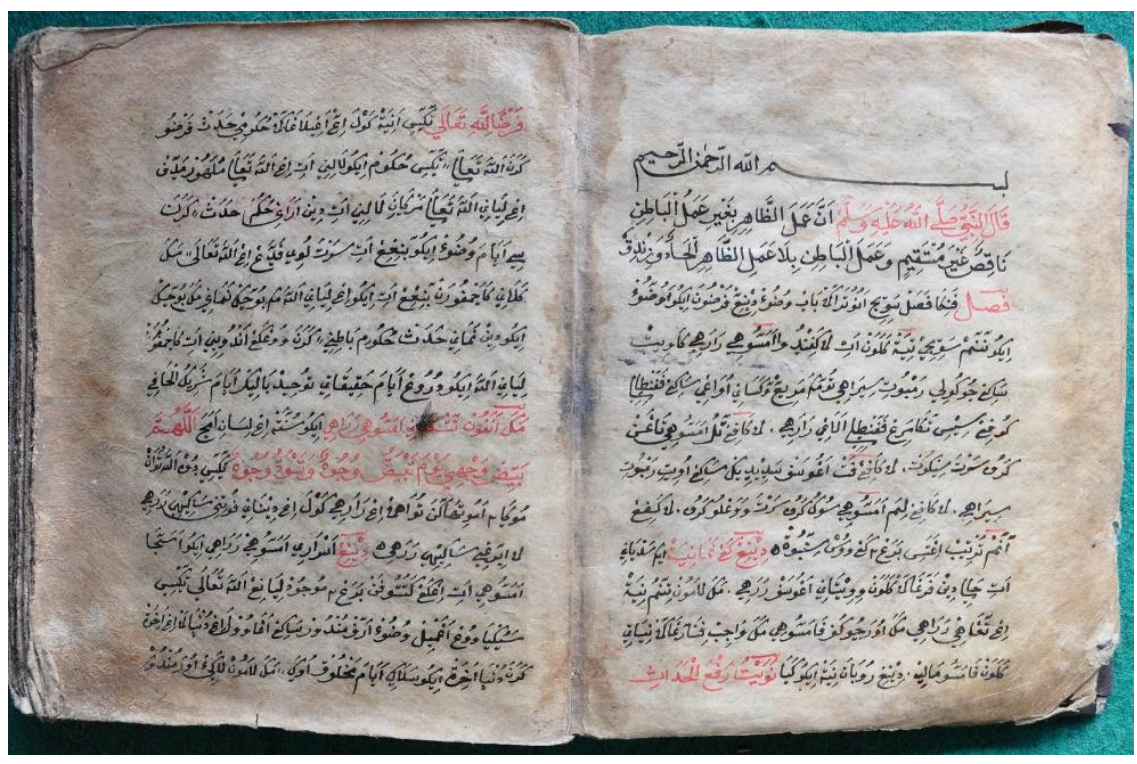

1001 GPR 01_DSC0145

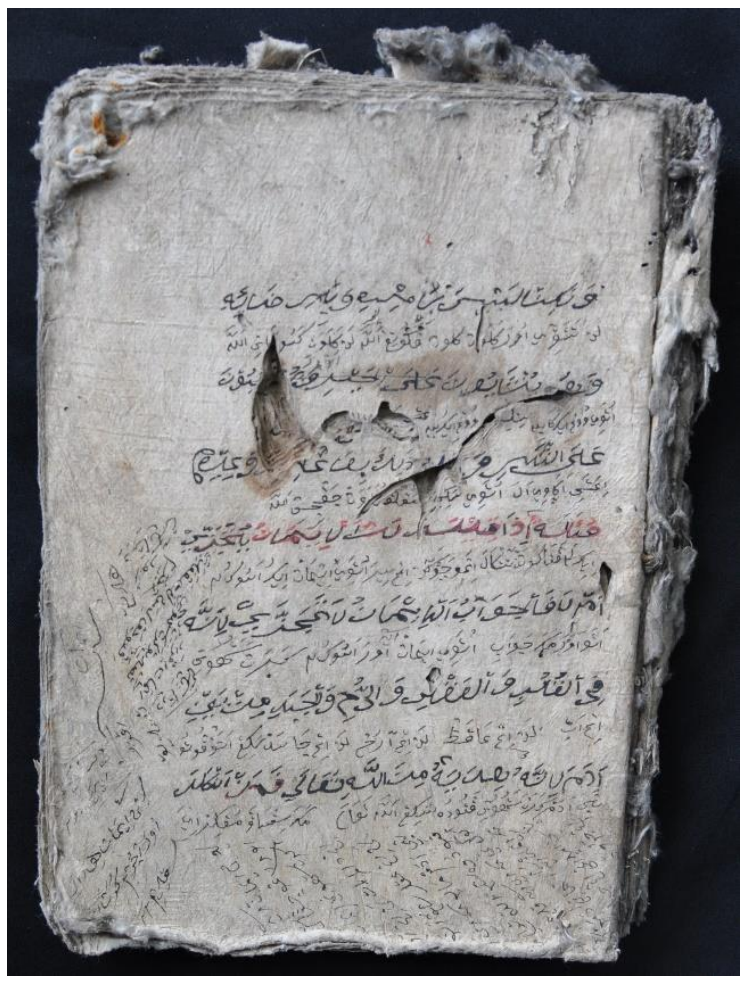

1150 BTBT 20 HLM 1 DSC_0001 


\begin{tabular}{|l|l|l|l|}
\hline $\begin{array}{l}\text { BLAS/SUM/16/FI/ } \\
62\end{array}$ & $\begin{array}{l}\text { KITAB FIKIH } \\
\text { BERSUCI DAN } \\
\text { TAUHID }\end{array}$ & 4,3 & $\begin{array}{l}\text { Fikih, Akaid dan } \\
\text { ilmu kalam }\end{array}$ \\
\hline BT-BT 37 & Arab & Arab & Prosa \\
\hline 192 hlm. & 11,19 baris/hlm. & $26.5 \times 18$ & Kertas Daluwang \\
\hline Aziz & \multicolumn{2}{|l}{} \\
\hline \multicolumn{2}{|l|}{ Dusun Nyabungan, Jenangger, Batang-Batang. } \\
\hline
\end{tabular}

Di dalam naskah terdapat empat teks; teks pertama menjelaskan tentang air, bersuci, teks kedua berisi tentang fatwa-fatwa politik, teks ketiga berisi mengenai tauhid, dan teks keempat berisikan mengenai tauhid.

Naskah ini dimiliki oleh Aziz dari Haji As'ad dari Suhilal dari Kiai Siwallah. Tahun dan tempat penyusunan tidak disebutkan, hanya terdapat keterangan "Teks 1 penulisan selesai pada hari kamis waktu dhuhur", teks 2,3,4 tidak diketahui. Kondisi naskah rusak sedang, masih dapat dibaca. Tinta menggunakan warna hitam merah.

\begin{tabular}{|l|l|l|l|}
\hline $\begin{array}{l}\text { BLAS/SUM/16/FI/ } \\
63\end{array}$ & $\begin{array}{l}\text { KITAB JAM'U } \\
\text { FURUDIN }\end{array}$ & 4,3 & $\begin{array}{l}\text { Fikih, Akaid Ilmu } \\
\text { Tata Bahasa } \\
\text { Arab }\end{array}$ \\
\hline $\begin{array}{l}\text { MCT/AWR/100/20 } \\
12\end{array}$ & Arab & Arab & Prosa \\
\hline 396 hlm. & $7,11,15$ baris/hlm. & $26 \times 17.5$ & Kertas Daluwang \\
\hline K.H. A Waris & & \\
\hline Muncek Tengah Kenteng
\end{tabular}

Naskah ini berisi delapan teks. Teks pertama menjelaskan tentang peristiwa lailatul qadar, bila masuk Ramadan hari Ahad maka turun lailatul qadar tanggal 27 Ramadan, bila masuk Ramadan hari Senin lailatul qadar turun malam 29 dan doa-doa. Teks kedua bernama kitab Mufid syarah Daurah. Selesai ditulis pada Selasa hari kamis 18 Ramadhan setelah subuh sebelum zuhur zaman ke tujuh, teks ini menjelaskan ilmu tauhid dan implementasinya. Teks ketiga bernama Jam'u Furudin disusun oleh Moh. Zahid merupakan rangkuman dari beberapa kitab yang menjelaskan tentang bersuci, berwuḍu, salat dengan terinci. Teks keempat menjelaskan tentang ilmu tajwid seperti nun mati bertemu huruf fa' dinamakan ikhfa. Teks kelima bernama Samarqandi menjelaskan akidah 50 dengan hukum akal. Teks keenam merupakan kumpulan doa-doa. Teks ketujuh bernama Syarah Durratul Fakhirah menjelaskan tentang ilmu tauhid. Teks kedelapan bernama al-Farqu menjelaskan ujub dan kibir melahirkan kebesaran sesuatu.

Naskah milik K.H. A Waris dari K.H. Miftakhul Khair dari K.H. Syamsul Arifin dari K.H. Moh Nur dari K.H. Abdul Kairan dari K.H. Zaidun (Syeh Umar). 


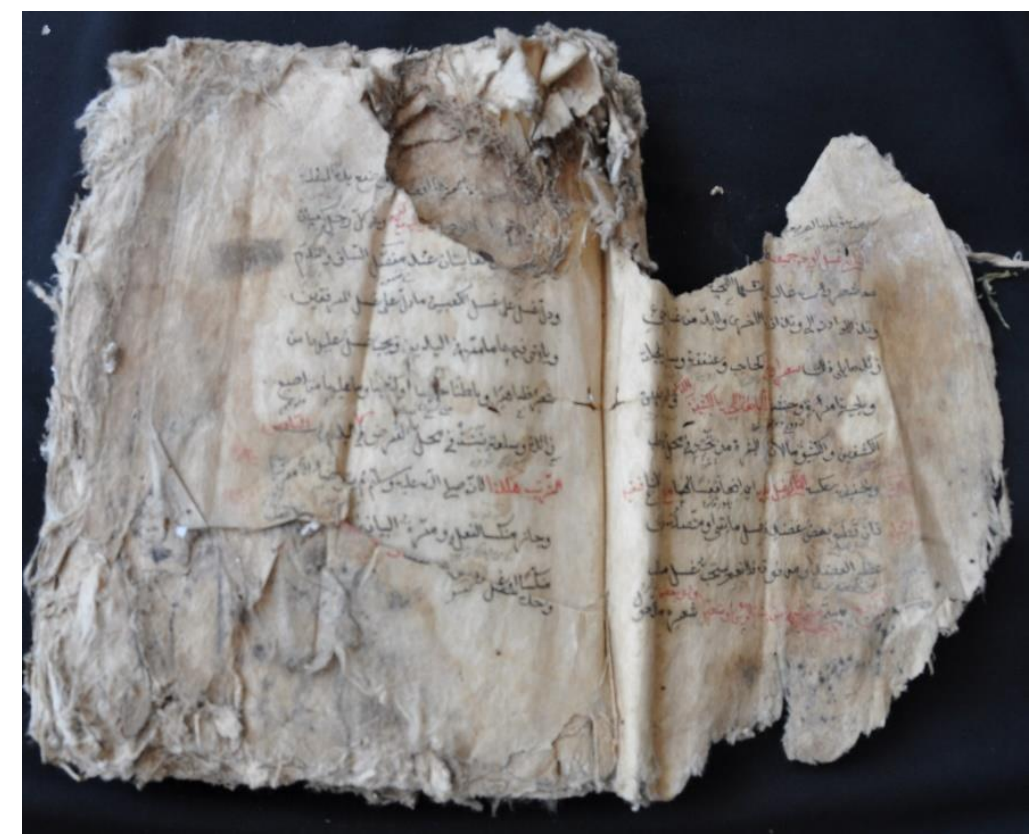

1167 BTBT 37 HLM 2,3 DSC_0003

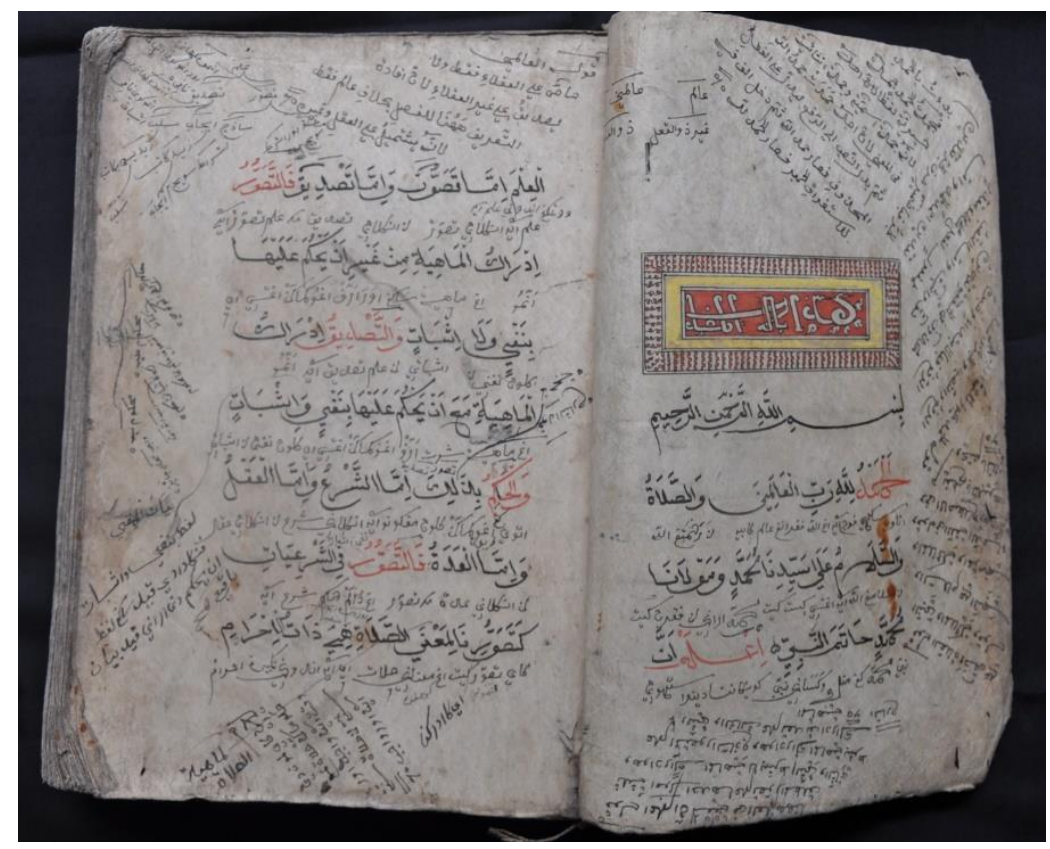

12101 MCT AWR 1002012 HLM 1,2 Img9270 


\begin{tabular}{|l|l|l|l|}
\hline $\begin{array}{l}\text { BLAS/SUM/16/FI/ } \\
64\end{array}$ & $\begin{array}{l}\text { KITAB } \\
\text { PENGOBATAN, } \\
\text { FIKIH } \\
\text { MUAMALAH, } \\
\text { DAN DOA }\end{array}$ & 4,5 & $\begin{array}{l}\text { Fikih, Akhlak } \\
\text { dan tasawuf }\end{array}$ \\
\hline BT-BT 45 & Jawa & Arab & Prosa \\
\hline 76 hlm. & 13 baris/hlm. & $22.5 \times 15.5$ & Kertas Daluwang \\
\hline Kiai Khalid & \\
\hline Dusun Nyabungan, Jenangger, Batang-Batang. \\
\hline
\end{tabular}

Naskah ini menjelaskan tentang pengobatan, jual beli, khiyar, qirad, suluh, khiwala, doadoa, hari-hari baik untuk mengerjakan sesuatu.

Naskah ini dimiliki oleh Kiai Khalid dari Kiai Fadlun dari Kiai Khomsidin. Tahun dan tempat penyusunan tidak disebutkan. Kondisi naskah tanpa sampul, tulisan dapat dibaca. Tinta menggunakan warna hitam.

\begin{tabular}{|l|l|l|l|}
\hline $\begin{array}{l}\text { BLAS/SUM/16/FI/ } \\
65\end{array}$ & $\begin{array}{l}\text { KITAB FIKIH } \\
\text { MUAMALAH } \\
\text { DAN DOA }\end{array}$ & 4,5 & $\begin{array}{l}\text { Fikih, Akhlak } \\
\text { dan tasawuf }\end{array}$ \\
\hline BT-BT 46 & Arab & Arab & Prosa \\
\hline 90 hlm. & $22 \times 15$ & Kertas Daluwang \\
\hline Kiai Khalid & \multicolumn{2}{|l}{} \\
\hline \multicolumn{2}{|l|}{ Dusun Nyabungan, Jenangger, Batang-Batang. } \\
\hline
\end{tabular}

Naskah ini menjelaskan tentang jual beli, khiyar, qirad, suluh, khiwala, doa-doa, harihari baik untuk mengerjakan sesuatu.

Naskah ini dimiliki oleh Kiai Khalid dari Kiai Fadlun dari Kiai Khomsidin. Tahun dan tempat penyusunan tidak disebutkan. Kondisi naskah rusak, hanya dapat dibaca sebagian. Tinta menggunakan warna hitam. 


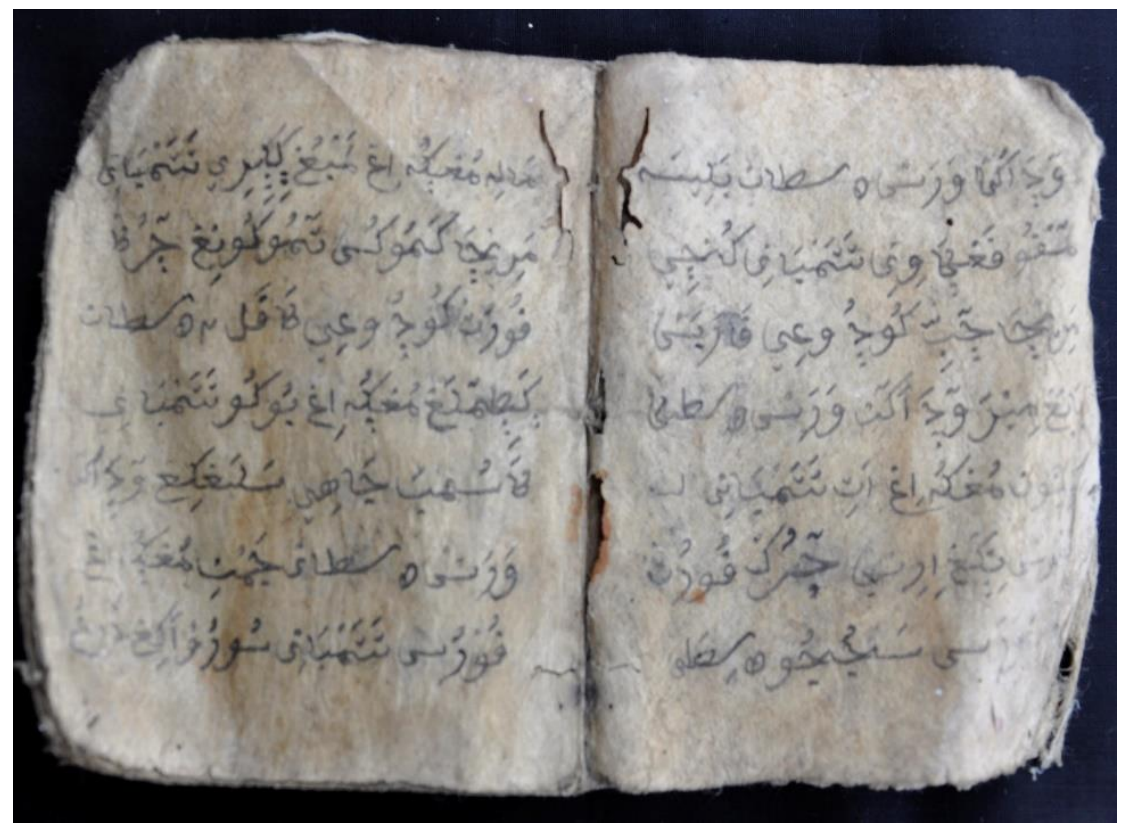

1175 BTBT 45 HLM 4,5_DSC0003

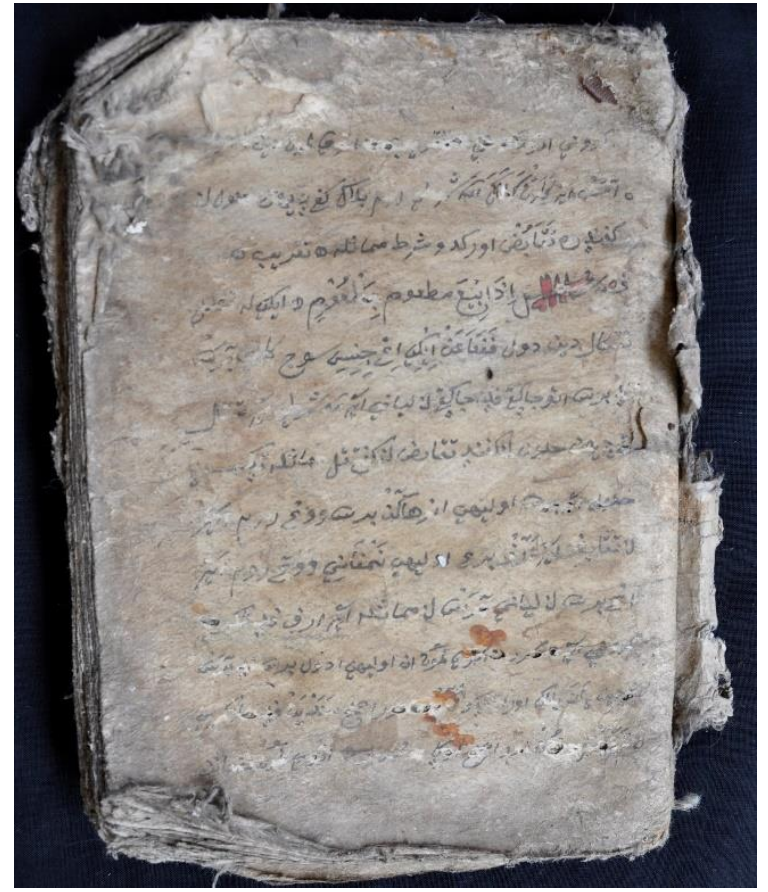

1176 BTBT 46 HLM 2,3_DSC0038 


\begin{tabular}{|l|l|l|l|}
\hline $\begin{array}{l}\text { BLAS/SUM/16/FI/ } \\
66\end{array}$ & $\begin{array}{l}\text { KITAB AHKĀM } \\
\text { ȚAHARAH DAN } \\
\text { LAIN-LAIN }\end{array}$ & 4,0 & $\begin{array}{l}\text { Fikih, doa, doa al } \\
\text { istinfar, Fikih, } \\
\text { tafsir surat al } \\
\text { fatihah }\end{array}$ \\
\hline GPR 9 & Arab, Arab pegon & Arab, Arab pegon & prosa \\
\hline 320 hlm. & 15 baris/hlm. & $29.5 \times 20$ & Kertas berserat \\
\hline Kiai Masduki & \\
\hline \multicolumn{2}{|l|}{ Gapura Barat, Gapura, Sumenep } \\
\hline
\end{tabular}

Naskan berisi beberapa teks. Teks pertama bernama Kitab Ahkamu Taharah menjelaskan tentang air, wuḍu, istinja', mandi wajib dan sebab-sebabnya, zakat, puasa, haji, muamalah, waris. Teks kedua berupa doa. Teks ketiga berisi doa al istinfar. Teks keempat tafsir surat al fatihah. Teks kelima berisi tauhid. Teks keenam berisi sifat nabi. Teks ketujuh, delapan, dan sembilan merupakan kelanjutan dari teks sebelumnya.

Naskah ini dikoleksi oleh Kiai Masduki Gapura, Kabupaten Sumenep. Naskah baik, teks jelas terbaca.

\begin{tabular}{|l|l|l|l|}
\hline $\begin{array}{l}\text { BLAS/SUM/16/FI/ } \\
67\end{array}$ & $\begin{array}{l}\text { KITAB TANYA } \\
\text { JAWAB TAUHID } \\
\text { DAN FIQH }\end{array}$ & 4,3 & Fikih, tauhid \\
\hline GPR 12 & Arab & Arab & prosa \\
\hline 96 hlm. & 7 baris/hlm. & $28.5 \times 19$ & Kertas berserat \\
\hline Kiai Masduki & \multicolumn{2}{|l}{} \\
\hline Gapura Barat, Gapura, Sumenep
\end{tabular}

Naskah berisi tiga teks. Teks pertama kitab fikih, cara menjelaskan dengan model tanya jawab. Teks kedua kitab tauhid, menjelaskan tentang wajibnya membaca syahadat, kemudian arti dari kalimat syahadat. Teks ketiga doa dari ayat-ayat Alquran, hukum akal, dan macam-macamnya.

Naskah ini dikoleksi oleh Kiai Masduki Gapura, Kabupaten Sumenep. Naskah baik, teks jelas terbaca. 


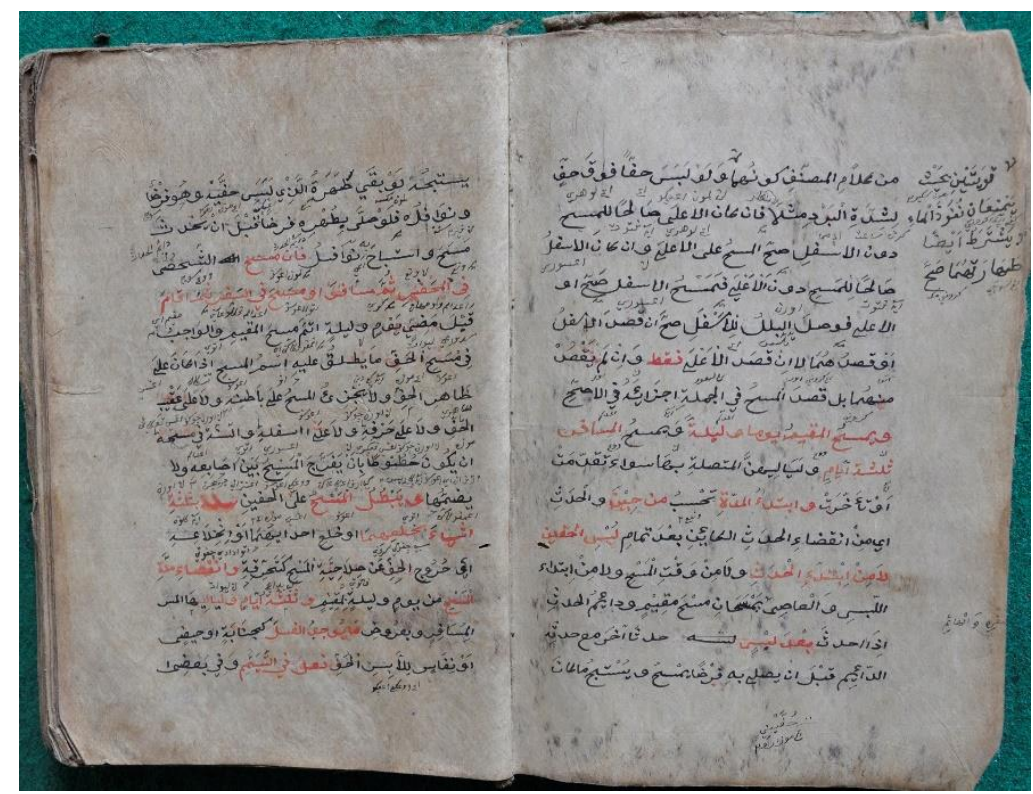

1009 GPR 09 DSC0013.2

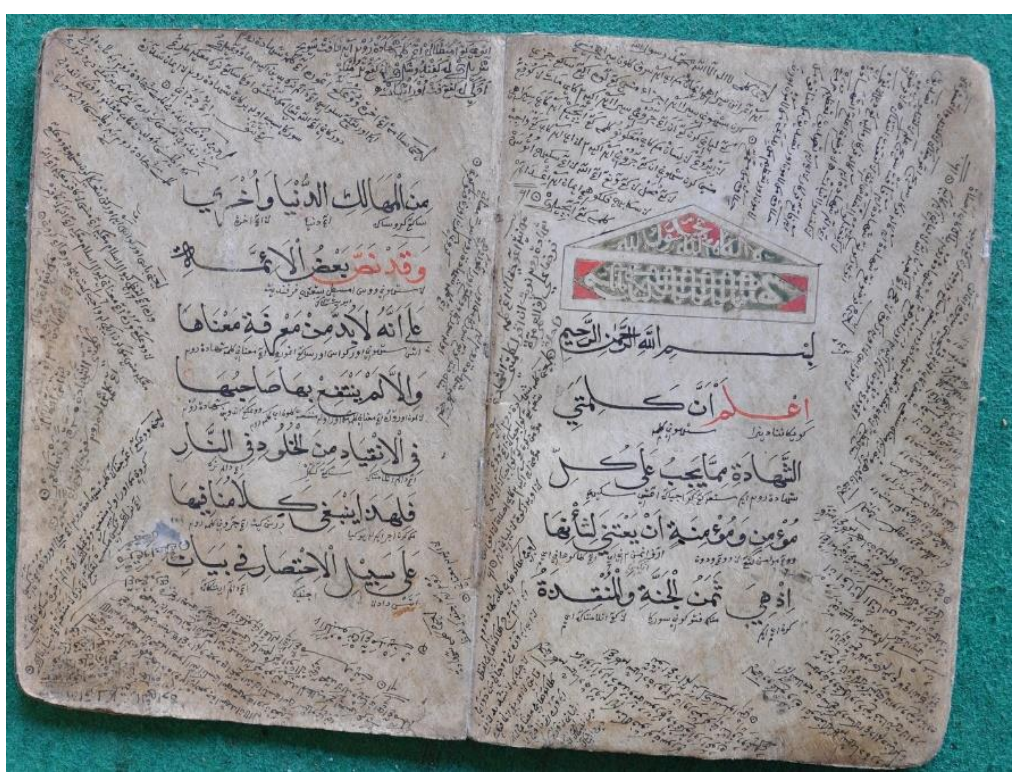

1012 GPR 12_DSC0024.2 


\begin{tabular}{|l|l|l|l|}
\hline $\begin{array}{l}\text { BLAS/SUM/16/FI/ } \\
68\end{array}$ & $\begin{array}{l}\text { KITAB SYARAH } \\
\text { SITTIN }\end{array}$ & 4,3 & Fikih, Tauhid \\
\hline GPR 25 & Arab, Jawa Pegon & Arab & Prosa \\
\hline 76 hlm. & 10 baris/hlm. & 17 x14.6 & Kertas Eropa \\
\hline Kiai Mansur & $\begin{array}{l}\text { Disimpan oleh cucu angkat Kyai Mansur Majid yang bernama Kyai Hafas di dusun } \\
\text { Lambi Cabi, Gapura Tengah, Gapura, Sumenep }\end{array}$ \\
\hline
\end{tabular}

Naskah berisi beberapa teks, meliputi fikih, hukum akal, tauhid (kitab Zurah), dan lainnya. Teks ditulis menggunakan tinta hitam dan tinta merah sebagai penjelas. Naskah disalin pada hari Selasa ba'da asyar, bulan Syawal, tanggal 29 tahun 1312.

Naskah milik Kiai Hafas dari Kiai Mansur. Kondisi fisik naskah dalam keadaan rusak, tetapi tulisan masih bisa dibaca.

\begin{tabular}{|c|c|c|c|}
\hline $\begin{array}{l}\text { BLAS/SUM/16/FI/ } \\
69\end{array}$ & $\begin{array}{l}\text { KITAB AD- } \\
\text { DURARUL } \\
\text { BAHIYAH }\end{array}$ & 4 & $\begin{array}{l}\text { Hukum } \\
\text { Islam/Fikih }\end{array}$ \\
\hline $\begin{array}{l}\text { PJGSGG/MDN/148 } \\
/ 2012\end{array}$ & Arab & Arab & Prosa \\
\hline $124 \mathrm{hlm}$. & 7 baris/hlm. & $21 \times 16$ & Kertas Daluwang \\
\hline
\end{tabular}

Teks bernama Addurarul Bahiyah disusun oleh Sayid Bakri Syato, yang memiliki kitab Azhari, teks ini bagian depan menjelaskan kewajiban muslim untuk mengerjakan kewajiban kepada Allah seperti iman, syariat.

Naskah ini dimiliki oleh H. Madani dari K. Abdul Karim Kondisi naskah tergolong baik. 


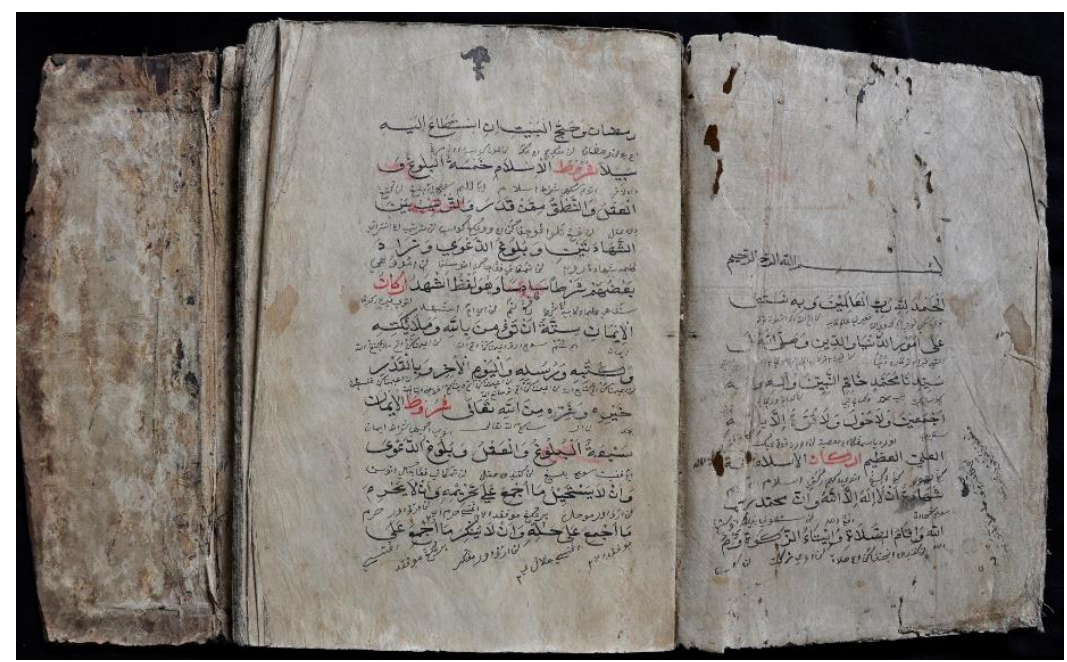

1111 GPR 25 HLM 1,2_DSC0090

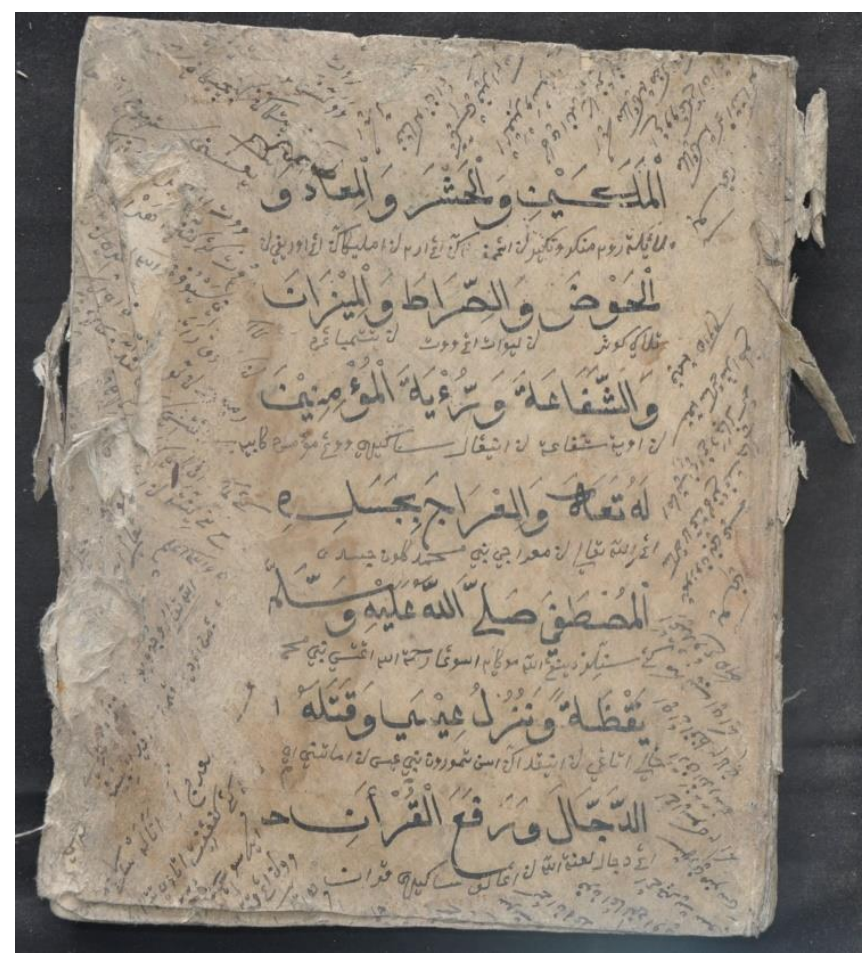

12149 PJGSGG MDN 1482012 HLM 1 Img12274 


\begin{tabular}{|l|l|l|l|}
\hline $\begin{array}{l}\text { BLAS/SUM/16/FI/ } \\
70\end{array}$ & KITAB HAJI & $\mathbf{4 , 5}$ & $\begin{array}{l}\text { Hukum } \\
\text { Islam/Fikih dan } \\
\text { Akhlak/Tasawuf }\end{array}$ \\
\hline $\begin{array}{l}\text { PJGSGG/HSM/156 } \\
/ 2012\end{array}$ & Arab & Arab & Prosa \\
\hline $18 \mathrm{hlm}$. & 2 baris/hlm. & $21 \times 17$ & Kertas Daluwang \\
\hline K.H. Hasim & \\
\hline Pajung, Sergang, Batu Putih, Sumenep & \\
\hline
\end{tabular}

Teks menjelaskan tentang niat salat sunnah, haji, ihram, dan doa-doa, siapa yang menemui Ramadan dan berpuasa di Makkah maka akan dicatat seribu Ramadan.

Naskah ini dimiliki oleh K.H. Hasim dari K.H. Azhari. Kondisi naskah tergolong baik.

\begin{tabular}{|l|l|l|l|}
\hline $\begin{array}{l}\text { BLAS/SUM/16/FI/ } \\
71\end{array}$ & $\begin{array}{l}\text { KITAB FIKIH } \\
\text { DAN LAIN-LAIN }\end{array}$ & 4,3 & $\begin{array}{l}\text { Tauhid, Fikih, } \\
\text { asrorul fatihah, } \\
\text { ma'rifatu an } \\
\text { nikah,kitab } \\
\text { tauhid dan kitab } \\
\text { fasholatan }\end{array}$ \\
\hline SMN 1 & Arab, Jawa pegon & Arab, Arab pegon & prosa \\
\hline 218 hlm. & $30 \times 25$ & Kertas () \\
\hline Kiai Said Abdullah & \multicolumn{2}{|l|}{} \\
\hline PP Matholiul Anwar Pengarangan Sumenep \\
\hline
\end{tabular}

Naskah terdiri dari beberapa kitab. Kondisinya kurang terawat sehingga sebagian rusak dengan iluminasi. Teks pertama menjelaskan rukun iman dengan model tanya jawab dari rukun iman dan perinciannya. Teks kedua menjelaskan fikih dimulai tent ang pentingnya mencari ilmu.

Naskah dimiliki oleh Kiai Sa'id Abdullah, Pengarangan Sumenep. 


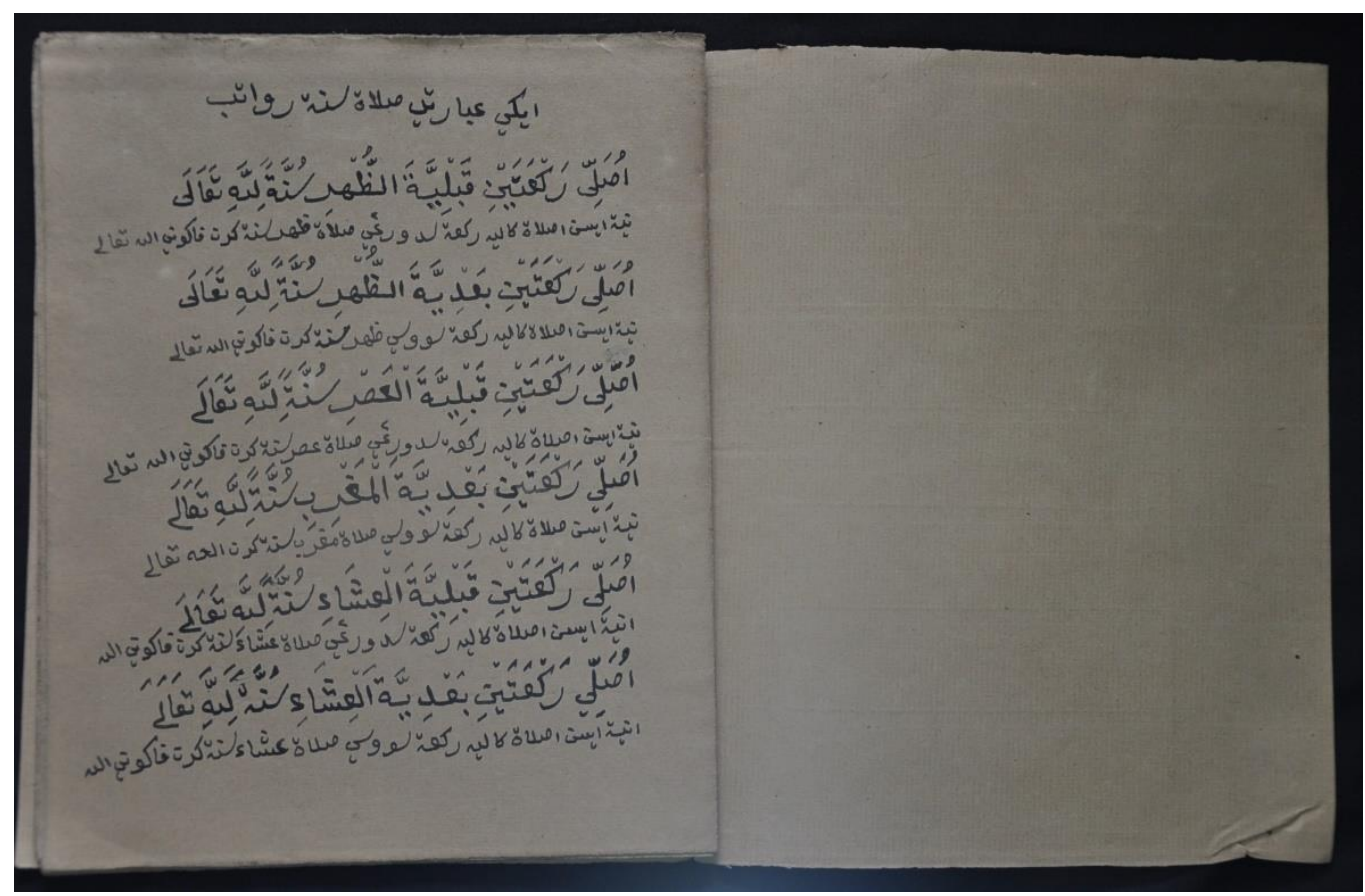

12157 PJGSGG HSM 1562012 HLM 1 Img12847 


\section{AT}

\section{Akhlak dan tasawuf}

\begin{tabular}{|l|l|l|l|}
\hline $\begin{array}{l}\text { BLAS/SUM/16/AT } \\
\mathbf{1}\end{array}$ & $\begin{array}{l}\text { KITAB MAQSUD } \\
\text { TUJUH NABI } \\
\text { MUHAMMAD }\end{array}$ & $\mathbf{5}$ & Tasawuf \\
\hline GPR 3 & Arab, Jawa (pegon) & Arab, Arab pegon & Prosa \\
\hline 19 hlm. & $\begin{array}{l}19 \text { s.d. } 20 \\
\text { baris/hlm. }\end{array}$ & $25 \times 19$ & Kertas berserat \\
\hline \multicolumn{2}{|l|}{ Kiai Masduki } & \\
\hline \multicolumn{2}{|l|}{ Gapura Barat, Gapura, Sumenep } \\
\hline
\end{tabular}

Di awal teks naskah ini menyebutkan "Inilah ilmu maksud tujuh Nabi Muhamad".Teks ini menjelaskan perumpamaan-perumpmaan nilai-nilai luhur disamping juga ilmu tauhid seperti kaata wahdah yang menunjukkan hakekat manusia yaitu ruh idlafi yang dibalut dengan empat perkara yakni wujud, ilmu, an nur, syuhud, dan lainnya.

Naskah ini dikoleksi oleh Kiai Masduki Gapura, Kabupaten Sumenep. Naskah baik, teks jelas terbaca.

\begin{tabular}{|l|l|l|l|}
\hline $\begin{array}{l}\text { BLAS/SUM/16/AT } \\
\text { 2 }\end{array}$ & $\begin{array}{l}\text { KITAB } \\
\text { MUBĀRAK DAN } \\
\text { LAIN-LAIN }\end{array}$ & $\mathbf{5}$ & $\begin{array}{l}\text { Primbon, } \\
\text { Tasawuf, } \\
\text { kumpulan doa- } \\
\text { doa }\end{array}$ \\
\hline GPR 4 & Arab, Jawa (pegon) & Arab, Arab pegon & prosa \\
\hline 74 hlm. & 5 hal-16 hal & $24.3 \times 18.5$ & Kertas berserat \\
\hline Kiai Masduki & \multicolumn{2}{|l}{} \\
\hline \multicolumn{2}{|l|}{ Gapura Barat, Gapura, Sumenep }
\end{tabular}

Naskah ini berisi lima teks. Teks pertama berisi primbon menjeaskan nama untuk anak. Teks kedua menjelaskan tentang syahadat dan sifatnya. Teks ketiga berupa Macapat. Teks keempat berisi tentang baik dan buruk (rijalullah dilangit ketujuh). Teks kelima berupa kumpulan doa-doa seperti doa salat, doa taubat.

Naskah ini dikoleksi oleh Kiai Masduki Gapura, Kabupaten Sumenep. Naskah baik, teks jelas terbaca. 


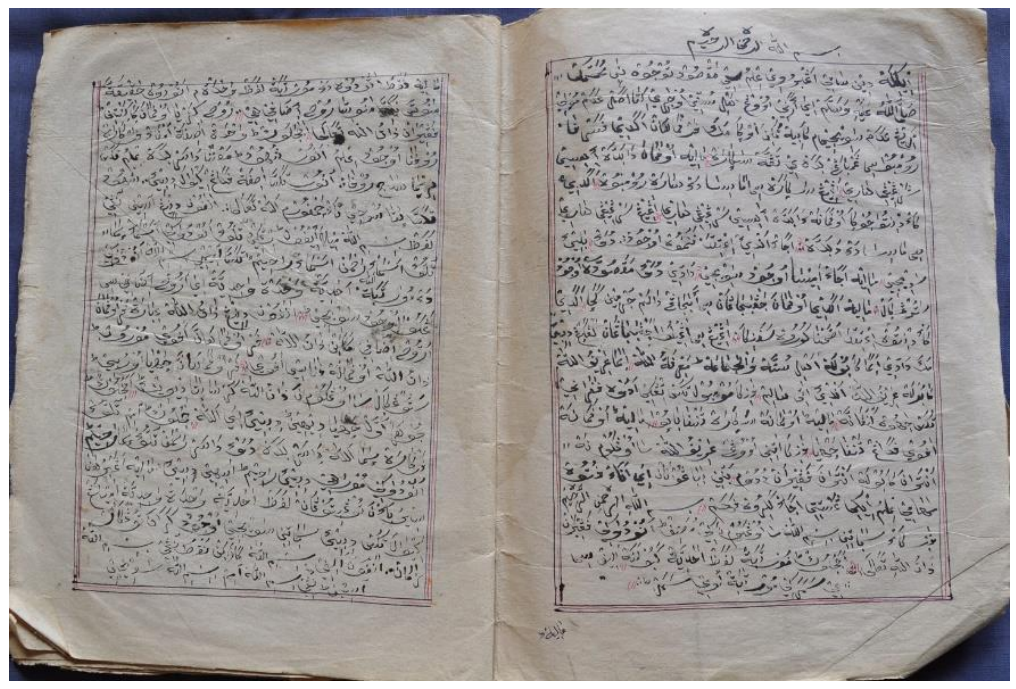

\section{GPR 03_DSC0003.3}

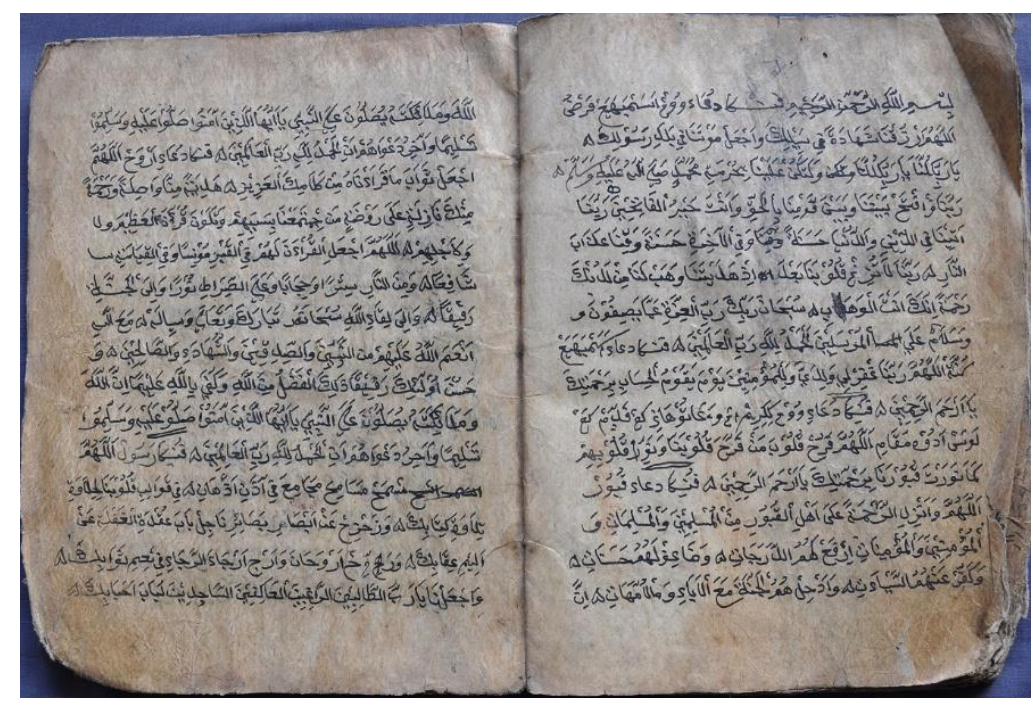

1004 GPR 04_DSC0032.2 


\begin{tabular}{|l|l|l|l|}
\hline $\begin{array}{l}\text { BLAS/SUM/16/AT } \\
\text { 3 }\end{array}$ & $\begin{array}{l}\text { KITAB } \\
\text { HOROSKOP } \\
\text { JAWA DAN } \\
\text { KITAB ILMU } \\
\text { BATIN }\end{array}$ & 5 & $\begin{array}{l}\text { Primbon Jawa, } \\
\text { Tasawuf }\end{array}$ \\
\hline GPR 6 & Arab, Jawa pegon & Arab, Arab pegon & prosa \\
\hline 334 hlm. & 18 baris/hlm. & $28.7 \times 21.5$ & Kertas () \\
\hline Kiai Masduki & & \\
\hline Gapura Barat, Gapura, Sumenep & \\
\hline
\end{tabular}

Naskah ini menjelaskan tentang horoskop jawa, ilmu batin, ilmu tasawuf, dan primbon. Dalam bab terakhir berceritera tentang Pangeran Bintoro Demak.

Naskah ini dikoleksi oleh Kiai Masduki Gapura, Kabupaten Sumenep. Naskah baik, teks jelas terbaca.

\begin{tabular}{|l|l|l|l|}
\hline $\begin{array}{l}\text { BLAS/SUM/16/AT } \\
\text { /4 }\end{array}$ & $\begin{array}{l}\text { KITAB } \\
\text { TASAWUF }\end{array}$ & $\mathbf{T}$ & Tasawuf \\
\hline GPR 16 & Arab & Arab & Puisi \\
\hline 37 hlm. & 11 baris/hlm. & $22 \times 17.5$ & Kertas Eropa \\
\hline Ilyas & \\
\hline \multicolumn{2}{|l|}{ Durbugan Banjar Barat, Gapura Sumenep } \\
\hline
\end{tabular}

Naskah ini berisi keterangan tentang beberapa aspek dalam tasawuf meliputi taubat, qana'ah, tawakal, ikhlas, adab bagi qari' dan huffadz (penghafal Alquran), ilmu, ta'lim, tanda-tanda ulama yang baik, adab akal, dan adab tidur. Pada halaman sampul dalam terdapat tulisan dengan aksara Arab berbunyi "hadza haq haji Utsman Bayuayu wanuqilat hadza al-haq ila "Abdihi Muhammad 'Aqil Talesek". Beberapa kata dan kalimat dalam teks terdapat terjemahan dengan model jenggotan/gandul dengan aksara Arab bahasa Jawa (pegon) dengan tinta hitam dan biru. Naskah disusun pada malam Jumat bulan Zulqaidah tanpa tahun.

Naskah milik Ilyas, dari Qosim, dari Kiai Idrur, dari Kiai Mahdi. Naskah bersampul kertas tipis warna cokelat, dan kondisi naskah dalam keadaan rusak tetapi tulisan masih dapat dibaca. 


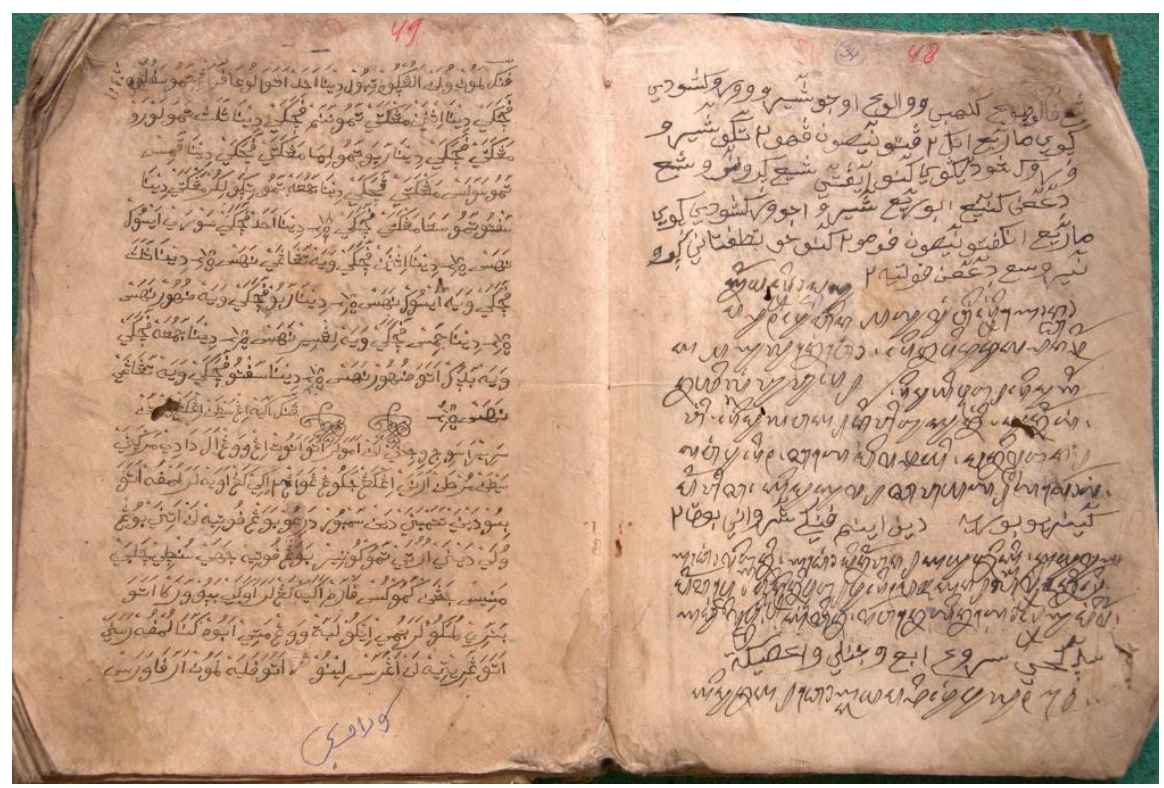

\section{GPR 06_DSC0018.3}

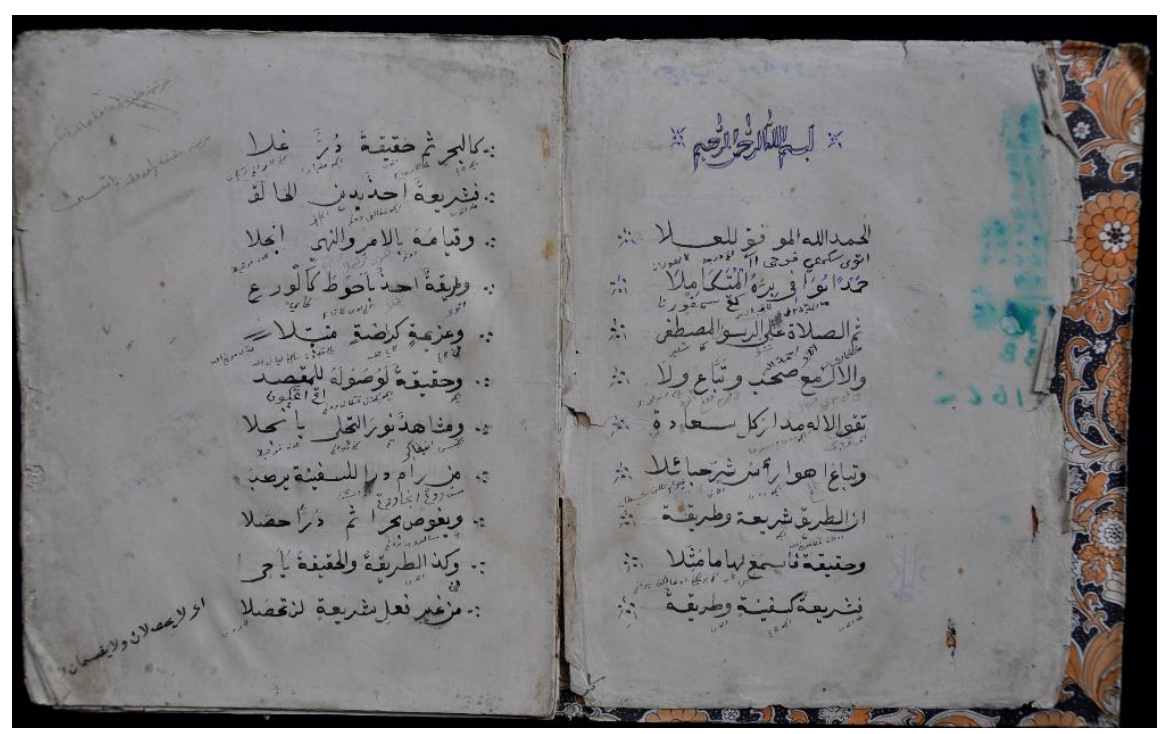

1102 GPR 16 HLM 2,3_DSC0022 


\begin{tabular}{|l|l|l|l|}
\hline $\begin{array}{l}\text { BLAS/SUM/16/AT } \\
\text { /5 }\end{array}$ & KITAB DOA & 5 & $\begin{array}{l}\text { Akhlak dan } \\
\text { Tasawuf }\end{array}$ \\
\hline GPR 36 & Arab & Arab & Prosa \\
\hline 136 hlm. & 7 baris/hlm. & $13.5 \times 9$ & Kertas Daluwang \\
\hline Ibnu Aqil & \\
\hline Dusun Pangabesan, Gapura Timur, Gapura, Sumenep \\
\hline
\end{tabular}

Naskah berisi kutipan ayat-ayat Kitab Alquran dan doa-doa. Pada tiap akhir ayat ditandai dengan lingkaran warna merah. Teks naskah ditulis menggunakan tinta hitam tanpa penomoran halaman.

Naskah milik Ibnu Aqil dari ayahnya yang bernama Sarmidi. Kondisi naskah dalam keadaan rusak tanpa sampul, tetapi tulisan masih dapat dibaca.

\begin{tabular}{|l|l|l|l|}
\hline $\begin{array}{l}\text { BLAS/SUM/16/AT } \\
\text { /6 }\end{array}$ & $\begin{array}{l}\text { KITAB FADILAH } \\
\text { RAMĀPAN }\end{array}$ & 5 & $\begin{array}{l}\text { Akhlak dan } \\
\text { tasawuf }\end{array}$ \\
\hline GPR 38 & Arab, Jawa Pegon & Arab & $\begin{array}{l}\text { Prosa dan Puisi } \\
\text { pada halaman } \\
\text { paling akhir }\end{array}$ \\
\hline 14 hlm. & 13 baris/hlm. & $24.5 \times 17.5$ & Kertas Eropa \\
\hline Kiai Zahidi Bisri & \\
\hline \multicolumn{2}{|l|}{ Dusun Pasar Pocok, Desa Paloklo'an, Gapura, Sumenep } \\
\hline
\end{tabular}

Naskah berisi materi tentang fadilah bulan Ramadhan disalin oleh Kyai Minhaji. Teks ditulis menggunakan tinta hitam, tanpa sampul dan terdapat cap kertas bergambar seperti Gajah dan tulisan "Andrea Galiani".

Naskah milik Kiai Zahidi Bisri dari Kiai Khudaifi, dari Kiai Masyhuri. Kondisi naskah dalam keadaan baik meskipun beberapa halaman depan hilang namun tulisan masih bisa dibaca. 


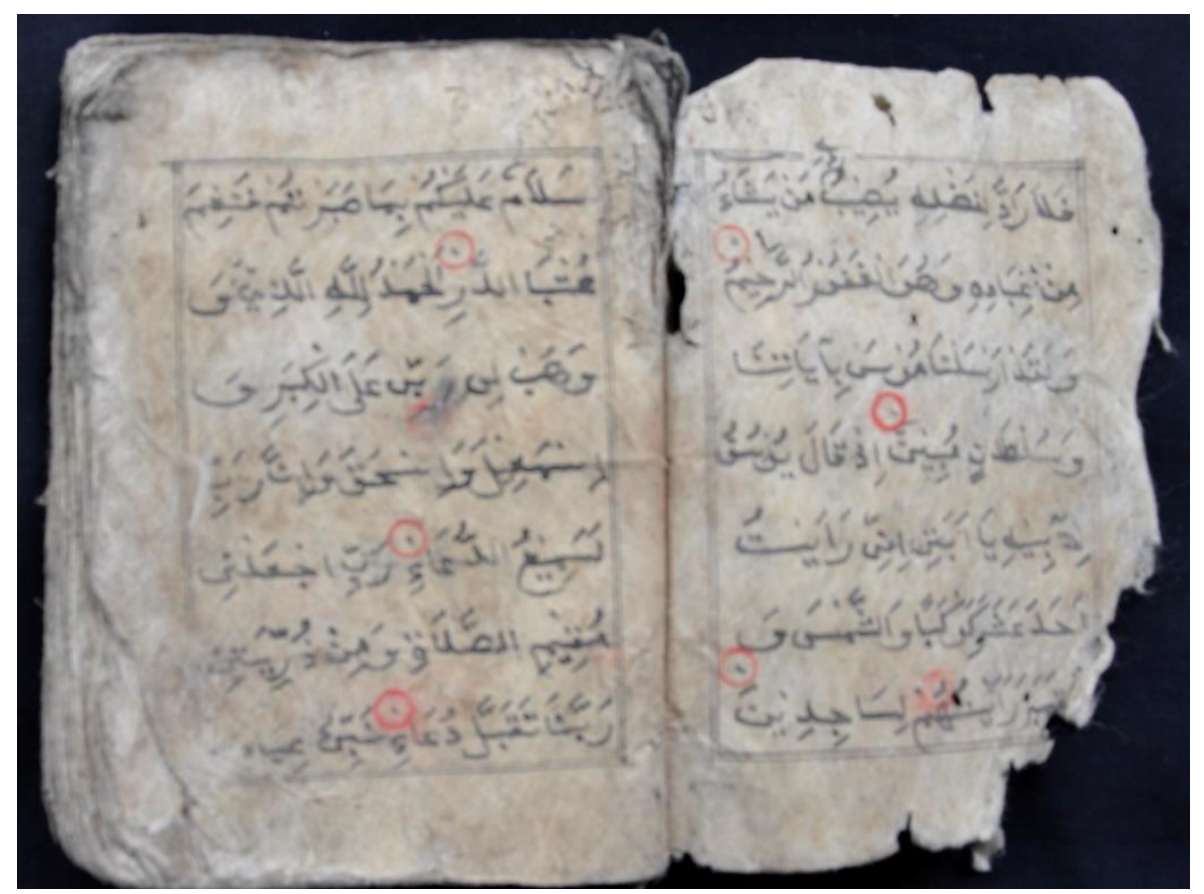

1122 GPR 36 HLM 4,5_DSC0036

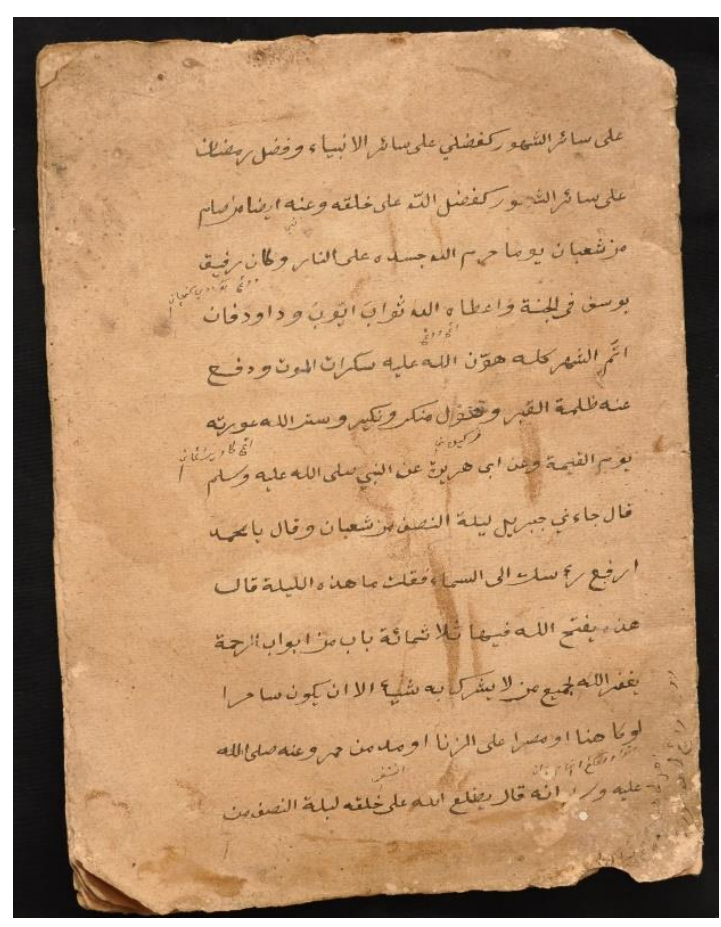

1124 GPR 38 HLM 1 DSC_0096 


\begin{tabular}{|l|l|l|l|}
\hline $\begin{array}{l}\text { BLAS/SUM/16/AT } \\
/ 7\end{array}$ & $\begin{array}{l}\text { KITAB AN- } \\
\text { NI'AM 'ALA } \\
\text { NAZAM AL- } \\
\text { HIKAM }\end{array}$ & 5 & Tasawuf \\
\hline GDG 2 & Arab, Jawa Pegon & Arab & $\begin{array}{l}\text { Puisi dan natsar } \\
\text { (prosa) }\end{array}$ \\
\hline 16 hlm. & bervariasi & $20 \times 16$ & Kertas \\
\hline \multicolumn{2}{|l}{ Kiai Fayad/Nyai Zainab } \\
\hline \multicolumn{2}{|l}{ Pesantren Karai, Karai Gending, Sumenep } \\
\hline
\end{tabular}

Naskah berisi tentang pembahasan materi tasawuf. Naskah disusun di Sampang, Madura dan pengarang naskah bernama Abdul Wakhid bin Khuzaifah. Teks naskah ditulis dengan menggunakan tinta hitam.

Naskah milik Nyai Zainab. Kondisi naskah dalam keadaan baik dan tulisan masih dapat dibaca.

\begin{tabular}{|l|l|l|l|}
\hline $\begin{array}{l}\text { BLAS/SUM/16/AT } \\
\text { /8 }\end{array}$ & $\begin{array}{l}\text { KITAB TATA } \\
\text { CARA } \\
\text { BERPERILAKU }\end{array}$ & $\mathbf{5}$ & $\begin{array}{l}\text { Akhlak dan } \\
\text { tasawuf }\end{array}$ \\
\hline BT-BT 41 & Arab & Arab & Prosa \\
\hline $24 \mathrm{hlm}$. & 9 baris/hlm. & $24 \times 17$ & Kertas Eropa \\
\hline Aziz & \multicolumn{2}{|l}{} \\
\hline Dusun Nyabungan, Jenangger, Batang-Batang.
\end{tabular}

Naskah ini menjelaskan tat a cara berperilaku bukan hanya kepada sesama manusia, juga dalam beribadah yang dilengkapi dengan sabda nabi dan ayat Alquran.

Naskah ini dimiliki oleh Aziz dari Haji As'ad dari Suhilal dari Kiai Siwallah. Tahun dan tempat penyusunan tidak disebutkan. Kondisi naskah rusak, tetapi masih dapat dibaca. Tinta menggunakan warna hitam. 


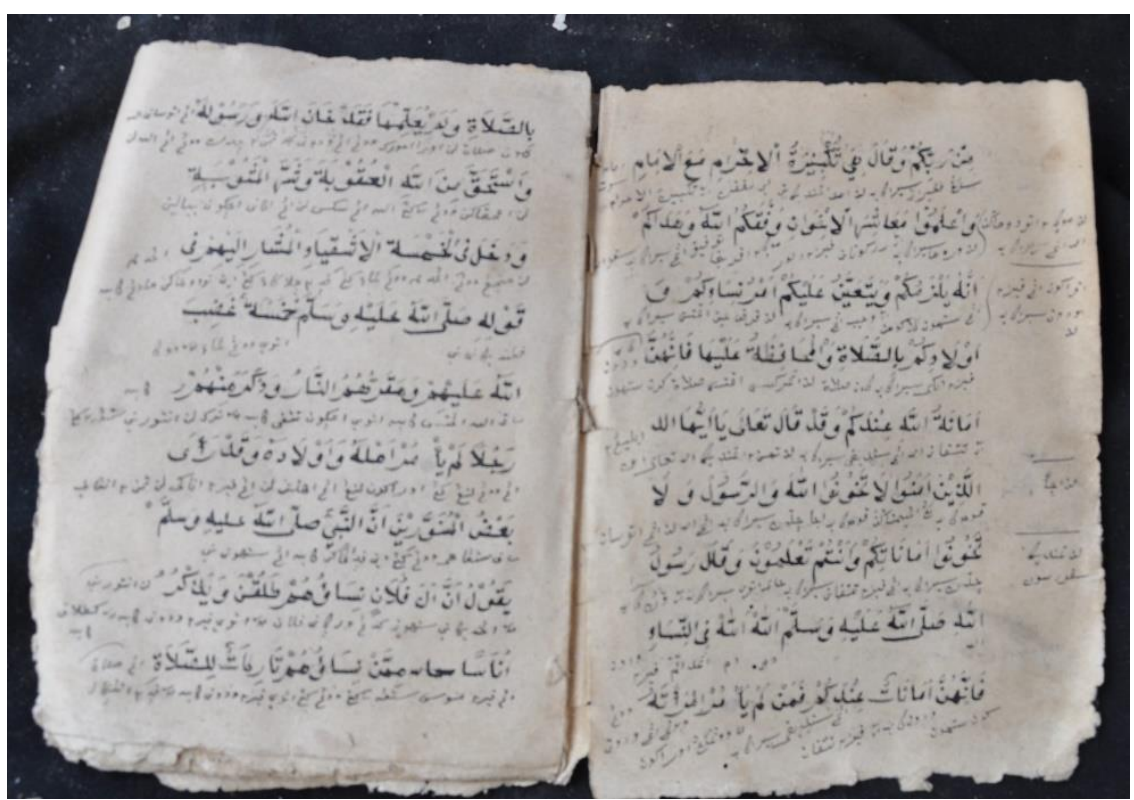

1171 BTBT 41 HLM 2,3 DSC_0270 


\begin{tabular}{|l|l|l|l|}
\hline $\begin{array}{l}\text { BLAS/SUM/16/AT } \\
\mathbf{9}\end{array}$ & $\begin{array}{l}\text { KITAB AMAL } \\
\text { BAIK DAN } \\
\text { BURUK }\end{array}$ & $\mathbf{5}$ & $\begin{array}{l}\text { Akhlak dan } \\
\text { tasawuf }\end{array}$ \\
\hline BT-BT 43 & Jawa Madura & Arab & Prosa \\
\hline $12 \mathrm{hlm}$. & 16 baris/hlm. & $28 \times 17$ & Kertas Daluwang \\
\hline Aziz & \\
\hline Dusun Nyabungan, Jenangger, Batang-Batang. \\
\hline
\end{tabular}

Naskah ini menjelaskan mengenai seorang yang berbuat baik akan menerima pahala dengan tangan kanan, dan kiri bila menerima keburukan.

Naskah ini dimiliki oleh Aziz dari Haji As'ad dari Suhilal dari Kiai Siwallah. Tahun dan tempat penyusunan tidak disebutkan. Kondisi naskah rusak. Tinta menggunakan warna hitam dan merah.

\begin{tabular}{|l|l|l|l|}
\hline $\begin{array}{l}\text { BLAS/SUM/16/AT } \\
\text { /10 }\end{array}$ & $\begin{array}{l}\text { KITAB DOA } \\
\text { KEKEBALAN }\end{array}$ & 5 & $\begin{array}{l}\text { Akhlak dan } \\
\text { tasawuf }\end{array}$ \\
\hline BT-BT 44 & Madura & Arab & Prosa \\
\hline $66 \mathrm{hlm}$. & 7 baris/hlm. & $12 \times 9$ & Kertas Daluwang \\
\hline Aziz & \\
\hline Dusun Nyabungan, Jenangger, Batang-Batang. \\
\hline
\end{tabular}

Naskah ini menjelaskan mengenai doa-doa kekebalan dan sebagainya.

Naskah ini dimiliki oleh Aziz dari Haji As'ad dari Suhilal dari Kiai Siwallah. Tahun dan tempat penyusunan tidak disebutkan. Kondisi naskah rusak, tetapi masih dapat dibaca. Tinta menggunakan warna hitam. 


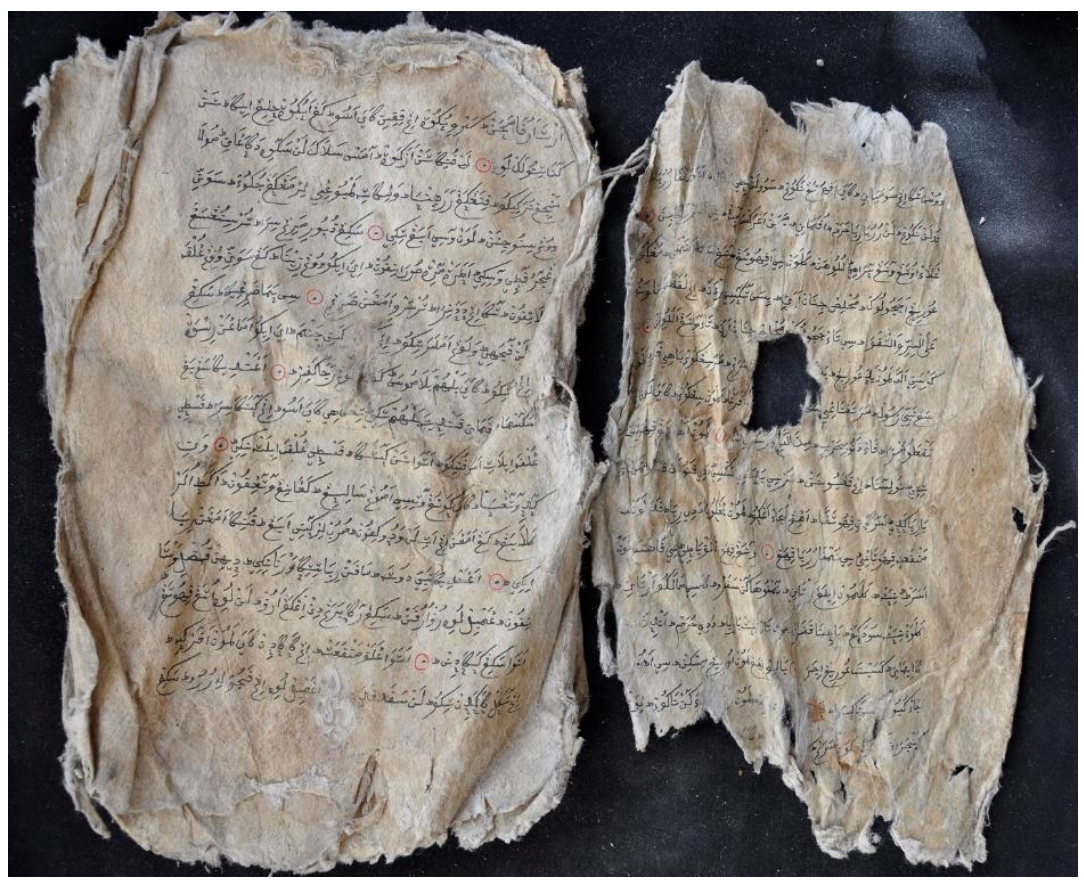

1173 BTBT 43 HLM 2,3 DSC0029

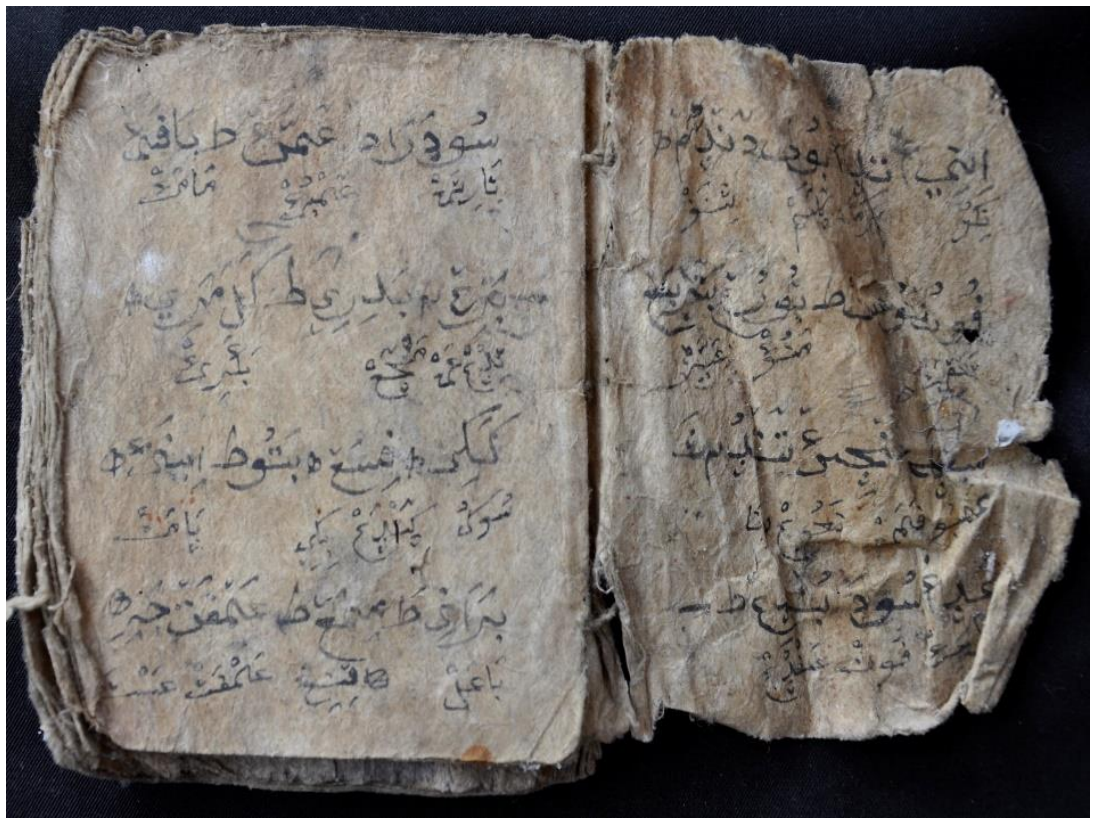

1174 BTBT 44 HLM 2,3_DSC0037 


\begin{tabular}{|l|l|l|l|}
\hline $\begin{array}{l}\text { BLAS/SUM/16/AT } \\
/ 11\end{array}$ & $\begin{array}{l}\text { KITAB FATHUR } \\
\text { RAHMĀN }\end{array}$ & 5 & Tasawuf \\
\hline $\begin{array}{l}\text { LCGPTR/KHQ/07/ } \\
2012\end{array}$ & Arab & Arab & Prosa \\
\hline 76 hlm. & 11 baris/hlm. & $24 \times 18$ & Kertas Daluwang \\
\hline K.H. Quraisyi & \\
\hline Lambi Cabi, Gapura Tengah, Gapura & \\
\hline
\end{tabular}

Naskah ini menjelaskan tentang tasawuf, pada teks ketiga menjelaskan tentang akaid 50.

Naskah ini tersimpan di rumah K.H. Quraisyi yang berasal dari kakeknya, K.H. Masyhuri

\begin{tabular}{|l|l|l|l|}
\hline $\begin{array}{l}\text { BLAS/SUM/16/AT } \\
/ 12\end{array}$ & $\begin{array}{l}\text { KITAB } \\
\text { TASAWUF }\end{array}$ & $\mathbf{5}$ & Tasawuf \\
\hline $\begin{array}{l}\text { LCGPTR/KHQ/08/ } \\
2012\end{array}$ & Arab & Arab & Prosa \\
\hline $18 \mathrm{hlm}$. & 9 baris/hlm. & $25 \times 18$ & Kertas Daluwang \\
\hline K.H. Quraisyi & & \\
\hline Lambi Cabi, Gapura Tengah, Gapura & \\
\hline
\end{tabular}

Naskah ini menjelaskan tentang ilmu tasawuf.

Naskah ini tersimpan di rumah K.H. Quraisyi yang berasal dari kakeknya, K.H. Masyhuri 


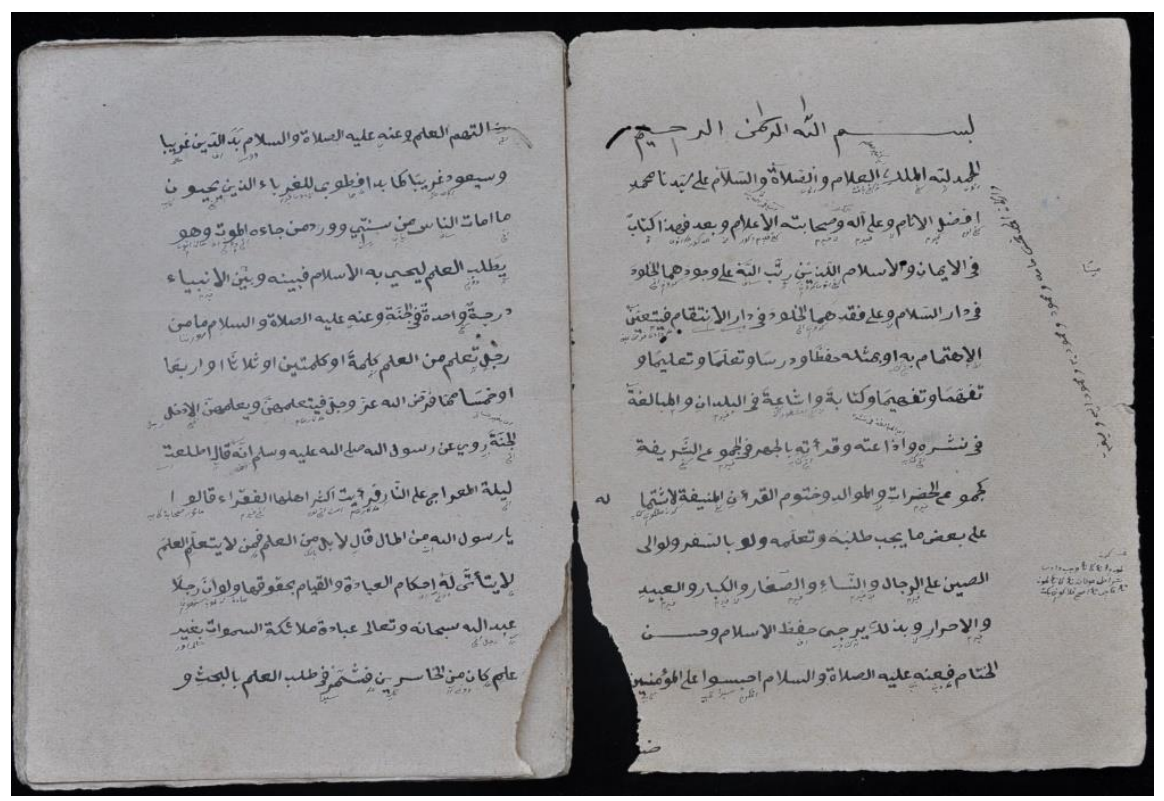

12007 LCGPTR KHQ 072012 HLM 1,2 Img0438

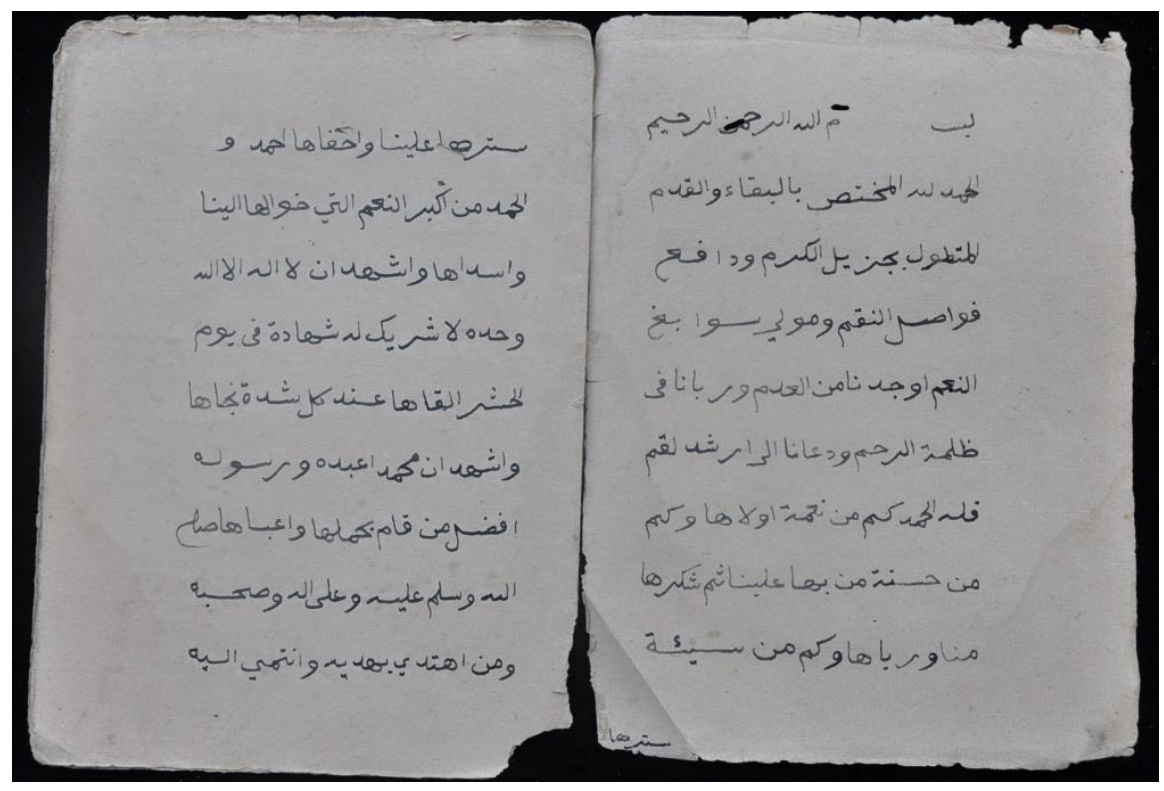

12008 LCGPTR KHQ 082012 HLM 1,2 Img0481 


\begin{tabular}{|l|l|l|l|}
\hline $\begin{array}{l}\text { BLAS/SUM/16/AT } \\
/ 13\end{array}$ & $\begin{array}{l}\text { KITAB } \\
\text { TASAWUF }\end{array}$ & 5 & Tasawuf \\
\hline $\begin{array}{l}\text { LCGPTR/KHQ/12/ } \\
2012\end{array}$ & Arab & Arab & Prosa \\
\hline $24 \mathrm{hlm}$. & 12 baris/hlm. & $24.5 \times 17.5$ & Kertas Daluwang \\
\hline K.H. Quraisyi & \\
\hline Lambi Cabi, Gapura Tengah, Gapura & \\
\hline
\end{tabular}

Naskah ini menjelaskan tentang ilmu tasawuf, cara mengasah hati, mengingat Allah Swt secara terus menerus.

Naskah ini tersimpan di rumah K.H. Quraisyi yang berasal dari kakeknya, K.H. Masyhuri

\begin{tabular}{|l|l|l|l|}
\hline $\begin{array}{l}\text { BLAS/SUM/16/AT } \\
/ 14\end{array}$ & $\begin{array}{l}\text { KITAB DOA DAN } \\
\text { TAHLIL }\end{array}$ & $\mathbf{5}$ & $\begin{array}{l}\text { Akhlak dan } \\
\text { Tasawuf }\end{array}$ \\
\hline $\begin{array}{l}\text { GPRB/SMHS/26/2 } \\
012\end{array}$ & Arab & Arab & Prosa \\
\hline $48 \mathrm{hlm}$. & 9 baris/hlm. & $14.5 \times 11$ & Kertas Daluwang \\
\hline K.H. Samhadi Siraj & & \\
\hline Gapura Barat, Gapura &
\end{tabular}

Naskah ini berisi kumpulan doa dan bacaan tahlil.

Naskah ini berasal dari K.H. Samhadi Siraj, dari K.H.M. Siraj, dari K.H. Abdul Syakur 


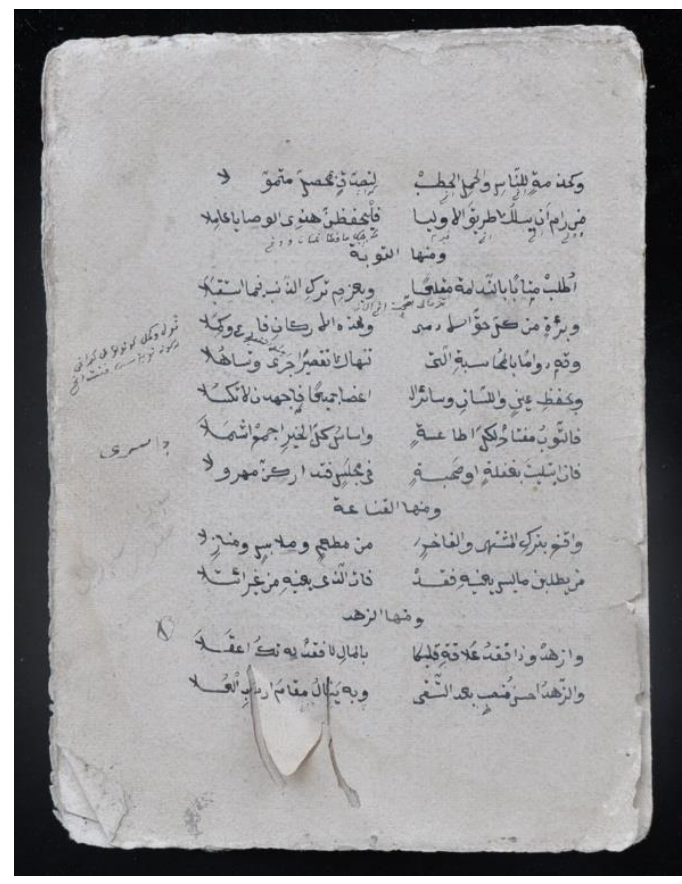

12012 LCGPTR KHQ 122012 HLM 1,2 Img0530

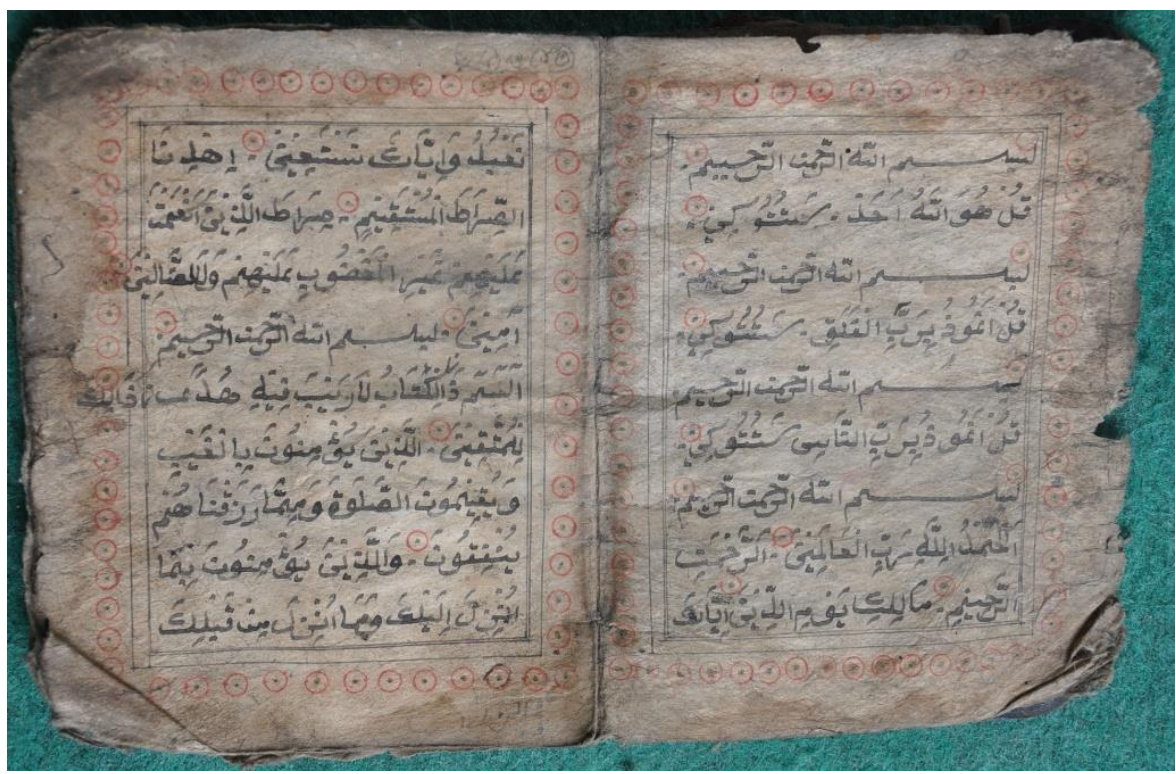

12026 GPRB SMHS 262012 HLM 2,3 Img2031 


\begin{tabular}{|l|l|l|l|}
\hline $\begin{array}{l}\text { BLAS/SUM/16/AT } \\
/ 15\end{array}$ & KITAB DOA & $\mathbf{5}$ & $\begin{array}{l}\text { Akhlak dan } \\
\text { Tasawuf }\end{array}$ \\
\hline $\begin{array}{l}\text { GPRB/SMHS/27/2 } \\
012\end{array}$ & Arab & Arab & Prosa \\
\hline $86 \mathrm{hlm}$. & 11 baris/hlm. & $17 \times 11$ & Kertas Daluwang \\
\hline K.H. Samhadi Siraj & \\
\hline Gapura Barat, Gapura
\end{tabular}

Naskah berisi kumpulan doa.

Naskah ini berasal dari K.H. Samhadi Siraj, dari K.H.M. Siraj, dari K.H. Abdul Syakur

\begin{tabular}{|l|l|l|l|}
\hline $\begin{array}{l}\text { BLAS/SUM/16/AT } \\
/ 16\end{array}$ & $\begin{array}{l}\text { KITAB DOA DAN } \\
\text { FAEDAHNYA }\end{array}$ & $\mathbf{5}$ & $\begin{array}{l}\text { Akhlak dan } \\
\text { Tasawuf }\end{array}$ \\
\hline $\begin{array}{l}\text { SGG/MGR/53/201 } \\
2\end{array}$ & Arab & Arab & Prosa \\
\hline $92 \mathrm{hlm}$. & 18 baris/hlm. & $24 \times 16$ & Kertas Daluwang \\
\hline Maghfur & \multicolumn{2}{|l}{} \\
\hline Sergang Batu Putih
\end{tabular}

Teks ini berisi kumpulan doa dan faedahnya serta tentang martabat zikir.

Naskah ini milik Maghfur dari K.H. Abdul Ghoffar. Kondisi naskah baik, teks terbaca. 


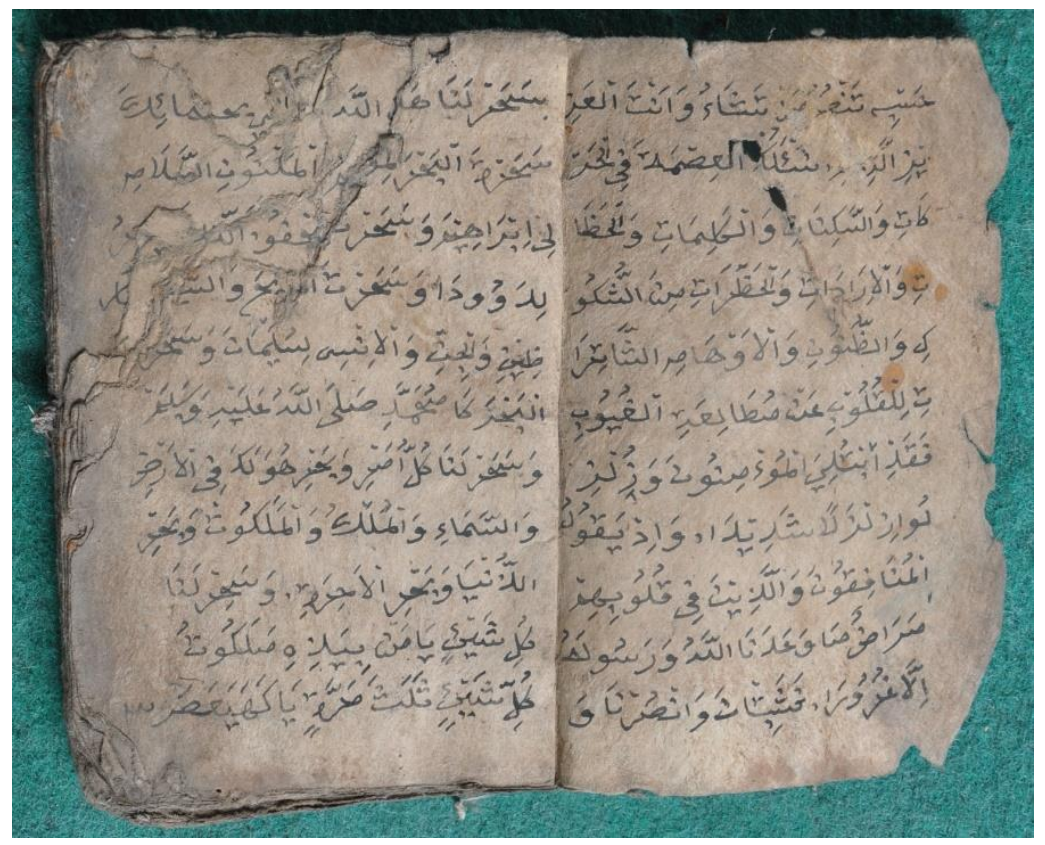

12027 GPRB SMHS 272012 HLM 2,3 Img2055

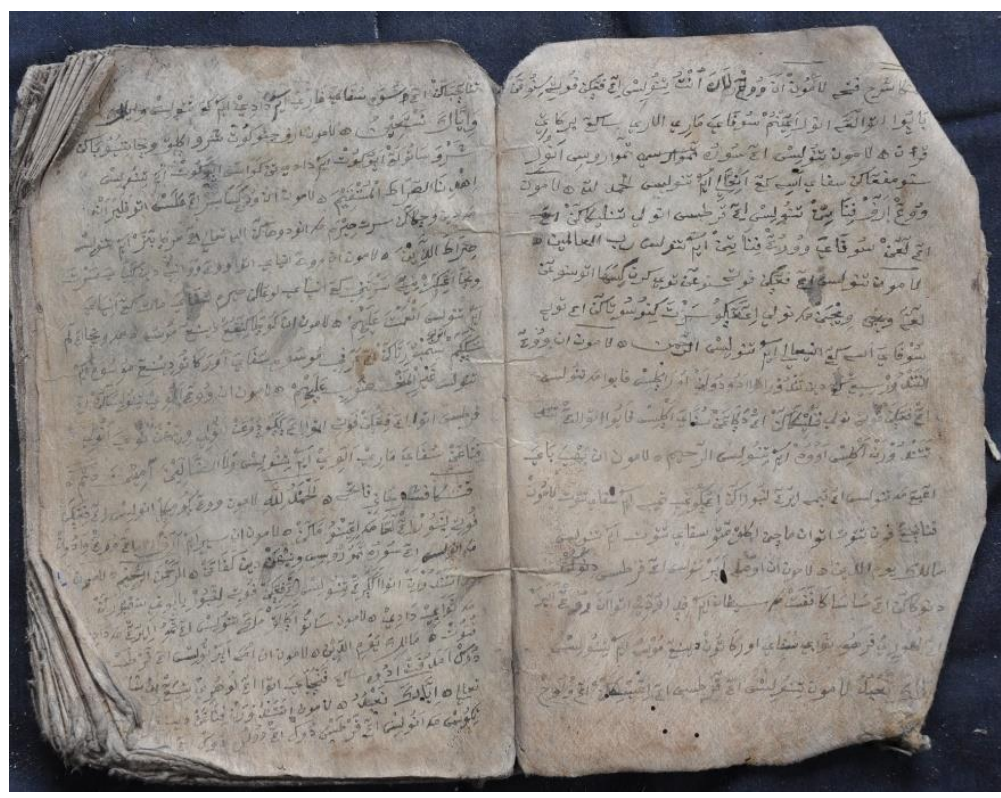

12053 SGG MGR 532012 HLM 5,6 Img5087 


\begin{tabular}{|l|l|l|l|}
\hline $\begin{array}{l}\text { BLAS/SUM/16/AT } \\
/ 17\end{array}$ & KITAB AKHLAK & 5 & Akhlak \\
\hline $\begin{array}{l}\text { BTLN/HSN/62/201 } \\
2\end{array}$ & Arab & Arab & Prosa \\
\hline 40 hlm. & 7 baris/hlm. & $20 x 17$ & Kertas Daluwang \\
\hline Husnan & & \\
\hline Bantilan, Batu Putih &
\end{tabular}

Naskah ini berisi tentang akhlak. Naskah ini menjelaskan tentang maksiat tangan, telinga, hidung dan sebaginya.

Naskah ini milik Husnan dari K. Sahrun. Kondisi naskah baik, teks terbaca.

\begin{tabular}{|l|l|l|l|}
\hline $\begin{array}{l}\text { BLAS/SUM/16/AT } \\
/ 18\end{array}$ & $\begin{array}{l}\text { KITAB } \\
\text { TASAWUF }\end{array}$ & $\mathbf{5}$ & $\begin{array}{l}\text { Akhlak dan } \\
\text { Tasawuf }\end{array}$ \\
\hline $\begin{array}{l}\text { SGG/MFHM/70/20 } \\
12\end{array}$ & Arab & Arab & Prosa \\
\hline 20 hlm. & 9 baris/hlm. & $24 \times 18$ & Kertas Daluwang \\
\hline M Fahim & \\
\hline Sergang, Batu Putih, Sumenep
\end{tabular}

Teks ini berisi tentang orang berbuat baik namun termasuk riya dan maksiatnya hati, sedang maksiatnya perut adalah memakan barang riba, makan barang curian, marah.

Naskah ini milik M. Fahim dari K. Shidiq. Kondisi naskah baik, teks terbaca. 


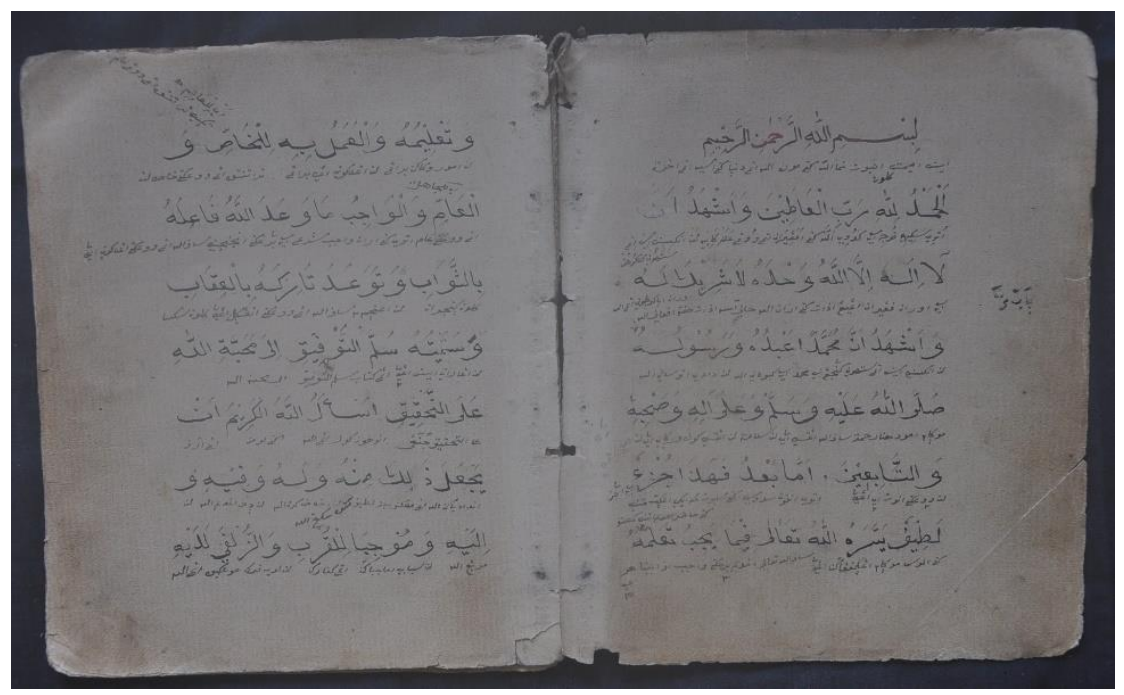

12063 BTLN HSN 622012 HLM 1,2 Img5600

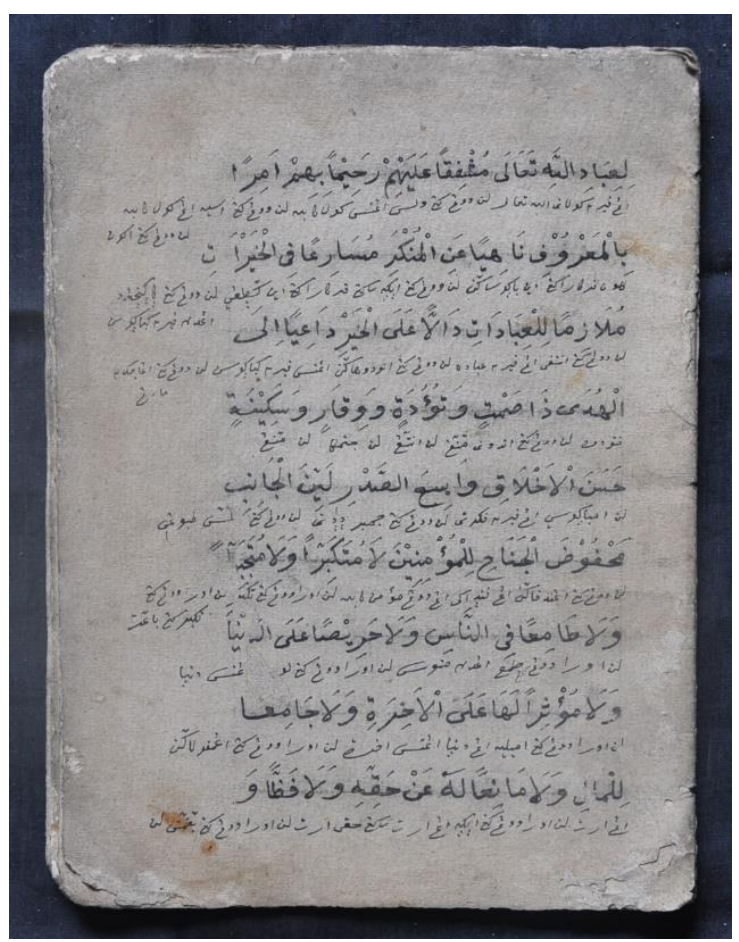

12071 SGG MFHM 702012 HLM 1 Img5926 


\begin{tabular}{|l|l|l|l|}
\hline $\begin{array}{l}\text { BLAS/SUM/16/AT } \\
/ 19\end{array}$ & KITAB SYUKUR & $\mathbf{5}$ & $\begin{array}{l}\text { Akhlak dan } \\
\text { Tasawuf }\end{array}$ \\
\hline $\begin{array}{l}\text { SGG/MFHM/71/20 } \\
12\end{array}$ & Arab & Arab & Prosa \\
\hline 48 hlm. & 7 baris/hlm. & $21.5 \times 16.5$ & Kertas Daluwang \\
\hline M Fahim & \\
\hline Sergang, Batu Putih, Sumenep
\end{tabular}

Teks ini berisi tentang syukur itu harus dikaitkan dengan kesmpurnaan Allah. Dalam masalah kebaikan maupun lainnya syukur itu lebih umum daripada hamdalah atau memuji Allah.

Naskah ini milik M. Fahim dari K. Shidiq. Kondisi naskah baik, teks terbaca.

\begin{tabular}{|l|l|l|l|}
\hline $\begin{array}{l}\text { BLAS/SUM/16/AT } \\
/ 20\end{array}$ & $\begin{array}{l}\text { KITAB } \\
\text { MA'RIFATUL } \\
\text { ISLAM DAN } \\
\text { LAIN-LAIN }\end{array}$ & $\mathbf{5}$ & Akhlak \\
\hline $\begin{array}{l}\text { BTLN/MSK/112/2 } \\
012\end{array}$ & Arab & Arab & Prosa \\
\hline $137 \mathrm{hlm}$. & $5,9,11$ baris/hlm. & $30 \times 20$ & Kertas Daluwang \\
\hline Miski & & \\
\hline Bantilan Batu Putih & \\
\hline
\end{tabular}

Naskah ini berisi tiga belas teks. Teks pertama menjelaskan akidah 50. Teks kedua menjelaskan bahwa berwudu isyarat bersuci dari yang kelihatan dengan air sampai tidak hilang kecuali dengan sucinya bekas sifat sebab air rahasia kehidupan. Teks ketiga menjelaskan tentang akidah 50. Teks kelima bernama Ma'rifatil Islam menjelaskan syariat tarekat dan hakekat. Teks keenam bernama Syartul Batiniyah menjelaskan tentang persyaratan batin dalan beribadat seperti syarat batin salat. Teks ketujuh bernama Ma'rifatul Ulum menjelaskan tentang żikir dan doa. Teks kedelapan menjelaskan tentang arti salat. Teks kesembilan menjelaskan tentang salat sebagai mi'rajul muslimin. Teks kesepuluh bernama Bidayah al-Aqidah al-Saniyah menjelaskan agama dengan model tanya jawab. Teks kesebelas bernama Riyadu al-Sălihin menjelaskan manfaat dan tidaknya ilmu kecuali mengagungkan guru dan ahlinya. Teks kedua belas bernama Mukarramu al-Sultan menjelaskan mengajak kepada kebaikan dan menghindari keburukan dalam berpolitik. Teks ketiga belas bernama Nuqayah menjelaskan ilmu tauhid aliran Asy'araiyah. Teks keempat belas bernama kitab alDurriyah menjelaskan tentang anak Adam.

Naskah ini milik Miski dari K.H. Syamsudin. Kondisi naskah cukup baik, teks terbaca. 


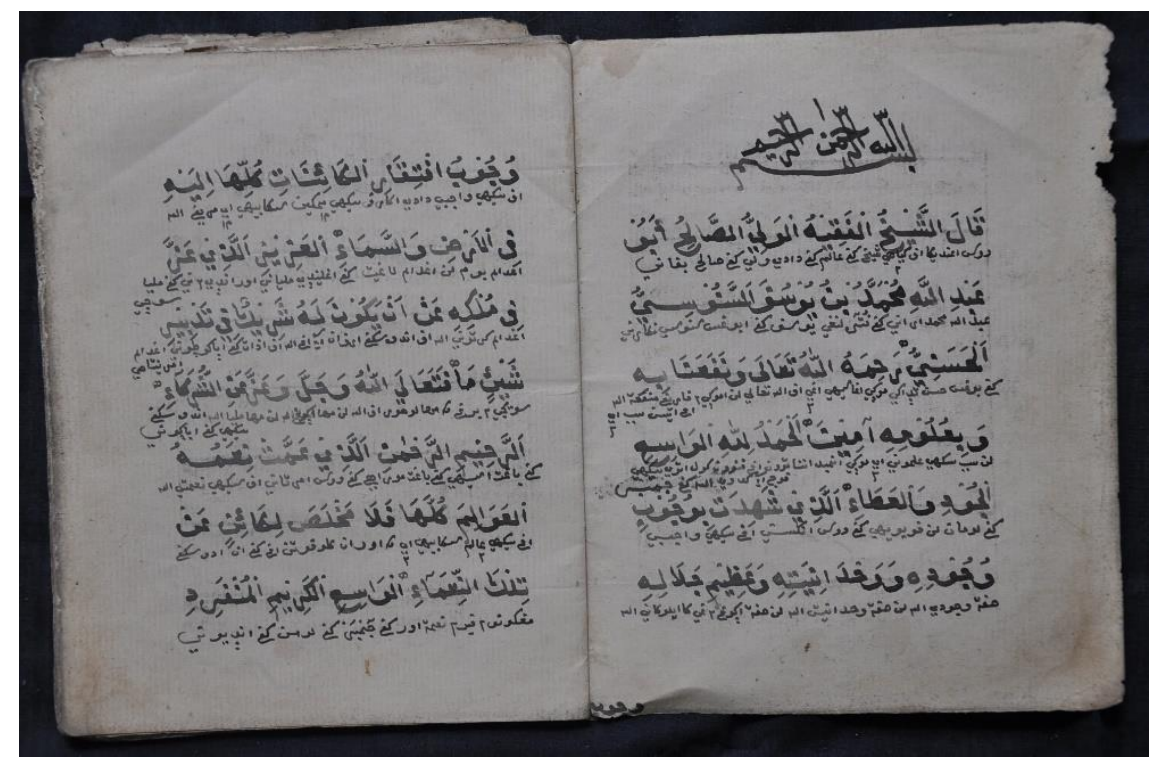

12072 SGG MFHM 712012 HLM 1,2 Img5939

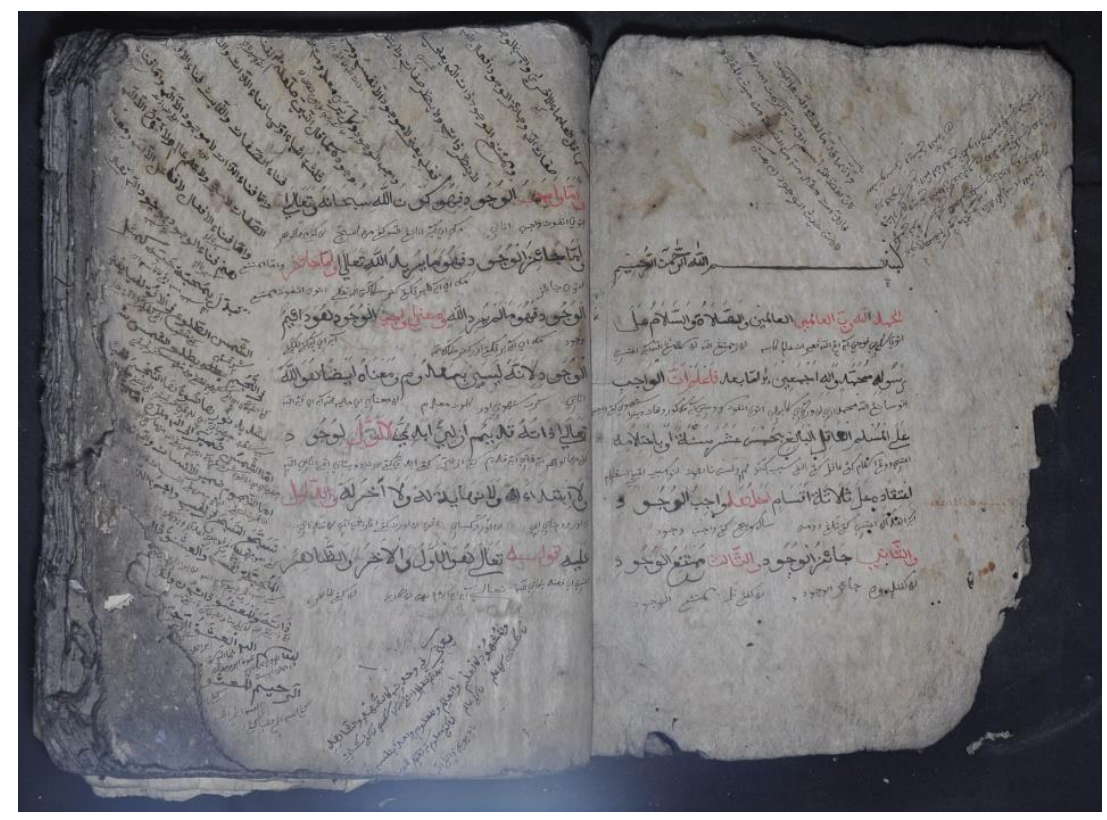

12113 BTLN MSK 1122012 HLM 1,2 Img10138 


\begin{tabular}{|l|l|l|l|}
\hline $\begin{array}{l}\text { BLAS/SUM/16/AT } \\
\text { /21 }\end{array}$ & $\begin{array}{l}\text { KITAB } \\
\text { PENCIPATAAN } \\
\text { MANUSIA }\end{array}$ & $\mathbf{5}$ & $\begin{array}{l}\text { Akhlak dan } \\
\text { Tasawuf }\end{array}$ \\
\hline $\begin{array}{l}\text { NYBK.BTBT/ARF } \\
\text { S/118/2012 }\end{array}$ & Arab & Arab & Prosa \\
\hline 36 hlm. & 7 baris/hlm. & $10.5 \times 15.5$ & Kertas Daluwang \\
\hline Arif Sudarsono & & \\
\hline Nyabakan Timur Batang-Batang & \\
\hline
\end{tabular}

Naskah ini menjelaskan tentang asal mula kejadian manusia kemudian untuk apa dijadikan dan kemana akhir manusia.

Naskah ini milik Arif Sudarsono dari Syahral. Kondisi naskah cukup baik, teks terbaca.

\begin{tabular}{|l|l|l|l|}
\hline $\begin{array}{l}\text { BLAS/SUM/16/AT } \\
\mathbf{2 2}\end{array}$ & $\begin{array}{l}\text { KITAB SIKAP } \\
\text { WAJIB }\end{array}$ & $\mathbf{5}$ & $\begin{array}{l}\text { Akhlak dan } \\
\text { tasawuf }\end{array}$ \\
\hline $\begin{array}{l}\text { JNGR/HSM/125/20 } \\
12\end{array}$ & Arab & Arab & Prosa \\
\hline $10 \mathrm{hlm}$. & 7 baris/hlm. & $26 \times 18$ & Kertas Daluwang \\
\hline Hosmah & \\
\hline Jenangger, Batang-batang
\end{tabular}

Naskah ini menjelaskan tentang sifat yang wajib diketahui oleh muslim.

Naskah ini dimiliki oleh Hosmah dari K Ahyar dari K Abdullah. Tahun dan tempat penyusunan, penulisan ulang, maupun pemrakarsa tidak dicantumkan. Naskah dalam kondisi cukup baik/cukup bisa dibaca. 


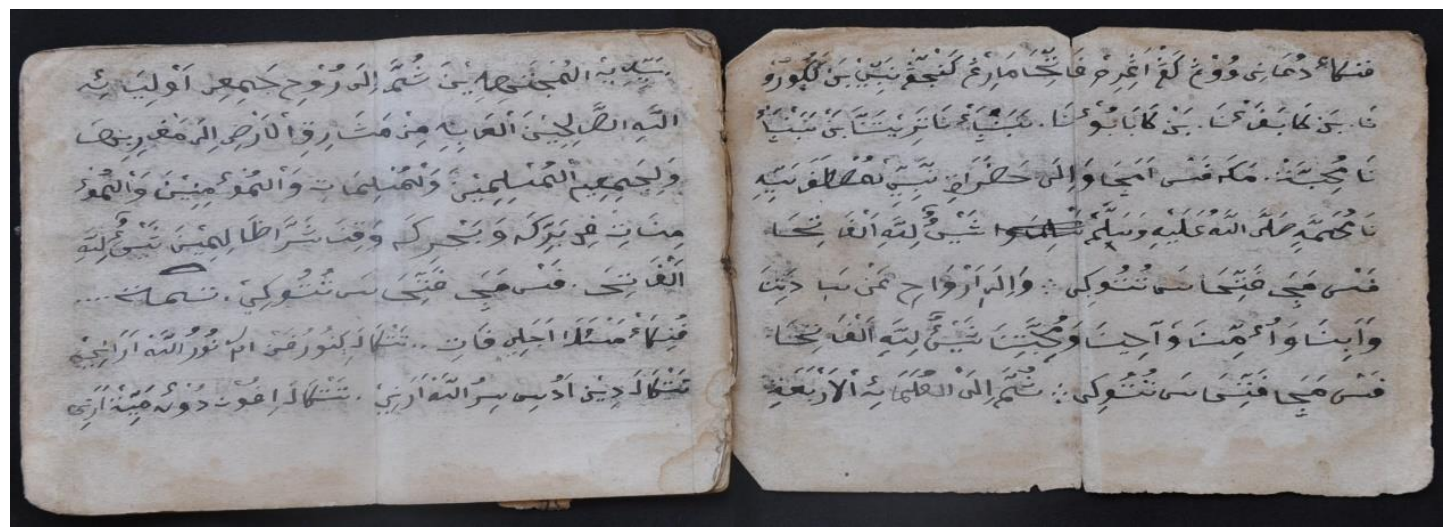

12119 NYBKBTBT ARFS 1182012 HLM 1,2 Img10472

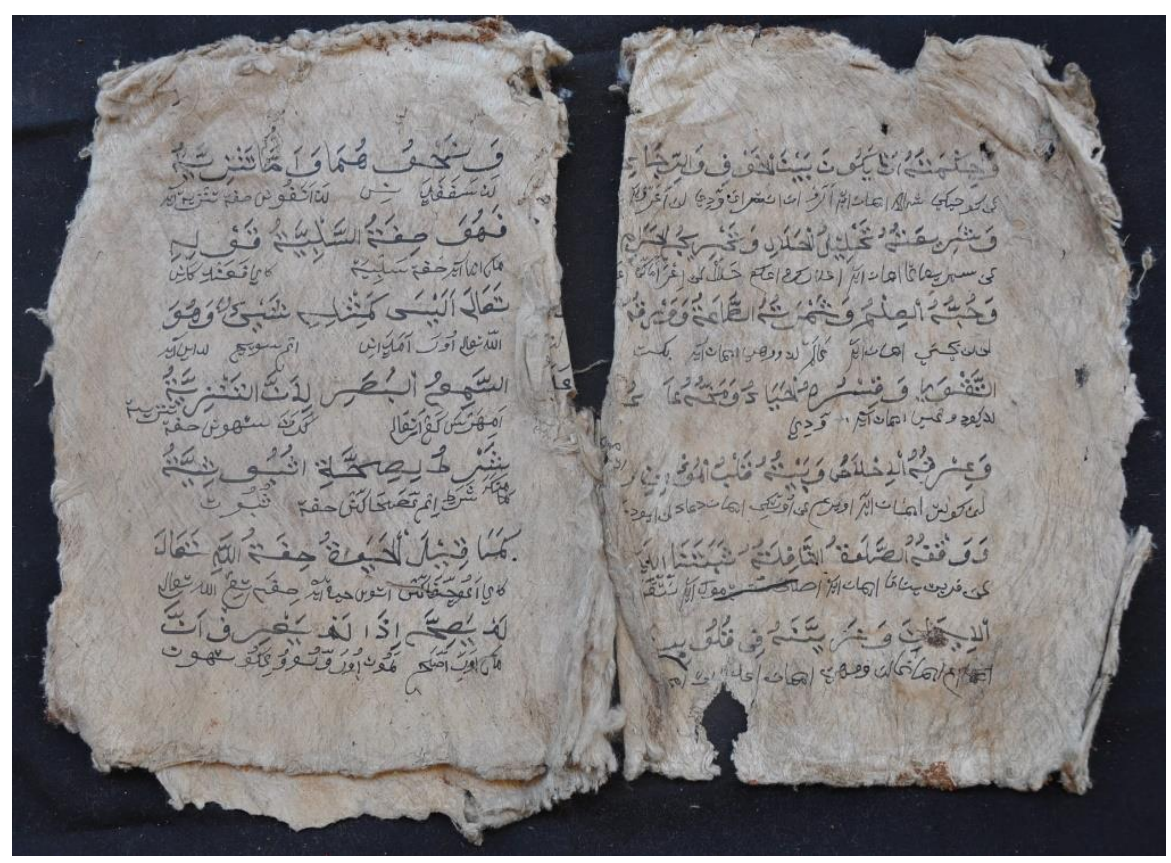

12126 JNGR HSM 1252012 HLM 2,3 Img10726 


\begin{tabular}{|l|l|l|l|}
\hline $\begin{array}{l}\text { BLAS/SUM/16/AT } \\
/ 23\end{array}$ & $\begin{array}{l}\text { KITAB } \\
\text { SAFINATUL } \\
\text { BAHRIYAH }\end{array}$ & $\mathbf{5}$ & Akhlak/Tasawuf \\
\hline $\begin{array}{l}\text { PJGSGG/MDN/149 } \\
/ 2012\end{array}$ & Arab & Arab & Prosa \\
\hline $163 \mathrm{hlm}$. & 13 baris/hlm. & $21.5 \mathrm{x} 17$ & Kertas Daluwang \\
\hline H. Madani & & \\
\hline \multicolumn{2}{|l}{ Pajung Sergang Sergang, Batu Putih } \\
\hline
\end{tabular}

Teks bernama Safinatul Bahriyah, ditulis oleh Jalaluddin Al Mahalli, menjelaskan tentang akhlak/tasawuf. Teks kedua Asmāul Ḥusnā, menjelaskan tentang Asmaul Husna.

Naskah ini dimiliki oleh H. Madani dari K. Abdul Karim Kondisi naskah tergolong baik.

\begin{tabular}{|l|l|l|l|}
\hline $\begin{array}{l}\text { BLAS/SUM/16/AT } \\
\text { /24 }\end{array}$ & $\begin{array}{l}\text { KITAB HAJ DAN } \\
\text { TASAWUF }\end{array}$ & $\mathbf{5}$ & Akhlak/Tasawuf \\
\hline $\begin{array}{l}\text { PJGSGG/MDN/150 } \\
2012\end{array}$ & Arab & Arab & Prosa \\
\hline 34 hlm. & 7 baris/hlm. & $21 \times 17$ & Kertas Daluwang \\
\hline H. Madani & \multicolumn{2}{l}{} \\
\hline \multicolumn{2}{|l|}{ Pajung Sergang Sergang, Batu Putih }
\end{tabular}

Naskah berisi dua teks, teks pertama menjelaskan tentang tata cara tawaf dan memegang hajar aswad, teks kedua menjelaskan tentang syariat, hakikat, dan makrifat.

Naskah ini dimiliki oleh H. Madani dari K. Abdul Karim Kondisi naskah tergolong cukup baik. 


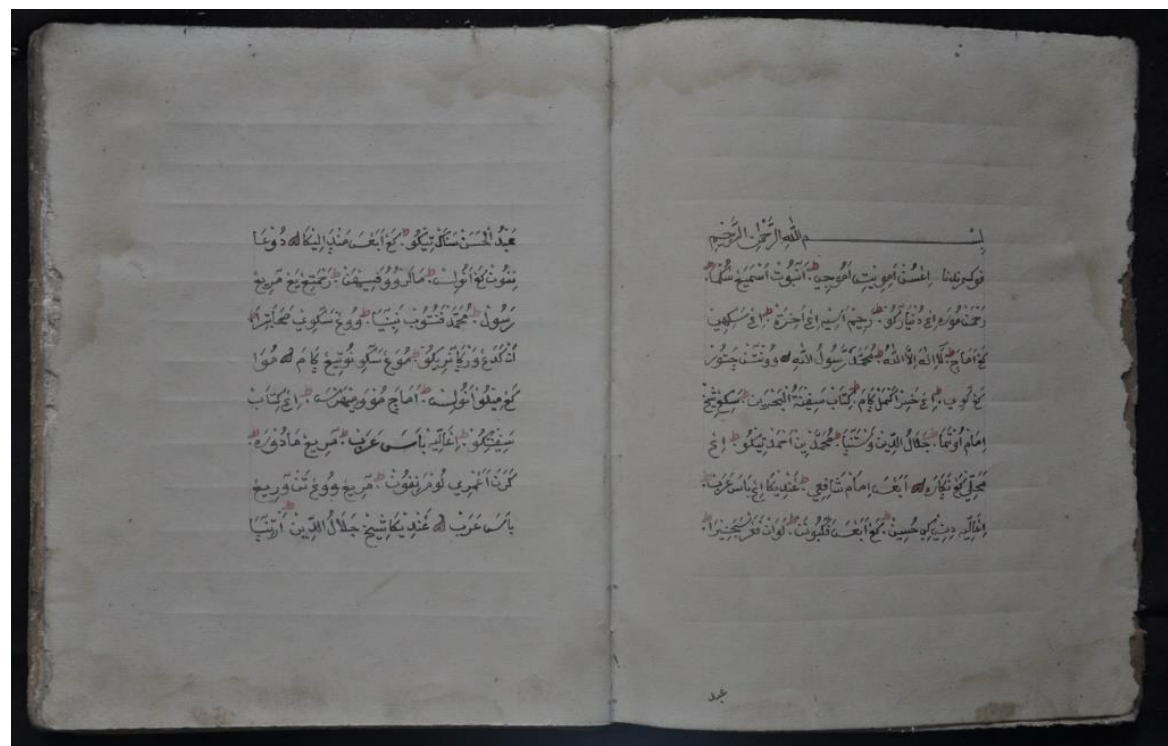

12150 PJGSGG MDN 1492012 HLM 1,2 Img12381

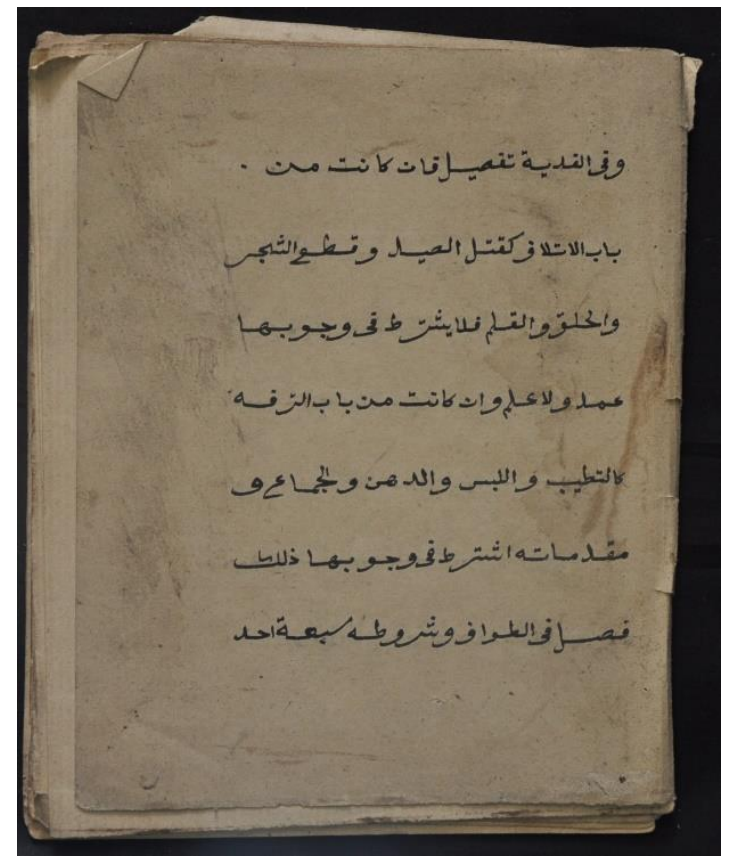

12151 PJGSGG MDN 1502012 HLM 1 Img12467 


\begin{tabular}{|l|l|l|l|}
\hline $\begin{array}{l}\text { BLAS/SUM/16/AT } \\
\text { /25 }\end{array}$ & $\begin{array}{l}\text { KITAB } \\
\text { MACAPAT 0 }\end{array}$ & $\mathbf{5}$ & Akhlak/Tasawuf \\
\hline $\begin{array}{l}\text { PJGSGG/ASFL/15 } \\
1 / 2012\end{array}$ & Jawa & Arab & Prosa \\
\hline $166 \mathrm{hlm}$. & 13 baris/hlm. & $21 \times 17$ & Kertas Daluwang \\
\hline H. Madani & \multicolumn{2}{l}{} \\
\hline \multicolumn{2}{|l|}{ Pajung Sergang Sergang, Batu Putih } \\
\hline
\end{tabular}

Naskah ini berisi tembang Mocopatan.

Naskah ini dimiliki oleh A. Saifullah dari K.H. Abdul Aziz. Kondisi naskah tergolong baik.

\begin{tabular}{|l|l|l|l|}
\hline $\begin{array}{l}\text { BLAS/SUM/16/AT } \\
\text { /26 }\end{array}$ & $\begin{array}{l}\text { KITAB } \\
\text { MACAPAT 0 }\end{array}$ & $\mathbf{5}$ & Akhlak/Tasawuf \\
\hline $\begin{array}{l}\text { PJGSGG/ASFL/15 } \\
2 / 2012\end{array}$ & Jawa & Arab & Prosa \\
\hline $\begin{array}{l}152 \mathrm{hlm} . \\
\text { H. Madani }\end{array}$ & 13 baris/hlm. & $20 \times 15.5$ & Kertas Daluwang \\
\hline \multicolumn{2}{|l|}{ Pajung Sergang Sergang, Batu Putih } \\
\hline
\end{tabular}

Naskah ini berisi tembang Mocopatan.

Naskah ini dimiliki oleh A. Saifullah dari K.H. Abdul Aziz. Kondisi naskah tergolong baik. 


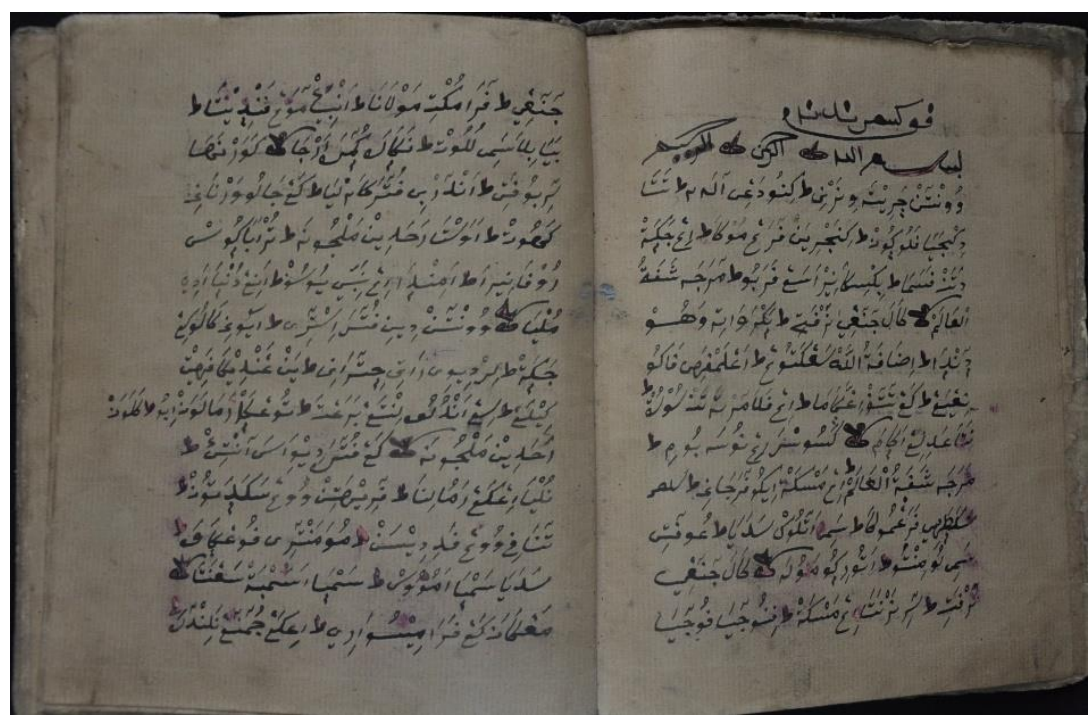

12152 PJGSGG ASFL 1512012 HLM 1,2 Img12490

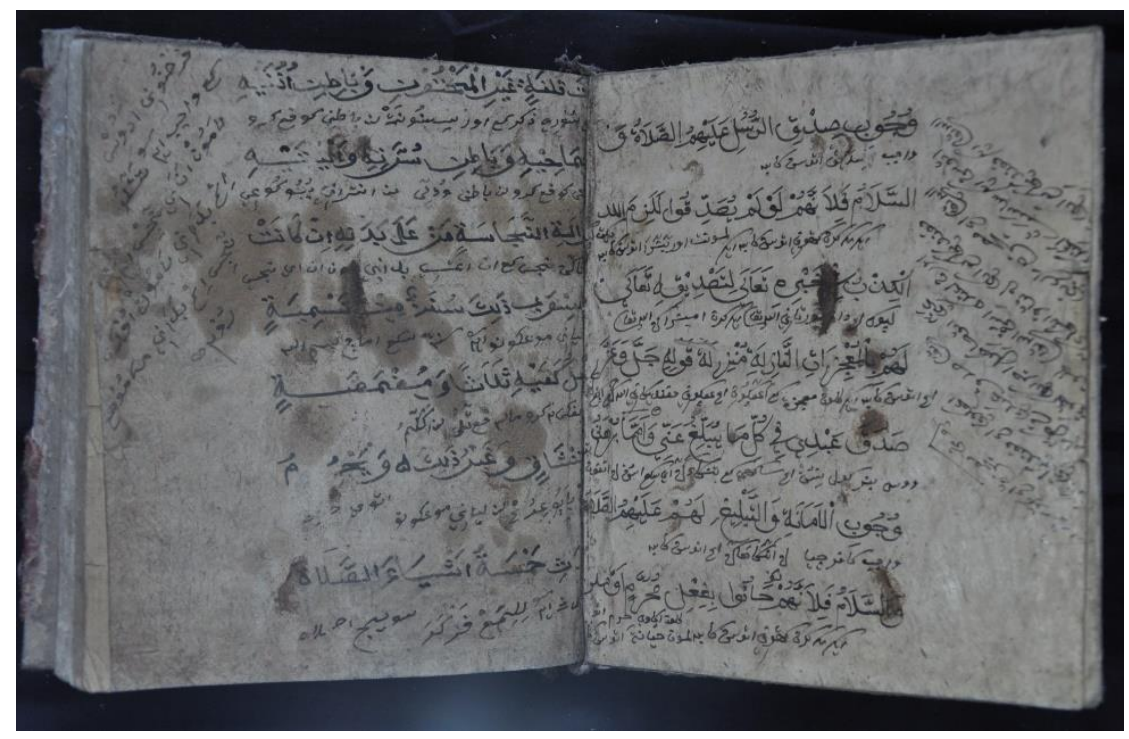

12153 PJGSGG ASFL 1522012 HLM 1,2 Img12647 


\begin{tabular}{|l|l|l|l|}
\hline $\begin{array}{l}\text { BLAS/SUM/16/AT } \\
\text { /27 }\end{array}$ & $\begin{array}{l}\text { KITAB } \\
\text { MAKSIAT }\end{array}$ & $\mathbf{5}$ & Akhlak/Tasawuf \\
\hline $\begin{array}{l}\text { PJGSGG/HSM/154 } \\
/ 2012\end{array}$ & Arab & Arab & Prosa \\
\hline $28 \mathrm{hlm}$. & 9 baris/hlm. & $27.5 \times 20$ & Kertas Daluwang \\
\hline K.H. Hasim & \\
\hline Pajung, Sergang, Batu Putih, Sumenep & \\
\hline
\end{tabular}

Teks ini menjelaskan tentang maksiatnya lisan, telinga, mata, tangan, kaki, hati, dan sebagainya.

Naskah ini dimiliki oleh K.H. Hasim dari K.H. Azhari. Kondisi naskah tergolong cukup baik.

\begin{tabular}{|l|l|l|l|}
\hline $\begin{array}{l}\text { BLAS/SUM/16/AT } \\
\text { /28 }\end{array}$ & KITAB AKHLAK & $\mathbf{5}$ & $\begin{array}{l}\text { Akhlak, Bahasa, } \\
\text { dan tasawuf }\end{array}$ \\
\hline GPR 26 & Arab & Arab & Prosa \\
\hline $295 \mathrm{hlm}$. & $13,10,7$ baris/hlm. & $23.9 \times 16.3$ & Kertas Eropa \\
\hline Abdur Rahim & \\
\hline \multicolumn{2}{|l}{ Dusun Nai'an Atas, Gapura Barat, Gapura Sumenep } \\
\hline
\end{tabular}

Naskah berisi beberapa teks. Teks-teks tersebut meliputi ilmu nạwwu, tauhid, fikih. Ditulis oleh Nuh Soleh bin Roif Ibrahim. Akhlak mengambil dari nasehatnya Imam Nashir Ibrahim al-Bajuri. Tauhid dengan terjemahan model jenggotan/gandul, tasawuf, akidah,

Naskah milik Abdur Rochim dari Kiai Ro'i. Teks ditulis menggunakan tinta hitam dan merah sebagai penjelas. Kondisi fisik naskah dalam keadaan baik dan tulisan bisa dibaca dengan jelas. 


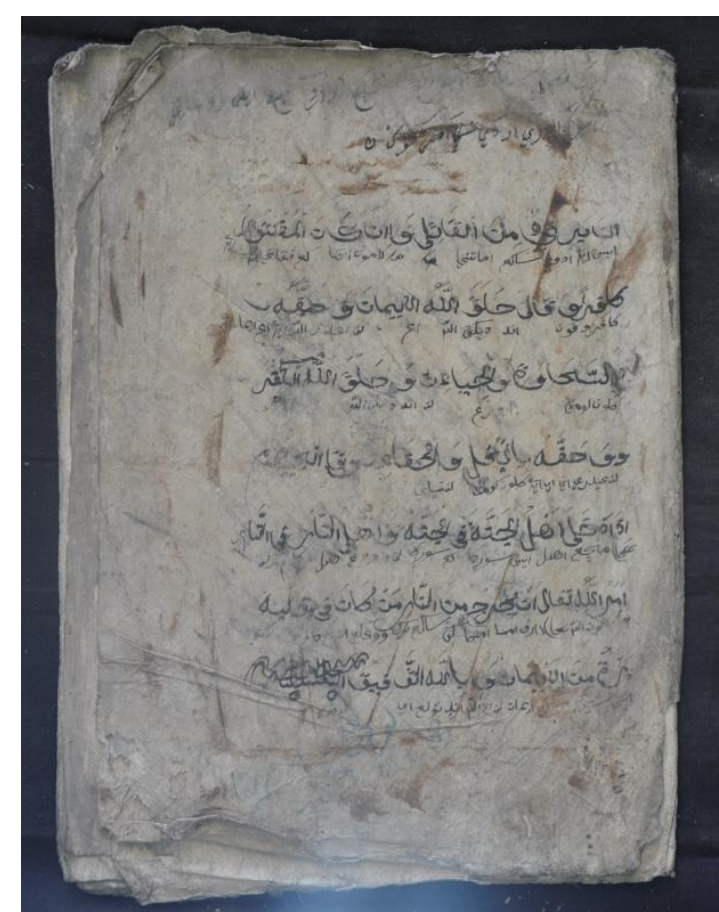

12155 PJGSGG HSM 1542012 HLM 1 Img12785

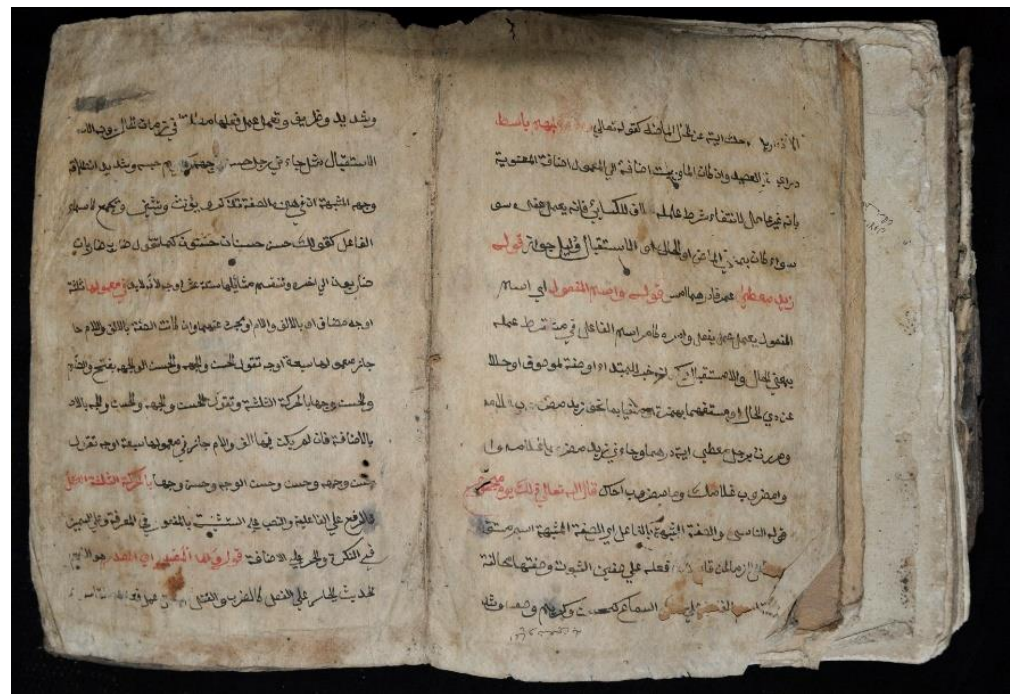

1112 GPR 26 HLM 1,2_DSC0199 


\section{SB}

\section{Sosial dan Budaya Islam}

\begin{tabular}{|l|l|l|l|}
\hline $\begin{array}{l}\text { BLAS/SUM/16/SB/ } \\
1\end{array}$ & $\begin{array}{l}\text { KITAB } \\
\text { MACAPAT 0 }\end{array}$ & $\mathbf{6}$ & Sastra \\
\hline $\begin{array}{l}\text { JNGR/SUDFD/129 } \\
/ 2012\end{array}$ & Jawa & Arab & Prosa \\
\hline $118 \mathrm{hlm}$. & 15 baris/hlm. & $21 \times 16$ & Kertas Daluwang \\
\hline Kiai Su'udi Fadhal & \\
\hline Jenangger, Batang-batang & \\
\hline
\end{tabular}

Nasakah ini berisi tembang macapat.

Naskah ini dimiliki oleh Su'udi dari K. Ru'an dari Nyai Saruti dari K.H. Hadi dari K.H. Kamsiyah dari K. Biramah. Naskah dalam kondisi cukup baik/cukup bisa dibaca

\begin{tabular}{|l|l|l|l|}
\hline $\begin{array}{l}\text { BLAS/SUM/16/SB/ } \\
2\end{array}$ & $\begin{array}{l}\text { KITAB } \\
\text { MACAPAT 0 }\end{array}$ & 6 & Sastra \\
\hline $\begin{array}{l}\text { JNGR/SUDFD/135 } \\
/ 2012\end{array}$ & Jawa & Arab & Prosa \\
\hline 60 hlm. & 11 baris/hlm. & $8 \times 13$ & Kertas Daluwang \\
\hline Kiai Su'udi Fadhal & & \\
\hline Jenangger, Batang-batang
\end{tabular}

Naskah ini berisi tembang macapat dengan bahasa Jawa.

Naskah ini dimiliki oleh K. Su'udi Fadlal dari Rosyidah dari K. Irsyad dari K.H. Hadi dari Kamsah dari K. Biramah. Naskah dalam kondisi cukup baik/cukup baik terbacanya. 


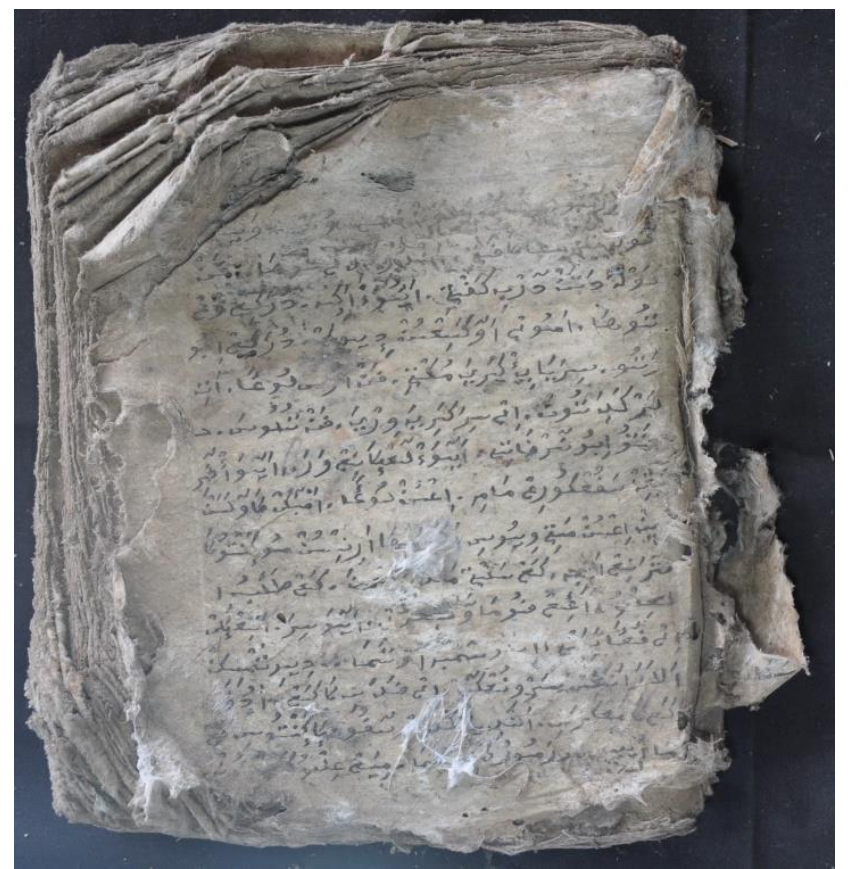

12130 JNGR SUDFD 1292012 HLM 1 Img10867

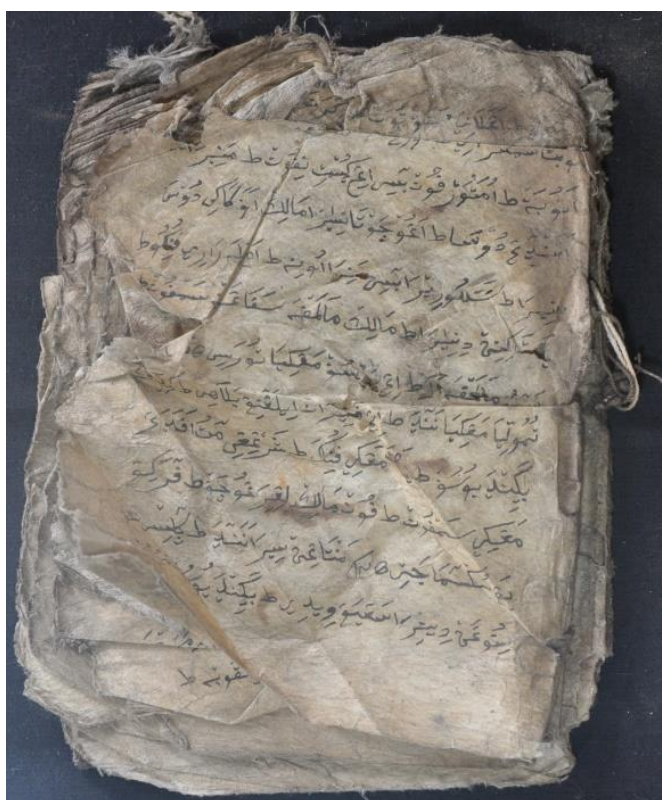

12136 JNGR SUDFD 1352012 HLM 1 Img11066 


\section{FIP}

\section{Filsafat dan Perkembangannya}

\begin{tabular}{|l|l|l|l|}
\hline $\begin{array}{l}\text { BLAS/SUM/16/FIP } \\
/ 1\end{array}$ & $\begin{array}{l}\text { KITAB CERITA } \\
\text { WAYANG }\end{array}$ & 7 & $\begin{array}{l}\text { Seni/Filsafat } \\
\text { Islam }\end{array}$ \\
\hline $\begin{array}{l}\text { PJGSGG/MWYH/1 } \\
63 / 2012\end{array}$ & Jawa & Arab & Prosa \\
\hline 86 hlm. & 19 baris/hlm. & $33 \times 20$ & Kertas Daluwang \\
\hline Nyai Mu'awiyah & & \\
\hline Pajung ,Sergang, Batu Putih, Sumenep & \\
\hline
\end{tabular}

Teks ini menjelaskan tentang cerita wayang.

Naskah ini dimiliki oleh Nyai Mu'awiyah dari Nyai Dzuriyah. Kondisi naskah tergolong cukup baik.

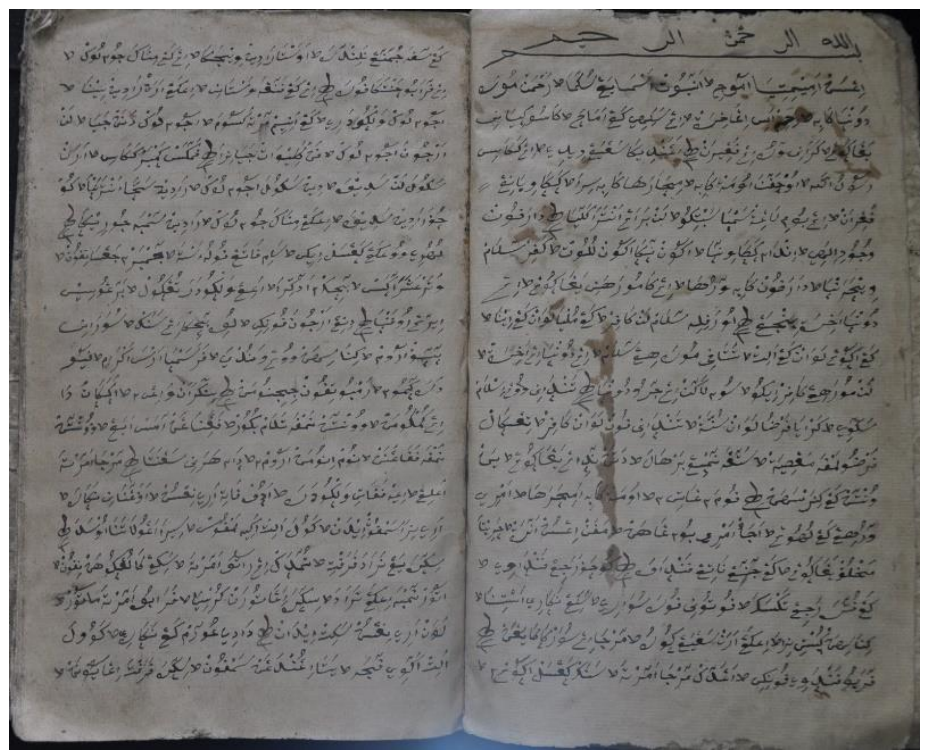

12164 PJGSGG MWYH 1632012 HLM 1,2 Img13037 


\section{SI \\ Sejarah Islam dan Bibliografi}

\begin{tabular}{|l|l|l|l|}
\hline $\begin{array}{l}\text { BLAS/SUM/16/SI/ } \\
1\end{array}$ & $\begin{array}{l}\text { KITAB SEJARAH } \\
\text { NABI }\end{array}$ & $\mathbf{9}$ & $\begin{array}{l}\text { Sejarah Islam dan } \\
\text { Bibliografi }\end{array}$ \\
\hline BT-BT 13 & Arab & Arab & Prosa, Mocopat \\
\hline $134 \mathrm{hlm}$. & 11 baris/hlm. & $21 \times 16$ & Kertas Daluwang \\
\hline Khasyieun & \\
\hline Dusun Laok Saba, Nyabakan Timur, batang-Batang \\
\hline
\end{tabular}

Naskah ini berisi sejarah Nabi.

Naskah ini dimiliki oleh Khasyieun dari Kiai Muhabi dari Kiai Hasyim dari Kiai Sawabi. Tahun dan tempat penyusunan disebutkan pada Alif bak, tahun nun, 926. Kondisi naskah rusak, tetapi masih dapat dibaca. Tinta menggunakan warna hitam dan ungu.

\begin{tabular}{|l|l|l|l|}
\hline $\begin{array}{l}\text { BLAS/SUM/16/SI/ } \\
2\end{array}$ & KITAB MI'RĀJ & $\mathbf{9}$ & Sejarah \\
\hline $\begin{array}{l}\text { MDGT/AMR/40/20 } \\
12\end{array}$ & Jawa & Arab Pegon & Prosa \\
\hline 98 hlm. & 12 baris/hlm. & $21 \times 18$ & Kertas Daluwang \\
\hline Kiai Amir & \\
\hline \multicolumn{2}{|l}{} \\
\hline
\end{tabular}

Naskah ini teksnya diambil dari Kitab Mi'raj yang menjelaskan sejarah para nabi, kejadian alam, malaikat, jagad raya, dan sebagainya.

Naskah ini milik K. Amir dari K. Abdus Salam. Kondisi naskah cukup baik, beberapa berlubang, teks terbaca. 


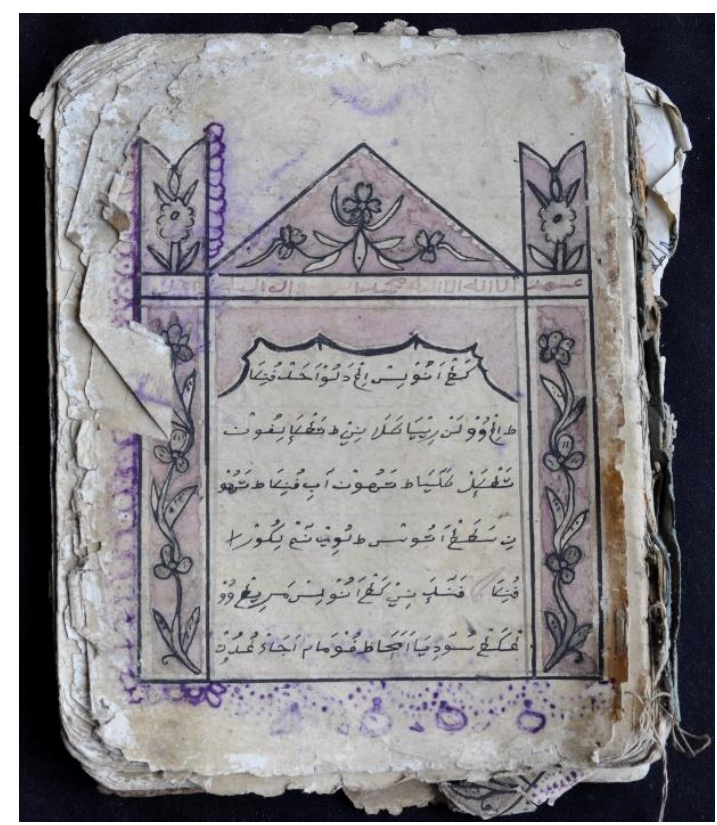

1143 BTBT 13 HLM 1_DSC0002

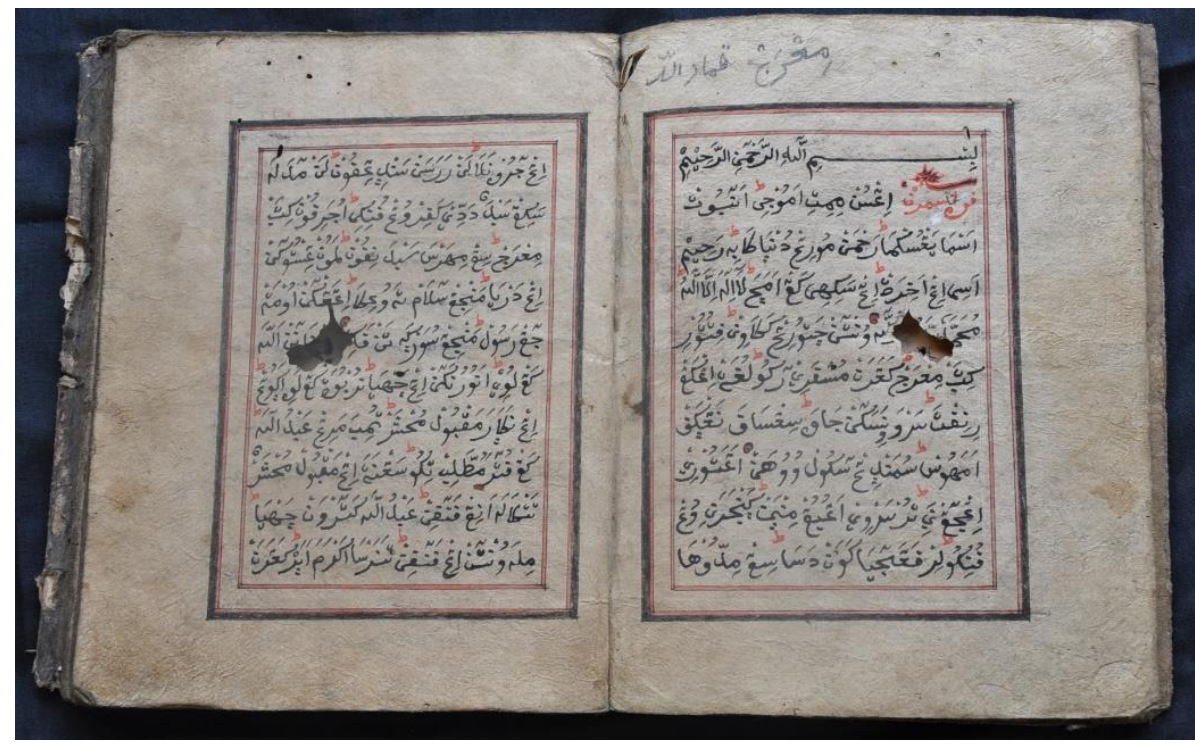

12040 MGT AMR 402012 HLM 1,2 Img3319 


\begin{tabular}{|l|l|l|l|}
\hline $\begin{array}{l}\text { BLAS/SUM/16/SI/ } \\
\mathbf{3}\end{array}$ & KITAB MI'RĀJ & $\mathbf{9}$ & sejarah \\
\hline $\begin{array}{l}\text { NYBK.TFQHDYT/ } \\
119 / 2012\end{array}$ & Arab & Arab & Prosa \\
\hline 140 hlm. & 12 baris/hlm. & $19.5 \times 14$ & Kertas Daluwang \\
\hline Taufiq Hidayat & & \\
\hline Nyabakan Timur Bat ang-Batang
\end{tabular}

Naskah ini bernama teks Mi'raj menjelaskan tentang nabi mi'raj bertemu Allah dan mendapatkan perintah salat.

Naskah ini milik Taufiq Hidayat dari Pathan.

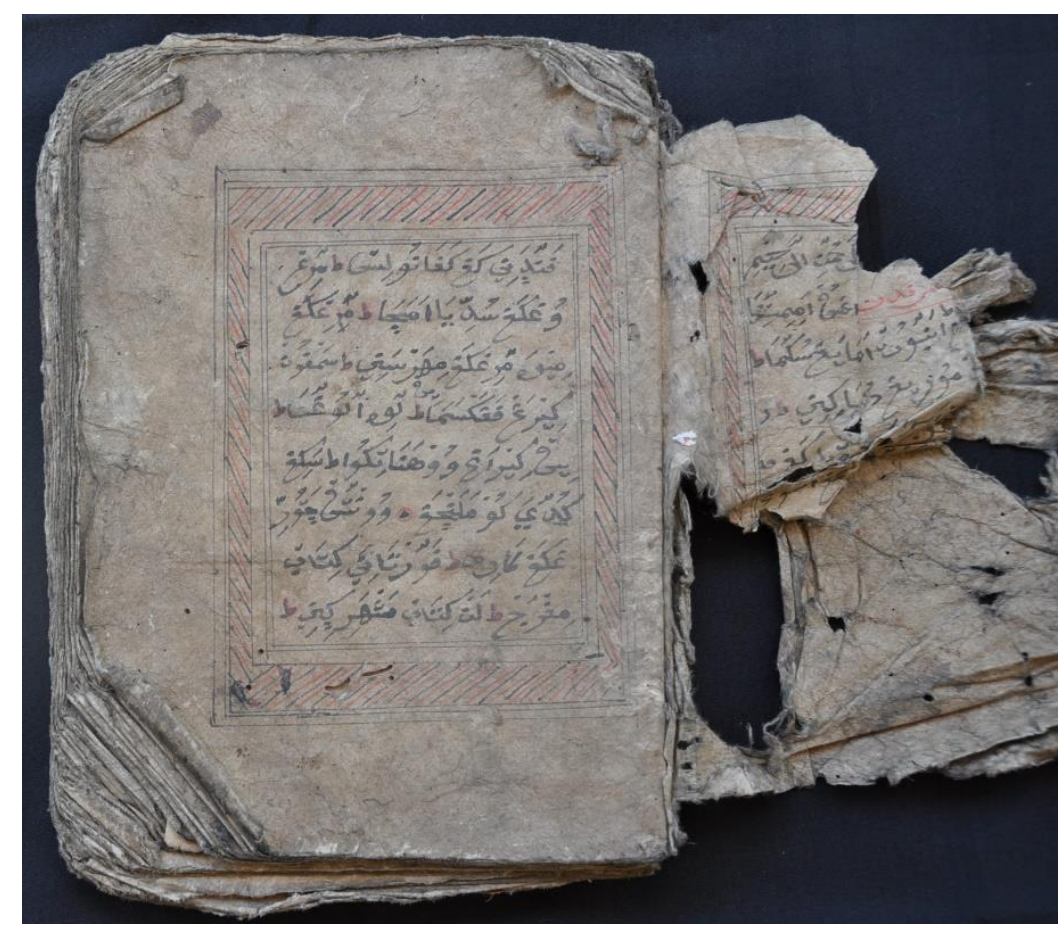

12120 NYBK TFQHDYT 1192012 HLM 4,5 Img10492 


\section{KATALOG \\ NASKAH KEAGAMAAN

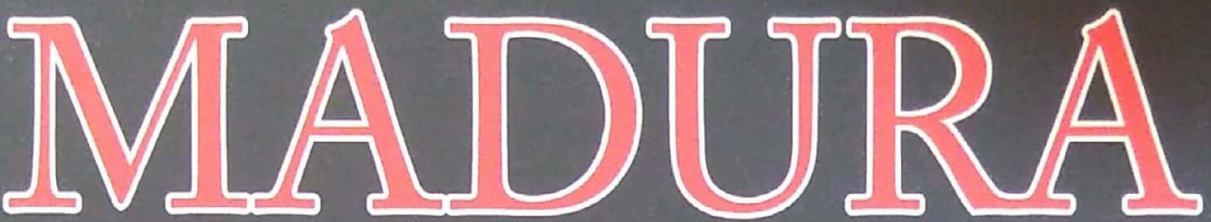

Katalogisasi naskah-naskah nusantara telah banyak dilakukan. Akan tetapi, jika dicermati katalog-katalog yang sudah ada tersebut mengidentifikasi naskah yang sudah terkumpul di perpustakaan atau museum, yang konotasinya merupakan naskah yang berasal dari lingkungan kerajaan atau keraton. Jika benar demikian, maka inventarisasi

dan identifikasi naskah yang ada di masyarakat belum banyak dilakukan.

Sudah mafhum bahwa naskah senantiasa dipengaruhi keadaan zaman, terkait bahasa dan kebudayaannya. Mengkaji naskah dapat memahami dan menghayati pandangan serta cita-cita yang menjadi pedoman hidup generasi sebelumnya.

Menggali warisan nenek moyang yang agung nilainya di dalam naskah dapat diartikan pula sebagai usaha melestarikan dan mengembangkan kebudayaan bangsa Indonesia karena kebudayaan lama itu merupakan akar berpijaknya pandangan masyarakat saat ini.

Madura sangat tepat dijadikan sebagai lokasi penelusuran naskah keagamaan Islam. Madura sejak masa lampau telah menjadi basis penyebaran agama Islam dan masyarakatnya menjadi masyarakat muslim berpengaruh di Jawa Timur. Komunitas muslim di Madura menguat dengan majunya kerajaan muslim, kemudian diikuti merebaknya pusat-pusat pendidikan dari pondok pesantren, majelis taklim, dan madrasah diniyah.
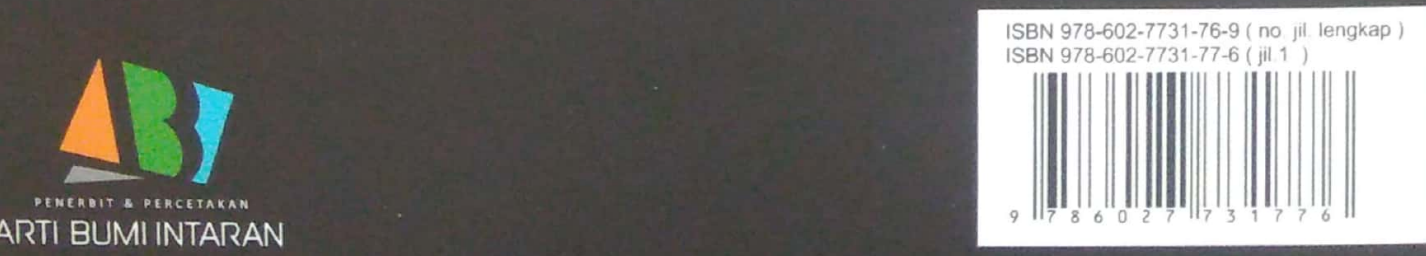

ARTI BUMI INTARAN 